\title{
Arqueologia na Amazônia Central Vista de Uma Perspectiva da Região do Lago do Limão
}
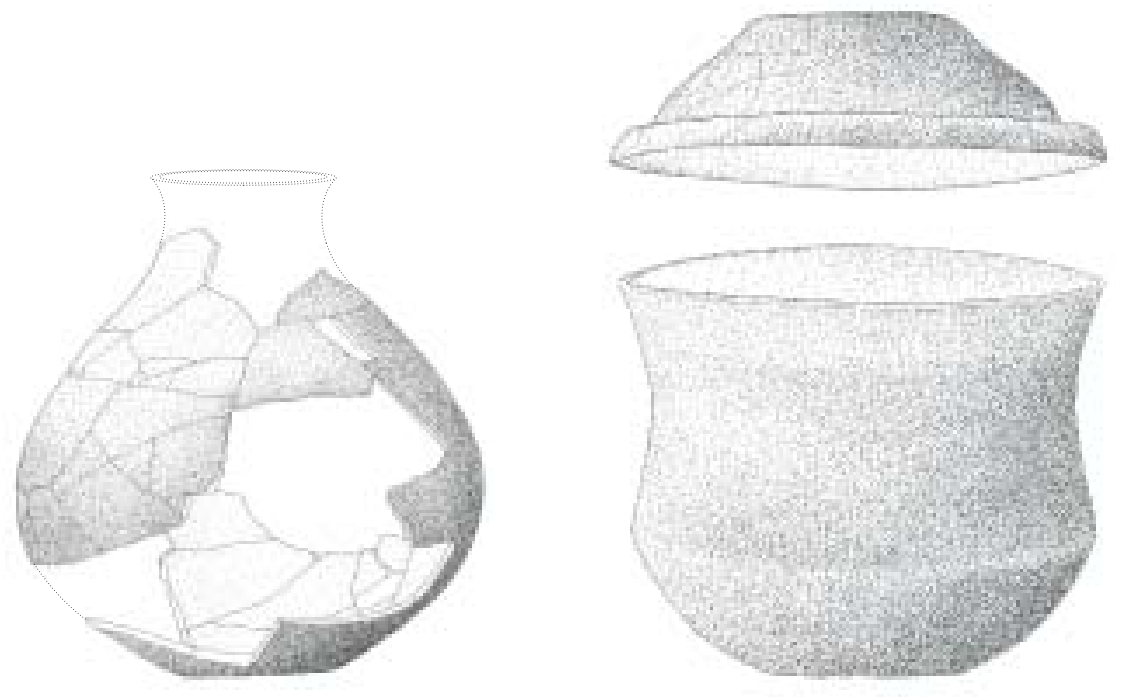

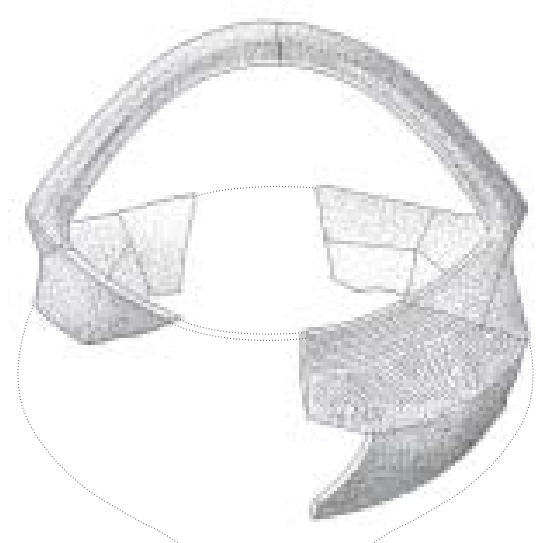

Claide de Paula Moraes

Bolsista FAPESP - processo 03/10284-4

Dissertação apresentada ao programa de Pós-Graduação em Arqueologia, do Museu de Arqueologia e Etnologia da Universidade de São Paulo, para obtenção do título de Mestre em Arqueologia.

Orientador: Prof. Dr. Eduardo Góes Neves

São Paulo

2006 
UNIVERSIDADE DE SÃO PAULO

MUSEU DE ARQUEOLOGIA E ETNOLOGIA

PROGRAMA DE PÓS-GRADUAÇÃO EM ARQUEOLOGIA

\section{Arqueologia na Amazônia Central Vista de Uma Perspectiva da Região do Lago do Limão}

Claide de Paula Moraes Bolsista FAPESP - processo 03/10284-4 
Pro meu pai, meu exemplo. 
I do not accept the view postulated by certain other scholars that there was a sharp contrast in cultural level between the Circum-Caribbean peoples and the Tropical Forest peoples (Donald Lathrap). 


\section{AGRADECIMENTOS}

Muitas pessoas contribuíram para a realização deste trabalho, talvez a memória falhe e eu não consiga agradecer a todos aqui. Gostaria de agradecer em primeiro lugar meu orientador, Eduardo Neves, que mesmo me conhecendo pouco, me convidou para integrar sua equipe. À FAPESP pela concessão de uma bolsa para a realização da pesquisa. Aos proprietários dos sítios trabalhados, Sr. José, Sr. Tibério, Sr. Eduardo e Mário pela boa recepção e autorização para trabalhar em suas terras. Aos colegas do Projeto Amazônia Central, Cláudio Roberto e Valdirene Feitoza, pessoas que me receberam como se fosse um integrante de sua família e proporcionaram a mim a oportunidade de conhecer um pouco a vida nas comunidades amazônicas. Anne, que no decorrer do processo, além de muita ajuda, se tornou minha esposa e mãe do meu filho (Rafael). Carlos Augusto (Tijolo), Levemilson (Delegado), Francisco (Pupunha), Edimar (Nego) e Ermenegildo (Bené), homens do campo, no melhor sentido que o adjetivo possa ter. Manuel Arroyo, Helena Lima e Juliana Machado com quem pude aprender muito sobre Arqueologia Amazônica. Marjorie, Eduardo Kazuo, Elaine, Fábio, Raoni, Marcio, Anderson, Ricardo, Thiago, Danilo, Sarah, Eduard (Holandês), Bob, Randy, Anna, Patrícia, Regivaldo, Leandro (Ceará), Caroline, Francisco Pugliese, Bernardo, Fernando (Caminhão), Miguel, Lúcia, Fabiano, Rafael, Gilcilene, Sinval, Raul e Frederico por muita ajuda no campo e no laboratório. Marcos Brito pelos elaborados mapas. Valdirene (Irmã), pelos desenhos do material cerâmico, a parte bonita do trabalho. Leonda (Pai), Valda (Mãe), Claidvon (Irmão) e Henrique (Sobrinho) pela ajuda no laboratório durante suas férias em Manaus. Adriana Sampaio, sempre facilitando as idas e vindas. E finalmente James Petersen (in memória), que infelizmente não poderá ler essa dissertação. 


\section{SUMÁRIO}

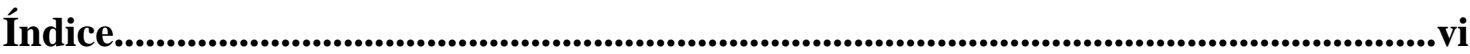

Índice de Figuras..................................................................................................................viii

Índice de Gráficos.................................................................................................................xii

Índice de Tabelas................................................................................................................xiv

Índice de Anexos............................................................................................................................xv

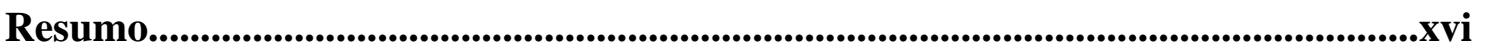

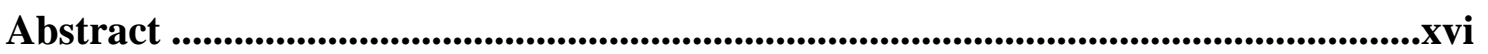

Introdução ...................................................................................................................01

Capítulo I ...........................................................................................................................05

Capítulo II ....................................................................................................................................16

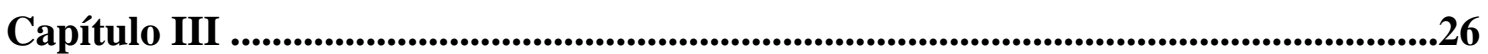

Capítulo IV .................................................................................................................................69

Capítulo V...........................................................................................................127

Capítulo VI.......................................................................................................................166

Considerações Finais ...........................................................................................................184

Referências Citadas ................................................................................................188

Anexos 


\section{ÍNDICE}

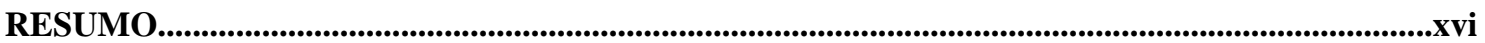

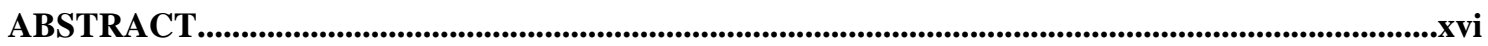

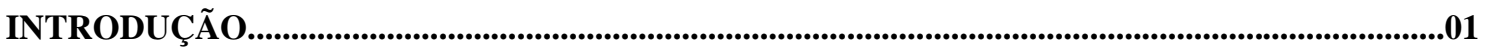

\section{Em Busca do Dados}

Capítulo I - ARQUEOLOGIA NA AMAZÔNIA ………..................................................................................05

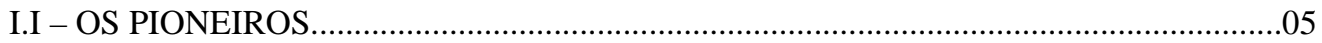

I.II - A CRIAÇÃO DOS MODELOS TEÓRICOS E OS DEBATES...........................................06

I.III - O PROJETO AMAZÔNIA CENTRAL......................................................................14

Capítulo II - A ÁREA DE TESTE DAS HIPÓTESES...................................................................................16

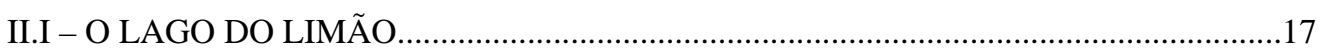

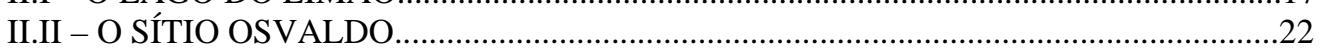

\section{Aqui Estão Eles}

Capítulo III - O LEVANTAMENTO ARQUEOLÓGICO ..........................................................................26

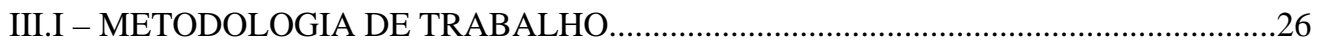

III.II - METODOLOGIA DE LEVANTAMENTO APLICADA...........................................22

III.III - SÍTIO CAMPO DO SÃO JORGE (Am-Ir-63)..............................................................

III.IV - SÍTIO CINCO UNIDOS (Am-Ir-64) ...........................................................................

III.V - SÍTIO CINCO UNIDOS II (Am-Ir-65) _....................................................................... 38

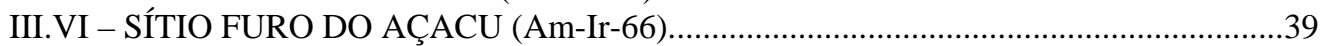

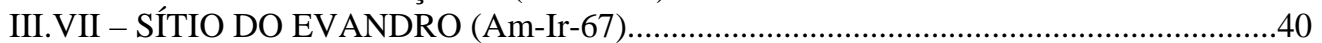

III.VIII - SÍTIO DO MACUMBEIRO (Am-Ir-68)..................................................................4

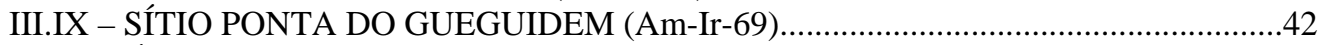

III.X - SÍTIO GUEGUIDEM II (Am-Ir-70),_.......................................................................4

III-XI - SÍTIO FURO DO AVÔ CHICO (Am-Ir-71) .................................................................4

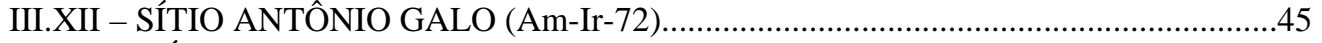

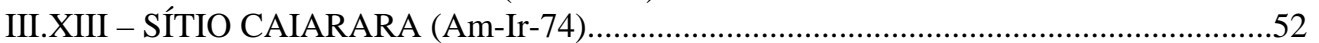

III.XIV - SÍTIO DONA ROSA (Am-Ir-75) _........................................................................

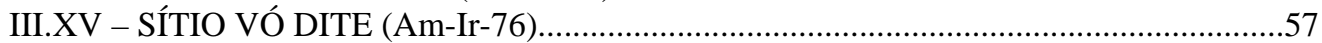

III.XVI - SÍTIO LAGO DO LIMÃO (Am-Ir-11) ...............................................................

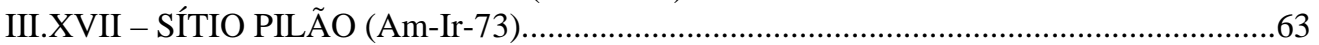

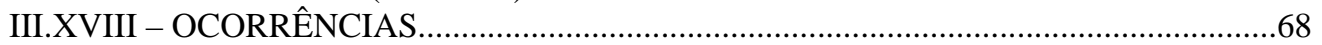

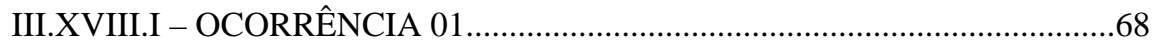

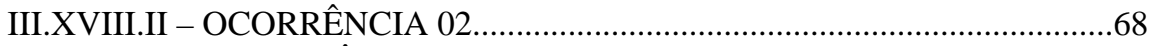

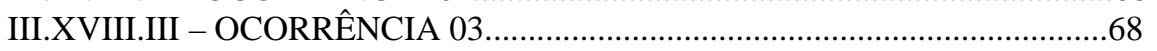

Capítulo IV - ESCAVAÇÃO DOS SÍTIOS..........................................................................................................69

IV.I - O SÍTIO ANTÔNIO GALO..............................................................................................

IV.I.I - A AMPLIAÇÃO DAS INTERVENÇÕES NO SÍTIO................................75

IV.I.I.I - UNIDADES N-913 E-437, N-914 E-437 e N-915 E-437...76

IV.I.I.II - UNIDADE N-505 E-400................................................77

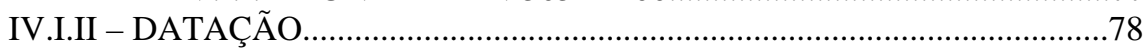

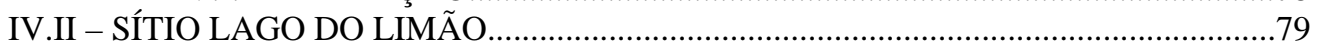

IV.II.I - A PRIMEIRA UNIDADE ESCAVADA NO SÍTIO..................................84

IV.II.II - A INTENSIFICAÇÃO DAS ESCAVAÇOES........................................90

IV.II.II.I - AMPLIAÇÃO DA UNIDẢDE N-1976 E-500.................91

IV.II.II.II - O SEPULTAMENTO EM URNA...................................93 


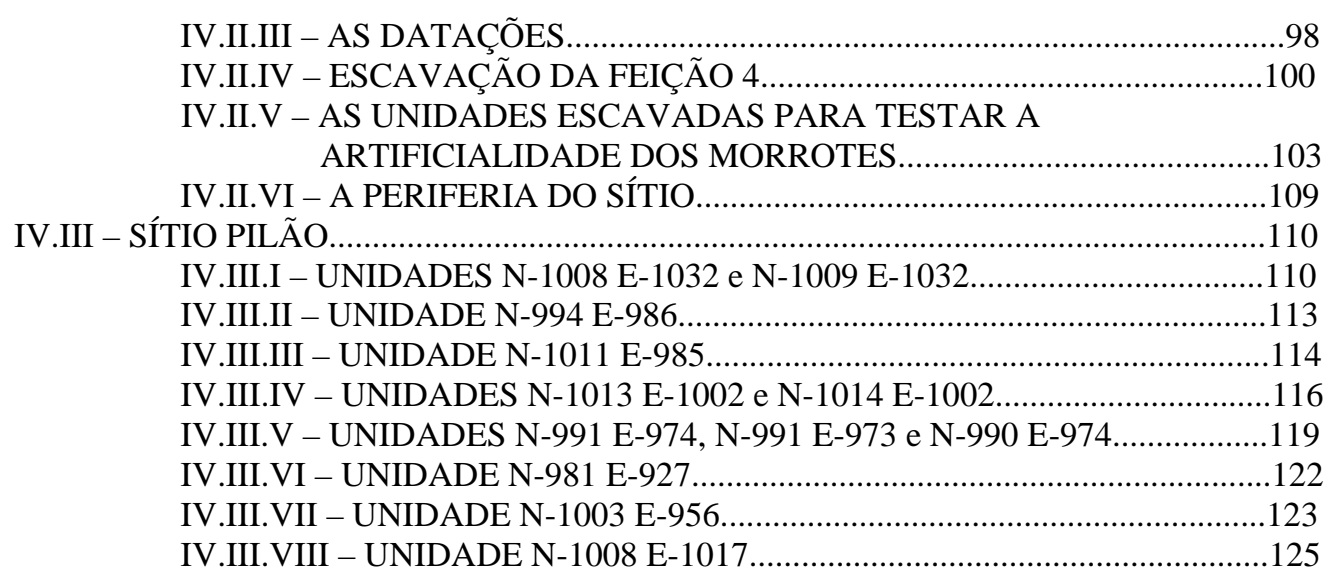

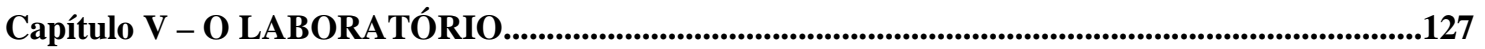

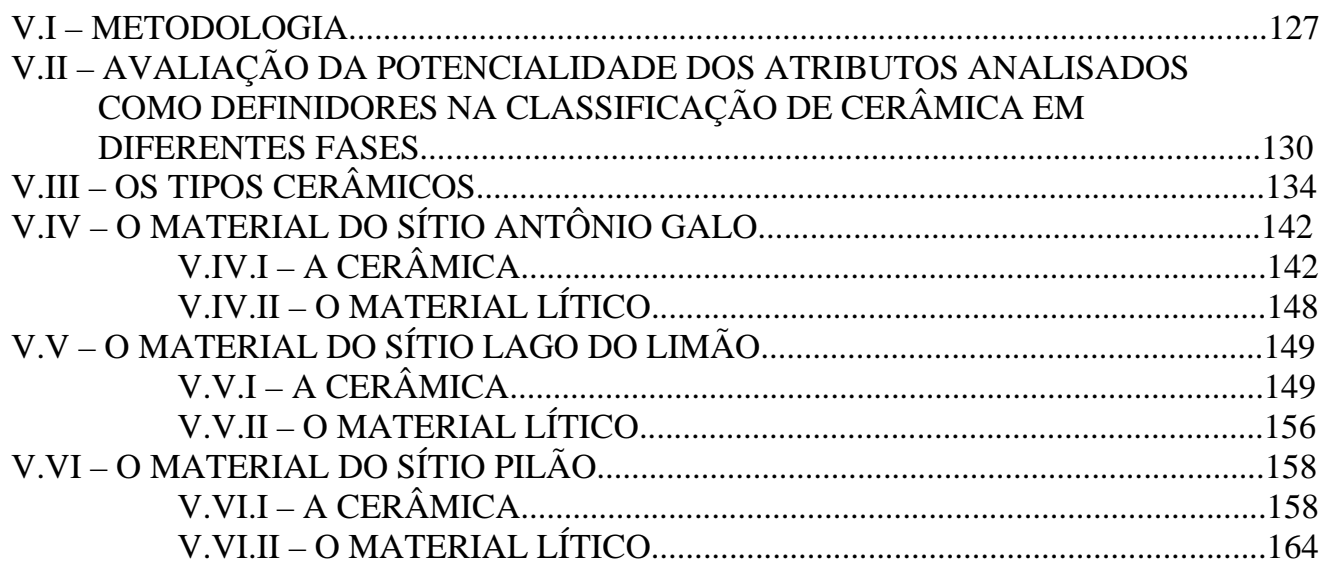

\section{O que Fazer com Eles?}

Capítulo VI - CORRELACIONANDO OS DADOS COLETADOS NOS

SÍTIOS ARQUEOLÓGICOS......................................................................................................166

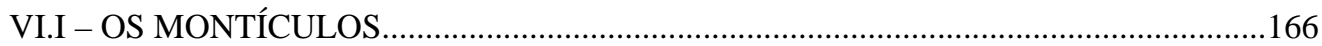

VI.II - “CURRAL DE TARTARUGA DE ÍNDIO”............................................................172

VI.III - PISO HABITACIONAL, SEPULTAMENTO E DATAS POR MAS.......................173

VI.IV - COMO PODEMOS TRATAR A CERÂMICA? .........................................................177

VI.V - ALDEIAS CIRCULARES - OCUPAÇÕES ARAWAK x TUPI - UMA

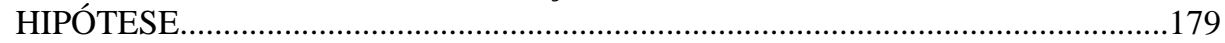

CONSIDERAÇÕES FINAIS ............................................................................................................................184

REFERÊNCIAS CITADAS..............................................................................................188

ANEXOS 


\section{ÍNDICE DE FIGURAS}

\section{Capítulo II}

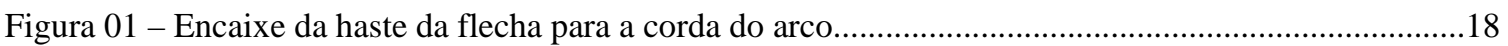

Figura 02 - Ponta de flecha feita artesanalmente com metal...............................................................19

Figura 03 - Pescaria com arco e flechas............................................................................................19

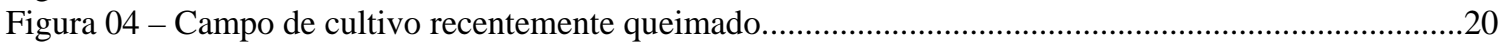

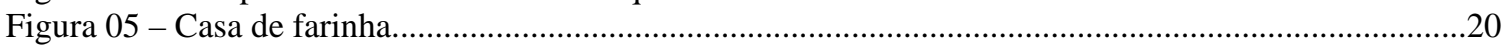

Figura 06 - Massa de mandioca sendo comprimida no tipiti para que saia o suco tóxico...............................20

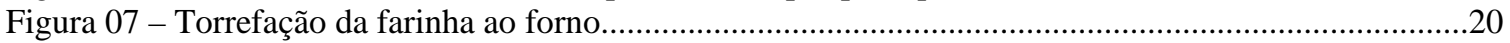

Figura 08 - Lago do Limão e ao fundo um exemplo dos açaizais existentes às margens...............................21

Figura 09 - Recipiente de cerâmica utilizado para armazenamento de água....................................................21

Figura 10 - Recipiente reutilizado como vaso para planta.......................................................................21

Figura 11 - Fragmento de cerâmica cabocla encontrado em área de descarte de lixo doméstico...................21

Figura 12 - Fragmento de cerâmica cabocla temperado com cariapé em grande proporção...........................22

\section{Capítulo III}

Figura 13 - Travessia de um furo do lago do Limão quase seco, um exemplo dos igapós existentes

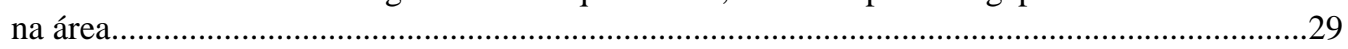

Figura 14 - Lago do Limão, navegação por um dos igapós...........................................................................30

Figura 15 - Solo das tradagens do sítio Campo do São Jorge...........................................................................34

Figura 16 - Fragmentos de cerâmica da fase Paredão encontrados nas tradagens e superfície do sítio

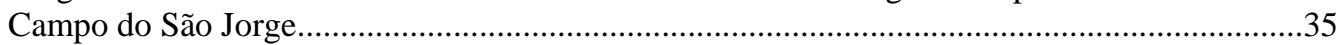

Figura 17 - Fragmentos de cerâmica da fase Guarita encontrados nas tradagens e superfície do sítio Campo do São Jorge..............................................................................................................

Figura 18 - Fragmentos de cerâmica da fase Manacapuru encontrados na superfície do sítio Campo

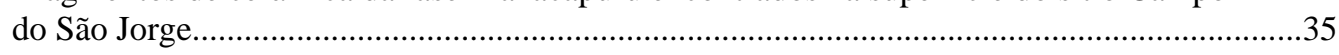

Figura 19 - Vista parcial do sítio Cinco Unidos com lago ao fundo................................................................

Figura 20 - Vista parcial do sítio Cinco Unidos, com destaque para a estrada onde foi possível encontrar alguns fragmentos de cerâmica......................................................................................37

Figura 21 - Fragmentos de cerâmica da fase Paredão encontrados no sítio Cinco Unidos................................37

Figura 22 - Fragmentos de cerâmica da fase Guarita encontrados no sítio Cinco Unidos...............................37

Figura 23 - Vista parcial do sítio Cinco Unidos II, área de plantio de pimenta onde é possível ver a presença de terra preta e fragmentos de cerâmica........................................................................38

Figura 24 - Vista de um montículo no sítio Cinco Unidos II, o desnível da superfície onde estão as pessoas evidencia o centro e a borda da estrutura.......................................................................38

Figura 25 - Fragmentos de cerâmica da fase Paredão encontrados no sítio Cinco Unidos II..........................39

Figura 26 - Fragmentos de cerâmica da fase Guarita encontrados no sítio Cinco Unidos II.............................39

Figura 27 - Vista parcial do sítio Furo do Açacu, com destaque para a formação de capoeira nas antigas áreas de cultivo.

Figura 28 - Material cerâmico encontrado no sítio Furo do Açacu, um fragmento de borda com engobo branco associado à fase Guarita e um fragmento de alça associado à fase Paredão.......40

Figura 29 - Vista parcial do sítio do Evandro no local da plantação de mandioca.........................................41

Figura 30 - Material cerâmico encontrado no sítio do Evandro.......................................................................41

Figura 31 - Vista parcial do sítio do Macumbeiro, com destaque para os pomares abandonados.................42

Figura 32 - Exemplo do material cerâmico encontrado no sítio do Macumbeiro.............................................42

Figura 33 - Vista parcial do sítio Ponta do Gueguidem, com destaque para a recente derrubada da mata que compõe o local

Figura 34 - Exemplo de material cerâmico encontrado no sítio Ponta do Gueguidem....................................43

Figura 35 - Exemplo de fragmento de cerâmica encontrado no sítio Gueguidem II........................................44

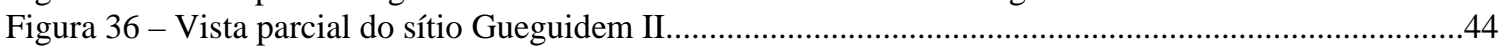

Figura 37 - Vista parcial do barranco onde estão aflorando os vestígios do sítio Furo do Avô Chico...........44

Figura 38 - Percutor e lasca de arenito...................................................................................................

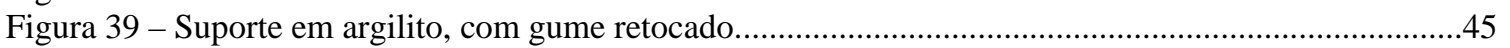

Figura 40 - Material cerâmico associado à terra preta evidenciado no sítio Antônio Galo..............................45 
Figura 41 - Vista parcial do sítio Antônio Galo, com destaque para um montículo que pode ser visto pelo desnível da superfície onde estão as pessoas.

Figura 42 - Fragmentos de cerâmica da fase Paredão encontrados nas tradagens do sítio Antônio Galo.

Figura 43 - Fragmentos de cerâmica da fase Guarita encontrados nas tradagens do sítio

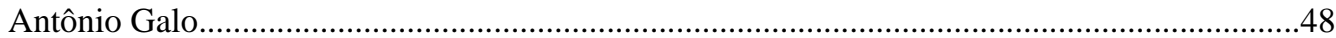

Figura 44 - Solo evidenciado nas tradagens do sítio Antônio Galo...........................................................50

Figura 45 - Fragmentos de cerâmica da fase Paredão coletados na superfície do sítio Antônio Galo.

Figura 46 - Fragmentos de cerâmica da fase Guarita coletados na superfície do sítio

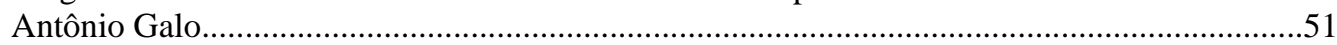

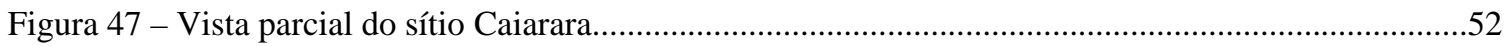

Figura 48 - Fragmentos de cerâmica evidenciados no sedimento removido pelas raízes dos

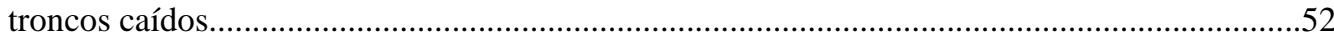

Figura 49 - Área do sítio Dona Rosa vista da margem oposta do lago, próximo ao sítio Osvaldo...............53

Figura 50 - Fragmentos de cerâmica da fase Guarita encontrados na superfície e tradagens

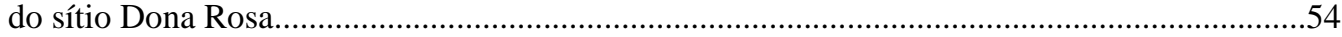

Figura 51 - Fragmento de cerâmica Paredão encontrado na superfície do sítio Dona Rosa.........................54

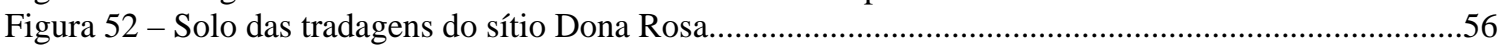

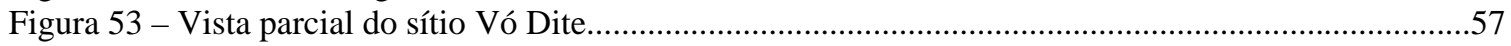

Figura 54 - Fragmento de cerâmica da fase Manacapuru encontrado no sítio Vó Dite.................................57

Figura 55 - Fragmentos de cerâmica da fase Paredão encontrados no sítio Vó Dite....................................57

Figura 56 - Fragmentos de cerâmica da fase Guarita encontrados no sítio Vó Dite.....................................57

Figura 57 - Vista parcial do sítio Lago do Limão, área com alta concentração de vestígios

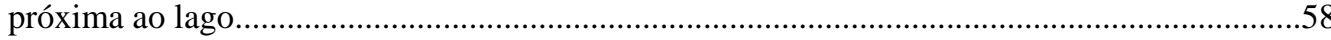

Figura 58 - Fragmentos de cerâmica possivelmente associados à fase Açutuba, encontrados nas

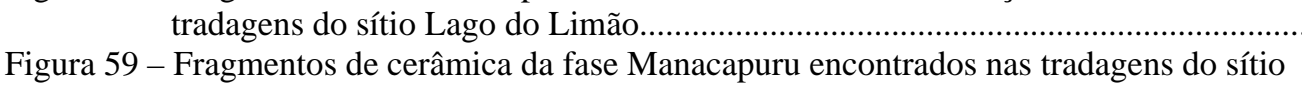

Figura 60 - Fragmentos de cerâmica da fase Paredão encontrados nas tradagens do sítio

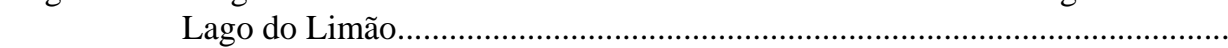

Figura 61 - Fragmentos de cerâmica da fase Guarita encontrados nas tradagens do sítio Lago do Limão.

Figura 62 - Fragmentos de cerâmica Cabocla encontrados nas tradagens do sítio Lago do Limão..............60

Figura 63 - Solo das tradagens do sítio Lago do Limão........................................................................62

Figura 64 - Vista parcial do sítio Pilão..........................................................................................63

Figura 65 - Exemplos de fragmentos associados à fase Paredão encontrados nas tradagens do sítio Pilão.

Figura 66 - Solo evidenciado nas tradagens do sítio Pilão.

\section{Capítulo IV}

Figura 67 - Unidade N-938 E-456, nível 10 - 20 cm, fragmentos de cerâmica e manchas de terra queimada.

Figura 68 - Unidade N-938 E-456, base do nível 30-40 cm, fragmentos de cerâmica da fase

Paredão e terra queimada.

Figura 69 - Vaso cerâmico reconstituído.

Figura 70 - Perfis da unidade N-938 E-456, sítio Antônio Galo.................................................................74

Figura 71 - Vista parcial do montículo 17, à esquerda a depressão que provavelmente é o negativo do montículo............................................................................................... 75

Figura 72 - Unidade N-915 E-437, nível $20-30$ cm, fragmentos de cerâmica na base do nível....................76

Figura 73 - Unidade N-505 E-400, base do nível 2, 10 a 20cm..............................................................77

Figura 74 - Amostra de cerâmica Paredão enviada para datação...............................................................78

Figura 75 - Remoção de blocos de lateria para limpeza de perfil onde havia sido retirada a terra preta......79

Figura 76 - Limpeza de perfil no local onde foi retirada a terra preta....................................................79

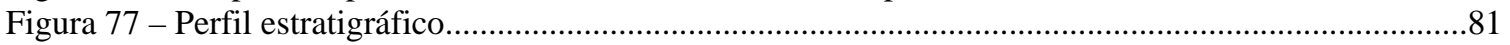

Figura 78 - Fragmentos de cerâmica da fase Manacapuru, limpeza de perfil...........................................82

Figura 79 - Fragmentos de cerâmica da fase Paredão, limpeza de perfil....................................................82

Figura 80 - Fragmentos de cerâmica da fase Guarita, limpeza de perfil..................................................82

Figura 81 - Demarcação da unidade N1976 E500...............................................................................84 
Figura 82 - Unidade N-1976 E-500, nível 10-20cm, fragmento de cerâmica da fase

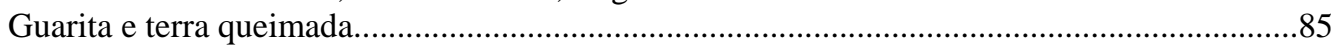

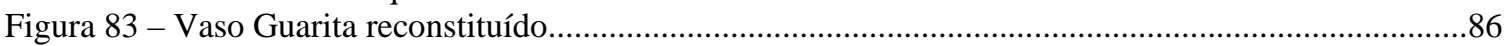

Figura 84 - Unidade N-1976 E-500, nível 40-50 cm com destaque para o aparecimento da feição $1 . \ldots \ldots \ldots . . . .86$

Figura 85 - Unidade N1976 E500, nível $60-70$ cm, com destaque para as feições 1, 2 e 3........................87

Figura 86 - Unidade N-1976 E-500, feições vistas nos perfis sul à esquerda e norte à direita.....................88

Figura 87 - Perfil da face Sul das Unidades N-1976 E-498, 499, 500 e 501..........................................89

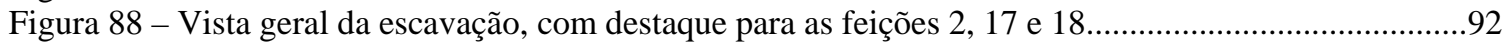

Figura 89 - Planta da escavação apresentando as feições identificadas e o sepultamento em urna (a extremidade nordeste da nome às quadras)..............................................................92

Figura 90 - Urna Funerária com tampa e vaso fragmentado, identificados no perfil leste da

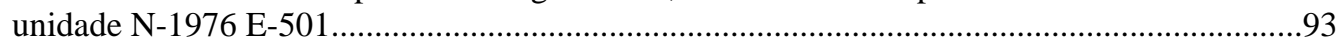

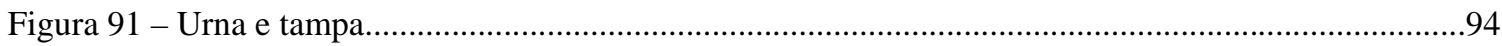

Figura 92 - Seqüência de retirada dos ossos da urna.......................................................................96

Figura 93 - Amostra de cerâmica Manacapuru enviada para datação......................................................99

Figura 94 - Amostra de cerâmica Paredão enviada para datação.............................................................99

Figura 95 - Amostra de cerâmica Guarita enviada para datação...........................................................100

Figura 96 - Detalhe da trincheira escavada na feição 4, com destaque para a diferença na coloração do sedimento nas paredes demarcando os limites da feição e os negativos de buracos de estacas preenchidos com terra preta na base .....................................................101

Figura 97 - Perfil da Trincheira escavada na Feição 4 .......................................................................102

Figura 98 - Unidade N-1937 E-550, base da escavação, com destaque para lente de fragmentos de cerâmica evidenciada nos perfis..................................................................103

Figura 99 - Unidade N-1937 E-550, perfil Oeste..............................................................................105

Figura 100 - Unidade N1950 E558, base da escavação, com destaque paras as feições 5, 6 e 7...............106

Figura 101 - Unidades N-1950 E-558 e N-1951 E-558, perfil Oeste.......................................................107

Figura 102 - Unidade N1923 E542, base da escavação....................................................................108

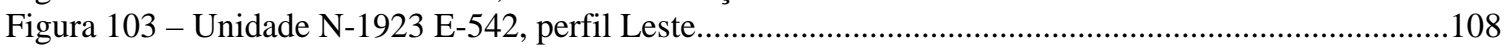

Figura 104 - Unidade N-2017 E-760, perfil Leste..............................................................................109

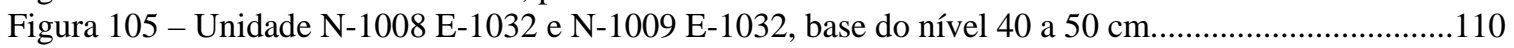

Figura 106 -Unidades N-1008 E-1032 e N-1009 E-1032, perfil Oeste....................................................112

Figura 107 - Unidade N-994 E-986, base do nível 20 a $30 \mathrm{~cm}$, onde é possível notar um

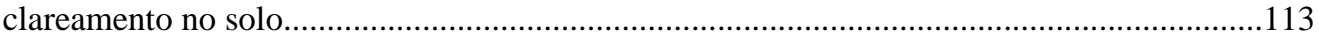

Figura 108 - Unidade N-994 E-986, perfil Norte..................................................................................114

Figura 109 - Unidade N-1011 E-985, base do nível 10 a $20 \mathrm{~cm}$, com destaque para fragmentos do mesmo vaso que remontam.........................................................................114

Figura 110 - Vaso Paredão remontado em laboratório.....................................................................115

Figura 111 - Unidade N-1011 E-985, perfil Norte.............................................................................116

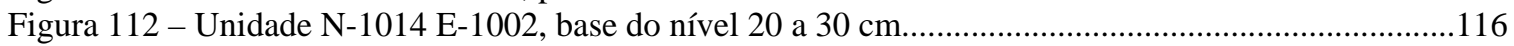

Figura 113 - Unidades N-1013 E-1002 e N-1014 E-1002, perfil Leste....................................................118

Figura 114 - Unidade N-991 E-974, perfil sul, com destaque para feição de estrutura de combustão.........119

Figura 115 - Unidades N-991 E-974 e N-990 E-974, perfil Leste.............................................................121

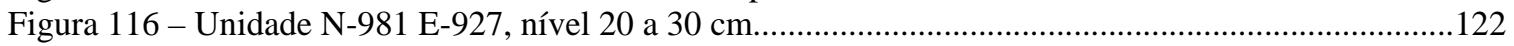

Figura 117 - Unidade N-981 E-927, perfil Norte...................................................................................123

Figura 118 - Unidade N-1003 E-956 com fragmentos de cerâmica evidenciados na escavação................123

Figura 119 - Unidade N-1003 E-956, perfil Norte................................................................................124

Figura 120 - Superfície da área entre os montículos, com destaque para a grande concentração de laterita e um fragmento de cerâmica com apêndice típico da fase Paredão........................125

Figura 121 - Unidade N-1008 E-1017, perfil Norte..........................................................................126

\section{Capítulo V}

Figura 122 - Exemplos de fragmentos de cerâmica classificados por cores da superfície da pasta............144

Figura 123 - Exemplares de vasos com contorno simples e composto; forma irrestritiva e restritiva.........146

Figura 124 - Exemplares de lábios arredondados, planos, incisos, ponteados, inciso ponteado e acanalados

Figura 125 - Material lítico encontrado no sítio Antônio Galo (conta de colar, lasca fragmentada e fragmentos de lasca)

Figura 126 - Material lítico encontrado no sítio Lago do Limão (afiadores, calibradores, lascas, fragmentos de lasca e fragmentos de lâmina de machado)...... 
Figura 127 - Conta de colar (escala $1 \mathrm{~cm})$......

Figura 128 - Exemplar sem correlação com outros tipos..................................................................163

Figura 129 - Material lítico encontrado no sítio Pilão (lascas, afiadores e calibradores)...........................164

Figura 130 - Material lítico, sítio Pilão (afiador, fragmento de lâmina de machado,

lascas e contas de colar).

\section{Capítulo VI}

Figura 131 - Diferentes etapas do processo hipotético de formação dos montículos artificiais. 


\section{ÍNDICE DE GRÁFICOS}

\section{Capítulo III}

Gráfico 01 - Densidade de material cerâmico evidenciada nas tradagens do sítio Campo do São Jorge.

Gráfico 02 - Densidade de material cerâmico evidenciada nas tradagens do sítio Antônio Galo..............47

Gráfico 03 - Densidade de material cerâmico evidenciada nas tradagens do sítio Dona Rosa...................54

Gráfico 04 - Densidade de material cerâmico evidenciada nas tradagens do sítio Lago do Limão.............60

Gráfico 05 - Densidade de material cerâmico evidenciada nas tradagens do sítio Pilão...........................65

\section{Capítulo IV}

Gráfico 06 -Unidade N-938 E-456, densidade do material cerâmico por níveis....................................73

Gráfico 07 - Unidade N-915 E-437, densidade do material cerâmico por níveis....................................76

Gráfico 08 - Unidade N-505 E-400, densidade do material cerâmico por níveis.....................................77

Gráfico 09 - Densidade de material cerâmico evidenciada na limpeza de perfil no sítio Lago do Limão.

Gráfico 10 - Quantidade de cerâmica das diferentes fases encontradas na limpeza de perfil realizada no sítio Lago do Limão.

Gráfico 11 - Cerâmicas "diagnósticas” evidenciadas na limpeza de perfil distribuídas por nível...............83

Gráfico 12 - Quantificação das diferentes cerâmicas encontradas no sítio Lago do Limão......................84

Gráfico 13 - Unidade N-1976 E-500, material cerâmico por nível.....................................................88

Gráfico 14 - Unidade N-1937 E-550, material cerâmico por nível.....................................................104

Gráfico 15 - Unidade N-1008 E-1032, densidade de material por nível.............................................111

Gráfico 16 - Unidade N-1009 E-1032, densidade de material por nível..............................................111

Gráfico 17 - Unidade N-994 E-986, densidade de material por nível.................................................113

Gráfico 18 - Unidade N-1011 E-985, densidade de material por nível...............................................115

Gráfico 19 - Unidade N-1013 E-1002, densidade de material cerâmico por nível.................................117

Gráfico 20 - Unidade N-1014 E-1002, densidade de material cerâmico por nível..................................117

Gráfico 21 - Unidade N-991 E-974, densidade de material cerâmico por nível.....................................120

Gráfico 22 - Unidade N-991 E-973, densidade de material cerâmico por nível....................................120

Gráfico 23 - Unidade N-990 E-974, densidade de material cerâmico por nível......................................120

Gráfico 24 - Unidade N-981 E-927, densidade de material cerâmico por nível.....................................122

Gráfico 25 - Unidade N-1003 E-956, densidade de material cerâmico por nível...................................124

Gráfico 26 - Unidade N-1008 E-1017, densidade de material cerâmico por nível.................................125

Gráfico 27 - Espessura das bordas em ordem crescente, medidas em milímetros...................................143

Gráfico 28 - Espessura das bases em ordem crescente, medidas em milímetros...................................143

Gráfico 29 - Espessura das paredes em ordem crescente, medidas em milímetros................................144

Gráfico 30 - Diâmetro das bordas em ordem crescente, representado em milímetros..............................146

Gráfico 31 - Diâmetro das bases em ordem crescente, representado em milímetros................................147

Gráfico 32 - Espessura das bordas em ordem crescente, medidas em milímetros..................................150

Gráfico 33 - Espessura das bordas apresentadas por fases..............................................................150

Gráfico 34 - Espessura das bases em ordem crescente, medidas em milímetros.....................................151

Gráfico 35 - Espessura das paredes em ordem crescente, medidas em milímetros.................................151

Gráfico 36 - Diâmetro das bordas em ordem crescente, representado em milímetros.............................154

Gráfico 37 - Diâmetro das bases em ordem crescente, representado em milímetros...............................154

Gráfico 38 - Espessura das bordas em duas seqüências em ordem crescente, a primeira é referente à Unidade N-991 E-974 e a segunda seqüência é referente à unidade N-1011 E-985. As medidas estão em milímetros.

Gráfico 39 - Espessura das bases em duas seqüências em ordem crescente, a primeira é referente à Unidade N991 E-974 e a segunda seqüência é referente à unidade N-1011 E-985. Medidas em milímetros.

Gráfico 40 - Espessura das paredes em duas seqüências em ordem crescente, a primeira é referente à Unidade N991 E-974 e a segunda seqüência é referente à unidade N-1011 E-985. Medidas em milímetros. 
Gráfico 41 - Diâmetro das bordas em duas seqüências em ordem crescente, a primeira é referente à Unidade N991 E-974 e a segunda seqüência é referente à unidade N-1011 E-985. Representado em milímetros.

Gráfico 42 - Diâmetro das bases em duas seqüências em ordem crescente, a primeira é referente à Unidade N991 E-974 e a segunda seqüência é referente à unidade N-1011 E-985. Representado em milímetros. 


\section{ÍNDICE DE TABELAS}

\section{Capítulo IV}

Tabela 01 - Relação dos fragmentos de ossos identificados com as partes do esqueleto..........................97

Tabela 02 - Datas obtidas para o sítio Lago do Limão.......................................................................100

Capítulo V

Tabela 03 - Descrição sumária dos atributos analisados na cerâmica..................................................130

Tabela 04 - Tipos de antiplástico encontrados na pasta de argila......................................................145

Tabela 05 - Tipos de antiplástico encontrados na pasta de argila......................................................153

Tabela 06 - Tipos de antiplástico encontrados na pasta de argila.......................................................161 


\section{ÍNDICE DE ANEXOS}

Anexo 01 - Mapa com os sítios arqueológicos identificados na área do PAC até 2002.

Anexo 02 - Mapa do sítio Osvaldo.

Anexo 03 - Datas radiocarbônicas (não calibradas) obtidas na escavação do sítio Osvaldo (agosto 1999).

Anexo 04 - Mapa com os sítios arqueológicos identificados nas áreas de entorno do lago do Limão.

Anexo 05 - Ficha de número de proveniência.

Anexo 06 - Ficha de tradagem.

Anexo 07 - Ficha de sondagem.

Anexo 08 - Ficha de unidade.

Anexo 09 - Mapa do sítio Campo do São Jorge.

Anexo 10 - Mapa do sítio Antônio Galo.

Anexo 11 - Mapa do sítio Dona Rosa.

Anexo 12 - Mapa do sítio Lago do Limão.

Anexo 13 - Mapa do sítio Pilão.

Anexo 14 - Ficha de catalogação de ossos.

Anexo 15 - Material cerâmico reconstituído, tipo 1 - Cuia com pedestal.

Anexo 16 - Material cerâmico reconstituído, tipo 2 - Cesta com alça.

Anexo 17 - Material cerâmico reconstituído, tipo 3 - Vasos com Flange Mesial.

Anexo 18 - Material cerâmico reconstituído, tipo 4 - Vasos com Bordas Irregulares e Diâmetro Oval.

Anexo 19 - Material cerâmico reconstituído, tipo 5 - Alguidar.

Anexo 20 - Material cerâmico reconstituído, tipo 6 - Assador.

Anexo 21 - Material cerâmico reconstituído tipo 7 - Cuia.

Anexo 22 - Material cerâmico reconstituído, tipo 8 - Prato.

Anexo 23 - Material cerâmico reconstituído, tipo 9 - Tigela.

Anexo 24 - Material cerâmico reconstituído, tipo 10 - Potes com Gargalo.

Anexo 25a - Material cerâmico reconstituído, tipo 11 - Vasos Globulares (com boca restritiva e tendência a formação de pescoço, com boca muito restritiva e com boca muito restritiva e tendência a formação de pescoço.

Anexo 25b - Material cerâmico reconstituído, tipo 11 - Vasos Globulares (com boca restritiva).

Anexo 26 - Material cerâmico reconstituído, tipo 12 - Vasos com Colo.

Anexo 27 - Exemplar de cerâmica do tipo 13 - Trempe, motivos decorativos da cerâmica e Calibradores.

Anexo 28 - Tipos de bases encontrados na coleção dos sítios estudados. 


\section{RESUMO}

Neste trabalho apresentamos os resultados obtidos com o levantamento, escavação e análise material arqueológico provenientes de sítios na região do lago do Limão, município de Iranduba - AM. Os dados obtidos após a identificação de 15 sítios arqueológicos são comparados aos trabalhos já executados na região, com vistas a responder algumas hipóteses criadas para interpretar o processo de ocupação da região amazônica antes da chegada dos europeus. Com o trabalho identificamos algumas peculiaridades relacionadas à fase Paredão, tais como construção de montículos artificiais e assentamentos em aldeias circulares. A partir dos dados obtidos apresentamos uma hipótese interpretativa para a chegada da cerâmica policrômica associada à fase Guarita na Amazônia Central, fato que acreditamos estar relacionado também ao surgimento da fase Paredão.

Palavras Chaves - levantamento arqueológico, montículos, unidades habitacionais, aldeias circulares e fase Paredão

\section{ABSTRACT}

The results obtained from survey, excavation and material analysis of archaeological material found in sites in the lago do Limão region, Amazonas State, Brazil are presented herein. The data gathered after the identification of 15 archaeological sites is compared to work previously done in the region, aiming to determine the occupational process of the pre-colonial Amazonian region. Peculiarities related to the Paredão phase $\left(7^{\text {th }}\right.$ to $12^{\text {th }}$ century $\mathrm{AD}$ ) are identified herein, such as the construction of artificial mounds and ring village settlements From the data obtained, an interpretative hypothesis is presented for the arrival of the polychrome ceramics associated with the Guarita phase $\left(9^{\text {th }}\right.$ to $15^{\text {th }}$ century AD) in Central Amazon, a fact that we believe to be also related to the upcoming of the Paredão phase.

Key words - archaeological survey, mounds, habitation units, ring villages and Paredão phase 


\section{INTRODUÇÃO}

Neste trabalho apresentamos os resultados de uma pesquisa de levantamento e escavação de sítios arqueológicos na área de entorno do Lago do Limão, município de Iranduba, Estado do Amazonas.

No levantamento pretendíamos identificar sítios arqueológicos com o objetivo de entender o tamanho, densidade e a duração da ocupação dos sítios existentes às margens do Lago do Limão. Os resultados ajudariam a acrescentar dados para o teste de algumas hipóteses gerais da arqueologia Amazônica.

Na região proposta para o levantamento já havia sido escavado o sítio Osvaldo ${ }^{1}$ (anexo 02), para o qual já se dispunha de um grande número de informações. O objetivo era comparar os dados levantados aos já existentes sobre o sítio estudado, posteriormente comparar os dados produzidos com os já existentes no Projeto Amazônia Central (PAC) e com os trabalhos sobre Amazônia como um todo.

Com o estudo dos dados preliminares do PAC e a identificação, delimitação, caracterização ambiental, mapeamento, plotagem, classificação, análise e datação dos novos vestígios coletados, estamos esboçando uma proposta de compreensão da articulação entre os sítios arqueológicos localizados na região do Lago do Limão.

Segundo as definições adotadas por Araújo (2001), de sistema de assentamento e padrão de assentamento, a busca de nossa pesquisa é principalmente a de padrão, pois estamos partindo do pressuposto de estar tratando com população vivendo de modo sedentário, vide a formação de espessos pacotes de terra preta, e o recorte de nossa área de pesquisa não seria suficiente para alcançar um sistema mais complexo de utilização do espaço em diferentes estações do ano. Estamos em busca do que seria denominado padrão de assentamento, que aqui é entendido como a forma de construção do espaço de habitação. Deste ponto de vista, já estamos trabalhando de antemão com um sistema de assentamento onde os sítios estão ocupando as margens de um lago. Nossa busca é pela forma dos sítios e a relação temporal entre eles, e se estas teriam um caráter distintivo,

1 O Osvaldo é um dos sítios trabalhados em detalhe pelo Projeto Amazônia Central (PAC), do qual esta proposta de mestrado é um subprojeto. 
por exemplo, fazendo uma comparação com os sítios encontrados às margens dos grandes rios.

A problemática geral ora apresentada está intimamente ligada ao teste de modelos teóricos criados para interpretar a ocupação da Amazônia em períodos précoloniais. Dividimos o trabalho em três partes: na primeira- Em Busca do Dados apresentamos o processo executado para chegar ao material de estudo. Para a familiarização do leitor com os modelos teóricos, primeiramente apresentaremos um histórico do desenvolvimento das pesquisas em arqueologia na região da floresta tropical, principalmente na Amazônia brasileira. Nesta ocasião, também estaremos apresentando sinteticamente os objetivos do PAC e os principais tipos de vestígios arqueológicos encontrados até então na área de pesquisa do projeto.

Na sequiência estaremos apresentando nossa área de pesquisa, a região do lago do Limão no município de Iranduba - AM. Região onde está localizado o sítio Osvaldo (Am-Ir-07), que foi trabalhado em detalhe pelo PAC e que também tem importância fundamental no desenvolvimento de nosso projeto, pois é principalmente baseado nos dados do sítio Osvaldo que nossos trabalhos estão sendo orientados no decorrer da pesquisa.

Feita a contextualização, chagamos à segunda parte - Aqui Estão Eles -onde apresentamos a metodologia adotada nas diferentes fases do trabalho. Estaremos apresentando a metodologia aplicada no campo e laboratório, onde justificamos algumas adaptações feitas em função da realidade do ambiente. Ocasião em que também apresentaremos uma breve discussão a respeito da opção por um levantamento oportunístico da área em questão.

Apresentamos os sítios arqueológicos identificados, os sítios selecionados para um trabalho de delimitação com tradagens e os motivos da seleção. Aqui também traremos os resultados do processamento do material em laboratório e o detalhamento dos trabalhos realizados no campo dedicando mais espaço aos sítios Antônio Galo, Lago do Limão e Pilão.

E finalmente, na terceira parte - O Que Fazer Com Eles? - discutiremos os resultados obtidos com o trabalho nos sítios apresentando novas possibilidades de 
interpretação da sequiência de ocupação da Amazônia Central no período dos sítios de ceramistas. 
Em Busca do Dados 


\section{Capítulo I-ARQUEOLOGIA NA AMAZÔNIA}

\section{$\underline{\text { I.I - OS PIONEIROS }}$}

Neves (1999) divide a história da pesquisa arqueológica na Amazônia em dois períodos: o primeiro tem início na segunda metade do século XIX e chega até a Segunda Guerra Mundial e o segundo tem início no pós-guerra e chega aos dias de hoje. As coleções de peças arqueológicas oriundas de sítios da Amazônia estão nos museus espalhados pelo mundo desde o século XIX. Principalmente a belíssima cerâmica Marajoara, que sempre despertou o interesse de pesquisadores, colecionadores e contrabandistas. É também desse período o início das escavações em busca de vestígios das populações extintas do território amazônico. Em 1857, Barbosa Rodrigues pesquisou sítios arqueológicos nos vales dos rios Tapajós, Jamundá, Trombetas, Urubu, entre outros (Barreto e Machado 2001:246).

As primeiras incursões aos sítios arqueológicos tinham principalmente $o$ objetivo de adquirir exemplares inteiros, principalmente peças decoradas. As primeiras cerâmicas, que atraíram a atenção dos exploradores, foram as, finamente decoradas, cerâmicas Marajoara, Santarém, Cunani e Miracanguera (Brochado e Lathrap 1982:2).

É também no século XIX que começa a exploração dos chamados "tesos" da ilha de Marajó. Em 1871, Ferreira Penna a serviço do Museu Paraense, realizou explorações no aterro do Pacoval (Barreto 1992:207). Ferreira Penna também identificou sambaquis fluviais no rio Pará e os famosos cemitérios Maracá no Amapá. Desde então os sítios se tornaram conhecidos, atraindo novos exploradores que realizaram coletas nos locais já identificados e também foram em busca de novos vestígios.

Charles Frederick Hartt, seu assistente W. S. Barnard, os norte-americanos J. B. Steere e O. Derby, também foram guiados por Ferreira Penna em muitas escavações em diferentes regiões da Amazônia. São creditados também a Ferreira Penna os primeiros esforços para a criação de leis de proteção aos sítios arqueológicos e à proibição da saída de peças do Brasil (Barreto 1992).

Além de formar inúmeras coleções de peças arqueológicas, os primeiros exploradores também estavam interessados em interpretar a origem das culturas e 
estabelecer sequiências regionais para os sítios explorados. Steere, Penna e Ladislau Netto, observaram diferenças nos estratos do aterro Pacoval, percebendo que havia mudanças no estilo do material depositado.

Em 1882, Ladislau Netto contratou um egiptólogo, Paul l'Epine, que acreditou ter identificado na cerâmica Marajoara, hieróglifos egípcios, indianos, chineses e mexicanos. Desde a publicação dos resultados deste trabalho os quadros comparativos estiveram sempre em pauta na interpretação dos vestígios arqueológicos no Brasil (Prous 1991:9).

As evidências de grandes sítios arqueológicos na região amazônica remontam aos anos 1920 quando o etnólogo Curt Nimuendaju, entre 1923 e 1926 identificou sítios com cerâmica dos antigos Tapajó. As pesquisas em Santarém, Alter do Chão e Samaúma revelaram 65 sítios, o que ele dizia não representar nem a metade dos sítios pertencentes a essa cultura (Barreto 1992:228). Os resultados das pesquisas de Nimuendajú só foram publicados recentemente (Nimuendajú 2004). Mas anteriormente, seus dados foram e vem sendo utilizados por muitos pesquisadores que vieram depois dele.

Entre estes pesquisadores, Nordenskiöld (1930), partidário da idéia de influências externas para a cerâmica de Santarém. Ele propunha que os traços comuns entre as cerâmicas Santarém e as da América Central e Antilhas seriam as cabeças de pássaros modeladas, os vasos trípodes, a representação de cariátides e os ornamentos zoomórficos de rãs em posição de salto.

A pesquisadora norte-americana Helen C. Palmatary, em 1939, inaugura os estudos descritivos de coleções arqueológicas da Amazônia, tentando organizar uma tipologia dos vasos cerâmicos.

\section{I.II - A CRIAÇÃO DOS MODELOS TEÓRICOS E OS DEBATES}

Os grandes aterros de Marajó e os sítios identificados por Nimuendaju supostamente seriam o resultado de ocupações com grandes densidades demográficas e um nível de complexidade social elevado. Duas hipóteses bem conhecidas na literatura das pesquisas arqueológicas na Amazônia foram então desenvolvidas para explicar o significado dos vestígios dos grandes assentamentos.

A primeira hipótese remonta a idéias desenvolvidas desde a década de 1940, pelo antropólogo norte-americano Robert Lowie (1948) e depois desenvolvidas por Julian 
Steward, que elaborou o conceito de cultura de "floresta tropical". Segundo este conceito, limitações ecológicas no ambiente tropical impossibilitavam o crescimento demográfico e o desenvolvimento de sociedades complexas. Para o pesquisador, houve um movimento migratório de populações sub-andinas de nível cultural denominado "circum-caribe", que saíram do noroeste da América do Sul em direção ao litoral Atlântico. Esses povos teriam chegado à foz do rio Orinoco e se separado em dois grupos: um teria se dirigido às Antilhas, mantendo assim o padrão cultural tradicional, e o outro grupo teria chegado à foz do rio Amazonas e subido o rio continente adentro, embrenhando-se na floresta tropical (Steward 1948).

O ambiente tropical teria impossibilitado o grupo de manter seu padrão cultural, pois os solos pobres os teriam impedido de praticar agricultura intensiva. Por este motivo, esses povos teriam abandonado suas características mais complexas, como chefia, cultos etc. Sua cultura, então, teria se estabilizado em um nível denominado "de floresta tropical" (Steward 1948). Surge então o conceito degeneracionista de cultura em função do ambiente tropical como forma de explicar o povoamento do território da floresta tropical amazônica.

No final dos anos quarenta e início dos anos cinqüenta, temos no Brasil o que se denomina o "período formativo" das pesquisas de duas linhas teóricas que dividiram a arqueologia brasileira em dois pólos vigentes até hoje. A linha de pesquisa norteamericana, trazida pelo casal Clifford Evans e Betty J. Meggers, que no ano de 1949 1950, deu início em suas pesquisas na foz do rio Amazonas. E a linha francesa trazida pelo casal Joseph Emperaire e Annette Laming que, em 1954, foi convidado para escavar sambaquis do Paraná e São Paulo.

O casal de arqueólogos norte-americanos, Clifford Evans e Betty Meggers, veio para o Brasil escavar na foz do rio Amazonas para obter dados de trabalhos de campo para testar o modelo criado por Steward, já que o padrão de sofisticação da cerâmica e a "monumentalidade" dos sítios encontrados na ilha de Marajó seria uma anomalia dentro do modelo proposto para a Amazônia (Meggers e Evans 1957).

Meggers e Evans interpretaram os vestígios arqueológicos de Marajó como sendo de uma civilização que teria migrado para a Ilha. A suposição é que essa civilização tenha vindo dos Andes ou do noroeste do continente e trouxe consigo o padrão de desenvolvimento social encontrado nos grandes aterros e na diversidade da elaboração da cerâmica. Tal padrão de desenvolvimento não teria sido mantido em função das condições ambientais determinantes. O solo pobre da Ilha não proporcionou à 
civilização a manutenção de seu modelo de agricultura, decaindo então para o nível de desenvolvimento de "floresta tropical".

De acordo com as premissas do determinismo ecológico e ambiental que eram as bases deste modelo teórico, Meggers (1971) define dois padrões de assentamentos distintos para o ambiente da floresta tropical amazônica: o ambiente de terra firme e o ambiente de várzea. Meggers utilizou comparações de estudos de grupos indígenas contemporâneos, Camayurá, Jívaro, Kayapó, Sirionó, para definir toda a área de terra firme como uma área culturalmente idêntica e inferior em produtividade primária à área de várzea. A várzea, por sua vez, foi interpretada através de relatos de cronistas da época da colonização, como um ambiente onde se estabeleceram grandes aldeias com padrão de organização social hierarquizado. Meggers supõe que o padrão mais desenvolvido de alguns grupos da várzea seria oriundo de influências externas associada a combinação de fatores ambientais favoráveis.

Com relação aos grandes sítios na Amazônia, para Meggers, não se pode identificar nenhuma ocupação grande ou de caráter permanente entre a quantidade de sítios investigados. O que foge do padrão dos sítios menores, foi interpretado como produto de múltiplas re-ocupações pela mesma ou sucessivas fases ao longo do tempo (Meggers 1990:202).

Uma característica do trabalho desenvolvido por Meggers e Evans foi a definição de tradições e fases através do material cerâmico coletado. Eles utilizaram uma metodologia de seriação da cerâmica, onde o material era agrupado tendo como traços diagnósticos as características morfológicas, decorativas e, principalmente, o tipo de tempero adicionado à pasta de argila para reduzir a plasticidade.

Meggers tinha bastante confiança nos resultados obtidos pelas seriações, que no seu entendimento não seriam meras cronologias relativas. Em sua perspectiva, as seriações ajudariam a identificar unidades sociais pré-históricas que podiam ser comparadas às comunidades dos grupos indígenas sobreviventes. Isso teria tornado possível não somente a comparação entre padrão de assentamento e a demografia de comunidades, passadas e presentes, mas também teria permitido avaliar as causas e conseqüências das diferenças. Para Meggers a interpretação de seqüências seriadas seria como “impressões digitais” de comunidades pré-históricas (Meggers 1990:184).

Duas outras contribuições importantes do casal norte americano; o Programa Nacional de Pesquisas Arqueológicas (PRONAPA), iniciado em 1965, que buscava um mapeamento de sítios no Brasil, com o objetivo de definir fronteiras culturais; e o 
Programa Nacional de Pesquisas Arqueológicas na Bacia Amazônica (PRONAPABA), em 1977, que buscava dar continuidade ao reconhecimento de sítios arqueológicos, agora na Bacia Amazônica. Entre os pesquisadores que fizeram parte do PRONAPABA, estavam Odemar Dias Jr., do Instituto de Arqueologia Brasileira, que desenvolveu pesquisas no Acre e nos rios Juruá e Purus; Eurico Theófilo Miller, da Universidade Católica do Rio Grande do Sul, que desenvolveu pesquisas em Rondônia, Mato Grosso e Médio Madeira; e Celso Perota, da Universidade Federal do Espírito Santo, que desenvolveu pesquisas nos rios Tapajós, Xingu e Purus. Todos esses pesquisadores trabalharam sobre a coordenação de Mário F. Simões (Meggers 1992a: 22).

Contrário ao modelo proposto por Meggers, Donald Lathrap lança o que pode ser considerado o segundo modelo interpretativo da pré-história amazônica. Apesar de não ter trabalhado diretamente no Brasil e sim na Amazônia peruana, ele propôs um modelo em que todos os sistemas agrícolas da América do Sul teriam se derivado de um sistema antigo de cultivo de mandioca, centrado nas várzeas da Amazônia ou norte da América do Sul. Dando um novo sentido ao conceito de cultura de floresta tropical, Lathrap propôs que o centro de desenvolvimento cultural da América do Sul estaria localizado nas proximidades da cidade de Manaus (Lathrap 1970:74).

Conhecido como modelo cardíaco, esta outra vertente de interpretação do desenvolvimento cultural amazônico, criada por Lathrap, foi posteriormente desenvolvida nos trabalhos de Brochado e Lathrap (1982), Brochado (1984), Lathrap e Oliver (1987) e Oliver (1989).

Para Lathrap, as origens do desenvolvimento cultural na Amazônia teriam que ser relacionadas com a idade e origem das principais plantas cultivadas. Em sua perspectiva, o processo de domesticação dos principais cultivos da região amazônica, (os tubérculos) seria tão antigo que eles não possuem mais a capacidade de formar sementes. Um dos mais importantes, a mandioca (Manihot esculenta), teria sido domesticada por volta de sete mil anos atrás (Lathrap 1970:48).

Para Lathrap, a uniformidade da manufatura dos utensílios encontrados nos sítios arqueológicos da bacia amazônica leva a pensar que o desenvolvimento cultural da região teve início entre as primeiras levas migratórias para o continente americano. (Lathrap 1970:60).

No mesmo período em que as sociedades complexas da região caribenha são encontradas pelos colonizadores, às margens dos grandes rios da bacia Amazônica é 
relatado no século XVI pelos cronistas um padrão de organização social, política e demográfica semelhante (Lathrap 1970:47).

Entre as críticas feitas ao modelo interpretativo do desenvolvimento cultural na América, apresentado por Steward no Handbook of South American Indians, e aplicado por Meggers e Evans, principalmente o contraste entre o modo de vida dos habitantes da bacia amazônica e o dos ocupantes da costa caribenha no período pré-colombiano, está o trabalho de Myers (1973:235), que critica a comparação entre culturas circumcaribenhas do período do contato com os europeus e as culturas da floresta tropical dos tempos em que Steward realizou o seu trabalho (1948), dado que existem quatro séculos de mudança cultural acelerada pelas interferências coloniais sendo desconsiderados entre os períodos comparados.

$\mathrm{Na}$ década de 80, o debate a respeito das origens e do padrão de desenvolvimento cultural na Amazônia foi acrescido pelos trabalhos de Anna Roosevelt. Ela apresenta vários dados que se opõem às proposições de Meggers (1971), sugerindo que o cultivo de milho associado a outros meios favoráveis, proporcionou o desenvolvimento de sociedades complexas com organização social que pode ser chamada de cacicado. Além disso, os cacicados teriam se desenvolvido de forma autóctone e sem nenhuma influência dos Andes (Roosevelt 1992:70-79).

Roosevelt identificou também sítios muito antigos, tanto de épocas précerâmicas, como as cerâmicas mais antigas da América, datados em 11 e 7 mil anos respectivamente (Roosevelt, et al. 2002; Roosevelt, et al. 1991; Roosevelt, et al. 1996). Estas novas descobertas reascenderam o debate a respeito da antiguidade da ocupação humana na Amazônia, dando indícios que as teorias de Lathrap (1970) tinham grandes probabilidades de estarem corretas.

Roosevelt talvez seja quem fez as críticas mais fortes ao trabalho de Meggers. Para ela, as comparações etnográficas foram utilizadas como se os indígenas atuais fossem uma janela para o passado pré-histórico da Amazônia. Para Roosevelt os autores que utilizam este tipo de comparação acabam criando um modo de vida que provavelmente nunca existiu na Amazônia (Roosevelt 1989:33 e 34).

Em um texto de 1995, Early Pottery in the Amazon - Twenty Years of Scholarly Obscurity, Roosevelt lançou críticas muito sérias, fazendo uma reavaliação dos dados bibliográficos e dos arquivos de registros e correspondências sobre os resultados de datações radio-carbônicas do Smithsonian Instituition, acusando Meggers e Evans de terem omitido datas antigas que poderiam mudar a compreensão das seqüências de 
ocupação da Amazônia (Roosevelt 1995:119). Roosevelt também faz críticas a Meggers e outros autores por terem utilizados os pressupostos do determinismo ecológico para justificar a impossibilidade da emergência de grandes sociedades na Amazônia. A autora diz que apesar da forte influência da teoria, erros podem ser identificados em vários aspectos e se tivesse sido discutida em detalhe não teriam mais tanta influência. Para Roosevelt, o determinismo ecológico se justificaria muito mais pelos objetivos colonialistas norte-americanos, visto que estes consideravam a América Latina um campo a ser explorado e para onde poderiam levar suas influências de "cultura mais desenvolvida" (Roosevelt 1991:103 -106). No mesmo texto, Roosevelt faz comparações que deixam até os mais otimistas quanto à emergência de sociedades complexas na Amazônia receosos, pois ela compara os povos pré-coloniais amazônicos às sociedades do Nilo, Hindu e Mesopotâmia. Para ela, estes povos teriam se desenvolvido de forma semelhante (Roosevelt 1991:111).

Desde então a questão mais debatida na arqueologia amazônica passou a ser referente à possibilidade de ter ou não existido grandes populações vivendo de forma sedentária, com um grau de complexidade sócio-política do tipo cacicados.

Tradicionalmente, as pesquisas arqueológicas na Amazônia sempre tiveram um viés voltado para a antropologia (Meggers 1971), as analogias etnográficas sempre estiveram presentes nos modelos interpretativos da ocupação pré-colonial da região amazônica. Porém, o padrão de assentamento atual não condiz com a teoria dos grandes sítios (Roosevet 1991).

Rebatendo as críticas, Meggers diz que nem os dados etnográficos nem os arqueológicos são consistentes para provar a existência de grandes populações na Amazônia. Ela também considera que a instabilidade climática da região, secas prolongadas e grandes enchentes, afetaram diretamente a fauna, a flora e, consequentemente, a adaptação humana no período pré-colonial (Meggers 1995:30).

Em 1995, Robert Carneiro publicou um texto com o objetivo de rever os dados apresentados por Roosevelt (1991), onde ele sugere que depois de uma leitura muito atenta é possível constatar divergências entre o objeto e os fatos apresentados pela autora. As fortes críticas de Roosevelt quanto ao trabalho de Meggers e seus seguidores fazem parte dos pontos destacados por Carneiro. Segundo ele, Roosevelt critica fortemente o determinismo ecológico, mas no decorrer do texto dela é possível identificar trechos em que fica claro o uso e a admissão de que fatores ecológicos influenciam na vida social (Carneiro 1995:46 e 47). 
A outra crítica deste autor é quanto a autodenominação de Roosevelt, de ser ela a responsável pela mudança de paradigma na interpretação da pré-história amazônica. Roosevelt acusa os etnólogos de terem contribuído para propagar os erros de Meggers. Carneiro, um destes etnólogos, faz referências a uma série de trabalhos desenvolvidos por ele, a partir de dados etnográficos, que se opõem aos argumentos de limitação ambiental. Carneiro afirmou que trinta anos antes do texto de Roosevelt (1991) ser publicado, ele já estava em debate contra os argumentos de Meggers (Carneiro 1995:48). Ele afirmou também não querer ser o primeiro nem o único a defender a idéia da existência de cacicados na Amazônia. Para isso, ele cita que as idéias já eram defendidas no trabalho de Lathrap (1970) (Carneiro 1995:50).

Carneiro também é contra os argumentos de Roosevelt que associam a emergência de cacicados ao cultivo do milho. Ele diz ter dados etnográficos e fontes históricas consistentes o bastante para comprovar que os recursos aquáticos disponíveis na várzea dos grandes rios seriam o bastante para manter este padrão de complexidade (Carneiro 1995:54).

Carneiro lança argumentos, que foram aprofundados por Denevan (1996), sobre a importância da exploração interligada entre a várzea e a terra firme. Ele descreve o processo que culminou no surgimento dos cacicados, estando associados os recursos aquáticos disponíveis na várzea e o cultivo da mandioca. A terra firme é perfeitamente viável para o cultivo de mandioca, segundo dados etnográficos obtidos por este autor (Carneiro 1995:57 e 58).

O fator responsável pela não emergência de cacicados nas áreas de interflúvio teria sido a falta dos recursos aquáticos como parte da dieta. Estes tiveram que ser substituídos pela caça que requer mais mobilidade, impedindo a completa sedentarização.

Viveiros de Castro (1996) também aponta algumas falhas nas interpretações de Roosevelt, dizendo que o modelo proposto por ela é tão baseado nos padrões de determinismo ecológico tradicional quanto os de Meggers e Evans. Roosevelt insiste em um contraste genérico entre a várzea e a terra firme como um determinante da evolução cultural.

Desenvolvendo uma hipótese alternativa para explicar a exploração dos diferentes ambientes amazônicos, a debatida dicotomia entre a várzea e a terra firme, Denevan (1996) propõe um modelo que trabalha com um sistema de exploração que estaria se beneficiando tanto dos recursos da terra firme quanto da várzea. Segundo este modelo 
(Bluff Model), os sítios seriam consequentemente encontrados nas áreas de barrancas dos grandes rios, pois estes locais estariam livres das cheias e estrategicamente permitiriam a exploração da várzea e da terra firme.

Denevan busca referências etnohistóricas dos viajantes do século XVI para mostrar que os grandes assentamentos estavam localizados nas barrancas (Bluffs), na várzea e na terra firme, todos interligados. Para ele as evidências da interligação entre os sítios da várzea, das barrancas e da terra firme, são encontradas nos relatos contidos nos textos dos viajantes, apontando a existência de estradas que ligavam as duas áreas.

Mais recentemente, Michael Heckenberger desenvolve pesquisas no alto Xingu e também fez parte da equipe do PAC na Amazônia Central. Heckenberger tem feito grandes descobertas, através de analogias etnográficas, com relação ao cultivo da mandioca por parte dos índios da Amazônia. Os resultados apontam para a existência de sítios grandes e com um nível de complexidade social elevado, atestado pela identificação de estruturas defensivas (valas defensivas), estradas ligando uma aldeia e outra. Heckenberger propôs a hipótese de que tais sítios teriam sido ocupados por populações com uma economia baseada na agricultura da mandioca complementada pela caça e a pesca como principal fonte de subsistência, o que desassocia a existência de complexidade cultural influenciada pelos Andes, pela cultura do milho e também à limitação às áreas de várzea amazônica (Heckenberger 1998 e 2005; Heckenberger, et al. 1999).

Se os dados arqueológicos são precários para entender o padrão de ocupação da região amazônica, os dados etnohistóricos utilizados por autores como Roosevelt (1980) e Antônio Porro (1995), que buscam nos relatos de cronistas viajantes do período colonial as evidências de grandes sociedades complexas, não são menos precários. Os viajantes tinham a necessidade de justificar o financiamento de suas expedições e para isto poderiam estar exagerando nos seus relatos. O que descredibiliza os relatos de viajantes são as passagens fantasiosas, que estão também presentes em suas obras. Segundo Mattos (1980:21): “A lenda do 'país das Amazonas', que deu nome à região, é produto da mitologia grega transplantada pelos espanhóis para o ambiente do Novo Mundo." Existem narrativas que mencionam guerreiras montando cavalos, animais que não existiam na região amazônica nesta época, motivos que levam os autores que defendem a impossibilidade de ter existido grandes sociedades complexas na Amazônia a não aceitar os relatos como convincentes do grau de complexidade existido antes da colonização. 


\section{I.III - O PROJETO AMAZÔNIA CENTRAL}

Criado em 1995 pelas iniciativas do Dr. Eduardo Neves (Universidade de São Paulo) e dos Drs. Michael Heckenberger (Universidade da Florida) e James Petersen (Universidade de Vermont), o PAC vem sendo desenvolvido em uma região com formato triangular e área aproximada de $900 \mathrm{~km}^{2}$, delimitada ao sul pelo rio Solimões, a oeste pelo rio Ariaú e a nordeste pelo rio Negro, no Estado do Amazonas (anexo 01). Além dos três rios principais, a área de pesquisa conta com uma variada rede hidrográfica composta por igarapés, igapós e lagos, bastante explorados pela ocupação humana, tanto no presente quanto no passado. Somando-se os resultados de nossos trabalhos já são conhecidos mais de 100 sítios arqueológicos nessa região.

Esta é, certamente, uma área chave para a arqueologia Amazônica, pois conforme dito anteriormente Lathrap (1970), Brochado e Lathrap (1982), Brochado (1984), Lathrap e Oliver (1987) e Oliver (1989) sugeriram que o centro de origem cultural sul-americano teria que ser buscado nas proximidades de Manaus. Portanto os problemas específicos de pesquisa encontrados nessa região amostral são válidos para a construção e teste de modelos interpretativos para toda a Amazônia, ou conforme propunha os autores anteriormente citados, talvez toda a América do Sul. Deste modo, os principais objetivos do PAC, desde a sua criação, foram produzir dados que pudessem contribuir para um melhor entendimento da arqueologia da Amazônia Central, mas que também auxiliassem na resolução de problemas mais amplos da arqueologia das terras baixas da América do Sul. Conforme descreve um de seus coordenadores (Neves 2000 e 2002) as principais problemáticas levantadas pelo projeto são:

1) A emergência de sociedades complexas do tipo cacicado na Amazônia pré-colonial;

2) A possibilidade da ocorrência de assentamentos sedentários, com grande densidade demográfica e de longa duração de ocupação em ambientes de floresta tropical;

3) O uso de dados arqueológicos para o estudo da distribuição dos padrões pré-coloniais de distribuição lingüística nas terras baixas da América do Sul;

4) $\mathrm{O}$ estabelecimento de cronologias controladas para a arqueologia Amazônica.

Em seus onze anos de existência o PAC já soma muitos resultados. Atualmente a área de confluência dos rios Negro e Solimões é a região melhor datada na Amazônia brasileira. Muitos resultados de pesquisa deram origem a publicações de trabalhos no 
Brasil e exterior (Heckenberger, et al. 1999, 2001; Neves 2001 e 2006; Neves e Petersen 2006, Neves, et al. 2003 e 2004; Petersen, et al. 2001, 2004 e 2005, Lima et al 2005).

Outro objetivo importante do PAC é a formação de novos pesquisadores, que já conta com algumas dissertações de mestrado concluídas (Costa 2002; Donatti 2003; Lima 2003; Machado 2005) e outras de mestrado e doutorado em andamento (Costa 2004; Pinto Lima 2004; Chirinos 2003 e o trabalho ora apresentado), o que confere à pesquisa um caráter integrado único na arqueologia brasileira. 


\section{Capítulo II - A ÁREA DE TESTE DAS HIPÓTESES}

Consideramos que a área de entorno do lago do Limão seria adequada para testar as hipóteses alternativas discutidas anteriormente. Trata-se de uma região onde um sítio já foi escavado em detalhe - o sítio Osvaldo - e onde a informação oral e levantamentos preliminares indicavam a ocorrência de outros sítios, condições permitiriam a verificação da ocorrência de articulações regionais entre sítios, como seria de se esperar em sistemas políticos do tipo cacicado, pois, como havíamos apontado em nosso projeto (Moraes 2003), o lago do Limão parece ser um micro ambiente importante no contexto da área de confluência dos rios Negro e Solimões.

Os trabalhos realizados pelo PAC apontavam para uma predominância de sítios das fases Guarita e Paredão na área de pesquisa em geral (Neves 2000 e Lima 2003). O contexto do lago do Limão seria então uma anomalia existente nesse padrão de ocorrência de sítios, pois havia sido identificado ali um sítio grande com vestígios da fase Manacapuru. Como supúnhamos que do ponto de vista produtivo o micro ambiente do lago teria sido importante em períodos pré-coloniais, trabalhos como o de Lathrap (1968b), Carneiro (1983) e Heckenberger (1998 e 2005) sugerem que as grandes populações pré-coloniais tinham sua dieta baseada na agricultura da mandioca complementada pela captura de uma gama variada de fauna aquática. As condições ambientais do lago do limão são perfeitas para esse tipo de exploração, pois além dos recursos do lago a acessibilidade tanto ao rio Negro quanto ao Solimões pode ser considerada relativamente fácil. Hipotetizamos que este poderia ser um território regional Manacapuru.

Queríamos saber como teria, supostamente, sido o processo de estabelecimento e manutenção do controle desse micro ambiente por parte dos povos que nos legaram os vestígios da fase Manacapuru. Existem vestígios de estruturas defensivas identificadas em outros sítios trabalhados pelo PAC (Neves 2003). Isto, associado a uma certa contemporaneidade entre as datas já obtidas para vestígios de diferentes fases, nos permitem aludir sobre a existência de disputa territorial no ambiente. O levantamento de sítios da área de entorno do lago nos permitiria testar estas hipóteses. Além disso, o trabalho forneceria dados que extrapolam o contexto local, podendo ser úteis para 
contribuir com problemas de pesquisa válidos para todo o contexto de ocupação précolonial da Amazônia.

\section{II.I - O LAGO DO LIMÃO}

O lago do Limão está localizado aproximadamente na metade do curso do rio Ariaú (anexo 01), sendo um tributário de sua margem direita. O rio Ariaú é de fato um "furo", denominação local para designar os cursos d'água que conectam dois cursos d'água distintos. O Ariaú tem suas águas fluindo do rio Solimões para o Negro na maior parte do ano, porém na época das enchentes pode acontecer uma mudança de corrente e as águas fluem do Negro para o Solimões.

Segundo Neves (2000: 26) é quase certo que tal conexão entre o Negro e o Solimões já era de conhecimento das populações pré-coloniais da área, para mostrar isso ele cita Sternberg (1998). Nesta obra, é apresentado um mapa do encontro das águas do Solimões e Negro, de autoria Antônio da Silva Pontes e Ricardo Franco de Almeida Serra, datado de 1781, onde o rio Ariaú é denominado "furo que vai a Solimõens".

O lago do Limão é também um destes furos, pois na época da cheia ele conecta o rio Ariaú e o lago Grande, um outro lago que recebe águas do rio Solimões. Segundo Neves (2000:26) o lago do Limão, de fato, tem mais a forma de um igarapé que propriamente a de um lago. Para este autor, suas características formais permitem que ele seja classificado como uma "ria", denominação para os rios ou igarapés inundados como conseqüência do aumento do nível do mar ocorrido durante o início do Holoceno.

Atualmente a origem do nome do lago é quase desconhecida pelos moradores da região. Durante a realização dos trabalhos de campo, a maioria das pessoas questionadas não sabia o motivo do local ser chamado de lago do Limão. Apenas alguns dos moradores mais velhos souberam responder esta questão. De acordo com eles, na boca do lago existia uma feitoria onde era feita a salga do pirarucu (Arapaima gigas), peixe supostamente muito abundante no lago em épocas anteriores. Hoje esse tipo de peixe dificilmente é visto pelo lago. No local desta feitoria havia um limoeiro, o único da região. Por isso, quando alguém queria se referir ao local, usava a denominação "boca do limão". De "boca do limão" passou a lago do Limão que hoje também é o nome do povoado existente às margens do lago. 
Hoje em dia o povoado é constituído por cerca de mil habitantes, uma população basicamente cabocla, uma grande porcentagem vinda de outras localidades Amazônicas, principalmente Manaus. Os nascidos no local possivelmente são descendentes dos Mura, ocupantes da região no período colonial (Nimuendajú 1948, 1987).

A grande maioria dos moradores comprova ter também descendência nordestina, resultado das grandes levas de trabalhadores que vieram em busca da prosperidade da chamada Era da Borracha. Segundo Mattos (1980) houve uma coincidência entre o mito do El Dorado que veio dar um dom de atração à área dos seringais, e uma grande seca no nordeste no ano de 1877 , resultando no deslocamento para a exploração do látex, de uma população calculada em 300.000 pessoas.

O acesso ao povoado é feito através da rodovia Manuel Urbano, que liga os municípios de Manaus e Manacapuru. A distância entre o povoado e a balsa de travessia do rio Negro para Manaus, é de aproximadamente $40 \mathrm{Km}$, trecho totalmente asfaltado, inclusive com uma linha de transporte coletivo.

A história da formação do povoado coincide com a construção da rodovia Manuel Urbano, na década de 1970, e, principalmente, com a chegada da energia elétrica, também na mesma época. Esse evento fez com que as famílias que viviam espalhadas pelas margens do lago cultivando suas roças, viesse se juntar na área do entorno da capela, uma das primeiras construções do povoado, para usufruir do novo benefício. Desde então, grande parte dos moradores possuem uma casa na vila e trabalham em suas propriedades às margens do lago, que muitas vezes não têm mais moradia.

Apesar da relativa proximidade entre Manaus e o lago do Limão, antes da construção da estrada, para que os moradores das margens do lago se deslocassem até Manaus a única alternativa era o barco. O trajeto era feito via rio Ariaú e rio Negro: três dias de viagem a remo. Até os anos 1970, o relativo isolamento, proporcionou à população local a conservação de muitos costumes tradicionais. Um dos exemplos é a pesca com arco e flechas. Hoje com suas adaptações modernas, as flechas já não possuem mais a emplumação da haste e a ponta é feita de metal (figuras 01 e 02).

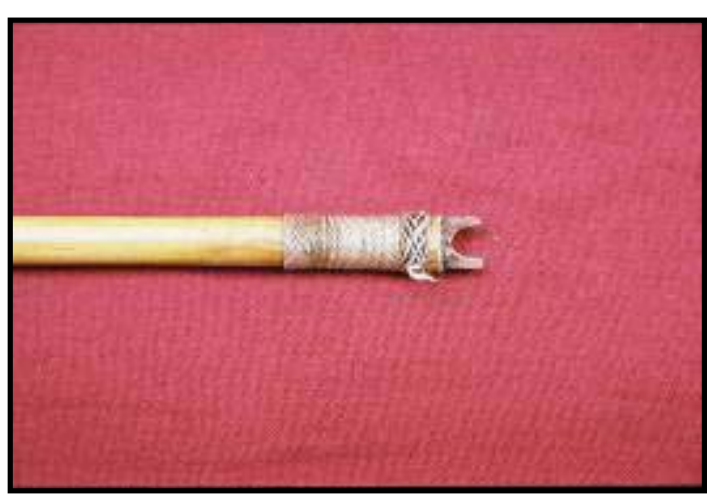

Figura 01: Encaixe da haste da flecha para a corda do arco. 
A pesca com arco e flecha no lago do Limão é praticada principalmente pelos homens, que começam a flechar ainda quando crianças (figura 03), mas é possível encontrar algumas mulheres que são hábeis nesse tipo de pescaria.

As roças são plantadas pelo método de agricultura de coivara, que consiste no corte e queima da vegetação arbórea para executar o plantio (figura 04). O principal produto cultivado é a mandioca (Manihot esculenta), tanto a sua versão doce, como a mandioca brava. Localmente as duas variedades são classificadas como macaxeira e mandioca respectivamente. Os diferentes tipos de farinha produzidos destes dois cultivos fazem parte da dieta diária dos moradores do lago do Limão. Além da mandioca são cultivados variados tipos de frutas e verduras, produtos não muito apreciados no cardápio diário dos moradores, quase cem por cento desta produção é destinada, principalmente, ao mercado de Manaus.

Importante de ser destacado também é o processo de produção dos derivados da mandioca. As chamadas casas de farinha (figura 05) são muito comuns em todo o entorno do lago. São construções específicas para o beneficiamento da mandioca, geralmente construídas próximo ao local de plantio. Entre os artefatos utilizados durante a produção de farinha é possível encontrar elementos indígenas, como é o caso do tipiti (figura 06), um recipiente de palhas trançadas onde se coloca a mandioca ralada para que o suco possa ser extraído da massa. Para ser transformada em farinha (figura 07) a massa de mandioca tem que estar seca e, é também durante o processo de compressão da massa, que se extrai o ácido cianídrico existente na mandioca brava.

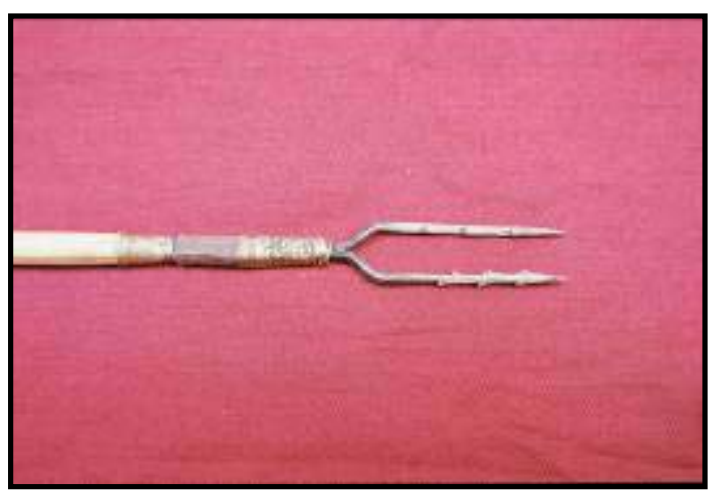

Figura 02: Ponta de flecha feita artesanalmente com metal.

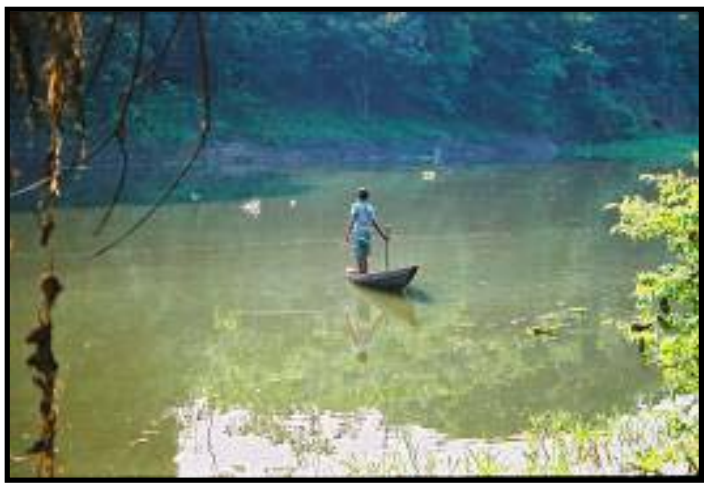

Figura 03: Pescaria com arco e flechas. 


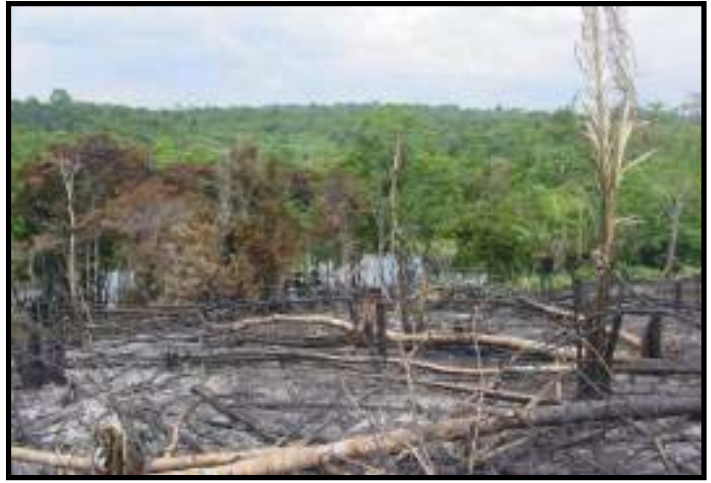

Figura 04: Campo de cultivo recentemente queimado.

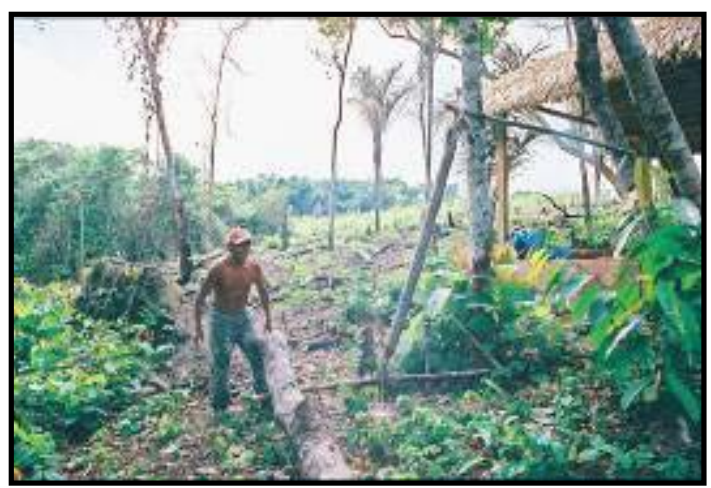

Figura 06: Massa de mandioca sendo comprimida no tipiti para que saia o suco tóxico.

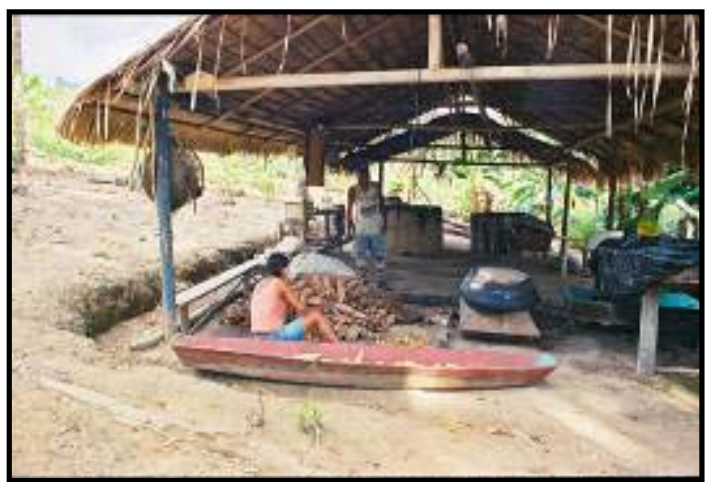

Figura 05: Casa de farinha.

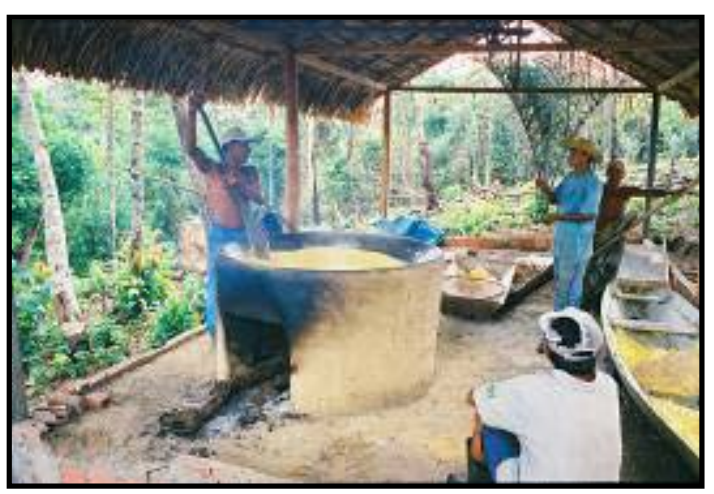

Figura 07: Torrefação da farinha ao forno.

O lago do Limão é notável por suas belas paisagens formadas pelos açaizais muito abundantes em suas margens (figura 08). Destacamos também a importância da coleta dos frutos do açaí (Euterpe oleracea), bacaba (Oenocarpus bacaba), pupunha (Bactris gasipaes), cupuaçu (Theobroma grandiflorum), castanha da Amazônia (Bertholletia excelsa), cacau (Theobroma cacau), entre outros. Estes frutos são muito importantes na composição da dieta dos moradores do lago e com a popularização de alguns deles, no caso, principalmente o açaí, a coleta se torna também uma importante fonte de renda. $\mathrm{O}$ açaí atualmente é processado em máquinas elétricas, mas ainda é possível encontrar alguns exemplos de extração artesanal da polpa do fruto no pilão de madeira.

Durante nosso trabalho de campo identificamos também a presença de cerâmica cabocla, que segundo informações dos moradores mais velhos, deixou de ser produzida há cerca de trinta anos, data que coincide com a chegada da estrada e da energia elétrica. Com o crescimento industrial de Manaus, a facilidade de adquirir vasilhas de alumínio 
aumentou, substituindo assim as peças que eram produzidas em argila. Ainda é possível encontrar em algumas casas, potes de cerâmica sendo utilizados para armazenar água (figura 09), além de outros reutilizados como vasos para plantas (figura 10), ou na maioria das vezes apenas os fragmentos das vasilhas já descartadas (Figura 11).

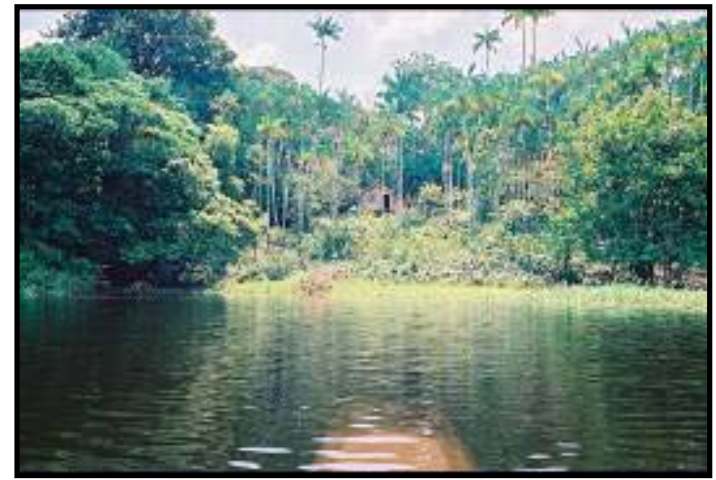

Figura 08: Lago do Limão e ao fundo um exemplo dos açaizais existentes às margens.

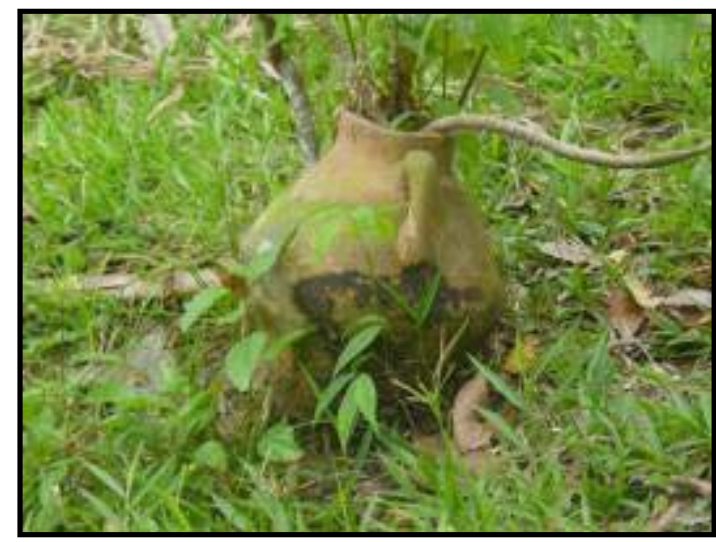

Figura 10: Recipiente reutilizado como vaso para planta.

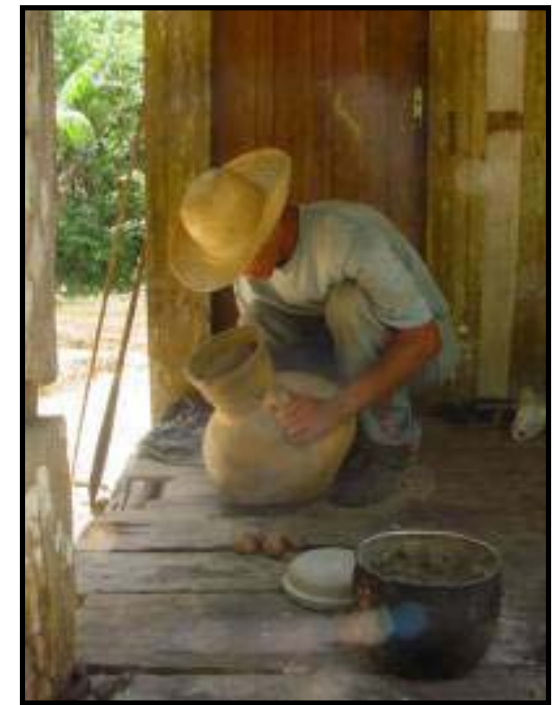

Figura 09 - Recipiente de cerâmica utilizado para armazenamento de água.

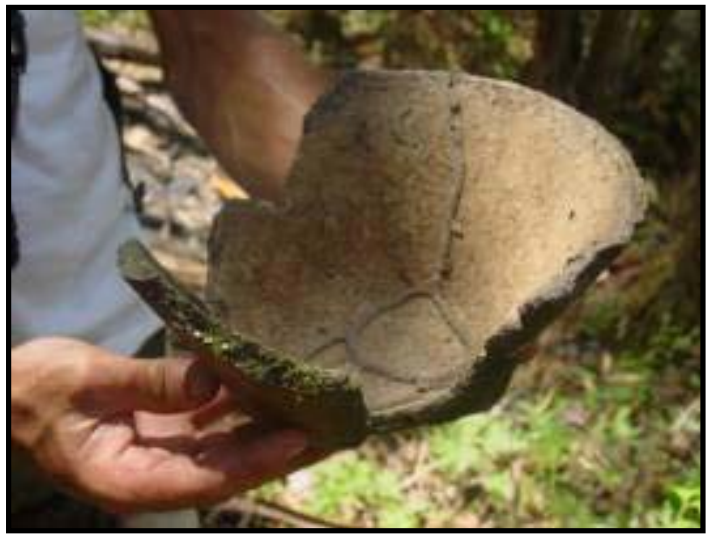

Figura 11 - Fragmento de cerâmica cabocla encontrado em área de descarte de lixo doméstico.

Não conseguimos encontrar ceramistas entre os moradores do lago, mas podemos identificar através das peças e fragmentos encontrados, que a produção era bem semelhante a dos períodos pré-coloniais. A cerâmica cabocla foi produzida através da técnica de roletes. Também é possível identificar na pasta de argila o uso de cariapé (antiplástico vegetal), adicionado em grande quantidade (figura 12). Tanto a técnica de produção, quanto o cariapé, são identificados na cerâmica pré-colonial dos sítios da 
região. O que diferencia muito a cerâmica cabocla da pré-colonial são o acabamento e a forma dos recipientes, muito distintos dos encontrados nos sítios arqueológicos.

Outro exemplo de costume tradicional abandonado é o consumo de epadu (Erythroxylum coca), a coca amazônica. No século XVIII Padre João Daniel descreveu o uso do epadu com as seguintes palavras:

“[...] como também o do célebre chá padu, que usam alguns índios, especialmente os naturais do rio Negro, cujas folhas trazidas na boca suprem a falta do sono, e mastigadas matam a fome, e sede além de outros

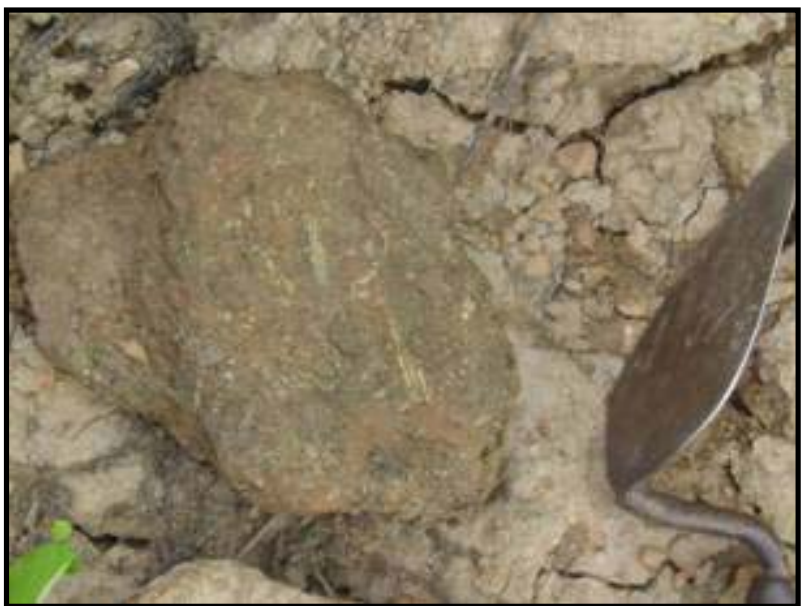

Figura 12 - Fragmento de cerâmica cabocla temperado com cariapé em grande proporção. admiráveis efeitos [...]” (Daniel 2004).

O assunto não é muito comentado entre os moradores do lago do Limão, pois na década de 1980, esse costume foi erradicado à força pela polícia federal, mas entre uma conversa e outra surge a receita: "as folhas torradas ao forno eram socadas no pilão, produzindo um pó que era consumido com farinha de tapioca”, além das qualidades listadas no século XVIII, algumas propriedades medicinais também são atribuídas ao epadu.

Essas e outras coisas fazem do Lago do Limão um lugar com uma história rica não só nos tempos pré-coloniais, motivo que justifica o espaço dedicado aqui para algumas peculiaridades da história recente do lugar.

\section{$\underline{\text { II.II - O SÍTIO OSVALDO }}$}

Conforme descreve Neves (2000), o sítio Osvaldo encontra-se na margem sul do lago do Limão, tem dimensões calculadas em 1120 por 320 metros, com o pacote arqueológico atingindo a profundidade aproximada de $80 \mathrm{~cm}$. O solo de ocupação apresenta-se de forma bem argilosa e com coloração bastante escura (terras pretas antropogênicas). O sítio está assentado sob uma espécie de península, com orientação $\mathrm{N}-\mathrm{S}$, que avança para as margens do lago em sua extremidade norte. As extremidades W, S e NE da península são delimitadas por enseadas conectadas ao lago (anexo 02). 
A cerâmica encontrada no sítio está associada à fase Manacapuru da Tradição Borda Incisa (Meggers and Evans 1961 e Hilbert 1968) ou Barrancóide (Lathrap 1968a, Heckenberger et al. 1998 e Lima et al. 2006). As características do material cerâmico, grosso modo, seriam: a presença de incisões em linhas finas com motivos geométricos, flanges labiais, apliques zoomórficos, engobo vermelho e predominância do cauixi como antiplástico adicionado à pasta de argila. (Abreu 2000:02). Uma série de datações foi elaborada para este sítio (anexo 03), nas quais, descartando algumas datas problemáticas, seria possível situar a ocupação entre os séculos VII e VIII da era Cristã (Neves 2000).

Foi encontrado material arqueológico em densidade bastante elevada no sítio Osvaldo. Os resultados dos trabalhos de campo, bem como as análises preliminares do material arqueológico em laboratório e as datações radiocarbônicas obtidas indicam que o sítio é unicomponencial e que foi ocupado por algumas décadas por centenas de indivíduos. Tal hipótese é baseada na densidade dos depósitos cerâmicos e na profundidade e área da terra preta no local (para maiores detalhes ver Neves 2000, 2003 e Chirinos 2003).

Outra hipótese, baseada no padrão descontínuo de distribuição de cerâmicas e de terra preta, formando áreas de concentração distintas dentro do sítio, sugere a possibilidade de se tratar de uma antiga aldeia formada por um grupo de malocas dispostas em forma circular ou elíptica ao redor de um pátio central (Neves 2000 e 2003), hipótese que vem sendo testada por um trabalho para fins de elaboração de dissertação de Mestrado do aluno de Pós-graduação do Museu de Arqueologia e Etnologia da USP, Ricardo Chirinos Portocarrero.

Consideramos que o sítio Osvaldo poderia nos ajudar a evidenciar existência de articulações regionais no período pré-colonial da Amazônia Central. Assim, para podemos confirmar esta hipótese, seria preciso conhecer outros sítios arqueológicos nos arredores do lago. Queríamos saber se na região do lago do Limão só existem vestígios de sítios da fase Manacapuru. E, se esse fosse o caso, queremos verificar se são contemporâneos aos do sítio Osvaldo, o que poderia demonstrar a existência de sistemas políticos hierárquicos regionais do tipo cacicado, como propõe Roosevelt (1992).

Contávamos também com a hipótese de haver uma diversidade cronológica e cultural de ocupações na área do lago do Limão, pois conforme aponta Lima (2003) há uma predominância de sítios da fase Guarita, da tradição policrômica da Amazônia, nas áreas de terra firme. Um dos nossos objetivos era confirmar se o lago do Limão era ou 
não uma exceção a esse padrão identificado. Os primeiros dados levantados a este respeito são descritos no capítulo a seguir. 
Aqui Estão Eles 


\section{Capítulo III - O LEVANTAMENTO ARQUEOLÓGICO}

Os sítios arqueológicos identificados foram inicialmente registrados com base na disposição dos vestígios em superfície. Foi coletada na superfície amostras de fragmentos tais como: bordas, bases, apliques ou elementos decorativos e ainda materiais líticos, já que em sítios multicomponenciais, os exemplares não decorados, ou que não apresentam informações de características formais (bordas e bases) são muito difíceis de classificar.

\section{$\underline{\text { III.I - METODOLOGIA DE TRABALHO }}$}

Em nossa proposta os trabalhos de campo deveriam ser desenvolvidos de acordo com os métodos já utilizados no âmbito do PAC, seguindo uma metodologia básica desenvolvida no Archaeological Research Center da University of Maine at Farmington e posteriormente adaptada às condições de terreno da região amazônica. Em seguida, as condições no campo levaram à reformulação dessa proposta. Esta seção apresentará brevemente a proposta original para que se possam avaliar as modificações realizadas.

Conforme descrito por Neves (2000), e já testado em etapas anteriores, os sítios podem ser trabalhados em três níveis diferentes de resolução. As tradagens, o primeiro nível, são abertas sistematicamente, com espaçamento definido de acordo com os padrões do PAC. Na identificação dos sítios a metodologia é vantajosa, pois o trabalho é rápido e provoca uma pequena margem de destruição do patrimônio, dando uma boa noção da variabilidade da distribuição de vestígios no sítio arqueológico, auxiliando também em sua delimitação.

A malha de tradagens é estabelecida com o auxílio de bússola e GPS no primeiro momento. As tradagens são abertas em níveis artificiais de $20 \mathrm{~cm}$, por grupos de dois indivíduos: um responsável pela tradagem em si, outro pelo preenchimento da ficha de tradagem com informações sobre a profundidade das camadas arqueológicas, a coloração do sedimento das camadas (descritos com uma tabela de cores "Munsell") e a contagem do número de fragmentos obtidos.

Executado este primeiro nível de intervenções, caso ainda haja necessidade de obter dados mais detalhados dos sítios identificados, são aplicados os níveis 2 (abertura 
de sondagens de $0.5 \mathrm{~m}$ ) e 3 (abertura de áreas de escavação), também obedecendo os padrões metodológicos do PAC (Neves 2000). Esta metodologia já tem eficácia comprovada por trabalhos executados anteriormente (Neves 2000; Donatti 2003 e Lima 2003). Combinando as diferentes estratégias de aproximação nos sítios, bons resultados têm sido obtidos para a elaboração de uma cronologia para área de estudo e também tem dado informações básicas sobre os padrões de distribuição de vestígios nos sítios trabalhados.

Nossa proposta previa a realização de um levantamento oportunístico, já que, conforme havíamos apontado, o objetivo era aumentar a quantidade de sítios conhecidos e mapeados no âmbito de um projeto maior, o PAC, e não a cobertura total da área. Porém, como apontado naquela ocasião, (Moraes 2003:13 e 14) sabemos que as críticas a esse tipo de levantamento são grandes. Justificamos então que, apesar do levantamento ser oportunístico, estaríamos explorando as áreas propícias à existência de sítios arqueológicos, mesmo não tendo informação dos atuais ocupantes. A informação oral é importante, mas temos que estar cientes que os moradores não são arqueólogos.

A opção por um levantamento oportunístico pode ser bem sucedida se levamos em conta o que Schiffer chamou de obtrusiveness, que seria uma espécie de escala de probabilidade de identificação de um sítio arqueológico (Schiffer et al 1978:6). Os sítios que serão estudados têm um alto grau de visibilidade, e sua detecção pode ser feita com técnicas simples de levantamento arqueológico, já que são sítios grande e densos com material arqueológico (principalmente fragmentos de cerâmica e terras pretas) de fácil identificação.

A área demarcada para o levantamento é vistoriada procurando evidências arqueológicas em superfície e sub-superfície que atestem ocupações pretéritas destes locais.

Propusemos também a utilização de meios de locomoção como veículos, quando os acessos permitissem, de barco ou o caminhamento a pé quando as áreas fossem de acesso mais difícil. A utilização de alguns equipamentos como bússola e GPS, bem como o apoio com mão-de-obra para ajudar na abertura dos acessos, também foram considerados fundamentais. A intervenção no solo também estava prevista, pois julgamos que os vestígios arqueológicos poderiam estar encobertos.

A previsão inicial era que executaríamos principalmente a primeira etapa descrita na metodologia. O material proveniente da etapa de trabalho seria processado e analisado em laboratório, caso houvesse necessidade de se obter dados complementares, 
seria feito o retorno a alguns sítios específicos, executando a segunda e se fosse o caso a terceira etapa de trabalho descritas na metodologia.

\section{III.II - METODOLOGIA DE LEVANTAMENTO APLICADA}

Os trabalhos foram realizados de 30 de agosto a 14 de outubro de 2004, ocasião em que foram identificados 15 sítios arqueológicos (anexo 04). Os sítios foram identificados em alguns casos pela informação dos moradores, que podem ser considerados como os últimos re-ocupantes das áreas com presença de terras pretas de índio, solos muito úteis para o cultivo, em função do aumento da fertilidade conseguido pelos ocupantes pré-coloniais, responsáveis pela formação dos sítios arqueológicos.

Portanto, podemos considerar que os moradores da comunidade já “prospectaram” toda a região, em busca das áreas com terra preta, que no caso são as áreas propícias ao plantio de frutas e verduras, para serem comercializadas em Manaus. Como será apresentado adiante, praticamente todos os sítios com presença de terra preta foram identificados através da informação dos moradores. Porém nosso levantamento também identificou alguns sítios sem a presença de terra preta, além de um sítio lítico, identificados através de caminhamentos e da observação das áreas onde a visibilidade da superfície permitiu.

Inicialmente, a estratégia de trabalho foi o percorrimento de todo o lago, observando as margens e visitando os locais onde áreas de cultivo ou pastagens foram abertas, bem como as sedes ou casas de farinha, algumas já abandonadas, locais que além da boa visibilidade do solo, em algumas oportunidades pudemos conversar com os proprietários ou com pessoas que estavam trabalhando. Para este tipo de ambiente a vistoria de superfície é muito adequada (Schiffer, et al. 1978).

Este tipo de abordagem foi bem sucedido, pois mesmo que nos locais visitados não houvesse vestígios arqueológicos, muitas vezes saíamos com a informação de que havia terra preta em outro local. Desse ponto de vista o levantamento torna-se tendencioso, pois caso se pergunte aos moradores por áreas onde é possível encontrar fragmentos de cerâmica, dificilmente se conseguirá uma informação, mas perguntando por um local de terra preta, na maioria das vezes serão dadas informações sobre locais onde há sítios arqueológicos. Porém, essa tendência não é problemática, pois a proposta do trabalho é tentar entender a inter-relação dos sítios com um sítio grande e com 
presença de terra preta - sítio Osvaldo. Portanto, a probabilidade de correlação cronológica será muito maior com outros sítios com os mesmos padrões.

Outro fator que auxilia na identificação da terra preta é o crescimento de um arbusto cheio de espinhos, localmente conhecido como limorana (Chomelia anisomeris), que cresce praticamente só nas áreas de terra preta, talvez em função de sua melhor fertilidade.

Nas indagações aos moradores, um dos locais mais informados quando perguntamos sobre a presença de terra preta, é o do próprio sítio Osvaldo, pois parece que este é um dos maiores sítios da região e, conseqüentemente, tem uma extensão de área com terra preta bastante grande.

Algumas adaptações foram feitas à metodologia proposta no projeto, para que pudéssemos ter noção da quantidade de trabalho que teríamos. Primeiro optamos por não fazer intervenções de sub-superfície nos sítios encontrados. Foram feitas apenas anotações relativas à densidade de vestígios encontrados em superfície e o tipo de vegetação existente no local. Foi feito também caminhamento para tentar conseguir informações iniciais referentes ao tamanho dos sítios. Foram marcadas as coordenadas com o uso de GPS, de um ou mais pontos no sítio, além da produção de fotografias para caracterização do local. Após oito dias de trabalho tínhamos percorrido praticamente todas as margens do lago e anotado informações sobre 14 sítios.

Para a execução dos trabalhos utilizamos quase sempre uma pequena canoa de madeira, com motor de 2HP (rabeta), alugada na própria comunidade. A canoa tinha que ser pequena, pois o lago é cheio de braços com muita vegetação do tipo igapó, o que dificulta o acesso de alguns lugares (figuras 13 e 14).

Em alguns casos, o motor teve que ser abandonado e tivemos que nos locomover a remo, devido à dificuldade de acesso. Com a canoa levantamos as margens e por trilhas existentes em

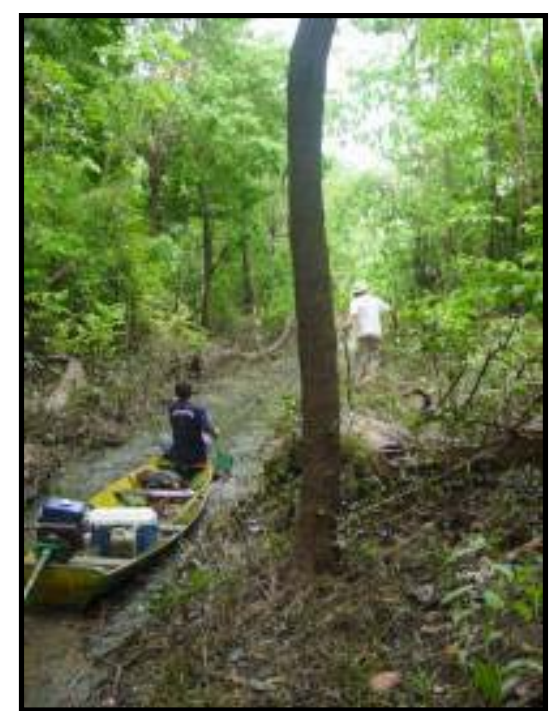

Figura 13 - Travessia de um furo do lago do Limão quase seco, um exemplo dos igapós existentes na área. terra, acessamos os locais um pouco mais distantes do lago. Excetuando-se o acesso ao povoado e um dos locais visitados (sítio Cinco Unidos), o restante não possui estradas de rodagem. 
Após percorrermos todas as margens do lago e identificarmos 14 sítios arqueológicos, optamos por abandonar a proposta inicial de intervenções de subsuperfície na tentativa de localizar sítios arqueológicos. Considerando que tínhamos uma boa amostragem da área e um grande volume de trabalho pela frente, optamos por utilizar intervenções de sub-superfície com fins de delimitação dos sítios já conhecidos. Se o leitor observar o anexo 04, verá que foram identificados sítios arqueológicos em toda a extensão do lago. Assim, apesar do levantamento ter sido oportunístico, foram atingidos bons resultados.

A definição de Schiffer et al. (1978:2), para levantamento arqueológico (archaeological survey), considerando-o um conjunto de técnicas e estratégias para avaliar a probabilidade de detecção de sítios arqueológicos com a melhor relação de investimento de trabalho e obtenção de resultados de acordo com as características do material e do ambiente a ser estudado, reflete bem a nossa tomada de decisão por um levantamento probabilístico. .

Com a quantidade de sítios identificados, e o problema de pesquisa por nós levantado, uma amostragem para estudo mais detalhado seria a

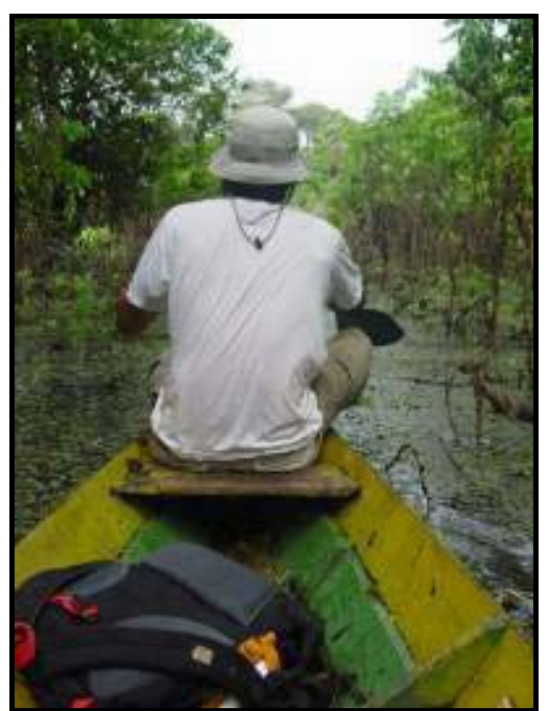

Figura 14: Lago do Limão, navegação por um dos igapós. tomada de decisão mais acertada. Visto que uma boa quantidade de sítios, distribuídos por toda a área de pesquisa, já havia sido encontrada, não tínhamos mais necessidade de aprofundar as técnicas de levantamento.

Os resultados obtidos mostram que a opção por um levantamento oportunístico foi bem sucedida, pois proporcionou agilidade na identificação dos sítios. Devido às características dos sítios pesquisados, mesmo com a superficialidade do levantamento efetuado, acreditamos que uma prospecção exaustiva da região produziria dados muito semelhantes, porém com um volume de trabalho muito maior.

A quantidade de sítios identificada surpreendeu nossas expectativas. Como resultado, tivemos que optar pela delimitação de uma amostra dos sítios encontrados, deixando o restante para trabalhos futuros no âmbito do PAC. Foram escolhidos quatro sítios para delimitação. Os critérios de seleção foram: a localização no espaço, de modo que tivéssemos uma boa amostra comparativa ao sítio Osvaldo; a representatividade dos vestígios; a extensão dos sítios, todos com presença de terra preta. 
Começamos os trabalhos de delimitação dos sítios estabelecendo uma malha de tradagens com espaçamento de 50 metros, tradagens com até um metro de profundidade e cerca de 20 centímetros de diâmetro; dispostas numa linha que estimávamos ser a maior extensão do sítio. Desta forma as linhas não obedecem os pontos cardeais, sendo que para localização, foram nomeadas a partir de um ponto zero, com identificação de NE, SW, NW e SE, de acordo com os pontos cardeais e da distância com relação ao ponto zero. Dessa forma uma tradagem a 150 metros sudoeste do ponto zero recebeu a identificação SW-150. Após um número mínimo de duas tradagens sem presença de material arqueológico e superfície sem presença de vestígios, consideramos atingidos os limites do sítio. Linhas de tradagens transversais à primeira também foram abertas, em alguns casos, para melhor delimitação do sítio.

Após a abertura da primeira linha de tradagens, optamos pela redução da malha para 25 metros, para melhor amostragem dos vestígios. Também optamos pela substituição do trado manual, por uma cavadeira "boca-de-lobo", já que o solo muito argiloso dos sítios dificulta o trabalho com o trado. Perdemos um pouco na homogeneidade do diâmetro das tradagens com a mudança, mas ganhamos tempo na execução dos trabalhos.

As tradagens foram locadas com auxílio de bússola, trena e GPS. Com as informações das tradagens foram produzidos croquis que deram origem aos mapas de sítios apresentados.

As informações sobre tipo de solo, características do ambiente e material arqueológico encontrado, foram descritas em ficha de tradagem (ver conjunto de fichas, anexos 5 a 8) e em caderneta de campo. Com essas estratégias de aproximação obtivemos os dados apresentados adiante.

Uma dificuldade encontrada durante os trabalhos de delimitação de sítios foi o fato de muitas vezes eles estarem implantados sobre muitas propriedades diferentes, pois na região do lago do Limão os terrenos são pequenas posses. Em alguns casos não conseguimos autorização de todos os proprietários para realizar as tradagens, de forma que dois sítios tiveram a delimitação de sub-superfície parcialmente realizada.

Com o objetivo de esclarecer à comunidade as intenções de nosso trabalho, foi proposto à direção da escola local, a realização de uma palestra sobre a natureza do trabalho arqueológico. Os resultados foram muito positivos, pois além do esclarecimento à comunidade de quais são as intenções da pesquisa arqueológica, 
despertamos o interesse de participação de alguns comunitários que agora participam como colaboradores nos trabalhos de campo.

Neste capítulo apresentaremos apenas os dados referentes à caracterização geral e, quando foi executada, a delimitação dos sítios arqueológicos. Os trabalhos de escavação serão apresentados em capítulo seguinte.

\section{III.III - SÍTIO CAMPO DO SÃO JORGE (Am-Ir-63)}

O local já era conhecido por meu colega de trabalho, Cláudio, que é morador do lago do Limão. Situado à margem sul do lago, a aproximadamente 550 metros sudeste do povoado (anexo 04), nas coordenadas 20M 0795887 - UTM 9647110. O sítio encontra-se na propriedade do Sr. Emidio Lima das Flores, (conhecido como Negão).

Em vistoria no local constatamos uma grande extensão com presença de fragmentos de cerâmica em superfície. Os vestígios podem ser vistos desde o quintal da propriedade, passando por um campo de futebol, até chegar a uma área de cultivo já com formação de capoeira, totalizando uma área de aproximadamente 300X250 metros. Nas áreas observadas constatamos a presença de terra preta. Além dos locais com boa visibilidade foi possível perceber que havia muitos outros encapoeirados, com a presença de limorana (Chomelia anisomeris), um arbusto muito freqüente na terra preta, o que supostamente seria um indicador da continuidade da área do sítio arqueológico.

Dois pontos foram destacados a princípio na primeira observação: 1- entre os vestígios observados em superfície constatamos a presença de muitos fragmentos de alça, um traço característico da cerâmica Paredão. 2- constatamos também a presença de montículos em diferentes locais do sítio. Montículos são construções artificiais, comuns na área de pesquisa, cuja fase ou fases pertencentes ainda não são claras. Em outro sítio escavado pelo PAC, sítio Hatahara (Am-Ir-13), o estudo aprofundado sobre o processo de formação dos montículos (Machado 2005), vem constatando que estes podem ter funções diversificadas, entre elas a de eventos funerários.

No sítio, além da coleta de superfície, foram abertas tradagens para verificar a distribuição horizontal e vertical dos vestígios. No total foram recuperados 295 fragmentos de cerâmica nas tradagens. Conforme pode ser visto no anexo 09 e figura 15, o sítio apresenta material arqueológico e terra preta em grande densidade e profundidade. Os vestígios aparecem desde a superfície até a profundidade de $80 \mathrm{~cm}$, concentrados principalmente entre 0 e $20 \mathrm{~cm}$ (gráfico 01). 


\begin{tabular}{|c|c|c|c|c|}
\hline \multicolumn{5}{|c|}{ Densidade de Cerâmica por Nível } \\
\hline \multicolumn{5}{|c|}{ 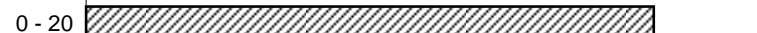 } \\
\hline $20-40 \mathbb{Z}$ & 18 & & & \\
\hline $40-60 \mathbb{Z}$ & & & & \\
\hline $60-80 \mathbb{Z}$ & & & & \\
\hline 0 & 50 & 100 & 150 & 200 \\
\hline
\end{tabular}

Gráfico 01 - Densidade de material cerâmico evidenciada nas tradagens do sítio Campo do São Jorge. 


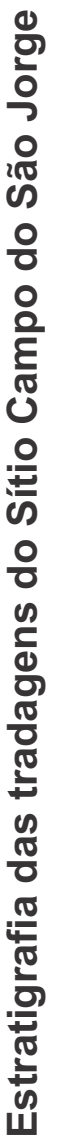

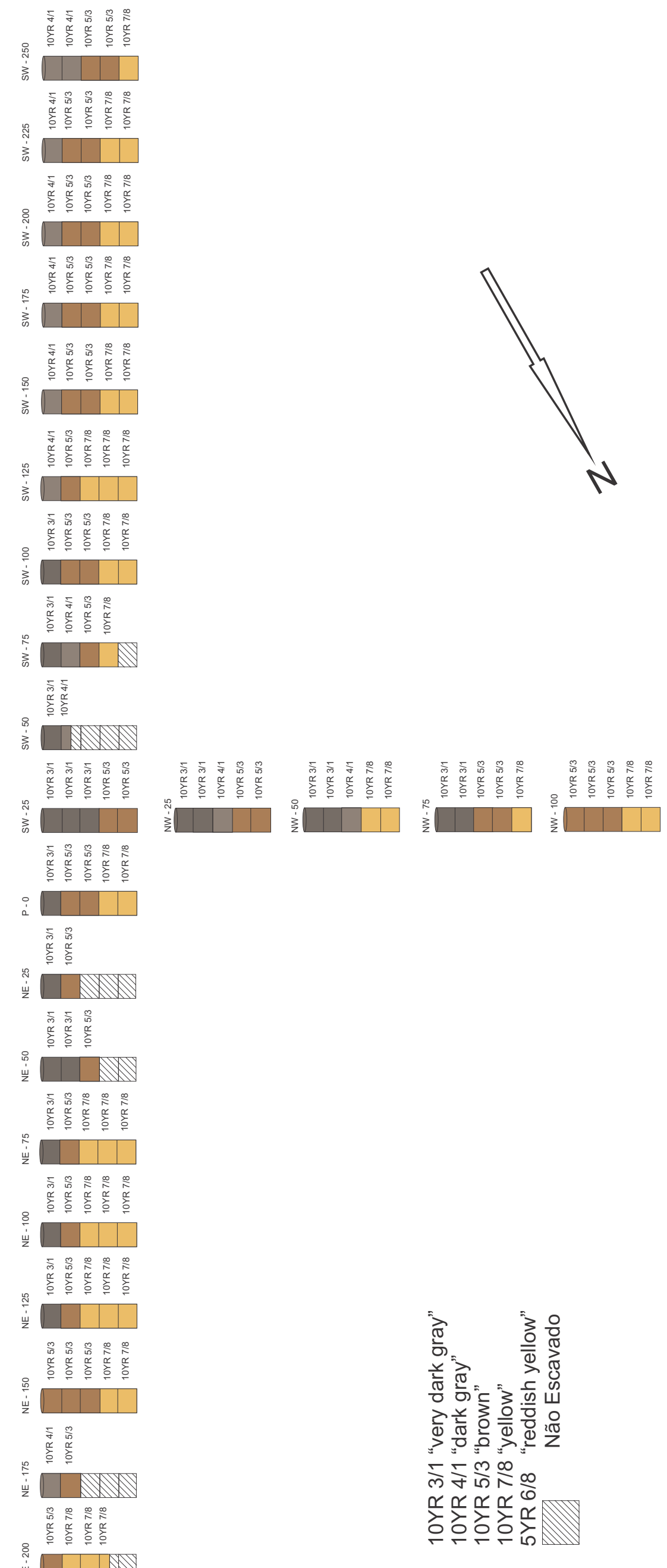


Dos 295 exemplares coletados nas tradagens, 21 foram classificados como fragmentos diagnósticos ${ }^{2}$ (13 bordas, duas bases e seis fragmentos com algum tipo de decoração), dos quais dois são fragmentos de cerâmica da fase Paredão, seis são fragmentos de cerâmica da fase Guarita e o restante não foi possível identificado (figuras 16 e 17).

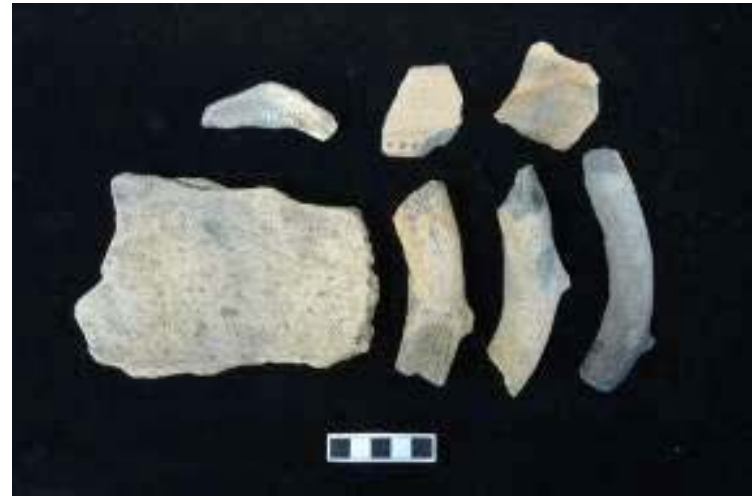

Figura 16 - Fragmentos de cerâmica da fase Paredão encontrados nas tradagens e superfície do sítio Campo do São Jorge.

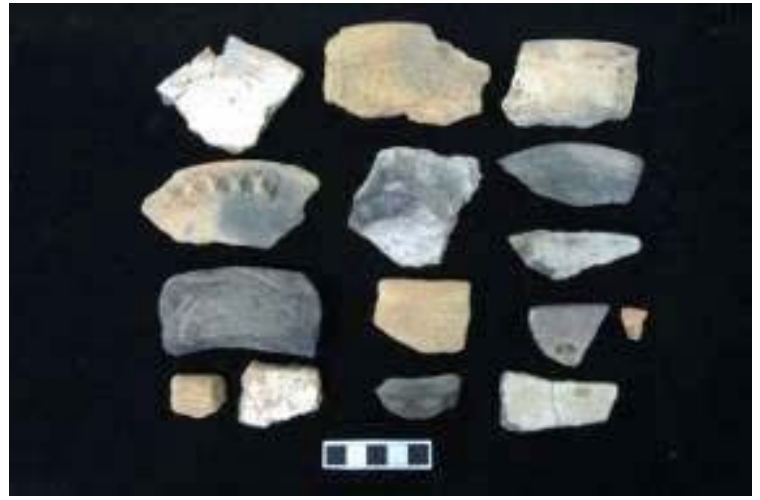

Figura 17 - Fragmentos de cerâmica da fase Guarita encontrados nas tradagens e superfície do sítio Campo do São Jorge.

Além do material coletado nas tradagens foi feita uma coleta de fragmentos em superfície na área de maior concentração do sítio (proximidades dos montículos). Foram recolhidos 15 fragmentos, sendo dois de cerâmica da fase Manacapuru, cinco de cerâmica da Fase Paredão e oito de cerâmicas da fase Guarita (figuras 16, 17 e 18).

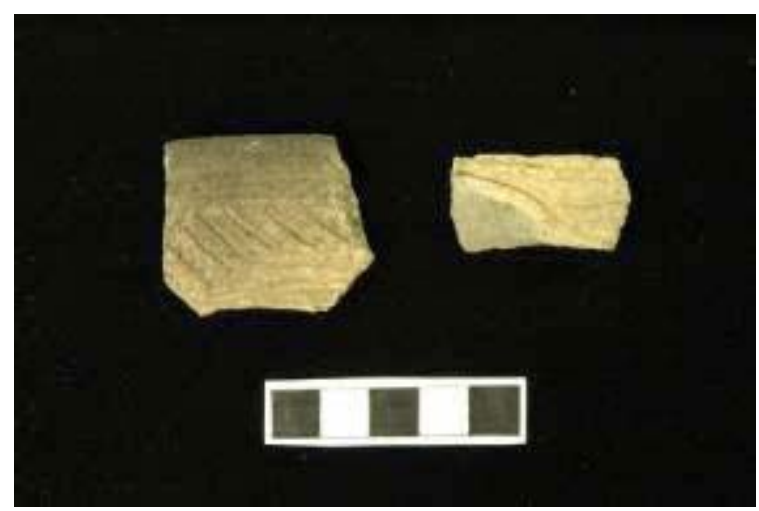

Figura 18 - Fragmentos de cerâmica da fase Manacapuru encontrados na superfície do sítio Campo do São Jorge.

\footnotetext{
${ }^{2}$ Foram considerados diagnósticos aqueles fragmentos que apresentam algum traço característico de forma (borda, base, alça...) ou algum traço decorativo.
} 
O material arqueológico está principalmente associado a áreas com ocorrência de terra preta. A terra preta atinge profundidades maiores na porção central do sítio, principalmente na linha de tradagens NW (figura 15), atingindo profundidades de até 60 $\mathrm{cm}$. Nas diferentes partes do sítio que foram tradadas foi possível identificar uma variação na textura do sedimento, que passou de arenosa na superfície a argilosa nas camadas mais profundas. De acordo com a escala da tabela de solos "Munsell" as camadas com material arqueológico têm cores variando entre 10YR 3/1 "very dark gray”, 10YR 4/1 “dark gray”, 10YR 5/3 “brown” e 7/8 “yellow", a última quase sempre estéril. As diferentes camadas evidenciadas nas tradagens abertas no sítio podem ser vistas na figura 15. Em algumas tradagens a base rochosa foi evidenciada antes da profundidade de um metro.

Com o resultado da triagem do material coletado no sítio Campo do São Jorge concluímos que existe uma predominância de materiais associados à fase Guarita, seguida pela ocorrência de materiais associados à fase Paredão e em menor proporção a presença de materiais associados à fase Manacapuru.

\section{III.IV - SÍTIO CINCO UNIDOS (Am-Ir-64)}

O sítio encontra-se na propriedade do Sr. Rodolfo Antônio Torres Barbosa, às margens do lago, cerca de 4500 metros a sudeste do povoado, em uma espécie de furo que conecta o lago do Limão ao lago Grande, outra zona já estudada pelo projeto (Donatti 2003). O sítio está localizado nas coordenadas 20M 0798460 UTM 9644174 (anexo 04 e figura 19). A vegetação do local é composta por áreas de pastagem, capoeiras em diferentes estágios de crescimento e uma plantação de maracujá.

A superfície do sítio não oferece boa visibilidade, mas identificamos alguns fragmentos de cerâmica em áreas expostas pela abertura de uma estrada (figura 20). Na própria pastagem encontramos alguns fragmentos e na plantação de maracujá também foi possível identificar fragmentos de cerâmica, pois a visibilidade da superfície era melhor. Constatamos que se trata de um sítio com presença de terra preta.

Identificamos também a presença de feições discretas na paisagem, que podem ser montículos, pois o terreno já foi bastante antropizado, ações que podem ter tornado os montículos menos evidentes. Um trabalho de prospecção de sub-superfície seria necessário para confirmar a hipótese. 
O Sr. Rodolfo nos informou que a área do sítio onde a terra é mais preta e há uma maior concentração de fragmentos de cerâmica, fica em um local onde a capoeira está muito fechada. Como nosso trabalho tinha o princípio de identificar os pontos de sítios arqueológicos, deixamos a constatação para uma possível volta ao local, pois a abertura de acesso na capoeira demandaria muito esforço e tempo de trabalho.

A cerâmica foi encontrada em baixa densidade. Foi difícil estimar a extensão do sítio, pois uma pequena parte dele está em área de fácil acesso. Segundo informações do proprietário, a área de terra preta é grande, mas somente com um trabalho de delimitação através de tradagens poderemos ter dados mais precisos.

Foram coletados nove fragmentos na superfície do sítio Cinco Unidos, cinco pertencentes à fase Paredão e quatro pertencentes à fase Guarita (figuras 21 e 22).

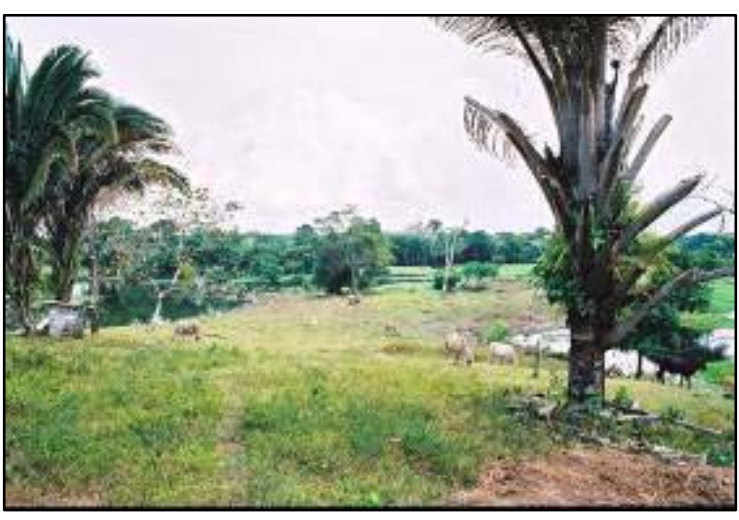

Figura 19: Vista parcial do sítio Cinco Unidos com lago ao fundo.

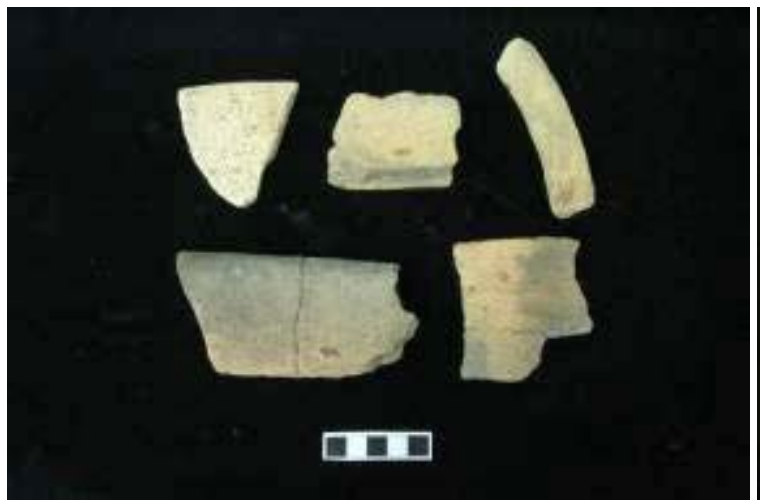

Figura 21 - Fragmentos de cerâmica da fase Paredão encontrados no sítio Cinco Unidos.

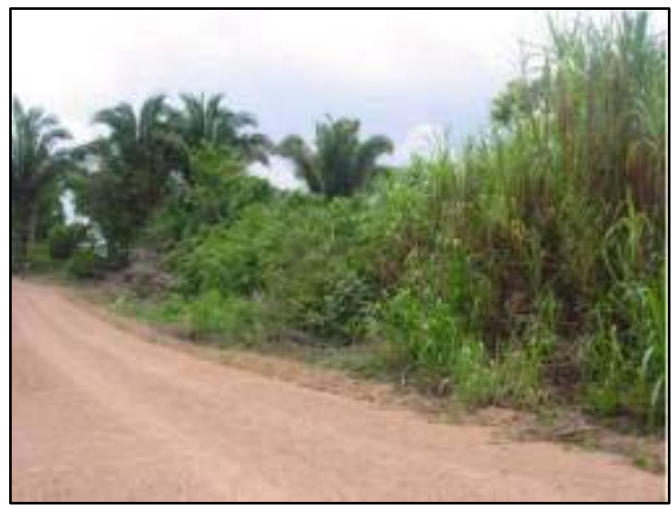

Figura 20: Vista parcial do sítio Cinco Unidos, com destaque para a estrada onde foi possível encontrar alguns fragmentos de cerâmica.

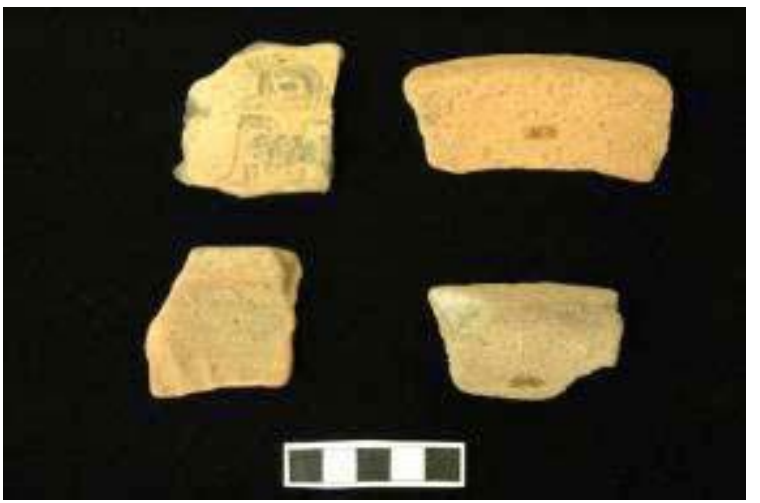

Figura 22 - Fragmentos de cerâmica da fase Guarita encontrados no sítio Cinco Unidos. 


\section{III.V - SÍTIO CINCO UNIDOS II (Am-Ir-65)}

O sítio encontra-se a cerca de 250 metros noroeste do sítio Cinco Unidos e a cerca de 4250 metros sudeste do povoado do lago do Limão, nas coordenadas 20M 0798258 UTM 9644342 (anexo 04). Os dois sítios são separados por um pequeno braço do lago e uma descontinuidade entre as áreas com terras pretas. A descontinuidade pode ser observada em locais de passagem do gado, onde há erosão no solo, o que evidencia uma camada de latossolo amarelo estéril entre os dois sítios.

Trata-se de uma área de cultivo de frutas e verduras onde não conseguimos descobrir o nome do proprietário. No local é possível identificar fragmentos de cerâmica em média densidade. Toda a área cultivada é composta por terras pretas (figura 23).

Além das áreas cultivadas foi possível identificar fragmentos de cerâmica também em locais onde as plantações já foram abandonadas e o mato já começa a crescer. Identificamos também a presença de montículos (figura 24). Geralmente na superfície e nos estratos destas estruturas a concentração de cerâmica é maior, pois os fragmentos fazem parte do material construtivo (Machado 2003).

A área de dispersão dos vestígios identificada por nós foi estimada em cerca de 350 metros, porém o entorno da área com boa visibilidade pode também fazer parte do sítio.

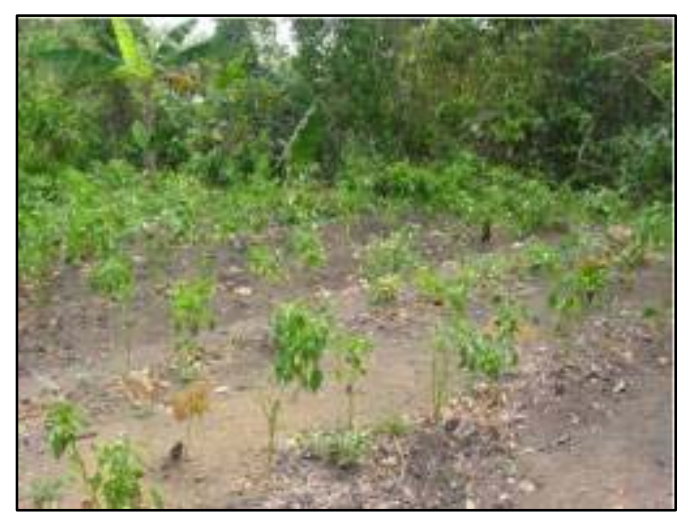

Figura 23: Vista parcial do sítio Cinco Unidos II, área de plantio de pimenta onde é possível ver a presença de terra preta e fragmentos de cerâmica.

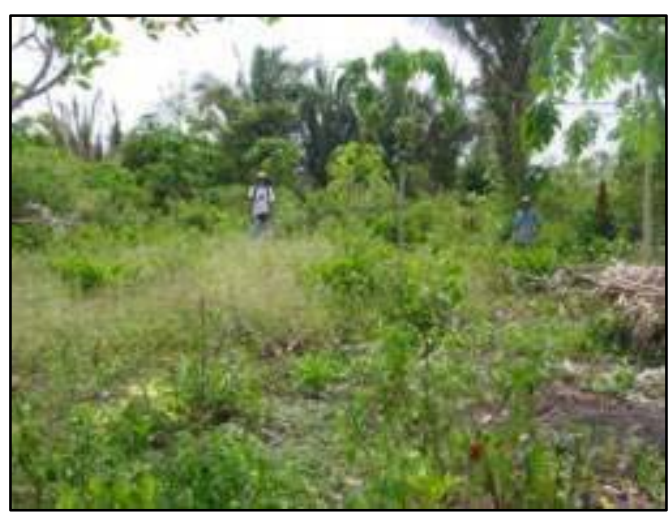

Figura 24: Vista de um montículo no sítio Cinco Unidos II, o desnível da superfície onde estão as pessoas evidencia o centro e a borda da estrutura.

Foram coletados 13 fragmentos na superfície do sítio Cinco Unidos II, oito pertencentes à fase Paredão e cinco pertencentes à fase Guarita (figuras 25 e 26). 


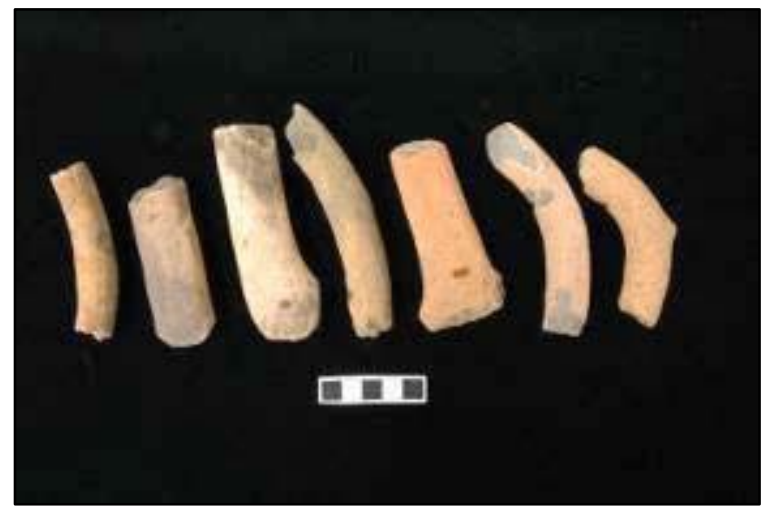

Figura 25 - Fragmentos de cerâmica da fase Paredão encontrados no sítio Cinco Unidos II.

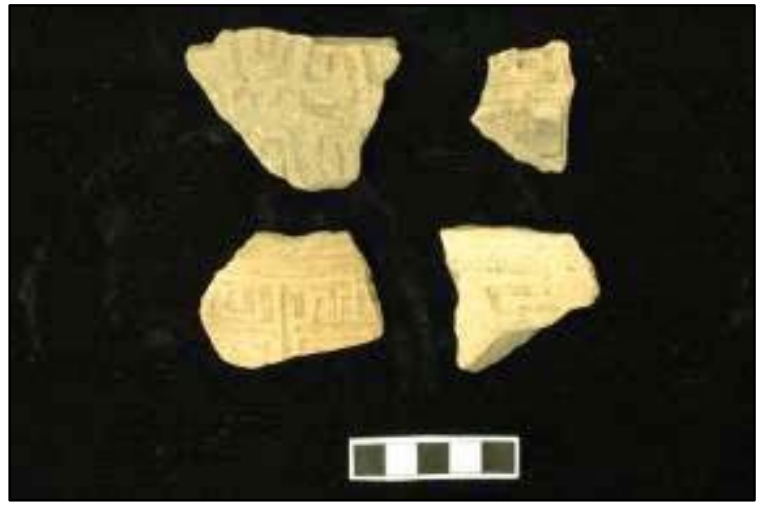

Figura 26 - Fragmentos de cerâmica da fase Guarita encontrados no sítio Cinco Unidos II.

\section{III.VI - SÍTIO FURO DO AÇACU (Am-Ir-66)}

O nome do sítio foi dado em função do nome do furo ao lado do qual ele fica à margem. Está localizado cerca de 3500 metros sudeste do povoado, nas coordenadas 20M 0797816 UTM 9645902 (anexo 04). O local encontra-se abandonado, sendo formado por antigos pomares e áreas de cultivo já com capoeira em crescimento (figura 27). Segundo informações, o nome do proprietário do terreno é Moisés.

Apesar da pouca visibilidade da superfície do local, identificamos fragmentos de cerâmica em grande densidade. Os fragmentos estão também associados a terra preta. Uma vistoria rápida do local nos fez concluir que se trata de um sítio grande, pois percorremos cerca de 300 metros do local, sempre com presença de vestígios na superfície. Esta não é a área total do sítio, já que existem partes mais encapoeiradas que não foram vistoriadas. $\mathrm{O}$ material que pode ser diagnosticado é pertencente às fases Paredão e Guarita (figura 28). No local também existem estruturas no solo que parecem ser montículos.

A princípio trata-se de um sítio cerâmico de grandes proporções, multicomponencial, com alta densidade de vestígios em superfície, associados às fases Paredão e Guarita. Os vestígios estão associados à terra preta e no local também foram evidenciadas estruturas no solo do tipo montículos. 


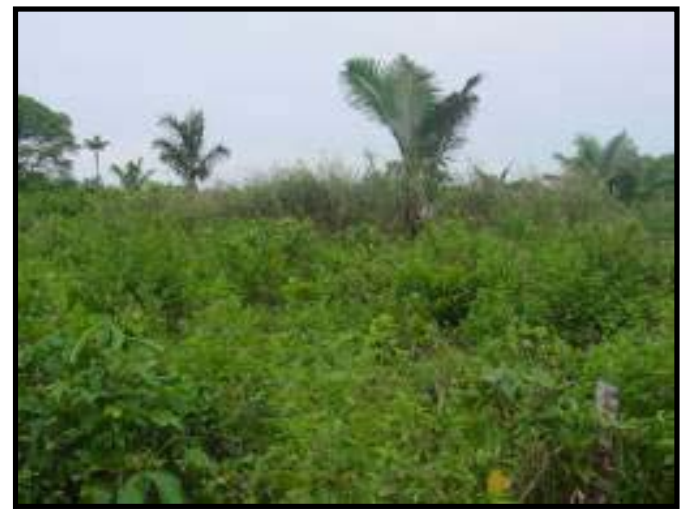

Figura 27: Vista parcial do sítio Furo do Açacu, com destaque para a formação de capoeira nas antigas áreas de cultivo.

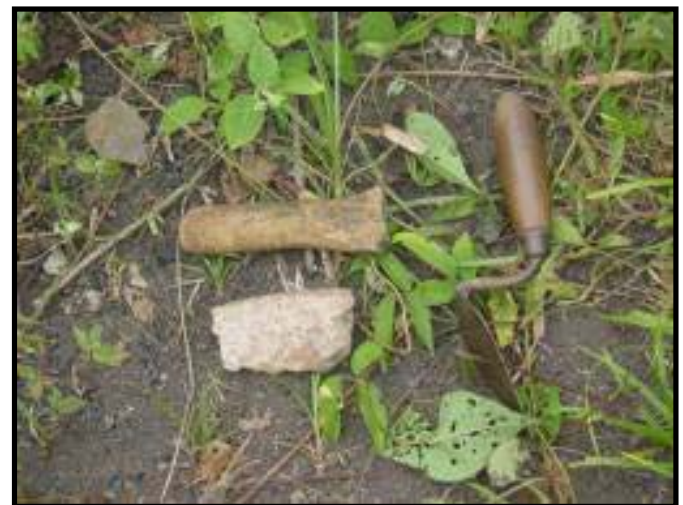

Figura 28: Material cerâmico encontrado no sítio Furo do Açacu, um fragmento de borda com engobo branco associado à fase Guarita e um fragmento de alça associado à fase Paredão.

\section{III.VII - SÍTIO DO EVANDRO (Am-Ir-67)}

O sítio foi encontrado em uma área de cultivo de mandioca. Está localizado a cerca de 1600 metros sudeste do povoado, um pouco mais afastado da margem do lago (cerca de 250 metros), nas coordenadas 20M 0796859 UTM 9646746 (anexo 04). Foi dado ao sítio o mesmo nome do proprietário. O local onde foram evidenciados os fragmentos de cerâmica está com boa visibilidade, pois a plantação de mandioca foi feita recentemente (figura 29). Apesar da boa visibilidade, os vestígios ocorrem em baixíssima densidade e, ao contrário dos sítios anteriores, no local não há a presença de terra preta.

Os trabalhadores que estavam fazendo a colheita da mandioca, em uma área adjacente ao local, nos informaram que quando estão processando a terra sempre encontram fragmentos de cerâmica. Os fragmentos por nós encontrados são bem pequenos e erodidos, (figura 30) dificultando a identificação da fase a que pertence os vestígios.

A princípio trata-se de um sítio cerâmico unicomponencial, pequeno e com baixíssima densidade de vestígios, muito fragmentados e erodidos, de afiliação não identificada. 


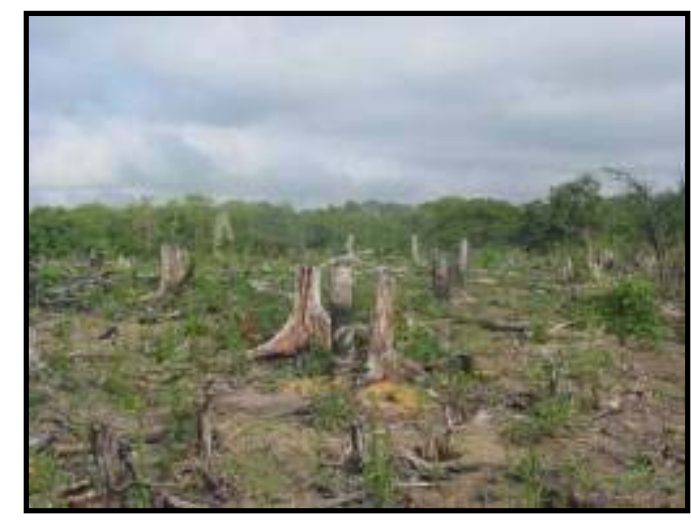

Figura 29: Vista parcial do sítio do Evandro no local da plantação de mandioca.

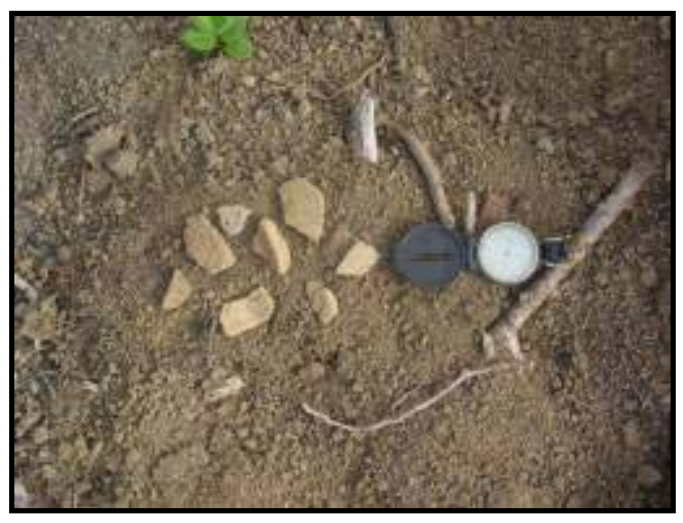

Figura 30: Material cerâmico encontrado no sítio do Evandro.

\section{III.VIII - SÍTIO DO MACUMBEIRO (Am-Ir-68)}

O nome do sítio foi dado em função dos poderes atribuídos ao falecido dono da propriedade. O local é conhecido por todos os moradores do lago como sítio do Macumbeiro, uma denominação tão popular que não conseguimos ficar sabendo o nome do falecido proprietário, nem se a propriedade possui outro nome. Trata-se de um local abandonado, situado a cerca de 1600 metros sudeste do povoado e exatamente em frente ao sítio do Evandro, na margem oposta do lago, nas coordenadas 20M 0796960 UTM 9647026 (anexo 04).

No sítio são encontrados antigos pomares de mangueiras e pés de laranja, entre outras árvores frutíferas, além de áreas de capoeiras em diferentes estágios de crescimento (figura 31). Das antigas construções, só existem ruínas do que parece ter sido uma casa de farinha. Tivemos a informação de haver terra preta na propriedade, porém, devido ao estado de abandono do sítio, o solo está com muita cobertura vegetal, o que dificulta a visibilidade dos vestígios em superfície.

Encontramos fragmentos de cerâmica próximos ao porto do lago e cerca de 200 metros acima no antigo pomar (figura 32). São fragmentos pequenos, já bastante erodidos. Não foi possível constatar a presença de terra preta.

Ao que tudo indica trata-se de um sítio cerâmico, possivelmente unicomponencial, de pequenas proporções e baixa densidade de vestígios em superfície, porém é preciso levar em consideração a cobertura vegetal. A informação da presença de solos antropogênicos precisa ser confirmada por trabalhos mais intensivos no sítio. 


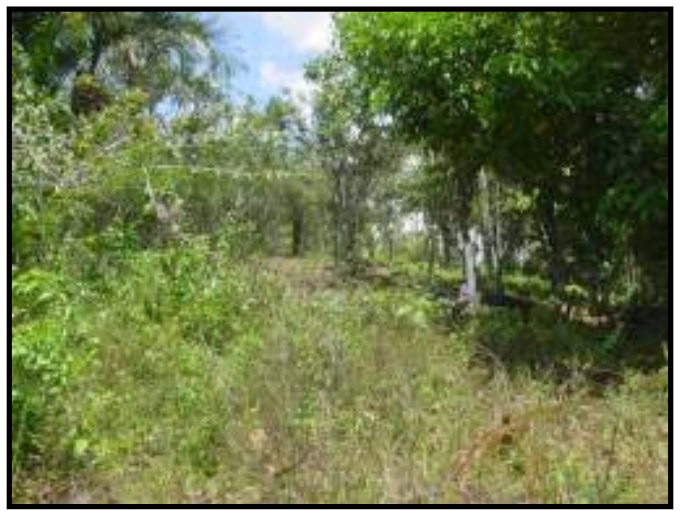

Figura 31: Vista parcial do sítio do Macumbeiro, com destaque para os pomares abandonados.

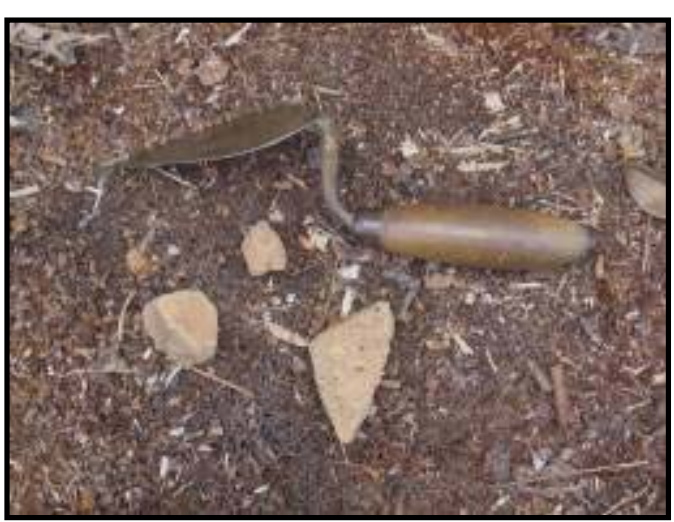

Figura 32: Exemplo do material cerâmico encontrado no sítio do Macumbeiro.

\section{III.IX - SÍTIO PONTA DO GUEGUIDEM (Am-Ir-69)}

Foi dado ao sítio o mesmo nome do braço do lago existente no local. Situado cerca de 1500 metros sudeste do povoado do lago do Limão e cerca de 250 metros noroeste do sítio do Macumbeiro, nas coordenadas 20M 0796755 UTM 9647072 (anexo 04). Trata-se de uma área recentemente aberta para a construção de uma casa e quintal. Por ocasião de nossa visita, a mata tinha sido recém derrubada (figura 33) e uma casa estava sendo construída. Não ficamos sabendo quem era o proprietário do terreno, pois não havia ninguém no local.

Identificamos uma pequena mancha de terra preta, com cerca de 30 metros de diâmetro e no local foi possível constatar a presença de alguns fragmentos de cerâmica sem decoração (figura 34). Pareceu-nos um sítio relativamente bem preservado, pois somente agora estavam derrubando a mata no local.

As considerações preliminares são que este é um sítio cerâmico, supostamente unicomponencial, de pequenas proporções, com a presença de solos antropogênicos. Os fragmentos identificados não possibilitaram a associação dos vestígios a nenhuma das fases conhecidas na região. 


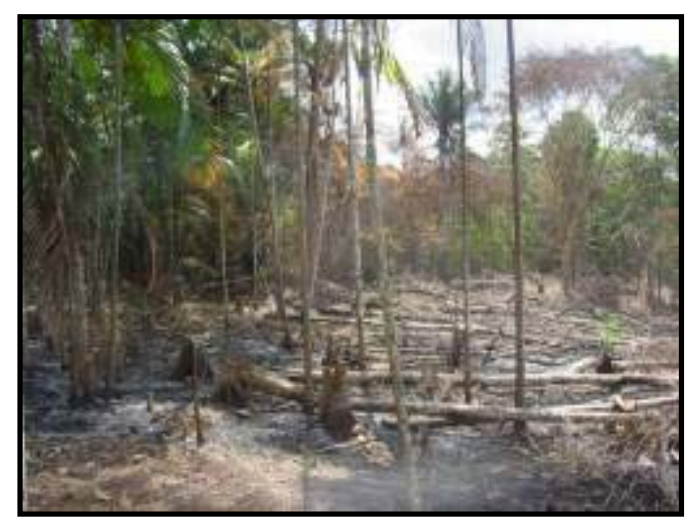

Figura 33: Vista parcial do sítio Ponta do Gueguidem, com destaque para a recente derrubada da mata que compõe o local.

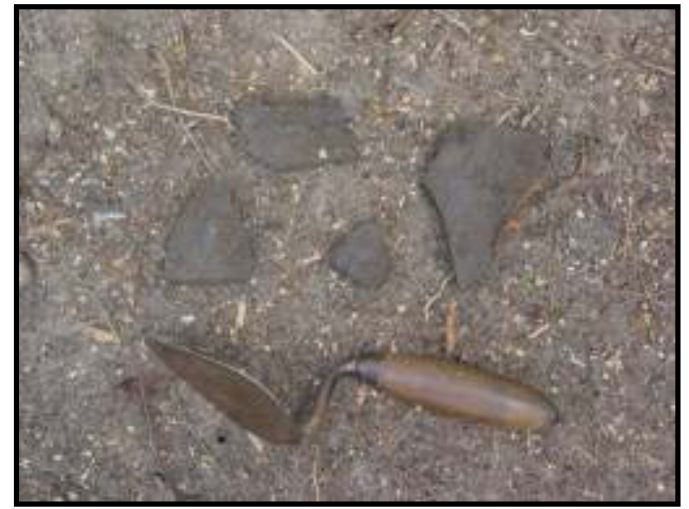

Figura 34: Exemplo de material cerâmico encontrado no sítio Ponta do Gueguidem.

\section{$\underline{\text { III.X - SÍTIO GUEGUIDEM II (Am-Ir-70) }}$}

O sítio também está às margens do lago, no mesmo braço que o sítio anterior, a cerca de 200 metros sudoeste do sítio Ponta do Gueguidem e cerca de 1200 metros do povoado, nas coordenadas 20M 0796755 UTM 9647072 (anexo 04). Parece ser a mesma propriedade do sítio anterior, porém o local já possui benfeitorias antigas.

Os vestígios foram encontrados em baixa densidade, são fragmentos de cerâmica já bastante erodidos (figura 35). O sítio não parece realmente denso em vestígios, mas o local está com pouca visibilidade no solo (figura 36), o que dificulta a identificação dos vestígios. Fomos informados de que no local havia terra preta, mas só foi possível constatar a presença de um solo um pouco escuro, muito arenoso e sem a presença de fragmentos de cerâmica ${ }^{3}$.

Em princípio trata-se de um sítio cerâmico, possivelmente unicomponencial, com baixa densidade de vestígios. O tamanho do sítio foi difícil de ser estimado, pois a superfície está com pouca visibilidade. A informação da presença de solos antropogênicos no sítio não pode ser confirmada, talvez um trabalho mais aprofundado no local venha mudar o quadro. Os fragmentos de cerâmica encontrados não nos possibilitaram associação a nenhuma fase arqueológica.

\footnotetext{
${ }^{3}$ As cerâmicas estão sempre presentes nos solos antropogênicos.
} 


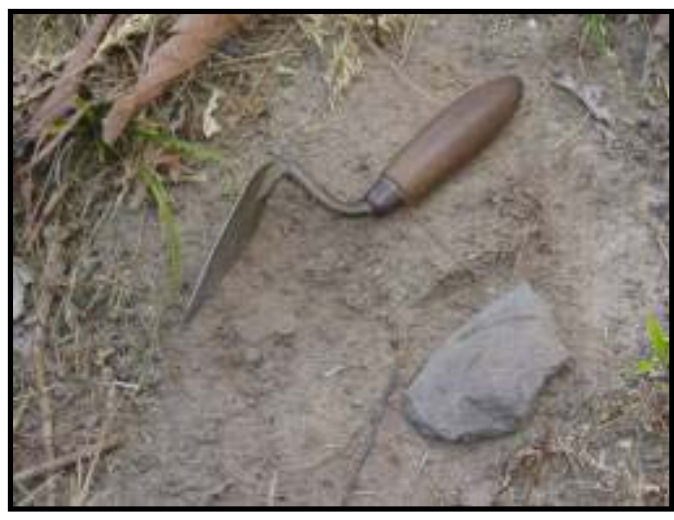

Figura 35: Exemplo de fragmento de cerâmica encontrado no sítio Gueguidem II.

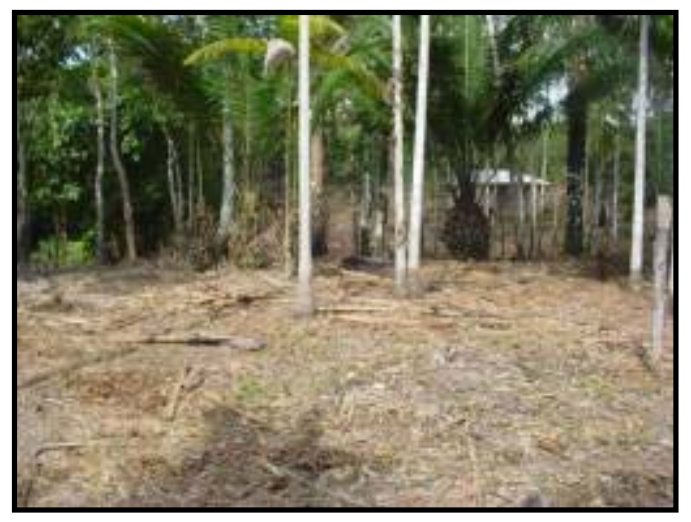

Figura 36: Vista parcial do sítio Gueguidem II.

\section{III-XI - SÍTIO FURO DO AVÔ CHICO (Am-Ir-71)}

Foi dado ao sítio o mesmo nome do furo do lago ao qual ele fica às margens, cerca de 250 metros oeste do povoado, nas coordenadas 20M 0794924 UTM 9647314 (anexo 04). Não conseguimos saber quem é o proprietário do terreno.

Chegamos até o local do sítio com a informação de que havia ali fragmentos de cerâmica aflorando pelo barranco do lago. Após a vistoria, constatamos tratar-se de cerâmica cabocla, portanto recente. Uma outra constatação foi a presença de material lítico lascado. Foi possível identificar no barranco do lago algumas lascas, suportes com presença de retoques e um percutor. Os vestígios estão dispostos por cerca de 150 metros em um barranco de 3 metros de altura (figura 37). Acima do barranco, na superfície do local, não foi encontrado material lítico.

A grande maioria dos vestígios foi lascada sob um argilito amarelo que aflora em plaquetas no próprio barranco, onde estão as evidencias arqueológicas (figura 38). Foram encontradas também algumas lascas e um percutor de arenito (figura 39). A princípio trata-se de um sítio lítico, unicomponencial.

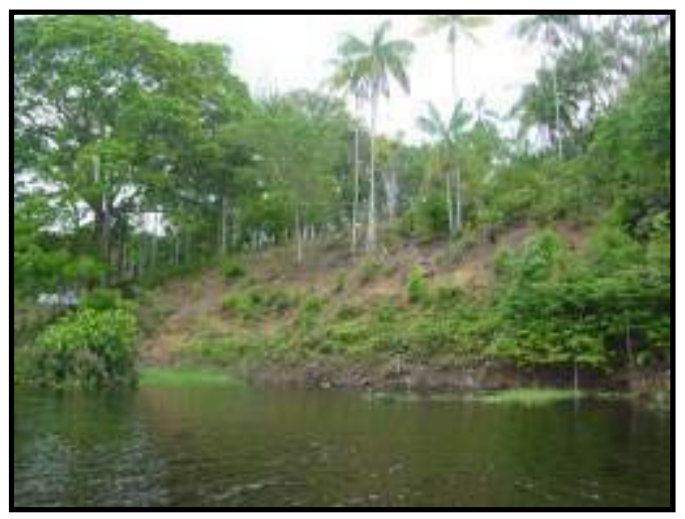

Figura 37: Vista parcial do barranco onde estão aflorando os vestígios do sítio Furo do Avô Chico. 


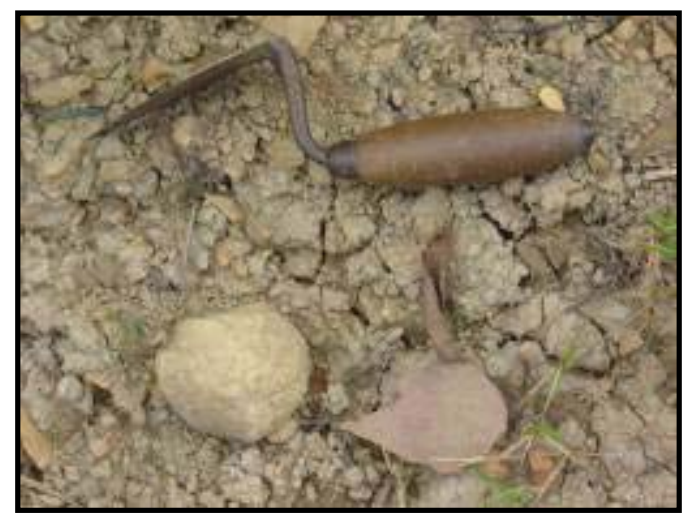

Figura 38: Percutor e lasca de arenito.

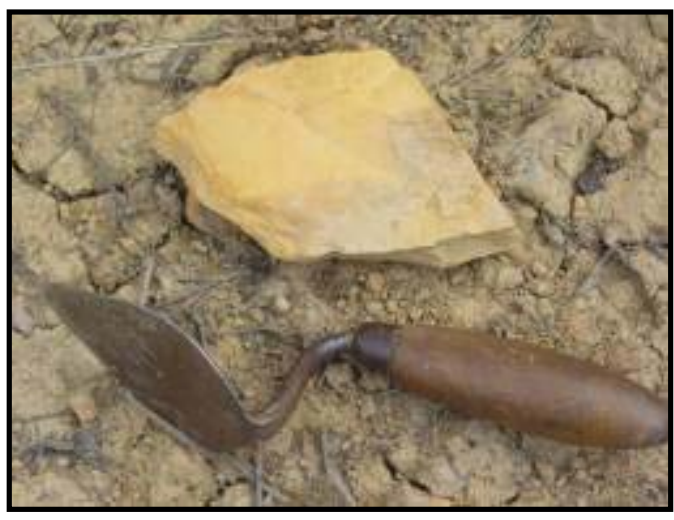

Figura 39: Suporte em argilito, com gume retocado.

\section{III.XII - SÍTIO ANTÔNIO GALO (Am-Ir-72)}

Foi dado ao sítio o mesmo nome do falecido proprietário de um dos terrenos que o compõe. O sítio encontra-se a sudeste do povoado, cerca de 1500 metros, nas coordenadas 20M 0796183 UTM 9646108 (anexo 04). O local apresenta boa visibilidade na superfície, sendo formado por pomares e áreas de cultivo de mamão e maracujá.

Encontramos material cerâmico em alta densidade aflorando na superfície. Os fragmentos estão também associados à terra preta (figura 40). Uma vistoria rápida do local nos fez concluir que se trata de um sítio grande, pois percorremos cerca de 500 metros, sempre com presença de vestígios na superfície. Um destaque importante no local é a presença de muitos montículos (figura 41). No entorno das áreas cultivadas existem capoeiras com a presença de limorana, o que pode ser um indicativo de continuidade da área do sítio.

O sítio também foi trabalhado em maior resolução, através da abertura de tradagens. Como ele parecia ser o maior de

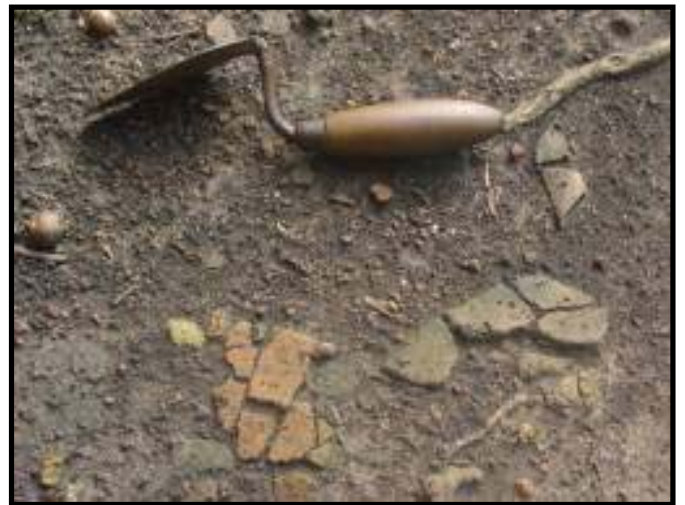

Figura 40: Material cerâmico associado à terra preta evidenciado no sítio Antônio Galo. todos os sítios encontrados, e nele era possível notar a presença de grande quantidade de montículos, consideramos importante delimita-lo para conhecer melhor a estratigrafia e 
disposição dos vestígios, para também colocalo numa escala de comparação com o sítio Osvaldo.

Iniciamos a delimitação do sítio com a marcação de uma linha de tradagens no sentido sudoeste-nordeste a $30^{\circ}$, o que os vestígios em superfície representavam ser a maior extensão do sítio. A marcação foi efetuada utilizando bússola, trena e GPS. Em um ponto aparentemente central abrimos

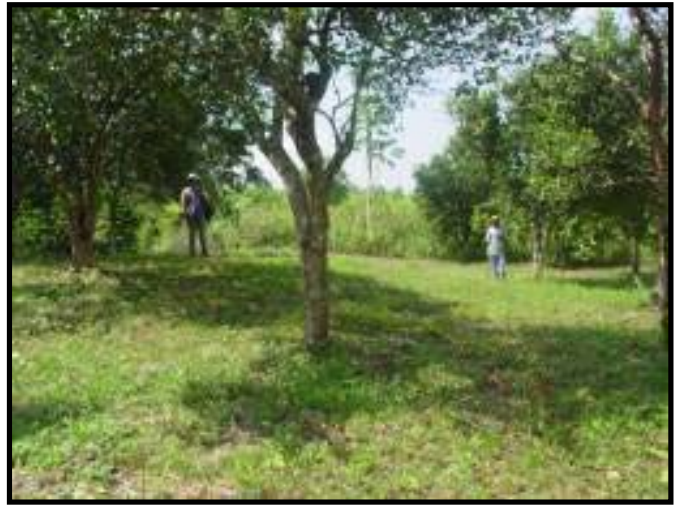

Figura 41 - Vista parcial do sítio Antônio Galo, com destaque para um montículo que pode ser visto pelo desnível da superfície onde estão as pessoas.

uma tradagem denominada ponto zero (P-0) e partindo dai, em uma malha de 50 metros, fomos abrindo tradagens no sentido nordeste do sítio. Na delimitação do sítio, nossa equipe contava com três pessoas, de modo que uma ficou responsável pela abertura de picadas para a marcação da linha e outra pela abertura das tradagens. A terceira pessoa fez a verificação do sedimento, coleta e contagem dos fragmentos, por níveis de 20 centímetros, e a descrição das características do solo e ambiente, anotadas na ficha de tradagem (anexo 06).

Após a abertura da oitava tradagem (NE-400), decidimos reduzir a malha para 25 metros, para uma melhor amostragem do sítio. Como pode ser visto no anexo 10, após NE-325, os vestígios arqueológicos não estão mais presentes.

Demos início então à abertura das tradagens na parte sudoeste do sítio. Após SW175 (anexo 10), as tradagens não evidenciaram mais a presença de material arqueológico, porém a oeste da linha os vestígios eram abundantes em superfície, o que mostra que a área do sítio continuava nessa direção, mas só mais próximo da margem do lago.

No ponto com maior concentração de material em superfície e maior profundidade da camada de terra preta, entre as tradagens NE-50 e NE-150, abrimos uma linha transversal à primeira, no sentido sudeste-noroeste, tendo como ponto inicial a tradagem NE-125. Com a segunda linha buscávamos identificar a extensão do sítio neste sentido. $\mathrm{Na}$ parte noroeste, o sítio chega até a margem do lago e, na parte sudeste, os vestígios foram encontrados até SE-175 (anexo 10).

Abrimos mais uma linha no sentido sudeste-nordeste, tendo como ponto inicial a tradagem SW-100. A linha foi denominada sudeste-noroeste 2. No sentido noroeste, os 
vestígios estão representados até a margem do lago e, no sentido sudeste, foi aberta uma tradagem (SE/2-25) que não evidenciou a presença de material arqueológico. Após a tradagem há uma mudança no relevo, uma elevação e o solo passa a ser composto por muita laterita, sem presença de vestígios em superfície.

Paralelamente à abertura das tradagens, foram sendo plotados os montículos evidenciados no sítio. Foi feita a medição da distância das estruturas com relação à tradagem mais próxima. Também foram medidas as dimensões aproximadas de comprimento e largura dos montículos. Desenhamos os montículos no croqui de sítio, produzido em papel milimetrado. Na ocasião também foi anotada a coordenada UTM do ponto central de cada uma das estruturas. Foram identificados 25 montículos, plotados em escala no anexo 10. Após a delimitação, com os dados da vistoria de superfície e das tradagens, estimamos que o sítio Antônio Galo possua uma área de 700x400 metros.

Foram coletados 791 fragmentos de cerâmica nas tradagens, dos quais 64 foram classificados como diagnósticos (39 bordas, 13 bases e 12 fragmentos com algum tipo de decoração). São 34 fragmentos de cerâmica Paredão, 14 fragmentos de cerâmica Guarita e o restante não foi possível identificar a afiliação (figuras 42 e 43). Como pode ser visto no gráfico abaixo, a cerâmica está concentrada principalmente nos primeiros $20 \mathrm{~cm}$ do pacote arqueológico.

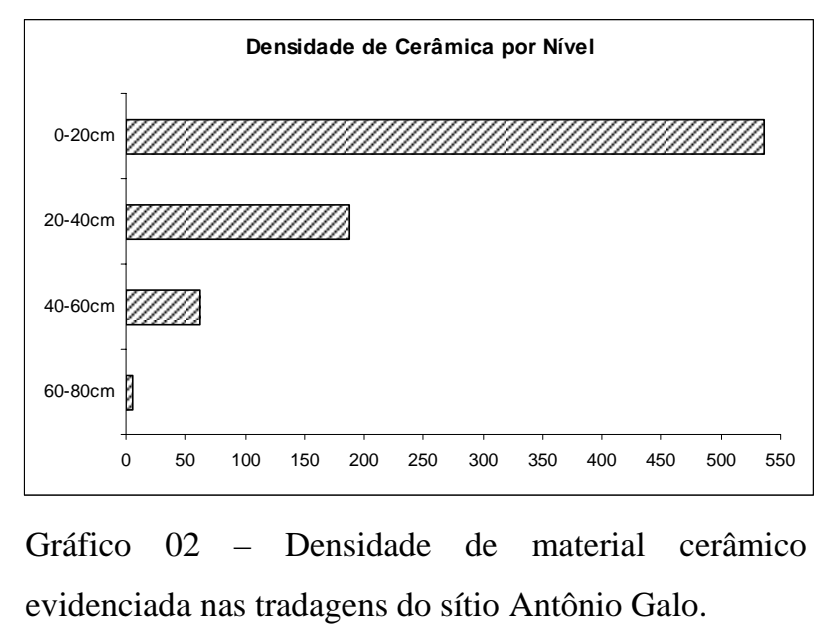




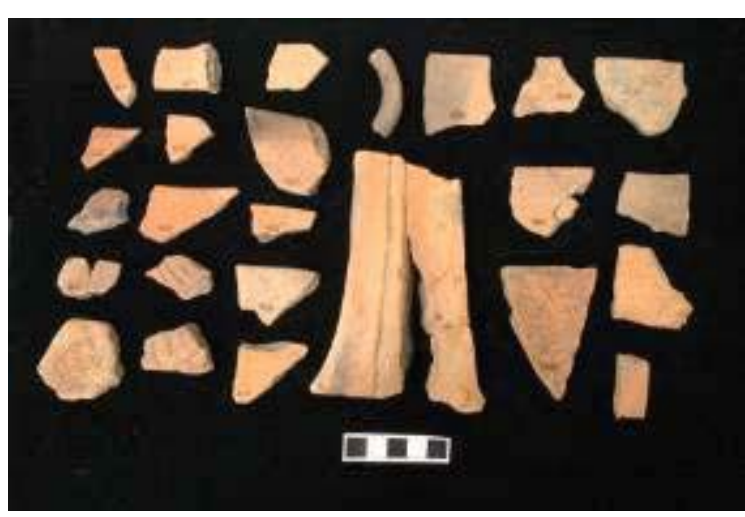

Figura 42 - Fragmentos de cerâmica da fase Paredão encontrados nas tradagens do sítio Antônio Galo.

O sítio apresenta uma particularidade interessante para nossa problemática de estudo: conforme pode ser visto no anexo 10, a cerâmica da fase Guarita está representada principalmente na porção central, enquanto a cerâmica Paredão ocorre em toda a área. O contexto estratigráfico de deposição das cerâmicas não representa com exatidão a sequiência das ocupações, mas as cerâmicas da fase Guarita aparecem principalmente nos primeiros $20 \mathrm{~cm}$. Já as cerâmicas da fase Paredão estão representadas desde a superfície até $60 \mathrm{~cm}$.

Conforme pode ser visto na figura 44, raramente o pacote de terra preta atinge profundidades maiores que $20 \mathrm{~cm}$, o que parece incompatível com as dimensões do sítio. Mesmo onde as tradagens foram feitas sobre os montículos, o pacote de terra preta não apresentou variação significativa na profundidade. As áreas não são tão contínuas como no sítio Lago do Limão, porém, como a malha de tradagens tem pouca cobertura da totalidade do sítio, não é ainda possível fazer considerações mais detalhadas a este respeito. Se o leitor observar o anexo 10, verá que a maior densidade de material está principalmente associada aos montículos. Existem duas áreas com concentração de cerâmica: a principal na porção centro-norte do sítio e outra, menos densa, na porção sudoeste. Na última só foram identificadas cerâmicas pertencentes à fase Paredão.

Com as tradagens foi possível identificar a presença de solos quase sempre com textura argilosa, sendo que a plasticidade aumenta de acordo com a profundidade. Nas proximidades do lago as tradagens apresentaram solo com textura mais arenosa.

De acordo com a escala da tabela de solos "Munsell" as camadas com material arqueológico têm cores variando entre 10YR 2/1 "black"; 10YR 2/2 "very dark brown";10YR 3/1 "very dark gray"; 10YR 3/4 e 4/6 "dark yellowish "brown"; 10YR 4/1 "dark gray"; 10YR 4/2 "dark grayish brown"; 10YR 4/3 e 5/3 "brown"; 10YR 5/2 "grayish brown"; 10YR 5/4, 5/6 e 5/8 "yellowish brown"; 10YR 6/4 "light yellowish 
brown"; 10YR 6/6 "brownish yellow"; 10YR 7/6 e 7/8 "yellow", após 6/4, quase sempre estéril. As diferentes camadas evidenciadas nas tradagens abertas no sítio podem ser vistas na figura 44. 


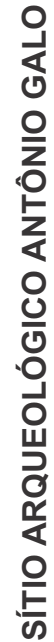

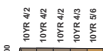

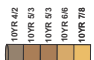

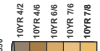

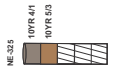

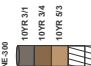

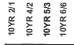

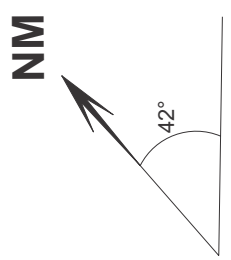

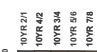

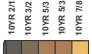

돈

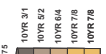

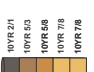

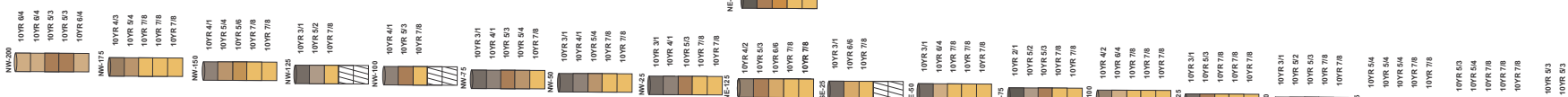

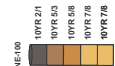

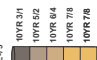

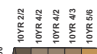

$\frac{1}{30}$

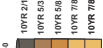

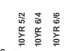

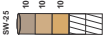

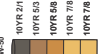

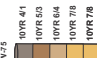

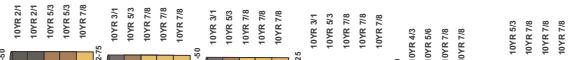

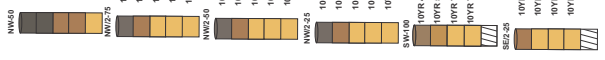

每)

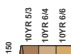

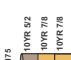

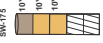

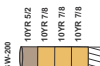

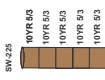

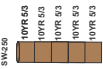

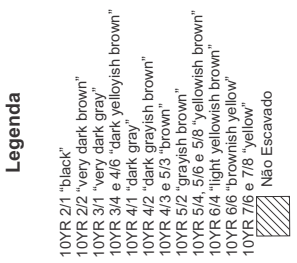

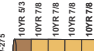


Além das tradagens, foi feita ainda uma coleta de superfície na área central do sítio e outra na parte sudoeste. Dos fragmentos coletados 14 são pertencentes à fase Paredão e 22 à fase Guarita (figuras 45 e 46). Os fragmentos de cerâmica da fase Guarita são todos provenientes da parte central do sítio.

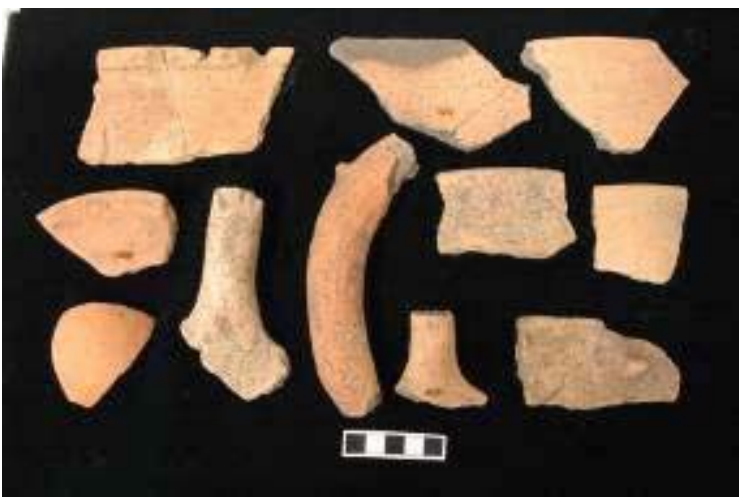

Figura 45 - Fragmentos de cerâmica da fase Paredão coletados na superfície do sítio Antônio Galo.

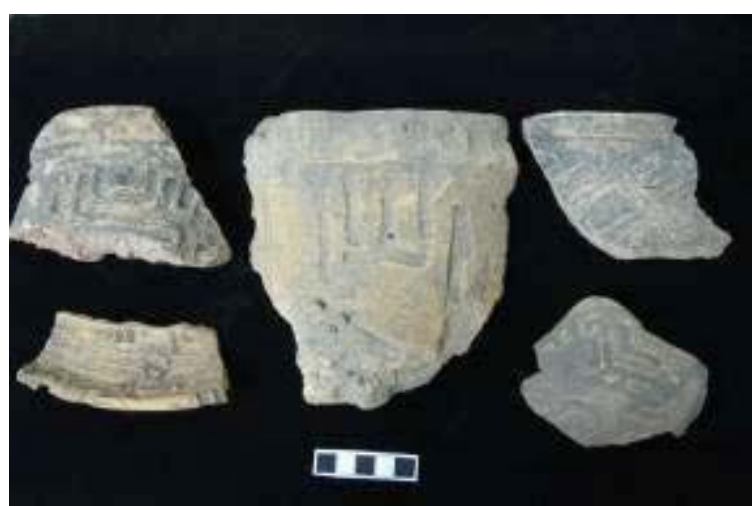

Figura 46 - Fragmentos de cerâmica da fase Guarita coletados na superfície do sítio Antônio Galo.

Após o processamento dos dados coletados em campo e a triagem do material coletado no sítio Antônio Galo foi possível produzir informações importantes que podem ajudar na compreensão do processo de ocupação pré-colonial da área de pesquisa. Se voltarmos novamente ao anexo 10, poderemos observar que a cerâmica da fase Guarita ocorre principalmente na porção central do sítio. Nessa área os montículos são maiores e sua disposição não apresenta uma organização muito clara. $\mathrm{Na}$ extremidade sudoeste o material Guarita parece não estar presente. Como essa parte do sítio apresenta áreas muito encapoeiradas, não foi possível identificar um padrão mais apurado da distribuição dos vestígios na paisagem. Na extremidade norte fica bastante clara a disposição dos montículos $12,13,14,15,16,17$ e 18 em circulo, o que pode corresponder a uma parte mais preservada do sítio.

De acordo com os dados apresentados anteriormente levantamos a seguinte hipótese: o sítio Antônio Galo apresenta cerâmicas da fase Paredão por toda a sua extensão, os vestígios da fase Guarita correspondem a uma ocupação posterior e ocupam uma área menor, principalmente na porção central do sítio. Parece haver uma parte do sítio mais preservada, se os montículos são os correlatos de unidades domésticas no sítio, teríamos então os vestígios de uma aldeia circular na extremidade norte da área mapeada. Se a hipótese for confirmada, o restante do sítio poderia ser o resultado de re-ocupações ou re-locação das unidades habitacionais ao longo do tempo (Meggers 1971; Meggers 1992b). Vale lembrar que o sítio Osvaldo, com o qual estamos 
comparando os resultados de nosso levantamento, é um possível correlato de uma aldeia (Neves 2000).

\section{III.XIII - SÍTIO CAIARARA (Am-Ir-74)}

O sítio foi encontrado em uma área que está sendo preparada para cultivo de mandioca. Está localizado a cerca de 700 metros leste do povoado, um pouco mais afastado da margem do lago (cerca de 200 metros), nas coordenadas 20M 0796181 UTM 9647640 (anexo 04). O sítio encontra-se na propriedade da Sra. Aldenize Oliveira Araújo. O local onde foram evidenciados os fragmentos de cerâmica está com boa visibilidade, pois a vegetação foi queimada recentemente (figura 47). Apesar da boa visibilidade, os vestígios ocorrem em baixa densidade e no local também não há a presença de terra preta.

Os fragmentos de cerâmica foram encontrados embaixo das raízes das árvores, que quando caíram expuseram os vestígios que estavam enterrados (figura 48). Também foram encontrados fragmentos de cerâmica na superfície no quintal da propriedade.

A princípio é um sítio cerâmico unicomponencial, pequeno e com baixa densidade de vestígios. Não foi possível identificar a que fase os vestígios pertencem.

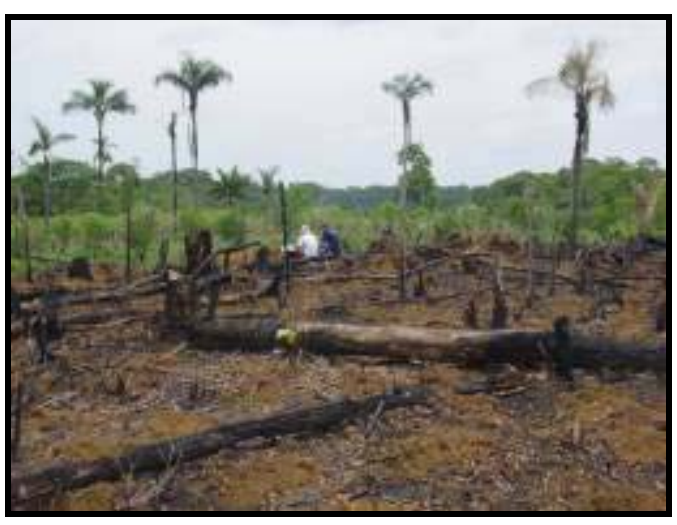

Figura 47: Vista parcial do sítio Caiarara.

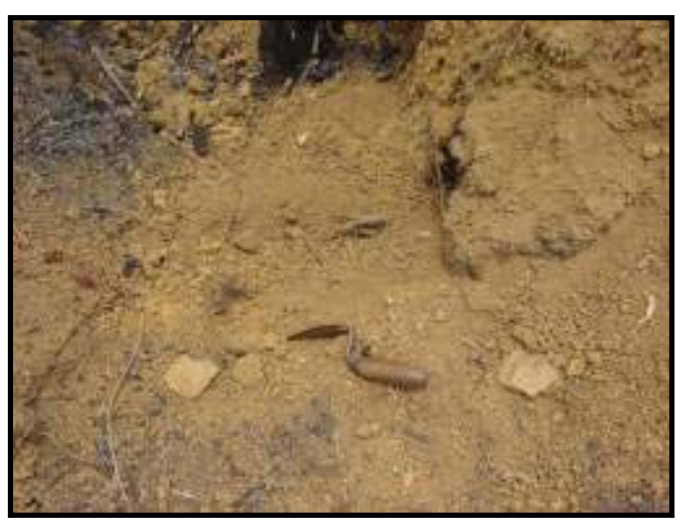

Figura 48: Fragmentos de cerâmica evidenciados no sedimento removido pelas raízes dos troncos caídos.

\section{$\underline{\text { III.XIV - SÍTIO DONA ROSA (Am-Ir-75) }}$}

Está localizado a cerca de 500 metros leste do povoado, no lado oposto ao sítio Osvaldo (figura 49). Parte do sítio encontra-se na propriedade da Sra. Rosa e outra parte 
na propriedade do Sr. Raimundo. O sítio fica nas coordenadas 20M 0795733 UTM 9647432 (anexo 04). O local encontra-se com boa visibilidade, com pomares e áreas de cultivo de verduras nos quintais de ambas as propriedades.

Encontramos material cerâmico aflorando na superfície do sítio. Os fragmentos estão também associados à terra preta. A princípio não foi possível estimar a extensão do sítio arqueológico, pois, fora dos quintais, as áreas de capoeira são de difícil acesso. NO sítio também evidenciamos a presença de montículos.

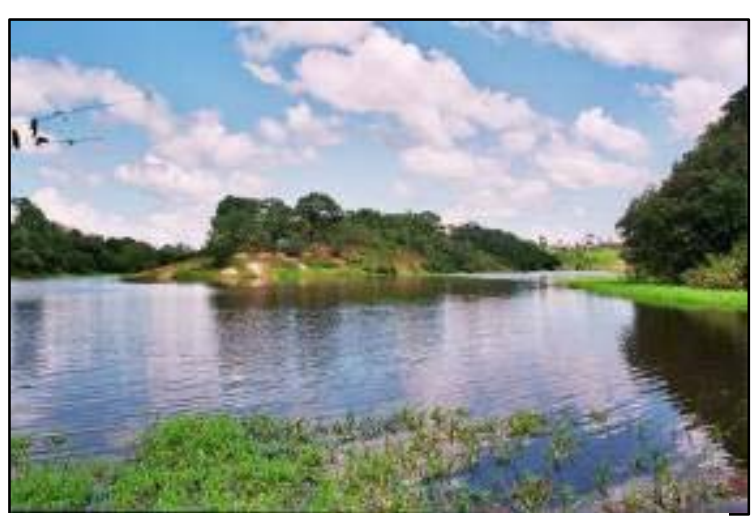

Figura 49: Área do sítio Dona Rosa vista da margem oposta do lago, próximo ao sítio Osvaldo.

O sítio Dona Rosa está implantado sobre uma península cercada pelo curso principal do lago do Limão e um furo a oeste do sítio (anexo 04 e figura 49). Iniciamos os trabalhos de delimitação do sítio com a marcação de um ponto zero no centro da península. No sítio nossa equipe de trabalho contava apenas com dois integrantes. Foi demarcada uma linha no sentido nordeste-sudoeste, a $50^{\circ}$, o que coincidia com o centro do eixo de orientação da porção de terra, cercada por água a noroeste e sudeste.

A malha de tradagens foi estabelecida em 25 metros. No sentido sudoeste os vestígios estão na superfície ou em profundidade até a margem do lago. No sentido nordeste os vestígios não aparecem mais após a tradagem NE-175. Do mesmo modo que no sítio Antônio Galo, também foram plotados os montículos, apenas quatro estruturas foram evidenciadas (anexo 11).

Nas laterais da linha de tradagem verificamos que os vestígios estavam dispostos em superfície até a margem do lago, portanto optamos por não abrir outra linha transversal à primeira. Desse modo, após dois dias de trabalho, verificamos que o sítio Dona Rosa tem dimensões de 350x350 metros.

Conforme pode ser visto no anexo 11, o sítio apresenta baixa densidade para os padrões de nossa área de pesquisa, visto que a tradagem com maior concentração de vestígios (NE-50) apresenta apenas 22 fragmentos. No geral, os fragmentos cerâmicos aparecem até $40 \mathrm{~cm}$ de profundidade (apenas um fragmento foi evidenciado abaixo de $40 \mathrm{~cm}$ ), concentrados principalmente nos primeiros $20 \mathrm{~cm}$. Foram coletados 52 fragmentos de cerâmica nas tradagens abertas no sítio. O gráfico 03 apresenta a densidade do material por níveis artificiais de $20 \mathrm{~cm}$. 


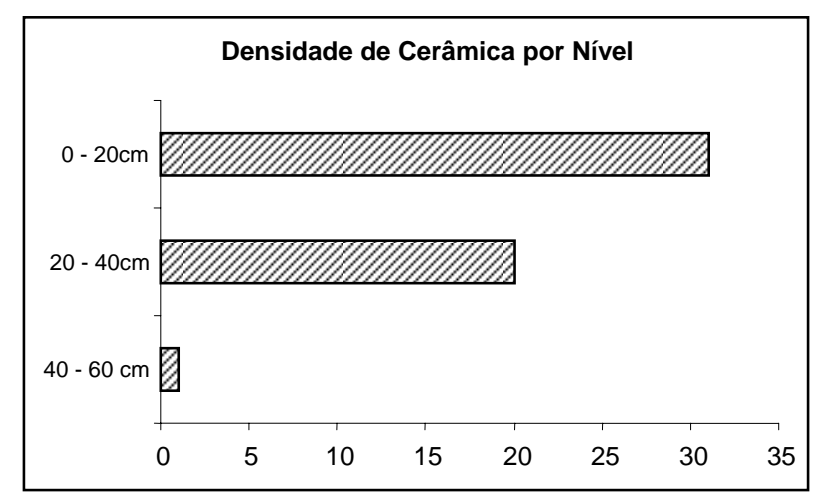

Gráfico 03 - Densidade de material cerâmico evidenciada nas tradagens do sítio Dona Rosa.

Dos 52 exemplares coletados nas tradagens nove foram classificados como fragmentos diagnósticos (quatro bordas, três bases e dois fragmentos com algum tipo de decoração), dos quais quatro são fragmentos de cerâmica Guarita (figura 50). Para o restante não foi possível identificar a fase pertencente.

Além do material coletado nas tradagens, foi feita uma coleta de superfície nas duas áreas de maior concentração do sítio (proximidades dos montículos 1, 2 e 4). Foram recolhidos 12 fragmentos, sendo 11 de cerâmicas da fase Guarita e apenas um fragmento de cerâmica da fase Paredão (figuras 50 e 51).

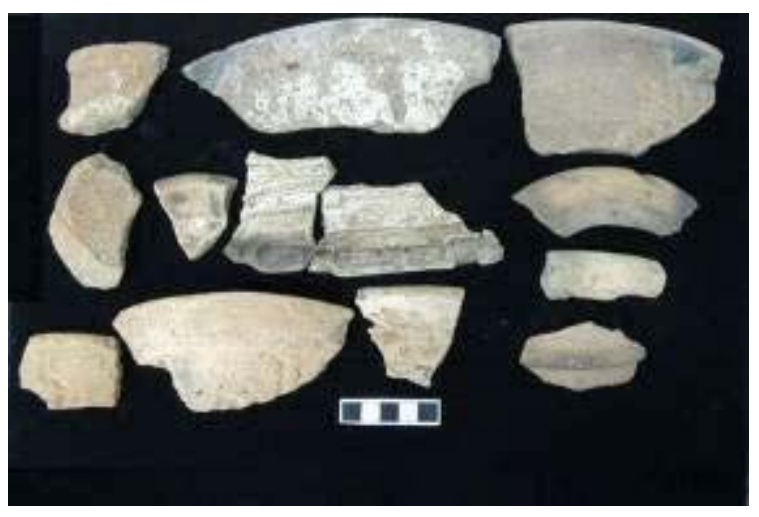

Figura 50 - Fragmentos de cerâmica da fase Guarita encontrados na superfície e tradagens do sítio Dona Rosa.

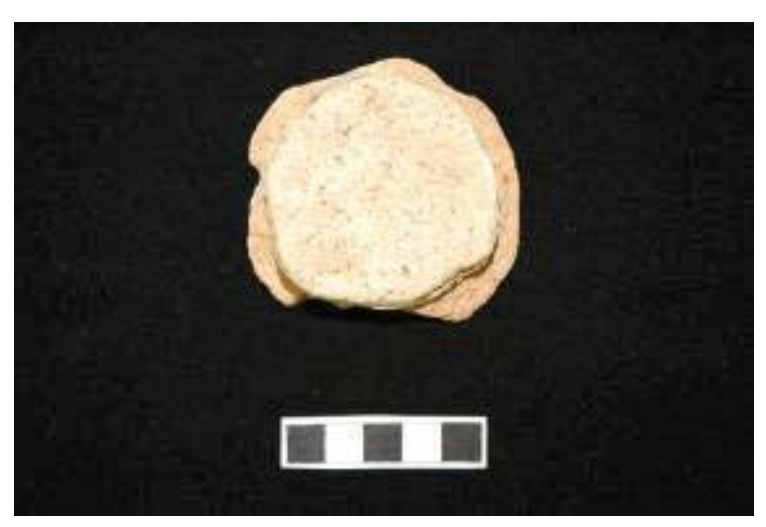

Figura 51 - Fragmento de cerâmica Paredão encontrado na superfície do sítio Dona Rosa.

O material arqueológico está principalmente associado a áreas com ocorrência de terra preta. A terra preta atinge profundidades maiores nos locais onde aparecem estruturas que parecem montículos artificialmente construídos, porém nos pontos onde foram abertas tradagens a terra preta não ultrapassa a profundidade de $40 \mathrm{~cm}$. Nas áreas com presença de material arqueológico o solo tem textura argilosa e granulação fina, com ocorrência de fragmentos de laterita em alguns casos. De acordo com a escala da 
tabela de solos "Munsell" as camadas com material arqueológico têm cores variando entre 10YR 3/1 “very dark gray”, 10YR 4/1 “dark gray” e 10YR 5/3 “brown”. As diferentes camadas evidenciadas nas tradagens abertas no sítio podem ser vistas na figura 52.

Com o resultado da triagem do material coletado no sítio Dona Rosa concluímos que existe uma predominância de materiais associados à fase Guarita, com ocorrência em menor escala de materiais associados à fase Paredão. 


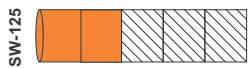

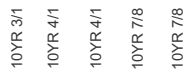

ํํำ

亳

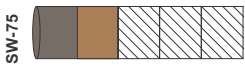

$\begin{array}{lll}\overline{5} & \overline{0} & 0 \\ 0 & 0 \\ 0 & 0 & 0 \\ 0 & 0 & 0 \\ 0 & 0 & 0 \\ 0 & 0 & 0\end{array}$

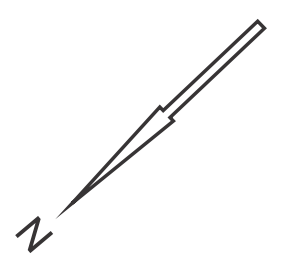

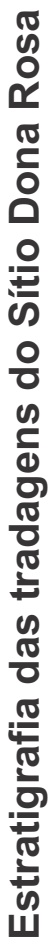

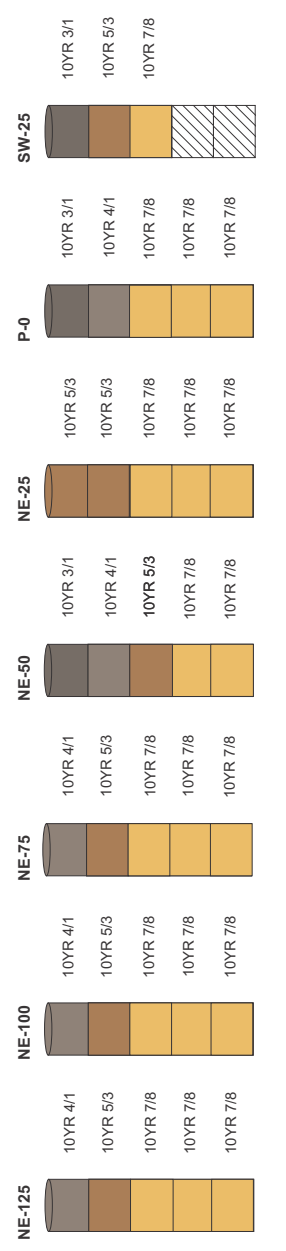

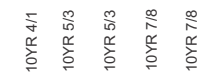

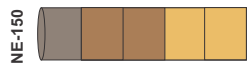

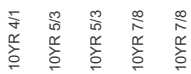
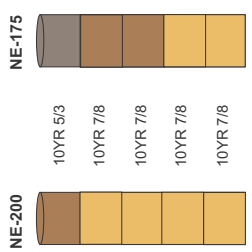

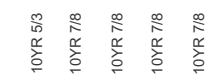

ָㅗํ
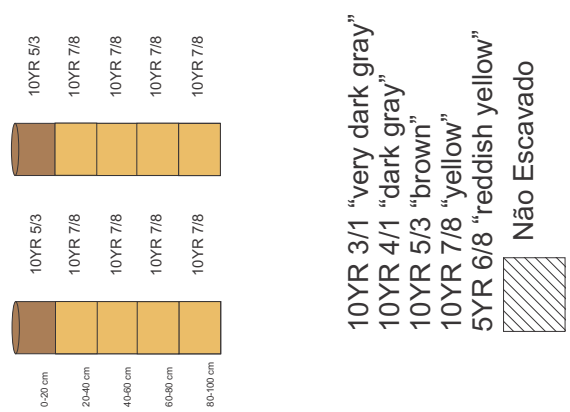


\section{III.XV - SÍTIO VÓ DITE (Am-Ir-76)}

Foi dado ao sítio o mesmo nome da propriedade onde ele se encontra. O local está a cerca de 1200 metros noroeste do povoado, na propriedade do Sr. Antônio Adivam da Silva, nas coordenadas 20M 0794420 UTM 9648390 (anexo 04). A superfície do sítio apresenta boa visibilidade, com áreas de cultivo de maracujá e mandioca (figura 53).

Os vestígios encontrados são fragmentos de cerâmica, que podem ser vistos na superfície. Os fragmentos estão também associados à terra preta. Uma vistoria rápida do local nos fez concluir que se trata de um sítio pequeno, pois a terra preta e os fragmentos parecem estar dispostos por uma área de cerca de 150 metros. As adjacências da área foram vistoriadas e não apresentaram vestígios.

Foram coletados 11 fragmentos na superfície do sítio Vó Dite, um pertencente à fase Manacapuru, quatro pertencentes à fase Paredão e seis pertencentes à fase Guarita (figuras 54, 55 e 56).

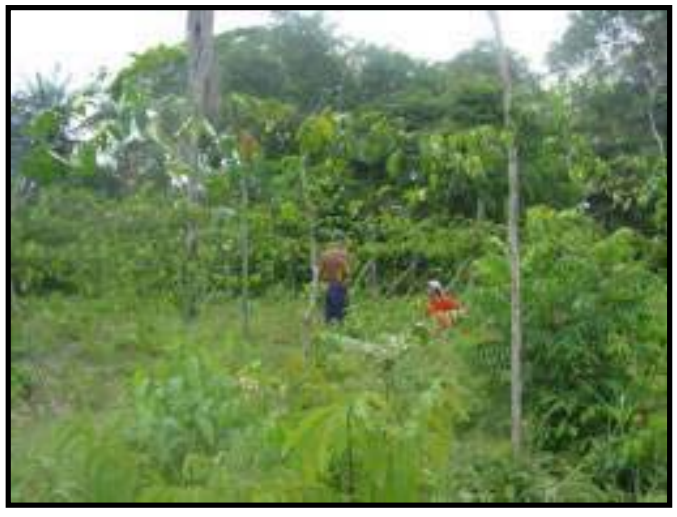

Figura 53: Vista parcial do sítio Vó Dite.

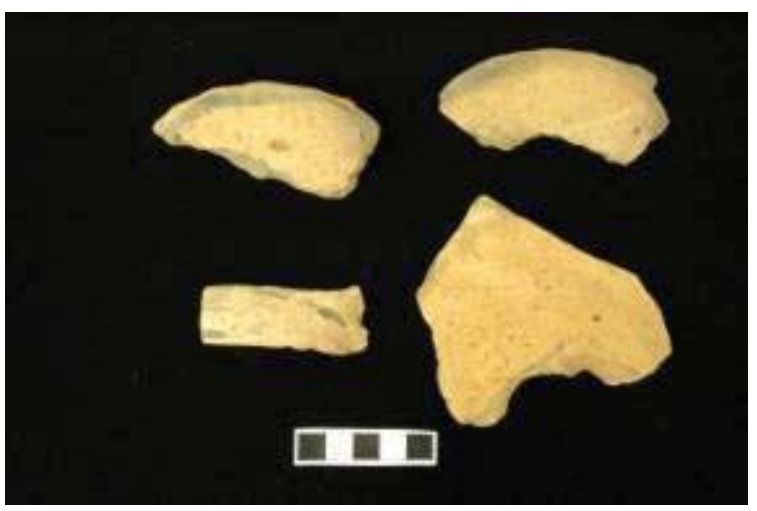

Figura 55 - Fragmentos de cerâmica da fase Paredão encontrados no sítio Vó Dite.

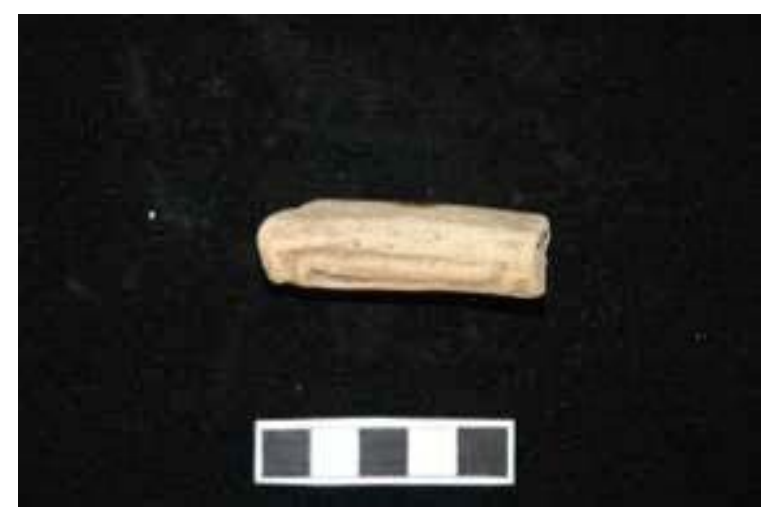

Figura 54 - Fragmento de cerâmica da fase Manacapuru encontrado no sítio Vó Dite.

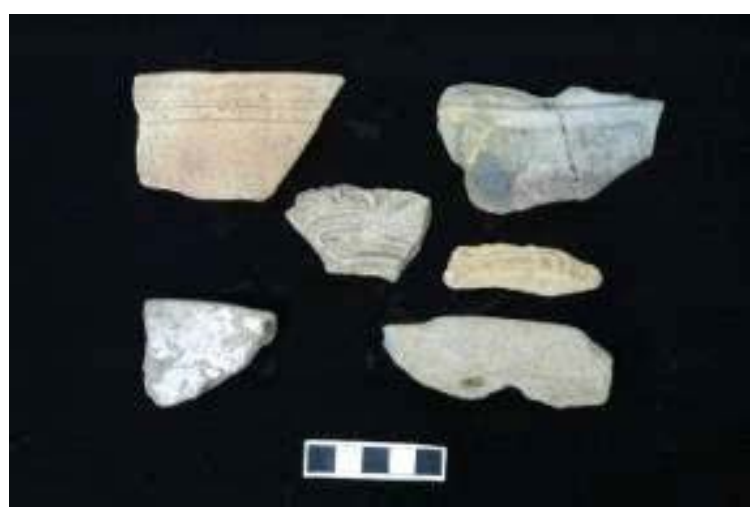

Figura 56 - Fragmentos de cerâmica da fase Guarita encontrados no sítio Vó Dite. 


\section{$\underline{\text { III.XVI - SÍTIO LAGO DO LIMÃO (Am-Ir-11) }}$}

O sítio já havia sido cadastrado em etapas anteriores do PAC (Neves 2000:04), porém não havia sido feitas maiores considerações a respeito do material encontrado. Fizemos uma vistoria de superfície, da mesma maneira descrita nos sítios anteriores.

O sitio está localizado praticamente na área urbana do povoado, os vestígios estão dispostos por cerca de sete propriedades, chácaras que vão desde a estrada de acesso ao povoado até, aproximadamente 700 metros a oeste, onde está a margem do lago. Os vestígios apresentam maior concentração nas proximidades do lago, nas coordenadas 20M 0794962 UTM 9647614 (anexo 04). O local encontra-se com boa visibilidade, sendo composto por pomares (figura 57) e áreas de cultivo de mandioca.

Encontramos material cerâmico em alta densidade aflorando na superfície. Os fragmentos estão também associados à terra preta. Uma vistoria rápida do local nos fez concluir que se trata de um sítio grande, pois percorremos cerca de 400 metros do local, sempre com presença de vestígios na superfície.

O sítio apresenta muito boa visibilidade dos vestígios arqueológicos em sua porção

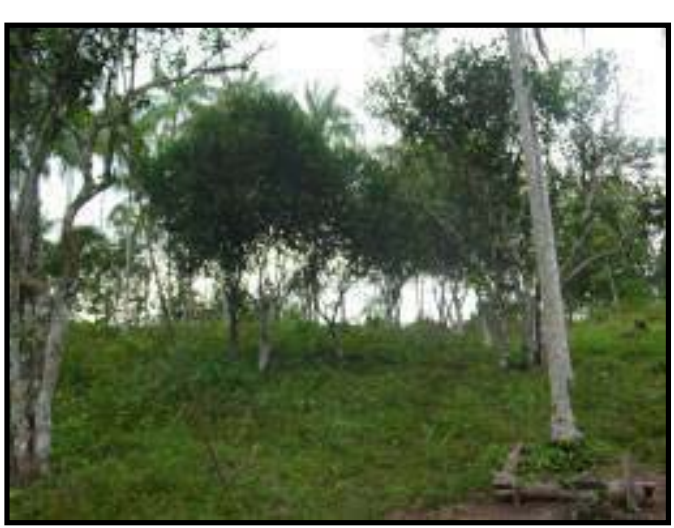

Figura 57: Vista parcial do sítio Lago do Limão, área com alta concentração de vestígios próxima ao lago. oeste, próxima ao lago, motivo pelo qual decidimos abrir primeiramente uma linha no sentido nordeste-sudoeste, a $78^{\circ}$, pois nessa direção os limites do sítio não estavam tão claros.

Aproveitamos uma estrada que corta o terreno desde o asfalto até a margem do lago (anexo 12), como referência para marcação da linha de tradagens, pois fazendo isso economizaríamos tempo com a abertura de picadas. Como a estrada foi aberta com máquina, decidimos utiliza-la como linha, mas relocamos as tradagens para 5 metros ao sul, de forma que fossem feitas em área mais preservada.

Partindo do ponto zero (anexo 12), no sentido nordeste, identificamos vestígios até a tradagem NE-225. No sentido oposto os vestígios foram identificados até a margem do lago, 300 metros após o ponto zero.

Após o término desta linha de tradagens, marcamos outra transversal a ela, tendo como ponto inicial a tradagem SW-250. Nesse sentido atingiríamos a parte com maior 
concentração de vestígios no sítio. No sentido noroeste da linha foram evidenciados vestígios arqueológicos até a tradagem NW-75. No sentido oposto, lamentavelmente, não conseguimos a autorização de um dos proprietários para realizar a abertura das tradagens. Foram abertas tradagens até SE-125, sempre com presença de material. Sabemos que os vestígios estão dispostos em superfície até o furo do lago, cerca de 300 metros depois da última tradagem realizada (anexo 12).

Para o nosso problema de pesquisa, o sítio Lago do Limão pode ser um dos mais relevantes para comparação com o sítio Osvaldo, já que se trata de um sítio denso e multicomponencial, com uma representatividade importante do componente Manacapuru.

Foram coletados 869 fragmentos de cerâmica nas tradagens, dos quais 106 foram classificados como diagnósticos ( 52 bordas, 22 bases e 32 fragmentos com algum tipo de decoração). São três fragmentos de cerâmica possivelmente Açutuba, 10 fragmentos de cerâmica Manacapuru, 14 fragmentos de cerâmica Paredão, 11 fragmentos de cerâmica Guarita, três fragmentos de cerâmica Cabocla (figuras 58, 59, 60, 61 e 62). Para o restante não foi possível identificar a afiliação.

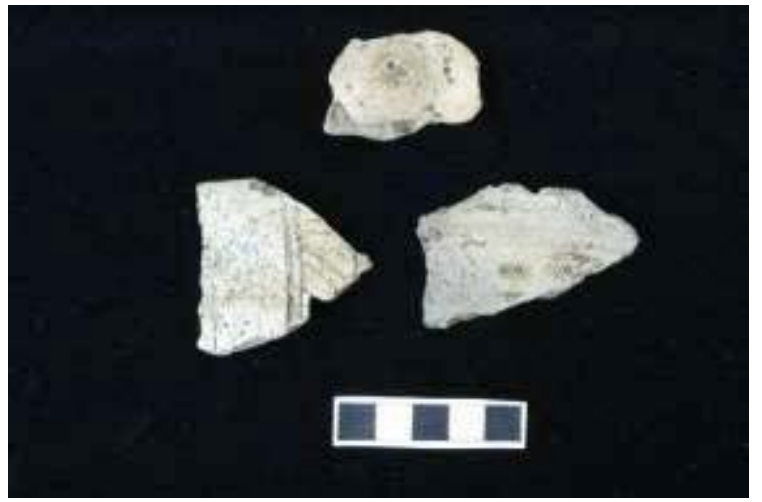

Figura 58 - Fragmentos de cerâmica possivelmente associados à fase Açutuba, encontrados nas tradagens do sítio Lago do Limão.

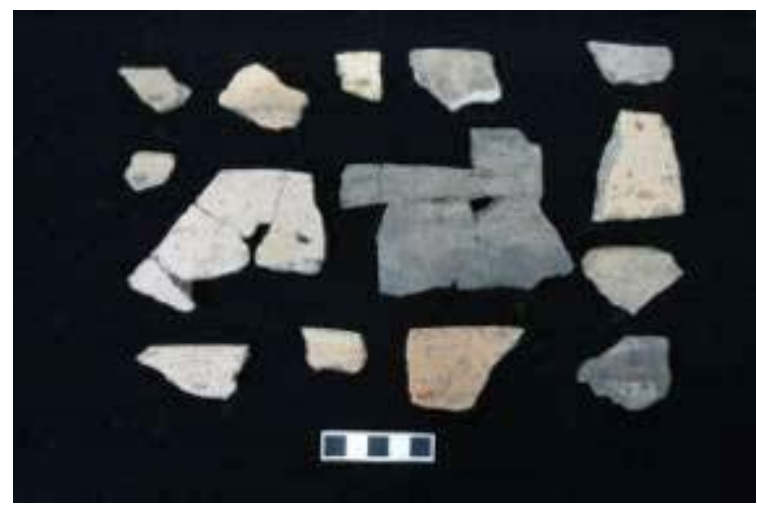

Figura 60 - Fragmentos de cerâmica da fase Paredão encontrados nas tradagens do sítio Lago do Limão.

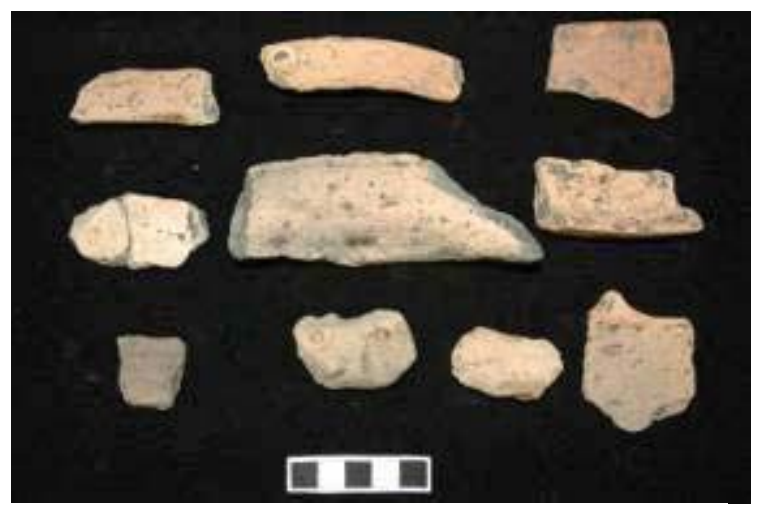

Figura 59 - Fragmentos de cerâmica da fase Manacapuru encontrados nas tradagens do sítio Lago do Limão.

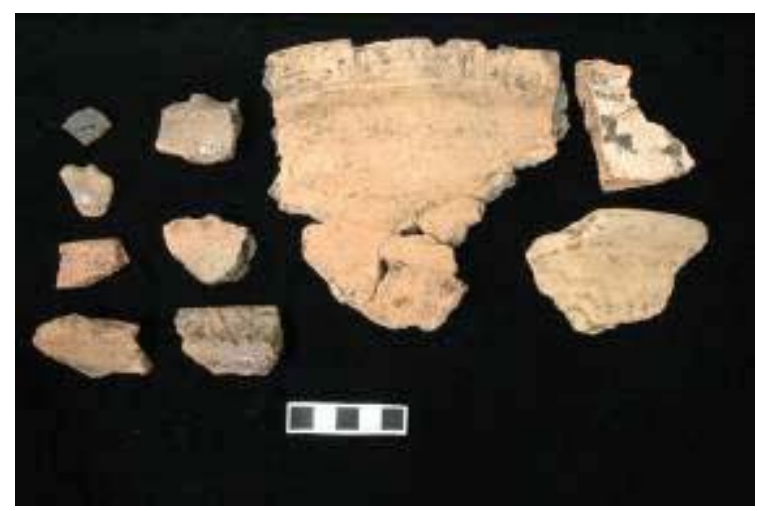

Figura 61 - Fragmentos de cerâmica da fase Guarita encontrados nas tradagens do sítio Lago do Limão. 


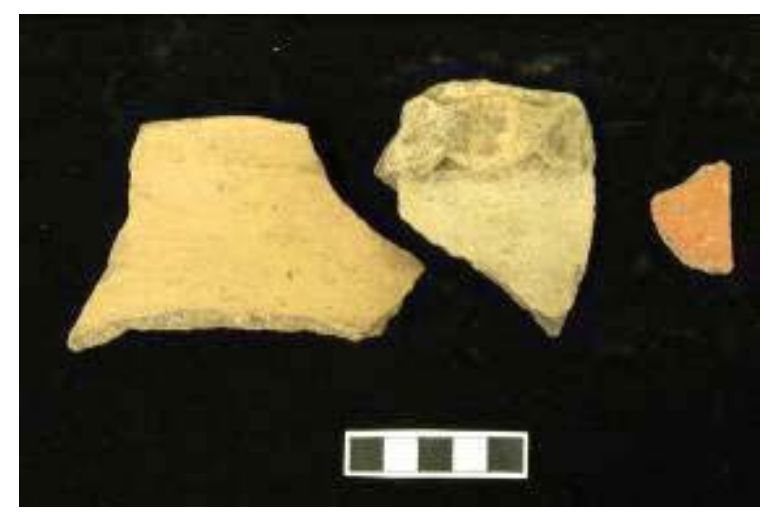

Figura 62 - Fragmentos de cerâmica Cabocla encontrados nas tradagens do sítio Lago do Limão.

Como nos exemplos anteriores, a cerâmica aparece em maior densidade nos níveis mais superficiais do sítio (gráfico 04).

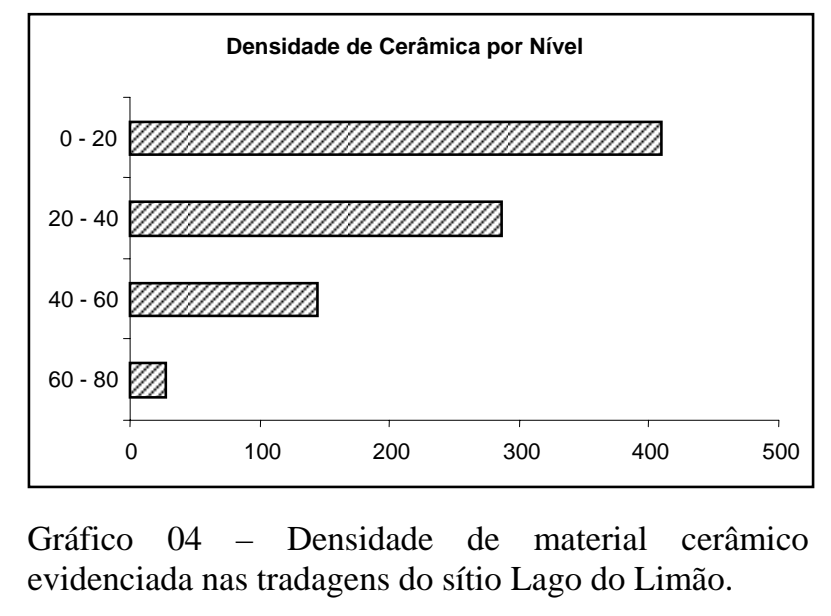

O contexto de deposição das cerâmicas é bastante complexo, mas de um modo geral há uma predominância de cerâmica associada à fase Guarita nos primeiros $20 \mathrm{~cm}$ de profundidade. A cerâmica associada à fase Paredão também ocorre principalmente entre 0 e $40 \mathrm{~cm}$ de profundidade. A cerâmica associada à fase Manacapuru praticamente não ocorre antes dos $20 \mathrm{~cm}$ de profundidade. A amostra de cerâmica possivelmente associada à fase Açutuba é muito pequena nas tradagens, o que dificulta a interpretação de sua distribuição na estratigrafia. A cerâmica Cabocla ocorre em áreas isoladas apenas nos primeiros $20 \mathrm{~cm}$.

O material arqueológico está principalmente associado a áreas com ocorrência de terra preta, que atinge profundidades maiores na área mais próxima ao lago. Praticamente toda a margem do lago ocupada pelo sítio é composta por uma mancha 
contínua de terra preta, mais profunda nas tradagens da porção central da linha nortesul, atingindo cerca de $60 \mathrm{~cm}$ de profundidade, o que coincide também com a maior concentração de material arqueológico (figura 63 e anexo 12). De acordo com os dados obtidos através das tradagens, a mancha de terra preta avança aproximadamente 250 metros da margem do lago para o sentido leste do sítio. O limite sul não foi testado com tradagens em função da falta de autorização do proprietário do terreno, porém, pela observação da superfície, que tem boa visibilidade, foi possível constatar que o sítio continua com presença de terra preta até um furo do lago a aproximadamente 300 metros da tradagem SE-125 (anexo 04).

A dispersão de material arqueológico vai muito além da área com presença de terra preta, porém a densidade de vestígios é muito menor. Desse modo, como pode ser visto no anexo 12 e figura 63, o sítio tem um núcleo com alta densidade de vestígios e presença de terra preta e uma área periférica, com menor densidade de material, onde não ocorre terra preta.

Nas diferentes partes do sítio que foram tradadas foi possível identificar a presença de solos, quase sempre com textura argilosa, desde a superfície até as camadas mais profundas, em alguns pontos a textura do solo é um pouco mais arenosa nas camadas superficiais, principalmente nas proximidades do lago. É grande a presença de laterita no sedimento e em algumas partes a base de laterita aparece antes de um metro de profundidade.

De acordo com a escala da tabela de solos "Munsell" as camadas com material arqueológico têm cores variando entre 10YR 2/1 "black”, 10YR 3/1 “very dark gray”, 10YR 4/1 “dark gray”, 10YR 5/3 “brown” 10YR 5/6 “yellowish brown” e 7/8 “yellow”, esta última quase sempre estéril. As diferentes camadas evidenciadas nas tradagens abertas no sítio podem ser vistas na figura 63 . 


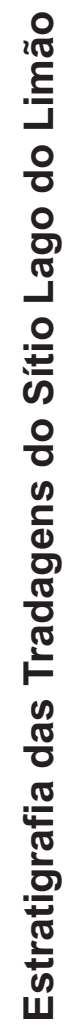

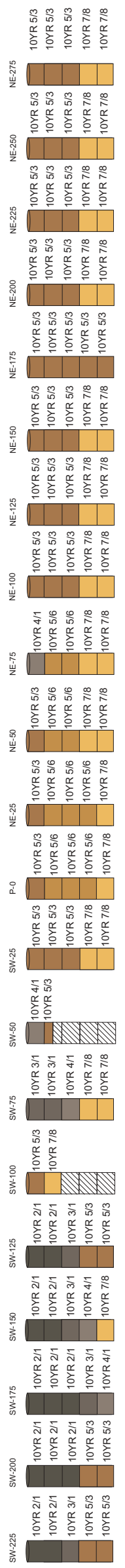

Uy:

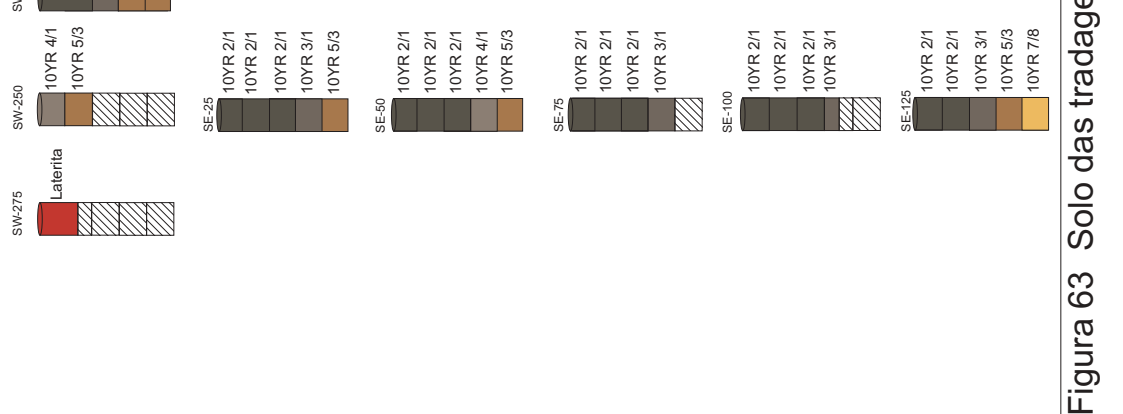




\section{III.XVII.- SÍTIO PILÃO (Am-Ir-73)}

Este local também já era conhecido por meu colega de trabalho, Cláudio. Situado a aproximadamente 500 metros sul do sítio Antônio Galo e cerca de 2000 metros sudeste do povoado, nas coordenadas 20M 0796190 UTM 9645666 (anexo 04). O sítio encontra-se na propriedade do Sr. Almir.

Em vistoria no local, constatamos uma grande extensão com presença de fragmentos de cerâmica em superfície. Os vestígios podem ser vistos em áreas de cultivo de mandioca e maracujá (figura 64). Nas áreas observadas constatamos também a presença de terra preta.

Os vestígios observados são fragmentos de cerâmica da fase Paredão. Constatamos também a presença de montículos em diferentes locais do sítio.

Feitos os registros, consideramos o sítio como sendo cerâmico, unicomponencial, de grandes proporções, pois nas primeiras observações estimamos que os vestígios estejam dispersos por pelo menos 300 metros, área que pode ser ampliada após um trabalho mais aprofundado de delimitação do sítio. O material cerâmico encontrado na superfície é da fase Paredão, associados a solos antropogênicos, com a presença de

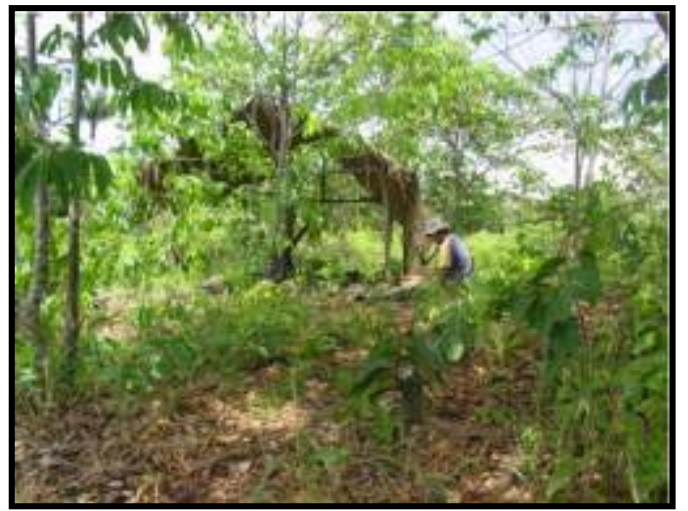

Figura 64: Vista parcial do sítio Pilão. estruturas artificiais do tipo montículos.

O sítio Pilão está situado na área de impacto direto da obra de construção do Gasoduto Coari-Manaus, empreendimento projetado pela PETROBRAS para transportar o gás natural extraído em Urucu para a cidade de Manaus. Fizemos parte da equipe de salvamento do sítio e dessa maneira acrescentamos também os resultados do trabalho de delimitação e escavação do sítio.

Com o objetivo de obter uma amostra de parte do sítio antes da destruição pela execução da obra, os trabalhos foram concentrados na faixa de impacto do gasoduto. Mesmo na delimitação do sítio, as tradagens foram intensificadas na faixa, de modo que três linhas de tradagens paralelas foram abetas acompanhado o eixo projetado para o gasoduto. A partir de uma tradagem na parte central do sítio, foram abertas linhas de tradagem em uma malha de 25 metros. As três linhas cortam o sítio de leste a oeste e 
como pode ser visto no anexo 13, neste sentido o sítio possui extensão aproximada de 250 metros.

A abordagem do sítio no campo foi a mesma dos outros levantados, algumas pequenas diferenças na delimitação do sítio serão vistas em função da abertura das linhas de tradagem ter sido executada com a presença de um topógrafo em campo. De modo que a nomenclatura das tradagens será um pouco diferente da vista nos outros sítios, pois foi utilizado o mesmo sistema de plotagem das unidades de escavação adotando dois eixos (norte e oeste), partindo de um ponto zero imaginário que se localiza fora do sítio arqueológico, de forma que todas as intervenções serão endereçadas com números positivos. Por exemplo, em um ponto supostamente central do sítio nomeamos a intervenção como sendo a tradagem N-1000 W-1000 (norte 1000 oeste 1000), ou seja, o ponto está a 1000 metros a norte e a oeste do ponto zero que certamente ficará fora do sítio. O restante das intervenções terá seu endereço de acordo com a distancia a norte e a oeste do ponto zero.

Como já havíamos identificado em nossa primeira vistoria existem muitos montículos na área central do sítio. Com o trabalho de prospecção e topografia identificamos 12 estruturas, 8 delas no que será a faixa do gasoduto. Os montículos têm se tornado, cada vez mais, um ponto chave dentro do nosso trabalho e também dentro dos objetivos gerais do PAC, visto que eles já foram até tema de trabalho de mestrado (Machado 2005). Como existe a possibilidade das estruturas estarem ligadas a contextos funerários, era necessário entender bem os montículos antes de liberar a área para a construção do gasoduto.

No sentido norte-sul foram abertas mais duas linhas de tradagem cortando o sítio que possui aproximadamente 300 metros nesta direção.

Duas tradagens na extremidade leste, N-975 E-1175 e N-975 E-1225, apresentaram material arqueológico em baixa densidade, como era um ponto desconectado do sítio, o que pode ser visto pelo intervalo com tradagens estéreis (anexo 13), constatamos logo que se tratava da periferia de um outro sítio arqueológico, ao qual demos o nome de sítio Jacuraru. O novo sítio parece ocupar toda a península ao sul da linha de tradagem (anexos 04 e 13).

Após os trabalhos de delimitação constatamos que o sítio Pilão possui uma área de $300 \times 250$ metros.

Um fato importante constatado com a delimitação do sítio foi a identificação de um conjunto constituído pelos montículos $1,2,3,4,5,6$, e 7 em formato de circulo 
(anexo 13). Com o restante dos montículos não é possível perceber uma ordenação muito lógica, mas os montículos 8, 9 e 10 parecem estar associados a um momento de re-locação do que seria a primeira aldeia. Os montículos 11 e 12 talvez sejam partes de um terceiro momento de ocupação, porém a área do sítio está muito encapoeirada, no local os trabalhos de delimitação não foram muito intensificados. Portanto uma prospecção mais detalhada seria necessária para fazermos inferências mais embasadas.

Foram coletados 606 fragmentos de cerâmica nas tradagens, dos quais 68 foram classificados como diagnósticos (27 bordas, 29 bases e 12 fragmentos com algum tipo de decoração). O sítio é associado unicamente à fase Paredão (figura 65). Como pode ser visto no gráfico abaixo, a cerâmica está concentrada principalmente nos primeiros $40 \mathrm{~cm}$ do pacote arqueológico.

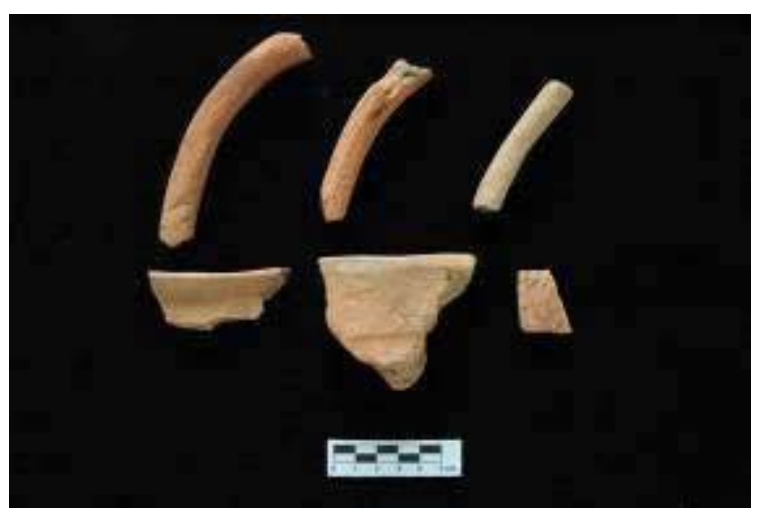

Figura 65 - Exemplos de fragmentos associados à fase Paredão encontrados nas tradagens do sítio Pilão.

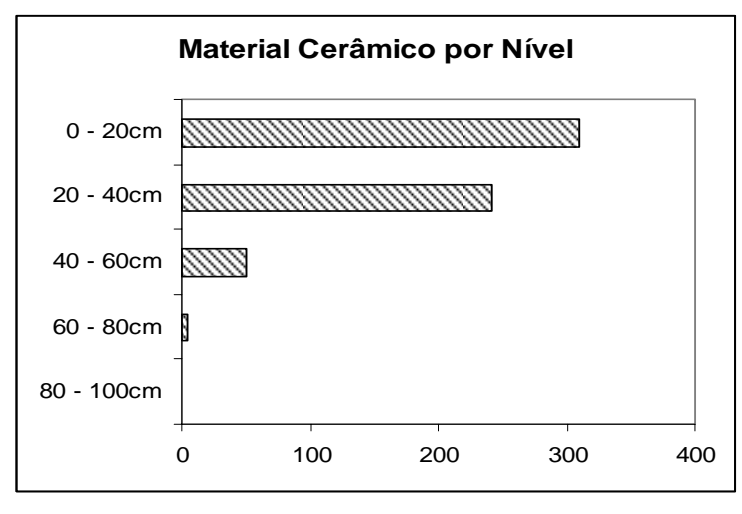

Gráfico 05 - Densidade de material cerâmico evidenciada nas tradagens do sítio Pilão.

Observando a figura 66, podemos notar que raramente o pacote de terra preta atinge profundidades maiores que $20 \mathrm{~cm}$, situação muito semelhante à constatada no sítio Antônio Galo, que dista cerca de 300 metros norte do sítio Pilão (anexo 04). 
Mesmo onde as tradagens foram feitas sobre os montículos, o pacote de terra preta não apresentou variação significativa na profundidade. $\mathrm{O}$ material cerâmico está principalmente concentrado nos montículos e na porção oeste do sítio, próximo à unidade N-1003 E-956, que aparenta ser uma área de descarte como apresentaremos em capítulo adiante.

A textura do solo acompanha o padrão dos sítios anteriores quase sempre com textura argilosa, sendo que a plasticidade aumenta de acordo com a profundidade. Nas proximidades do lago as tradagens apresentaram solo com textura mais arenosa.

De acordo com a escala da tabela de solos "Munsell" as camadas com material arqueológico têm cores variando entre 10YR 2/1 "black"; 10YR 2/2 "very dark brown"; 10YR 3/1 "very dark gray"; 10YR 3/2 "very dark grayish brown"; 10YR 3/3 "dark brown"; 10YR 3/4, 3/6, 4/4 e 4/6 “dark yellowish brown”; 10YR 4/1 "dark gray"; 10YR 4/2 “dark grayish brown”; 10YR 5/1 "gray”; 10YR 5/2 "very dark graish brown"; 10YR 4/3 e 5/3 "brown"; 10YR 5/4, 5/6 e 5/8 "yellowish brown"; 10YR 6/3 "pale brown"; 10YR 6/4 "light yellowish brown"; 10YR 6/6 e 6/8 "brownish yellow"; 10YR 7/6 e 7/8 "yellow", após 5/3 quase sempre estéril. As diferentes camadas evidenciadas nas tradagens abertas no sítio podem ser vistas na figura 66. 

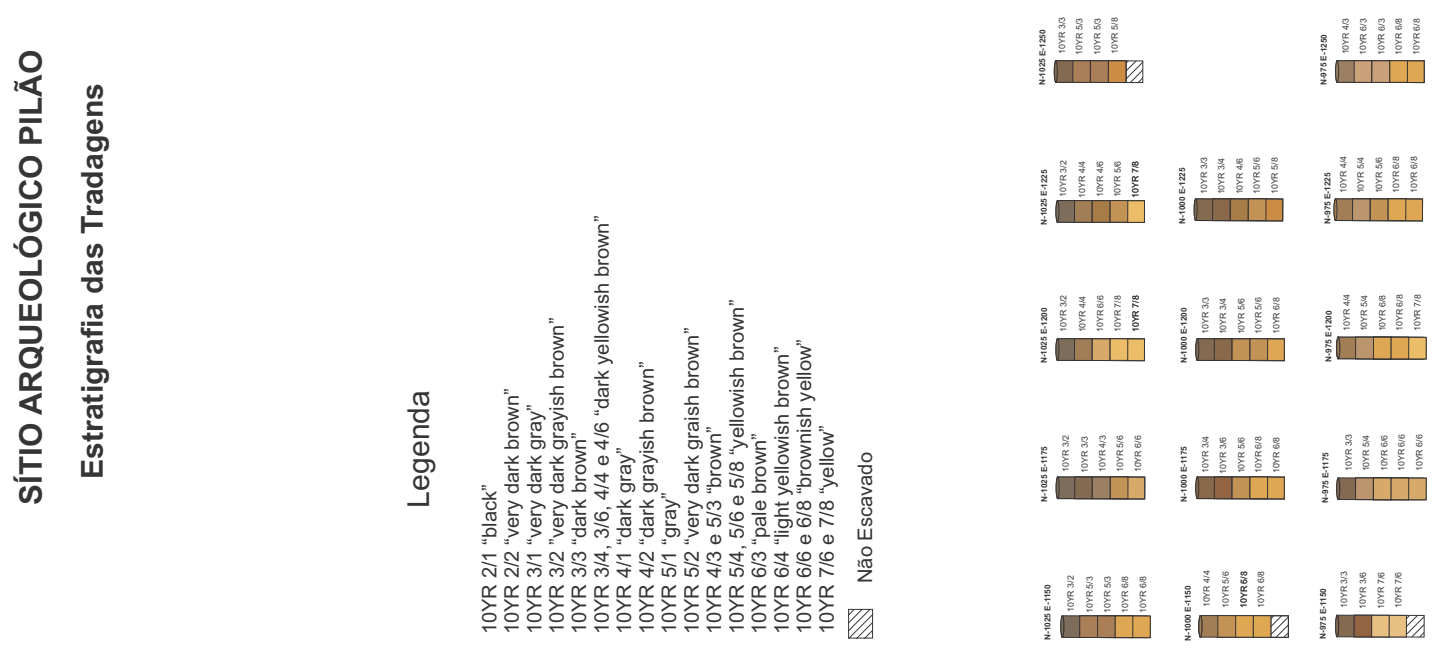

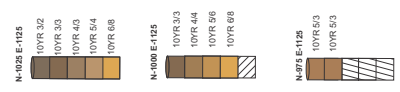

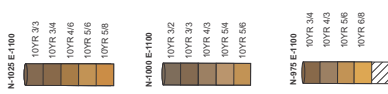

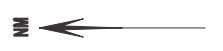

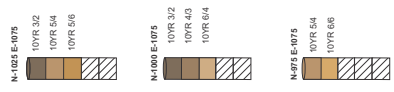

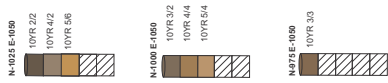

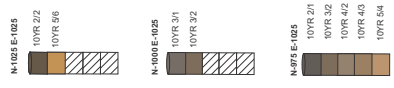

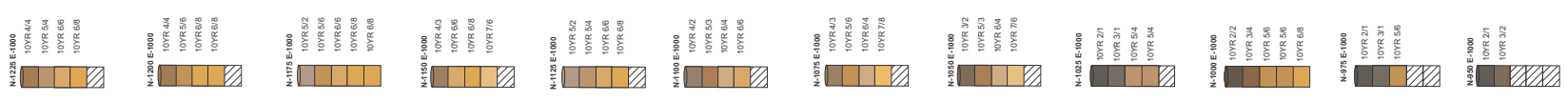

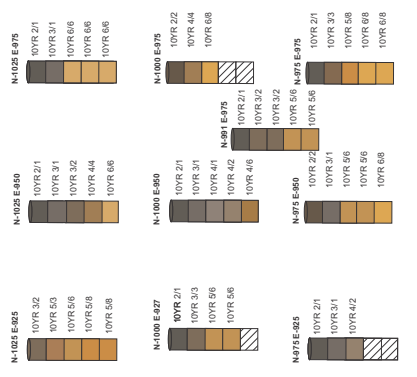

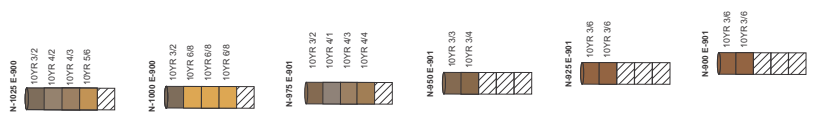

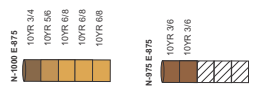




\section{$\underline{\text { III.XVIII - OCORRÊNCIAS }}$}

Além dos sítios acima mencionados foram registrados três pontos de ocorrências isoladas de material arqueológico. São pontos onde evidenciamos apenas um ou mais fragmentos de cerâmica, mas as vistorias dos seus arredores não foram capazes de caracterizá-los como sítios arqueológicos. Os pontos são descritos abaixo:

\section{III.XVIII.I - OCORRÊNCIA 01}

Na propriedade do Sr. Jonas Lima da Cunha, coordenadas 20M 0798149 UTM 9645656, foi encontrado um fragmento de cerâmica no canteiro de cebolas do quintal. O Sr. Jonas nos informou que já encontrou outros fragmentos pelo local, porém em nossa vistoria, não identificamos nenhum outro vestígio.

\section{III.XVIII.II - OCORRÊNCIA 02}

Na propriedade do Sr. Moisés, coordenadas 20M 0798139 UTM 9645900, foi encontrado um fragmento de alça, fragmento típico da fase Paredão. Após vistoria do local não foi encontrado nenhum outro vestígio.

\section{III.XVIII.III - OCORRÊNCIA 03}

Na propriedade do Sr. Paulo da Silva Batista, coordenadas 20M 0796077 UTM 9646990, foram encontrados três fragmentos de cerâmica. Foram vistoriadas as imediações do local, mas nenhum outro vestígio foi encontrado. 


\section{Capítulo IV - ESCAVAÇÃO DOS SÍTIOS}

A primeira etapa de campo proporcionou a identificação dos sítios e coleta de material em uma parte deles. Após o processamento e análise prévia do material em laboratório decidimos realizar mais uma etapa de campo para trabalhos mais aprofundados em dois dos sítios identificados. O trabalho de campo foi realizado nos sítios Lago do Limão (Am-Ir-11) e Antônio Galo (Am-Ir-72), no período de 19 a 25 de janeiro de 2005, com a participação de quatro pessoas. Os sítios foram delimitados com tradagens na etapa anterior, intervenção que consideramos suficiente para levantar dados sobre a distribuição dos vestígios no espaço do sítio, sendo assim, optamos pela execução direta do nível 3 de intervenção nos sítio, abrindo diretamente unidades de $1 \mathrm{~m}^{2}$, uma em cada sítio, escavadas em níveis artificiais de $10 \mathrm{~cm}$.

As intervenções feitas até então nos sítios arqueológicos tinham sido eficazes para a identificação, delimitação e noção da variabilidade vestígios, um trabalho rápido que provoca uma pequena margem de destruição do patrimônio (Neves 2000). Com a abertura de unidades de escavação buscávamos uma amostra mais controlada dos vestígios do sítio e também a coleta de carvões para datação dos contextos estudados. Foram abertas duas unidades de 1 x $1 \mathrm{~m}$, uma em cada sítio.

Com o objetivo de avançar um pouco mais o nível de detalhamento nos sítios Lago do Limão e Antonio Galo, foi realizada mais uma etapa de campo. Podemos dizer que foi aplicado o que seria um nível 4, que não estava previsto em nossa proposta de trabalho nos sítios. As atividades executadas foram: a produção de mapas topográficos para os dois sítios, a abertura de áreas de escavação mais amplas, o corte de um dos montículos do sítio Antônio Galo e a exploração de áreas diferentes nos sítios para entender melhor os contextos de ocupação.

A etapa foi realizada como um sítio escola: na oportunidade, várias pessoas tiveram o primeiro contato com o trabalho de campo na Amazônia. Um dos objetivos do Projeto Amazônia Central é a formação de novos pesquisadores, o sítio escola vinha atender também esse objetivo. Um trabalho de educação patrimonial também estava sendo realizado junto aos professores e alunos de algumas escolas do município de Iranduba, entre elas a escola do lago do Limão. 
O campo contou com a participação de 34 pessoas, entre elas doutores, doutorandos, mestres, mestrandos, graduados, graduandos, alunos do ensino médio e auxiliares de campo.

Programado para ser realizado ao longo do mês de agosto de 2005, o campo foi interrompido no dia 13, em função do assassinato de um dos membros do grupo, o Professor James Petersen, um dos coordenadores do projeto. Após o ocorrido o campo foi paralisado, permanecendo apenas uma pequena parte da equipe (cinco pessoas), para finalizar algumas das escavações em andamento.

\section{IV.I - O SÍTIO ANTÔNIO GALO}

Feito o levantamento dos sítios, percebemos que a região do lago do Limão não apresentava uma predominância de sítios associados à fase Manacapuru, ao contrário, os sítios Paredão foram encontrados em maior escala que os sítios associados às outras fases. Com a constatação decidimos investir em um trabalho mais aprofundado em sítios que pudessem fornecer dados relativos à fase Paredão, para um melhor entendimento da ocupação da região do lago.

O sítio Antônio Galo apresentou um contexto interessante. Além de vários montículos, a distribuição de material vista nas tradagens apontava para áreas unicomponenciais no sítio. Esta era uma boa oportunidade para entender o processo de formação dos sítios arqueológicos Paredão e Guarita, além de acrescentar dados na tentativa de responder uma pergunta que vem sendo feita desde o início do PAC. A que fase ou fases pertence os montículos artificiais e qual o propósito de sua construção?

Queríamos testar se realmente as cerâmicas da fase Guarita estavam restritas à parte central do sítio e, consequentemente, se a parte do sítio com os montículos dispostos em forma de circulo se tratava de uma área com contexto mais preservado, sendo uma aldeia circular. Para isso, precisávamos entender um pouco melhor o processo de formação dos montículos.

Havia muito trabalho a ser feito e o tempo não nos era favorável: além de termos apenas três dias, janeiro é um mês muito chuvoso no Amazonas e isso prejudica bastante o andamento dos trabalhos. Decidimos então restringir o trabalho à abertura de uma unidade de escavação, N-938 E-456, na periferia do montículo 16 (anexo 10). O ideal seria escavar uma área na porção central desta estrutura, porém apenas com base na observação do relevo era possível imaginar que teríamos uns dois metros de pacote 
arqueológico a ser escavado. Geralmente os montículos apresentam densidade de vestígios arqueológicos muito elevada (Machado 2005:23). Como seria o primeiro montículo a ser escavado no sítio, para não correr o risco de ter que parar a escavação antes de se chegar à base do pacote arqueológico, optamos por escavar uma parte mais baixa, na periferia do montículo, mas que ainda assim nos daria informação sobre a estratigrafia da estrutura (anexo 10).

A escavação dos primeiros $10 \mathrm{~cm}$ da unidade revelou a presença de uma alta densidade de fragmentos de cerâmica de grandes dimensões, alguns quebrados in situ, mas estruturados em partes maiores. Durante o próprio trabalho de campo foi possível perceber que são fragmentos de cerâmica da fase Paredão. Também identificamos várias remontagens. O sedimento é pouco compactado e tem coloração bastante escura, mostrando que há a formação de terra preta mesmo nessa área, que está situada na periferia do sítio (anexo 10). O sedimento apresentou textura muito argilosa desde a superfície. Foi registrada também a presença de muito carvão no sedimento escavado no nível. Foram identificados também alguns fragmentos de trempe neste nível.

Quando iniciamos a escavação do nível 2, de 10 a $20 \mathrm{~cm}$ de profundidade, percebemos que os fragmentos de cerâmica continuavam grandes, estruturados e em alta densidade dando mostras de um contexto bem preservado. Por este motivo coletamos várias amostras com proveniência individual dos muitos carvões evidenciados. Neste nível identificamos muitas manchas de terra queimada (figura 67). O sedimento apresentou uma mudança de coloração para uma matriz mais amarelada antes da base do nível.

Nos nível 3, 4 e 5, 20 a $50 \mathrm{~cm}$ de profundidade, a densidade de fragmentos apresenta redução gradativa, porém, continuam sendo fragmentos grandes, com muitas remontagens observadas. Todos os fragmentos que puderam ser diagnosticados são pertencentes à fase Paredão. O solo continua apresentando textura bastante argilosa e a coloração é

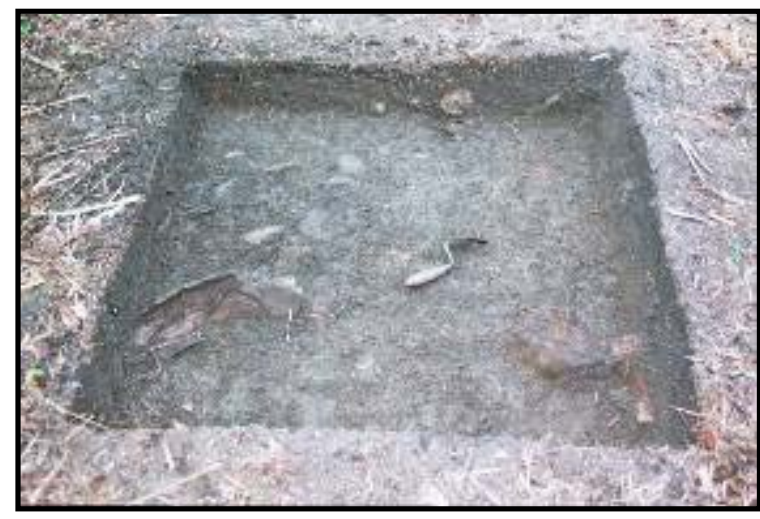

Figura 67 - Unidade N-938 E-456, nível 10 - 20 $\mathrm{cm}$, fragmentos de cerâmica e manchas de terra queimada. cada vez mais amarelada. Continua aparecendo muito carvão na unidade, destacamos também a presença de muita terra queimada, presente em manchas grandes. Como pode ser visto na figura 68 e 69, foi encontrado um fragmento de cerâmica Paredão, 
apresentando quase metade de um vaso, quebrado in situ. No nível $30-40 \mathrm{~cm}$ apareceram mais fragmentos de trempe na escavação.

No nível 6, dos 50 aos $60 \mathrm{~cm}$ de profundidade, o solo é, também, muito argiloso e compacto e coloração amarelada. Aparecem ainda alguns fragmentos de cerâmica, porém a densidade diminui comparada ao nível superior.

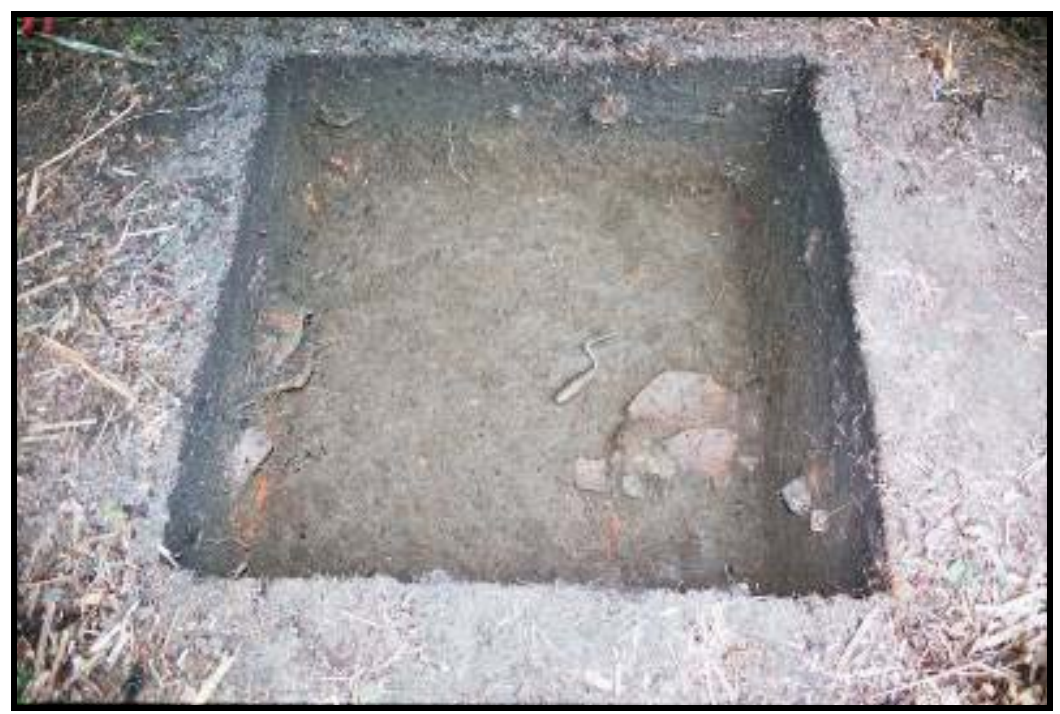

Figura 68 - Unidade N-938 E-456, base do nível 30-40 cm, fragmentos de cerâmica da fase Paredão e terra queimada.

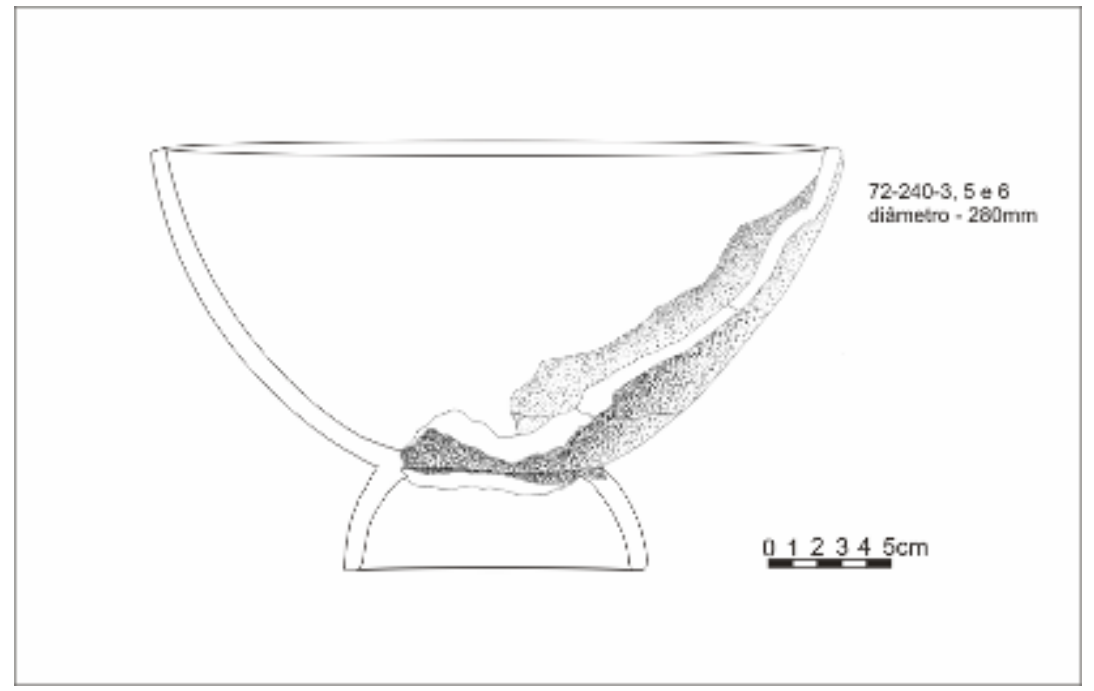

Figura 69 - Vaso cerâmico reconstituído.

Os dois próximos níveis escavados não apresentaram material arqueológico. $\mathrm{O}$ solo muda para uma camada de coloração mais amarelada, continuando muito argiloso e compacto. 
Após a escavação dos dois níveis foram desenhados os perfis, norte, oeste e sul (figura 70). Os dados referentes à densidade do material por nível podem ser vistos no gráfico 06.

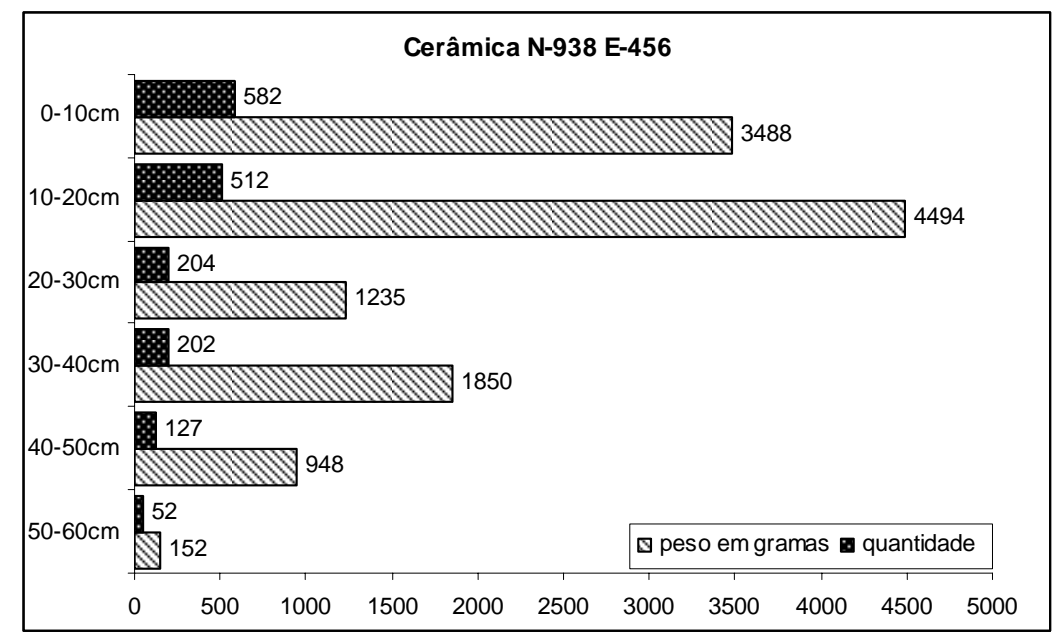

Gráfico 06 -Unidade N-938 E-456, densidade do material cerâmico por níveis.

Com a unidade de escavação terminada podemos acrescentar alguns dados ao nosso conhecimento sobre o sítio Antônio Galo. Como será apresentado na descrição da cerâmica, o material proveniente da unidade é exclusivamente pertencente à fase Paredão, o que ajuda a reforçar a hipótese de um contexto bem preservado e unicomponencial na parte do sítio onde os montículos estão dispostos em circulo. $\mathrm{O}$ estado de fragmentação da cerâmica também parece corroborar a possibilidade de estarmos tratando com um contexto relativamente bem preservado.

O pacote de terra preta é pouco espesso na estratigrafia. Parece que o montículo tem um processo de formação muito rápido, talvez um único evento, antes da formação de solos antropogênicos. Em um dos montículos do sítio (M17) isso fica mais evidente, pois ao lado da elevação há uma depressão que parece ser o local onde a terra foi retirada para a construção da estrutura (anexo 10).

Para ampliar a gama de dados sobre o sítio Antônio Galo ainda precisávamos escavar algumas outras áreas, tais como: o topo de algum dos montículos e a extremidade oeste do sítio, para produzir datas e amostra de material das diferentes partes que o compõem, o que poderá ajudar a entender se existem vários eventos de ocupação e se temos realmente uma aldeia circular em uma das extremidades.

Isso já havia sido previsto para a terceira etapa de campo, como será apresentado a seguir, apesar de muitos avanços, nem tudo que havia sido planejado pôde ser executado. 

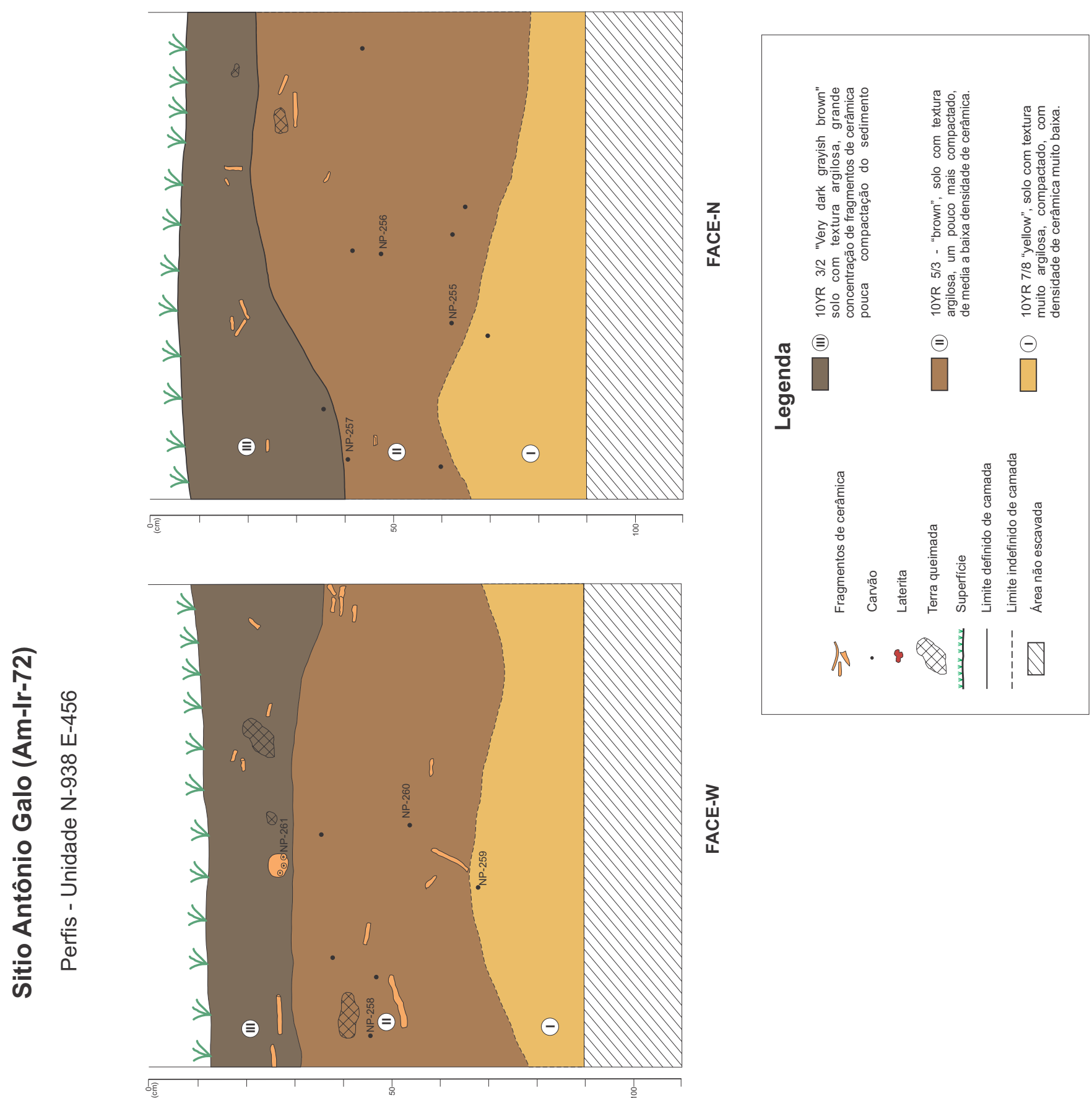

㩯

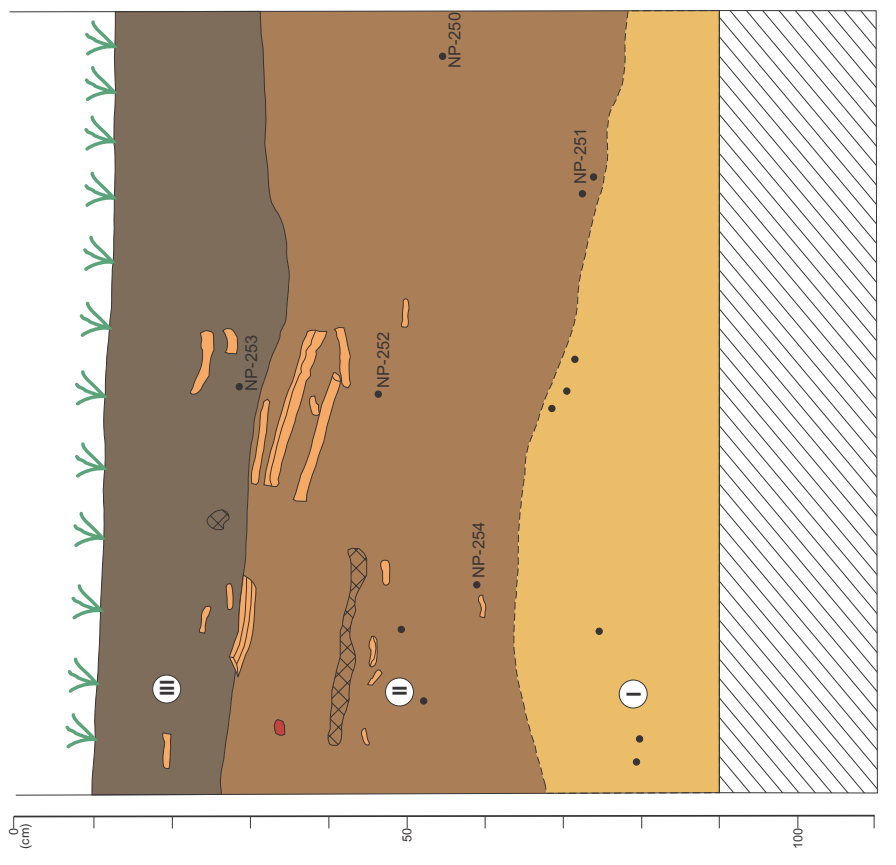

㟧 


\section{IV.I.I - A AMPLIAÇÃO DAS INTERVENÇÕES NO SÍTIO}

Inicialmente foram demarcadas três unidades de escavação no topo do montículo 17, são elas: N913 E437, N914 E437 e N-915 E-437 (anexo 10 e figura 71). A idéia era iniciar as escavações em uma área de 3 x 1 metro, para depois ampliar, fazendo uma trincheira que cortaria o montículo do centro até a borda. O montículo 17, além de ser um dos mais altos, apresenta uma depressão do lado que parece ser o negativo de onde o solo teria sido retirado para sua construção.

Outra unidade de escavação, N-505 E-400, foi demarcada nas proximidades da tradagem NW/2-100, próxima à margem do lago, na porção oeste do sítio. Com a abertura da unidade buscávamos uma amostra de cerâmica dessa parte do sítio para comparar com a outra coletada na extremidade nordeste.

Buscávamos também amostras de carvão para produzir datações e assim verificar se existe alguma diferença cronológica na ocupação do sítio.

A etapa de campo foi paralisada em decorrência do assassinato do Dr. James Petersen. Após o acontecimento, lamentável e inaceitável, apenas uma pequena parte da equipe, cinco pessoas, retornou ao campo para finalizar algumas das escavações que estavam em andamento.

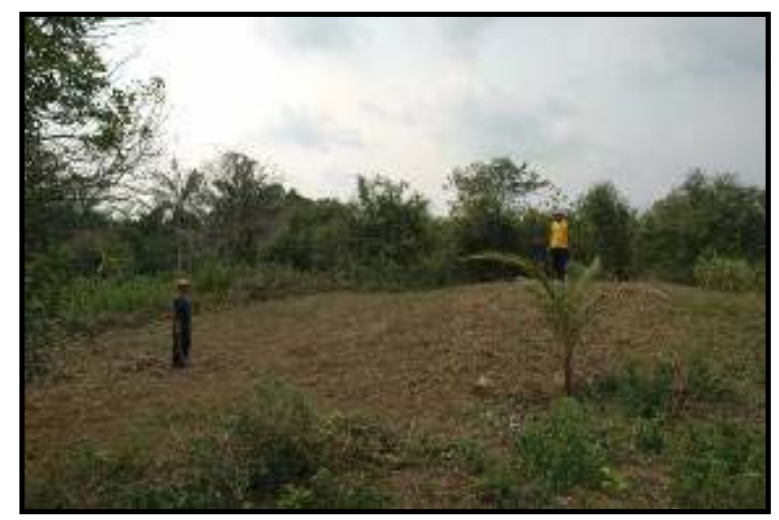

No sítio Antônio Galo, como o Figura 71 - Vista parcial do montículo 17, à esquerda a depressão que provavelmente é o negativo do montículo.

estágio das escavações era apenas

inicial, não houve a retomada do trabalho, só foram recobertos os níveis já escavados.

Desta forma as intervenções no sítio Antônio Galo, ficaram para uma próxima oportunidade. O que não foi possível antes da finalização de nosso trabalho de mestrado.

A descrição das informações obtidas nas escavações realizadas na etapa de campo segue adiante: 


\section{IV.I.I.I - UNIDADES N-913 E-437, N-914 E-437 e N-915 E-437}

As unidades foram abertas concomitantemente no ponto mais alto do montículo 17 (anexo 10). A superfície do montículo apresenta terra preta, porém a coloração não é muito escura (10 YR 5/1 "gray"). Todas as quadras apresentaram solo argiloso compactado, com grande quantidade de cerâmica, unicamente associada à fase Paredão. As unidades apresentam situação muito semelhante, sendo assim, os dados a seguir são da unidade N-915 E-437, escavada até a profundidade de $40 \mathrm{~cm}$. As outras unidades tiveram a escavação paralisada em níveis anteriores, mas apresentam a mesma situação.

$\mathrm{Na}$ superfície os fragmentos são pequenos, provavelmente em função das práticas agrícolas exercidas no local. De 0 a $40 \mathrm{~cm}$, a densidade de fragmentos aumenta gradativamente (gráfico 07), o solo não apresenta variações significativas na textura e coloração. Nos níveis mais profundos o material escavado apresenta fragmentos maiores (figura 72). Se comparados os dados de densidade da escavação no montículo 16 com os do gráfico abaixo, o montículo 17 provavelmente apresentaria densidade mais elevada no final da escavação, porém deve ser levada em conta a posição das unidades

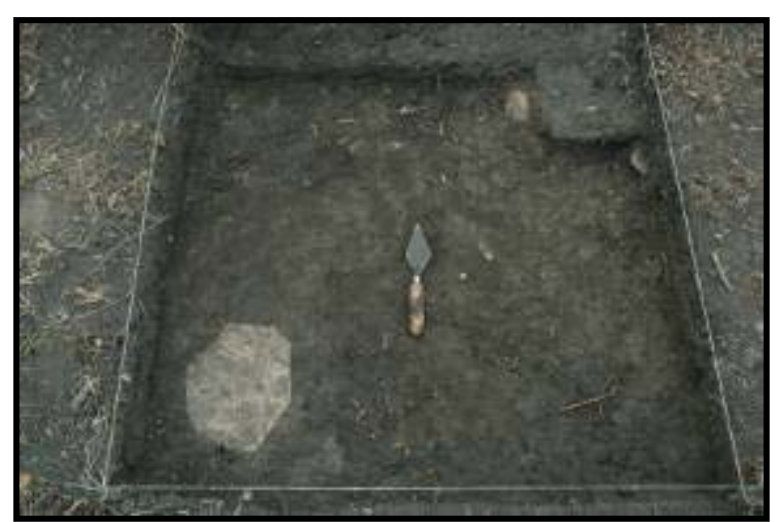

Figura 72 - Unidade N-915 E-437, nível 20-30 cm, fragmentos de cerâmica na base do nível. nos montículos.

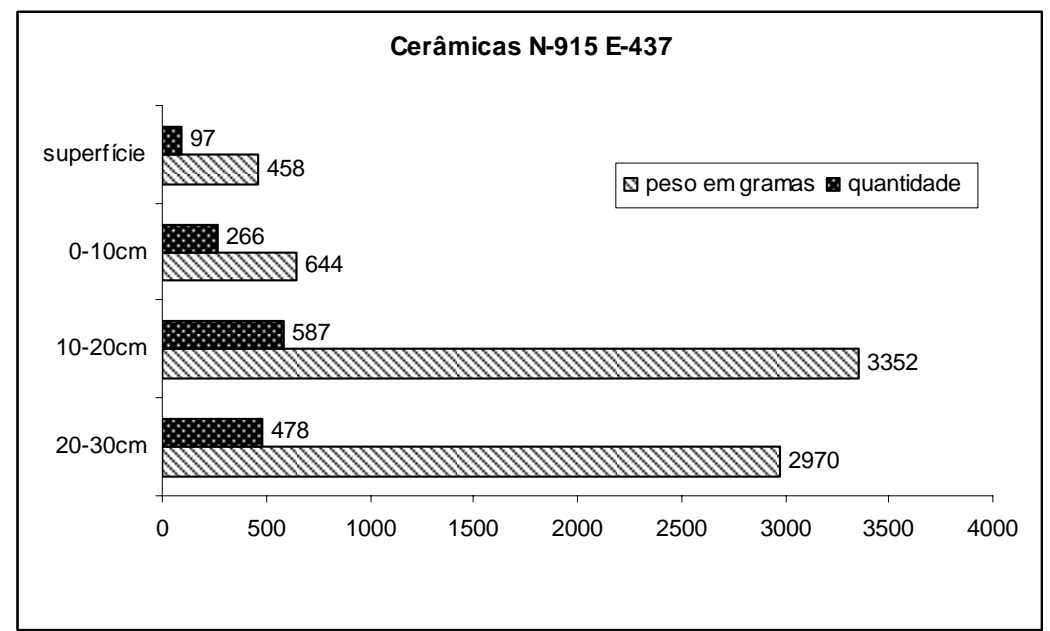

Gráfico 07: Unidade N-915 E-437, densidade do material cerâmico por níveis. 


\section{IV.I.I.II - UNIDADE N-505 E-400}

A unidade foi aberta na porção oeste do sítio, na área onde a densidade de fragmentos nas tradagens era mais elevada, nessa parte do sítio, como dito anteriormente, com a unidade buscávamos um contraponto do material escavado na porção nordeste, para testar a possibilidade de diferenças cronológicas e/ou estilísticas nos materiais deixados no sítio arqueológico. A unidade foi marcada nas proximidades da tradagem NW/2-100 (anexo 10).

O local apresenta terra preta de coloração escura na superfície, sendo uma área de capoeira de médio porte. Os três níveis escavados apresentaram material cerâmico bastante fragmentado, em densidade um pouco menos elevada que nas unidades dos montículos (figura 73), aparecem também

alguns fragmentos de trempe. Aos $30 \mathrm{~cm}$ o solo apresenta certo clareamento, dando mostras de que a camada de terra preta está chegando ao fim. A unidade não pode ser finalizada. Com o processamento do material em laboratório constatamos que o

material escavado é todo pertencente à

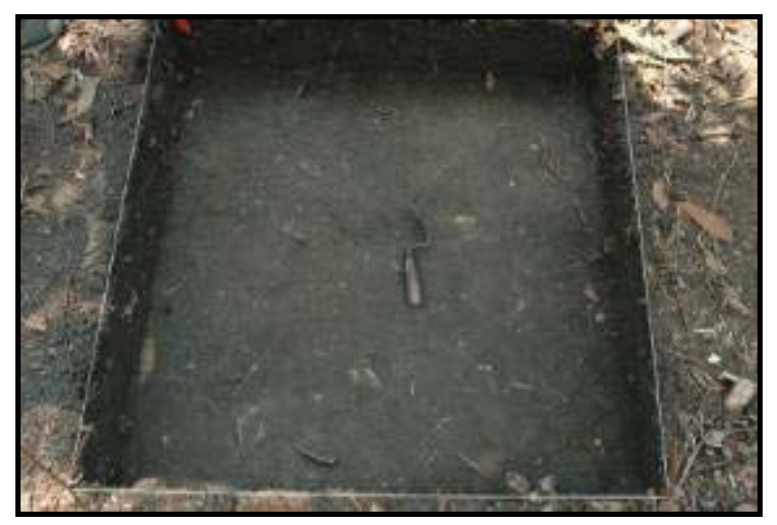

Figura 73 - Unidade N-505 E-400, base do nível 2,10 a $20 \mathrm{~cm}$. fase paredão. Para efeito de comparação de densidade no sítio, mesmo com a unidade inacabada, segue abaixo gráfico 08 apresentando o material cerâmico por nível escavado.

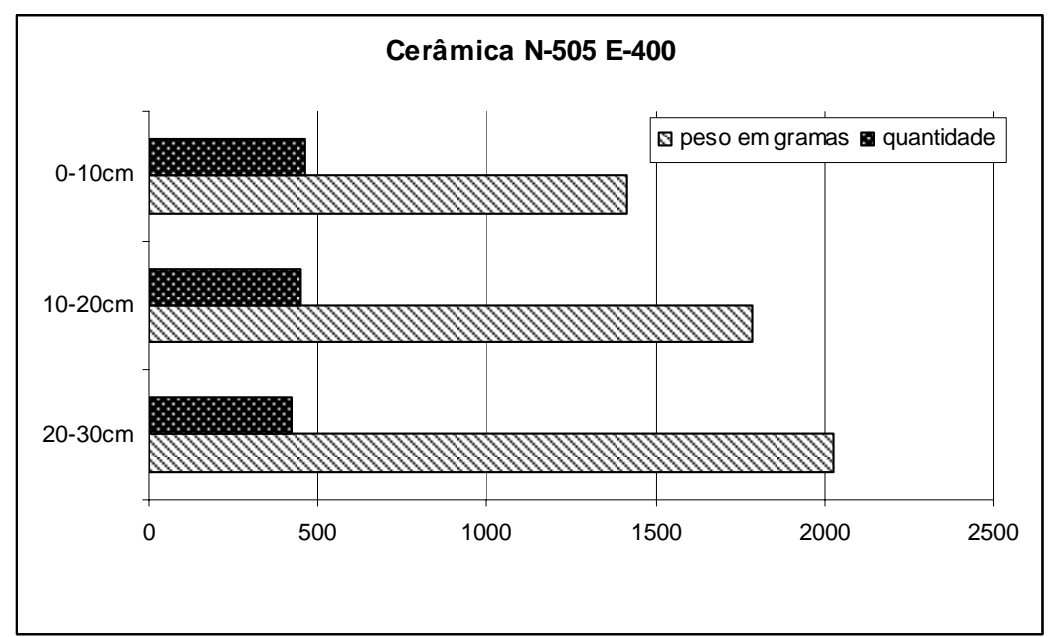

Gráfico 08: Unidade N-505 E-400, densidade do material cerâmico por níveis. 


\section{IV.I.II - DATAÇÃO}

Escolhemos uma amostra do contexto unicomponencial do sítio, um fragmento de cerâmica foi enviado a Oxford para datação por AMS (NP 240) (figura 74). A amostra de cerâmica Paredão provem dos estratos mais profundos (30 e $40 \mathrm{~cm}$ ), o que seria do início da ocupação do sítio, da unidade N-938 E-456 escavada na parte baixa do montículo 16. O resultado foi uma data 734 \pm 27 DC (OxA-15505 potter, ceramic, d13C). A data é das ocupações mais antigas de sítios Paredão demonstrando continuidade entre a ocupação Manacapuru do sítio Osvaldo e os sítios Paredão da região do lago do Limão.

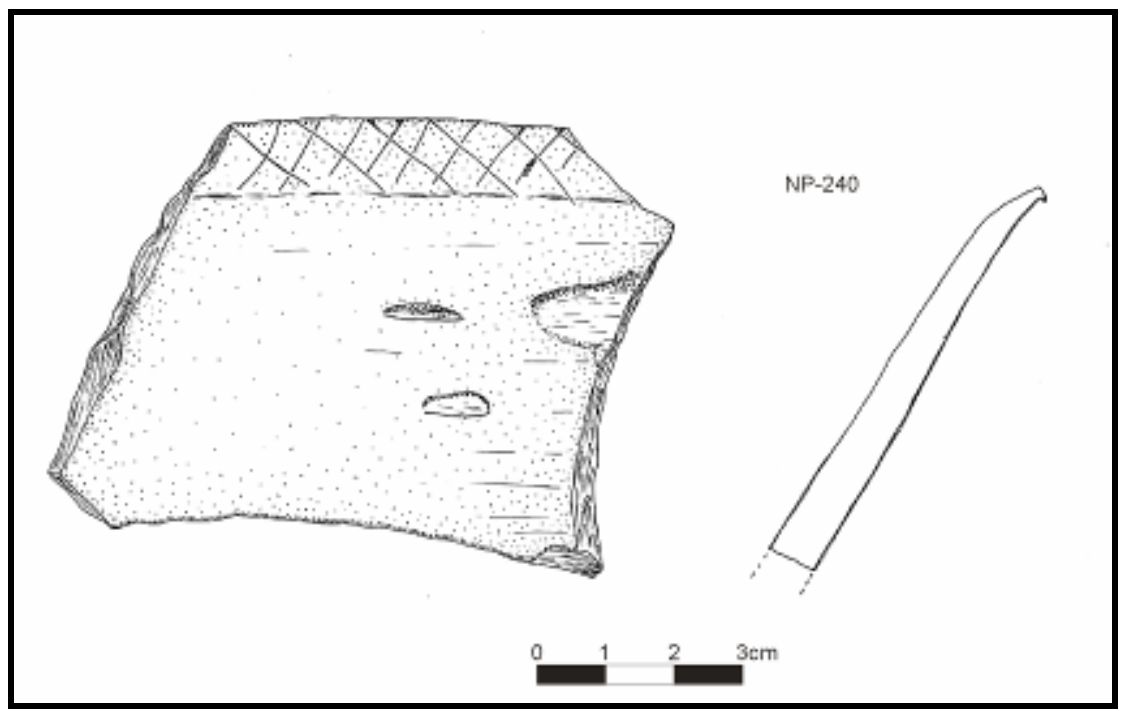

Figura 74 - Amostra de cerâmica Paredão enviada para datação. 


\section{IV.II - SÍTIO LAGO DO LIMÃO}

O sítio Lago do Limão apresentou contexto multicomponencial com cerâmicas das fases Manacapuru, Paredão e Guarita. Ampliar a intensidade de áreas escavadas no sítio certamente traria resultados interessantes, pois além de grande, o sítio apresentava um pacote de terra preta com quase um metro de profundidade.

No sítio havia um local onde foi retirada terra preta para produção de canteiros de hortas. Próximo ao desnível do barranco do lago, a 29 metros ao sul da tradagem SW-275 (anexo 12), a retirada da terra preta deixou uma cova (figura 75), aproveitada por nós para executar a limpeza de uma das paredes (parede leste), com objetivo de evidenciar os estratos do sítio arqueológico (figura 76).

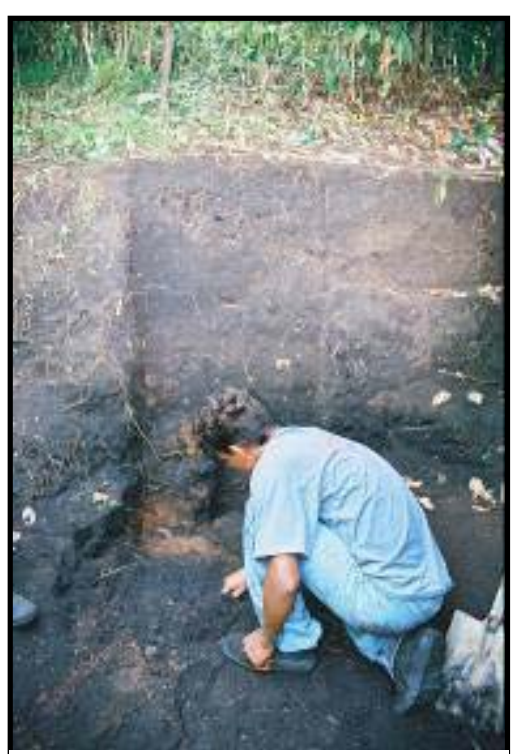

Figura 76: Limpeza de perfil no local onde foi retirada a terra preta.

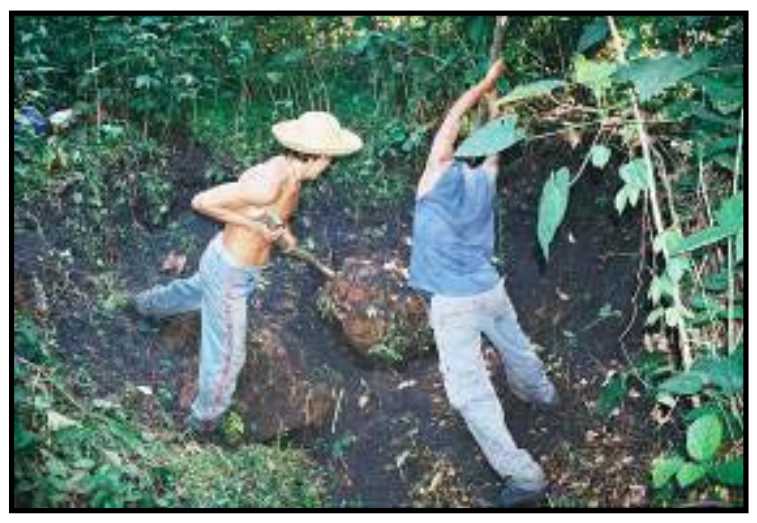

Figura 75: Remoção de blocos de lateria para limpeza de perfil onde havia sido retirada a terra preta.

Na ocasião, evidenciamos a presença de material recente nos estratos superficiais, cerâmica cabocla, louça, ferro e material orgânico (carvão, ossos e carapaças de quelônios). À medida que fomos aprofundando o corte o material recente foi diminuindo e começaram a aparecer vestígios pré-coloniais. Nos estratos inferiores efetuamos coletas de carvão.

Após o término do trabalho, com os dados da vistoria de superfície e das tradagens, estimamos que o sítio Lago do Limão possuía uma área de 550×500 metros. A limpeza de um perfil nos proporcionou dados relativos aos estratos do sítio e algumas amostras de carvão para datação.

Os vestígios recentes estão em um pacote com cerca de $90 \mathrm{~cm}$ de espessura. Abaixo do pacote há cerca de $80 \mathrm{~cm}$ de depósitos arqueológicos, com presença de

\footnotetext{
${ }^{4}$ O limite sudeste do sítio foi estimado com dados de vistoria de superfície.
} 
cerâmica pré-colonial. A terra preta está presente desde a superfície até quase a base de laterita, onde aparece uma pequena camada com o latossolo amarelo (figura 77). Após a triagem e quantificação do material coletado obtivemos os seguintes resultados: 1 - há um pico na densidade de cerâmica entre 40 e $90 \mathrm{~cm}$ de profundidade, coincidindo com o limite da profundidade da ocorrência de material recente (gráfico 09). 2 - as cerâmicas das fases Manacapuru, Paredão e Guarita (figuras 78, 79 e 80) ocorrem em densidades muito semelhantes conforme apresenta o gráfico 10 .

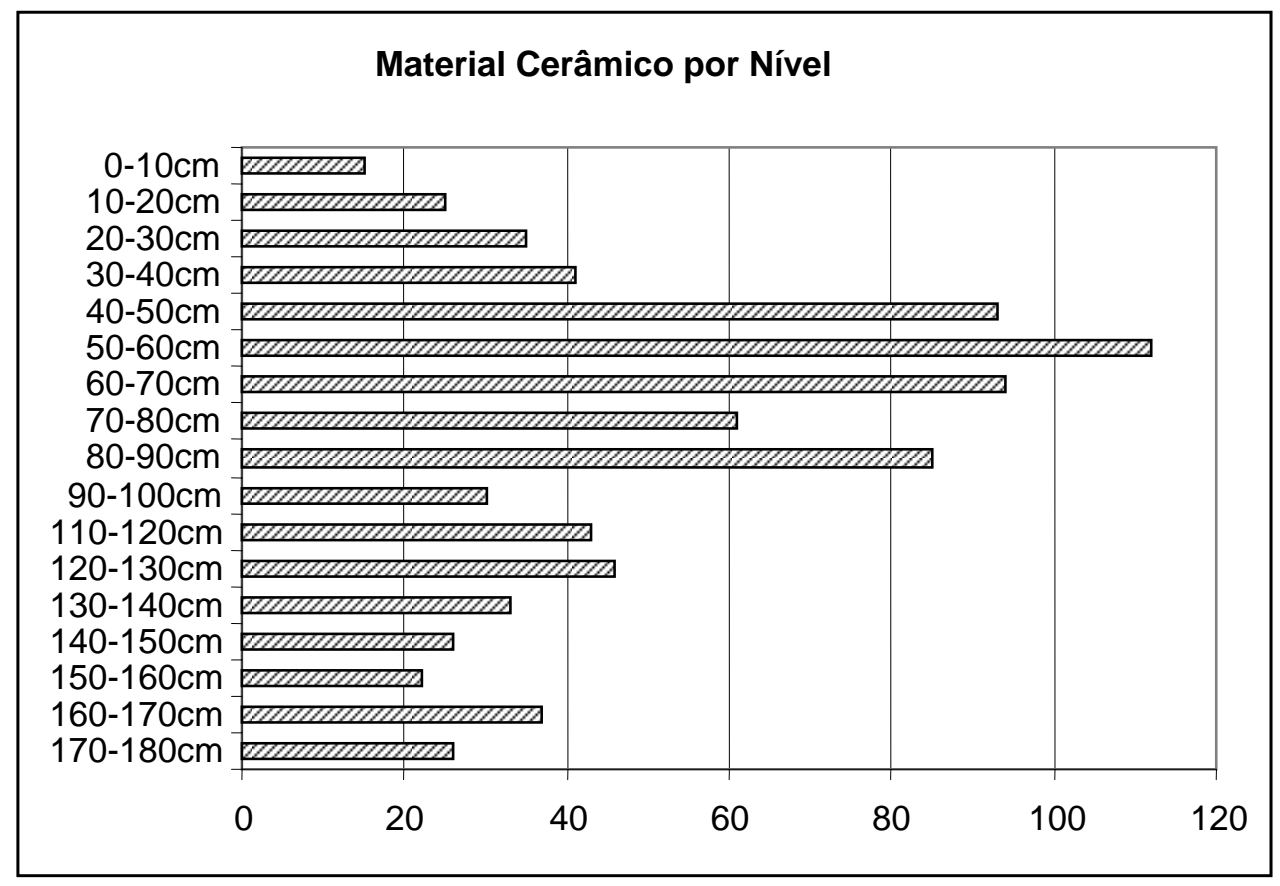

Gráfico 09 - Densidade de material cerâmico evidenciada na limpeza de perfil no sítio Lago do Limão. 


\begin{tabular}{|c|c|c|}
\hline 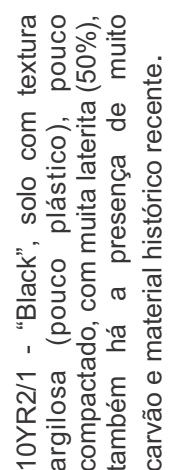 & 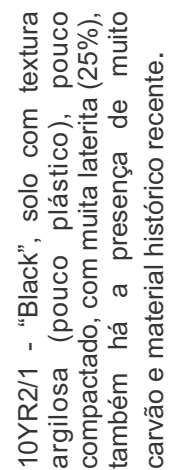 & 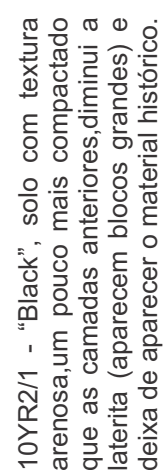 \\
\hline
\end{tabular}

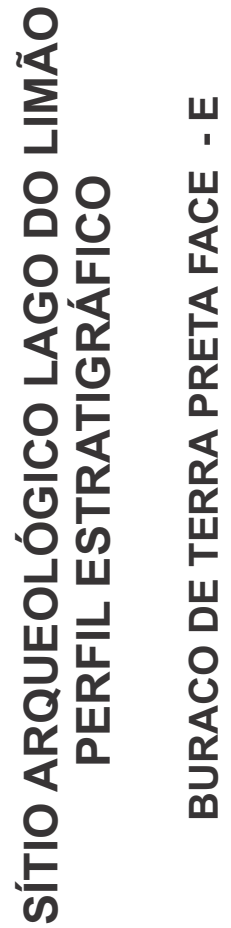
吕
(פ)
$\Theta$
$\odot$

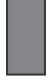

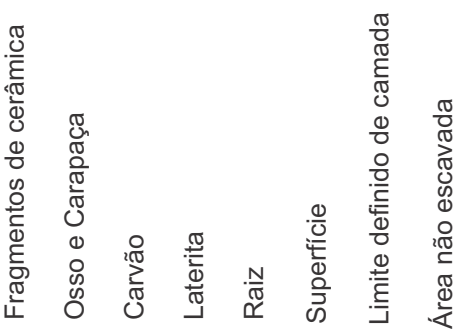

$\nabla 8 \cdot 0 \cdot$ 姜
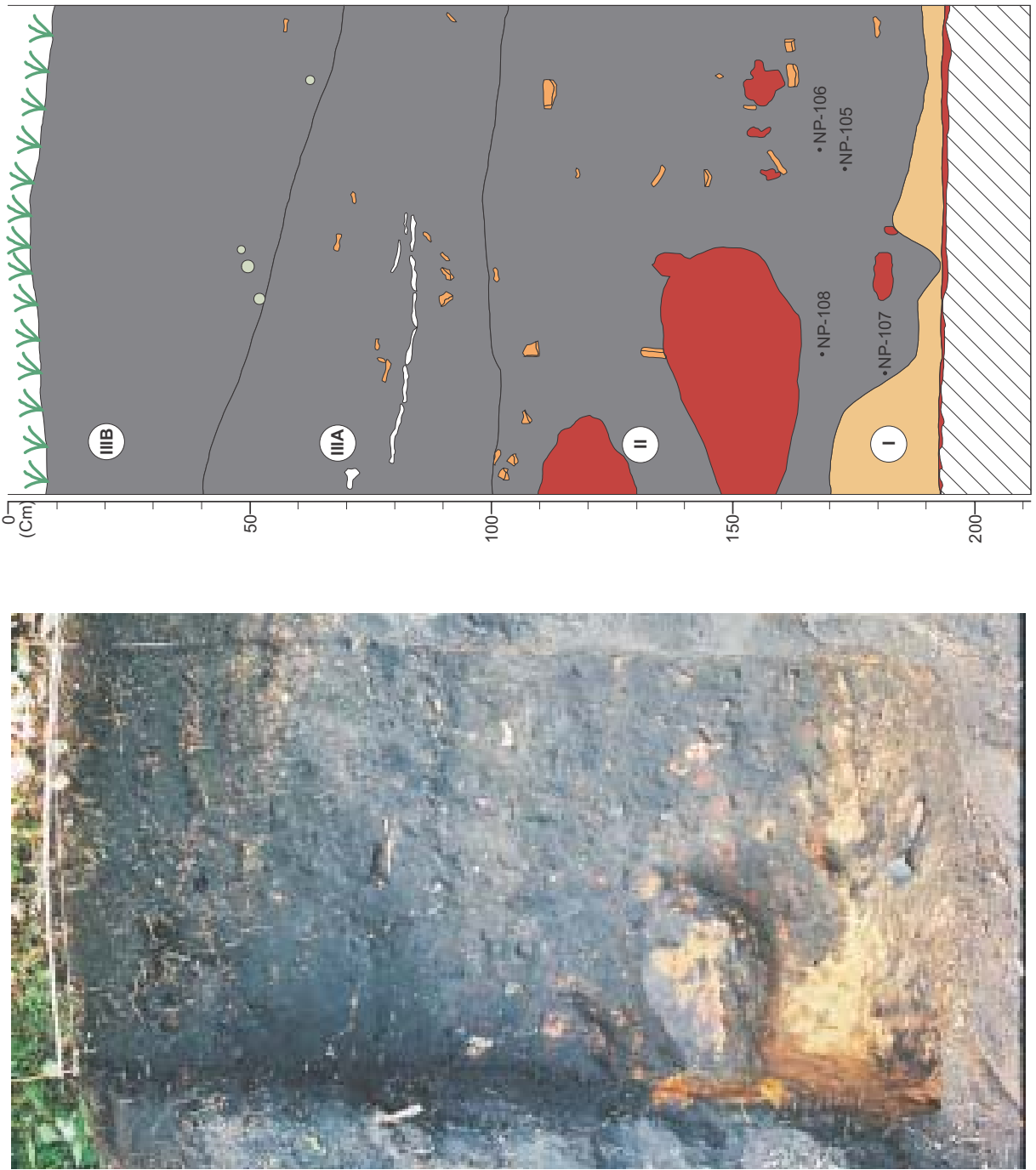


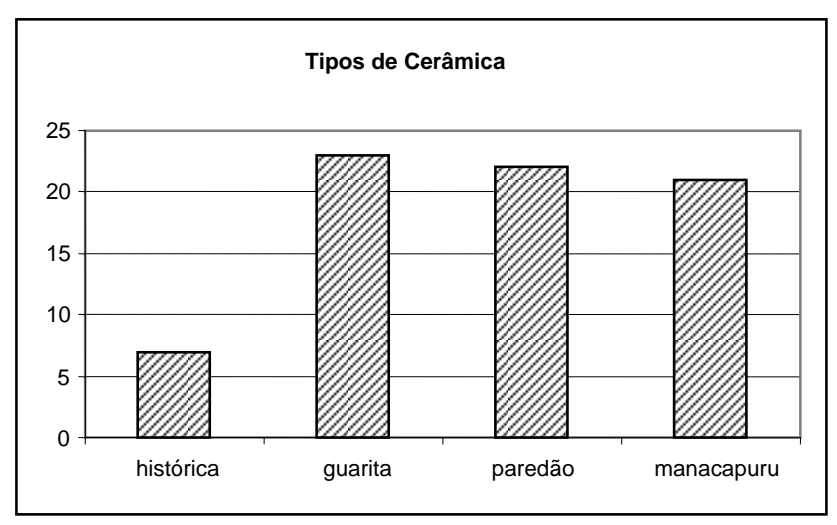

Gráfico 10 - Quantidade de cerâmica das diferentes fases encontradas na limpeza de perfil realizada no sítio Lago do Limão.

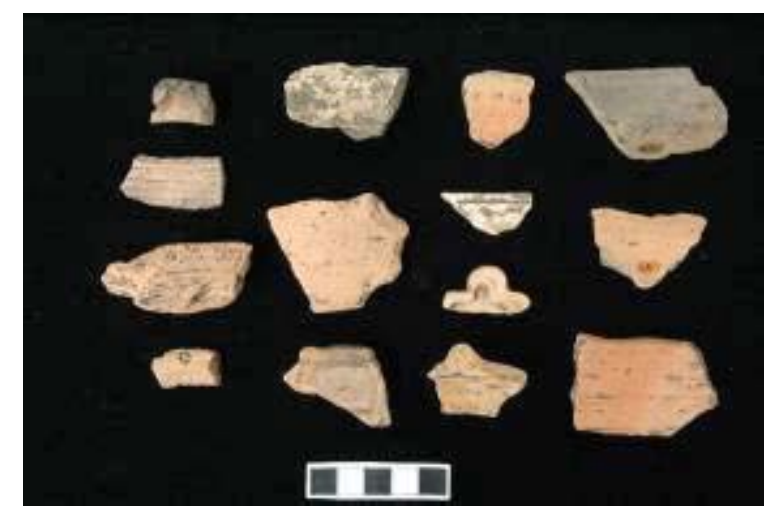

Figura 78 - Fragmentos de cerâmica da fase Manacapuru, limpeza de perfil.

Talvez o gráfico que nos ajude a interpretar melhor o contexto dessa parte do sítio seja o dos fragmentos de cerâmicas diagnósticas por nível (gráfico 11). Se o leitor observar o gráfico verá que não existe uma seqüência lógica na distribuição dos diferentes materiais por níveis. Excetuando o caso da cerâmica histórica ("cabocla"), que está representada

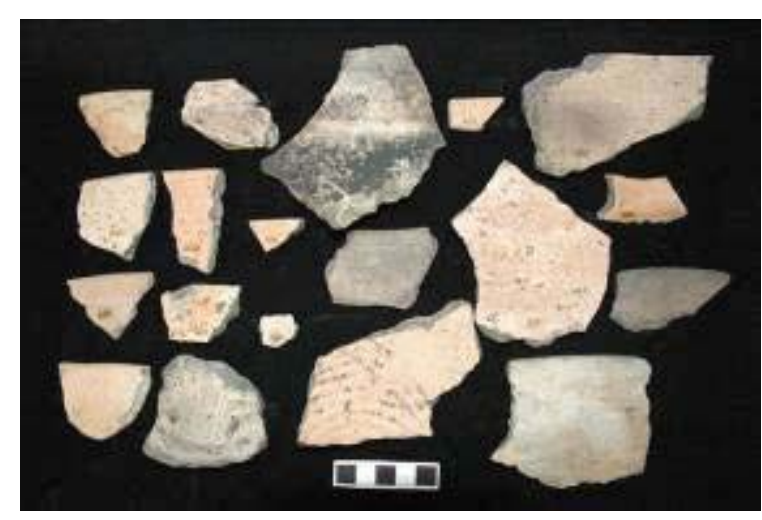

Figura 79 - Fragmentos de cerâmica da fase Paredão, limpeza de perfil.

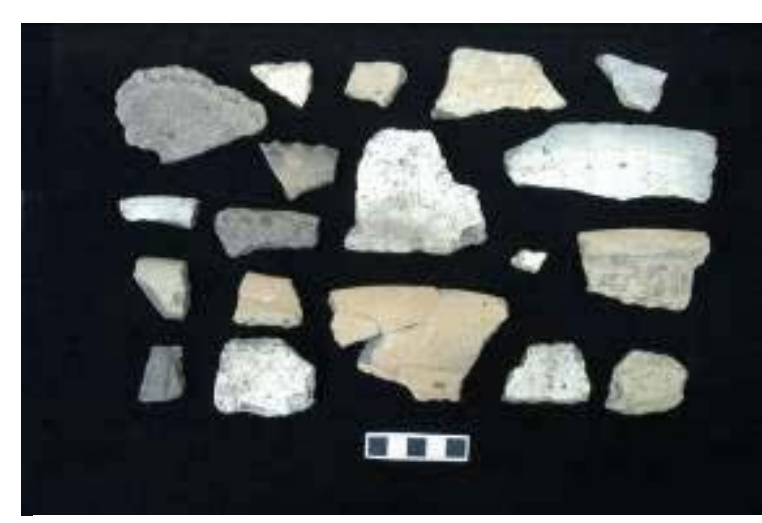

Figura 80 - Fragmentos de cerâmica da fase Guarita, limpeza de perfil. apenas até $70 \mathrm{~cm}$ de profundidade, o restante do material está completamente misturado em todos os níveis. Como estamos em uma área do sítio muito próxima ao barranco do lago e a área apresenta um certo declive, parece que estamos tratando com dois contextos distintos de deposição coluvial. O mais recente até $90 \mathrm{~cm}$ de profundidade, fica bem representado pela presença de materiais históricos e pelas características do 
sedimento descritas na figura 77. O pacote coluvial recente por sua vez, teria sepultado um pacote pré-colonial. Tal processo seria evidenciado pela presença de uma única camada perceptível através da textura e coloração do sedimento (um sedimento com textura arenosa, muito menos compactado que o predominante no sítio), associado à total perturbação horizontal do material cerâmico em todos os níveis.

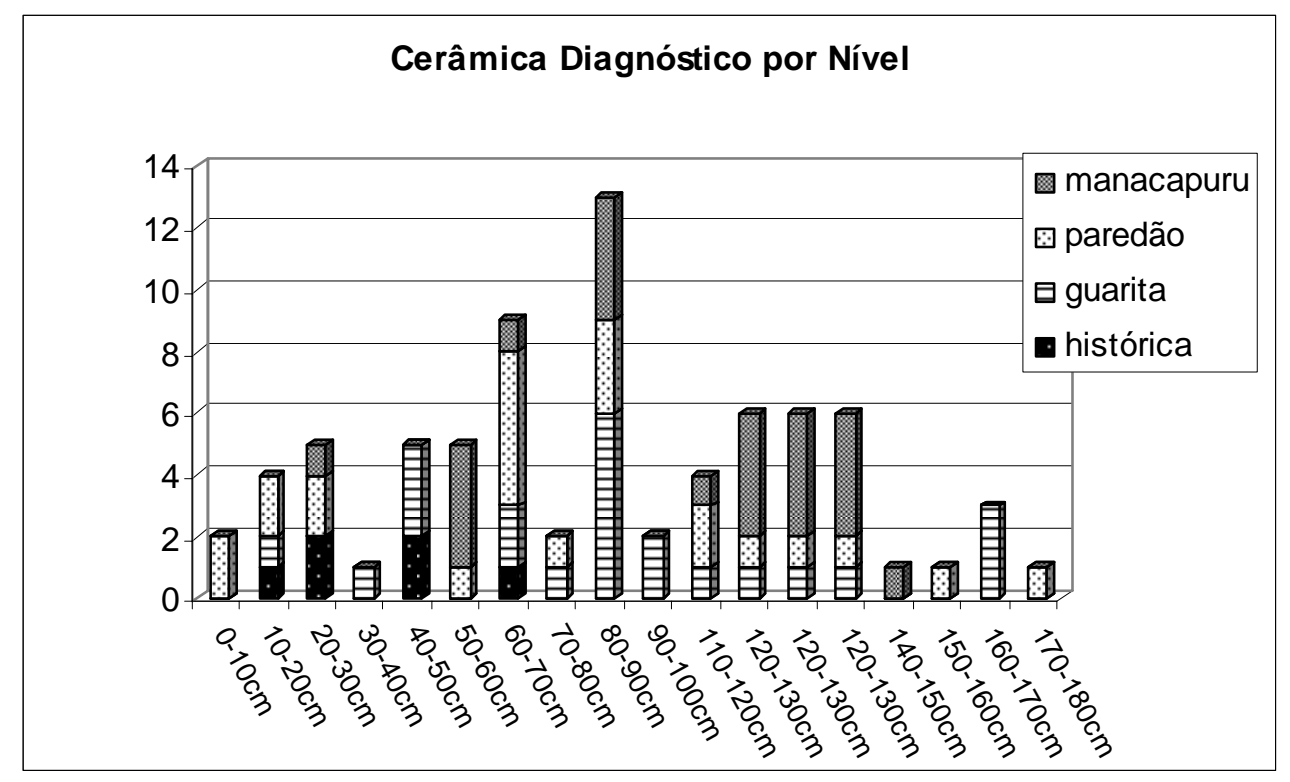

Gráfico 11 - Cerâmicas “diagnósticas” evidenciadas na limpeza de perfil distribuídas por nível.

Com o resultado da triagem do material coletado no sítio Lago do Limão, apresentado no gráfico 12, concluímos que seria um sítio importante para o aprofundamento dos trabalhos de campo pelas seguintes razões: em primeiro lugar, a presença de cerâmica da fase Manacapuru, bem representada no material diagnosticado e em segundo as grandes proporções do sítio, podem trazer um bom contexto comparativo com o sítio Osvaldo. Por último, temos também as camadas com cerâmicas das fases Paredão e Guarita bem representadas no sítio, o que permite situar a ocupação Manacapuru em uma cronologia local. Com o aprofundamento dos trabalhos poderemos levantar dados importantes para entender os processos de continuidade e mudança no espaço e no tempo e assim entender melhor a dinâmica de ocupação das margens do lago do Limão. 


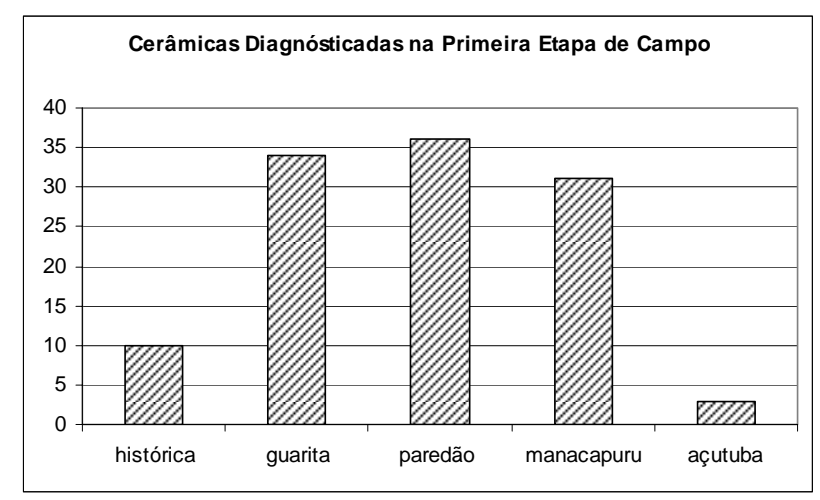

Gráfico 12 - Quantificação das diferentes cerâmicas encontradas no sítio Lago do Limão.

\section{IV.II.I - A PRIMEIRA UNIDADE ESCAVADA NO SÍTIO}

A tradagem SE-25 (anexo 12) havia apresentado uma alta concentração de fragmentos de cerâmica, 23 nos primeiros $20 \mathrm{~cm}$ de profundidade, 54 de 20 a $40 \mathrm{~cm}, 28$ de 40 a $60 \mathrm{~cm}$ e dois de 60 a $80 \mathrm{~cm}$. Além dos fragmentos foi observada a presença de muito carvão no sedimento e um pacote de terra preta relativamente profundo $(80 \mathrm{~cm}$, figura 63). Após o processamento do material identificamos fragmentos de cerâmicas das fases Guarita, Paredão e Manacapuru. Desse modo acreditamos que seria um bom local para abrirmos uma unidade de escavação.

Iniciamos os trabalhos de campo identificando o local que havia sido tradado no ano anterior, tarefa difícil, pois a vegetação cresce muito rápido no ambiente. Após a identificação foi demarcada uma unidade de 1x1 m (figura 81), ficando a tradagem na extremidade sudeste da unidade. Para adequação aos parâmetros do PAC, a unidade passou então a obedecer ao sistema de quadriculamento do sítio em dois eixos, sendo a unidade N-1976 E-500.

A unidade foi escavada em níveis artificiais de $10 \mathrm{~cm}$. Cada nível foi registrado em uma ficha (anexo 08), onde controlamos informações referentes às características do solo, densidade de material, pessoas responsáveis pelo trabalho e observações particulares de cada nível escavado.

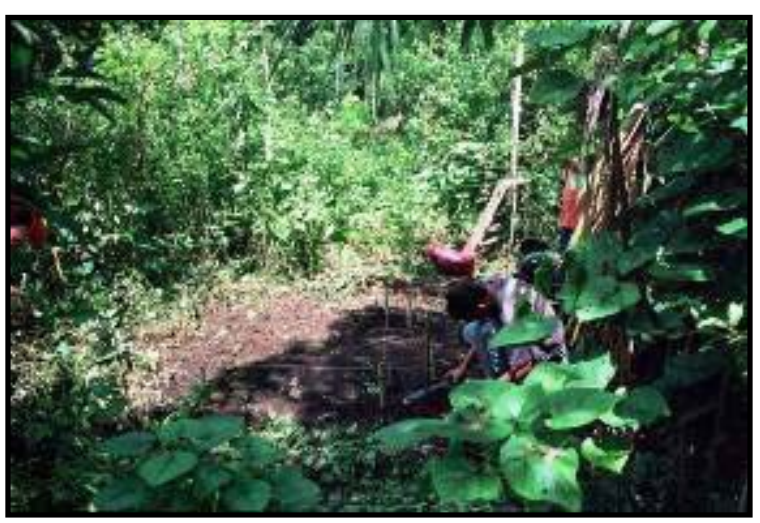

Figura 81 - Demarcação da unidade N1976 E500 
Como já havia sido percebido na tradagem SE-25, a terra preta está presente desde a superfície. Nos primeiros $10 \mathrm{~cm}$ de escavação as cerâmicas aparecem em baixa densidade, sendo fragmentos pequenos, o que provavelmente resulta da prática de agricultura feita durante muitos anos no local. De 10 a $20 \mathrm{~cm}$ de profundidade o tamanho e densidade dos fragmentos aumenta bastante, com destaque para várias remontagens percebidas no próprio campo. Encontramos quase a metade de um vaso fragmentado em partes menores, porém estruturado em um único conjunto (figura 82 e 83). Trata-se de um vaso da fase Guarita com decoração acanalada preenchendo o espaço entre a borda e uma pequena flange mesial existente na peça, bem como restos de engobo branco, principalmente dentro dos acanalados. Um outro fragmento do mesmo pote já havia sido encontrado na tradagem realizada em 2004. Além da cerâmica e da terra preta homogênea identificada na escavação, foi possível perceber também uma mancha com terra queimada (figura 82) próxima ao fragmento de cerâmica Guarita. O contexto foi de certa forma surpreendente, pois de acordo com os dados que tínhamos a respeito do sítio, as camadas mais superficiais já foram bastante perturbadas pela agricultura. Ficamos então na expectativa de encontrar cerâmicas ainda melhor preservadas nas camadas mais profundas do pacote arqueológico.

Com o início da escavação do nível 20 a $30 \mathrm{~cm}$, percebemos exatamente o inverso de nossas expectativas. Apesar da alta concentração, os fragmentos de cerâmica estavam bem menores e já não percebíamos as remontagens como no nível anterior. O solo aparentava estar mais compactado que nos níveis anteriores e a quantidade de fragmentos de laterita aumentou bastante também.

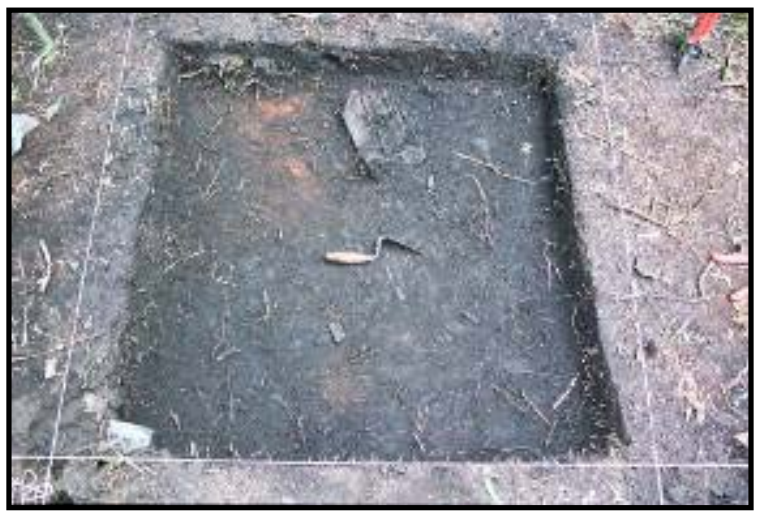

Figura 82 - Unidade N-1976 E-500, nível 10$20 \mathrm{~cm}$, fragmento de cerâmica da fase Guarita e terra queimada.

Dos 30 aos $40 \mathrm{~cm}$ a cerâmica atinge um de seus maiores picos de densidade, porém com fragmentos pequenos e desarticulados. A quantidade de fragmentos de laterita no sedimento também é muito grande, o solo tem textura argilosa e é bastante compactado.

No nível 5, 40 a $50 \mathrm{~cm}$ de profundidade, percebemos uma cerâmica muito fragmentada, com densidade de fragmentos um pouco menor que no nível superior. Algumas amostras de carvão foram coletadas com proveniência individual, com 
informações espaciais horizontais e verticais. O solo estava muito compactado, devido à sua textura argilosa o trabalho de escavação foi bastante difícil.

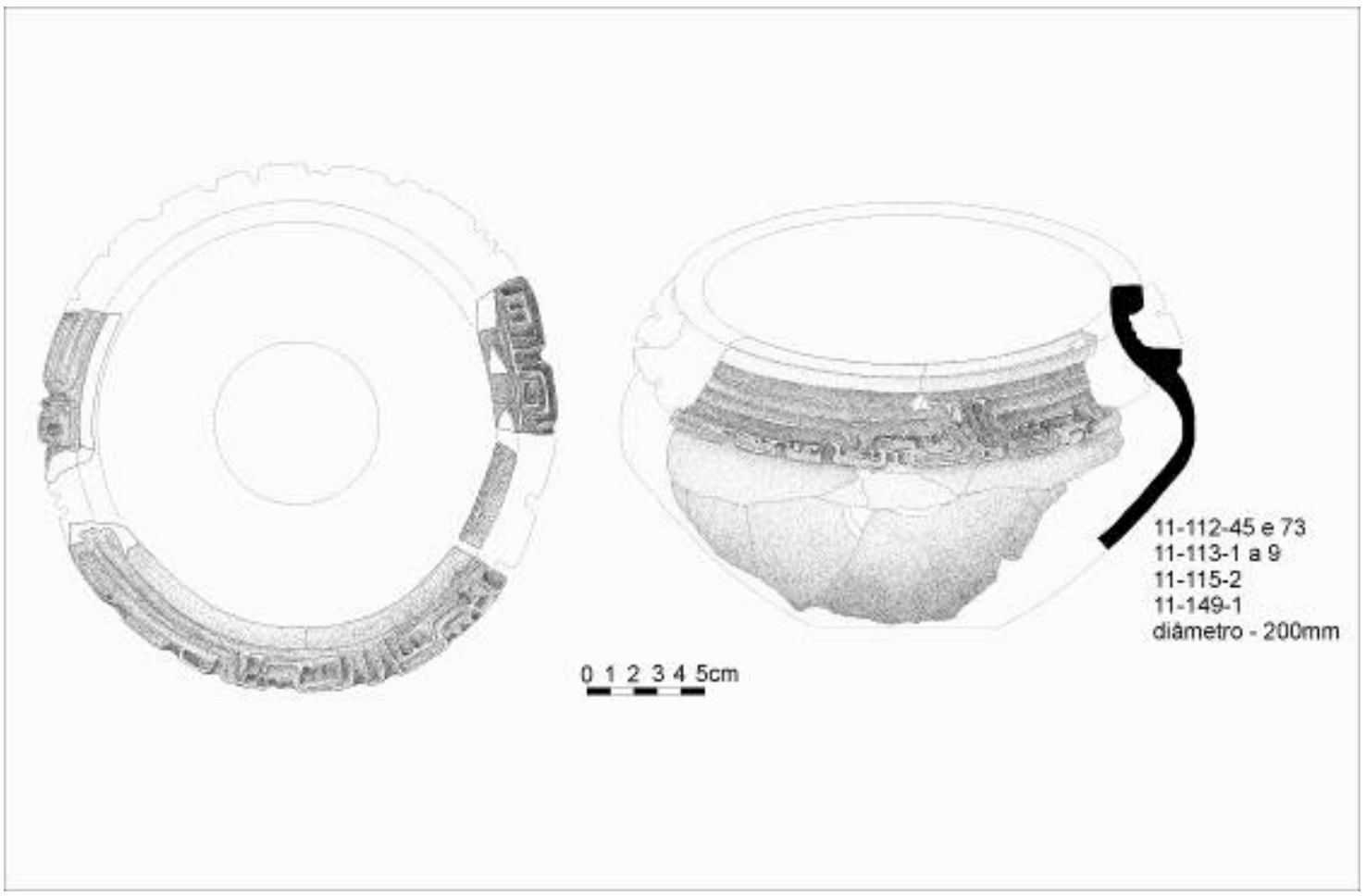

Figura 83 - Vaso Guarita reconstituído.

A quantidade de fragmentos de laterita no sedimento manteve-se bastante elevada, dando mostras até de um pequeno aumento. A terra preta apresentou tonalidades mais claras na base do nível, revelando uma feição no quadrante sudeste do perfil sul. Trata-se de uma feição circular que ocupa cerca de $30 \mathrm{~cm}$ do perfil, avançando aproximadamente $10 \mathrm{~cm}$ para o interior da unidade de escavação. A feição é preenchida com sedimento mais escuro (terra preta com a mesma coloração dos níveis anteriores) e menos compactado que o sedimento da unidade. Ao lado da feição também foi perceptível a presença de um sedimento de coloração amarelada (figura 84).

Escavando o nível 6, 50 a $60 \mathrm{~cm}$ de profundidade, percebemos uma diminuição na densidade de fragmentos de cerâmica, um solo de coloração bem

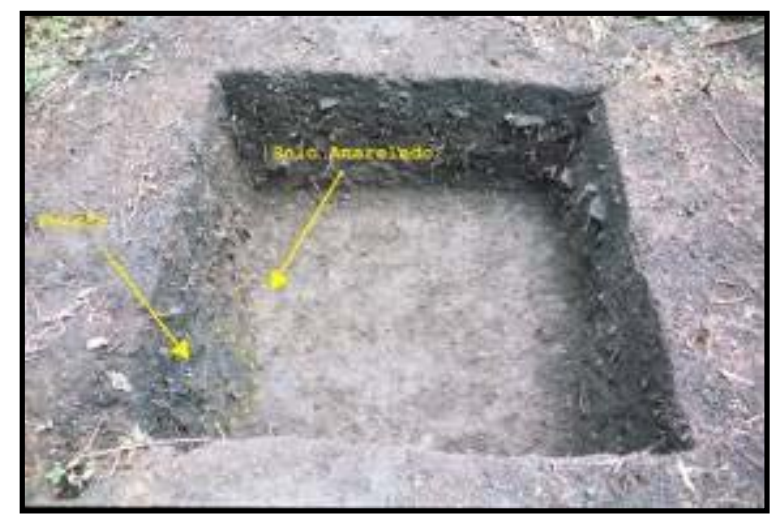

Figura 84 - Unidade N-1976 E-500, nível 40-50 $\mathrm{cm}$ com destaque para o aparecimento da feição 1 . 
mais clara que nos níveis superiores, já dando mostras do final da camada de terra preta. A quantidade de fragmentos de laterita no sedimento também apresentou uma redução considerável com relação ao nível superior. A compactação do solo parece a mesma descrita anteriormente. Com o clareamento do sedimento da unidade, a feição (F1) apresentada no parágrafo anterior se tornou mais evidente, mantendo aparentemente as mesmas dimensões. Uma mancha de sedimento mais escuro ficou visível no quadrante nordeste. Desta vez uma feição maior que ocupa uns $40 \mathrm{~cm}$ do perfil norte e avança uns $25 \mathrm{~cm}$ para o interior da unidade. Foi coletada uma amostra de carvão dentro da feição (F2).

No nível 7, dos 60 a $70 \mathrm{~cm}$ de profundidade, ficou bem claro o final da camada de terra preta, o sedimento é totalmente amarelado, os fragmentos de cerâmica aparecem principalmente associados às feições onde o sedimento ainda é a terra preta. Com o clareamento do sedimento as feições ficaram muito evidentes. Uma nova feição (F3) pôde ser percebida no quadrante sudoeste da unidade, também evidente no perfil sul. Trata-se de uma feição circular que ocupa cerca de $20 \mathrm{~cm}$ do perfil e avança uns 12 $\mathrm{cm}$ para dentro da unidade (figura 85). A densidade de fragmentos de laterita no sedimento continua diminuindo. Nesse nível também foram coletadas algumas amostras de carvão com proveniência individual.

No nível 8, dos 70 aos $80 \mathrm{~cm}$ de profundidade, o sedimento, com textura muito argilosa, já apresenta escassez de fragmentos de cerâmica que parece aparecer somente nas feições, os fragmentos de laterita quase não são mais vistos e as feições ficaram bem destacadas nos perfis. Uma amostra de carvão foi coletada próximo à F3.

No nível 9, 80 a $90 \mathrm{~cm}$ de profundidade, a situação é praticamente a mesma do nível superior, a única diferença é o total desaparecimento dos fragmentos de lateria no sedimento. Nesse nível as feições 2 e 3 já não estão mais presentes na base.

No nível 10, dos 90 aos $100 \mathrm{~cm}$ de profundidade, a única mudança percebida na escavação foi novamente a presença de um grande numero de fragmentos de laterita na base do nível. A feição 1 continua presente também na base.

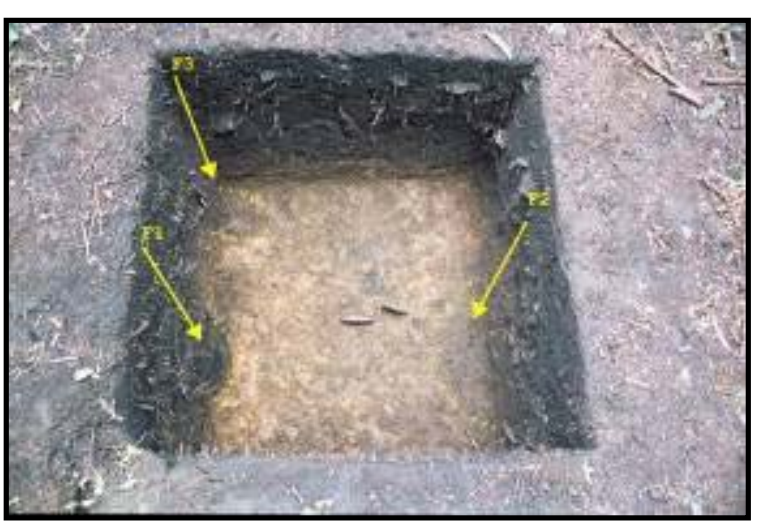

Figura 85 - Unidade N1976 E500, nível 60-70 cm, com destaque para as feições 1,2 e 3 . 
Finalizamos a unidade de escavação no nível 11, 100 a $110 \mathrm{~cm}$ de profundidade, onde não foram encontrados fragmentos de cerâmica, a feição 1 apresentou sua base em um sedimento já com bastante lateritas. Um conglomerado de laterita foi evidenciado entre 108 e $110 \mathrm{~cm}$. Todas as feições encontradas ficaram bastante evidentes nos perfis (figura 86).

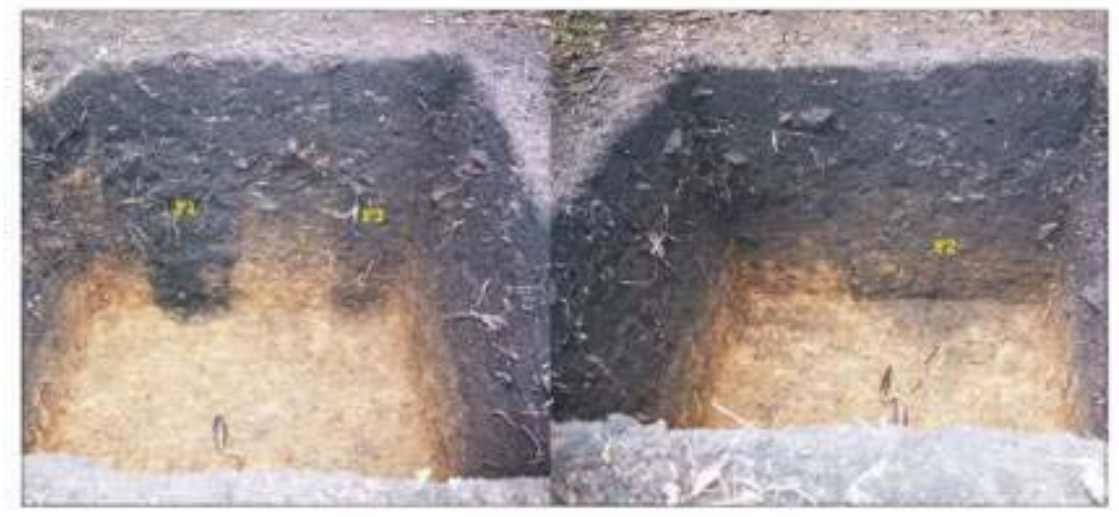

Figura 86 - Unidade N-1976 E-500, feições vistas nos perfis sul à esquerda e norte à direita.

Foram desenhados os perfis norte, oeste e sul e coletadas amostras de carvão que estavam nas paredes. As informações relativas à descrição das camadas, com padronização das cores através da escala da tabela de solos Munsell, podem ser vistas na figura 87. O gráfico 13 apresenta a densidade material cerâmico por nível.

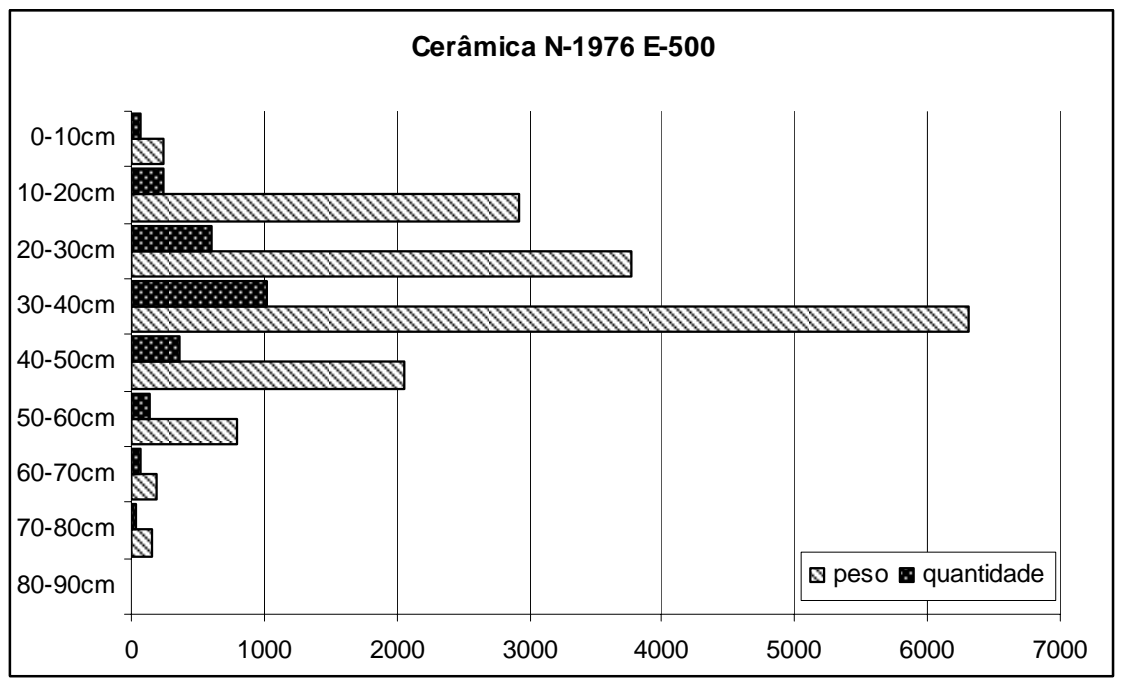

Gráfico 13 - Unidade N-1976 E-500, material cerâmico por nível.

Numa tentativa de interpretação do contexto da unidade escavada, apresentamos a seguinte hipótese: as feições 1 e 3 nos pareceram buracos de esteios preenchidos pelo sedimento das camadas superiores. Coincidindo com o início de F3 e o nível onde F1 fica perceptível no momento da escavação, há uma alta concentração de fragmentos de 


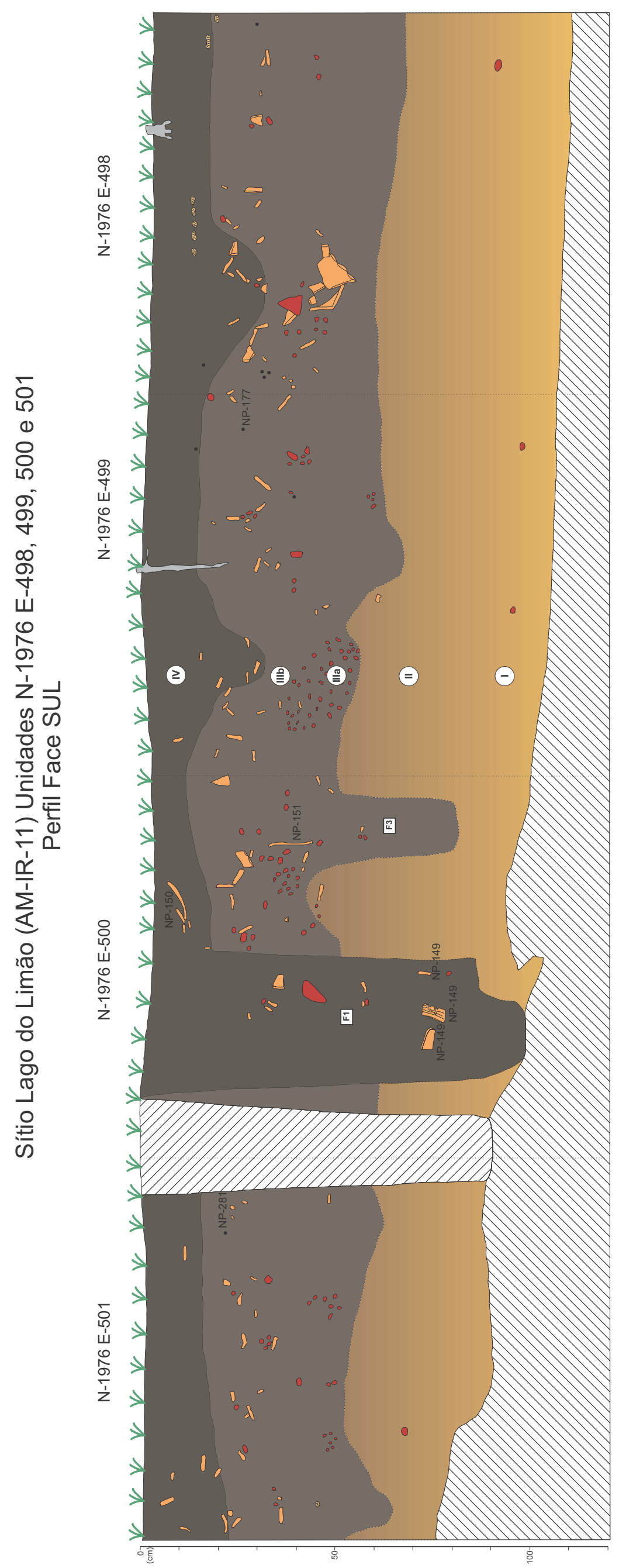

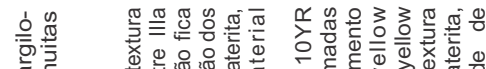

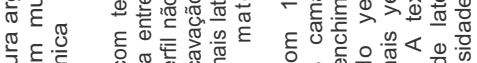

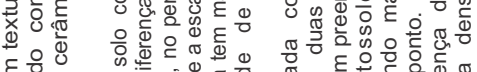

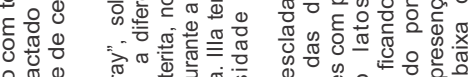

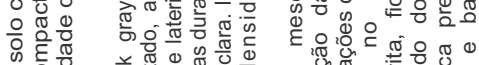

क

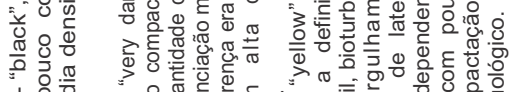

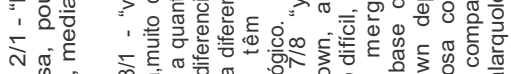

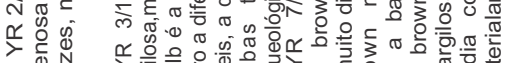

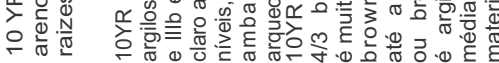
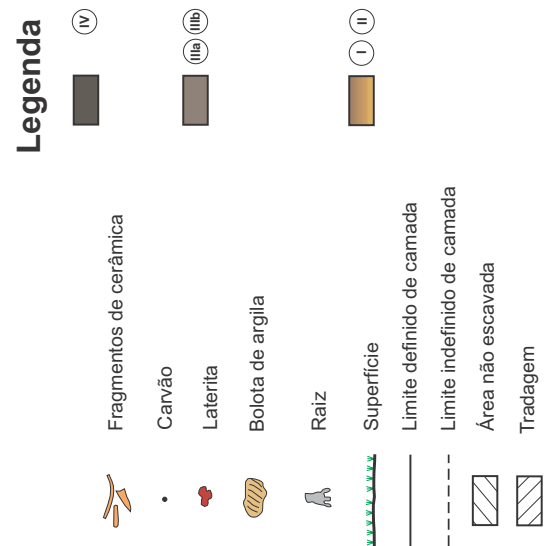

동 
lateria que vão diminuindo de acordo com a profundidade até o total desaparecimento para depois voltar a aparecer na base da escavação; ainda tentando relacionar, temos uma fragmentação muito maior da cerâmica coincidindo com uma compactação acentuada do sedimento no nível das feições (entre 30 e $50 \mathrm{~cm}$ ). Quando F1 se torna perceptível na escavação é possível notar a presença de uma mancha de sedimento da camada I, que provavelmente ficou depositado na superfície da época (entre 40 e $50 \mathrm{~cm}$ ) quando a feição foi escavada.

Acreditamos então que foi escavado o que seria o piso de uma unidade habitacional. O que apoiaria a hipótese seria a presença de negativos dos buracos onde estariam dois dos esteios da unidade, coincidindo com um piso construído com a adição de fragmentos de laterita (cascalho) no sedimento que foi muito compactado. A compactação teria provocado a alta fragmentação dos vestígios cerâmicos que estavam ali, ou foram adicionados, por ocasião da construção do piso.

$\mathrm{Na}$ etapa de campo, que será apresentada na seqüência, foi feita uma ampliação da área escavada. Algumas amostras coletadas já foram datadas. Dado que neste contexto temos a presença de cerâmicas das fases Manacapuru, Paredão e Guarita. Agora além de tentar verificar a presença de uma unidade habitacional, outra pergunta interessante seria a qual destas ocupações ela está associada.

Durante a etapa de campo de janeiro de 2005, em algumas conversas com os proprietários dos terrenos do sítio Lago do Limão, ficamos sabendo da presença de depressões existentes nas proximidades do lago que eles atribuem o nome de "curral de tartaruga de índio". Segundo nossos informantes as depressões são conhecidas por este nome pelas informações de seus avós que já eram moradores do local. Com a ajuda dos mesmos informantes identificamos três das depressões, duas menos evidentes e uma facilmente perceptível na paisagem (anexo 12).

\section{IV.II.II - A INTENSIFICAÇÃO DAS ESCAVAÇOES}

Iniciamos os trabalhos no dia 2 de agosto de 2005 com algumas intervenções no sítio. Diferentes atividades foram realizadas: paralelamente às escavações, começou a ser feito também o trabalho de topografia do sítio, foram demarcadas algumas unidades adjacentes à unidade N-1976 E-500. Com isto buscávamos mais vestígios que pudessem reforçar a hipótese de ali haver o que teria sido o piso de uma unidade habitacional. 
Foi aberta também uma trincheira de $8 \times 1 \mathrm{~m}$ em uma das feições conhecidas atualmente pela população local como "curral de tartaruga de índio". Buscávamos principalmente constatar se realmente se tratava de estruturas construídas ou depressões naturais do terreno. Alguns morrotes foram identificados em uma parte do sítio, quatro unidades de escavação foram abertas dentro e fora das elevações, com o objetivo de verificar se eles eram montículos artificiais ou faziam parte da estrutura natural da paisagem.

Uma unidade foi escavada fora da área de terra preta para verificar se haveria alguma diferença nos tipos de vestígios encontrados nas diferentes áreas do sítio.

\section{IV.II.II.I - AMPLIAÇÃO DA UNIDADE N-1976 E-500}

No total foram escavados mais $6,5 \mathrm{~m}^{2}$ adjacentes à unidade N-1976 E-500. De maneira geral as unidades apresentaram terra preta desde a superfície até a profundidade de $60 \mathrm{~cm}$.Uma grande quantidade de material cerâmico foi coletada. A densidade de cerâmica é grande desde a superfície, aumentando gradativamente até $40 \mathrm{~cm}$ de profundidade. Os padrões de compactação do solo e adição de fragmentos de laterita (cascalho), observados na primeira unidade escavada se repetiram, de um modo geral entre 30 e $50 \mathrm{~cm}$. Abaixo do piso diminui a densidade de cerâmica e após $60 \mathrm{~cm}$ de profundidade o solo fica amarelado. Com a mudança de cor do solo começam a aparecer algumas feições (figuras 86, 87, 88 e 89). Uma série de buracos de esteio preenchidos com terra preta. Foram identificadas 3 feições circulares com área maior, associadas à fase Manacapuru, (F2, F17 e F18). São buracos arredondados cavados no latossolo amarelo. A feição 17 apresenta um buraco maior e menos profundo, com outro menor e mais profundo ao centro, dando à feição a forma de um chapéu virado. No sítio Hatahara foi escavada uma feição muito semelhante (Machado 2005:80 e 81). Próximo à cidade de Manacapuru, nos trabalhos do Gasoduto Coari-Manaus, foi escavado um sítio unicomponencial da fase Manacapuru com muitas feições semelhantes. Esse tipo de feição também parece ser recorrente nas ocupações da fase Pocó do Baixo Amazonas (João Aires 2005, comunicação pessoal). 


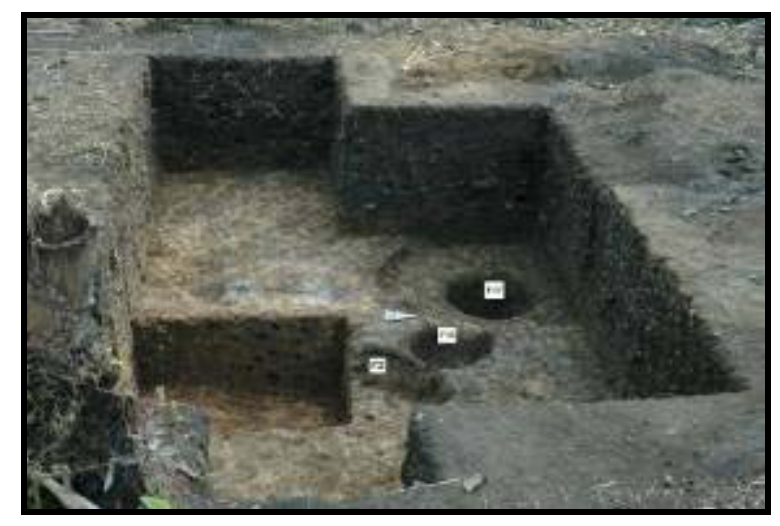

Figura 88 - Vista geral da escavação, com destaque para as feições 2,17 e 18 .

As feições identificadas, algumas muito semelhantes às vistas no perfil sul da unidade N-1976 E-500, ajudam a confirmar a hipótese de tratar-se de buracos onde estariam os esteios do que seria a unidade habitacional.

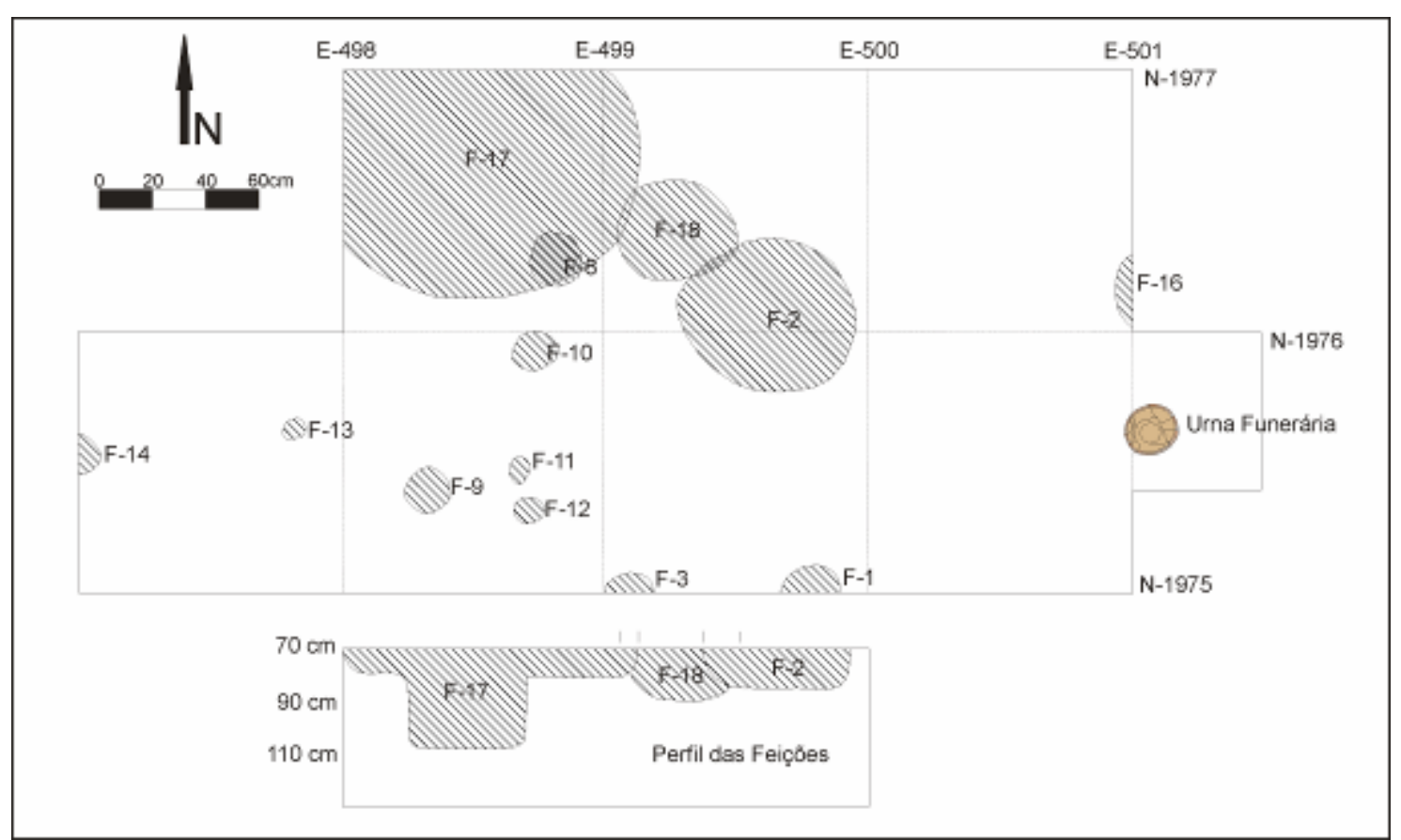

Figura 89 - Planta da escavação apresentando as feições identificadas e o sepultamento em urna (a extremidade nordeste da nome às quadras).

Em alguns pontos, o que seria o piso apresenta diferenças na textura do sedimento. Existem interrupções na camada de laterita, talvez isso seja decorrente de adaptações efetuadas na área interna da unidade habitacional. A distribuição das feições de buracos de esteios talvez ajude a reforçar essa interpretação. Se voltarmos à figura 89, poderemos notar a presença de feições de buracos de esteio com diâmetros variados, muito próximas umas das outras. Se as feições são de estruturas internas da unidade 
habitacional, os buracos foram cavados após a construção do piso e por isso no perfil da escavação fica visível a descontinuidade da camada de laterita, mesmo onde o solo apresenta a mesma coloração (figura 87).

\section{IV.II.II.II - O SEPULTAMENTO EM URNA}

Uma urna funerária de pequeno porte com tampa e um vaso parcialmente inteiro (figura 90, 91, 92 e 93) foram encontrados na parede leste da unidade N-1976 E-501. Com a ampliação da escavação para a retirada da urna percebemos que o sepultamento também corta o piso de laterita, ou seja, foi depositado em um evento posterior à construção da unidade habitacional. Sendo também uma atividade que teria contribuído para a interrupção do piso observada durante a escavação.

A urna funerária é um vaso pequeno, exemplar único da categoria na região. Trata-se de um vaso do tipo

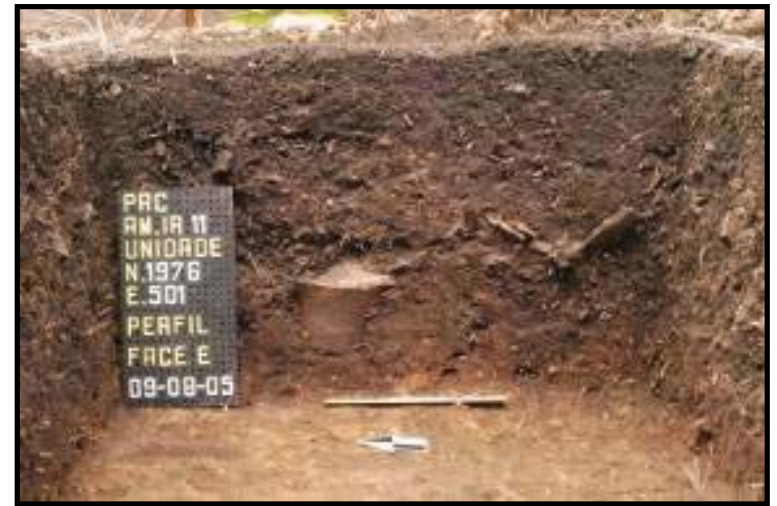

Figura 90 - Urna Funerária com tampa e vaso fragmentado, identificados no perfil leste da unidade N-1976 E-501.

12 (vaso com colo), medindo $18,5 \mathrm{~cm}$

de altura, diâmetro da borda: $23 \mathrm{~cm}$ e espessura da parede $0,7 \mathrm{~cm}$. A superfície da pasta apresenta cor "laranja A". O antiplástico é composto por cauixí, caco moído e mineral (ver atributos analisados no capítulo seguinte). A queima do vaso é incompleta com núcleo escuro. Foi construído com base plana modelada e paredes erguidas com roletes, inclinação da borda extrovertida, lábio plano com acabamento inciso em linhas finas. $\mathrm{O}$ vaso apresenta a superfície interna com aspecto besuntado e superfície externa com marcas de líquido escorrido, provavelmente de um uso anterior ao funerário.

Quando foi retirado do campo o vaso estava cheio de sedimento (terra preta 10YR2/1 - black). A urna estava coberta por uma tampa fragmentada, mas bem estruturada em um único conjunto. A tampa, um exemplar do tipo 8 (prato), medindo $5,4 \mathrm{~cm}$ de altura, 23,5 de diâmetro e 1,5 cm de espessura na borda. A superfície da pasta apresenta cor "laranja A". O antiplástico é composto por cariapé, mineral e cauixí. A queima da tampa é completa totalmente oxidada. Foi construído com base plana modelada e paredes erguidas com roletes, um rolete foi aplicado na face externa da borda, com inclinação direta, reforçando o lábio, que posteriormente tem engobo branco 
no acabamento. O prato tinha também decoração pintada, da qual só sobraram vestígios de pigmento marrom. Na parte interna da base existem marcas de uso, desgaste por atrito com algum outro artefato (colher), de um uso anterior ao funerário.

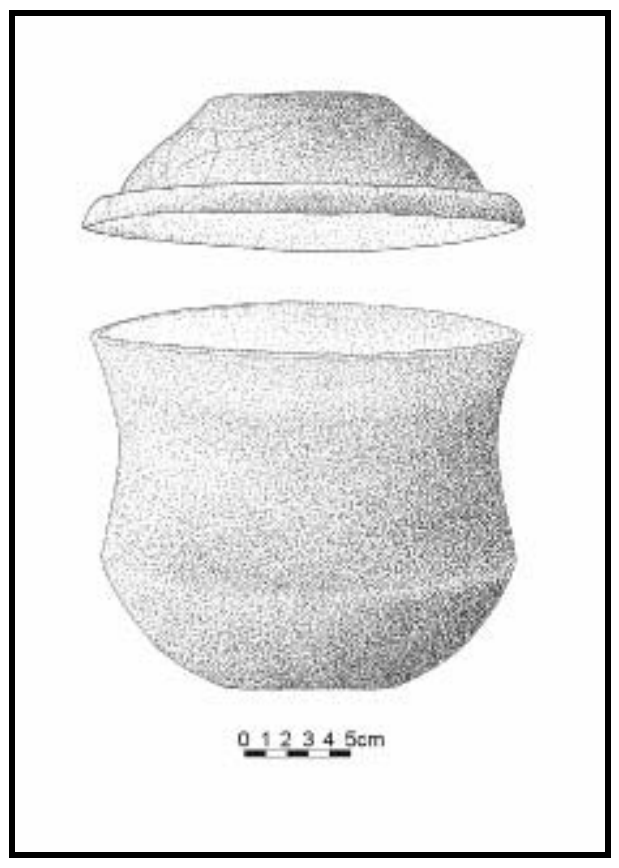

Figura 91 - Urna e tampa.

Optamos pela retirada do vaso sem escavar o conteúdo no campo. Deixamos essa fase para o laboratório, onde a escavação poderia ser feita com maior controle. Várias etapas foram seguidas durante a escavação da urna, como nós veremos alguns gestos tiveram que ser readaptados ao decorrer do trabalho. A retirada da tampa e dos fragmentos relacionados foi feita no campo. No laboratório o começo da escavação foi feita de $2 \mathrm{em} 2 \mathrm{~cm}$. Todo o sedimento retirado foi guardado.

Foi só no laboratório que descobrimos que no interior da urna existiam ossos humanos queimados e quebrados em fragmentos pequenos. Optamos então por abandonar a metodologia de escavação por níveis de $2 \mathrm{~cm}$, retirando os ossos por camadas, pois o sedimento visto na urna foi introduzido após a fragmentação da tampa de modo que quando os ossos apareceram quase não havia mais sedimento.

Como os ossos parecem ter sido depositados em um único momento, a retirada por camadas tem como finalidade o registro e a identificação de possíveis escolhas de quais ossos teriam sido depositados primeiro.

O material com o qual escavamos mudou durante o procedimento, no começo a escavação foi feita com espátulas e colheres de cozinha, mas por causa da quantidade de 
ossos e de sua fragmentação foi necessário aspirar a terra entre os ossos. Os ossos foram todo plotados por camadas (figura 92), recebendo um numero para cada indivíduo. Micro fragmentos ou fragmentos de ossos mexidos, para os quais não era possível determinar a posição foram colocados juntos em um saco de alumínio com um numero de proveniência para todos.

A desmontagem das camadas, descrição e análise dos ossos foram executadas por Anne Rapp Py-Daniel, os dados serão utilizados em sua dissertação de mestrado, de forma que apresentaremos aqui apenas algumas considerações preliminares do que já foi produzido. Os ossos foram plotados, numerados e descritos individualmente num banco de dados (anexo 14). Não foram lavados, pois devido à fragilidade eles poderiam se desintegrar. Após a análise os ossos foram conservados individualmente em pacotes de alumínio. Todos os fragmentos de ossos foram fotografados individualmente.

Durante a escavação percebemos que os ossos estavam muito fragmentados. Aqueles que foram numerados geralmente não passavam de $5 \mathrm{~cm}$ de comprimento, a maior parte deles estando entre 1 e $2 \mathrm{~cm}$ no eixo maior. Além do problema causado pela fragmentação a identificação foi dificultada por causa da queima e da conservação dos ossos, mas com exceção de algumas dúvidas, todos parecem ossos humanos.

Parece ter havido uma etapa de cremação com o esqueleto fresco, pois traços de queima e estrias de dilatação, devido ao líquido fervendo no interior dos ossos, estavam presentes na grande maioria dos fragmentos encontrados. Os interiores das camadas compactas ósseas são às vezes muito pretos e frágeis, uma hipótese seria o contato com maior quantidade de líquido durante a queima. A fragmentação dos ossos parece ter sido intencional, porém o impacto causado pela queima dificulta a leitura e o reconhecimento de marcas de corte ou pontos de impacto da quebra.

Todas as regiões anatômicas estão representadas nos fragmentos identificados, mas é interessante notar que somente uma raiz de dente foi encontrada. Os dentes podem ter sido arrancados intencionalmente, pois eles são geralmente as partes do esqueleto que se conservam melhor, além disso, os fragmentos de mandíbula identificados atestam alvéolos abertos e funcionais na hora da morte. 


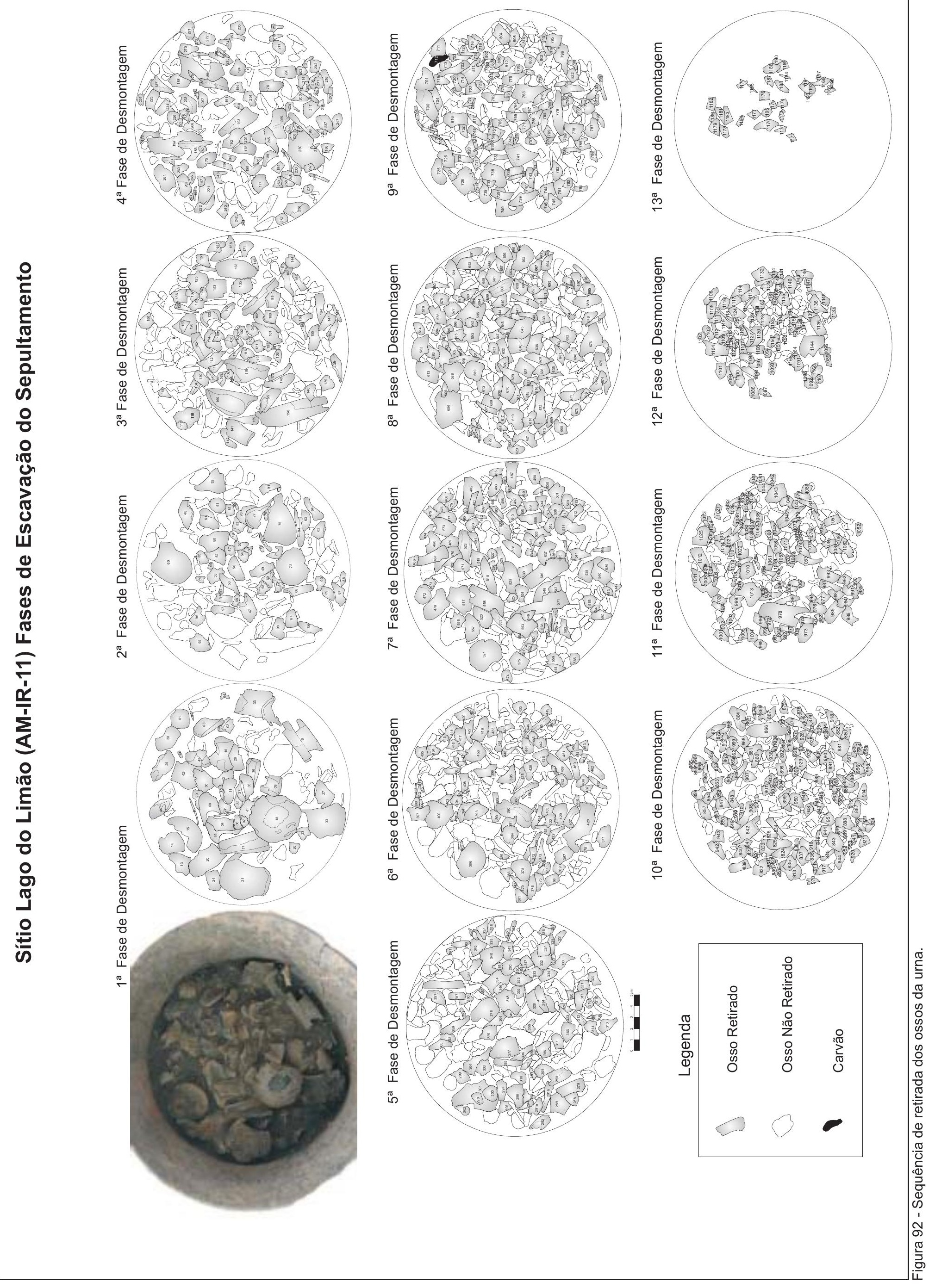


Os fragmentos que parecem pertencer aos ossos longos das pernas são muito robustos, existem também outros de diâmetro menos importante que têm uma camada compacta espessa e densa. Entretanto existe algo estranho, pois diáfises de ossos longos pequenos e finos também estão presentes em uma quantidade significante (seriam estes ossos das extremidades ou de fauna?).

Foram retirados 1199 fragmentos de ossos com proveniência, dos quais somente $141(11,80 \%)$ puderam ser identificados com "certeza" ou "grande probabilidade de acerto". Os ossos identificados representam as partes do esqueleto vistas na tabela 01 .

\begin{tabular}{|l|l|}
\hline \multicolumn{2}{|c|}{ Partes do esqueleto e suas porcentagens } \\
\hline Craniana & $42,55 \%$ \\
\hline Vertebral & $19,85 \%$ \\
\hline Costelas & $15,60 \%$ \\
\hline Mãos & $5,67 \%$ \\
\hline Membros superiores & $5,67 \%$ \\
\hline Bacia & $4,96 \%$ \\
\hline Pés & $2,83 \%$ \\
\hline Membros inferiores & $2,12 \%$ \\
\hline Dentes & $0,71 \%$ \\
\hline
\end{tabular}

Os ossos do crânio são mais fáceis de identificar, isso certamente influencia a alta porcentagem vista acima. A preservação de ossos frágeis como vértebras e costelas são provas da boa representatividade do esqueleto. A falta de dentes é um fato a ser destacado como foi apontado anteriormente.

Temos várias hipóteses quanto aos gestos efetuados antes do enterramento da urna:

Os ossos foram queimados, vários ossos apresentam traços de queima direta (manchas escuras na superfície) ou indireta (a cor do osso, branco opaco no exterior e preto no interior). A relativa boa conservação dos ossos em meio tropical e terreno ácido também pode ter se dado por conta da queima que eliminou a parte orgânica dos ossos mais rapidamente. Como dito anteriormente, os ossos foram queimados ainda frescos ou pelo menos não muito secos, pois, existia líquido dentro deles quando foram queimados. As evidências são as torções dos ossos, explosões e as rachaduras concêntricas devido à explosão do líquido em ebulição. Para que isso ocorra o corpo ou ossos semi-frescos devem ter sido colocados em contato direto com a fonte de calor.

A fragmentação dos ossos sugere que eles tenham sido quebrados intencionalmente (muito além do que é o normal durante o processo de queima), mas ainda não conseguimos saber se a quebra ocorreu antes ou após a queima. 
A falta de carvão misturado aos ossos e o fato de vários ossos pequenos estarem presentes (por exemplo, falanges) nos fazem pensar na possibilidade de existir um recipiente de queima. Mesmo se existe evidencia de terra queimada ao redor dos ossos não achamos que eles foram queimados em fogueiras sobre o solo, por causa da representatividade óssea (geralmente quando o corpo é queimado em fogueira ao ar livre faltam nos sepultamentos os ossos pequenos ou muito fragmentados).

Seja qual foi o procedimento ele foi muito minucioso, demonstrando a importância dos gestos. Parece que os últimos ossos a serem colocados na urna foram o crânio e algumas vértebras. Esse tipo de sepultamento é único, até o momento não existe outro na região, por isso é muito difícil fazer generalizações ou falar de práticas funerárias. Fica ainda mais difícil, pois o vaso utilizado como urna tem características tanto da fase Paredão, quanto Guarita. Certamente o sepultamento é de um período Guarita. A tampa é um prato da fase Guarita, o que não sabemos é se o vaso é Paredão e foi reutilizado num sepultamento Guarita, ou se estamos diante de um evento de interação direta entre os povos responsáveis pelos dois conjuntos cerâmicos.

\section{IV.II.III - AS DATAÇÕES}

Um passo importante seria saber a qual das fases pertenceria a unidade habitacional, para isso enviamos três amostras de cerâmica da escavação para serem datadas por AMS em Oxford. As amostras selecionadas foram:

Fragmento de cerâmica da fase Manacapuru (Figura 93), NP 227, coletado dentro da feição 18 entre 70 e $80 \mathrm{~cm}$ de profundidade. Trata-se de um aplique zoomorfo decorado com ponteados produzindo os olhos e o nariz; além de dois furos nas extremidades superior e inferior. São aplicados também motivos acanalados na parte que o conectaria ao vaso. A peça mede 56 × $41 \times 17 \mathrm{~mm}$, as bordas são cortadas e existem dois furos, um no centro e outro na parte que fragmentou. $\mathrm{O}$ antiplástico contido na pasta é o cauixi. Datando o fragmento provavelmente estaremos descobrindo a primeira ocupação do sítio e a data mínima deste conjunto de feições (o fragmento da amostra apresenta uma crosta de fuligem). 


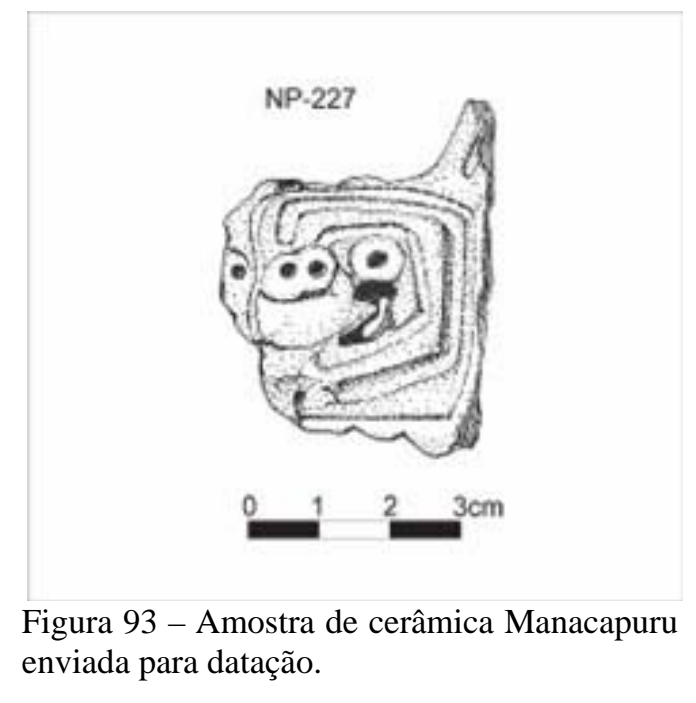

A segunda amostra é de um fragmento de cerâmica Paredão (figura 94), NP 282, que parece estar ligado ao contexto funerário descrito anteriormente. Alguns centímetros acima da urna funerária (aproximadamente $30 \mathrm{~cm}$ abaixo da superfície) (Figura 90), já sobre o que o que seria o piso da unidade Habitacional foi evidenciado outro vasilhame fragmentado, mas com grande parte estruturada em um único conjunto, este pertencente à fase Paredão. A amostra é um dos fragmentos desse vaso.

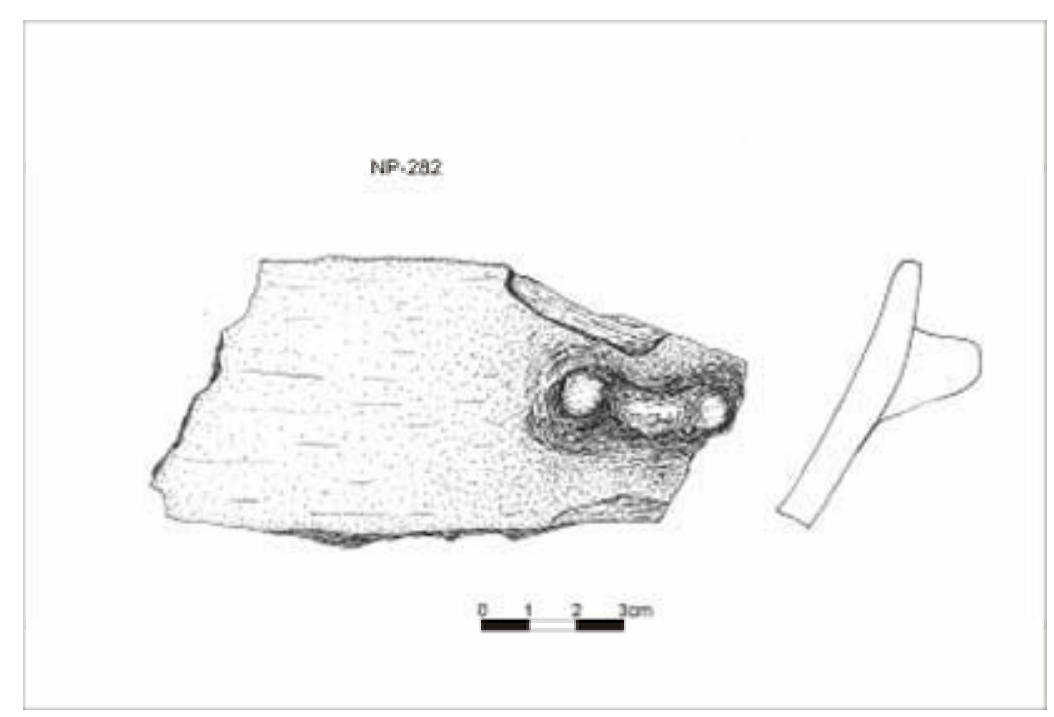

Figura 94 - Amostra de cerâmica Paredão enviada para datação.

A terceira Amostra é de um fragmento de cerâmica da fase Guarita (figura 95), NP 39, que tem quase a metade do pote evidenciado por volta de $20 \mathrm{~cm}$ de profundidade, e um fragmento evidenciado nos níveis mais profundos da feição 1, portanto datando o fragmento estaremos, além de datado o contexto da fase Guarita no sítio, também descobrindo que a feição, que é um dos buracos de esteio, foi escavada após a deposição do vasilhame, que teve uma de suas partes quebradas depositada dentro do buraco do esteio. 


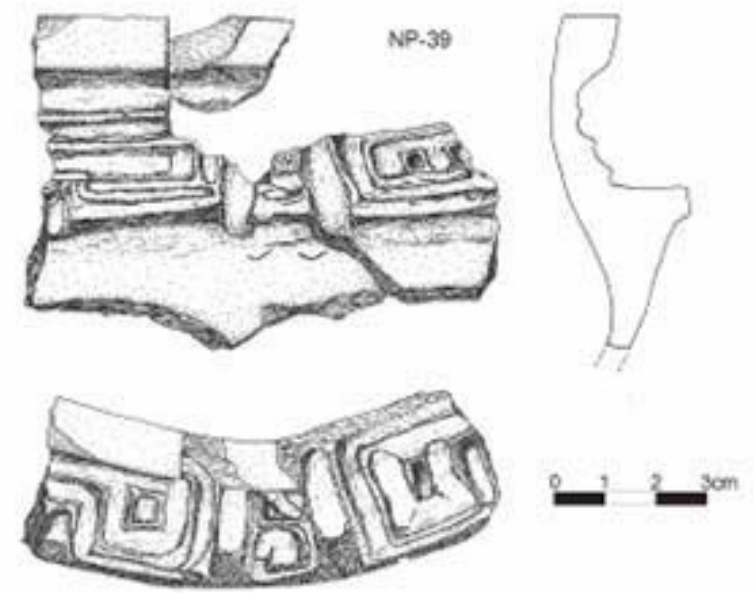

Figura 95 - Amostra de cerâmica Guarita enviada para datação.

O resultado das datações foi o seguinte:

\begin{tabular}{|c|c|c|c|c|}
\hline $\mathbf{N}^{\mathbf{0}}$ Amostra & Proveniência & Prof. & Data & $\mathbf{N}^{\mathbf{0}}$ Lab. \\
\hline PN39 & SE-25 & 0 a $20 \mathrm{~cm}$ & $1225 \pm 26$ DC & OxA-15504 \\
\hline PN 282 & N-1976 E-501 & $30 \mathrm{~cm}$ & $1104 \pm 27$ DC & OxA-15503 \\
\hline PN227 & N-1977 E-499 & 70 a $80 \mathrm{~cm}$ & $290 \pm 28$ DC & OxA-15502 \\
\hline
\end{tabular}

Tabela 02 - Datas obtidas para o sítio Lago do Limão.

\section{IV.II.IV - ESCAVAÇÃO DA FEIÇÃO 4}

Com uma outra área de escavação aberta no sítio, uma trincheira de 8x1 m, buscávamos verificar se as depressões existentes na superfície do sítio, que segundo informações dos moradores eram conhecidas por seu avós como "currais de tartaruga de índio", tinham mesmo sido artificialmente construídas.

Denominada F4, a feição é uma depressão de aproximadamente 12 metros no sentido N-S, por cerca de 6 metros E-W, com aproximadamente 1,2 metros de profundidade.

A trincheira foi escavada no sentido E-W na porção central da feição. Para o controle da escavação, a trincheira foi dividida em unidades de um metro quadrado. Os oito metros de extensão atingiram o centro e bordas da feição.

Com o término da escavação constatamos que se tratava mesmo de uma feição artificialmente construída. As paredes originais, verticalmente bem aprumadas, ficaram evidentes nos perfis escavados (figura 96 e 97). Durante a construção da feição, a camada de latossolo amarelo (horizonte B) foi escavado até a base de laterita. Posteriormente temos o preenchimento de parte da feição com o sedimento mais escuro (horizonte A) que erodiu de suas bordas. Além das paredes bem evidentes, 
identificamos também negativos de buracos preenchidos com sedimento escuro na base da escavação, junto ao que seria a borda da feição, provavelmente são buracos de estacas que cercavam o "curral de tartaruga".

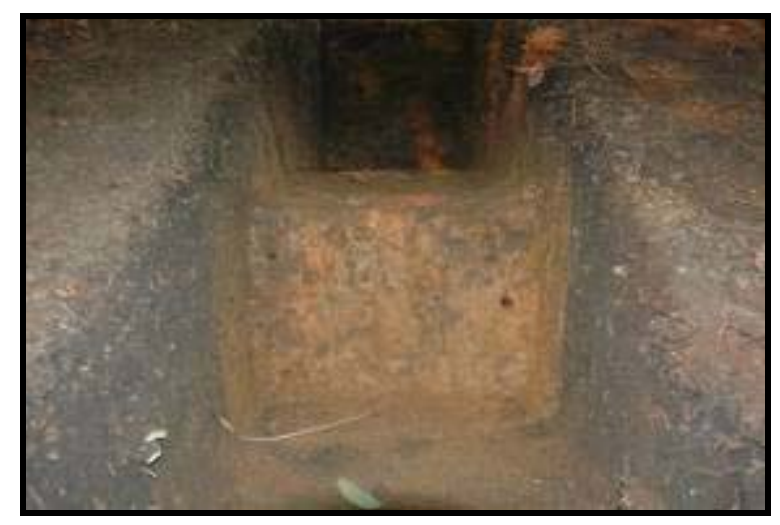

Figura 96 - Detalhe da trincheira escavada na feição 4, com destaque para a diferença na coloração do sedimento nas paredes demarcando os limites da feição e os negativos de buracos de estacas preenchidos com terra preta na base.

Junto ao sedimento escavado, além da cerâmica pré-colonial, foi observada grande quantidade de material histórico recente, cacos de telha, fragmentos de louça e alguns ossos de peixe-boi (Trichechus inunguis), um contexto bem semelhante ao dos primeiros $90 \mathrm{~cm}$ da cova na margem do lago onde fizemos a limpeza de perfil. Provavelmente F4 foi utilizada como depósito de lixo na época em que as casas dos proprietários dos terrenos ficavam à margem do lago. Novamente, precisamos analisar detalhadamente os dados produzidos no campo para melhor compreender esta feição, já que agora surge também a possibilidade de ela não estar relacionada ao período précolonial.

Uma busca na literatura regional, nos dados etnohistóricos e etnológicos, podem nos ajudar a compreender melhor se estamos mesmo diante do que teria sido um curral de tartaruga e se existe a possibilidade da prática da construção deste tipo de estrutura ter alcançado períodos mais recentes. De qualquer forma, já sabemos que F4 é mesmo uma intervenção antrópica na paisagem da margem do lago do Limão. 


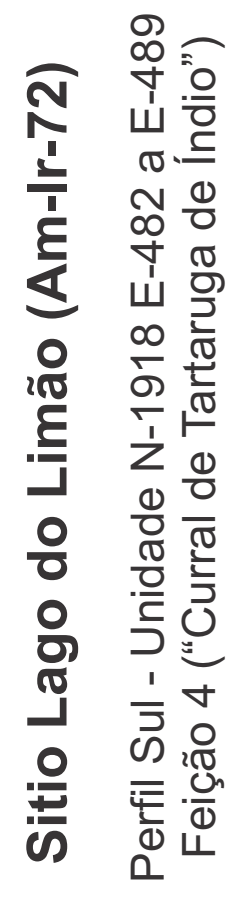

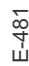

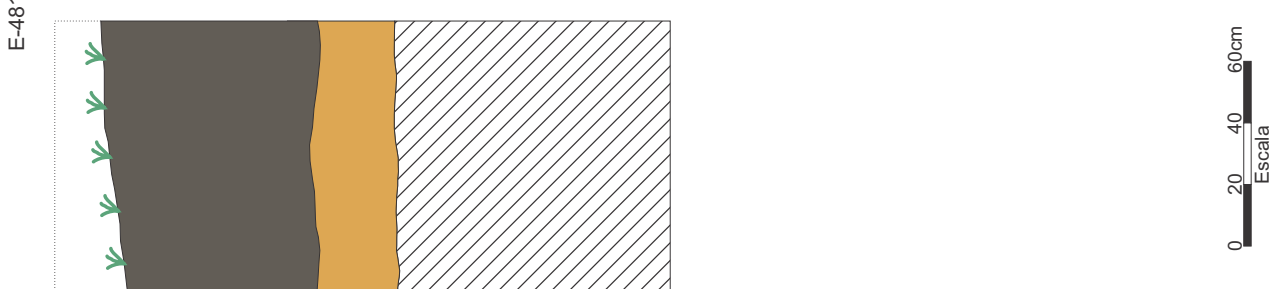

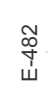

$\stackrel{\infty}{\stackrel{\infty}{W}}$

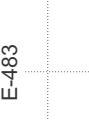

憘

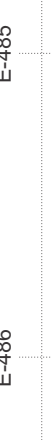

恿

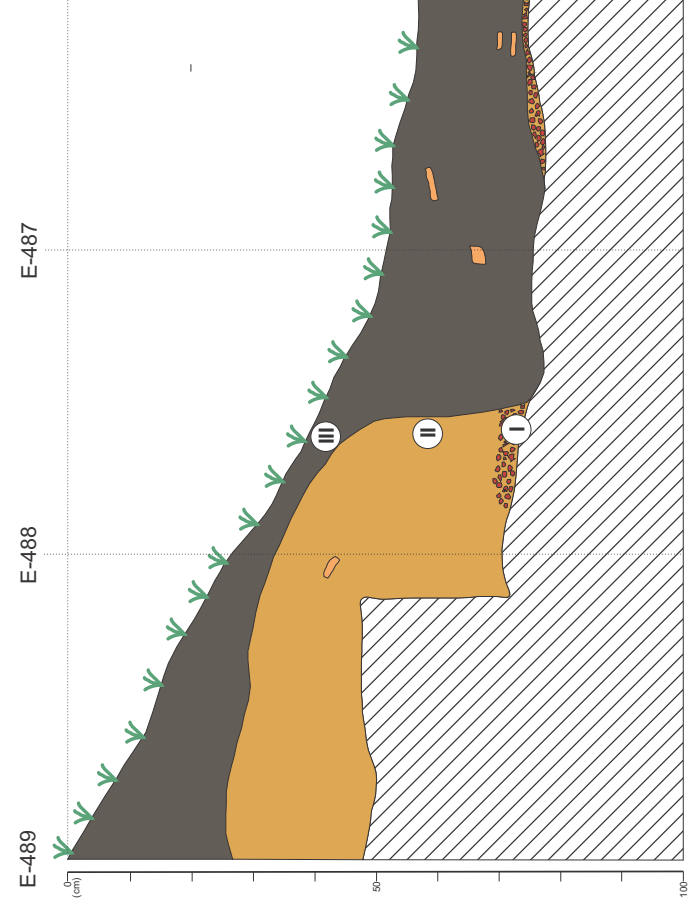

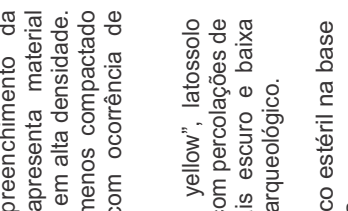

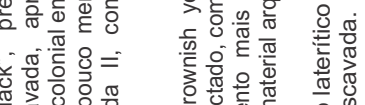

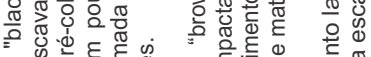

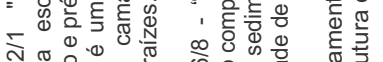

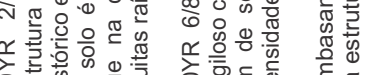

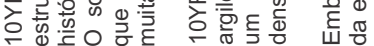

윰
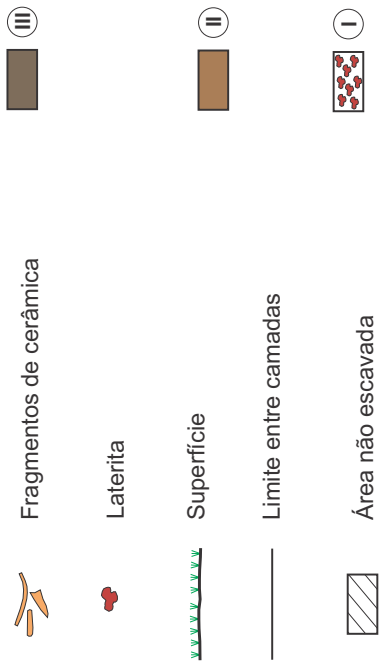
Foram abertas mais quatro unidades de escavação para verificar se duas elevações percebidas no sítio seriam montículos artificiais. Uma delas, N-1937 E-550, foi aberta no topo de uma das elevações; N-1950 E-558 foi aberta em uma elevação um pouco menos evidente, sendo depois ampliada em mais um metro quadrado; a ultima unidade, N-1923 E-542, foi aberta na área plana ao sul de N-1937 E-550 (anexo 12).

$\mathrm{Na}$ superfície dos morrotes havia uma alta concentração de laterita e muitos fragmentos de cerâmica. Nos sítios Antônio Galo e Pilão existem montículos feitos com laterita. Este tipo de estrutura já havia sido relatado na região desde a década de 70, em um sítio encontrado às margens da Rodovia Manuel Urbano, (sítio Capoeira dos Índios), identificado por integrantes do Projeto Rondon V (Souza 1970).

Na unidade N-1937 E-550 o contexto de deposição do material arqueológico é bastante semelhante ao das unidades N-1976 E-500 e unidades adjacentes. Existem diferenças relativas à densidade de material, que é muito maior nessa unidade (gráfico 14), e da quantidade de fragmentos de laterita, que é infinitamente maior. Há também uma camada com mais lateritas que chega até aproximadamente $40 \mathrm{~cm}$ de profundidade. A camada apresenta a maior densidade de cerâmicas, com fragmentos associados às fases Manacapuru, Paredão e Guarita. Aos $40 \mathrm{~cm}$ de profundidade fica muito clara uma lente de deposição de cerâmica (figuras 98 e 99), marcando a transição para uma camada com menos lateritas e uma quantidade menor de fragmentos de cerâmica. A laterita volta a aparecer em grande quantidade quando se aproxima da base de rocha compacta. Aqui a terra preta chega até a base rochosa, são vistas apenas manchas de latossolo amarelo.

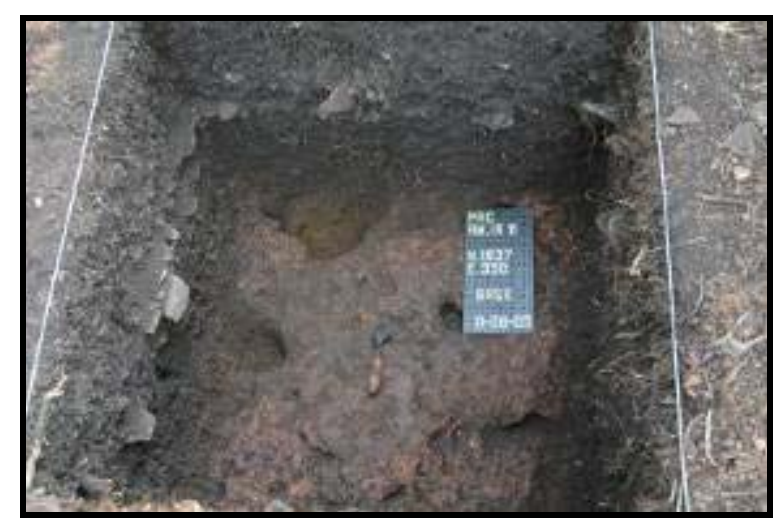

Figura 98 - Unidade N-1937 E-550, base da escavação, com destaque para lente de fragmentos de cerâmica evidenciada nos perfis. 


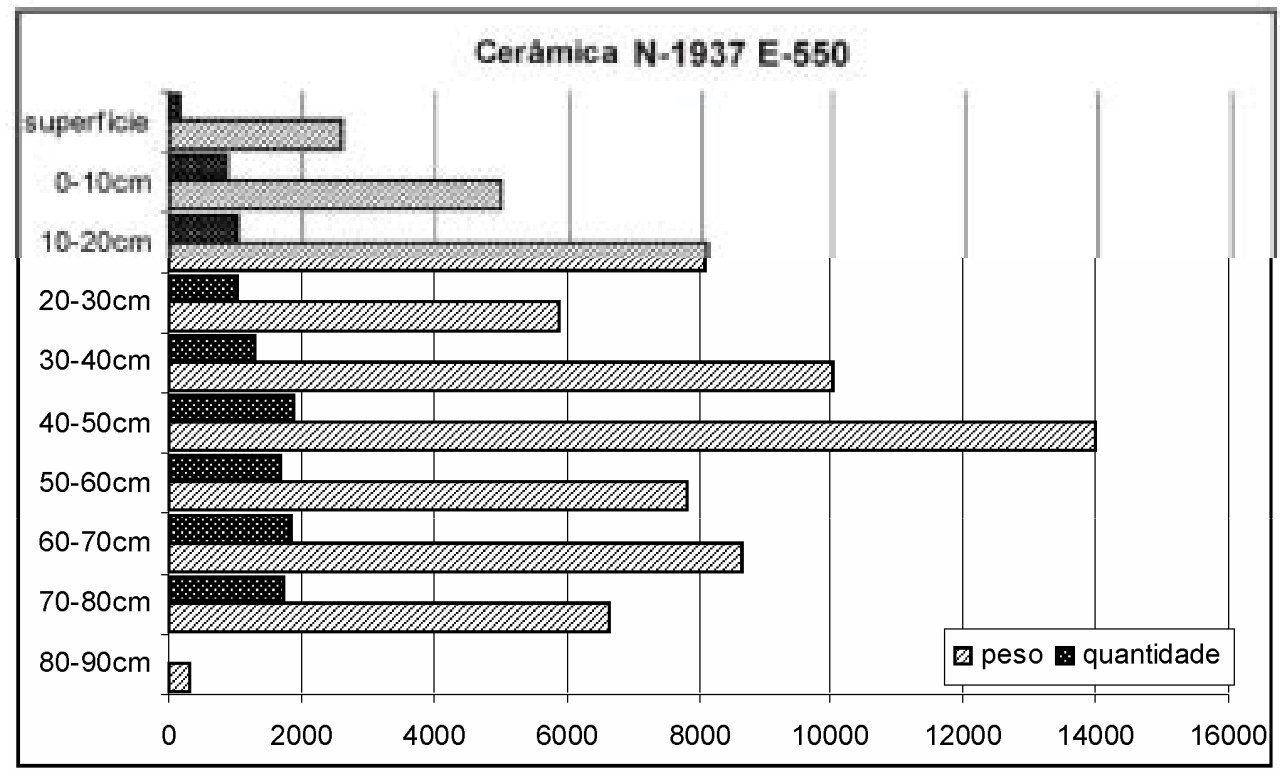

Gráfico 14 - Unidade N-1937 E-550, material cerâmico por nível. 


\title{
Sitio Lago do Limão (Am-Ir-11)
}

\author{
Unidade N-1937 E-550 \\ Perfil Oeste
}
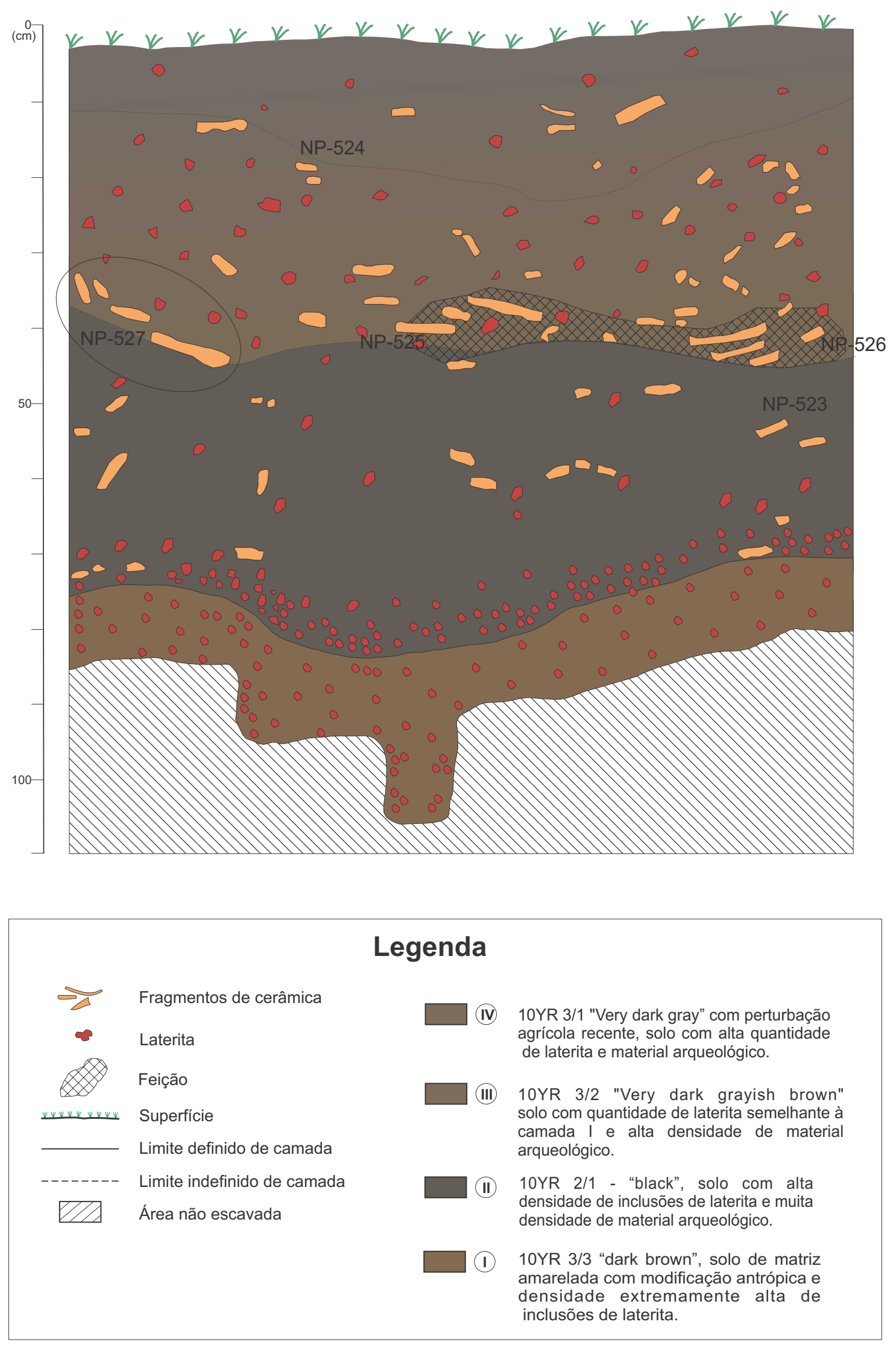

Figura 99 - Unidade N-1937 E-550, perfil Oeste. 
As unidades escavadas na elevação menos evidente, N-1950 E-558 e N-1951 E558, apresentaram também um pacote de sedimento com muitos fragmentos de laterita até a base. Desta vez ficou mais difícil perceber uma diferença de concentração de laterita nos níveis escavados. A cerâmica está concentrada até os $40 \mathrm{~cm}$, diminuindo gradativamente depois. Muitas bioturbações, uma grande quantidade de raízes e cupins perturbaram bastante o contexto arqueológico dessa parte do sítio. O pacote arqueológico é bem menos espesso, a base rochosa aparece entre 60 e $70 \mathrm{~cm}$ de profundidade e nela identificamos três feições F5, 6 e 7: buracos preenchidos com sedimento que parecem ter sido cavados na rocha (figura 100 e 101).

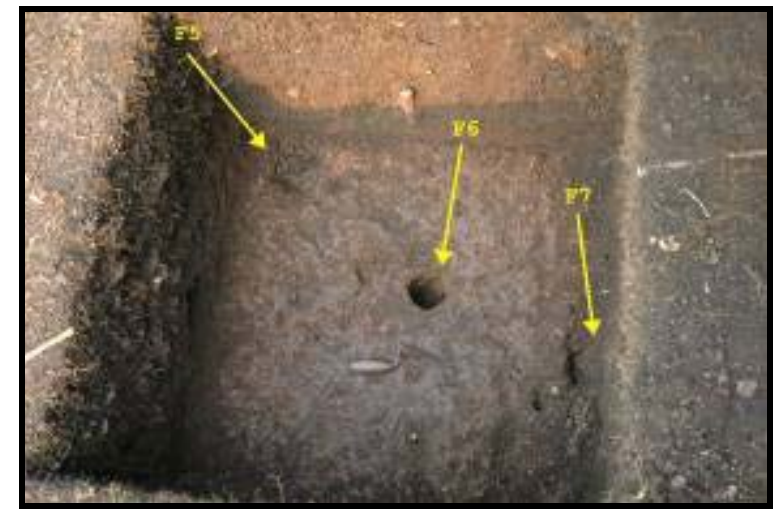

Figura 100 - Unidade N1950 E558, base da escavação, com destaque paras as feições 5, 6 e 7 . 

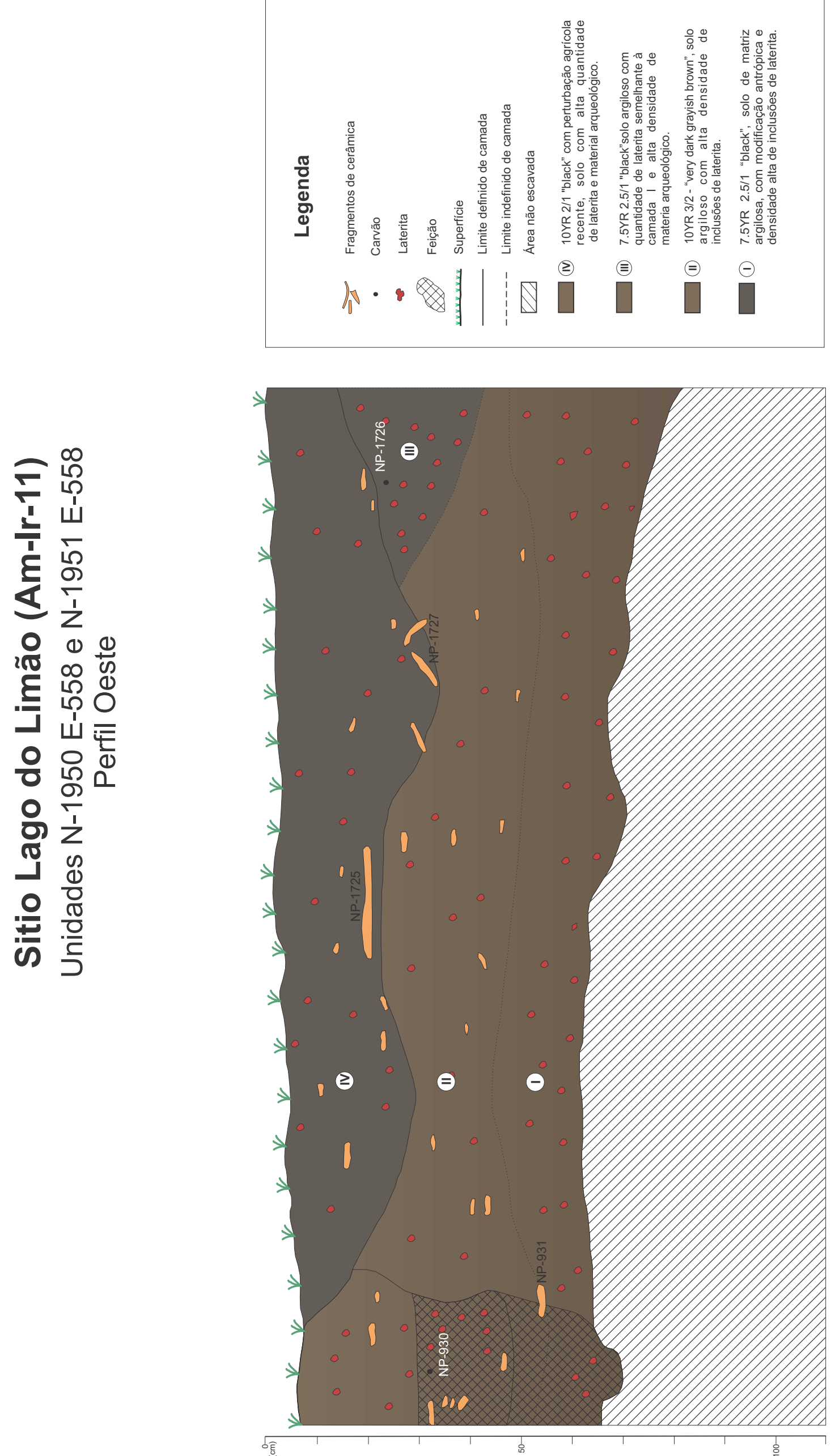

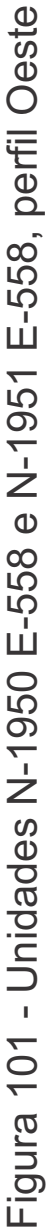


A unidade escavada na área plana, N-1923 E-542, também apresenta muita concentração de fragmentos de laterita, mas a densidade de fragmentos de cerâmica, apesar de bastante elevada, é menor que a evidenciada na unidade N-1937 E-550. O pacote arqueológico é bem pouco espesso, a base rochosa aparece por volta dos $35 \mathrm{~cm}$ (figuras 102 e 103). Foram evidenciados fragmentos de cerâmica pertencentes às fases Manacapuru, Paredão e Guarita misturados nos níveis da escavação desde a superfície. A terra preta aparece até a base rochosa.

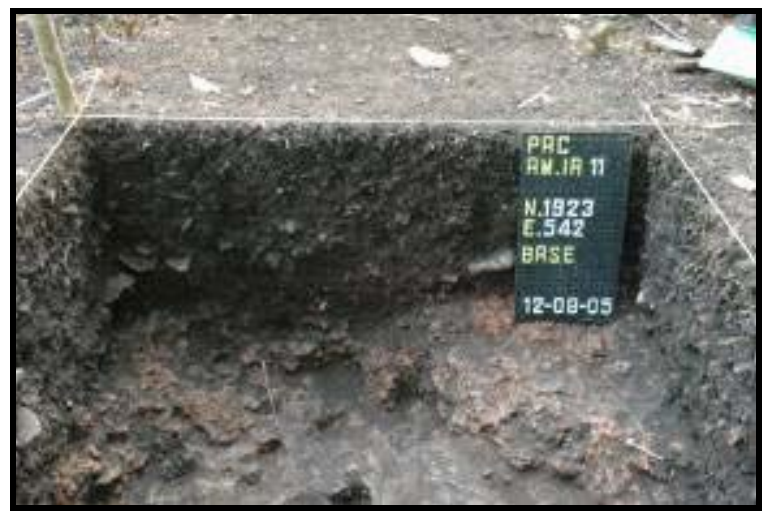

Figura 102 - Unidade N1923 E542, base da escavação.

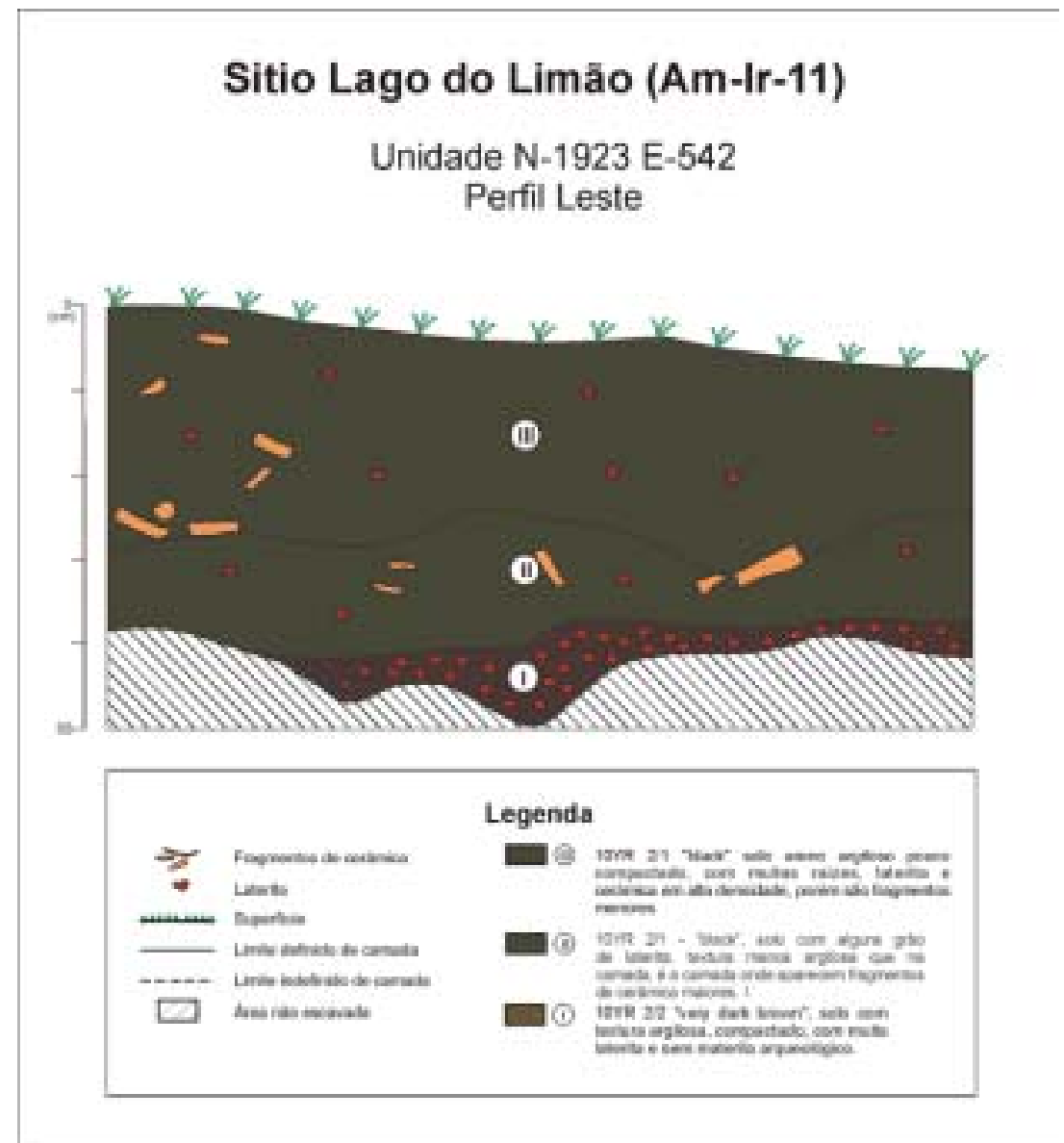

Figura 103 - Unidade N-1923 E-542, perfil Leste. 
A ultima intervenção realizada no sítio Lago do Limão foi a abertura de uma unidade de escavação fora da área de terra preta. Próximo à tradagem NE-25 foi aberta a unidade N-2017 E-760 (anexo 12). A escavação atingiu $80 \mathrm{~cm}$ de profundidade. A textura do solo é bastante argilosa, não é grande a ocorrência de fragmentos de laterita no sedimento, como ocorre nas áreas de terra preta (figura 104). Constatamos a presença de fragmentos de cerâmica e algumas bolotas de argila em baixa densidade, até a profundidade de $50 \mathrm{~cm}$. Parece ser mesmo uma área periférica do sítio, onde as atividades foram bem menos intensas gerando poucas evidencias arqueológicas.

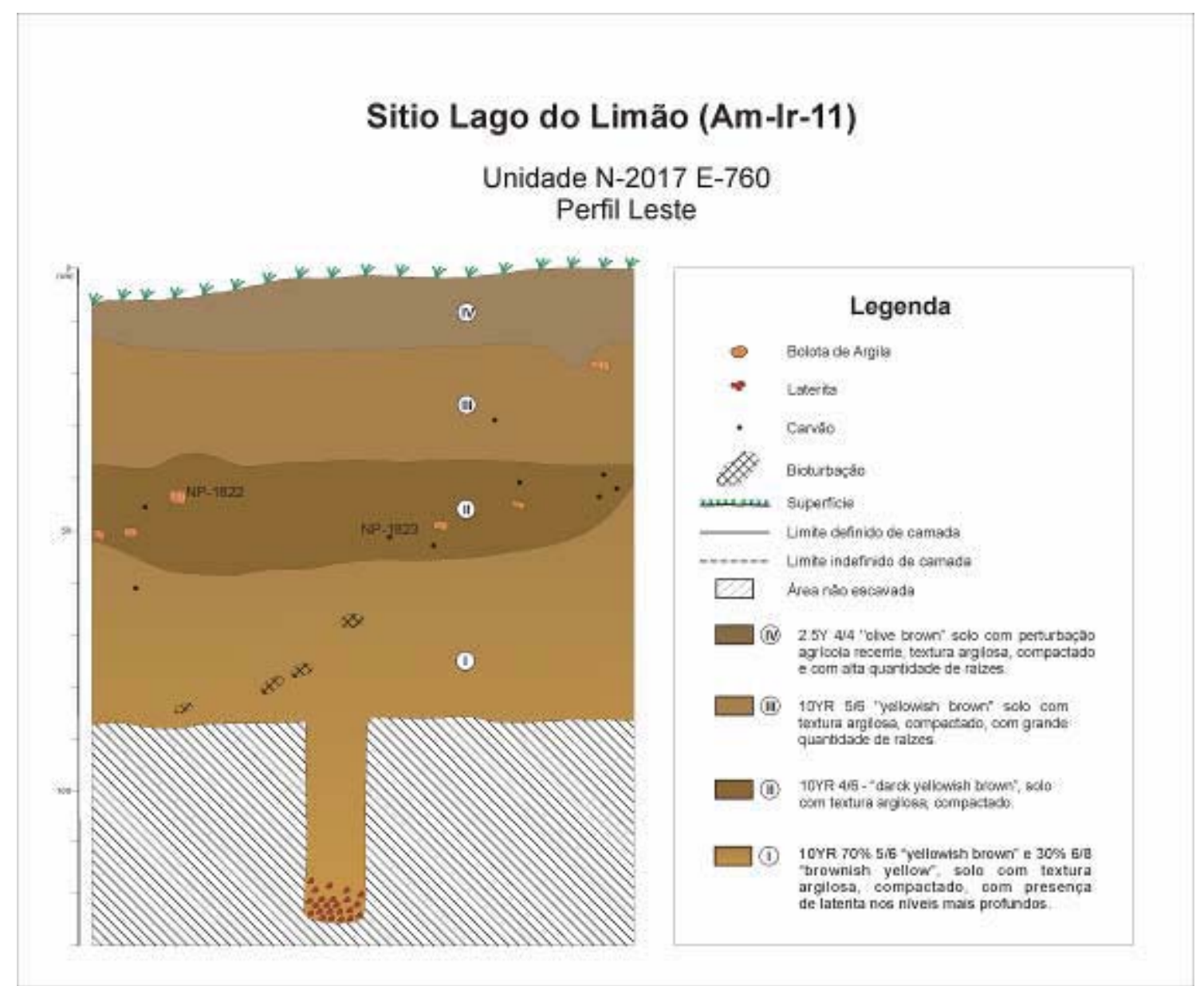

Figura 104 - Unidade N-2017 E-760, perfil Leste. 


\section{IV.III - SÍTIO PILÃO}

Os dados obtidos com a intensificação dos trabalhos no sítio Pilão (AM-IR-73) foram acrescentados ao nosso trabalho devido à relevância do sítio. A etapa de campo foi realizada em decorrência dos trabalhos de salvamento arqueológico na área do Gasoduto Coari-Manaus, empreendimento realizado pela PETROBRAS.

O caráter de salvamento nos levou a intensificar as intervenções na área de impacto direto do empreendimento, o que contribuiu muito com os resultados de nosso trabalho.

Um dos principais objetivos do trabalho no sítio era entender a diferença entre as camadas arqueológicas dentro e fora dos montículos. Como o sítio será parcialmente destruído, uma quantidade maior de escavações teria que ser executada na faixa do empreendimento que o afetaria. Como pode ser visto no anexo 13, quase todos os montículos que estavam na faixa do gasoduto foram escavados. Fora dos montículos foram abertas outras unidades de escavação para comparação dos diferentes contextos. A seguir apresentamos uma descrição das unidades escavadas:

\section{IV.III.I - UNIDADES N-1008 E-1032 e N-1009 E-1032}

As duas unidades foram abertas na parte mais alta do montículo 01 (anexo 13). A metodologia utilizada foi a mesma apresentada nos sítios anteriores.

A terra preta está presente desde a superfície, sendo a ocorrência de cerâmica, muito fragmentada, em baixa densidade até $20 \mathrm{~cm}$, isso provavelmente é decorrente da prática de agricultura no local. Dos 20 aos $50 \mathrm{~cm}$ aumenta a densidade de cerâmica, os fragmentos são um pouco maiores e o solo começa a clarear um pouco (figura 105).

Dos 50 aos $90 \mathrm{~cm}$ o material diminui novamente a densidade de ocorrência e o sedimento fica muito mais amarelado. Ocorre ainda, em todos os níveis, a

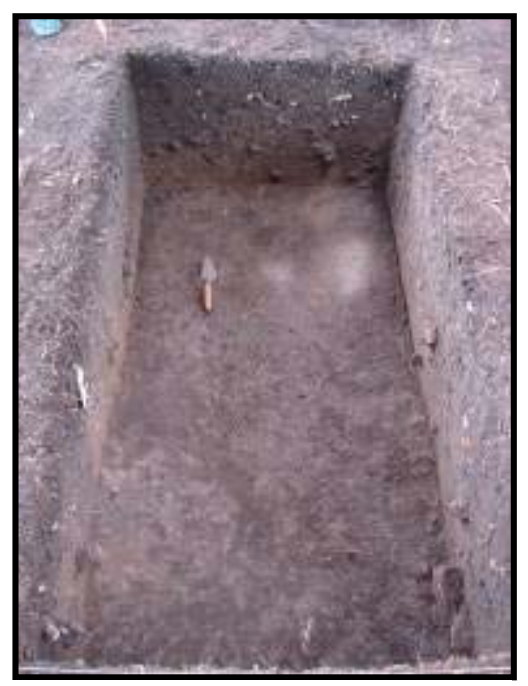

Figura 105 - Unidade N-1008 E1032 e N-1009 E-1032, base do nível 40 a $50 \mathrm{~cm}$. presença de fragmentos de trempe em alguns casos 
isolados de ocorrência de material lítico. Aos $60 \mathrm{~cm}$ de profundidade aparece uma feição, possivelmente de buraco de poste.

De 90cm em seguida os níveis são estéreis arqueologicamente. As informações apresentadas podem ser visualizadas nos gráficos 15 e 16 e na descrição do perfil das unidades (figura 106).

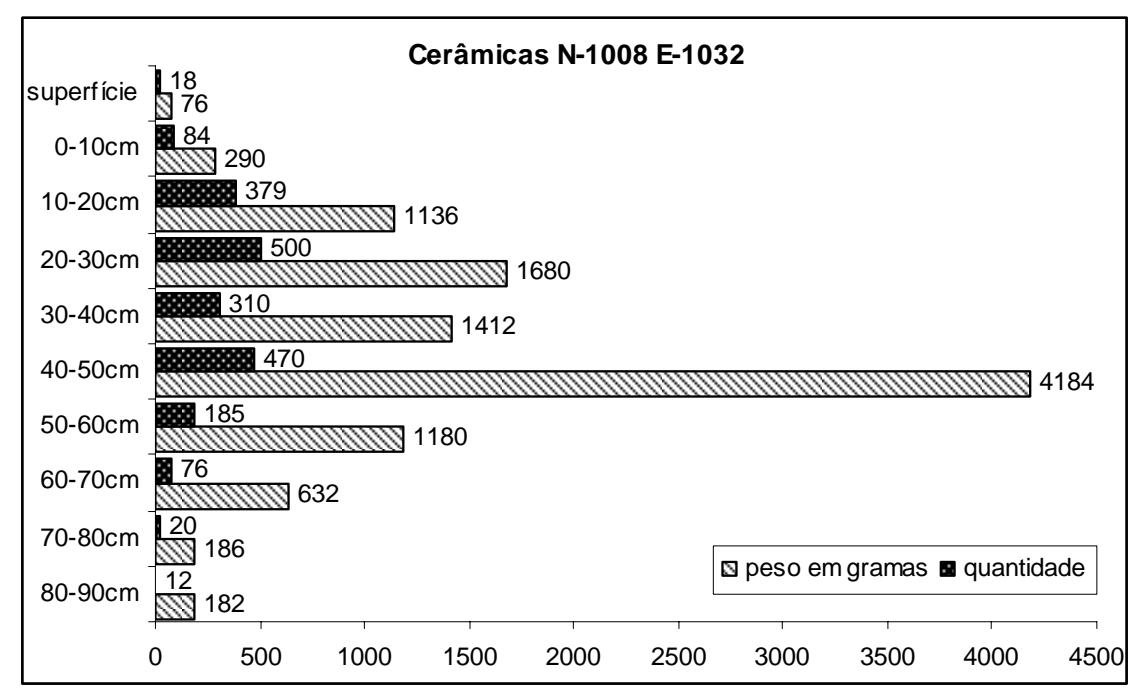

Gráfico 15 - Unidade N-1008 E-1032, densidade de material por nível.

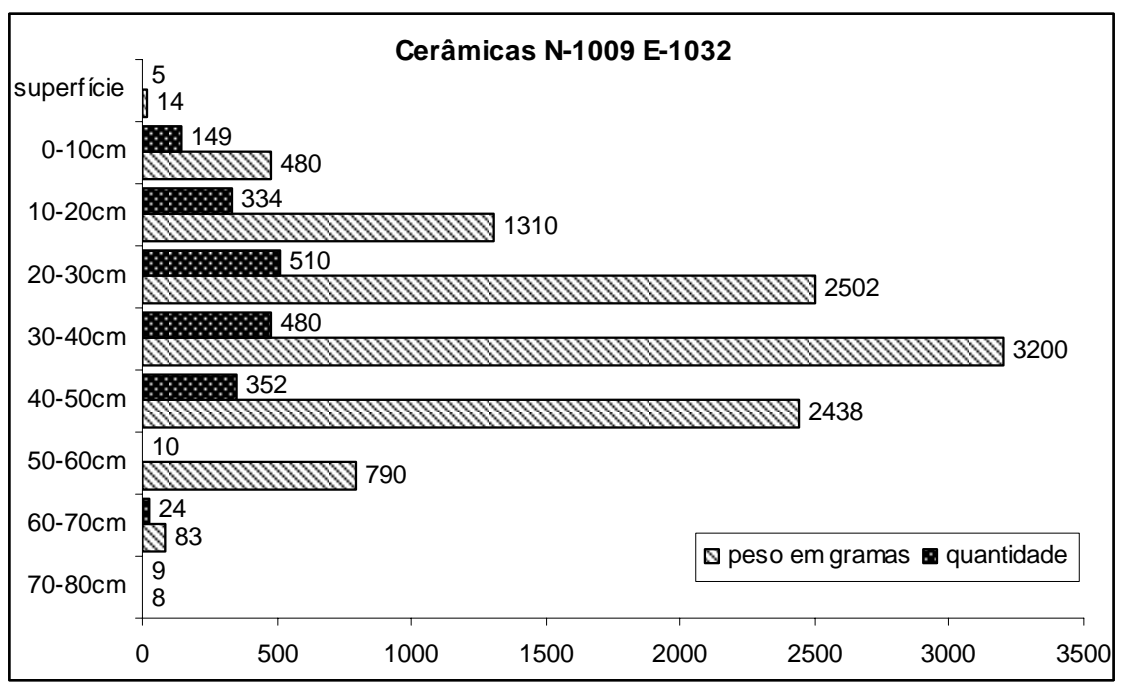

Gráfico 16 - Unidade N-1009 E-1032, densidade de material por nível. 

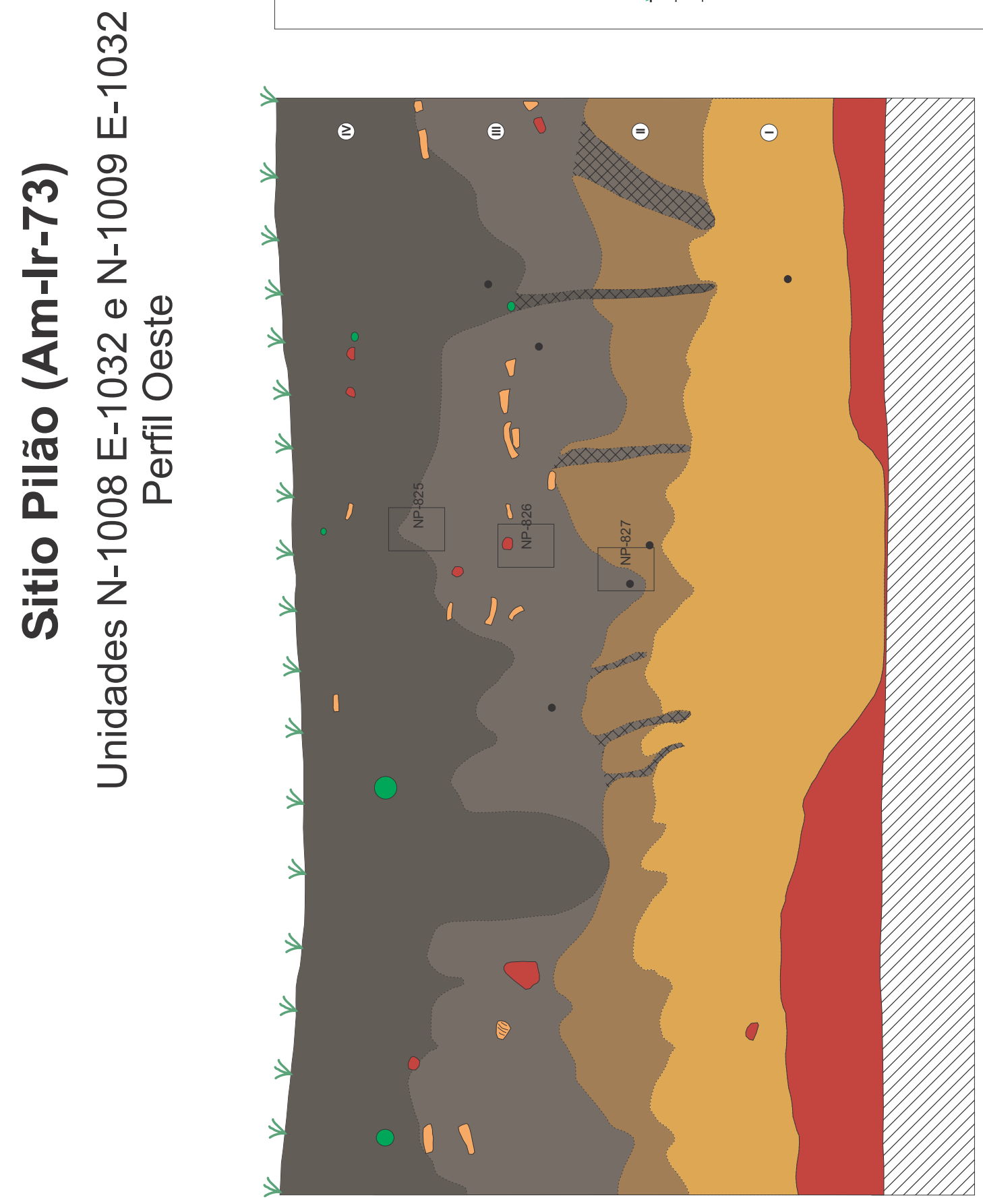

ठ్ㅡㄹ

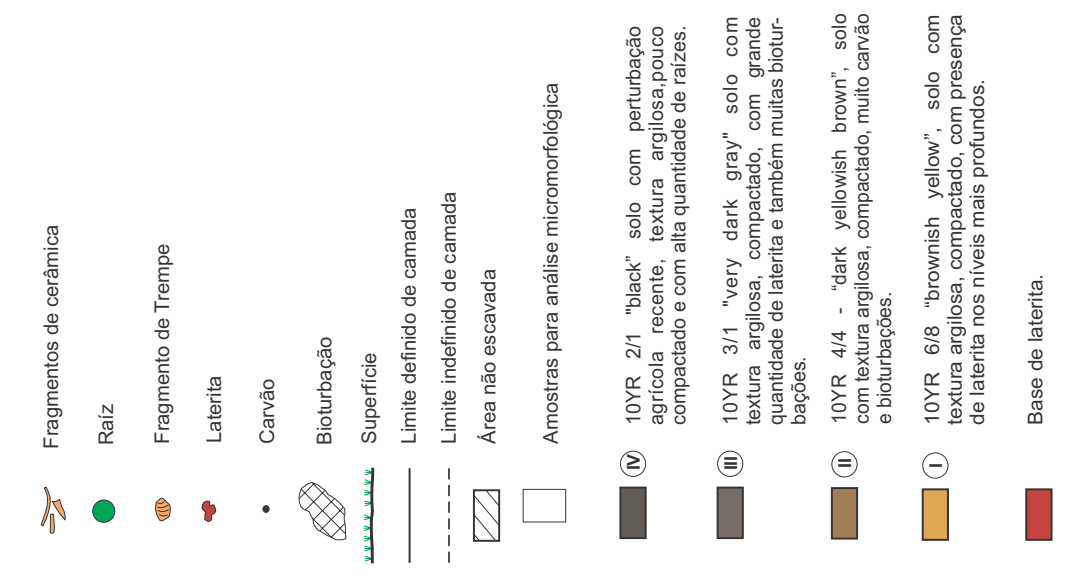


A unidade foi aberta no ponto mais alto do montículo 04 (anexo 13). A terra preta está presente desde a superfície, são encontradas cerâmicas, muito fragmentadas. A densidade de fragmentos de cerâmica é relativamente elevada de 0 a $30 \mathrm{~cm}$, sendo o pico de densidade entre 10 e $20 \mathrm{~cm}$, aparecem alguns artefatos líticos em alguns níveis. Os fragmentos de trempe estão presentes em todos os níveis. O aumento de densidade é inversamente proporcional ao grau de fragmentação. De 30 a $60 \mathrm{~cm}$ a densidade de cerâmica decai progressivamente. A partir de $30 \mathrm{~cm}$ o solo clareia muito para um tom amarelado (figura 107). Após $60 \mathrm{~cm}$ de profundidade a unidade fica completamente estéril arqueologicamente e o solo apresenta coloração bastante amarelada. As informações podem ser visualizadas no gráfico 17 e na descrição do perfil da unidade (figura 108).

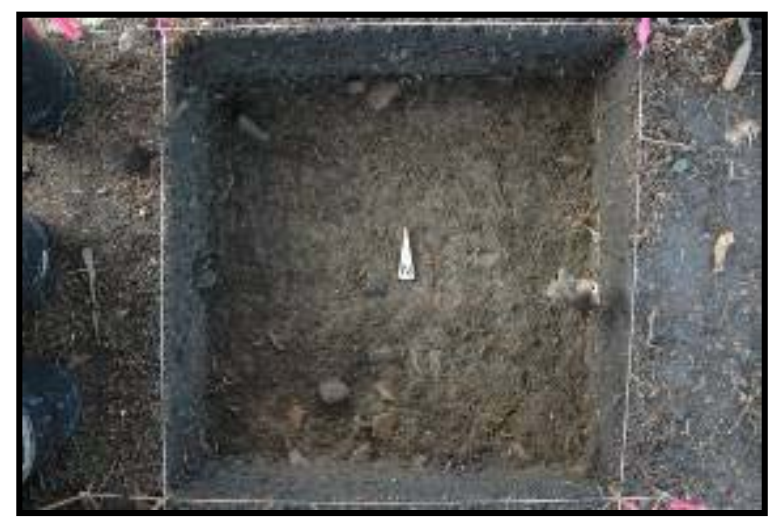

Figura 107 - Unidade N-994 E-986, base do nível 20 a $30 \mathrm{~cm}$, onde é possível notar um clareamento no solo.

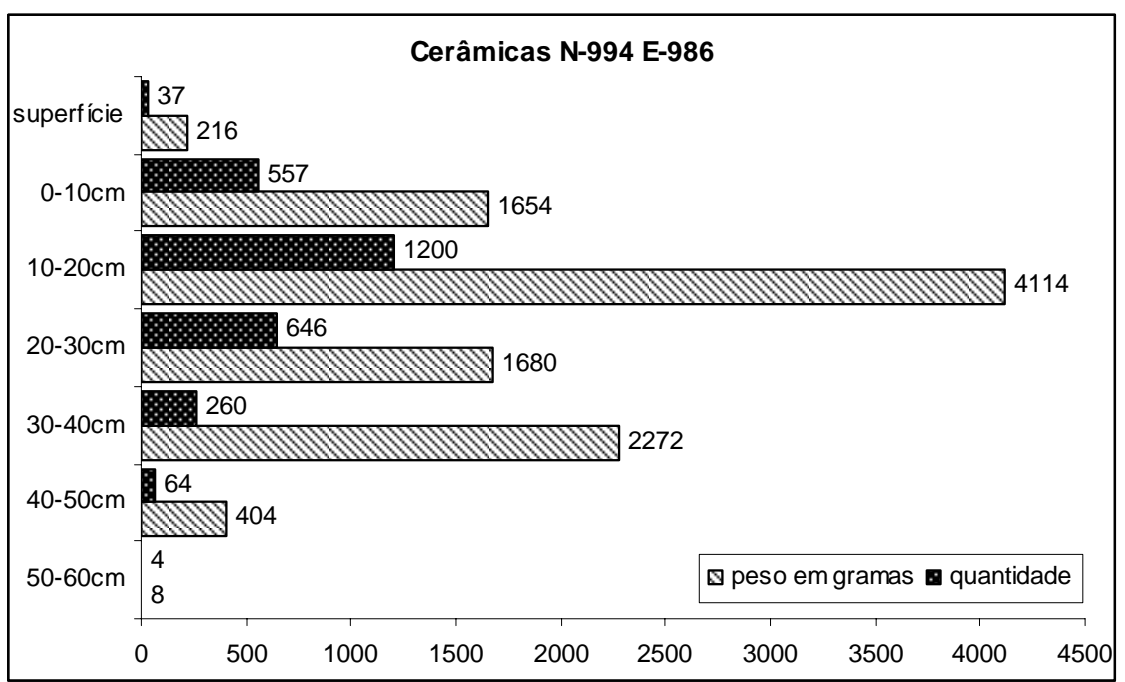

Gráfico 17 - Unidade N-994 E-986, densidade de material por nível. 


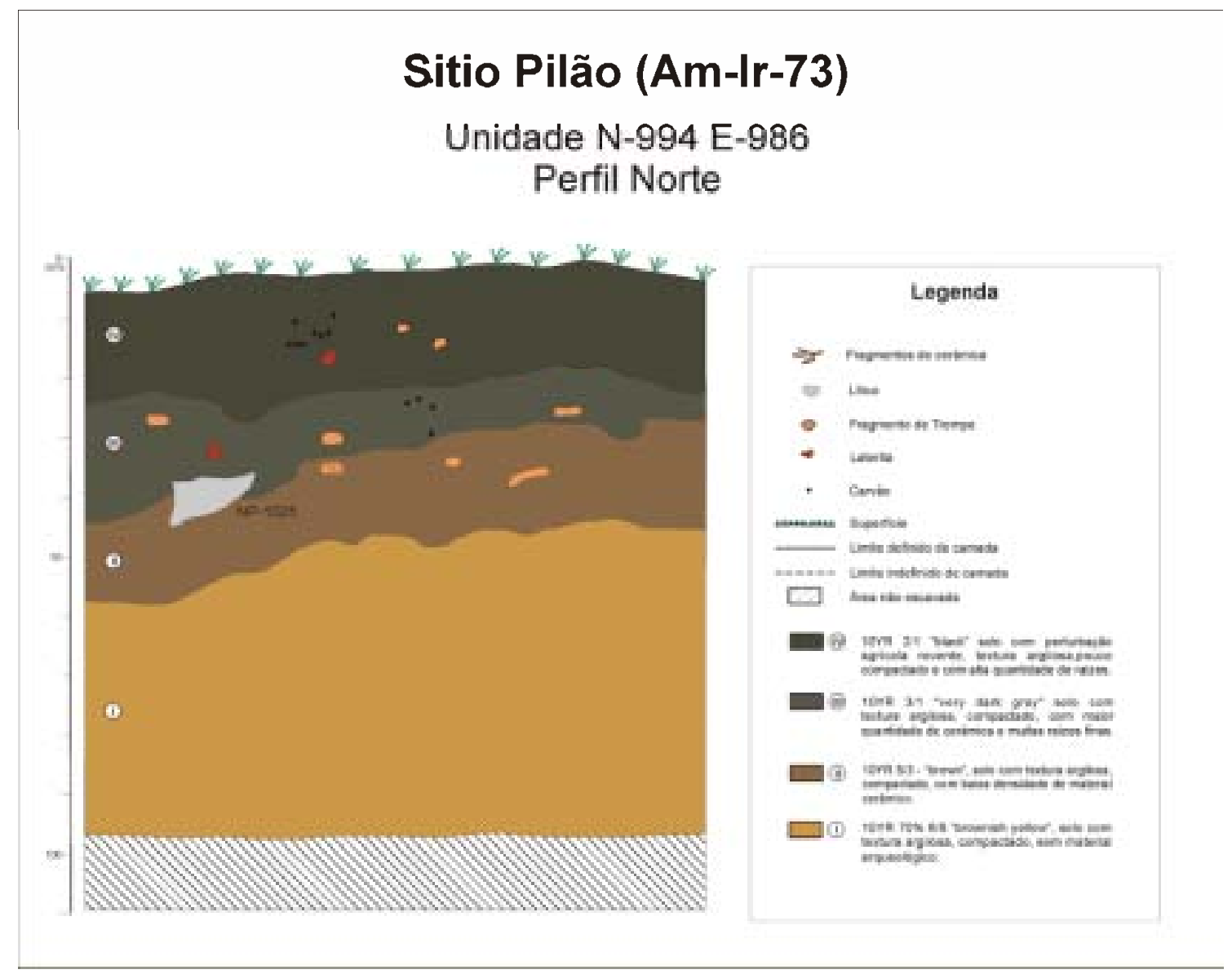

Figura 108 - Unidade N-994 E-986, perfil Norte.

\section{IV.III.III - UNIDADE N-1011 E-985}

A unidade foi aberta no ponto mais alto do montículo 05 (anexo 13). A terra preta está presente desde a superfície, com o mesmo padrão de cerâmicas muito fragmentadas visto anteriormente. $\mathrm{Na}$ unidade constatamos que o grau de fragmentação da cerâmica, principalmente nos níveis superficiais é decorrente de atividade antrópicas recentes. Como pode ser visto nas figuras 119 e 110 , os fragmentos, hoje muito pequeno, vistos na base do nível 10 a $20 \mathrm{~cm}$, são de um único pote, provavelmente depositado no local inteiro ou parcialmente fragmentado.

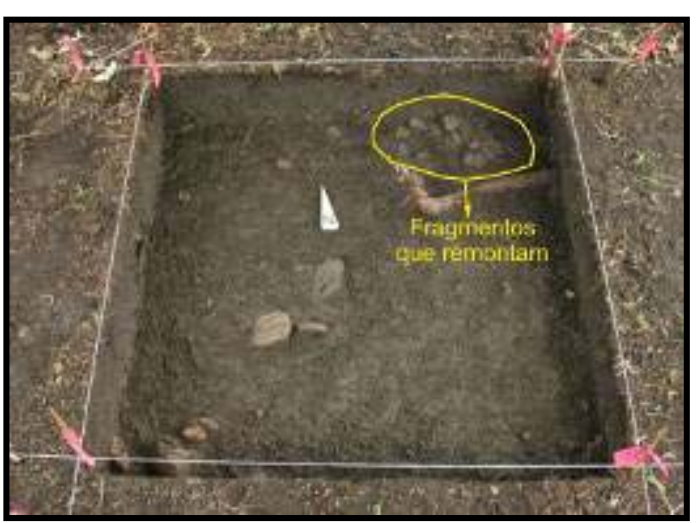

Figura 109 - Unidade N-1011 E-985, base do nível 10 a $20 \mathrm{~cm}$, com destaque para fragmentos do mesmo vaso que remontam.

A densidade de fragmentos de cerâmica é relativamente elevada de 0 a $30 \mathrm{~cm}$, sendo o pico de densidade entre 10 e $30 \mathrm{~cm}$. De 30 a $50 \mathrm{~cm}$ a densidade decai 
progressivamente. Na unidade é grande a presença de fragmentos de trempe em todos os níveis com material arqueológico. No nível 30 a $40 \mathrm{~cm}$ apareceram duas peças líticas. A partir de $30 \mathrm{~cm}$ o solo clareia muito para um tom amarelado. Após $50 \mathrm{~cm}$ de profundidade a unidade fica arqueologicamente estéril e o solo apresenta coloração bastante amarelada, informações que podem ser visualizadas no gráfico 18 e na descrição do perfil da unidade (figura 111).

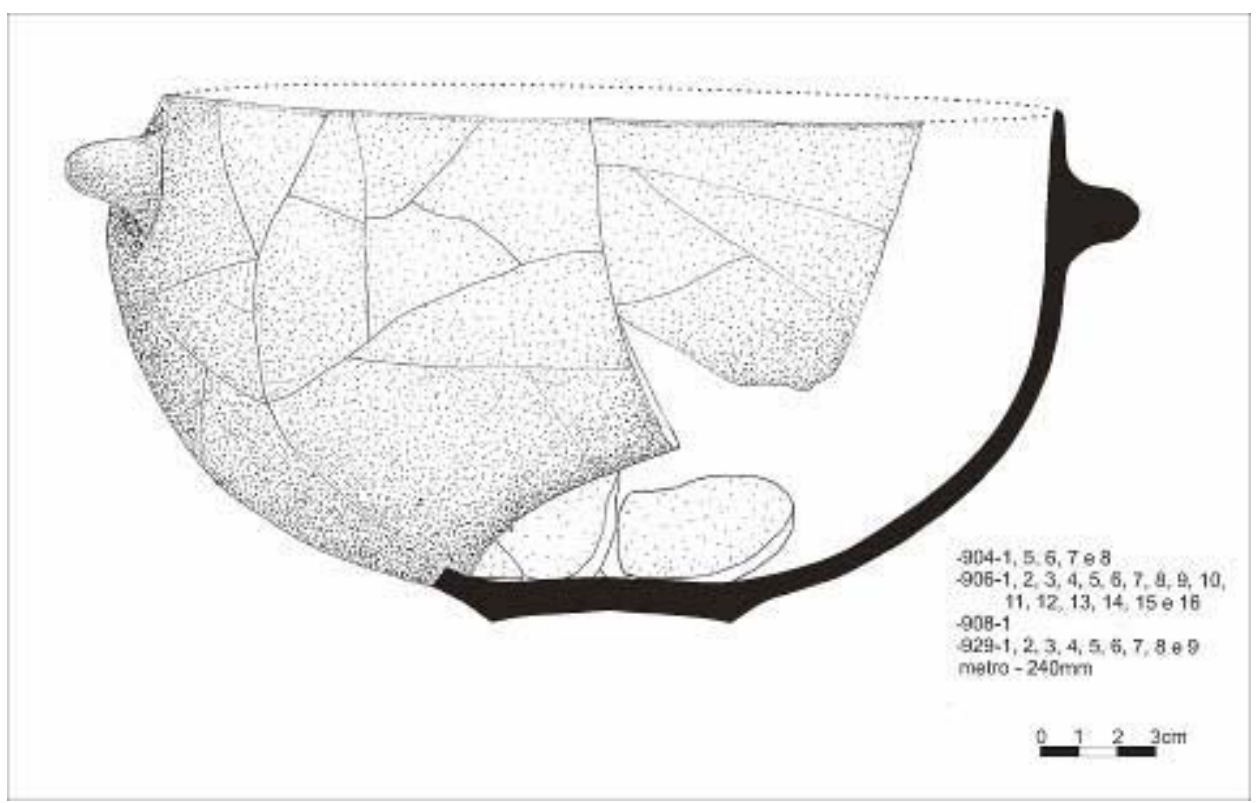

Figura 110 - Vaso Paredão remontado em laboratório.

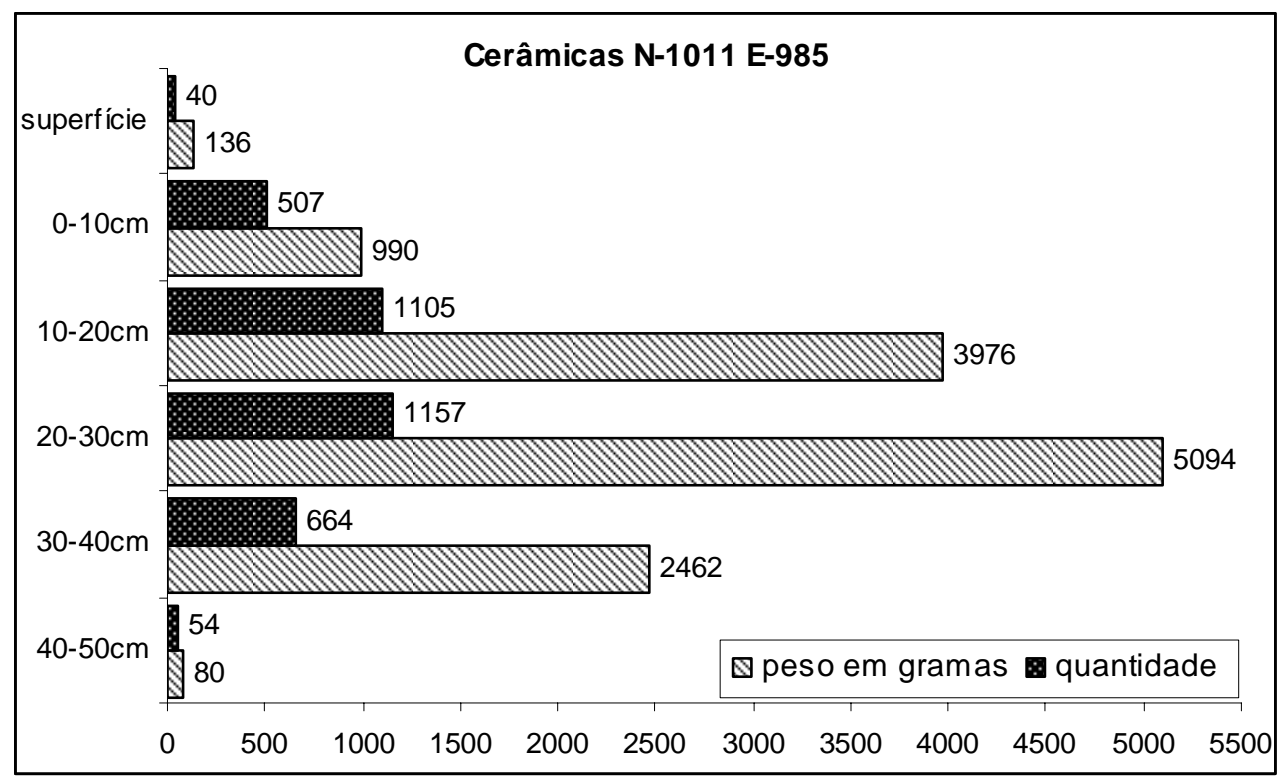

Gráfico 18 - Unidade N-1011 E-985, densidade de material por nível. 


\section{Sitio Pilão (Am-Ir-73)}

\section{Unidade N-1011 E-985 \\ Perfil Norte}
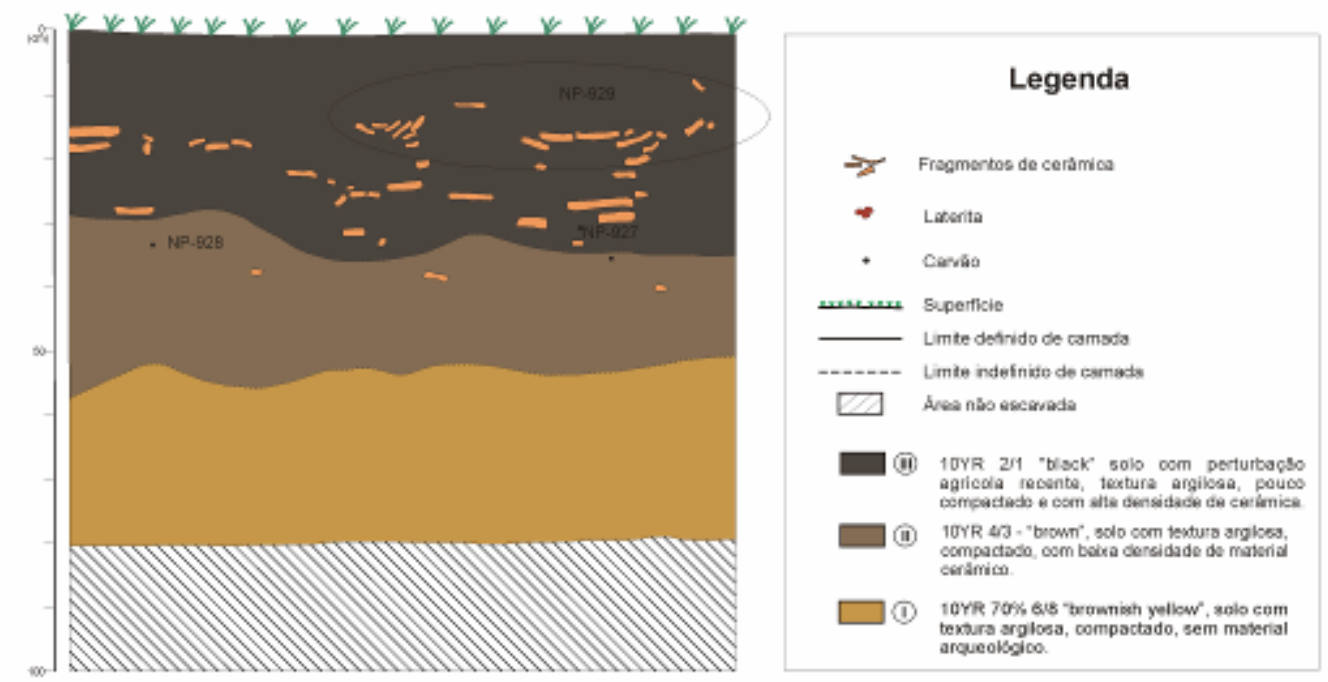

Figura 111 - Unidade N-1011 E-985, perfil Norte.

\section{IV.III.IV - UNIDADES N-1013 E-1002 e N-1014 E-1002}

As unidades foram abertas no ponto mais alto do montículo 08 (anexo 13). A terra preta está presente desde a superfície, porém não muito escura como na unidade anterior. As cerâmicas vistas na superfície também são bastante fragmentadas. A densidade de fragmentos de cerâmica é mais elevada do que nas unidades anteriores. A concentração de fragmentos é grande de 0 a $60 \mathrm{~cm}$, com o pico de densidade entre $10 \mathrm{e}$ $50 \mathrm{~cm}$. Nas duas unidades são evidenciados fragmentos maiores e mais espessos que nas unidades anteriores (figura 112), o que fica bem representado se comparamos os pesos nos gráficos. São vistos fragmentos de trempe em todos os níveis com material arqueológico. Alguns artefatos líticos também foram evidenciados. A partir de $50 \mathrm{~cm}$ o solo clareia muito para um tom amarelado. Com o clareamento do solo aparecem duas feições de buracos de postes na unidade N-1013 E-1002

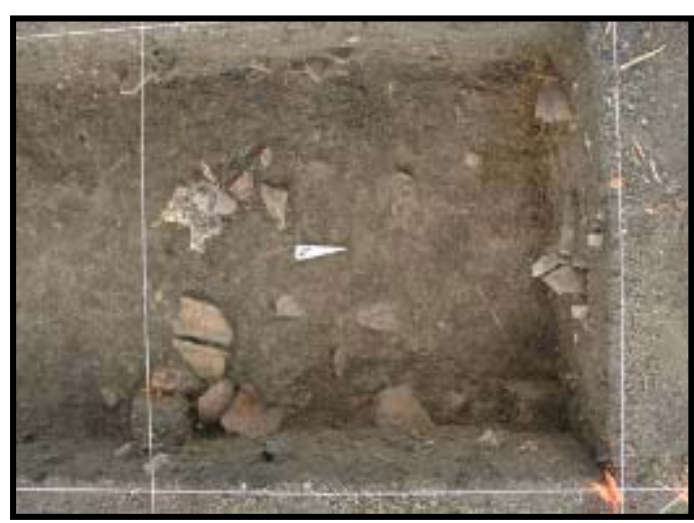

Figura 112 - Unidade N-1014 E-1002, base do nível 20 a $30 \mathrm{~cm}$. 
(uma talvez seja moderna). Após $70 \mathrm{~cm}$ de profundidade ainda ocorrem fragmentos de cerâmica, porém parece ser decorrente de bioturbações identificadas durante a escavação. Após $110 \mathrm{~cm}$ de profundidade não ocorrem mais os vestígios arqueológicos. Para visualizar as informações, ver gráficos 19, 20 e descrição do perfil das unidades (figura 113).

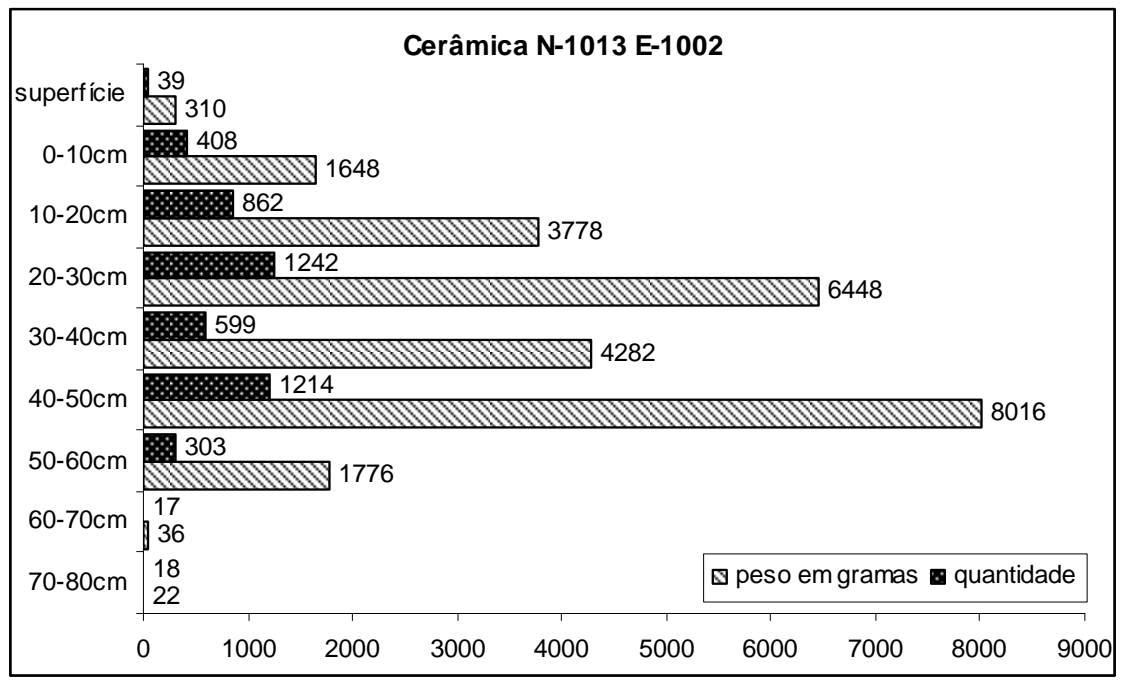

Gráfico 19 - Unidade N-1013 E-1002, densidade de material cerâmico por nível.

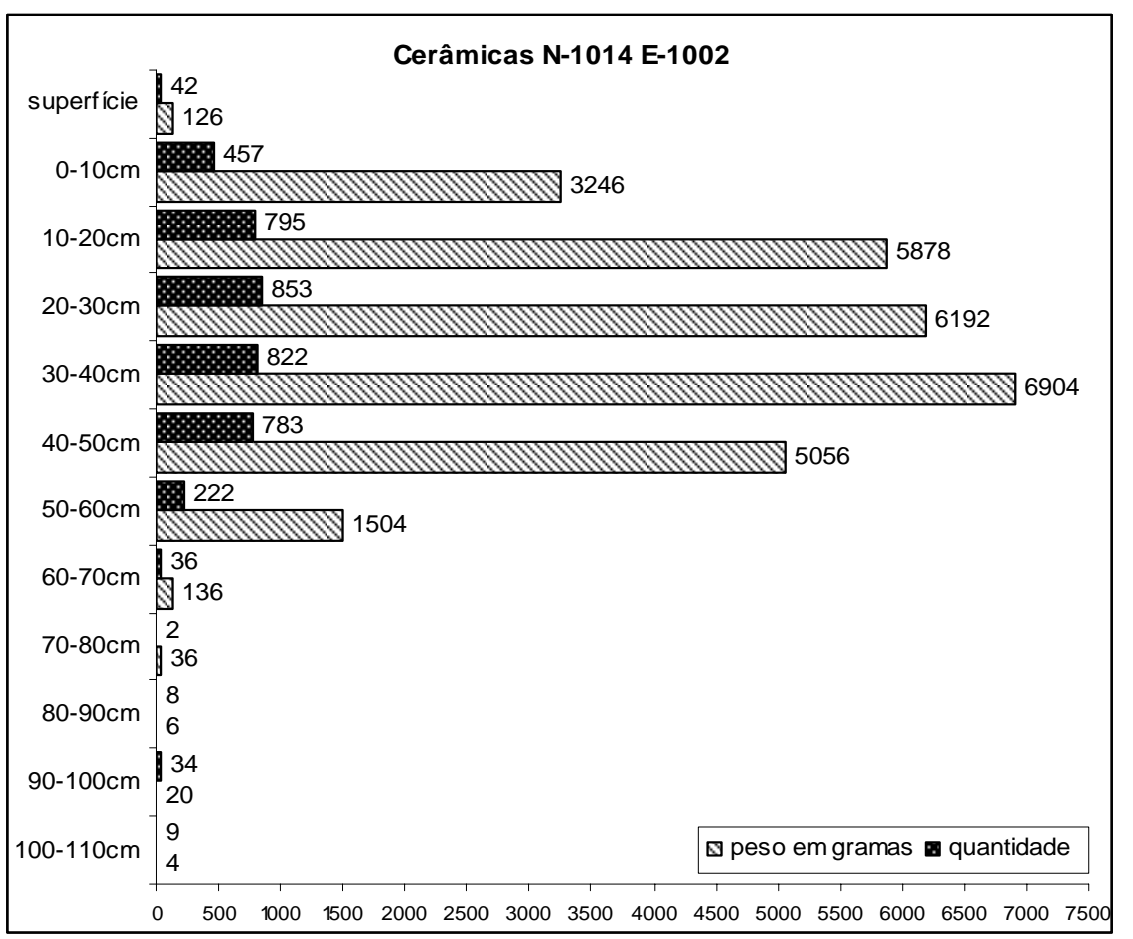

Gráfico 20 - Unidade N-1014 E-1002, densidade de material cerâmico por nível. 

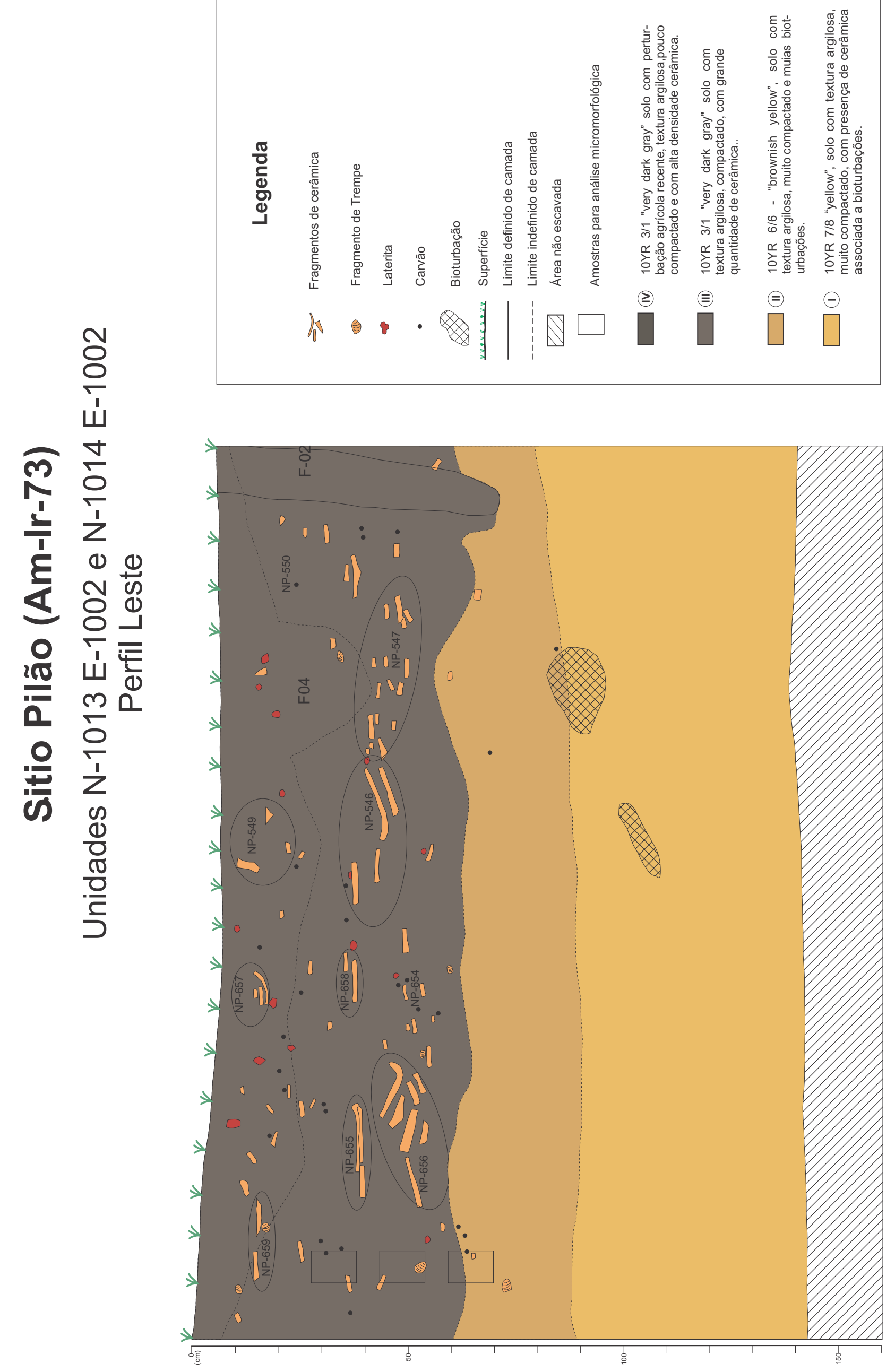
Foi aberta inicialmente a unidade N-991 E-974, como foi evidenciada uma alta concentração de fragmentos de cerâmica, fragmentos grandes, e uma feição que parecia evidenciar o local de uma estrutura de combustão, posteriormente foram abertas as unidades -991 E-973 e N-990 E-974. N-991 E-974 e N-991 E-973 estão no ponto mais alto do montículo. Já N-990 E-974 está na declividade para a borda do montículo 09 (anexo 13). A terra preta está presente desde a superfície até aproximadamente $30 \mathrm{~cm}$ de profundidade. As cerâmicas vistas na superfície também são bastante fragmentadas. A densidade de fragmentos de cerâmica é muito elevada desde o primeiro nível até $40 \mathrm{~cm}$, sendo o pico de densidade nos primeiros $20 \mathrm{~cm}$ da escavação. Se compararmos o peso nos gráficos, veremos que os fragmentos são maiores que os das unidades anteriores. A partir de $30 \mathrm{~cm}$ o solo clareia muito para um tom amarelado. Nesse ponto da escavação fica evidente uma mancha escura na parede norte (figura 114), com a continuação da escavação percebemos que se tratava de uma feição de uma estrutura de combustão. Após $60 \mathrm{~cm}$ de profundidade são evidenciadas três feições de buracos de poste, na unidade N-990 E-974, na unidade N991 E-973 e outra no perfil leste de N-991 E-974. O solo apresentava terra queimada, o sedimento que preenchia a feição era mais escuro, com uma grande quantidade de carvão. Após $80 \mathrm{~cm}$ de profundidade não ocorrem mais os vestígios arqueológicos. Essas informações podem ser visualizadas nos gráficos 21, 22, 23 e na descrição do perfil das unidades (figura 115).

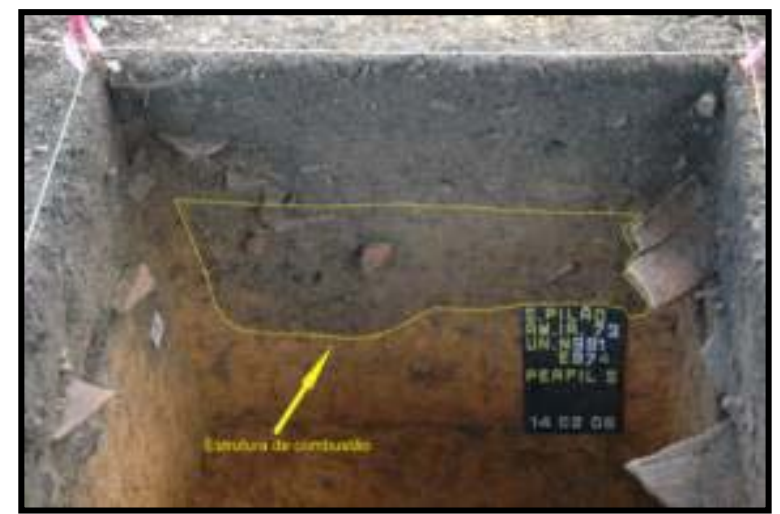

Figura 114 - Unidade N-991 E-974, perfil sul, com destaque para feição de estrutura de combustão. 


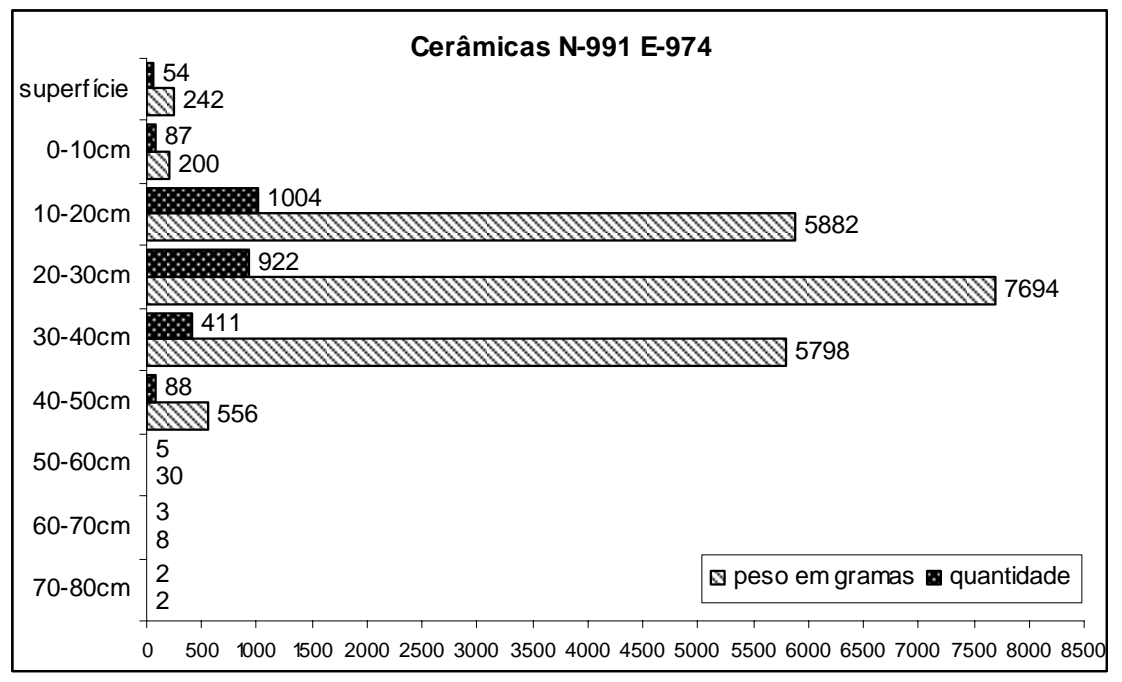

Gráfico 21 - Unidade N-991 E-974, densidade de material cerâmico por nível.

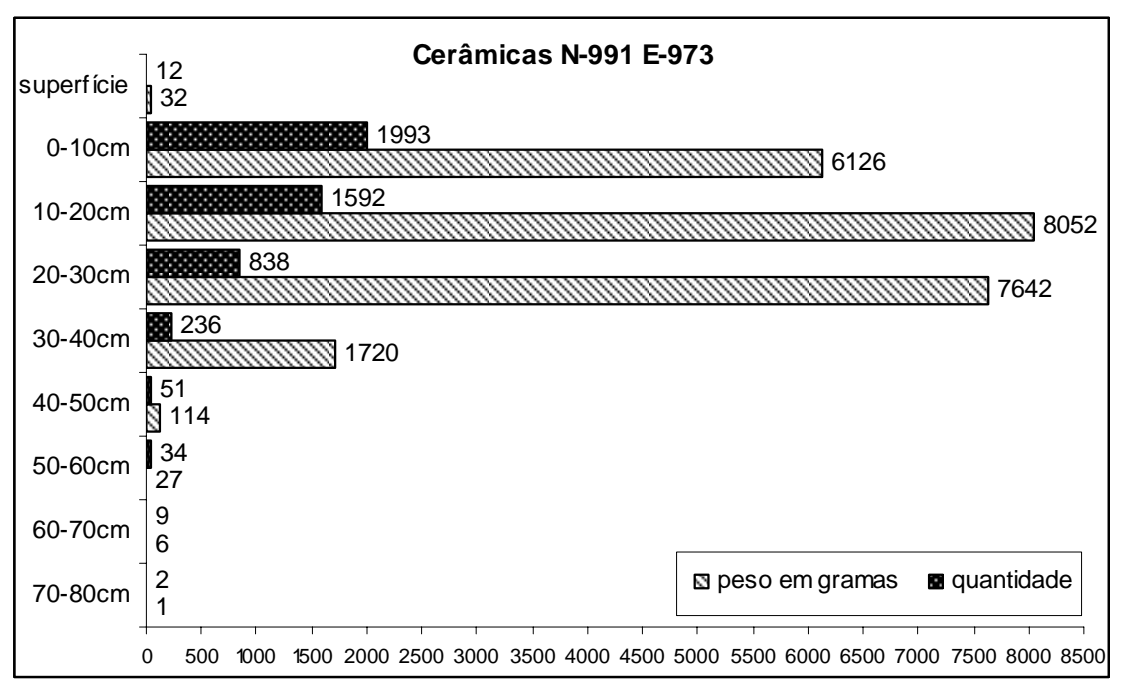

Gráfico 22 - Unidade N-991 E-973, densidade de material cerâmico por nível.

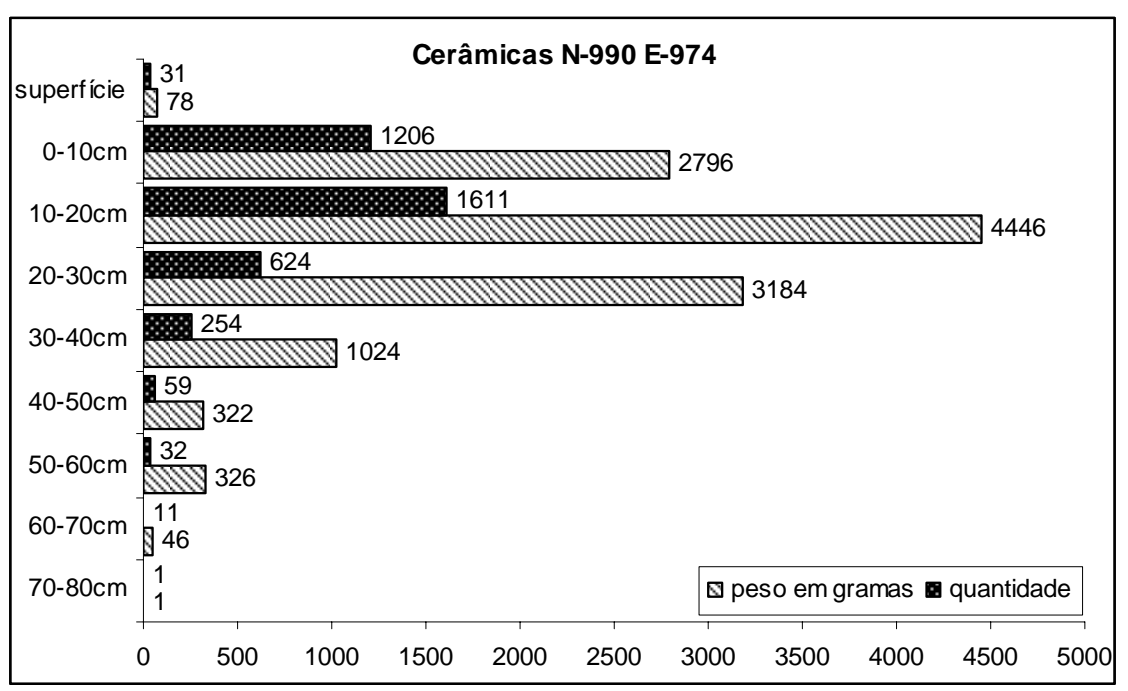

Gráfico 23 - Unidade N-990 E-974, densidade de material cerâmico por nível. 

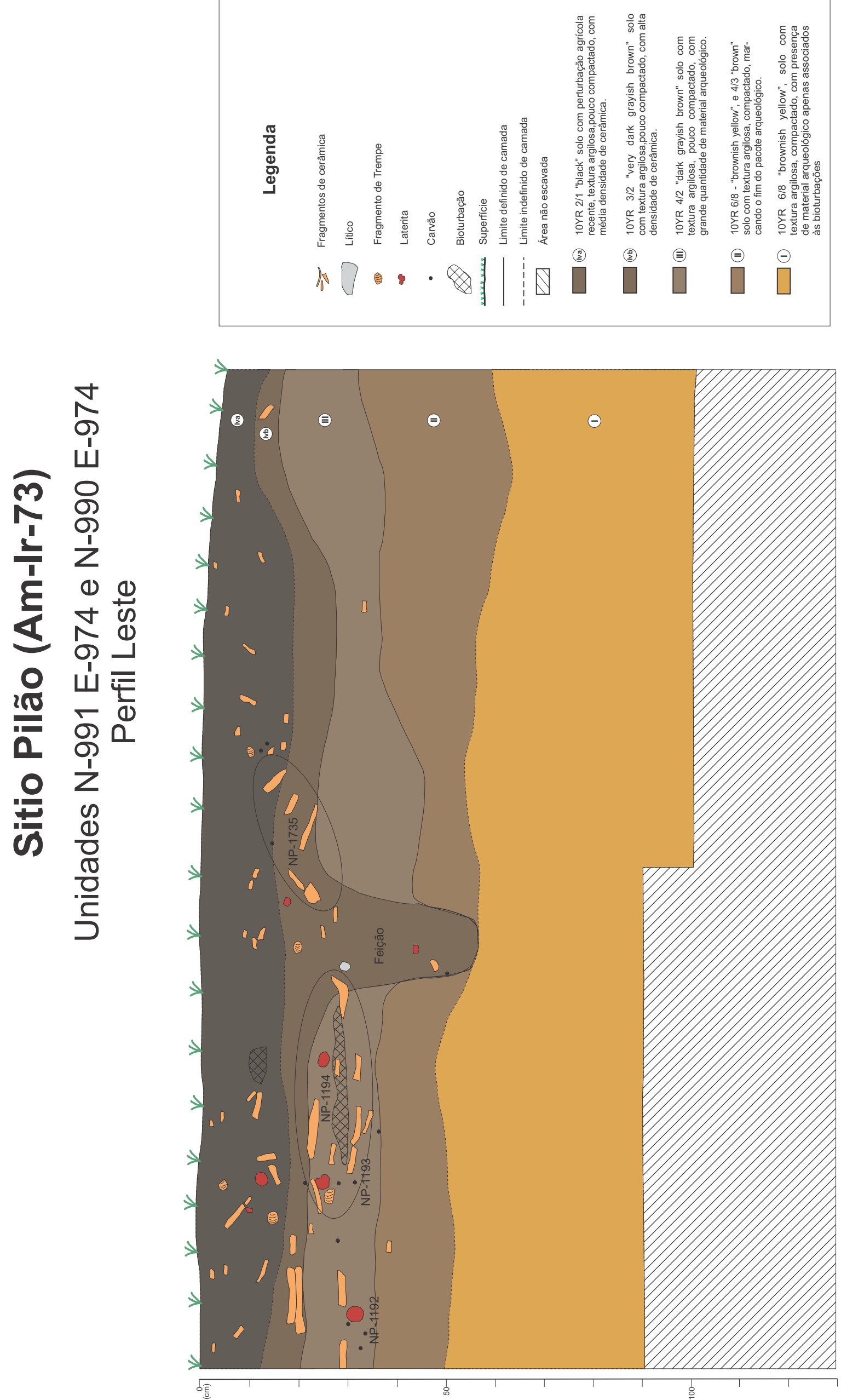
A unidade foi aberta com o objetivo de testar essa área do sítio, pois o montículo 10 é uma elevação um pouco diferente das demais, trata-se de uma elevação próxima ao desnível da vertente do lago (anexo 13). Como a tradagem no local apresentou uma camada de terra preta um pouco maior (figura 116), ali seria um bom local para escavação. A terra preta é muito escura na superfície do

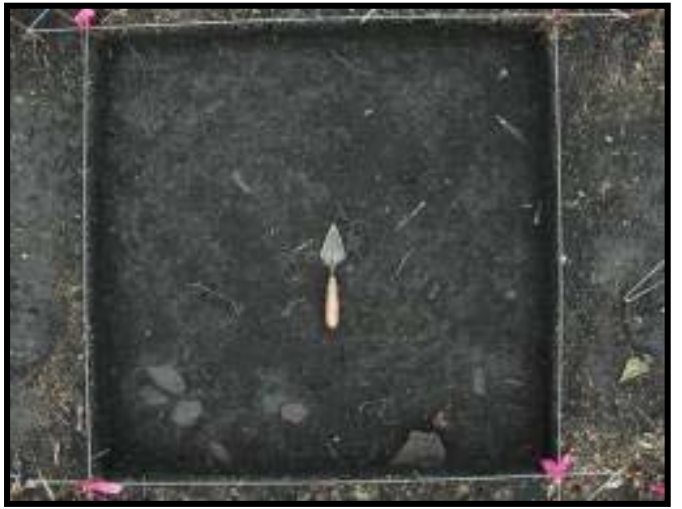

Figura 116 - Unidade N-981 E-927, nível 20 a $30 \mathrm{~cm}$.

montículo 10, com a escavação constatamos que ela está presente até a profundidade de $60 \mathrm{~cm}$. A densidade de fragmentos de cerâmica é elevada desde o primeiro nível, porém um pouco menor do que a vista nas unidades anteriores. Os dois primeiros níveis escavados são os mais densos, com alta densidade até $60 \mathrm{~cm}$. A homogeneidade do pacote arqueológico e a localização no sítio nos sugerem a possibilidade de se tratar de uma área de descarte. O pacote arqueológico termina aos $80 \mathrm{~cm}$ de profundidade, quando grande parte do piso já é composta por uma laje de laterita. As informações anteriores podem ser visualizadas no gráfico 24 e na descrição do perfil da unidade (figura 117).

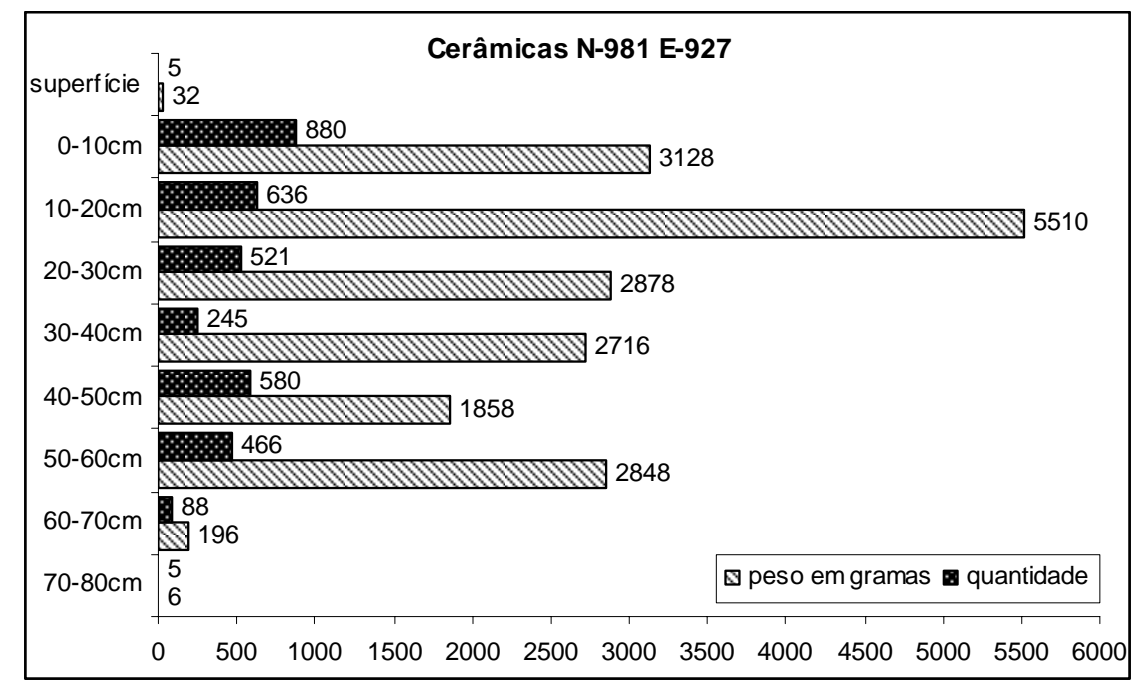

Gráfico 24 - Unidade N-981 E-927, densidade de material cerâmico por nível. 


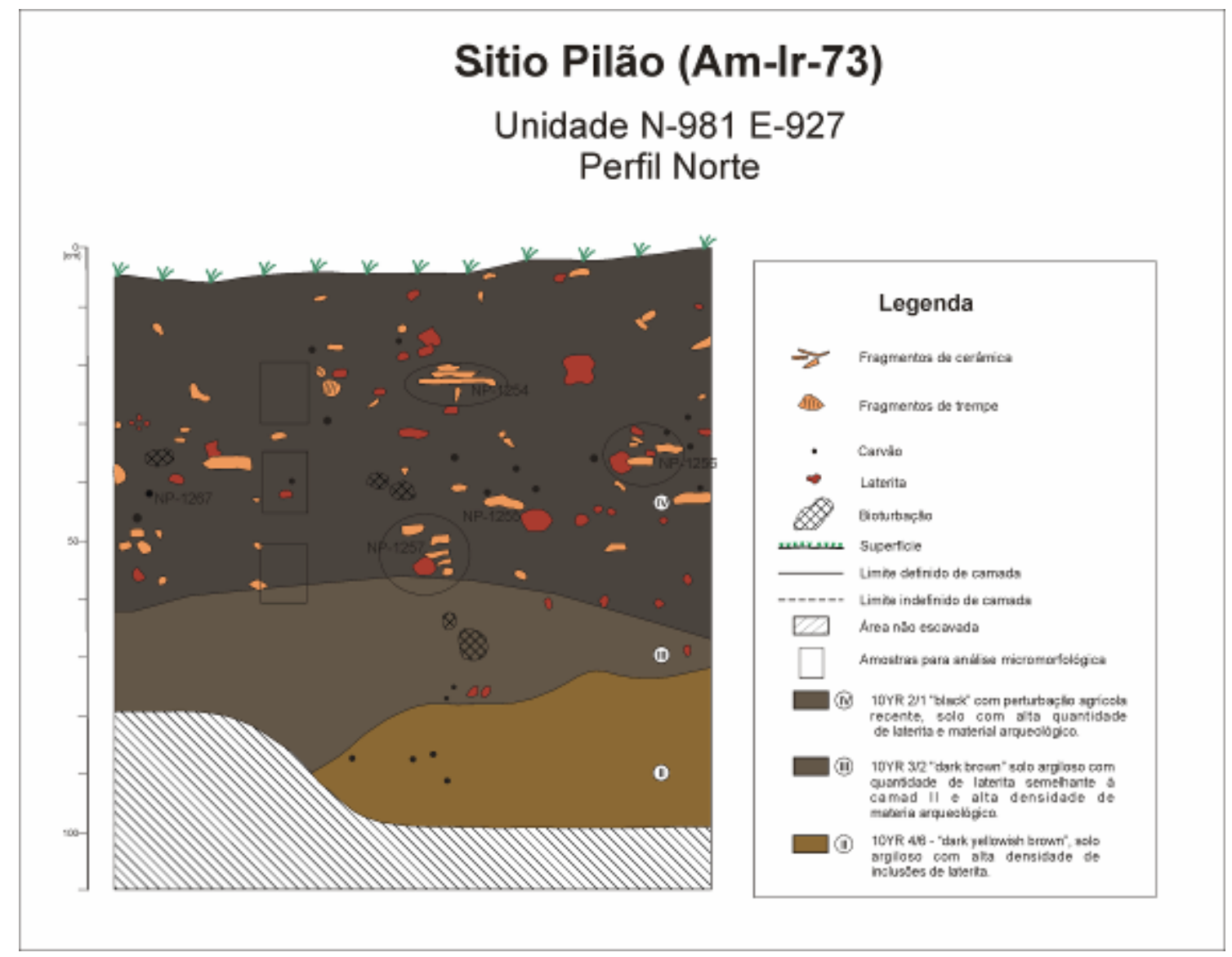

Figura 117 - Unidade N-981 E-927, perfil Norte.

\section{IV.III.VII - UNIDADE N-1003 E-956}

Esta também era uma área próxima ao declive da vertente do lago, a tradagem que havia sido feita nas proximidades apresentou alta concentração de cerâmica e ocorrência em profundidade maior que no restante do sítio. A unidade apresentou uma concentração de fragmentos de cerâmica muito elevada, sendo a unidade com os fragmentos maiores em todo o sítio. Como pode ser visto na figura 118 e no gráfico 25 os fragmentos são grandes e ocorrem em alta densidade. A terra preta está presente desde a superfície até a profundidade de $50 \mathrm{~cm}$ (figura 119). A concentração de fragmentos é grande de 0 a $60 \mathrm{~cm}$, com o pico de densidade entre 10 e $20 \mathrm{~cm}$. A partir de $50 \mathrm{~cm}$ o solo clareia muito para um tom amarelado. Após $70 \mathrm{~cm}$ de profundidade ainda ocorrem fragmentos de cerâmica, porém parece ser decorrente de

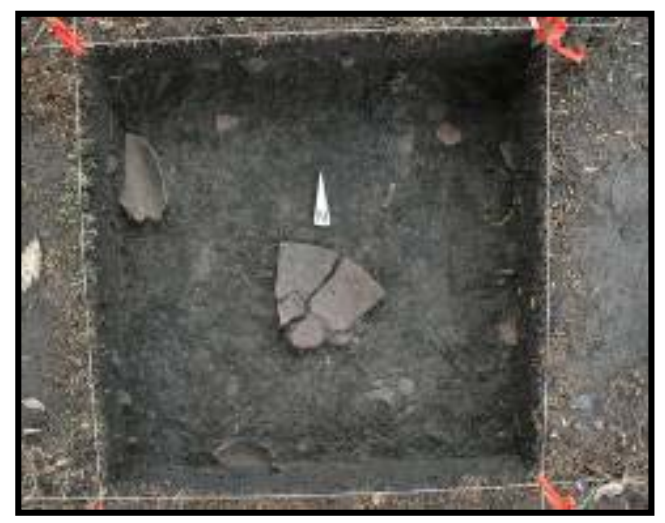

Figura 118 - Unidade N-1003 E-956 com fragmentos de cerâmica evidenciados na escavação. 
bioturbações identificadas durante a escavação. Após $100 \mathrm{~cm}$ de profundidade não ocorrem mais os vestígios arqueológicos.

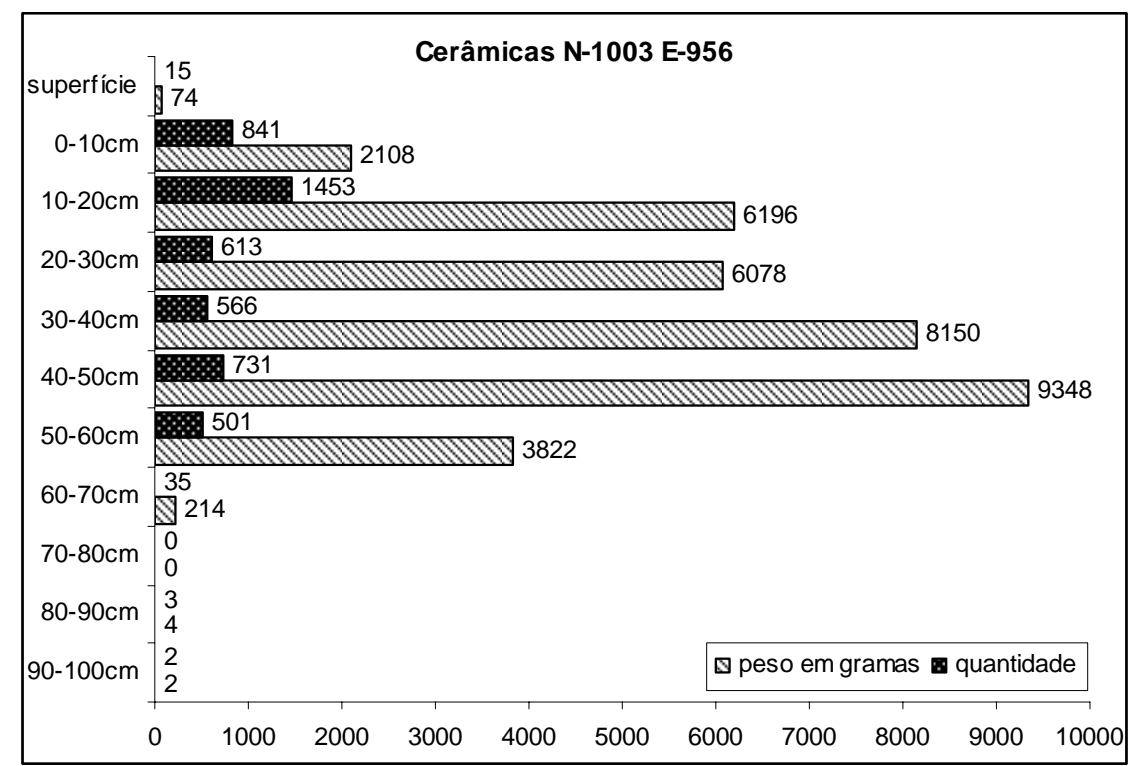

Gráfico 25 - Unidade N-1003 E-956, densidade de material cerâmico por nível.

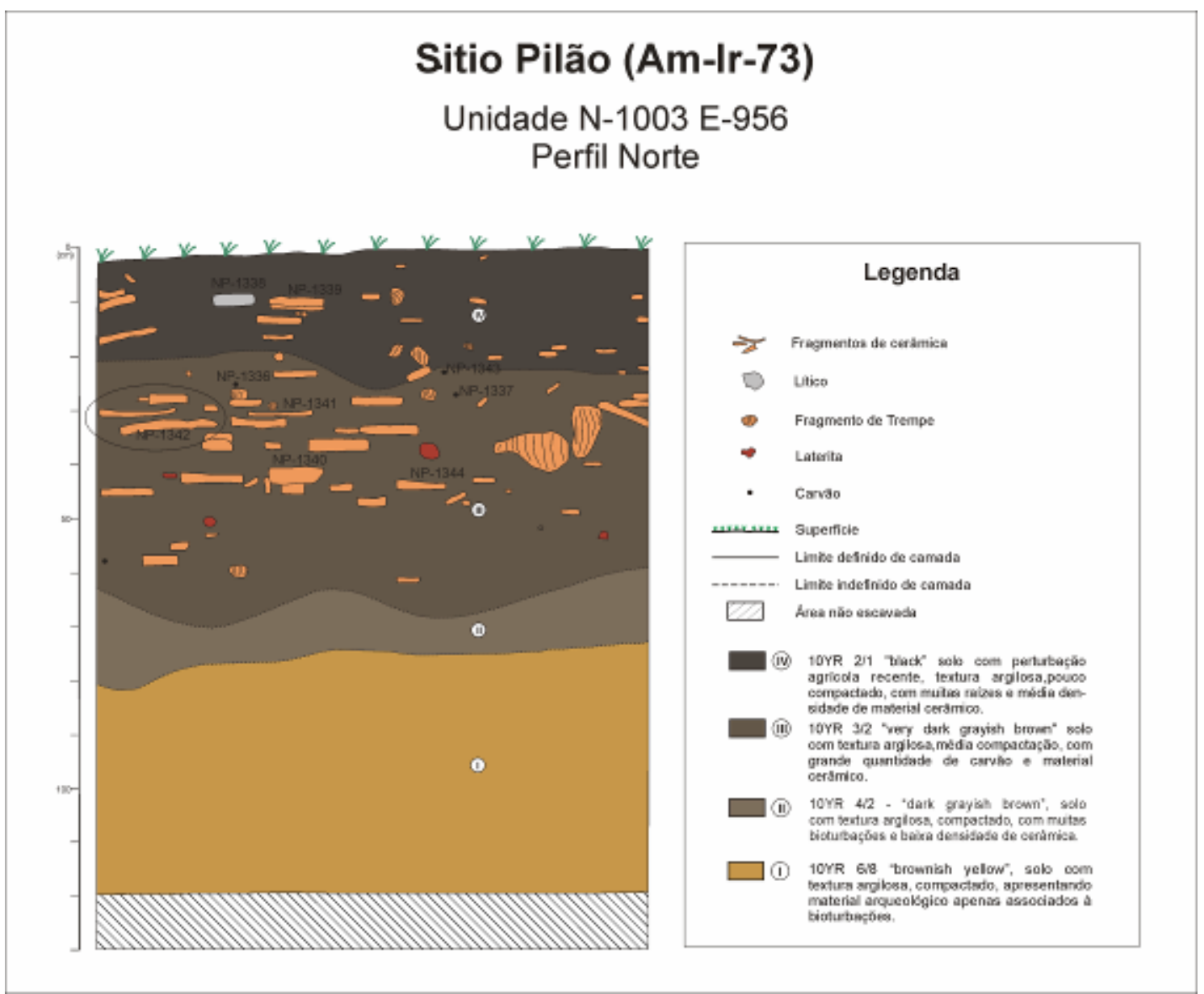

Figura 119 - Unidade N-1003 E-956, perfil Norte. 
A unidade foi aberta em uma área onde as camadas superficiais foram removidas para a construção dos montículos dispostos em círculo. Observando o local, percebemos que entre os montículos a camada de laterita estava exposta em vários pontos (figura 120), se os montículos configuram a forma da aldeia como é a nossa hipótese, esta área seria o pátio central entre as unidades habitacionais. A escavação foi aberta na área central entre os montículos (anexo 13). A terra preta está presente, porém sua coloração é bem mais clara que na maioria das unidades abertas, a profundidade de ocorrência também é um

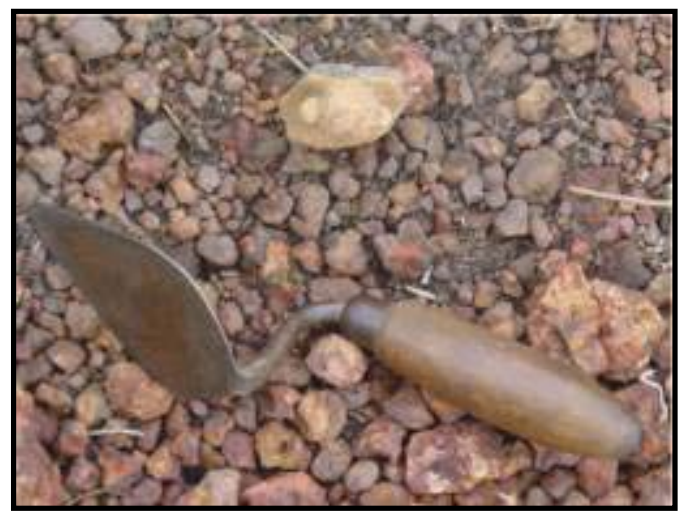

Figura 120 - Superfície da área entre os montículos, com destaque para a grande concentração de laterita e um fragmento de cerâmica com apêndice típico da fase Paredão. pouco menor, até $30 \mathrm{~cm}$. Como era de se esperar a densidade de fragmentos de cerâmica é muito inferior à das unidades escavadas nos montículos, apenas entre 10 e $20 \mathrm{~cm}$ de profundidade ocorre uma quantidade maior de cerâmica, no restante dos níveis a densidade é muito baixa (gráfico 26). Após $50 \mathrm{~cm}$ de profundidade ainda ocorrem fragmentos de cerâmica, porém isso parece ser decorrente de bioturbações identificadas durante a escavação. Após $110 \mathrm{~cm}$ de profundidade não ocorrem mais os vestígios arqueológicos. As informações podem ser visualizadas no gráfico 26 e na descrição do perfil da unidade (figura 121).

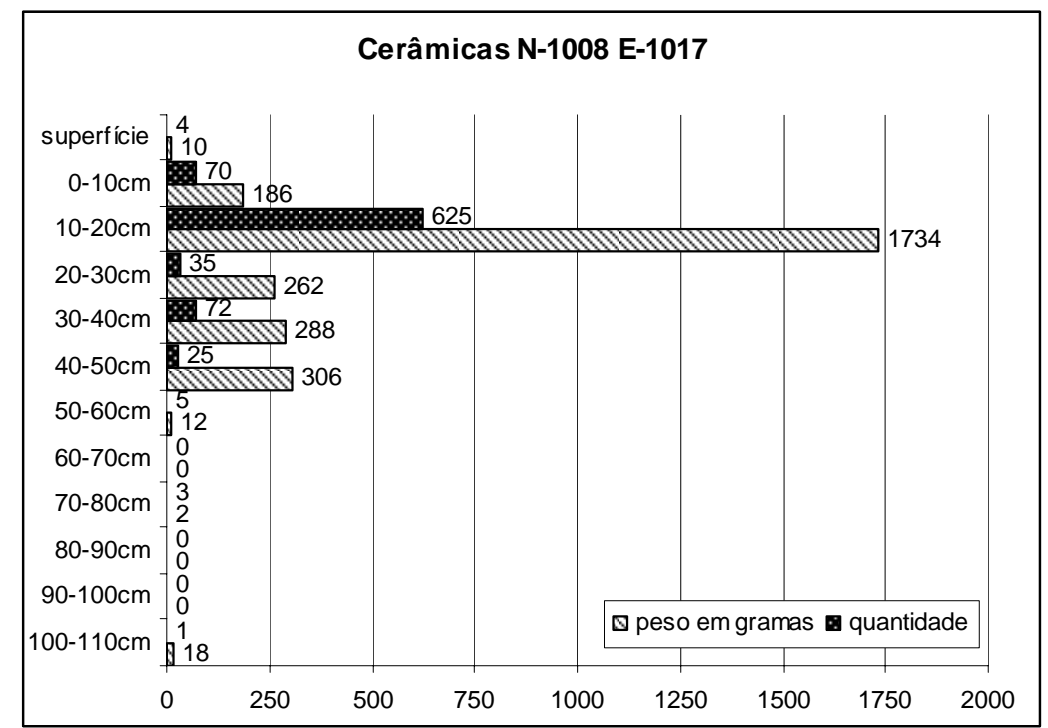

Gráfico 26 - Unidade N-1008 E-1017, densidade de material cerâmico por nível. 


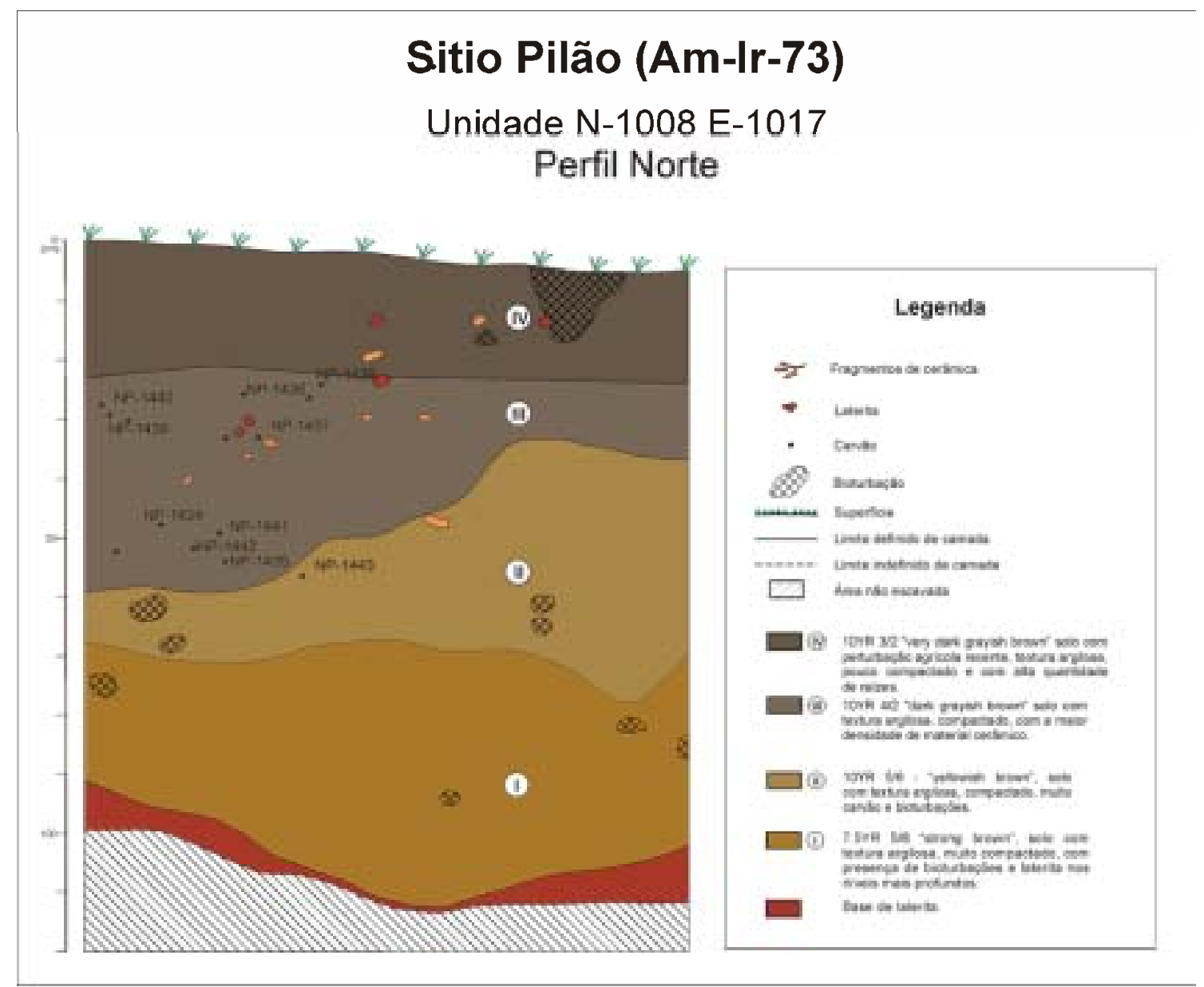

Figura 121 - Unidade N-1008 E-1017, perfil Norte. 


\section{Capítulo V - O LABORATÓRIO}

\section{V.I - METODOLOGIA}

O conceito de fase que estamos usando em nosso trabalho é o mesmo definido por Chmyz et alii (1976), onde fase é definida como: "Qualquer complexo de cerâmica, lítico, padrões de habitação, etc., relacionado no tempo e no espaço, num ou mais sítios." Independente do grupo ou grupos que os produziram, uma coisa é certa, existem diferenças técnicas, morfológicas, estilísticas e temporais no material estudado e é essa a separação que estamos fazendo com as fases. A cerâmica encontrada na área de pesquisa do PAC pode ser classificada dentro dos seguintes complexos: fase Açutuba (século III AC - IV DC), a fase Manacapuru (séculos IV a VIII DC), a fase Paredão (séculos VII e XII DC) e a fase Guarita (séculos IX-XVI DC).

De maneira sintética as características do material das diferentes fases são:

Fase Açutuba - Ocorrência de cariapé adicionado à pasta de argila, predominância de formas irrestritivas, decoração variada com motivos incisos curvilíneos, excisões sobre engobo vermelho, acanalados, apêndices zoomorfos, flanges labiais, flanges mesiais, engobo branco e pintura policrômica.

Fase Manacapuru - Ocorrência principalmente de cauixí adicionado à pasta de argila, predominância de formas restritivas, decoração variada com incisões retilíneas duplas, ponteado, apêndices zoomorfos, flanges labiais e engobo vermelho.

Fase Paredão - Predominância de cauixí adicionado à pasta de argila, vasos com paredes muito finas e bem queimadas, presença de vasos com alças, vasos com pedestais, decoração com incisões em linhas finas, pintura também em linhas muito finas, engobo vermelho e apliques antropomorfos estilizados (as cabecinhas Paredão) associados às urnas funerárias.

Fase Guarita - Predominância de cariapé adicionado à pasta de argila, ocorrência de vasos com borda reforçada, decoração policrômica com motivos geométricos (faixas grossas e linhas finas), decoração plástica acanalada, urnas funerárias antropomorfas, vasos com flange mesial, ocorrência de engobo branco e vermelho.

O material arqueológico recolhido no campo foi abordado em diferentes escalas de resolução. Todo o material coletado nas tradagens foi lavado, triado, pesado e 
quantificado. A triagem consiste na separação de bordas bases, fragmentos decorados e não decorados. Esta triagem é necessária em função da grande quantidade de material que é coletada nos sítios arqueológicos, A grande maioria do material decorado é passível de classificação quanto às fases arqueológicas existentes na região. $\mathrm{O}$ material não decorado também é muito importante e consiste na maior parte do que é recolhido.Os não decorados não são descartados da análise, pois, quando classificamos as bordas e bases estamos pegando uma grande quantidade de exemplares sem decoração, estes fragmentos nos darão informações importantes quanto às características dos vasos, diferente dos fragmentos de parede sem decoração que tem possibilidades de análise mais limitadas.

Após a triagem os fragmentos não decorados são quantificados e pesados. As bordas bases e fragmentos decorados além de quantificados e pesados são analisados seguindo uma ficha de atributos que vem sendo aprimorada nos trabalhos do PAC (para uma descrição detalhada dos atributos ver Machado 2005 e Lima 2005). O material arqueológico coletado foi abordado em diferentes escalas de resolução. Todo o material recolhido nas tradagens foi lavado, triado, pesado e quantificado. $\mathrm{O}$ material recolhido nas unidades de escavação foi trabalhado amostralmente, porém foram analisados muitos atributos das bordas bases e fragmentos decorados (tabela 03). Com os atributos analisados teremos mais condições de definir as características peculiares de cada fase cerâmica, acrescentando dados às definições descritas anteriormente.

Com a triagem, quantificação e pesagem foram produzidos os mapas e gráficos de densidade de material nos sítios arqueológicos. Com a triagem verificamos onde ocorriam materiais das diferentes fases com as quais estamos trabalhando.

A ficha de análise é resultado da mescla de vários atributos definidos por diferentes autores como: Shepard (1956), Meggers (1970), Chmyz et alii (1976), Rye (1981), Wüst (1994), Robrahn-González (1996), Machado (2005), Pinto Lima (2005), Tamanaha (2006) e algumas adaptações atuais discutidas pelos membros do PAC.

\begin{tabular}{|c|c|c|c|}
\hline & Atributos & Descrição & Variáveis \\
\hline 1 & Sítio & Sigla definida pelo IPHAN & \\
\hline 2 & $\begin{array}{c}\text { Número de } \\
\text { Proveniência }\end{array}$ & $\begin{array}{c}\text { Número seqüencial dado a todo } \\
\text { material recolhido no sítio } \\
\text { arqueológico }\end{array}$ & \\
\hline 3 & Localização & $\begin{array}{c}\text { Endereço do material no sítio } \\
\text { arqueológico }\end{array}$ & \\
\hline 4 & Nível & $\begin{array}{c}\text { Posição estratigráfica do material } \\
\text { arqueológico }\end{array}$ & \\
\hline 5 & Natureza & Categoria de material que está & Borda, base, parede, inflexão, \\
\hline
\end{tabular}




\begin{tabular}{|c|c|c|c|}
\hline & & sendo analisado & $\begin{array}{c}\text { alça, apêndice,fuso, flange } \\
\text { mesial, flange labial, vaso } \\
\text { inteiro, artefato modelado, } \\
\text { carimbo e asa }\end{array}$ \\
\hline 6 & Espessura & $\begin{array}{c}\text { Medida em mm do ponto mais } \\
\text { espesso da peça }\end{array}$ & \\
\hline 7 & Diâmetro & $\begin{array}{l}\text { Medida do diâmetro das bordas ou } \\
\text { bases quando possível }\end{array}$ & \\
\hline 8 & Cor da Superfície & $\begin{array}{l}\text { Cor aproximada da pasta da } \\
\text { cerâmica na face interna e externa }\end{array}$ & $\begin{array}{l}\text { Branca, laranja A, Iaranja B, } \\
\text { preta ou cinza e vermelha }\end{array}$ \\
\hline 9 & Antiplástico & $\begin{array}{c}\text { Tipos de antiplásticos encontrados } \\
\text { na pasta de argila }\end{array}$ & $\begin{array}{l}\text { Cauixi, cariapé, caco moído, } \\
\text { mineral, argila, osso, carvão e } \\
\text { areia }\end{array}$ \\
\hline 10 & $\begin{array}{l}\text { Técnica de } \\
\text { Manufatura }\end{array}$ & $\begin{array}{l}\text { Técnica utilizada para confecção } \\
\text { das peças }\end{array}$ & Roletado, modelado e moldado \\
\hline 11 & Queima & $\begin{array}{l}\text { Estado da superfície e núcleo dos } \\
\text { fragmentos após a queima }\end{array}$ & $\begin{array}{l}\text { Oxidante, redutora, oxidante } \\
\text { interna e redutora externa, } \\
\text { redutora interna e oxidante } \\
\text { externa e com núcleo reduzido } \\
\text { (sanduíche) }\end{array}$ \\
\hline 12 & Contorno do Vaso & Tipos de contorno do vaso & $\begin{array}{l}\text { Estamos associando vasos com } \\
\text { contorno infletido aos outros } \\
\text { tipos, de forma que o critério } \\
\text { definidor é a identificação de } \\
\text { partes distintas no } \\
\text { vaso. Exemplares com parte } \\
\text { serão classificados como } \\
\text { simples, duas compostos e mais } \\
\text { de duas complexo }\end{array}$ \\
\hline 13 & Forma do Vaso & $\begin{array}{l}\text { Relação entre o diâmetro da boca e } \\
\text { o diâmetro do corpo do vaso }\end{array}$ & Restritiva, irrestritiva e vertical \\
\hline 14 & $\begin{array}{l}\text { Inclinação da } \\
\text { Borda }\end{array}$ & $\begin{array}{c}\text { Posição da borda com relação ao } \\
\text { corpo do recipiente }\end{array}$ & Direta, extrovertida e introvertida \\
\hline 15 & Forma do Lábio & $\begin{array}{l}\text { Generalização do formato final dado } \\
\text { ao lábio de acordo com alguns } \\
\text { modelos pré-estabelecidos }\end{array}$ & $\begin{array}{l}\text { Apontado, biselado, roletado } \\
\text { interno (reforçado), roletado } \\
\text { externo, expandido, afilado, } \\
\text { arredondado, plano e acanalado }\end{array}$ \\
\hline 16 & $\begin{array}{l}\text { Acabamento do } \\
\text { Lábio }\end{array}$ & $\begin{array}{c}\text { Tratamento decorativo ou não } \\
\text { executado no lábio da peça }\end{array}$ & $\begin{array}{l}\text { Arredondado, plano, serrilhado, } \\
\text { ungulado, cortado, pintado, } \\
\text { engobado, inciso, acanalado, } \\
\text { digitado, ponteado e modelado }\end{array}$ \\
\hline 17 & Forma da Base & $\begin{array}{l}\text { Generalização do formato final dado } \\
\text { à base de acordo com alguns } \\
\text { modelos pré-estabelecidos }\end{array}$ & $\begin{array}{l}\text { Plana, côncava, convexa, com } \\
\text { pedestal e plana com marcas de } \\
\text { folha }\end{array}$ \\
\hline 18 & $\begin{array}{l}\text { Tratamento de } \\
\text { Superfície }\end{array}$ & Acabamento dado à peça & $\begin{array}{l}\text { Alisamento, enegrecimento ou } \\
\text { brunidura, resina, polimento e } \\
\text { escovado }\end{array}$ \\
\hline 19 & $\begin{array}{l}\text { Local da } \\
\text { Decoração }\end{array}$ & Interna ou externa & Interna, externa e ambas \\
\hline 20 & $\begin{array}{l}\text { Tipo de } \\
\text { Decoração }\end{array}$ & $\begin{array}{l}\text { Que técnica foi utilizada para } \\
\text { decorar a peça }\end{array}$ & $\begin{array}{c}\text { Pintada interna, pintada externa, } \\
\text { plástica interna, plástica externa, } \\
\text { engobo interno e engobo } \\
\text { externo }\end{array}$ \\
\hline 21 & Cor do Engobo & $\begin{array}{l}\text { Cor aproximada do banho dado às } \\
\text { peças }\end{array}$ & Branco, vinho e vermelho \\
\hline 22 & Tipo de Pintura & $\begin{array}{c}\text { Como são feitos os traços da } \\
\text { pintura }\end{array}$ & $\begin{array}{l}\text { Linhas finas, faixas grossas e } \\
\text { pós-queima }\end{array}$ \\
\hline 23 & Cor da Pintura & Cor aproximada da pintura aplicada & $\begin{array}{l}\text { Vinho, vermelha, alaranjada, } \\
\text { amarela, preta, branca, negativo }\end{array}$ \\
\hline
\end{tabular}




\begin{tabular}{|c|c|c|c|}
\hline & & & de pintura e marrom \\
\hline 24 & $\begin{array}{l}\text { Decoração } \\
\text { plástica }\end{array}$ & $\begin{array}{l}\text { Quais são os motivos plásticos } \\
\text { aplicados na decoração da peça }\end{array}$ & $\begin{array}{c}\text { Acanalado, inciso, apliques } \\
\text { modelados, ponteado, } \\
\text { digitado/ungulado, roletes } \\
\text { aplicados, excisão, esfera } \\
\text { aplicada, impressão de corda e } \\
\text { corrugado }\end{array}$ \\
\hline 25 & Marcas de Uso & $\begin{array}{l}\text { Sinais de desgaste ou acúmulo de } \\
\text { matéria nos fragmentos ou } \\
\text { recipientes }\end{array}$ & Fuligem, reciclagem e atrito \\
\hline 26 & Fase & $\begin{array}{c}\text { Fase arqueológica a que pertence o } \\
\text { fragmento ou recipiente }\end{array}$ & $\begin{array}{c}\text { Açutuba, Manacapuru, Paredão, } \\
\text { Guarita, Poço, Santarém, } \\
\text { Cabocla, etc... }\end{array}$ \\
\hline
\end{tabular}

Tabela 03 - Descrição sumária dos atributos analisados na cerâmica.

Outra etapa de estudo da cerâmica é a reconstituição das formas dos recipientes através dos fragmentos analisados. Como já foi apontado por Machado (2005), a complexidade e variabilidade das formas cerâmicas dificulta e limita muito a reconstrução das formas a partir de fragmentos. Partindo desse pressuposto a opção adotada em nosso trabalho foi a de reconstituição parcial dos fragmentos que não possibilitam uma estimativa segura da forma do recipiente e a reconstituição completa somente quando os fragmentos apresentam indicativos seguros da forma total. Investimos muito trabalho na reconstituição e os resultados podem ser vistos nos anexos 15 a 28.

Feita a reconstituição, agrupamos os tipos por semelhanças técnicas, morfológicas e decorativas, tentando assim, entender melhor as diferenças e semelhanças dos conjuntos cerâmicos das fases arqueológicas estudadas.

\section{V.II - AVALIACÃ̃O DA POTENCIALIDADE DOS ATRIBUTOS ANALISADOS}

\section{COMO DEFINIDORES NA CLASSIFICAÇÃO DE CERÂMICA EM DIFERENTES}

\section{FASES}

Para avaliar a potencialidade dos atributos analisados para a classificação da cerâmica nas diferentes fases temos que destacar a insuficiência de nossa amostra principalmente no tocante à fase Manacapuru. Inicialmente essa era para ser a principal fase em discussão no nosso trabalho, porém com o encaminhamento do campo e a identificação de uma predominância de sítios da fase Paredão, o foco mudou, pois a amostra coletada é principalmente representativa da fase Paredão. Nossa coleção de objetos Manacapuru conta com poucos exemplares passíveis de reconstituição, não 
temos representatividade da variedade de formas dentro da fase, nossa amostra é suficiente apenas para falar de algumas tendências quanto à composição da pasta, tipo de decoração e apenas alguns poucos atributos relacionados à morfologia.

Nossa coleção da fase Paredão é mais significativa, temos uma boa amostra da variabilidade formal dentro da fase, foi possível identificar as tendências relativas à composição da pasta e preferências pela forma de lábios, tipos e motivos decorativos mais aplicados, entre outros atributos. A boa representatividade deve ser creditada ao fato de termos trabalhado com sítios, ou contextos em sítios, com materiais exclusivos da fase Paredão, pois como apresentaremos adiante apesar de alguns atributos serem bastante eficientes na classificação da cerâmica, é necessário, na maioria das vezes, a associação de dois ou mais atributos para uma classificação segura, desse modo, quando os sítios ou contextos são multicomponenciais, grande parte da coleção fica inclassificável em função da semelhança entre indivíduos das diferentes fases.

A fase Guarita também esta bem representada em nossa coleção, apesar de não tanto quanto a fase Paredão, a amostra é suficiente para identificação de uma variada gama de formas e tendências de composição da pasta, morfologia e variedades decorativas relacionas ao acabamento das peças.

A seguir apresentaremos uma avaliação da ficha de análise e seus atributos.

1 - Natureza da Peça - O atributo, apesar de muito geral, pode ser um definidor classificatório para fases, pois algumas categorias são exclusivas de uma para outra fase. Por exemplo, a existência de flanges mesiais já exclui a possibilidade do indivíduo ser pertencente à fase Manacapuru, associa com grande probabilidade à fase Guarita, porém para isso, são necessárias correlações com outros atributos, pois apesar de pouco recorrente, é possível encontrar indivíduos da fase Paredão com esse traço diagnóstico.

2- Espessura - As peças da fase Paredão podem até ser diagnosticadas pela espessura, pois há uma tendência muito grande de produção de paredes muito finas nos exemplares, porém devido à grande variabilidade de tamanhos de vasos encontrados na coleção como um todo, o atributo não deve ser avaliado individualmente.

3 - Cor da superfície - Não é um bom critério classificatório, pois há uma grande variabilidade inter e intra-fases. 
4 - Diâmetro - Também não apresenta significância para definir classificação, a não ser no caso de exemplares com diâmetro ovalado, que no caso foram todos atribuídos à fase Paredão.

5 - Antiplástico - Tradicionalmente foi um atributo muito utilizado como definidor de fases na Amazônia, Meggers, Hilbert, Simões entre outros, sempre descreveram-no como definidor. Apesar de algumas tendências de ocorrência prioritária de certos antiplásticos em determinadas fases, a variabilidade de associações de diferentes componentes dentro da mesma fase é muito recorrente. $\mathrm{O}$ cariapé, quando predominante, tem grandes chances de ser associado à fase Guarita, porém é grande a ocorrência de exemplares com cauixí predominante. Além disso, podem ser identificados, em menor escala, exemplares na fase Paredão com cariapé predominante no antiplástico. No caso da amostra analisada em nosso trabalho, consideramos que com exceção da presença de carvão adicionado à pasta de argila que só foi verificada em exemplares da fase Paredão, nenhum outro componente pode ser usado como classificador isoladamente, só com a associação a outros atributos as tendências podem ser mais confiáveis.

6 - Técnica de Manufatura - Tem semelhança em todas as fases.

7 - Tipo de queima - Se analisado isoladamente não apresenta nenhuma possibilidade classificatória. Se analisado associado a outros atributos possui tendências discretas de possibilidade de classificação.

8 - Contorno do Vaso - Como analisado na ficha, as possibilidades podem ser identificadas em todas as fases. Se associado à forma ou outros atributos pode ser um bom definidor.

9 - Forma do Vaso - Na amostra analisada, só tem representatividade, se associada a outros atributos.

10 - Inclinação da Borda - Se analisada em associação com os tipos definidos ou outros atributos pode ser um bom critério definidor. 
11 - Forma do Lábio - Um bom atributo classificador, principalmente para a fase Guarita. Lábios reforçados externamente ou expandidos podem ser quase sempre associados a essa fase.

12 - Acabamento do Lábio - Quando o acabamento é dado com decoração, a associação a diferentes fases fica mais fácil, há uma tendência de lábios com incisões em linhas finas associados à fase Paredão, pintados à fase Guarita e cortados à fase Manacapuru, porém como a grande maioria não é decorado o mais indicado é utilizar esse atributo associado a outros como classificador.

13 - Forma da base - Pode ser um marcador de fase em casos específicos como as bases em pedestal, associadas à fase Paredão.

14 - Tratamento de Superfície - Há uma recorrência de quase todos os atributos analisados nas diferentes fases, porém quando o tratamento é o escovado pode ser associado com bastante seguridade à fase Manacapuru.

15 - Local da decoração - É muito significativo se analisado em associação a outros atributos como forma, espessura e tipo de decoração.

16 - Tipo e Local da Decoração - Idem. Anterior.

17 - Cor do Engobo - É um definidor com grande potencialidade principalmente para diferenciar a fase Guarita da fase Paredão. Se associado a outros atributos como, espessura dos fragmentos, antiplástico, tipo de pintura, entre outros, tem quase $100 \%$ de probabilidade de classificação correta.

18 - Tipo de Pintura - Um bom atributo classificador, principalmente para as fases Paredão e Guarita. Se associado a outros atributos como cor do engobo, forma, espessura, antiplástico, etc, tem grande potencialidade de classificação.

19 - Cor da Pintura - Se associado ao tipo de pintura pode se um bom marcador. 
20 - Decoração Plástica - Um ótimo atributo classificador, em alguns casos específicos é possível classificar artefatos com base neste único atributo.

21 - Marcas de Uso - Para o caso da coleção em questão, sem potencialidades.

22- Forma das Peças Reconstituídas - Principalmente no caso da fase Paredão é um ótimo atributo classificador.

\section{V.III - OS TIPOS CERÂMICOS}

Com base em trabalhos anteriores (Hilbert 1968, Donnati 2003, Machado 2005 e Lima 2005) e na análise de cerâmica de três sítios foram definidos alguns tipos cerâmicos característicos das fases arqueológicas estudadas. Optamos pela eleição da forma como critério definidor do tipo, sendo feita uma descrição das peculiaridades relativas à decoração, antiplástico, espessura, queima, cor, tipo e acabamento de lábio, que muitas vezes são fatores que diferenciam o material de uma fase e outras, sendo descritos quando presentes em cada tipo. Os tipos podem ser divididos em dois grupos básicos, um específico, onde os exemplares podem ser seguramente associados a uma ou outra fase (Tipos 1 a 4) e um grupo genérico onde os exemplares podem ocorrer em duas ou mais fases com pequenas diferenças técnicas e/ou decorativas (Tipos 5 a 13).

Não tratamos aqui com as características da fase Açutuba, pela não ocorrência de material na coleção analisada.

Tipo 1 - Cuia com pedestal

Exemplar exclusivo da fase Paredão, construído com base modelada, paredes e pedestais com roletes. São peças com diâmetro da borda entre 190 e $320 \mathrm{~mm}$, predomina a coloração do tipo "laranja A". O antiplástico mais encontrado é o cauixí acompanhado de mineral, às vezes acompanha também caco moído e/ou carvão. Foram encontrados exemplares com cariapé predominante associado a cauixí. A queima que mais aparece é a incompleta com núcleo escuro. As peças têm duas partes distintas o corpo e o pedestal, sendo então classificadas como compostas. A forma é sempre irrestritiva, borda com inclinação direta e lábio plano. O tratamento da superfície é o alisamento. 
Grande parte dos exemplares do grupo recebe decoração plástica na face interna da base, incisões largas ou acanalados, é rara a ocorrência de engobo vermelho (anexo 15).

Tipo 2 - Cesta com alça

Exemplar exclusivo da fase Paredão, construído com base plana modelada e paredes e alças roletadas. As paredes e a base são sempre muito finas (cerca de 5mm), enquanto a alça é sempre muito espessa (entre 10 e 30mm). A alça pode ser construída com apenas um grande rolete ou com a junção de até três roletes, a junção dos roletes pode ser totalmente mascarada pelo alisamento ou pode ficar visível em alguns casos. É difícil encontrar exemplares passíveis de reconstituição, mas a quantidade e variedade de tamanhos de alças encontradas, possibilita a suposição de que se trata de um tipo bastante produzido com tamanhos variados. Os exemplares reconstituídos que temos têm diâmetro da boca de cerca de $260 \mathrm{~mm}$. O antiplástico predominante é o cauixí acompanhado de mineral, às vezes acompanha também carvão e/ou caco moído. Foram encontrados exemplares com cariapé predominante acompanhado de cauixí. A queima que mais ocorre é a incompleta com núcleo escuro. As peças apresentam contorno simples, podendo ter boca restritiva ou irrestritiva, borda com inclinação direta e lábio afilado com acabamento plano ou arredondado. O tratamento da superfície é o alisamento. A decoração mais comum é o aplique de esferas na junção da alça com a parede, mas pode ocorrer também pintura em linhas finas na face externa, ocupando uma faixa desde o lábio até a metade do corpo da peça. Foram identificados exemplares com fuligem (anexo 16).

Tipo 3 - Vasos com Flange Mesial

O tipo é semelhante ao tipo 10, com acréscimo da flange. É muito característico da fase Guarita, porém foram encontrados, em um dos sítios analisados, exemplares equivalentes, com flanges não contínuas, pertencentes à fase Paredão.

As paredes e flanges são construídas com roletes. A espessura varia entre $4 \mathrm{e}$ $12 \mathrm{~mm}$ na fase Paredão; 7 e 13mm na fase Guarita. Na fase Paredão são verificados exemplares com coloração cinza/preta e "laranja A". Na fase Guarita predomina a coloração do tipo "laranja A". Na fase Paredão o antiplástico observado foi o cauixí associado a mineral, ocorre ainda os dois associados a carvão, caco moído e cariapé. Na 
fase Guarita o antiplástico é o cariapé associado a mineral e/ou caco moído; ou cauixí associado a mineral ou caco moído. A queima observada foi a redutora na fase Paredão e a queima completa, oxidada na fase Guarita. O contorno das peças é simples, restritivo, borda com inclinação extrovertida. Na fase Paredão a forma do lábio é o afilado ou arredondado, com acabamento inciso, plano ou ponteado. Na fase Guarita a forma do lábio é o roletado externo ou expandido, com acabamento plano. O tratamento da superfície é o alisamento. A decoração observada foi sempre plástica, principalmente incisões na flange ou no espaço entre a flange e o lábio, sendo digitado, inciso ou acanalado na fase Paredão. Na fase Guarita além da decoração plástica, alguns exemplares apresentam também engobo branco, sendo a decoração plástica com motivos acanalados (anexo 17).

Tipo 4 - Vasos com Bordas Irregulares e Diâmetro Oval.

Ocorre apenas na fase Paredão. O tipo é caracterizado pela ocorrência de bodas apresentando bicos e diâmetro oval. Construído com paredes roletadas. As paredes e a base são sempre muito finas (cerca de 5mm). É difícil encontrar exemplares passíveis de reconstituição. O antiplástico predominante é o cauixí acompanhado de carvão e mineral. A queima que mais ocorre é a incompleta com núcleo escuro. As peças apresentam contorno simples, podendo ter boca restritiva ou irrestritiva, borda com inclinação direta e lábio afilado com acabamento plano, inciso nos bicos ou arredondado. O tratamento da superfície é o alisamento. A decoração mais comum é o aplique de esferas na face externa e/ou incisões em linhas finas nos bicos formados pela borda (anexo 18).

Tipo 5 - Alguidar

É um tipo difícil diagnosticar, pois, geralmente não apresenta decoração. A identificação de sítios unicomponenciais associados à fase Paredão nos permite associar com segurança a ocorrência de Alguidar nessa fase, porém as limitações da amostra não nos permitem afirmar se ele ocorre ou não nas outras fases. Construído com a base plana, modelada sobre folhas e paredes roletadas. As paredes são sempre espessas (acima de $10 \mathrm{~mm}$ ), às vezes mais espessas que a base. São peças grandes com diâmetro quase sempre maior que $400 \mathrm{~mm}$, chegando a até $620 \mathrm{~mm}$. Predomina a coloração do 
tipo "laranja A". O antiplástico principal é o cauixí, às vezes acompanhado de mineral, muito raramente apresenta carvão e caco moído. A queima é variada ocorrendo todos os tipos avaliados. Os exemplares sempre apresentam contorno simples e forma irrestritiva. O tratamento da superfície é o alisamento, exceto a parte inferior da base que permanece com as mascas das folhas que as apoiavam. Os tipos de lábios mais comuns são os afilados e planos, com acabamento arredondado ou plano. Os alguidares não recebem decoração. Alguns exemplares apresentam fuligem (anexo 19).

Tipo 6 - Assador

Ocorre seguramente nas fases Paredão e Guarita, pelos mesmos motivos descritos no tipo Alguidar não podemos saber se ele ocorre ou não nas outras fases.Construído com a base plana, modelada sobre folhas, às vezes sem paredes ou com paredes muito baixas, apenas um ou dois roletes. São peças grandes com diâmetro entre 240 e 600, predomina a coloração do tipo "laranja A". O antiplástico predominante é o cauixí, às vezes acompanhado de mineral, muito raramente apresenta carvão e caco moído. A queima é variada ocorrendo todos os tipos avaliados. Os exemplares sempre apresentam contorno simples e forma irrestritiva. O tratamento da superfície é o alisamento, exceto a parte inferior da base que permanece com as mascas das folhas que as apoiavam. Os tipos de lábios mais comuns são os afilados e planos, com acabamento arredondado ou plano. Os exemplares analisados em nossa coleção não são decorados, mas é comum a ocorrência de decoração acanalada na borda de exemplares pertencentes à fase Guarita. Alguns exemplares apresentam fuligem (anexo 20).

Tipo 7 - Cuia

Exemplar típico da fase Paredão, mas pode ocorrer também nas fases Manacapuru e Guarita. Descreveremos aqui apenas as características das cuias Paredão, pois nossa amostragem desses exemplares nas outras fases é muito pequena. Construído com base modelada, geralmente plana ou côncava e paredes com roletes. São peças com diâmetro da borda entre 150 e 440mm, predomina a coloração do tipo "laranja A". O antiplástico mais encontrado é o cauixí acompanhado de carvão e mineral, às vezes acompanha também caco moído. A queima que mais aparece é a incompleta com núcleo 
escuro. A categoria tem necessariamente o contorno simples, com forma do vaso irrestritiva e a inclinação da borda direta. O tipo de lábio mais comum é o afilado com acabamento plano. Foram identificados também exemplares com acabamento inciso no lábio. O tratamento da superfície é o alisamento. São poucos os exemplares decorados, mas a decoração, quando observada, pode ser tanto interna quanto externa, sempre decoração plástica, sendo incisões finas no lábio ou o aplique de plugs modelados na face externa, talvez esse último tenha funções práticas e não somente estéticas. Principalmente os exemplares maiores apresentaram marcas de fuligem (anexo 21).

Tipo 8 - Prato

Ocorrem nas fases Manacapuru, Paredão e Guarita. Definimos como pratos todos os exemplares com diâmetro pelo menos três vezes maior que a altura. Construídos com base modelada, plana ou mais raramente convexa. As paredes são erguidas com roletes. A espessura varia entre 5 e $10 \mathrm{~mm}$ no caso da fase Paredão; entre 8 e $17 \mathrm{~mm}$ no caso das fases Manacapuru e Guarita. O Diâmetro da borda varia entre 340 e 420mm na fase Manacapuru; 140 e 320mm na fase Paredão; 70 a 340mm na fase Guarita. Predomina a coloração do tipo "laranja A". Na fase Paredão o antiplástico predominante é o cauixí acompanhado de mineral, às vezes acompanha também carvão, caco moído e cariapé. Na fase Guarita predomina o cariapé com mineral, às vezes cauixí e caco moído. Temos uma amostra muito pequena de material Manacapuru, mas o que temos tem antiplástico de cauixí com mineral. A queima predominante é a incompleta com núcleo escuro na fase Paredão; queima completa, totalmente oxidada nas fases Manacapuru e Guarita. O contorno das peças é simples com boca irrestritiva. A inclinação da borda é extrovertida na fase Manacapuru; predominantemente direta e raramente extrovertida na fase Paredão; direta ou extrovertida na fase Guarita. A forma do lábio é bastante variável nas diferentes fases, sendo expandidos, com acabamento inciso na fase Manacapuru. Na fase Paredão ocorre lábios afilados, arredondados, muito raramente expandidos, com acabamento preferencial inciso, seguido por arredondado, plano e cortado (muito raro). Na fase Guarita predomina os lábios reforçados externamente, expandidos, em menor escala os planos, com acabamento preferencial pintado ou em menor escala arredondados e planos. O tratamento da superfície é o alisamento. Na fase Manacapuru os pratos são decorados com incisões duplas paralelas na borda. Grande parte dos exemplares da fase Paredão recebe decoração plástica na 
face interna, incisões em linhas finas ocupando a borda e lábio. Os exemplares da fase Guarita são quase sempre decorados em ambas as faces. $\mathrm{O}$ mais comum é o engobo interno em toda a superfície e na parte externa somente no lábio. Predomina o engobo branco ou a associação entre branco vermelho ou vinho. Sobrepondo o engobo aparece motivos pintados, combinando linhas finas e faixas grossas; nas cores vermelho, marrom e vinho. A decoração plástica é rara, porém pode ocorrer (anexo 22).

Tipo 9 - Tigelas

Ocorre nas fases Manacapuru, Paredão e Guarita. Apresentaremos apenas as características dos exemplares da fase Paredão em função da falta de representatividade da coleção para as outras fases.

Definimos como tigelas todos os exemplares mais profundos que os pratos, ou seja, a altura nunca pode ser menor que um terço do diâmetro da boca. As paredes são erguidas com roletes. A espessura varia entre 5 e $7 \mathrm{~mm}$. O Diâmetro da borda varia entre 120 e 380mm. Predomina a coloração do tipo "laranja A". O antiplástico predominante é o cauixí acompanhado de carvão e mineral, pode ocorrer também sem o carvão. A queima predominante é a incompleta com núcleo escuro. O contorno das peças é simples com boca irrestritiva. Predomina a inclinação da borda extrovertida, ocorre também inclinação direta. A forma do lábio é principalmente o afilado, com frequiência também de lábios planos. É grande o número de lábios com acabamento decorado através de incisões em linhas finas. Nos exemplares sem decoração o acabamento de lábio mais comum é o plano. O tratamento da superfície é o alisamento. Uma grande parte dos exemplares da categoria recebe decoração plástica na face interna, quase sempre incisões em linhas finas ocupando a borda e lábio (anexo 23).

Tipo 10 - Potes com Gargalo

Ocorre nas fases Paredão e Guarita. Os exemplares são caracterizados por uma diferença acentuada entre o diâmetro do corpo e uma restrição formando um pescoço com diâmetro muito menor. Construídos com base modelada ou roletada, plana, côncava ou convexa e paredes erguidas com roletes. A espessura varia entre 4 e $9 \mathrm{~mm}$ no caso da fase Paredão; entre 12 e $23 \mathrm{~mm}$ no caso da fase Guarita. O Diâmetro da borda varia entre 90 e 240mm. Predomina a coloração do tipo "laranja A". Na fase Paredão o 
antiplástico predominante é o cauixí acompanhado de mineral, às vezes acompanha também carvão e/ou caco moído. Na fase Guarita o caco moído com mineral e/ou cauixí A queima predominante é a incompleta com núcleo escuro na fase Paredão e queima completa, totalmente oxidada na fase Guarita. O contorno das peças é composto pelo corpo e gargalo bem delimitados. A forma é restritiva com inclinação da borda extrovertida, lábios afilados, planos ou arredondados; com acabamento arredondado ou plano na fase Paredão; lábio expandido e acabamento arredondado na fase Guarita. O tratamento da superfície é o alisamento. Na fase Paredão é muito comum a presença de engobo vermelho na face interna e externa, decoração plástica com apliques modelado, podendo ser esferas aplicadas, zoomorfos, antropomorfos (as cabecinhas Paredão), ambos muito estilizados. A decoração plástica geralmente é aplicada no gargalo e ombros de vasos utilizados como urnas funerárias, unicamente encontradas na fase Paredão (Hilbert 1968). Na fase Guarita praticamente todos os exemplares recebem decoração pintada e/ou plástica no gargalo. É comum o uso de engobo branco e pintura vermelha ou marrom, combinando linhas finas e faixas grossas ou motivos geométricos acanalados, com ou sem engobo e pintura posterior (anexo 24).

Tipo 11 - Vasos globulares

O tipo pode ser subdividido em quatro grupos. Globulares de boca muito restritiva, Globulares de boca muito restritiva com tendências a formação de pescoço, Globulares de boca restritiva e Globulares de boca restritiva com tendência a formação de pescoço.

Nas fases Manacapuru e Guarita só foram identificados exemplares de vasos Globulares de boca restritiva, os outros três subtipos só foram vistos na fase Paredão. As paredes são erguidas com roletes. A espessura varia entre 9 e 16mm na fase Manacapuru; 4 e $6 \mathrm{~mm}$ na fase Paredão; a fase Guarita não tem representatividade suficiente para ser descrita.. O Diâmetro da borda varia entre 200 e 400mm na fase Manacapuru; 70 e 420mm na fase Paredão. Predomina a coloração do tipo "laranja A". $\mathrm{Na}$ fase Manacapuru o antiplástico observado foi apenas cauixí associado a mineral. Na fase Paredão o antiplástico predominante é o cauixí acompanhado de mineral ou cauixí carvão e mineral e uma discreta associação destes com cariapé e caco moído. A queima predominante é a incompleta com núcleo escuro em ambas as fases. O contorno das peças é simples, sempre com boca restritiva, borda com inclinação direta no primeiro e 
terceiro subtipos e extrovertida no segundo e quarto. Na fase Manacapuru a forma do lábio é roletado externo, expandido ou plano. O acabamento do lábio é plano ou inciso. Na fase Paredão a forma do lábio é principalmente o arredondado, plano, afilado e em menor escala biselado. O acabamento do lábio é arredondado, plano ou inciso. $\mathrm{O}$ tratamento da superfície é o alisamento. Uma grande parte dos exemplares da categoria recebe decoração plástica na face interna, quase sempre incisões em linhas finas ocupando a borda e lábio. Nos exemplares decorados a decoração é preferencialmente aplicada na face externa, decoração plástica na fase Manacapuru, incisões, digitados ou acanalados. Na fase Paredão a decoração plástica também é mais comum, com rara ocorrência de engobo vermelho ou pintura em linhas finas. Geralmente são incisões em linhas finas, às vezes acompanhadas de ponteados e/ou esferas aplicadas (anexos 25a e b).

Tipo 12 - Vasos com Colo

Ocorrem nas fases Paredão e Guarita. O tipo tem alguma semelhança com o tipo com Gargalo, porém o ponto de restrição que forma o colo não é tão fechado quanto no tipo com gargalo.

As paredes são erguidas com roletes. A espessura varia entre 5 e $9 \mathrm{~mm}$ na fase Paredão; 7 e 14mm na fase Guarita. O Diâmetro da borda varia entre 160 e 480mm na fase Paredão; 120 e 340mm na fase Guarita. Predomina a coloração do tipo "laranja A" e ambos os casos. Na fase Paredão o antiplástico observado foi o cauixí associado a carvão e mineral. Na fase Guarita o antiplástico é o cauixí acompanhado de caco moído e mineral. A queima predominante é a incompleta com núcleo escuro na fase Paredão e queima completa oxidada na fase Guarita. O contorno das peças é simples, restritivo, borda com inclinação extrovertida. Na fase Paredão a forma do lábio é o afilado ou arredondado, com acabamento inciso, plano ou ponteado. Na fase Guarita a forma do lábio é roletado externo ou expandido, com acabamento plano. O tratamento da superfície é o alisamento. A decoração observada foi sempre plástica, principalmente incisões na parte interna da borda e lábios, ou esferas aplicadas com ponteados na fase Paredão. Na fase Guarita a decoração é sempre externa, ocupando o colo, sendo decoração plástica com motivos acanalados ou incisos (anexo 26). 
Tipo 13 - Trempe

Ocorre nas fases Paredão e Guarita. Trata-se de um suporte cilíndrico compacto, utilizado para apoiar vasilhas acima do fogo. Na maioria das vezes é construído com "argila de má qualidade", o que da às peças um aspecto pouco elaborado, às vezes muito semelhantes a torrões de terra queimada. Provavelmente não recebe tratamento de queima prévio ao uso, a oxidação vista na pasta deve ser decorrente do uso na fogueira, como é um suporte compacto espesso, os vestígios encontrados têm os núcleos geralmente dissolvidos, pois a argila do interior permanece crua. Nos sítios analisados em nosso trabalho só encontramos trempes associadas à fase Paredão. Nos sítios Antônio Galo e Pilão a maioria dos fragmentos de trempe apresenta ossos de fauna adicionados à pasta de argila (anexo 27).

\section{V.IV - O MATERIAL DO SÍTIO ANTÔNIO GALO}

\section{V.IV.I - A CERÂMICA}

Como decidimos trabalhar com vários sítios arqueológicos e a densidade de material nos sítios da região é grande, tivemos que analisar detalhadamente apenas uma amostra do material de cada sítio escolhido. No sítio Antônio Galo a opção foi pela unidade N-938 E-456 que possui amostra mais representativa e escavação até o nível estéril.

Como já foi apontado no trabalho de Machado (2005) A divisão em fases e tradições, realizada nas décadas de 60 e 70, foram definidas basicamente a partir de um único atributo, o antiplástico (Hilbert 1968; Meggers and Evans 1970; Simões 1972).

No decorrer desse trabalho, através dos dados de análise expostos, tentaremos apresentar uma hipótese alternativa, sugerindo que os diferentes tipos de antiplástico utilizados na construção de peças cerâmicas estão principalmente ligados à disponibilidade sazonal de coleta dos materiais e talvez a diversidade seja o resultado da fabricação de vasos em diferentes épocas do ano. Sendo assim, nossa análise foi realizada observando uma série de atributos descritos na tabela 03 (item V.I), para tentar definir critérios mais seguros para classificação da cerâmica. 
Na unidade N-938 E-456 foram coletados 1697 fragmentos de cerâmica e 33 fragmentos de trempe. A cerâmica foi triada e o material separado para análise detalhada foi apenas um total de 229 peças, sendo 118 bordas, 71 bases e 40 fragmentos com algum tipo de decoração. As bordas tem espessura variando entre 3 e $15 \mathrm{~mm}$, a grande maioria mede entre 4 e $7 \mathrm{~mm}$ (gráfico 27).

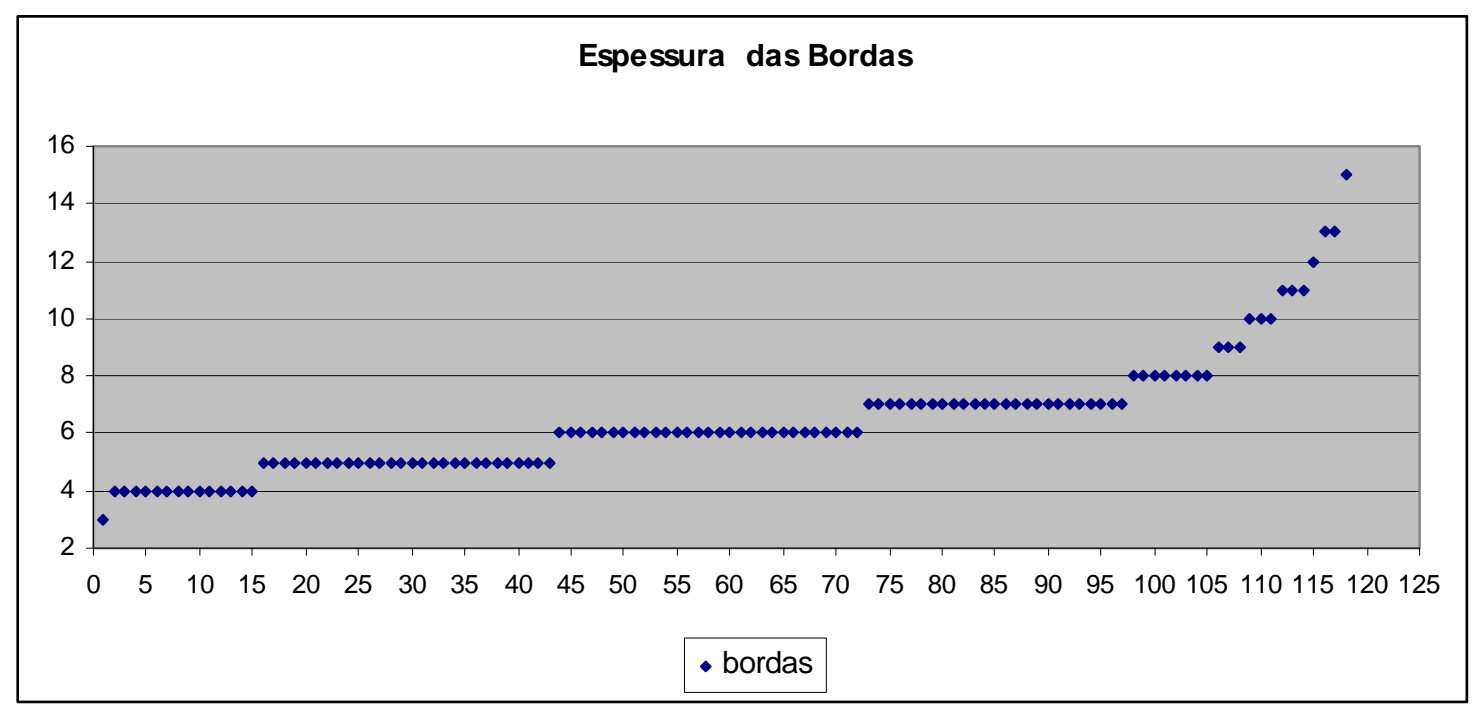

Gráfico 27 - Espessura das bordas em ordem crescente, medidas em milímetros(espessura na vertical e quantidade na horizontal).

As bases analisadas possuem espessura variando entre 5 e $18 \mathrm{~mm}$, com a maioria medindo entre 8 e $13 \mathrm{~mm}$ (gráfico 28).

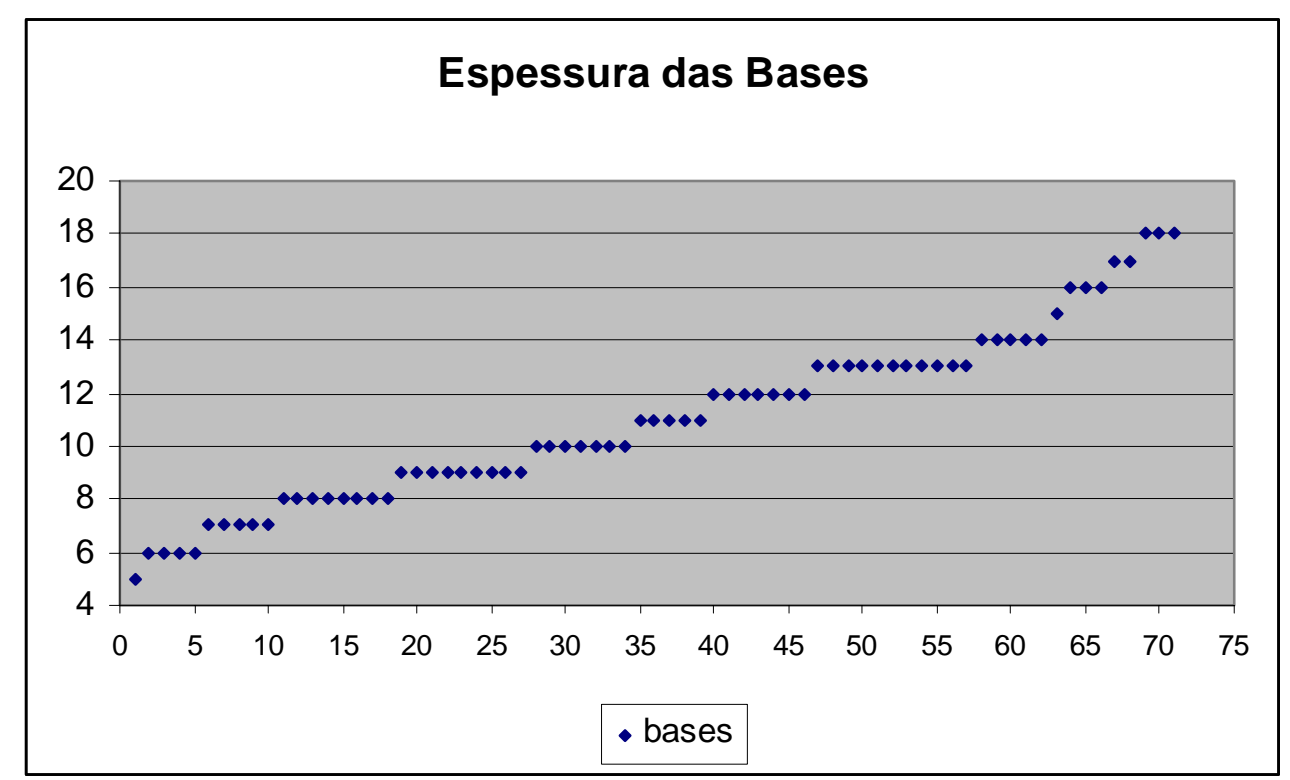

Gráfico 28 - Espessura das bases em ordem crescente, medidas em milímetros (espessura na vertical e quantidade na horizontal).

As paredes apresentam espessura variando entre 4 e $10 \mathrm{~mm}$, com a maioria entre 5 e $7 \mathrm{~mm}$ (gráfico 29). 


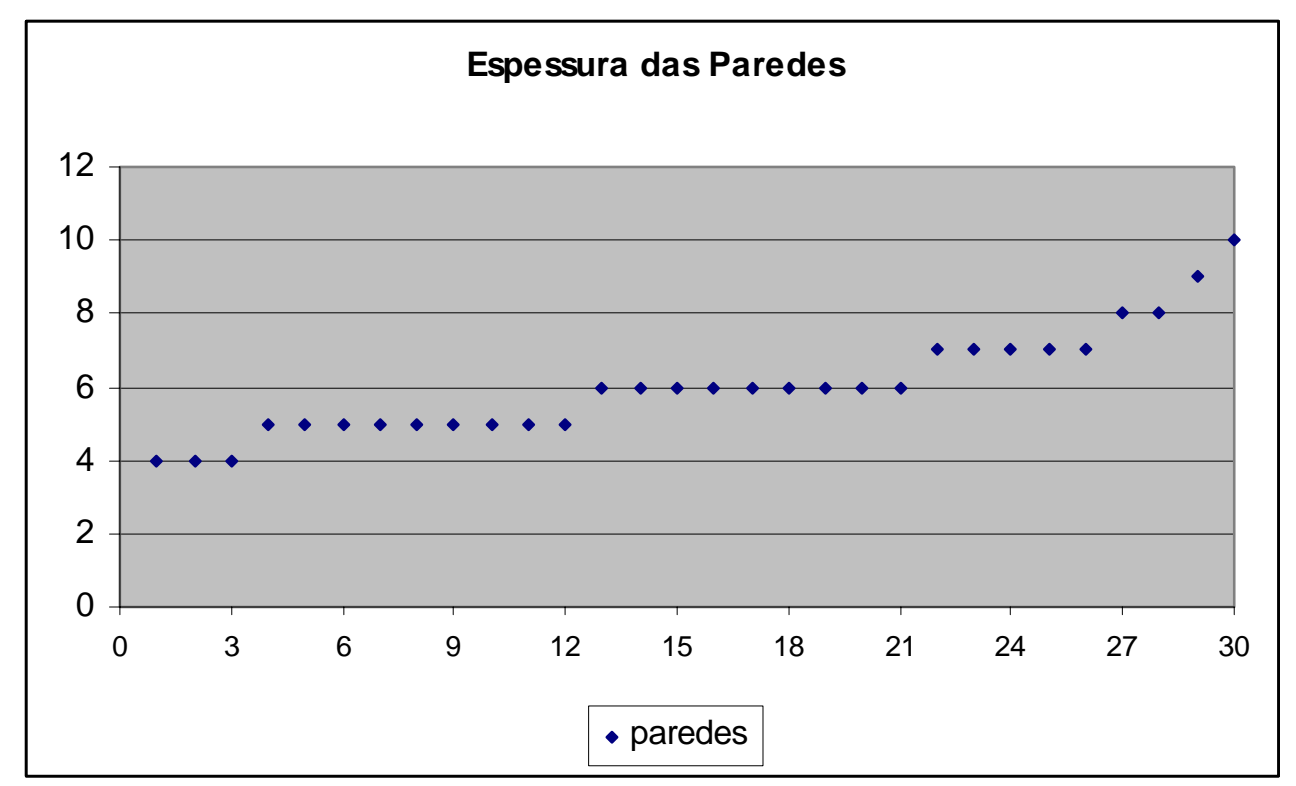

Gráfico 29 - Espessura das paredes em ordem crescente, medidas em milímetros (espessura na vertical e quantidade na horizontal).

Se compararmos os três gráficos acima, veremos que a tendência do material analisado é de exemplares com borda e paredes relativamente finas e bases um pouco mais espessas, mas ainda finas se confrontar com outros conjuntos cerâmicos.

A coloração da superfície dos fragmentos evidenciada foi principalmente o "laranja A" (146 face interna e 158 face externa), seguida por cinza ou preto (face interna 59 e face externa 48) e"laranja B" (24 face interna e 17 face externa) (figura 122).

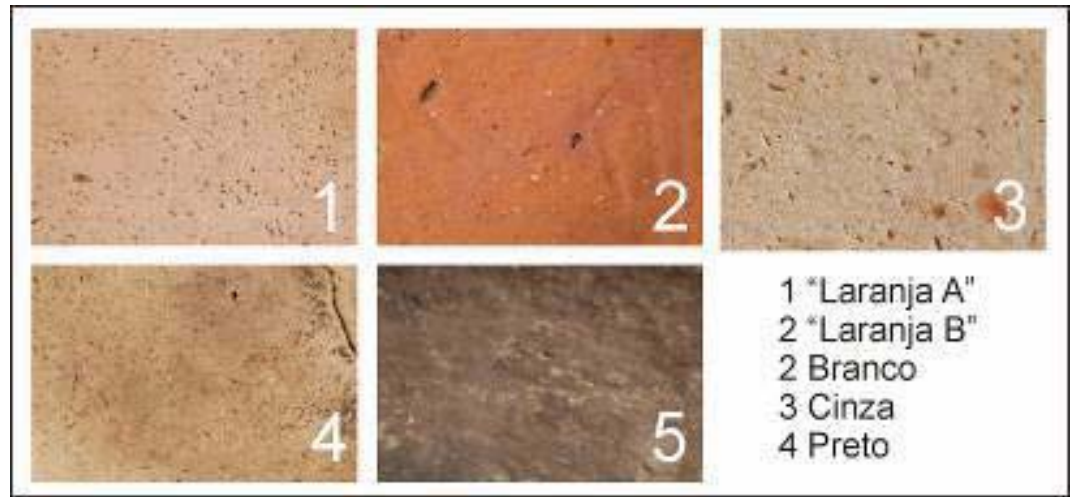

Figura 122 - Exemplos de fragmentos de cerâmica classificados por cores da superfície da pasta.

Os antiplásticos encontrados na pasta de argila são muito variados, o cauixí está presente em quase cem por cento dos fragmentos (227). É grande a quantidade de fragmentos contendo mineral (195), porém o mineral parece ser um componente da argila. Uma particularidade é a grande quantidade de fragmentos contendo carvão adicionado à pasta (118). Uma quantidade menor de fragmentos apresenta caco moído adicionado à pasta (56). O cariapé ocorre muito discretamente no material analisado. 
Existe muita variação na quantidade de antiplásticos contido na pasta a tabela 04 sintetiza esses dados.

\begin{tabular}{|c|c|c|c|c|c|c|}
\hline Tipos de antiplástico * & quant. & cauixí & mineral & carvão & $\begin{array}{l}\text { caco } \\
\text { moído }\end{array}$ & cariapé \\
\hline cariapé & 1 & & & & & 1 \\
\hline carvão + mineral & 1 & & 1 & 1 & & \\
\hline cauixí+cariapé+mineral & 1 & 1 & 1 & & & 1 \\
\hline mineral+caco moído+cauixí & 1 & 1 & 1 & & 1 & \\
\hline cauixí+mineral+carvão & 1 & 1 & 1 & 1 & & \\
\hline cauixí+carvão+mineral+cariapé & 1 & 1 & 1 & & & 1 \\
\hline carvão+cauixí & 2 & 2 & & 2 & & \\
\hline $\begin{array}{l}\text { cauixí+carvão+cariapé+caco } \\
\text { moído }\end{array}$ & 2 & 2 & & 2 & 2 & 2 \\
\hline $\begin{array}{l}\text { cauixí+caco } \\
\text { moído+carvão+mineral }\end{array}$ & 2 & 2 & 2 & 2 & 2 & \\
\hline cauixí+caco moído & 3 & 3 & & & $\frac{c}{3}$ & \\
\hline cariapé+cauixí & 1 & 1 & & & & 1 \\
\hline cauixí+carvão+caco moído & 3 & 3 & & 3 & 3 & \\
\hline carvão+mineral+cauixí & 3 & 3 & 3 & 3 & & \\
\hline cauixí+carvão & 5 & 5 & & 5 & & \\
\hline $\begin{array}{l}\text { cauixí+carvão+mineral+caco } \\
\text { moído }\end{array}$ & 7 & 7 & 7 & 7 & 7 & \\
\hline cauixí & 17 & 17 & & & & \\
\hline cauixí+caco moído+mineral & 16 & 16 & 16 & & 16 & \\
\hline $\begin{array}{l}\text { cauixí+carvão+caco } \\
\text { moído+mineral }\end{array}$ & 15 & 15 & 15 & 15 & 15 & \\
\hline cauixí+mineral+caco moído & 6 & 6 & 6 & & 6 & \\
\hline $\begin{array}{l}\text { cauixí+mineral+carvão+caco } \\
\text { moído }\end{array}$ & 1 & 1 & 1 & 1 & 1 & \\
\hline cauixí+mineral & 64 & 64 & 64 & & & \\
\hline cauixí+carvão+mineral & 76 & 76 & 76 & 76 & & \\
\hline Total & 229 & 227 & 195 & 118 & 56 & 6 \\
\hline
\end{tabular}

Tabela 04 - Tipos de antiplástico encontrados na pasta de argila. *o antiplástico que aparece em primeiro é predominante na sequiência

No material analisado todas as paredes foram construídas através da técnica de roletes, enquanto as bases são produzidas por modelagem. Cem por cento do material receberam alisamento como tratamento da superfície. As bases são principalmente planas (50 com marcas de folha e 18 alisadas), seguidas por uma quantidade discreta de bases com pedestal (3) e bases côncavas (2).

Nas peças onde esse critério pode ser observado, há uma predominância de vasos com contorno simples (58) e uma discreta aparição de exemplares com contorno composto (3) (figura 123). 

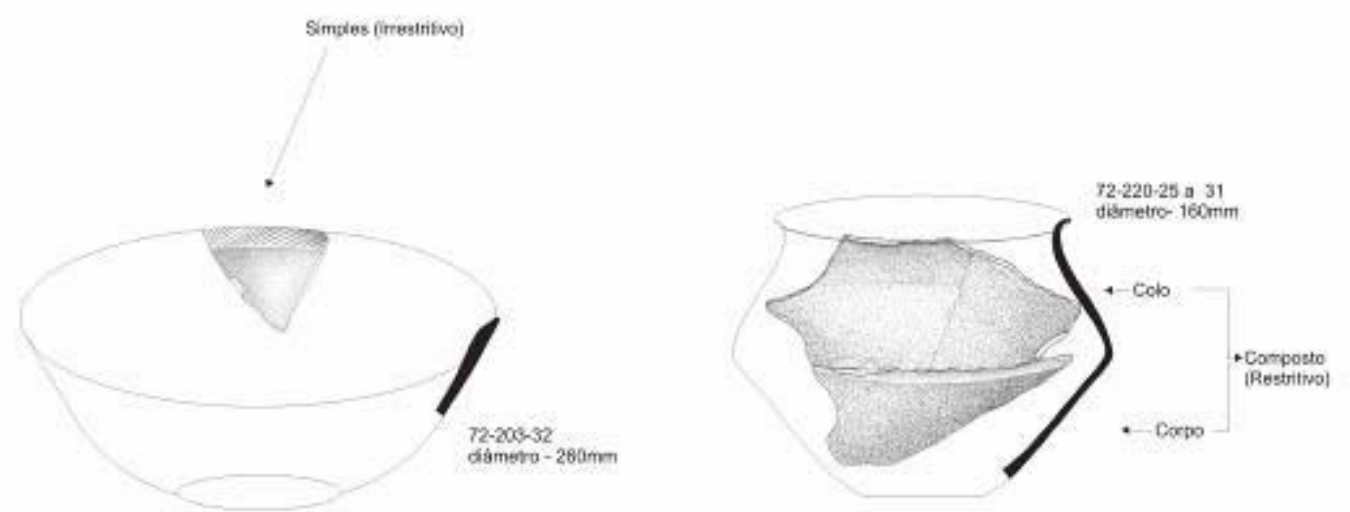

$0.23-4 \mathrm{~cm}$

Figura 123 - Exemplares de vasos com contorno simples e composto; forma irrestritiva e restritiva.

Já a forma dos vasos está principalmente representada pelos exemplares irrestritivos, (50) com diâmetro da boca maior que o diâmetro do corpo, e uma menor quantidade de vasos restritivos (9), com o diâmetro da boca menor que o diâmetro do corpo (figura 123).

O gráfico 30 representa os diâmetros de borda registrados no material analisado. A maioria dos vasos da coleção possuía diâmetro entre 150 e $350 \mathrm{~mm}$.

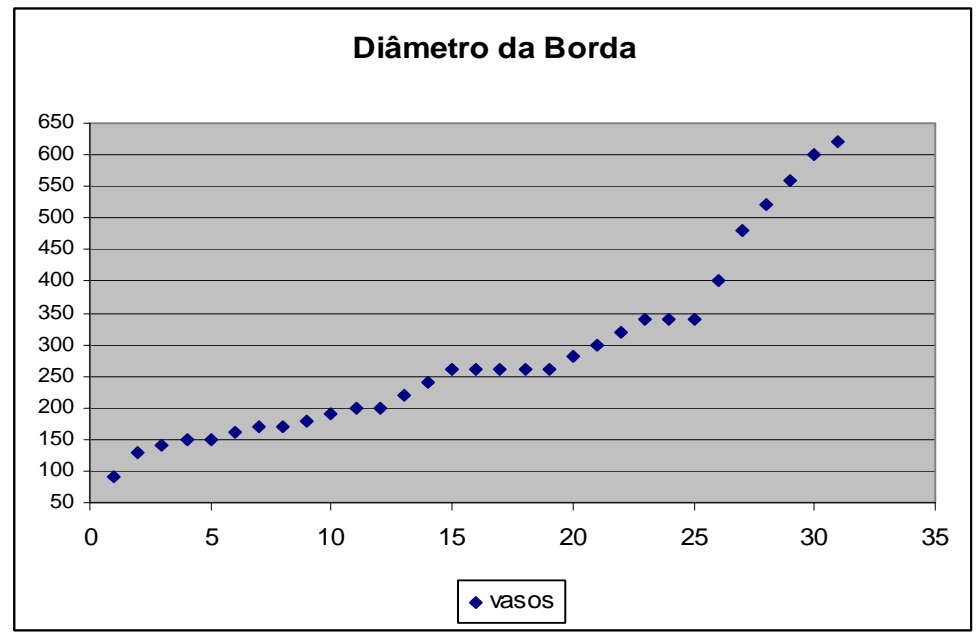

Gráfico 30 - Diâmetro das bordas em ordem crescente, representado em milímetros (diâmetro na vertical e quantidade na horizontal).

Já o diâmetro da base, com exceção dos assadores e alguidares, são sempre muito pequenos dificilmente ultrapassando $100 \mathrm{~mm}$ de diâmetro (gráfico 31). 


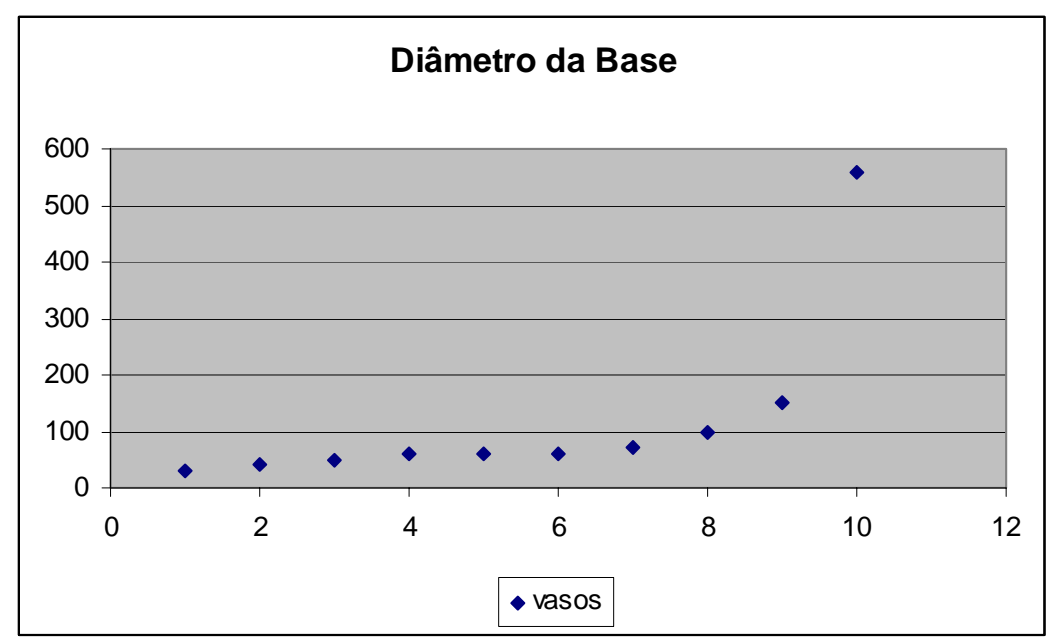

Gráfico 31 - Diâmetro das bases em ordem crescente, representado em milímetros (diâmetro na vertical e quantidade na horizontal).

A inclinação das bordas dos vasos é preferencialmente direta (43), apresentando também uma pequena porção de exemplares com inclinação extrovertida (18) (anexos 15 a 26).

A forma do lábio tem variação maior, com uma predominância, da quase totalidade, de lábios afilados (99); e em menor proporção planos (9), arredondados (6), apontados (4), roletado externo (1) e acanalado (1).

O acabamento dos lábios também é variado, sendo predominantes os acabamentos arredondados (60), seguidos por planos (45), incisos (11), ponteados (1), inciso ponteado (1) e acanalado (1) (figura 124).

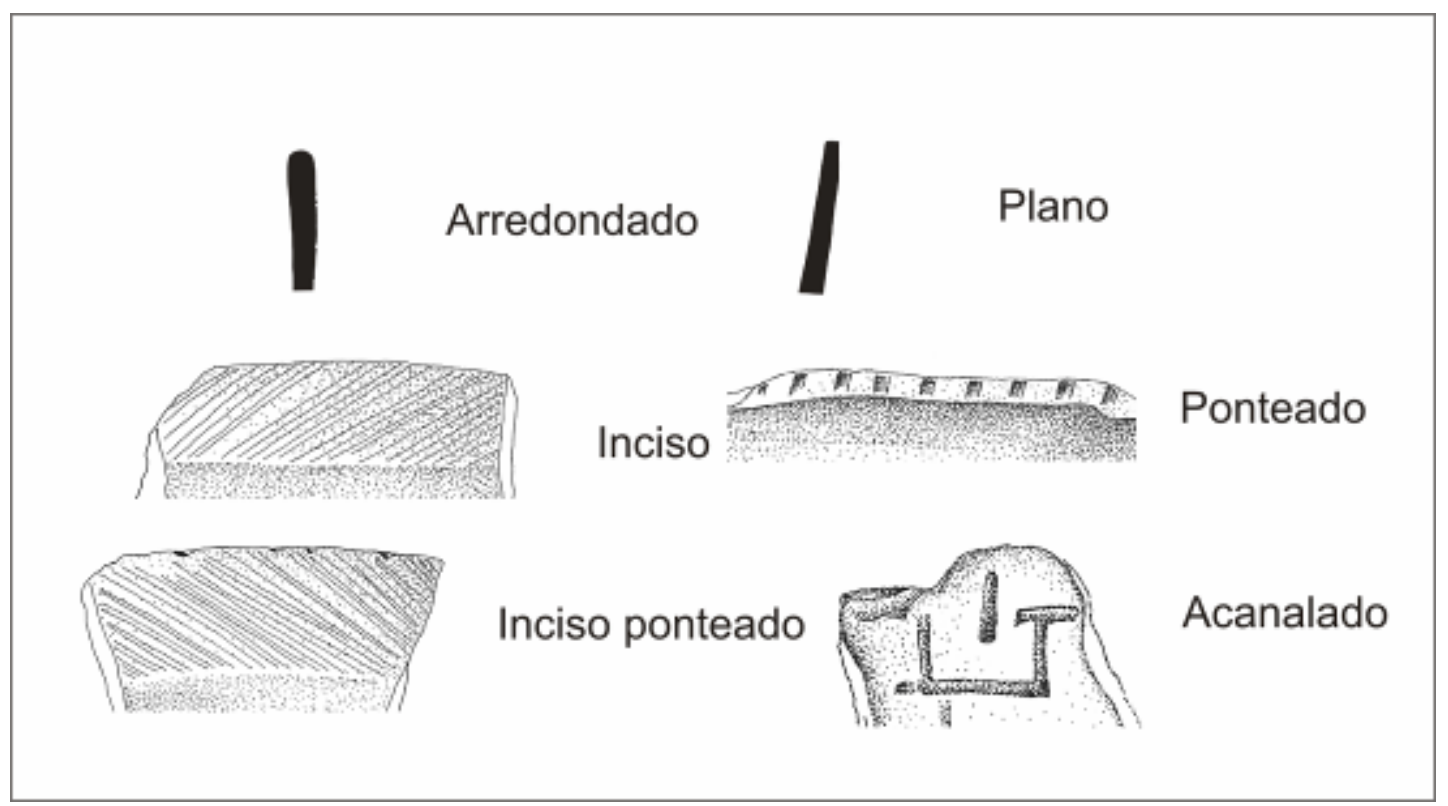

Figura 124 - Exemplares de lábios arredondados, planos, incisos, ponteados, inciso ponteado e acanalados. 
Do material analisado $74,7 \%$ não apresenta decoração, os outros 25,3\% apresentam decoração principalmente externa (29 peças), seguida por decoração interna (19 peças) e interna e externa (9 peças). A decoração consiste em engobo vermelho (32 peças) e decoração plástica (25 peças). Os tipos de decoração plástica são variados, destacam-se as incisões em linhas finas (11), apliques modelados (5), esferas aplicadas (5), ponteados (5).

Apenas 4 peças apresentaram marcas de uso, sendo marcas de fuligem (3) e fuligem e desgaste por atrito (1).

O sítio Antônio Galo apresenta material cerâmico da fase Paredão e Guarita, porém como foi apresentado anteriormente o material trabalhado é de uma parte unicomponencial da fase Paredão. A coleção analisada é pequena, mas as peças reconstituídas podem ser classificadas dentro dos seguintes conjuntos:

Tipo 1 - 7 peças; tipo $2-15$ peças; tipo 5 - 4 peças; tipo $6-1$ peça; tipo $7-5$ peças; tipo 8 - 3 peças; tipo $9-3$ peças; tipo $10-2$ peças; tipo $11-4$ peças; tipo $12-3$ peças, tipo 13 - 33 peças (anexos 15 a 28).

\section{V.IV.II - O MATERIAL LÍTICO}

A representatividade do material lítico encontrado no sítio Antônio Galo é que insignificante, são encontradas ocorrências muito discretas de refugos de lascamento (lascas e fragmentos de lascas), a matéria prima é o arenito, que ocorrem em afloramentos, principalmente às margens do rio Negro. Além das lascas foi encontrada também uma conta de colar esculpida em laterita (figura 125).

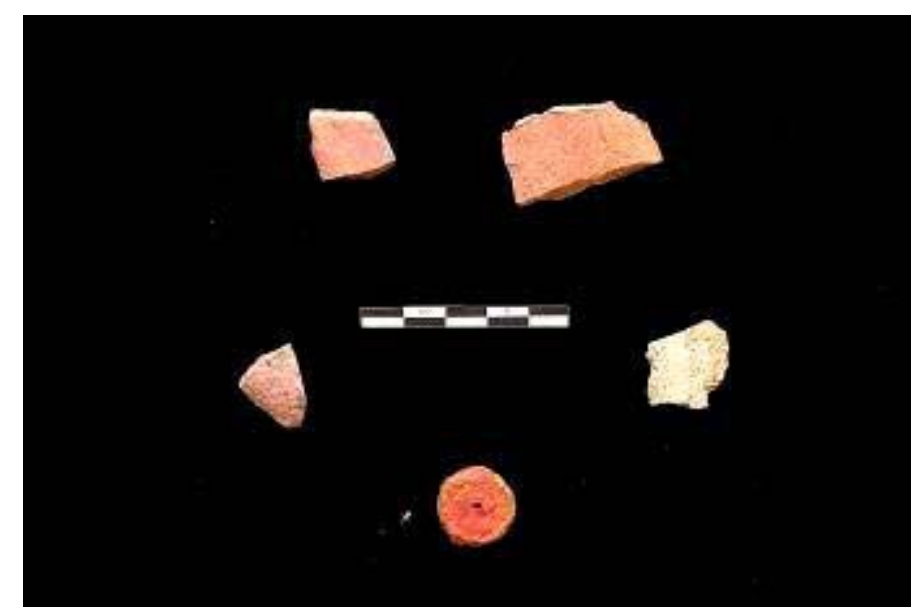

Figura 125 - Material lítico encontrado no sítio Antônio Galo (conta de colar, lasca fragmentada e fragmentos de lasca). 


\section{$\underline{\text { V.V - O MATERIAL DO SÍTIO LAGO DO LIMÃO }}$}

\section{V.V.I - A CERÂMICA}

No sítio Lago do Limão foram escolhidas duas unidades para análise detalhada. A opção foi pelas unidades N-1976 E-500 e N-1937 E-550. A primeira dá uma boa amostragem da escavação ampla realizada na área onde encontramos os vestígios da unidade habitacional e o sepultamento. A outra unidade, escavada no possível montículo artificial, apresentou densidade muito elevada e, portanto, uma boa coleção para análise. Ambas apresentam material pertencente às fases Manacapuru, Paredão e Guarita. A dificuldade nesse caso foi classificar o material dentro das diferentes fases, pois apenas uma pequena parte do material apresenta características distintivas.

No total foram coletados 14.309 fragmentos de cerâmica e 12 fragmentos de trempe. A densidade de material é muito maior em N-1937 E-550 (11.425 fragmentos de cerâmica). Na unidade N-1976 E-500 foram coletados 2.884 fragmentos de cerâmica e 9 fragmentos de trempe. A cerâmica foi triada e o material separado para análise detalhada foi um total de 1.676 (1.138 da primeira unidade e 538 da segunda), sendo 779 bordas, 275 bases e 622 fragmentos com algum tipo de decoração. Na unidade N1937 E-550 o material identificado é principalmente pertencente à fase Paredão (147 peças), seguido por Guarita (119 peças) e uma pequena quantidade de material Manacapuru (87 peças). Já na unidade N-1976 E-500 a grande maioria do material identificado é pertencente à fase Manacapuru (137 peças), seguida por Guarita (78 peças) e a quase ausência de material Paredão (3 peças).

As bordas tem espessura variando entre 3 e $32 \mathrm{~mm}$, a grande maioria mede entre 5 e $12 \mathrm{~mm}$ (gráfico 32). 


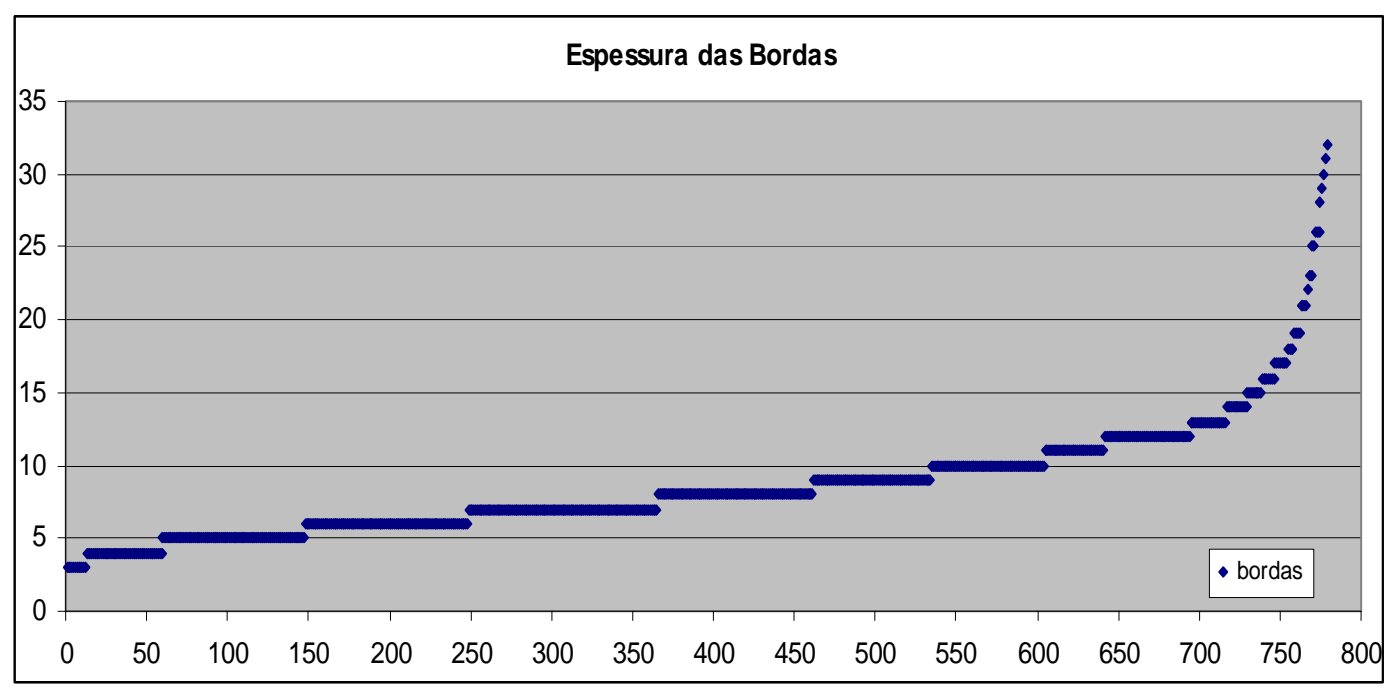

Gráfico 32: Espessura das bordas em ordem crescente, medidas em milímetros (espessura na vertical e quantidade na horizontal).

Conforme pode ser visto no gráfico 33 as bordas da fase Paredão tem tendência a serem menos espessas, enquanto as das fases Manacapuru e Guarita apresentam maior quantidade de bordas mais espessas.

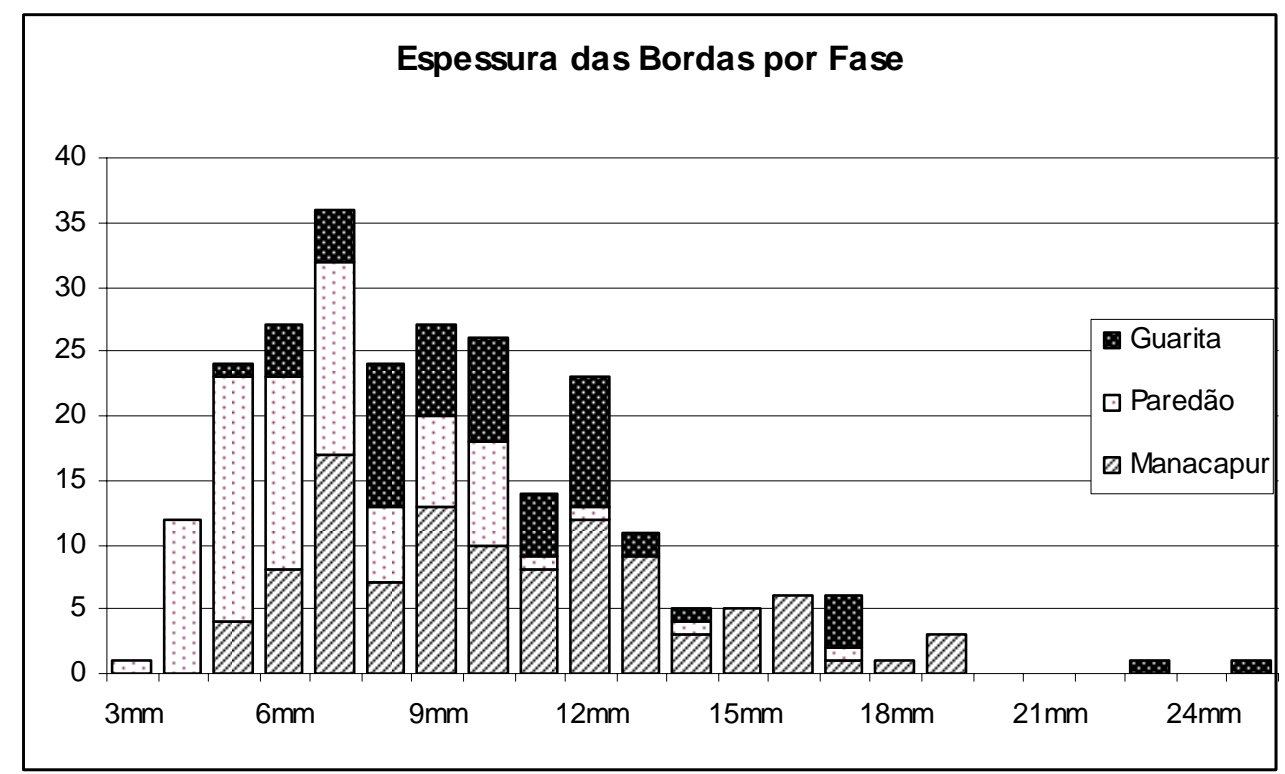

Gráfico 33 - Espessura das bordas apresentadas por fases (aqui não são apresentadas as bordas não classificadas).

As bases analisadas possuem espessura variando entre 4 e $26 \mathrm{~mm}$, com a maioria medindo entre 8 e $15 \mathrm{~mm}$ (gráfico 34). 


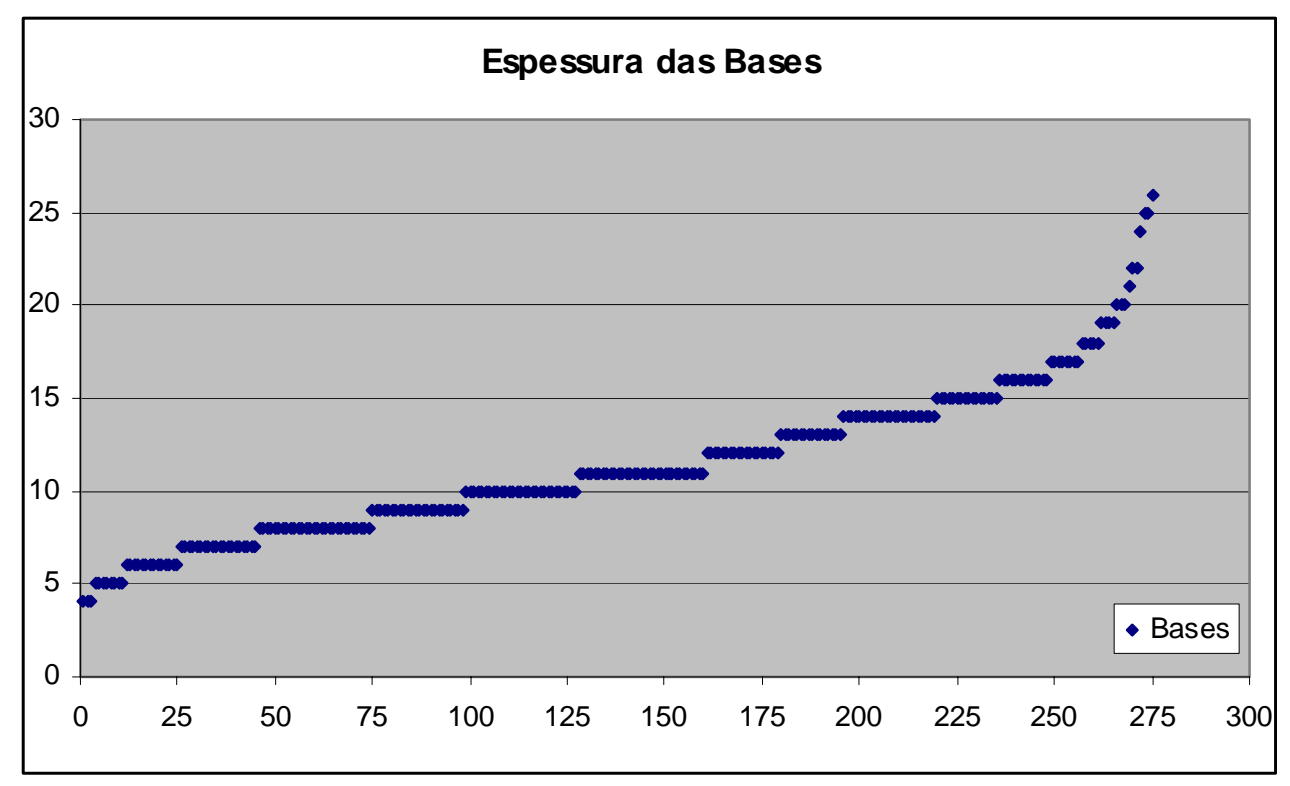

Gráfico 34 - Espessura das bases em ordem crescente, medidas em milímetros (espessura na vertical e quantidade na horizontal).

As paredes apresentam espessura variando entre 4 e $10 \mathrm{~mm}$, com a maioria entre 5 e $7 \mathrm{~mm}$ (gráfico 35).

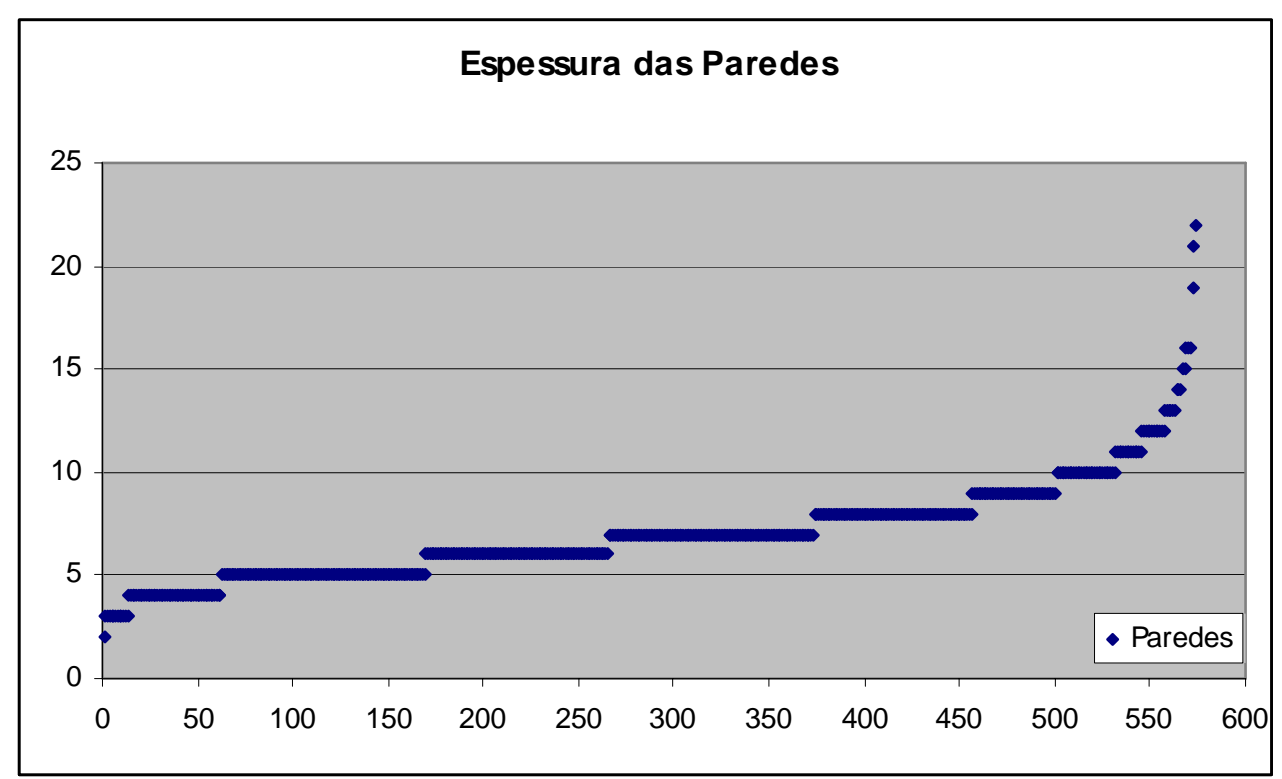

Gráfico 35 - Espessura das paredes em ordem crescente, medidas em milímetros (espessura na vertical e quantidade na horizontal).

As paredes e bases têm espessuras semelhantes nas três fases, com uma leve tendência a peças mais finas na fase Paredão.

A coloração da superfície dos fragmentos evidenciada foi principalmente o "laranja A" (1342 face interna e 1339 face externa), seguida por cinza ou preto (face interna 301 e face externa 304) e“laranja B” (21 face interna e 28 face externa). 
Os antiplásticos encontrados na pasta de argila são muito variados, é grande a quantidade de fragmentos contendo mineral (1629), porém o mineral parece ser um componente da argila. O cauixí está presente na grande maioria dos fragmentos (1548). O cariapé está presente em quantidade um pouco menor (346). Aparecem ainda fragmentos com caco moído adicionado à pasta (296). O antiplástico de carvão e argila é pouco representativo nesse material (26 e 4). Existe muita variação na quantidade de antiplásticos contido na pasta, a tabela 05 sintetiza os dados.

O cauixí está presente em quase todo o material, mas vale destacar que cem por cento do material Manacapuru têm a sua presença. O carvão ocorre apenas na fase Paredão. Caco moído predomina na fase Guarita, mas sua presença é vista também nas outras fases. O cariapé aparece mais na fase Guarita, mas pode ocorrer também na fase Paredão.

No material analisado todas as paredes foram construídas através da técnica de roletes, enquanto as bases são produzidas por modelagem. Cem por cento do material receberam alisamento como tratamento da superfície. 
z

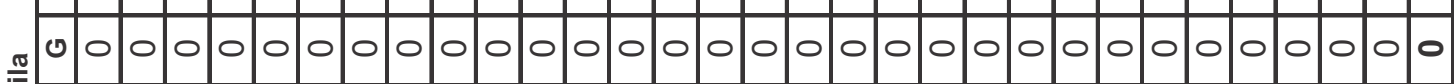

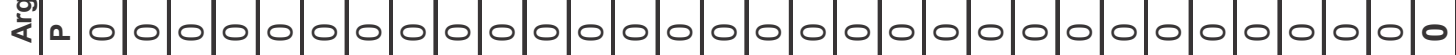

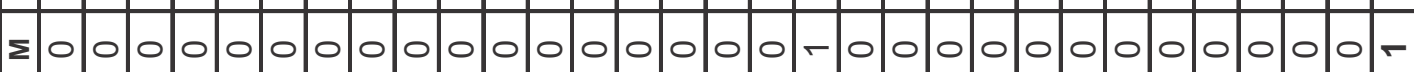
z 0 - -2 N 0 O

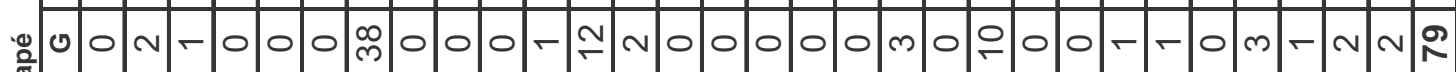
¿

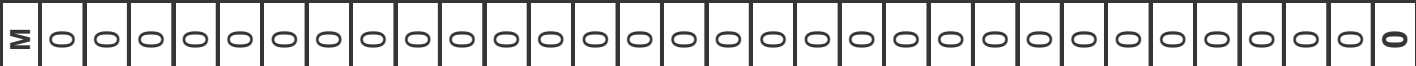

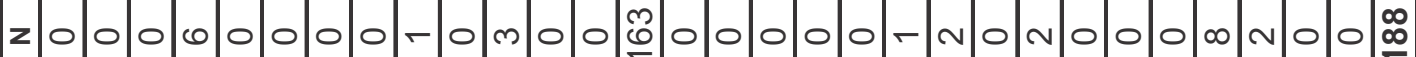

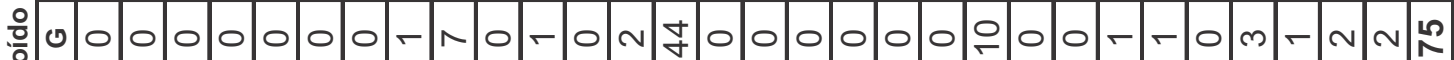

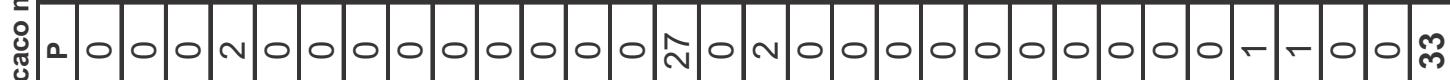

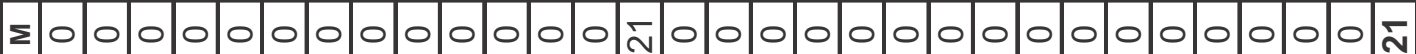

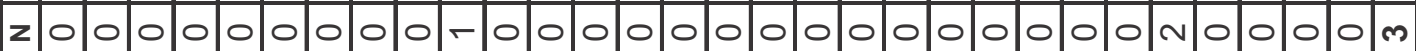

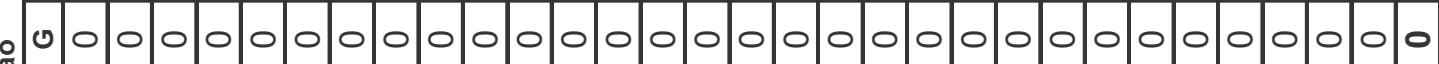

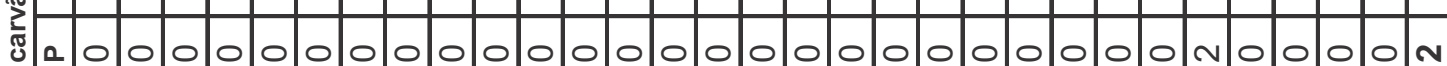

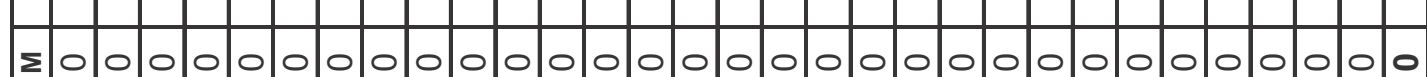

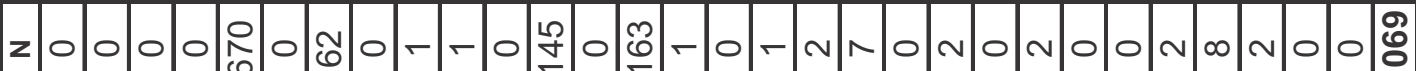

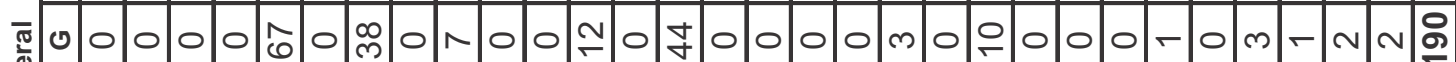
.

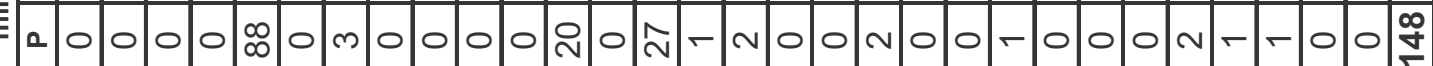

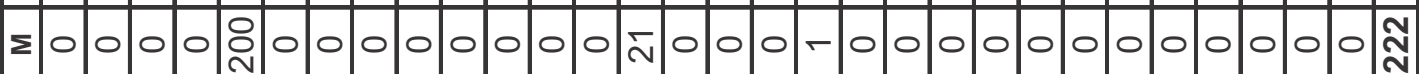

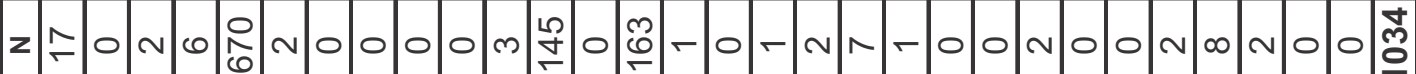

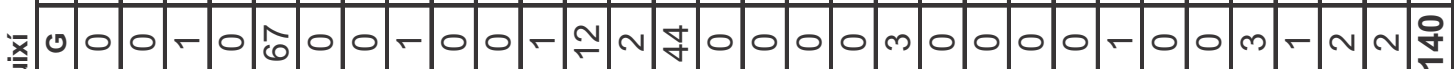

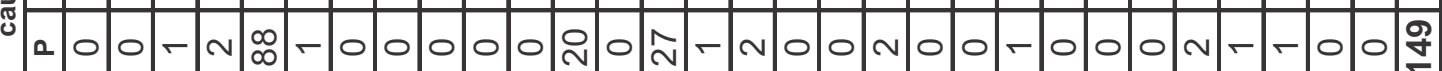

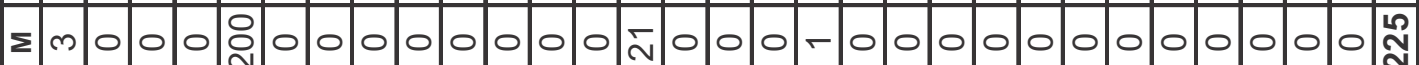

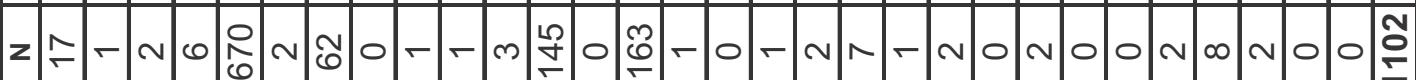

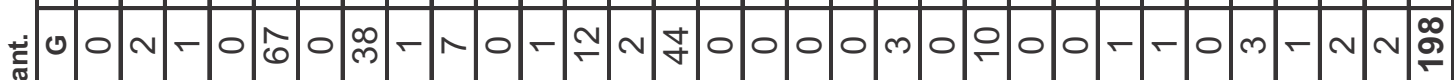

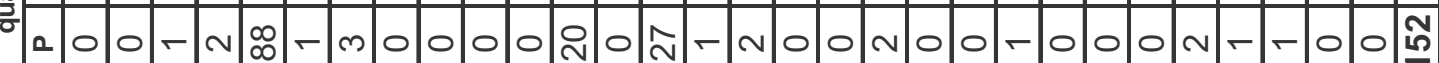

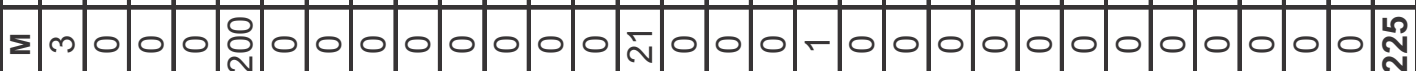


As bases são principalmente planas (136 alisadas e 103 com marcas de folha), seguidas por uma quantidade discreta de bases côncavas (19) e bases com pedestal (16).

Quanto ao contorno dos vasos, há uma predominância de vasos com contorno simples (123) e uma discreta aparição de exemplares com contorno composto (14).

Já a forma dos vasos está principalmente representada pelos vasos irrestritivos, (92) com diâmetro da boca maior que o diâmetro do corpo, e uma menor quantidade de vasos restritivos (39), com o diâmetro da boca menor que o diâmetro do corpo. O gráfico 36 representa os diâmetros de borda registrados no material analisado. A maioria dos vasos da coleção possuía diâmetro entre 100 e 300mm.

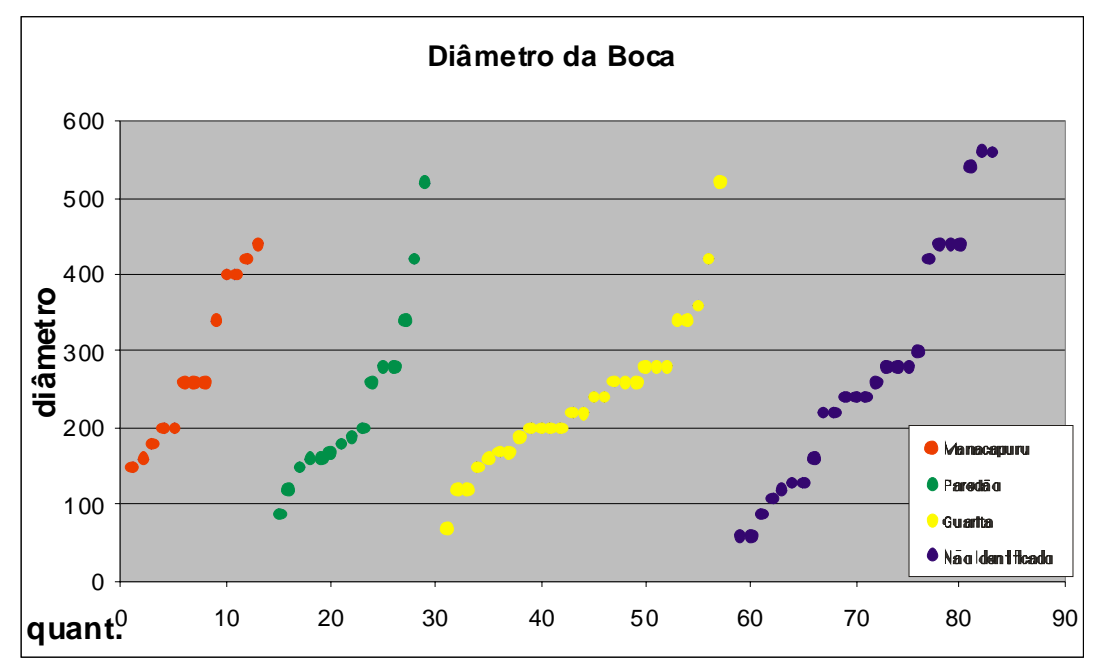

Gráfico 36 - Diâmetro das bordas em ordem crescente, representado em milímetros.

Já o diâmetro da base, com exceção dos assadores e alguidares, são na maioria menores que 100mm (gráfico 37).

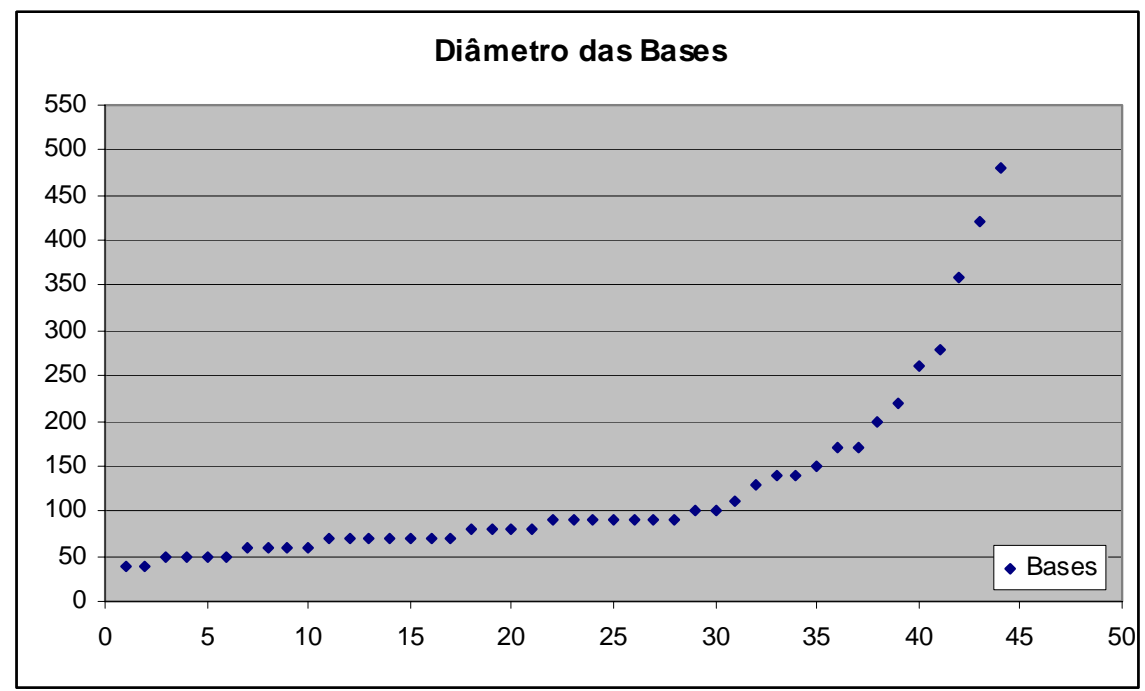

Gráfico 37 - Diâmetro das bases em ordem crescente, representado em milímetros (diâmetro na vertical e quantidade na horizontal). 
A inclinação das bordas dos vasos é preferencialmente direta (102 peças), sendo 42 de peças não identificadas, 34 de cerâmica Paredão, 15 de Guarita e 11 de Manacapuru. Aparece ainda uma porção de exemplares com inclinação extrovertida (35), ), sendo 19 de peças não identificadas, 10 de cerâmica Guarita, 3 de Paredão e 3 de Manacapuru.

A forma do lábio tem variação maior, com uma predominância de lábios afilados $(277)^{5}$. Esse tipo de lábio é muito recorrente na fase Paredão (50 peças), ocorrendo mais discretamente nas fases Manacapuru (12 peças) e Guarita (6 peças). Em seguida aparecem os lábios planos (184 peças). Nesse caso mais comuns na fase Manacapuru (37 peças), com presença menos significativa nas fases Paredão (15 peças) e Guarita (4 peças). Lábios expandidos também são recorrentes (169 peças). Esses são mais comuns nas fase Manacapuru (65 peças) e Guarita (36 peças), com representatividade mais discreta na fase Paredão (16 peças). Em seguida aparecem os lábios arredondados (120) peças, sendo Mananacapuru (7 peças), Paredão (7 peças) e Guarita (3 peças). Com menos representatividade, temos os lábios roletados externos (25 peças), principalmente associados à fase Guarita (12 peças), com pouca representatividade na fase Manacapuru (3 peças). Finalmente temos lábios apontados, acanalados e biselados, que juntos somam apenas 9 peças.

O acabamento dos lábios também é variado, sendo predominantes os acabamentos planos (359). Muito comum em todas as fases. Em seguida aparecem os lábios arredondados (284), também comuns em todas as fases. Na sequiência aparecem os lábios incisos (75), principalmente nas fases Manacapuru (32) e Paredão (18), raramente sendo observado na fase Guarita (1). O restante dos tipos de lábio tem pouca representatividade na coleção, são eles: cortados (13), ocorre principalmente na fase Manacapuru; ponteados (10), principalmente na fase Paredão; modelados (8) principalmente nas fases Manacapuru e Guarita; acanalados (6), principalmente na fase Guarita; digitados (6), também fase Guarita; pintados (5), exclusivamente Guarita; serrilhados, ungulados, inciso-cortado, cortado-acanalado, modelado-inciso, cortadoponteado, inciso-digitado, inciso-ponteado e ponteado-modelado somam 19 peças.

Do material analisado 52.6\% não apresentam decoração, os outros $47.4 \%$ apresentam decoração principalmente externa (662 peças), seguida por decoração interna (164 peças) e interna e externa (58 peças). A decoração consiste em engobo

\footnotetext{
5 A soma dos exemplares de cada fase extraída do valor total apresentará a quantidade de peças não identificadas presentes em cada categoria.
} 
vermelho (248 peças), branco (147 peças), vinho (34 peças), ocorrem ainda combinações dessas cores (10 peças). Algumas peças apresentam pintura (39) combinando motivos em linhas finas e faixas grossas, quase sempre associadas à fase Guarita. A decoração plástica também é muito freqüente, principalmente os motivos incisos (336), muito comuns nas fases Manacapuru e Paredão. Na seqüência temos os acanalados (68), principalmente associados à fase Guarita. O restante tem pouca representatividade sendo que: ponteados, apliques modelados, digitados, roletes aplicados, esferas aplicadas e algumas combinações de dois ou mais desses motivos apresentam uma soma de 76 peças

Apenas 15 peças apresentaram marcas de uso, sendo marcas de fuligem (10) e fuligem e desgaste por atrito (5).

No sítio Lago do Limão a coleção analisada é bem representativa de todas as fases. As peças reconstituídas podem ser classificadas dentro dos seguintes conjuntos:

Tipo 1 - 18 peças; tipo $2-8$ peças; tipo $3-7$ peças; tipo $5-4$ peças; tipo $6-5$ peças; tipo $7-6$ peças; tipo $8-22$ peças; tipo $9-3$ peças; tipo $10-4$ peças; tipo $11-14$ peças; tipo 12 - 5 peças; tipo 13 - 21 peças; e não classificado 1 peça (anexos 15 a 28).

\section{V.V.II - O MATERIAL LÍTICO}

No sítio Lago do Limão o material lítico também tem pouca representatividade. São encontrados principalmente suportes com faces apresentando polimento, provavelmente afiadores. A matéria prima é o arenito ou argilito, o segundo encontrado em afloramentos às margens do lago do Limão. Aparecem ainda calibradores, suportes com sulcos, geralmente peças de arenito mais friável. São encontrados também calibradores em fragmentos de cerâmica (anexo 28). Temos também fragmentos de lâmina de machado em basalto, contas de colar e alguns refugos de lascamento, lascas ou fragmentos de lascas (figuras 126 e 127). 


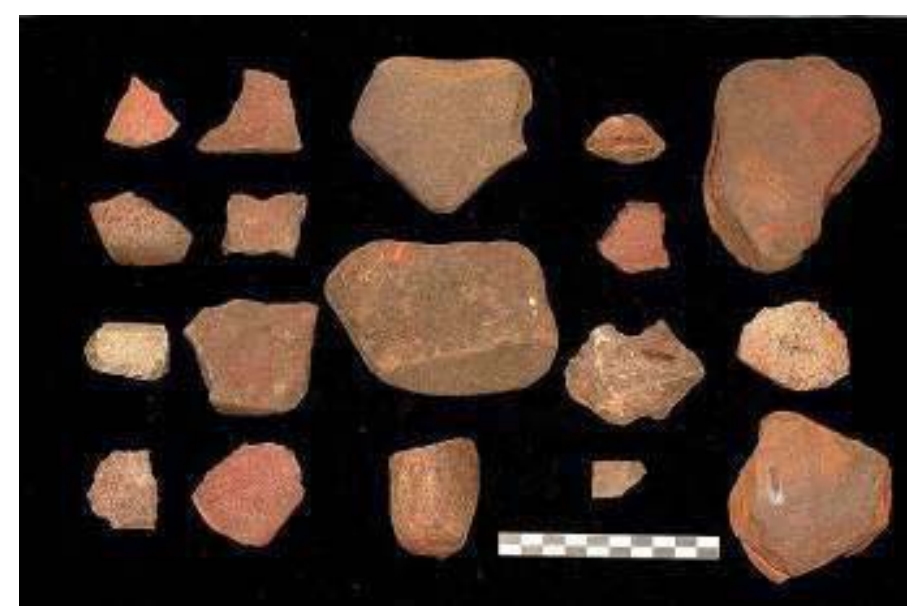

Figura 126 - Material lítico encontrado no sítio Lago do Limão (afiadores, calibradores, lascas, fragmentos de lasca e fragmentos de lâmina de machado).

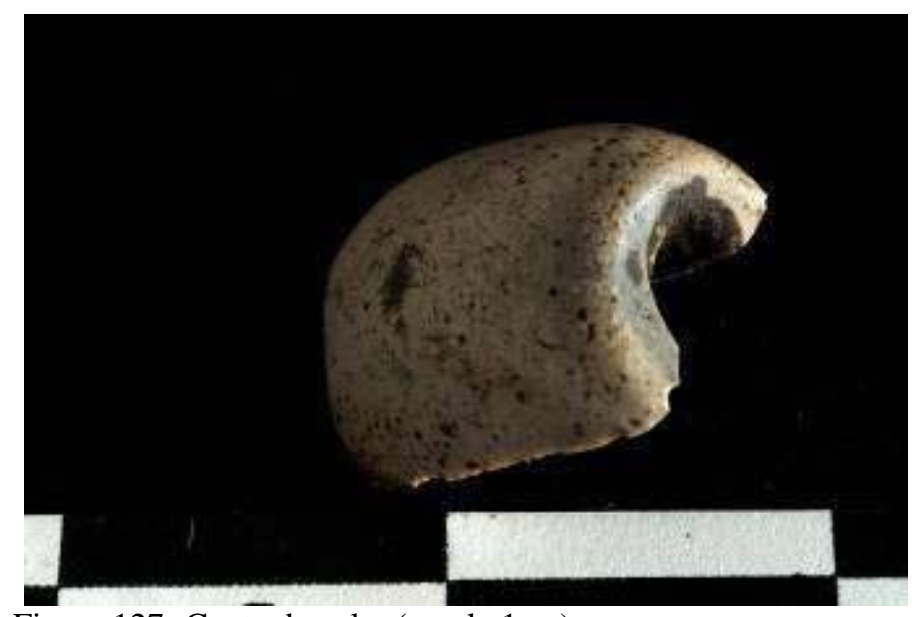

Figura 127- Conta de colar (escala 1cm). 


\section{$\underline{\text { V.VI - O MATERIAL DO SÍTIO PILÃO }}$}

\section{V.VI.I - A CERÂMICA}

No sítio Pilão foram escolhidas duas unidades para análise detalhada. A opção foi pelas unidades N-991 E-974 e N-1011 E-985. A primeira apresentou muita cerâmica e um contexto estratigráfico interessante. A segunda contrasta com a anterior, pois é uma unidade com menor densidade de material cerâmico. Ambas foram escavadas em montículos e apresentam apenas material associado à fase Paredão.

No total foram coletados 8.548 fragmentos de cerâmica e 2.560 fragmentos de trempe. A densidade de material é maior em N-991 E-974 (4.915 fragmentos de cerâmica e 1.665 fragmentos de trempe). Na unidade N-1011 E-985 foram coletados 3.633 fragmentos de cerâmica e 895 fragmentos de trempe. A diferença numérica não parece tão grande, mas isso é devido à grande fragmentação da cerâmica na unidade N1011 E-985. Se voltarmos aos gráficos de densidade e peso das duas unidades (gráficos 18 e 21; item IV.III), veremos que o material cerâmico de N-1011 E-985 não chega à metade do peso do material da outra unidade. A cerâmica foi triada e o material separado para análise detalhada foi um total de 616 peças (411 peças de N-991 E-974, 201 peças de N-1011 E-985 e algumas peças específicas de outras unidades), sendo 432 bordas, 105 bases e 79 fragmentos com algum tipo de decoração. As bordas tem espessura variando entre 3 e $21 \mathrm{~mm}$, a grande maioria mede entre 4 e $10 \mathrm{~mm}$ (gráfico $38)$. 


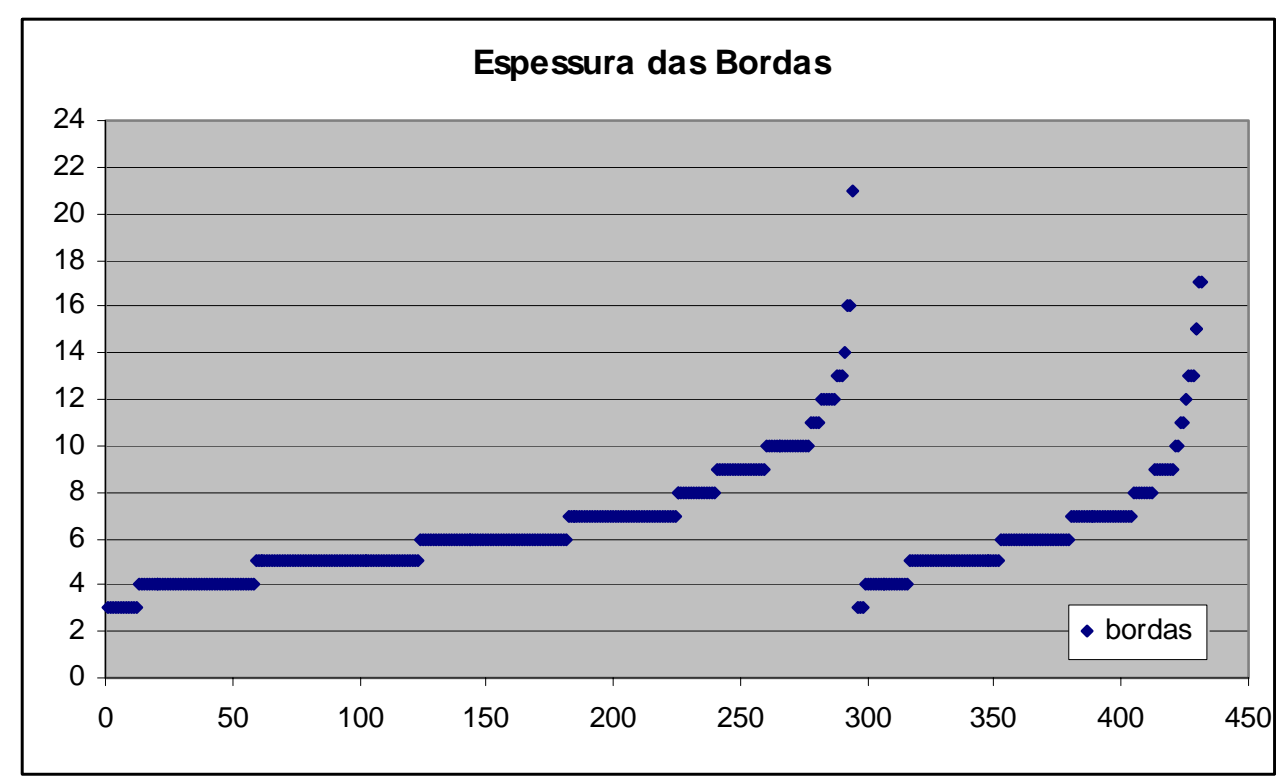

Gráfico 38 - Espessura das bordas em duas seqüências em ordem crescente, a primeira é referente à Unidade N-991 E-974 e a segunda sequiência é referente à unidade N-1011 E985. As medidas estão em milímetros (espessura na vertical e quantidade na horizontal).

As bases analisadas possuem espessura variando entre 4 e $18 \mathrm{~mm}$, com a maioria medindo entre 4 e 14mm (gráfico 39).

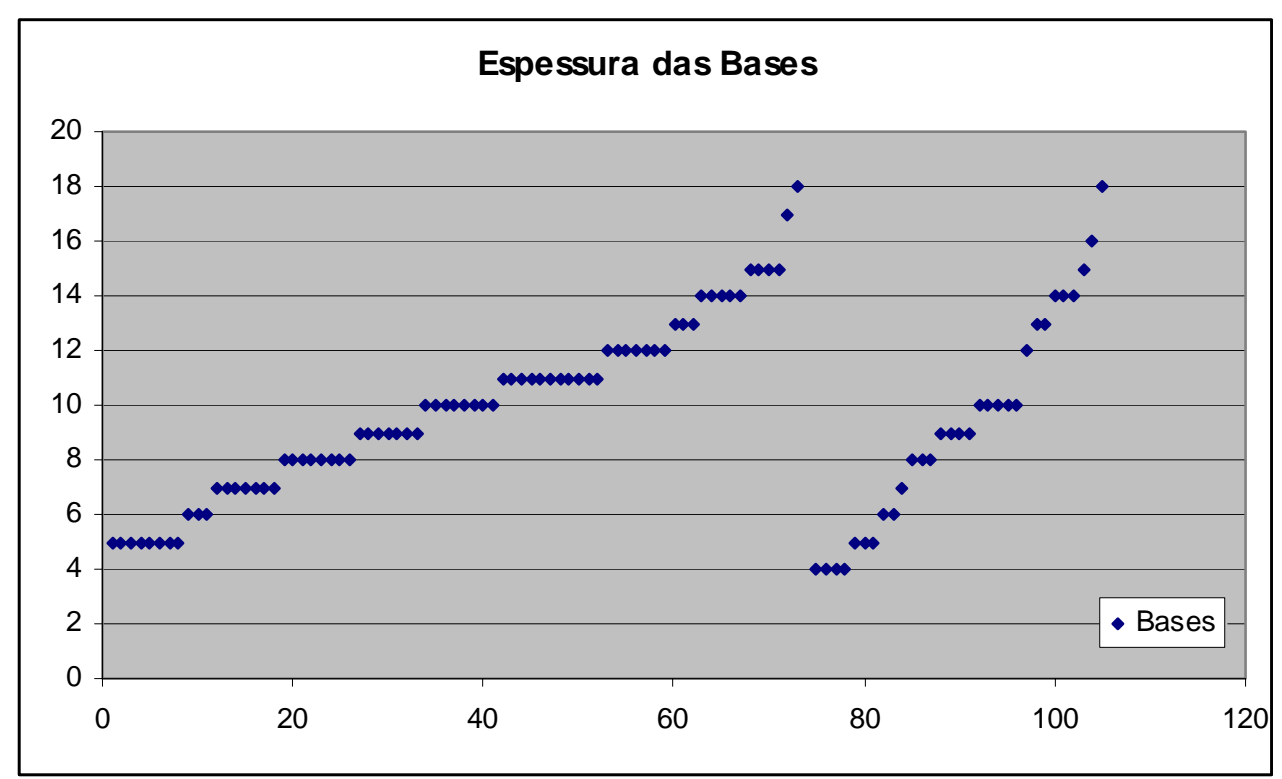

Gráfico 39 - Espessura das bases em duas seqüências em ordem crescente, a primeira é referente à Unidade N991 E-974 e a segunda sequiência é referente à unidade N-1011 E985. Medidas em milímetros (espessura na vertical e quantidade na horizontal).

As paredes apresentam espessura variando entre 3 e $14 \mathrm{~mm}$, com a maioria entre 4 e $7 \mathrm{~mm}$ (gráfico 40). 


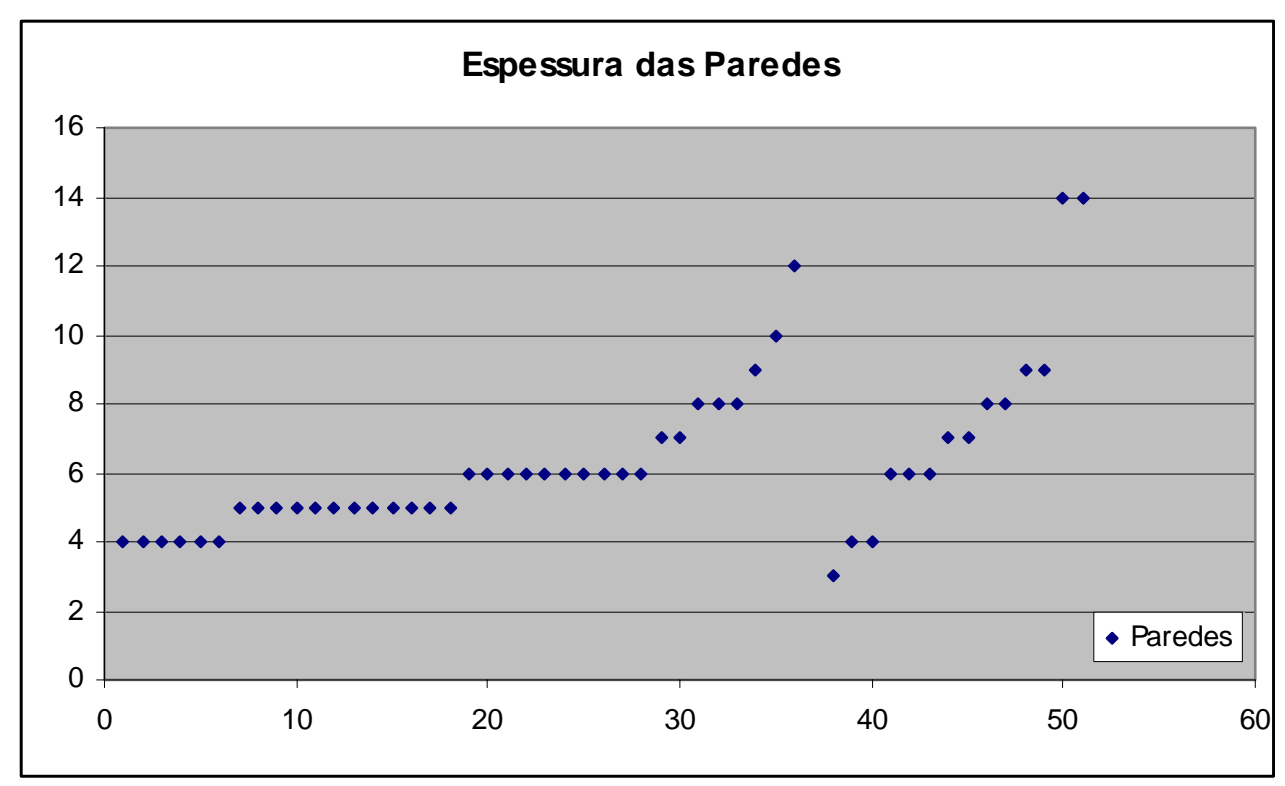

Gráfico 40 - Espessura das paredes em duas seqüências em ordem crescente, a primeira é referente à Unidade N991 E-974 e a segunda seqüência é referente à unidade N-1011 E-985. Medidas em milímetros (espessura na vertical e quantidade na horizontal).

Como no caso do sítio Antônio Galo, se compararmos os três gráficos acima, veremos que a tendência da cerâmica Paredão é de exemplares com borda e paredes relativamente finas e bases um pouco mais espessas, mas ainda finas se confrontar com outros conjuntos cerâmicos.

A coloração da superfície dos fragmentos evidenciada foi principalmente o "laranja A" (405 face interna e 376 face externa), seguida por cinza ou preto (face interna 140 e face externa 167), "laranja B" (61 face interna e 53 face externa) e branco (face interna 8 e externa 5).

Os antiplásticos encontrados na pasta de argila são muito variados, o cauixí está presente em quase cem por cento dos fragmentos (612). É grande a quantidade de fragmentos contendo mineral (536), porém o mineral parece ser um componente da argila. Como no sítio Antônio Galo é a grande quantidade de fragmentos contendo carvão adicionado à pasta (175). O cariapé ocorre muito discretamente no material analisado(18). Uma quantidade muito pequena de fragmentos apresenta caco moído adicionado à pasta (8). Existe muita variação na quantidade de antiplásticos contido na pasta a tabela 06 sintetiza esses dados. 


\begin{tabular}{|l|c|c|c|c|c|c|}
\hline Tipos de antiplástico * & quant. & cauixí & mineral & carvão & caco moído & cariapé \\
\hline cauixí & 67 & 67 & 0 & 0 & 0 & 0 \\
\hline cariapé & 1 & 0 & 0 & 0 & 0 & 1 \\
\hline mineral & 3 & 0 & 3 & 0 & 0 & 0 \\
\hline cauixí+caco moído & 1 & 1 & 0 & 0 & 1 & 0 \\
\hline cauixí+mineral & 344 & 344 & 344 & 0 & 0 & 0 \\
\hline cariapé+cauixí & 2 & 2 & 0 & 0 & 0 & 2 \\
\hline mineral+cauixí & 4 & 4 & 4 & 0 & 0 & 0 \\
\hline cauixí+carvão & 9 & 9 & 0 & 9 & 0 & 0 \\
\hline cauixí+cariapé+mineral & 10 & 10 & 10 & 0 & 0 & 10 \\
\hline cauixí+caco moído+mineral & 2 & 2 & 2 & 0 & 2 & 0 \\
\hline cauixí+mineral+cariapé & 3 & 3 & 3 & 0 & 0 & 3 \\
\hline cauixí+mineral+caco moído & 3 & 3 & 3 & 0 & 3 & 0 \\
\hline cauixí+carvão+mineral & 119 & 119 & 119 & 119 & 0 & 0 \\
\hline cauixí+mineral+carvão & 41 & 41 & 41 & 41 & 0 & 0 \\
\hline carvão+cauixí+mineral & 4 & 4 & 4 & 4 & 0 & 0 \\
\hline cauixí+cariapé+mineral+caco moído & 1 & 1 & 1 & 0 & 1 & 1 \\
\hline cauixí+cariapé+carvão+mineral & 1 & 1 & 1 & 1 & 0 & 1 \\
\hline cauixí+caco moído+carvão+mineral & 1 & 1 & 1 & 1 & 1 & 0 \\
\hline Total & $\mathbf{6 1 6}$ & $\mathbf{6 1 2}$ & $\mathbf{5 3 6}$ & $\mathbf{1 7 5}$ & $\mathbf{8}$ & $\mathbf{1 8}$ \\
\hline
\end{tabular}

Tabela 06 - Tipos de antiplástico encontrados na pasta de argila. *o antiplástico que aparece em primeiro é predominante na seqüência

No material analisado todas as paredes foram construídas através da técnica de roletes, enquanto as bases são produzidas por modelagem. Cem por cento do material receberam alisamento como tratamento da superfície. As bases são principalmente planas (42 com marcas de folha e 35 alisadas), seguidas por bases côncavas (17), uma quantidade discreta de bases com pedestal (9), aparecem ainda 2 bases convexas.

Nas peças onde o critério pode ser observado, há uma predominância de vasos com contorno simples (289) e uma discreta aparição de exemplares com contorno composto (10).

Já a forma dos vasos está principalmente representada pelos vasos irrestritivos, (220) com diâmetro da boca maior que o diâmetro do corpo, e uma menor quantidade de vasos restritivos (72), com o diâmetro da boca menor que o diâmetro do corpo. O gráfico 41 representa os diâmetros de borda registrados no material analisado. A maioria dos vasos da coleção possuía diâmetro entre 100 e 350mm. 


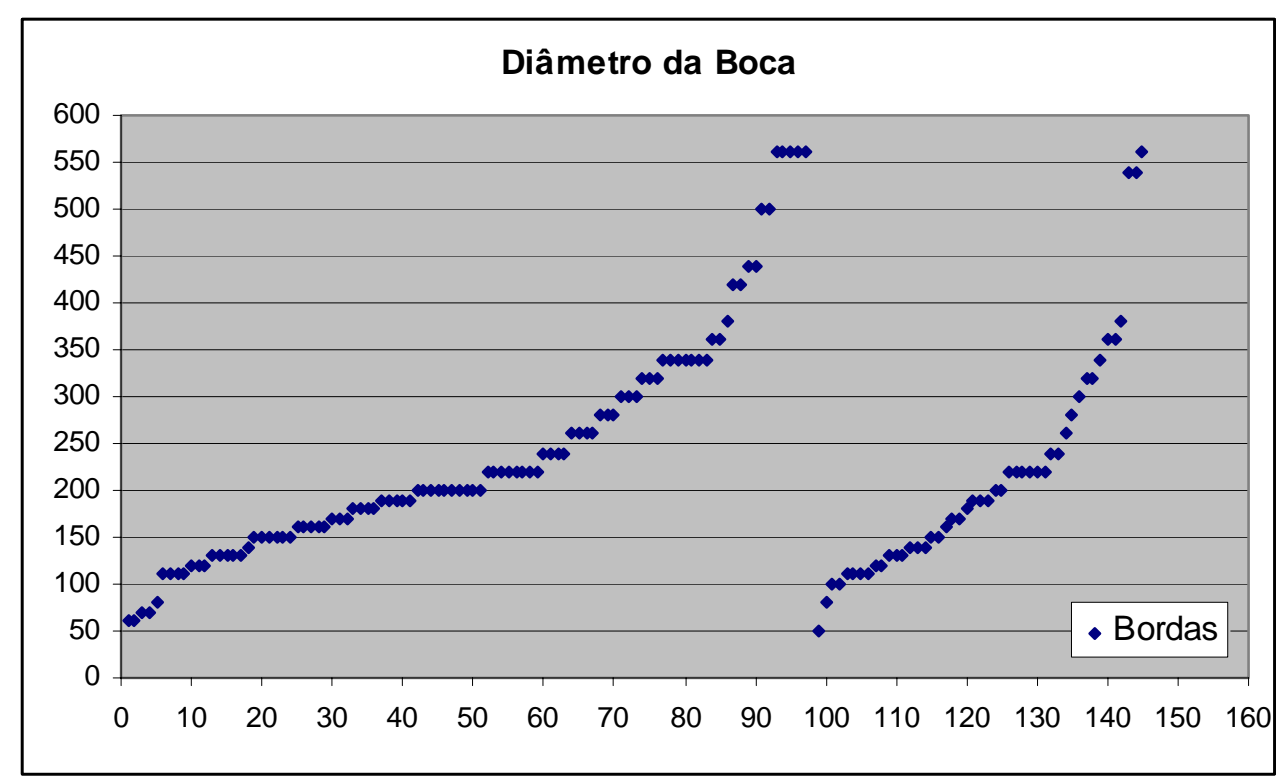

Gráfico 41 - Diâmetro das bordas em duas seqüências em ordem crescente, a primeira é referente à Unidade N991 E-974 e a segunda seqüência é referente à unidade N-1011 E985. Representado em milímetros (diâmetro na vertical e quantidade na horizontal).

Já o diâmetro da base, com exceção dos assadores e alguidares, são sempre muito pequenos dificilmente ultrapassando 100mm de diâmetro (gráfico 42).

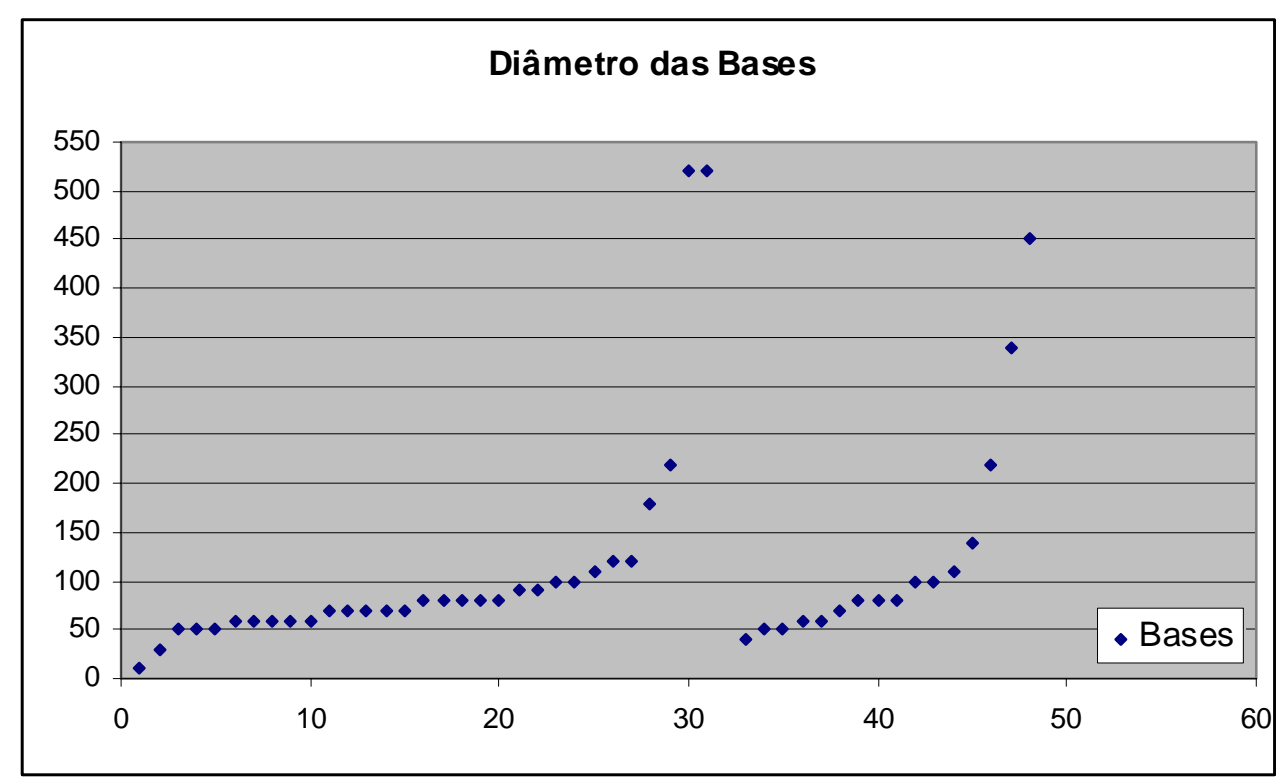

Gráfico 42 - Diâmetro das bases em duas seqüências em ordem crescente, a primeira é referente à Unidade N991 E-974 e a segunda seqüência é referente à unidade N-1011 E985. Representado em milímetros (diâmetro na vertical e quantidade na horizontal).

A inclinação das bordas dos vasos é preferencialmente direta (256), apresentando também uma pequena porção de exemplares com inclinação extrovertida (49). 
A forma do lábio tem variação maior, com uma predominância, de lábios afilados (200); seguida por planos (107), arredondados (94), apontados (22), biselados, roletados externos, roletados internos e expandidos somam 14 peças.

O acabamento dos lábios também é variado, sendo predominantes os acabamentos arredondados (209), seguidos por planos (159), incisos (54), modelados, cortados, ungulados, ponteados, acanalados, serrilhados e incisos ponteados juntos somam 15 peças.

Do material analisado $73,1 \%$ não apresenta decoração, os outros 26,9\% apresentam decoração principalmente externa (95 peças), seguida por decoração interna (59 peças) e interna e externa (12 peças). A decoração aplicada é principalmente plástica (125 peças), engobo vermelho (21 peças), aparece também a combinação de engobo e decoração plástica (14 peças), além de pintura (6 peças). Os tipos de decoração plástica são variados, destacam-se as incisões em linhas finas (69), apliques modelados (17), acanalados (9) esferas aplicadas (7), ponteados (5), ungulados, roletes aplicados e com impressão de corda junto somam 4 peças. Ocorre ainda a combinação de dois ou mais dos motivos apresentados anteriormente (16 peças).

Marcas de uso foram identificadas em 42 peças, sendo marcas de fuligem (32) e desgaste por atrito (10).

O sítio Pilão apresenta material cerâmico da fase Paredão, as peças reconstituídas podem ser classificadas dentro dos seguintes conjuntos:

Tipo 1 - 9 peças; tipo $2-6$ peças, tipo 3 - 10 peças, tipo $4-4$ peças; tipo 5 - 14 peças; tipo $6-7$ peças; tipo $7-17$ peças; tipo $8-7$ peças; tipo $9-19$ peças; tipo $10-8$ peças; tipo 11 - 28 peças; e tipo 12 - 2 peças; tipo 13 - 2560 peças (anexos 15 a 28). Uma peça não apresentou correlação com nenhum dos tipos figura.
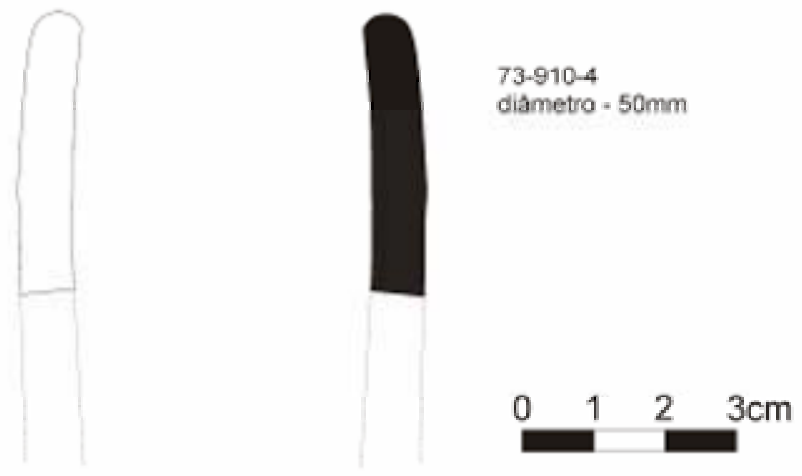

Figura 128 - Exemplar sem correlação com outros tipos. 
O material lítico encontrado no sítio está representado por afiadores em arenito ou laterita. São encontrados principalmente suportes com faces apresentando polimento, provavelmente. Aparecem também calibradores, fragmentos de lâmina de machado em basalto, contas de colar e alguns refugos de lascamento, lascas ou fragmentos de lascas (figuras 129 e 130).

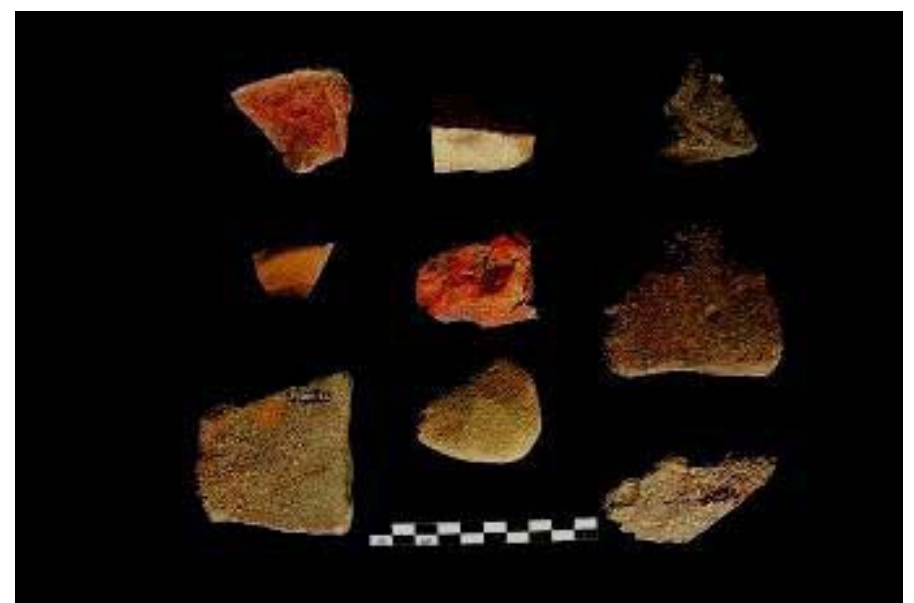

Figura 129 - Material lítico encontrado no sítio Pilão (lascas, afiadores e calibradores).

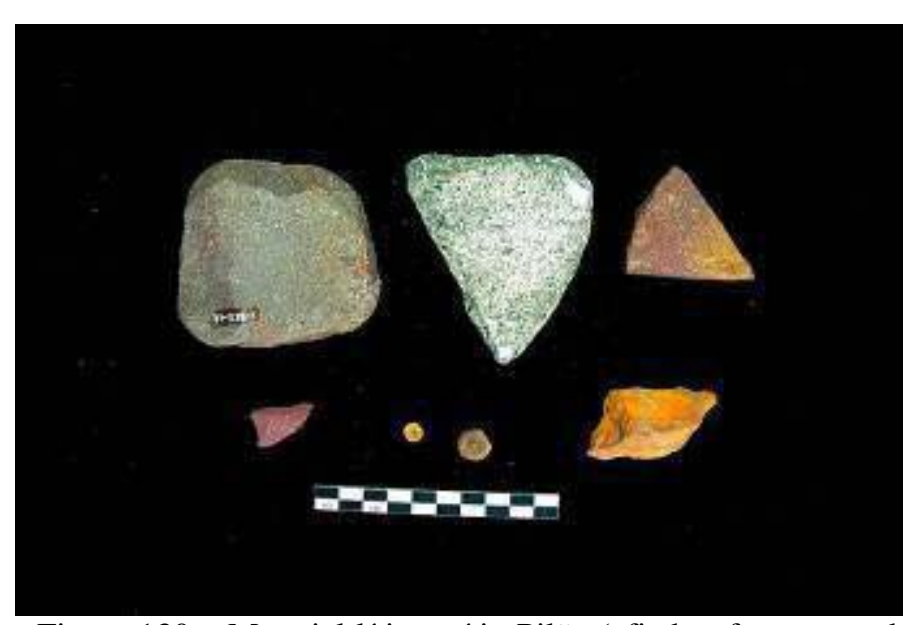

Figura 130 - Material lítico, sítio Pilão (afiador, fragmento de lâmina de machado, lascas e contas de colar). 
O que Fazer com Eles? 


\section{Capítulo VI - CORRELACIONANDO OS DADOS COLETADOS NOS SÍTIOS ARQUEOLÓGICOS}

Dos resultados obtidos com levantamento arqueológico realizado na área do lago do Limão, principalmente nos sítios Antônio Galo, Lago do Limão e Pilão, podemos destacar os avanços feitos no processo de entendimento das particularidades da fase Paredão. Nosso trabalho tem ênfase principal na coleta de dados no campo, daí a grande quantidade de resultados obtidos através da topografia, estratigrafia e observação da paisagem.

\section{VI.I - OS MONTÍCULOS}

Hoje podemos acrescentar mais algumas possibilidades de resposta para uma pergunta que fazemos e que vem sendo feita em trabalhos anteriores do PAC (Machado 2005:243). Quem construiu e por que montículos são construídos? Machado desassocia a construção de montículos da edificação de unidades habitacionais baseando-se na forma e tamanho das estruturas. No montículo estudado em seu trabalho existe uma grande quantidade de sepultamentos diretos. Para a autora uma possibilidade plausível seria a construção da estrutura estar diretamente relacionada a um ou mais eventos de sepultamento. No decorrer do trabalho de Machado(2005) são apresentados dados que nos levam a associar a construção do montículo à fase Paredão, porém, nas conclusões finais a autora acredita em uma possibilidade mais forte de associação com a fase Guarita.

Baseado nos dados produzidos pelo trabalho de Machado (2005) intensificamos as intervenções em montículos nos sítios da região do lago do Limão, pois a possibilidade de associação a evento funerários era uma das principais hipóteses.

Tivemos a sorte de identificar sítios unicomponenciais com a presença de montículos, o que facilitou a associação da estrutura aos construtores. No caso dos montículos identificados nos sítios do lago do Limão, todos parecem estar associados à fase Paredão. Um detalhe importante é a ausência de sepultamentos em todos os montículos pesquisados. No sítio Lago Grande (Donatti 2003), os montículos escavados também não apresentaram sepultamentos. 
Com os novos dados coletados, apresentamos uma outra alternativa para os motivos que levaram os povos pré-coloniais, no caso os responsáveis pelos vestígios da fase Paredão, a construírem montículos. Nossas hipóteses são baseadas tanto na estrutura em si, como na distribuição de conjuntos de montículos na paisagem.

Foram escavados montículos nos sítios Lago do Limão, Antônio Galo e Pilão. Os dois últimos, em contextos unicomponenciais da fase Paredão, são melhores para servir de base interpretativa para os montículos existentes no primeiro sítio que é multicomponencial.

Do sítio Antônio Galo surge nossa hipótese de associação de montículos a unidades habitacionais. Com o mapeamento dos montículos no sítio percebemos a distribuição circular de algumas das estruturas (anexo 12). Com a topografia e observação da paisagem percebemos que alguns dos montículos apresentam depressões nas proximidades, o que poderia ser o indicativo de local de retirada de solo para a sua construção. Depressões nas proximidades dos montículos são apontadas também no trabalho de Machado (2005:100). Acreditamos que as depressões podem ser um bom indicativo de construção do montículo em um único evento, descartando a possibilidade de acúmulo, intencional ou não, através do tempo.

As escavações no sítio Antônio Galo foram poucas, mas suficientes para revelar um contexto unicomponencial associado à fase Paredão. Como pode ser visto na descrição da escavação da unidade N-938 E-456 (item IV.I) a profundidade do pacote arqueológico e da camada de terra preta é pequena. O montículo parece ter sido construído nos primeiros momentos de ocupação do sítio. A densidade de cerâmica é pequena se comparada a de montículos em contextos multicomponenciais, ${ }^{6}$ como é o caso do montículo escavado no sítio Lago do Limão. Os fragmentos de cerâmica provavelmente ainda não eram matéria prima abundante por ocasião do processo de construção do circulo de montículos no sítio.

No sítio Pilão fica clara a utilização do solo dos arredores dos montículos para a sua construção. O sítio está localizado em uma península à margem do lago, um local elevado, onde a facilidade de drenagem de água na península favorece os processos de formação de laterita no solo. No caso a camada de laterita foi formada relativamente próxima da superfície. Durante a construção dos montículos a coleta de solo expôs a laterita. Nas imediações dos conjuntos de montículos hoje fica fácil perceber o solo

\footnotetext{
${ }^{6}$ Para uma comparação de densidade de cerâmica em contextos multicomponenciais ver Machado (2005).
} 
pedregoso na superfície. As escavações em áreas diversas do sítio ajudaram a perceber melhor as diferenças.

Novamente tivemos que voltar a olhar para a paisagem e topografia do ambiente para descobrir dados importantes sobre a ocupação do sítio. Como pode ser visto no anexo 13, os montículos 01 a 07 estão também dispostos em círculo. Nesse caso o sítio é totalmente unicomponencial. Uma análise detalhada da densidade de material cerâmico nas diferentes áreas escavadas no sítio revelou dados importantes relacionados ao processo de formação do sítio arqueológico. Comparando a densidade de cerâmica e a disposição dos montículos na paisagem, constatamos que existe um primeiro grupo de montículos com menor densidade de cerâmica, justamente o grupo circular, e um segundo grupo de estruturas com densidade de cerâmica muito maior. Voltemos ao anexo 13 para ficar mais clara a situação, os montículos 01 a 07 estão relacionados ao primeiro grupo, os montículos 08 a 10 têm densidade de cerâmica mais elevada e estão associados ao segundo grupo.

Nossa hipótese interpretativa do contexto dos montículos é a de que o grupo I está relacionado ao primeiro momento de ocupação do sítio e, como no sítio Antônio Galo, na ocasião da construção das estruturas não havia fragmento de cerâmica em abundancia. Já o segundo grupo de montículos, parece representar um momento de relocação da aldeia e, nesse caso, os fragmentos de cerâmica já teriam um papel mais importante como matéria prima durante a construção.

O sítio ainda não foi datado, o que seria importante para comparar a diferença cronológica entre esses dois eventos hipotéticos. Mas, mesmo sem as datas podemos recorrer a outro conjunto de dados a esse respeito. A comparação da cerâmica analisada em unidades representativas dos dois grupos de montículos não apresenta diferenças consideráveis, o que seria plausível, já que provavelmente a matéria prima cerâmica utilizada para a construção do segundo grupo de montículos deve ter sido produzida durante o primeiro momento de ocupação. $\mathrm{O}$ que nos leva à conclusão de que não existem diferenças consideráveis visíveis na cerâmica é a comparação do material recolhido em uma área provavelmente utilizada para descarte durante o segundo momento de ocupação que apresenta material cerâmico muito semelhante (unidade N981 E-927, item IV.III.VI). Acreditamos que o intervalo entre um momento e outro seja muito curto e talvez ininterrupto. $\mathrm{O}$ aumento da densidade populacional e a necessidade de expandir os locais de habitação pode ser uma explicação para a re-locação da aldeia, no caso vista pela construção de novos montículos. 
Por que estamos associando montículos a unidades habitacionais? Um fator importante para a associação é a disposição dos montículos nos sítios. Nos três sítios estudados podem ser vistos grupos circulares de montículos (anexos 10, 12 e 13). Montículos não são resultantes de acúmulo natural de refugos, pois em vários casos foi constatada a retirada de solo para a construção da elevação. Além disso, muitos vestígios arqueológicos encontrados nas escavações em montículos parecem estar associados a áreas domésticas. Todas as escavações em montículos no sítio Pilão apresentaram fragmentos de trempe (anexo 27) (suportes utilizados para apoiar vasilhas acima do fogo) em grande quantidade. Nas unidades N-990 E-974 e N-991 E-974 foi identificada uma estrutura de combustão. Nas unidades N-990 E-974, N-991 E-974, N991 E-973, N-1008 E-1032 e N-1013 E-1002 foram identificadas feições de buracos de postes, que provavelmente seriam das unidades habitacionais. No sítio Lago do Limão também foram encontradas feições semelhantes na base da escavação da unidade $\mathrm{N}$ 1950 E-558. Machado (2005:93 e 94) na descrição da estratigrafia do montículo estudado no sítio Hatahara, descreve a presença de várias feições, associadas a estruturas de combustão, feições com restos faunísticos, ambas parecendo ter sido utilizadas por períodos prolongados. Na mesma parte do texto é descrita uma feição provavelmente de um buraco de poste. Dados inéditos das ultimas escavações no sítio Hatahara revelaram a presença de mais feições de buracos de postes no mesmo montículo estudado por Machado.

Com a perceptível combinação das evidencias propomos o esquema hipotético apresentado na figura 131 para ilustrar o processo de formação dos montículos. Num contexto hipoteticamente semelhante ao dos sítios Antônio Galo e Pilão, durante a construção dos primeiros montículos o local apresenta pouco ou nenhum vestígio de ocupação humana (parte 1). O próprio solo das imediações é removido para construir uma superfície elevada com topo aplanado (parte 2). Essa estrutura serve de base para a construção de unidades habitacionais (parte 3). Uma das conveniências desse tipo de construção seria o não empoçamento de água na parte interna da edificação durante as chuvas torrenciais que ocorrem na região. Com o abandono ou re-locação das habitações para outros locais (parte 4), o montículo fica exposto às fortes chuvas e ações dos ocupantes do terreno que provocariam erosão (parte 5), deixando o montículo com o formato que encontramos hoje nos sítios arqueológicos (parte 6). 


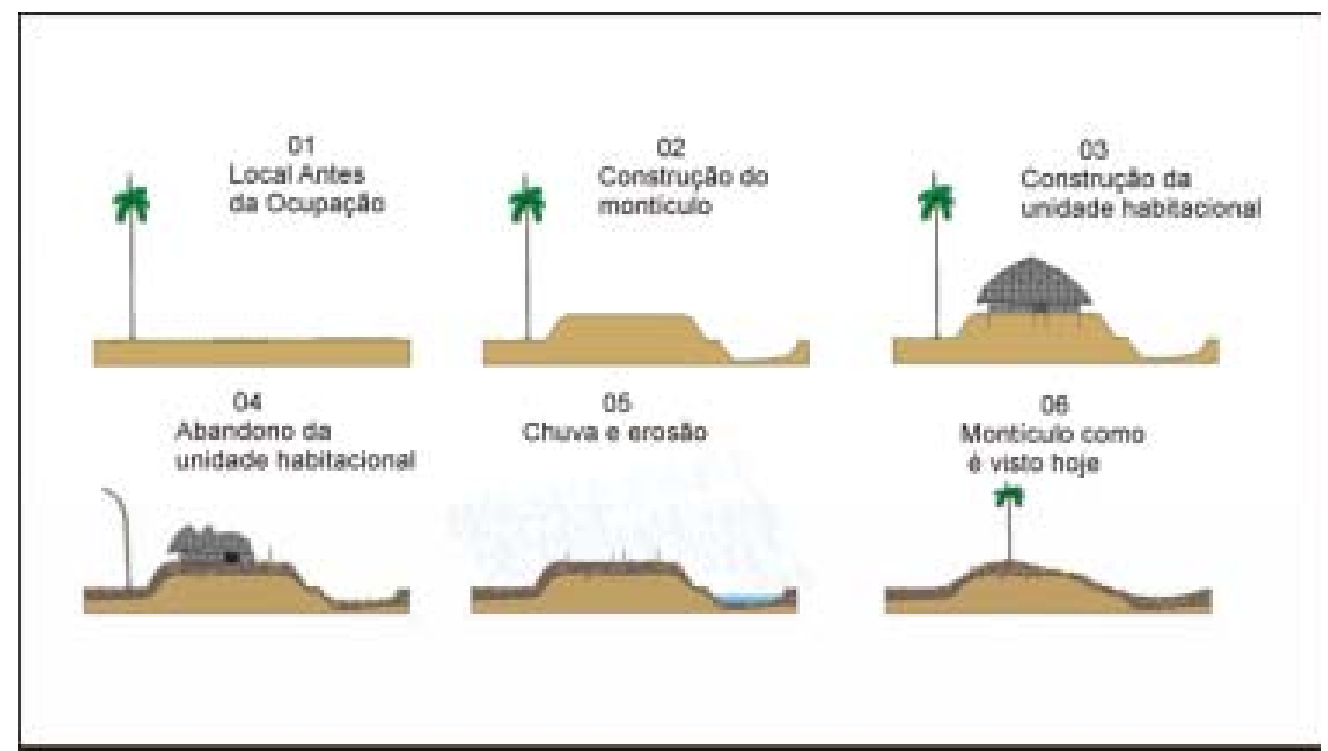

Figura 131 - Diferentes etapas do processo hipotético de formação dos montículos artificiais.

No sítio Lago do Limão pelo menos a maior elevação vista no terreno, onde está a unidade N-1937 E-550, parece ser artificial. As razões que embasam essa hipótese são as seguintes: primeiramente, há uma maior densidade de cerâmica nessa área do sítio, padrão semelhante ao dos montículos do sítio Hatahara. No caso em questão, fragmentos de cerâmica estão presentes até o substrato rochoso, sendo recobertos por uma camada de laterita. Em segundo lugar, o depósito arqueológico nas elevações é mais espesso que o das unidades adjacentes fora das elevações.

Como pode ser visto na figura 99 (item IV.II.V), há, no perfil da unidade escavada, uma camada arqueológica com baixa densidade de fragmentos de cerâmica nos primeiros $40 \mathrm{~cm}$ acima da base rochosa, ponto onde já é grande a concentração de fragmentos de laterita, que como pôde ser constatado nas unidades escavadas, ocorre naturalmente nas imediações (figuras 101 e 103). Na seqüência temos uma camada com muitos fragmentos de cerâmica, que talvez já seja parte do material construtivo da estrutura, há também uma quantidade maior de lateritas e fragmentos de cerâmica até a superfície. Os longos anos de agricultura no terreno podem ter mascarado um pouco o que seria o montículo, mas ao que tudo indica, ele não era realmente muito alto.

Não está ainda claro se a estrutura em questão se trata de um montículo stricto sensu, como os que já são conhecidos no PAC, mas algumas características pontuais parecem atestar que não se trata de um acúmulo natural. Como descrito anteriormente, os fragmentos de cerâmica e a terra preta estão presentes desde a base rochosa até a superfície, mas isso ocorre também nas áreas planas. Novamente o que parece ser um melhor indicador é a espessura do pacote arqueológico e a presença de laterita na matriz 
arqueológica. Fora da área elevada o pacote arqueológico é muito pouco espesso (figura 103), a concentração de cerâmica é menor e não se percebe uma diferença na quantidade de laterita ao longo da estratigrafia. $\mathrm{Na}$ elevação, no entanto, temos uma maior concentração de cerâmica por volta $40 \mathrm{~cm}$ de profundidade (no perfil fica clara a presença de uma camada cerâmica), e acima dela uma maior concentração de fragmentos de laterita (figuras 98 e 99). O pacote acima da concentração de cerâmica é mais espesso que todo o pacote arqueológico da unidade escavada na área plana $(\mathrm{N}$ 1923 E-542).

Levantamos algumas hipóteses para a formação do pacote mais espesso: $1-\mathrm{Na}$ superfície, que já poderia apresentar uma elevação decorrente da formação de solo arqueológico desde a base de laterita, foi depositada uma camada de fragmentos de cerâmica, posteriormente coberta com uma camada de laterita (cascalho), formando um aterro elevado no local. 2 - já havia um acúmulo de vestígios arqueológicos (talvez uma lixeira), acima da qual foi depositada uma camada de laterita para regularizar e elevar o terreno. 3 - uma outra possibilidade seria a de erosão das camadas superficiais nas imediações do morrote, diminuindo a espessura do pacote arqueológico nas imediações, permanecendo um morro testemunho que seria o local onde o pacote arqueológico é mais espesso.

Das possibilidades levantadas anteriormente, a última nos parece a mais improvável, não parece haver muitas evidências de processos erosivos na área do sítio em questão. As primeiras alternativas parecem mais plausíveis.

Observando a distribuição da cerâmica das diferentes fases na escavação da unidade N-1937 E-550, fica clara a grande movimentação do solo local durante e/ou após o processo de formação do sítio. As cerâmicas das fases Manacapuru, Paredão e Guarita estão presentes em todos os níveis arqueológicos. As cerâmicas Manacapuru e Paredão estão mais concentradas nos estratos inferiores, abaixo de $40 \mathrm{~cm}$ de profundidade, justamente no nível onde fica visível a camada de cerâmica (figura 98). A cerâmica Guarita aparece em maior quantidade nos níveis superficiais.

Se considerarmos a presença de cerâmica da fase Guarita ao longo de toda estratigrafia como estando em um contexto pouco remexido, teríamos que considerar o montículo como sendo uma construção da fase Guarita. Porém, se considerarmos o fato como sendo decorrente de perturbação dos depósitos anteriores, provocada durante ou depois da ocupação Guarita, podemos descartar a hipótese. 
Baseado na última possibilidade, nas evidências encontradas em outros sítios que associam os montículos principalmente à fase Paredão, na nossa hipótese de correlação entre montículos e unidades habitacionais, na existência de montículos associados à fase Paredão no sítio Lago do Limão e na identificação de um contexto de unidade habitacional Guarita desassociado de montículos encontrados no sítio (os dois últimos descritos adiante), tendemos a associar essa estrutura também à fase Paredão.

Se for esse o caso, a presença relativamente alta de cerâmica Manacapuru seria decorrente de uma primeira ocupação do local que teria fornecido a matéria prima cerâmica para a construção da elevação. Provavelmente o momento de construção do montículo já seria um período de re-locação de unidades da fase Paredão no local, pois a quantidade de cerâmica Paredão entre a matéria prima construtiva já é grande desde os primeiros níveis. Os vestígios da fase Guarita seriam de uma ocupação posterior que teria utilizado a localidade com outros fins, movimentando o pacote arqueológico já formado em ocupações anteriores.

Os montículos associados à fase Paredão existentes no sítio Lago do Limão, aos quais nos referimos acima, estão na extremidade sul do anexo 12, parte do sítio onde ainda não foram feitas intervenções de sub-superfície, mas o padrão circular de distribuição dos montículos é o mesmo encontrado nos sítios Antônio Galo e Pilão. Além disso, em vistoria de superfície constatamos alta densidade de vestígios cerâmicos da fase Paredão nessa parte do sítio. Talvez seja como no sítio Antônio Galo e o local apresenta contexto unicomponencial da fase Paredão. Se a hipótese estiver correta, poderia ser o primeiro momento de ocupação Paredão no sítio e o montículo 07, seria de um momento de re-locação ou re-ocupação do sítio. Mas ainda temos que conferi-la com escavações no futuro.

\section{VI.II - "CURRAL DE TARTARUGA DE ÍNDIO"}

Constatamos que as feições conhecidas como "curral de tartaruga de índio" existentes no sítio Lago do Limão realmente eram construções artificiais. A feição escavada (F-04) tem características muito semelhantes às descritas no século XVII por Cristóbal de Acuña:

Apesar de não lhes ser possível conservar por muito tempo a carne, não falta aos nativos habilidade no sentido de ter carne fresca de tartaruga durante todo o inverno [...] Para isso, fazem alguns viveiros grandes, 
cercados de paus, cavados por dentro, de sorte que, como lagoas de pouca profundidade, aparam sempre a água da chuva. [...] Ali, elas tem por prisão aquele pequeno cárcere, onde são alimentadas com galhos e folhas de árvores e permanecem vivas o tempo que eles julgarem suficiente. (Acunã 1641[1994]: 79 e 80)

Quando descreve uma batalha travada na província de Machiparo, Carvajal também fala de currais de tartaruga: [...] como había gran cantidad de comida, así de tortugas en corrales y alberques de água [...] en tanta abundancia que había para comer un real de mil hombres un año [...](Carvajal 1542 [1942]:27).

Não existe continuidade na tradição oral entre o período atual e o período de aldeamentos indígenas na região do lago do Limão, fator que nos faz questionar a antiguidade da feição escavada. Numa tentativa de encontrar correlações entre as feições e o período histórico, encontramos depoimentos de caboclos amazônicos que atestam a utilização de currais de tartarugas em períodos históricos recentes (Lima 2001:41). Com base nesses dados fica difícil saber a que período pertencem os currais, pois eles podem ter continuado a ser fabricados no período histórico, mas com nome de "curral de tartaruga de índio".

\section{VI.III - PISO HABITACIONAL, SEPULTAMENTO E DATAS POR AMS}

Outra informação importante conseguida através da documentação minuciosa da estratigrafia no sítio Lago do Limão, foi a descoberta de um piso de unidade habitacional identificado primeiramente com a escavação da unidade N-1976 E-500 e posteriormente confirmado com a ampliação da unidade.

$\mathrm{Na}$ área do sítio onde foi identificado o piso, o contexto arqueológico é extremamente complexo. As datações obtidas para fragmentos coletados na escavação revelaram uma sequiência de mil anos, depositada em um pacote arqueológico com aproximadamente $80 \mathrm{~cm}$ de espessura. A utilização de datação de fragmentos cerâmicos por Accelerator Mass Spectrometers (AMS) se apresentou como uma boa alternativa para melhorar nossa compreensão de contextos multcomponenciais.

No caso as amostras escolhidas para datação foram fragmentos de cerâmica e não fragmentos de carvão. As cerâmicas escolhidas foram fragmentos tipicamente reconhecidos como pertencentes às fases Manacapuru, Paredão e Guarita. Os resultados obtidos colocam as datas da fase Manacapuru em concordância com as definições 
anteriores (Lima et al 2005) (290 \pm 28 DC). A fase Paredão teve sua data mais tardia obtida por um fragmento coletado na escavação do piso da unidade habitacional (1104 \pm 27 DC). O contexto Guarita apresentou data condizente com as expectativas para o período da fase (1225 \pm 26 DC). A associação das datas às fases só foi possível por conhecermos previamente a associação das amostras datadas, pois caso tivessem sido datados carvões ficaria difícil dizer que uma data estaria associada a uma ou outra fase, uma vez que o contexto é multicomponencial. Principalmente a data tardia da fase Paredão teria sido erroneamente associada à fase Guarita.

A combinação de datas provenientes de amostras de carvão e fragmentos de cerâmica pode ser uma boa ferramenta para calibrar os resultados de diferentes métodos e amostras para produzir datas. Em sítios unicomponenciais como o Antônio Galo a datação de cerâmicas e carvões dos mesmos níveis pode fornecer um contraponto entre as duas possibilidades de amostras. Após isso, em sítios multicomponenciais como o Lago do Limão as datas obtidas com amostras de cerâmica podem ajudar na associação de amostras de carvão às diferentes fases.

Voltando à discussão do contexto do piso de unidade habitacional escavado no Lago do Limão, sob um solo de ocupação Manacapuru com feições circulares cavadas no latossolo estéril encontra-se uma camada de laterita e fragmentos de cerâmica Manacapuru, esporádicos fragmentos de cerâmica Paredão e fragmentos de cerâmica Guarita, muito quebrados pela compactação da camada. Interceptando a camada foram documentadas muitas feições de buracos de postes (figura 89), que, de acordo com nossa interpretação, estariam sustentado a unidade habitacional construída sob o piso. Muitas atividades executadas após a habitação pronta, novos postes para organização do espaço interno da moradia, sepultamentos como o encontrado na unidade N-1976 E501, buracos para fazer fogueira, teriam causado as várias interrupções no piso, observadas durante a escavação. Como saber quem teria sido responsável por tudo isso?

É possível saber pelo menos que foram os mesmos responsáveis pela produção da cerâmica que chamamos de Guarita. Como chegamos à constatação? Mil anos de seqüência cronológica necessitavam de interpretação após a chegada dos resultados de datação de três amostras. Tarefa difícil para tão pouca superfície escavada. Mas algumas observações nos ajudam na apresentação de alguns esboços interpretativos. A análise amostral da cerâmica de uma das unidades escavadas (N-1976 E-500) apresentou o seguinte: 
$-290 \pm 28$ DC, fase Manacapuru, os vestígios estão principalmente contidos no/ou abaixo do piso de laterita, são os fragmentos mais representados na coleção analisada; $-1104 \pm 27$ DC, fase Paredão, os vestígios são esporádicos, apenas três peças identificadas acima do piso de laterita, provavelmente trazidas de um contexto nas proximidades associado a essa fase;

- finalmente chegamos em $1225 \pm 26$ DC, fase Guarita, os vestígios aparecem por toda a estratigrafia, mas estão contidos principalmente no/ou acima do piso de laterita.

Muitos buracos de estacas foram encontrados durante a escavação e dentro de alguns deles foram encontrados fragmentos de cerâmica Guarita nos níveis mais profundos, portanto o solo que suportava os esteios da habitação já continha material associado à fase Guarita. Durante a escavação foi evidenciado um vaso de cerâmica Guarita fragmentado com boa parte dos fragmentos estruturados em um conjunto visto a $20 \mathrm{~cm}$ de profundidade (figuras 82 e 83). Mais fragmentos do mesmo vaso foram encontrados na primeira intervenção feita no local, a tradagem SE-25 e ainda um fragmento a $80 \mathrm{~cm}$ de profundidade dentro da feição $1^{7}$. Os fragmentos encontrados na tradagem foram encaminhados para datação e resultaram na data acima. Além dessas evidências, foi encontrado um sepultamento em urna, que claramente foi depositado depois da construção do piso de laterita. A cova feita para depositar a urna atravessa o piso de laterita e o vaso foi depositado logo abaixo dele. Falemos um pouco do sepultamento:

Os dados referentes a sepultamentos na Amazônia Central ainda são inconsistentes, mas de acordo com a descrição de Hilbert (1968), as urnas Guarita podem apresentar ossos humanos queimados e cinzas em seu interior. Geralmente as urnas são depositadas muito próximas à superfície. Os exemplares conhecidos são vasos antropomorfos com tampa, na maioria das vezes, ricamente decorados com policromia e decoração plástica.

As evidências do sepultamento no sítio Lago do Limão são: a cova cavada no piso de laterita, a urna, um prato utilizado como tampa e os fragmentos de ossos queimados contidos no interior da urna. Vários fatores nos levam a associar o sepultamento à fase Guarita. $\mathrm{O}$ contexto descrito anteriormente e a posição da urna com relação ao piso. A tampa da urna, um exemplar do tipo 8 (prato), com desgaste provocado por uso anterior ao sepultamento, portanto uma peça reutilizada. Os ossos

\footnotetext{
${ }^{7}$ Com exceção deste exemplar, pouquíssimas foram as remontagens de fragmentos de níveis diferentes observadas no material de todos os sítios escavados.
} 
queimados também são descritos em muitos sepultamentos da fase Guarita. A urna em si é um fator complicante, pois sua forma não tem correlação com outros exemplares Guarita, o pequeno colo apresentado pela peça, até que é semelhante ao de peças guarita, porém de um modo geral, os traços da peça são muito mais semelhantes à cerâmica Paredão, (pasta, espessura da parede e decoração com incisões finas no lábio). A urna também parece ser um vaso com utilização anterior à do sepultamento, algumas marcas de óleo podem ser vistas no interior e exterior da peça.

A não ser pela dessemelhança da urna o sepultamento do sítio Lago do Limão tem contexto e conteúdo muito semelhante aos descritos por Hilbert. Recentemente foram descobertas sete urnas antropomorfas associadas à fase Guarita no município de Altazes-AM. As urnas estavam no mesmo contexto, foram exumadas pela comunidade local, que confirmou a presença de cinza no interior dos recipientes.

A análise do conteúdo da urna exumada no Lago do Limão demonstrou boa representatividade dos ossos do corpo humano, falanges comumente ausentes em sepultamentos secundários foram identificadas no conteúdo da urna. Um fato curioso é a ausência de dentes mesmo com a constatação através de fragmentos do maxilar de que o indivíduo os possuía. Levando em consideração toda a distância que separa os fatos, João Daniel (1757-1783 [2004]:278) quando descreve os costumes canibais dos índios do rio Negro apresenta o seguinte relato:

Um dos enfeites mais ordinários nas mulheres é o trazerem seus grandes colares e gargantilhas, não de pérolas, aljofres e brilhantes, porém de dentes dos índios que matam, e comem algumas nações. [...] porque são divisas de nobreza e brasão de valentia. Nos dentes vão contando o número de homens a que deram honrada sepultura nas suas barrigas, e como fazem o rol dos mortos, e comidos, de sorte que por estes rosários contam os defuntos, e nestes colares têm uma viva memória de seus inimigos mortos, e quem tem rosário mais comprido é mais nobre [...].

Com as evidencias anteriores estamos associando a unidade habitacional e o sepultamento, que talvez tenha sido depositado dentro dela, à fase Guarita. Então poderíamos apresentar uma diferença nos padrões de construção de unidades habitacionais entre a fase Paredão e Guarita, no caso com e sem a construção de montículos. 


\section{VI.IV - COMO PODEMOS TRATAR A CERÂMICA?}

Na Amazônia Central o período de ocupação ceramista segue ininterrupto desde 300 AC até a chegada dos colonizadores europeus. A alta densidade de ocupação durante esse período representada pela grande quantidade de sítios arqueológicos, na maioria das vezes multicomponenciais, com extensas áreas de deposição de vestígios, muitas vezes em pacotes contendo exemplares que representam todo o período cronológico existente. Os quase dois mil anos de ocupação estão representados por pelo menos quatro fases arqueológicas (Açutuba, Manacapuru, Paredão e Guarita).

A complexidade de formação desse mosaico cultural através do tempo é ampliada devido à falta de lacunas entre uma fase e outra, principalmente por volta do século IX são encontrados vestígios de três das quatro fases identificadas. O processo de continuidade e interação entre as diferentes fases resulta em complexos cerâmicos diferenciados, mas com muitas características em comum, tornando a tarefa de classificação da cerâmica em sítios multicomponenciais muito difícil. A busca de traços diagnósticos de uma ou de outra fase dificilmente é bem sucedida se os exemplares não apresentam decoração ou forma típica de uma ou outra fase. Tipo de pasta, composição da argila, tipo de queima, espessura e contorno das paredes apresentam tendências em uma e outra fase, mas as tendências de uma fase podem ocorrer em menor proporção em uma ou todas as outras, o que torna quase impossível a classificação de fragmentos não decorados.

Felizmente pudemos contar com sítios unicomponenciais que possibilitaram um entendimento melhor de todo o conjunto artefatual relacionado a uma fase cerâmica (decorados e não decorados), o que torna o nosso entendimento da cerâmica da fase Paredão muito mais completo do que o das outras fases.

Os exemplos de semelhanças entre as fases vão se multiplicando em cada atributo analisado, mostrando grande caráter de continuidade e interação entre as fases. O acabamento dos vasos, no lábio das peças, apresenta distinção maior entre as fases. $\mathrm{Na}$ fase Manacapuru a tendência é de manter a mesma espessura da parede com lábios planos, cortados e acanalados. Na fase Paredão os lábios são geralmente mais finos que a parede, enquanto na fase Guarita a tendência é de reforçar o lábio deixando-o mais espesso que a parede.

O antiplástico, que no passado foi utilizado como um dos principais critérios classificadores de cerâmica na Amazônia, é um dos exemplos que apresenta tendências 
fortes de ocorrência predominante em uma fase, mas às vezes a mistura de todos os tipos avaliáveis pode ocorrer em menor proporção em todas as fases. Tomemos como exemplo o quadro apresentado no item V.V.I (tabela 05). As tendências de ocorrência de cauixí são predominantes na fase Manacapuru onde o antiplástico está presente em cem por cento do material, mas o cauixí também é muito significativo nas fases Paredão e Guarita, ocorrendo principalmente associado a outro antiplástico. O caco moído aparece em fragmentos grandes na pasta da cerâmica Manacapuru, ocorrendo também na fase Paredão em fragmentos muito menores, quase pulverizados, voltando a aparecer novamente em fragmentos grandes na fase Guarita. O cariapé é predominante na fase Guarita, mas ocorre principalmente associado a cauixí na fase Paredão. O carvão foi observado somente em exemplares da fase Paredão, mas não ocorre no material Paredão de todos os sítios. Tudo isso somado impossibilita dizer que um fragmento está associado a tal fase por apresentar um ou outro antiplástico.

Uma razão plausível para a ocorrência tão variada de antiplásticos poderia ser explicada não só como distintivo cultural como comumente foi feito no passado, mas como uma necessidade de buscar novas alternativas por falta de disponibilidade de um antiplástico no ambiente. O cauixí foi o principal antiplástico utilizado na fase Manacapuru, ocorrendo em quase todo o material. Na fase Paredão o cauixí continua predominante, mas muitas outras alternativas como carvão, caco moído e cariapé passam a ser conjugadas ao cauixí.

No final do período da fase Manacapuru e durante a fase Paredão parece haver um aumento na densidade populacional na região, consequentemente a produção de cerâmica também aumenta. Na coleção observamos na fase Paredão uma diminuição de fragmentos decorados, o que pode representar uma necessidade de produção de mais cerâmica utilitária. O cauixí é muito abundante em toda região amazônica, principalmente nos ambientes de água preta, porém no período em que os rios estão cheios a coleta do cauixí não pode ser feita. A necessidade de produção de muita cerâmica pode ter levado à busca de outras alternativas de antiplásticos na falta do cauixí.

Estudos de análise petrográfica da cerâmica como os apresentados por Machado (2005:212) podem ajudar a identificar possíveis correlações entre o antiplástico usado em diferentes épocas do ano. Machado apresenta três tipos de argila encontradas através das lâminas petrográficas e as tendências de ocorrência de um ou outro tipo de antiplástico em cada uma das argilas. Se conseguirmos comparar os tipos de argila 
coletados em fontes mais próximas ou mais distantes do rio, avaliáveis ou não durante cheia e vazante, aos tipos identificados nas lâminas, talvez tenhamos um mapa de tipos de argila coletados durante diferentes épocas do ano.

O período das fases Paredão e Guarita pode ter sido conflituoso como sugere Neves (2005), a necessidade de abandono repentino de uma aldeia ou a quebra de mais cerâmica do que o previsto pode ter levado à necessidade de produção de cerâmica fora das épocas em que o cauixí está avaliável. A interatividade com a fase Guarita, onde o cariapé parece ser predominante, pode ter influenciado sua utilização na fase Paredão e pela via contrária a utilização do cauixí na fase Guarita.

A cerâmica tem que ser analisada em associação com outros atributos e feições vistas nos sítios arqueológicos para uma melhor compreensão das particularidades de cada período. Uma boa alternativa, como ficou representado em nosso trabalho, é a busca por sítios unicomponenciais, representativos de cada fase cerâmica. Após um estudo detalhados de coleções de cerâmica específicas de uma fase, são conseguidas maiores informações a respeito de exemplares menos típicos, que poderão ser usadas em análises futuras de coleções de sítios multicomponenciais.

\section{VI.V - ALDEIAS CIRCULARES - OCUPAÇÕES ARAWAK x TUPI - UMA} HIPÓTESE

Chegamos a uma das principais conclusões de nosso trabalho, a identificação de aldeias circulares na Amazônia Central. Os três sítios estudados associam a ocupação da fase Paredão a aldeias circulares. Os dados obtidos no sítio Hatahara apresentados por Rebellato (2006) sugerem forma linear para as aldeias Guarita. Os relatos de Carvajal (1542 [1942]), com relação aos produtores de cerâmica polícroma contatados no século XVI, apontam para a configuração de assentamentos lineares às margens do rio Amazonas. Diante desse quadro, as evidencias vão distanciando os povos produtores dos vestígios das duas fases (Paredão e Guarita) que Machado (2005) tendeu a juntar.

Aldeias circulares vêm sendo documentadas arqueológica e etnograficamente no Brasil Central, no Alto Xingu e no Caribe (Heckenberger, et al. 1999; Petersen 1996; Wüst e Barreto 1999). Na região dos grandes rios da Amazônia os relatos de cronistas apresentam aldeias lineares às margens dos rios. No Brasil Central as primeiras evidências de aldeias circulares são datadas ao redor de 800 DC e estão associadas às fases Aratu e Uru (Wüst e Barreto 1999). No Caribe aldeias circulares estariam 
presentes em ocupações associadas à fase Saladóide datadas do século V AC, antigos ancestrais dos grupos Tainos, falantes de língua Arawak, (Petersen 1996).

Nos anos 70 Donald Lathrap propôs uma correlação entre cerâmicas amazônicas da tradição Borda Incisa (Hilbert 1968 e Meggers e Evans 1961) e grupos falantes de língua Arawak. Trabalhos recentes estão apresentando dados que reforçam essa correlação. A descoberta de um complexo cerâmico mais antigo que a fase Manacapuru, a fase Açutuba, que segundo os autores seria uma manifestação de grupos Saladóides e Barrancóides na Amazônia Central (Lima, et al. 2006:47). A fase Manacapuru seria a fase Açutuba com mudanças locais em um período cronológico distinto. Em seu trabalho recente Heckenberger apresenta o conceito de Arawak Diaspora como um modelo de ocupação pan-amazônica associado a falantes de troco lingüístico Arawak e aldeias circulares (Heckenberger 2005).

A primeira evidência de uma possível aldeia circular na Amazônia Central foi encontrada na região do lago do Limão, o sítio Osvaldo, associado à fase Manacapuru, que Neves (2000) propõe como sendo o correlato de uma aldeia com malocas dispostas em círculo, hipótese que vem sendo testada no trabalho de Chirinos (2006).

A identificação de mais três sítios com evidência de aldeias com formato circular associadas à fase Paredão solidifica e existência de aldeias circulares na Amazônia Central preenchendo uma lacuna entre a arqueologia Caribenha, Xinguana e do Brasil Central.

Se considerarmos a fase Paredão como sendo uma manifestação local de mudanças dentro da fase Manacapuru e utilizarmos essa correlação para definir os produtores de cerâmica da fase Paredão como possíveis falantes de língua Arawak poderemos acrescentar mais dados para a nossa hipótese de distanciamento entre fase Paredão e Guarita.

Segundo Porro (1995) e Nimuendajú (1944[1987]) os Omágua, Kokama e Yurimágua descritos pelos exploradores do século XVI e XVII eram falantes de língua do tronco lingüístico Tupi. Aldeias lineares às margens do rio e produção de cerâmica policrômica (Poblado de la Loza - Carvajal 1542 [1942]: 36) são características atribuídas a esse povo. Porro sugere como localidade da Aldeia da Louça a margem direita do rio Solimões em frente à Ilha dos Corós e a foz do rio Badajós (Porro 1996 mapa 9), onde hoje são identificados sítios predominantemente pertencentes à fase Guarita. Lathrap (1970:150) também propôs que os responsáveis pela dispersão do 
horizonte de estilo policrômico na Amazônia seriam os ancestrais dos Omagua e Cocama históricos.

Arqueologicamente a Amazônia Central apresenta sítios da fase Açutuba, Manacapuru, Paredão e Guarita desde a foz do rio Madeira até o município de Manacapuru, acima, até o rio Napo, são encontrados principalmente sítios com cerâmicas polícromas.

Em uma tentativa de síntese da arqueologia amazônica Evans e Meggers (1968) através de estudos realizados em sítios no rio Napo, Equador, de uma revisão bibliográfica e de coleções arqueológicas de sítios ao longo do curso do rio Amazonas (Solimões e Amazonas) e seus principais afluentes, propondo uma possível rota de migração que teria dado origem aos sítios da calha do grande rio, culminando na ocupação da fase Marajoara, também previamente pesquisada por esses dois autores (Meggers e Evans 1957).

Através da comparação de traços diagnósticos das cerâmicas polícromas encontradas na região amazônica com as cerâmicas da fase Napo, os autores traçam uma possível rota de dispersão do horizonte cerâmico, indo do sopé dos Andes até a ilha de Marajó. As comparações apresentam muitos traços semelhantes desde o Napo até a desembocadura do rio Madeira, ou um pouco mais abaixo no município de Itacoatiara. Depois os traços diagnósticos semelhantes até a ilha de Marajó são menos significativos. Os autores tinham em mente um movimento migratório de descida do rio pré-estabelecido, a pouca correlação entre traços da cerâmica Marajoara e a da fase Napo foi justificada com a possibilidade de rotas alternativas para a descida, vindo dos rios Japurá e/ou Iça.

Por ocasião da construção do modelo interpretativo as datas para sítios arqueológicos ainda eram escassas no trecho comparado. Datas eram avaliáveis para a

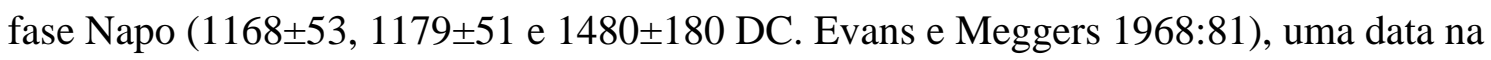
região de Coari (1150 DC. Evans e Meggers 1968:94 e 95) e o restante era apenas estimativa feita através dos resultados de seriações de coleções cerâmicas.

Quase quarenta anos depois apesar de muitas lacunas ainda existentes, avanços consideráveis foram obtidos com o estudo de arqueologia amazônica, trabalhos posteriores na ilha de Marajó (Roosevelt 1991 e Schaan 2004) demonstraram uma seqüência mais antiga para as ocupações na ilha e a possibilidade de desenvolvimento local da fase Marajoara. 
Trabalhos desenvolvidos na região de Coari (Caldarelli 1999) produziram uma seqüência de datas para a ocupação cerâmica com antiguidade que até agora não apresenta correlações com outras regiões datadas no estado do Amazonas (1.965 AC a 1.725 DC).

Na Amazônia central os trabalhos de Hilbert (1968) e Simões (1974 e 1987) começaram a definir uma seqüência cronológica para a região. As pesquisas do PAC, desenvolvidas há onze anos na região, hoje fazem da área uma das mais bem datadas da Amazônia. As mais de 100 datas produzidas pelo projeto refinaram bastante a cronologia iniciada por Hilbert e Simões. Os novos dados vão desde a descoberta de um período pré-cerâmico, até então desconhecido na região, com sítios datados em cerca de 6500 anos AC (Costa 2002; Neves 2003), a descoberta de um complexo cerâmico mais antigo (fase Açutuba $300 \mathrm{AC}-360 \mathrm{DC})^{8}$, além do refinamento das sequiências das fases Manacapuru (séculos IV -IX DC), Paredão (séculos VII a XII DC) e Guarita (séculos IX a XV DC).

De acordo com as novas hipóteses do PAC (Neves 2005a), a região do alto Madeira, em Rondônia, pode ter sido um centro de domesticação de plantas, uma das primeiras áreas com ocorrência de terras pretas e cerâmica polícroma, além de poder ser também o centro inicial de dispersão de povos falantes de línguas do tronco Tupi.

Com esses novos dados nossa proposta é de que a fase Guarita poderia estar marcando a chegada de povos falantes troco lingüístico Tupi na Amazônia Central. Ao contrário da rota proposta por Evans e Meggers, os produtores da cerâmica Guarita poderiam tem chegado ao Amazonas pelo rio Madeira, os dados até o momento apontam para um evento ocorrido por volta do século IX de nossa era. A continuidade de datações de fragmentos cerâmicos da fase Guarita por AMS poderá ajudar a precisar melhor o evento, já que geralmente os sítios da região são multicomponenciais e as cerâmicas Guarita estão nos extratos superficiais, que devido à perturbação recente não fornece boas amostras de carvão para datação.

Datas um pouco mais recuadas podem aproximar o evento da chegada dos povos da fase Guarita ao momento de transição da fase Manacapuru para a Fase Paredão, época em que os registros arqueológicos apontam para um aumento de densidade populacional na Amazônia Central. Em nosso cenário hipotético o encontro de falantes de tronco lingüístico Arawak e Tupi teria culminado nas mudanças culturais que

\footnotetext{
${ }^{8}$ Para maiores detalhes sobre a fase Açutuba ver Lima et al 2006.
} 
levaram à fase Paredão. O aumento demográfico pode estar representado pela intensa produção de cerâmica e terra preta vista em sítios como o Hatahara, Açutuba e Osvaldo (Machado 2005; Neves 2003; Lima 2004).

O aumento da densidade populacional pode ter levado a uma maior produção de cerâmica utilitária, vista em nosso trabalho pela diminuição de cerâmica decorada na fase Paredão. A intensificação de produção de cerâmica e o novo contato pode ter resultado na utilização de uma gama variada de antiplásticos na cerâmica Paredão, com a conjugação de antiplásticos presentes na fase Manacapuru e Guarita. Outro resultado pode ser também a melhoria de técnicas de confecção e queima das cerâmicas, observada através dos exemplares com paredes muito finas e bem queimadas na fase Paredão.

Como troca cultural acontece em dois pólos, algumas influências de uso de antiplásticos, modo de fabricação e decoração da cerâmica Manacapuru passam a ser observados também na fase Guarita, presença de cauixí, a urna funerária do Lago do Limão. Esse contato cultural deve ter se processado de maneira complexa, pois o período de ocorrência concomitante de cerâmica Paredão e Guarita na região é de pelo menos 300 anos. Estruturas defensivas encontradas em sítios arqueológicos da fase Paredão (Donatti 2003; Neves 2005b), podem evidenciar a existência de conflitos durante o período de contato.

Uma possível área de escape para os dois grupos, que parecem ainda se manterem distintos, seria um movimento em direção ao baixo Amazonas dos povos da fase Paredão, dando origem às cerâmicas da fase Konduri (1300 a 1500 DC) (Hilbert and Hilbert 1980) e Santarém (1000 a 1500 DC) (Gomes 2002); e os povos da fase Guarita em direção ao alto Amazonas (Solimões) representados pela predominância de sítios com cerâmica polícroma até o rio Napo.

Datas mais antigas para a fase Guarita poderão ser encontradas em sítios na região do baixo Madeira ou com a datação de novos fragmentos de cerâmica como sugerimos anteriormente, o que poderá tornar nossa hipótese mais consistente. 


\section{CONSIDERAÇÕES FINAIS}

As paginas escritas anteriormente são o resultado de aproximadamente 8.000 horas/indivíduo despedidas no campo remando, tentando fazer o motor da canoa funcionar, abrindo picadas, matando mosquitos (carapanãs), falando com pessoas, olhando para o chão, fazendo tradagem, medindo, topografando, escavando, anotando, desenhando, fotografando, corrigindo erros, tentando amenizar o ardor do sol, se escondendo da chuva... Tarefas executadas por muitas pessoas, com estilos de vida diferentes, mas com expressões extremamente semelhantes quando encontram uma urna funerária, um esqueleto, uma ponta de projétil, um fragmento de cerâmica ricamente decorado ou um novo sítio arqueológicos.

Às horas de campo acrescentamos incontáveis outras, passadas no laboratório, lendo texto ou discutindo com colegas do PAC, é principalmente daí que surgem as idéias sobre o que escrever, onde abrir novas escavações, a que materiais dedicar mais tempo de análise, um pouquinho de tudo isso resulta nesses fragmentos de história de tempos imemoriáveis esboçados aqui.

Nosso trabalho busca dados para entender o processo de ocupação pré-colonial das áreas de entorno do lago do Limão, dados utilizados para extrapolar algumas interpretações mais gerais também. A idéia do trabalho nasceu em função da existência de um sítio arqueológico unicomponencial associado à fase Manacapuru, sítio Osvaldo, datado entre o os séculos VII e VIII da era cristã. O sítio era uma anomalia dentro da área de pesquisa do Projeto Amazônia Central, pois a predominância encontrada é de sítios multicomponenciais, principalmente associados às fases Paredão e Guarita. Queríamos entender então se o lago do Limão poderia ter sido um território regional Manacapuru. Para isso fizemos um levantamento arqueológico que resultou na identificação de 15 novos sítios arqueológicos.

Após a identificação dos sítios, percebemos que no lago do Limão havia uma predominância de sítios da fase Paredão e não Manacapuru, como supúnhamos no início de nosso projeto, ou Guarita, como apontava trabalhos anteriores do PAC (Lima 2002).

Ocupações da fase Guarita também estão presentes, mas geralmente são sítios menores, ou os vestígios ocupam apenas partes da superfície de sítios multicomponenciais. Como os sítios identificados apresentam tamanho e densidade de 
materiais arqueológicos variados, escolhemos alguns para serem trabalhados em detalhe e assim tentar entender melhor o significado da variabilidade na ocupação das margens do lago do Limão.

Com os primeiros resultados o enfoque de nosso trabalho mudou um pouco. Guiada pelos resultados do levantamento nossa discussão passou a ter mais ênfase na ocupação da fase Paredão.

O processamento do material coletado na primeira etapa de campo revelou alguns sítios com presença de material da fase Manacapuru. Três sítios foram escolhidos para trabalhos mais detalhados: o sítio Lago do Limão, um sítio multicomponencial, com cerâmicas das fases Manacapuru, Paredão e Guarita. Os sítios Antônio Galo e Pilão representam as ocupações predominantes na nossa área de pesquisa, principalmente fase Paredão e também fase Guarita no caso do primeiro.

Após a realização de quatro etapas de campo e de análises do material coletado, além de características gerais do padrão de assentamento na área de pesquisa, pudemos identificar também particularidades intra-sítio, tais como: montículos, estruturas habitacionais, contextos funerários e os "currais de tartarugas", que são importantes para a definição dos diferentes contextos de ocupação da área do lago do Limão.

De acordo com as datações produzidas em trabalhos anteriores do PAC, temos certa lógica na seqüência de ocupações identificadas nos sítios de nossa área de pesquisa. As ocupações mais antigas não foram registradas nos sítios estudados, a ocupação inicial é de sítios pertencentes à fase Manacapuru e seria encontrada nos níveis mais profundos dos sítios. No período intermediário temos as ocupações da fase Paredão. As ocupações Guarita são mais superficiais e mais recentes. As datas produzidas em nosso trabalho são concordantes com as anteriores. Elas nos exemplificam que sítios complexos como o Lago do Limão são o resultado de longos períodos de ocupação, no caso uma seqüência de 1000 anos em um pacote de $80 \mathrm{~cm}$ de profundidade. As novas datas aproximam mais a fase Paredão e o período predominantemente Guarita. Isso mostra que a inter-relação entre essas duas fases pode ser mais intensa do que supúnhamos.

A sequiência cronológica das ocupações se entrecruza por volta do ano 1000 de nossa era. Esta data coincide com o período de maior densidade de sítios na região. Como pode ser observado em nosso trabalho esse é o período em que os sítios são maiores e há um processo de formação de terra preta mais intenso. Isso nos indica um pico na densidade populacional na região, de acordo com os nossos dados, associado às 
ocupações da fase Paredão. Alguns exemplos na área de pesquisa do PAC comprovam isso: o sítio Lago Grande (Donatti 2003) e o sítio Hatahara (Machado 2005).

Os sítios Paredão são predominantes, a densidade de cerâmica é maior, como pode ser observado com os resultados da análise do material dos sítios na fase Paredão há uma diminuição da porcentagem de peças decoradas no conjunto cerâmico, o que pode ser o resultado da necessidade de produção de mais vasilhas utilitárias em decorrência de uma população maior. Esse período também apresenta a maior densidade de produção de terra preta o que também ajuda a reforçar a hipótese de maior contingente populacional.

Na fase Paredão parece ter início o processo de construção de montículos artificiais. Como fica claro nos sítios estudados na região do lago do Limão, os montículos estão dispostos em circulo, nossa hipótese apresentada anteriormente é de que esses montículos estão onde seriam as unidades habitacionais, revelando o formato das aldeias circulares associado à fase Paredão. Essa é uma das principais contribuições de nosso trabalho, pois preenche uma lacuna entre a arqueologia caribenha, do Xingu e do Brasil Central e também nos leva a criação de uma hipótese de interação entre povos falantes de tronco lingüístico Arawak e Tupi na Amazônia Central.

As datações e os traços estilísticos da cerâmica sugerem um logo período de interação entre a fase Paredão e Guarita. Poderia haver um processo de mudança ocorrendo dentro do grupo responsável pelos vestígios da fase Manacapuru em função da chegada de povos produtores de cerâmica Guarita, mudando entre muitas outras coisas o modo de fazer cerâmica, levando ao material que hoje associamos à fase Paredão. Alguns dados nos levam a considerar uma forte possibilidade de chegada de outro povo no período Guarita. A distribuição da cerâmica Policrômica Guarita e algumas outras fases com pequenas diferenças estilísticas, mas com muito mais semelhanças que diferenças pode ser vista desde as proximidades da foz do rio Madeira até o rio Napo. Principalmente as urnas funerárias são muito semelhantes. A fase Paredão por outro lado, está concentrada nas proximidades de Manaus e apresenta alguns traços semelhantes com a cerâmica Konduri e talvez também a de Santarém. Cenário que poderia ser decorrente de escolhas de rotas diferentes de povos falantes de tronco lingüístico Arawak e Tupi que se encontraram na Amazônia Central.

Com base nos dados até agora obtidos, já podemos retomar algumas de nossas perguntas originais do projeto com alguns dados mais concretos. Inicialmente, queríamos saber qual seria o padrão de tamanho e densidade dos sítios arqueológicos. 
Atualmente podemos dizer que, na verdade, não existe um único padrão. Foram encontrados sítios grandes, pequenos, mais ou menos densos, unicomponenciais, multicomponenciais, com e sem presença de terra preta. Há uma variabilidade grande dos tipos de vestígios encontrados. O lago do Limão não é um território regional Manacapuru como pensávamos anteriormente, ou pelo menos não é apenas, pois os vestígios da fase Paredão, possivelmente de um período de continuidade da fase Manacapuru são os mais representativos.

Está claro que a região do lago do Limão foi mesmo um ambiente intensamente ocupado antes do início da colonização européia. Tal ocupação não se restringiu apenas a sítios da fase Manacapuru. Ao contrário, o entorno do lago apresenta uma densidade maior de vestígios das fases Paredão e Guarita, respectivamente.

Voltando aos grandes modelos de interpretação do processo de ocupação da Amazônia criados por Meggers, Lathrap e Roosevelt, nossos dados levam à conclusão de que a densidade populacional da Amazônia Central não é tão pequena e pouco desenvolvida como interpretou Meggers, nem tão grande e desenvolvida como interpretou Roosevelt. A ocupação na Amazônia central não é tão antiga quanto propunha Lathrap, mas várias de suas hipóteses, aliás, de todos esses autores, apresentam pontos que são válidos até hoje. Com base em muitos dados produzidos por esses autores terminamos nosso trabalho com uma hipótese de interpretação da diversidade encontrada através das fases arqueológicas da Amazônia Central, apresentando uma possibilidade para o aparecimento da cerâmica polícroma representada pela fase Guarita.

Para o futuro pretendemos ir em busca de dados sobre sítios na região do baixo rio Madeira que poderão ou não ajudar a acrescentar dados empíricos que validem nossa hipótese. 


\section{REFERÊNCIAS CITADAS}

Abreu, E. M.

2000 Estudo dos padrões de uso do espaço do Sítio Arqueológico Osvaldo (AM-IR-09). MAE/USP/FAPESP (Relatório de Iniciação Científica).

Acunã, C. d.

1641[1994] Novo descobrimento do grande rio das Amazonas. Agir, Rio de Janeiro.

Araújo, A. G. M.

2001 Teoria e método em arqueologia regional: um estudo de caso no Alto

Paranapanema, Estado de São Paulo. MAE/USP, (Tese de Doutorado).

Barreto, C. e J. Machado

2001 Exploring the Amazon, explaining the unknown: views from the past. In Unknown Amazon. Culture in Nature in Ancient Brazil, edited by C. McEwan, C. Barreto and E. G. Neves, pp. 232-251. 1st ed. The British Museum Press, London.

Barreto, M.

1992 História da Pesquisa Arqueológica no Museu Paraense Emílio Goeldi. Boletim do Museu Paraense Emílio Goeldi. Série Antropologia 8:203-94.

Brochado, J. P.

1984 An Ecological Model of the Spread of Pottery and Agriculture into Eastern South America, University of Illinois - PhD Dissertation.

Brochado, J. P. and D. W. Lathrap

1982 Chronologies in the New World: Amazonia.(Manuscrito inédito)

Caldarelli, S. B.

1999 Levantamento arqueológico em planejamento ambiental.

Revista do Museu de Arqueologia e Etnologia, Suplemento 3, 347-369.

Carneiro, R. L.

1983 The cultivation of Manioc Among the Kuikuru Indians of the Upper Xingu. In: Adaptative Responses in Native Amazonia, edited by R. B. Hames and W. T. Vickers, pp. 65-111. Academic Press, New York.

1995 The history of ecological interpretations of Amazonia: does Roosevelt have it right? In Indigenous Peoples and the Future of Amazonia: an Ecological Anthropology of an Endangered World, edited by L. E. Sponsel, pp. 45-69. Arizona Studies in Human Ecology, R. M. Netting, general editor. The University of Arizona Press, Tucson. 
Carvajal, G. d.

1542 [1942] Relación del Nuevo Descubrimiento del famoso Río Grande que descubrió por muy gran ventura el Capitán Francisco de Orellana. Transcrição de Oviedo y Medina, por Raul Reyes y Reyes. Biblioteca Amazonas, I, Quito.

Chirinos, R. P.

2003 Padrões de Assentamento no Sítio Osvaldo, Iranduba, Amazonas. Projeto de Mestrado. MAE/USP.

2006 Padrões de Assentamento no Sítio Osvaldo, Iranduba, Amazonas.

MAE/USP (Relatório de Qualificação).

Chmyz, Igor (ed.).

1976 Terminologia Arqueológica Brasileira para a Cerâmica. Segunda edição - revista e ampliada. Cadernos de Arqueologia - ano 1, ${ }^{\circ} 1$, Museu de

Arqueologia e Artes Populares, Universidade Federal do Paraná.

Costa, F. W.

2002 Análise das Indústrias Líticas da Área de Confluência dos Rios Negro e Solimões, MAE/USP (Dissertação de Mestrado).

2004 Estudo das Indústrias Líticas Pré-cerâmicas da Área de Confluência dos Rios Negro e Solimões. MAE/USP (Projeto de Doutorado).

Daniel, P. J.

2004 Tesouro descoberto no máximo Rio Amazonas I e II. Editora

Contraponto, Rio de Janeiro.

Denevan, W. M.

1996 A bluff model of riverine settlement in prehistoric Amazonia. Annals of the Association of American Geographers 86(4):654-681.

Donatti, P. B.

2003 A ocupação pré-colonial da área do lago grande, Iranduba, AM, MAE/USP (Dissertação de Mestrado).

Evans, C. e B. Meggers

1968 Archaeological Investigation on the Rio Napo, Eastern Ecuador. Smithsonian Contributions to Anthropology 6. Smithsonian Institution, Wasshington.

Gomes, D. M. C.

2002 Cerâmica arqueológica da Amazônia. Vasilhas da Coleção Tapajônica MAE-USP. Edusp/Fapesp/Imprensa Oficial do Estado, São Paulo.

Heckenberger, M. J.

1998 Manioc agriculture and sedentism in Amazonia: the Upper Xingu

example. Antiquity 72(277):633-648. 
2005 The Ecology of Power: Culture, Place, and Personhood in the Southern Amazon, A.D. 1000-2000. Routledge, New York.

Heckenberger, M. J., J. B. Petersen e E. G. Neves 1999 Village size and permanence in Amazonia: two archaeological examples from Brazil. Latin American Antiquity 10(4):353-376.

2001 Of lost civilizations and primitive tribes, Amazonia: reply to Meggers. Latin American Antiquity 12(3):328-333.

Hilbert, P. e K. Hilbert

1980 Resultados preliminares de pesquisa arqueológica nos rios Nhamundá e Trombetas, baixo Amazonas. Boletim do Museu Paraense Emilio Goeldi 75:111.

Hilbert, P. P.

1968 Archäologische Untersuchungen am mittleren Amazonas: Beiträge zur Vorgeschichte des südamerikanischen Tieflandes. Mit 164 Abbildungen und 11 Karten (vom Verfasser). Marburger Studien zur Völkerkunde; Bd. 1. Reimer, Berlin.

Lathrap, D. W.

1968a Aboriginal occupation and changes in river channel on the Central Ucayali, Peru. American Antiquity 33(1): 62-79.

1968b The "Hunting" Economies of the Tropical Forest Zone of South America. In: Man the Hunter, R. Lee \& I. DeVore, eds. pp. 23-29, Chicago: Aldine.

1970 The Upper Amazon. Ancient peoples and places. Thames \& Hudson, Southampton.

Lathrap, D. W. e J. Oliver

1987 Agüerito: el complejo policromo mas antiguo de America en la confluencia del Apure y el Orinoco (Venezuela). Interciencia 12:274-289.

Lima, D. M. e E. F. Alencar

2001 A lembrança da História: memória social, ambiente e identidade na várzea do Médio Solimões. Lusotopie:27-48.

Lima, H. P., E. G. Neves e J. B. Petersen 2006 La Fase Açutuba: Um novo complexo cerâmico na Amazônia Central. Arqueología Suramericana 2 - 1:26-52.

Lima, H. P.

2005 Cronologia da Amazônia Central: O significado da variabilidade da fase Manacapuru. MAE/USP (Relatório de Qualificação).

Lima, L. F.

2002 Levantamento dos Sítios de Interflúvio na Área de Confluência dos Rios Negro e Solimões, Estado do Amazonas. FAPESP(Relatório). 
2003 Levantamento Arqueológico das Áreas de Interflúvio na Área de

Confluência dos Rios Negro e Solimões, MAE/USP (Dissertação de Mestrado).

Lowie, Robert

1948 The Tropical Forests: An Introduction, In: Handbook of South American Indians, vol. 3, J. Steward, ed. Washington, DC: Bureau of American Ethnology, Smithsonian Institution, Bulletin 143, pp. 1-56.

Machado, J. S.

2003 Complexidade Social na Amazônia Central: um Estudo dos Montículos Artificiais do Sítio Hatahara. Paper apresentado no XII Encontro da Sociedade de Arqueologia Brasileira - SAB, São Paulo - SP.

2005 Montículos Artificiais na Amazônia Central: Um estudo de caso do sítio Hatahara, MAE/USP (Dissertação de Mestrado).

Mattos, C. d. M.

1980 Uma geopolítica pan-amazônica. Biblioteca do Exército, Rio de Janeiro.

Meggers B.

1970 Como interpretar a linguagem da cerâmica: Manual para Arqueólogos. Washington, DC: Smithsonian Institution.

1971 Amazonia: man and culture in a counterfeit paradise. Smithsonian Institution Press, Washington.

1990 Reconstrução do comportamento locacional pré-histórico na Amazônia. Boletim do Museu Paraense Emílio Goeldi - Série Antropologia 6(2):183-203.

1992a Cuarenta años de colaboración. In Prehistoria Sudamericana: Nuevas Perspectivas, edited by B. J. Meggers, pp. 26-13. Taraxacum, Washington: DC.

1992b Prehistoric population density in the Amazon Basin. In Disease and demography in the Americas, edited by J. W. Verano and D. H. Ubelaker, pp. 197-205. Smithsonian Institution Press, Washington D.C.

1995 Judging the future by the past: the impact of environmental instability on prehistoric Amazonian populations. In Indigenous Peoples and the Future of Amazonia: an Ecological Anthropology of an Endangered World, edited by L. E. Sponsel, pp. 1543. Arizona Studies in Human Ecology, R. M. Netting, general editor. The University of Arizona Press, Tucson.

Meggers, B. J. and C. Evans

1957 Archeological investigations at the mouth of the Amazon. Smithsonian Institution Bulletin No 167. Bureau of American Ethnology. Smithsonian Institution Press, Washington. 
1961 An experimental formulation of Horizon Styles in the Tropical Forest Area of South America. In Essays in Pre-Columbian Art and Archaeology, edited by S. K. Lothrop, pp. 372-388. Harvard University Press, Cambridge.

1970 Como Interpretar a Linguagem da Cerâmica: Manual para Arqueólogos. Smithsonian Institution, Washington, DC.

Moraes, C. P.

2003 Projeto de Levantamento Arqueológico das Margens do Lago do Limão, Município de Iranduba. MAE/USP.

Myers, T. P.

1973 Toward the Reconstruction of Prehistoric Community Patterns in the Amazon Basin. In Variation in Anthropology, edited by D. L. J. Douglas, pp. 233 - 252. Urbana:Illinois Archaeological Survey.

Neves, E. G.

1999 Duas Interpretações para Explicar a Ocupação Pré-Histórica na

Amazônia. In Pré-História da Terra Brasilis, edited by M. C. Tenório. Editora da UFRJ, Rio de Janeiro.

2000 Levantamento arqueológico da área de confluência dos rios Negro e Solimões, estado do Amazonas. USP/FAPESP. (Relatório).

2001 Indigenous Historical Trajectories in the Upper Rio Negro Basin. In Unknown Amazon. Culture in Nature in Ancient Brazil, edited by C. McEwan, C. Barreto and E. G. Neves, pp. 256-286. 1st ed. The British Museum Press, London.

2002 Levantamento Arqueológico da Área de Confluência dos rios Negro e Solimões, Estado do Amazonas:Continuidade das Escavações, Análise da Composição Química e Montagem de um Sistema de Informações Geográficas. FAPESP. (Relatório)

2003 Levantamento arqueológico da área de confluência dos rios Negro e Solimões, Estado do Amazonas: Continuidade das escavações, análise da composição química e montagem de um sistema de informações geográficas. Universidade de São Paulo (USP)/Fundação de Amparo à Pesquisa do Estado de São Paulo (FAPESP) (Relatório).

2005a Cronologias Regionais, Hiatos e Continuidades na História Pré-colonial da Amazônia. Museu de Arqueologia e Etnologia - Univrsidade de São Paulo (MAEUSP-FAPESP) (Projeto Temático).

2005b Warfare in Precolonial Amazonia: when Carneiro meets Clastres. In Warfare in Cultural Context: Practice Theory and the Archaeology of War, edited by A. Nielsen and W. Walker. University of Arizona Press, Tucson.

Neves, E. G. e J. Petersen

2006 Political Economy and Pré-columbian Landscape Transformations in Central Amazonia. BALÉE William e ERICKSON, Clark (eds.). Time and 
complexity in historical ecology: studies from the neotropical lowlands. New York: Columbia University Press, 279 - 309.

Neves, E. G., J. Petersen, R. Bartone e C. A. da Silva 2003 Historical and socio-cultural origins of Amazonian Dark Earths. In Amazonian Dark Earths: Origin, properties, management, edited by J. Lehmann, D. C. Kern, B. Glaser and W. Woods, pp. 29-50. Kluwer Academic Publishers, Dordrecht.

2004 The timing of terra preta formation in the central Amazon:

Archaeological data from three sites. In Amazonian dark earths: Explorations in space and time, edited by a. W. I. W. B. Glaser, pp. 125-134. Springer Verlag, Berlin.

Nimuendajú, C.

1948 The Mura and Piraha. In Handbook of South American Indians, edited by J. Steward, pp. 255 - 269. Bureau of American Ethnology, Bulletin 143. vol. 3. Smithsonian Institution, Washington, DC.

1987 Mapa etno-histórico de Curt Nimuendajú. IBGE, Rio de Janeiro.

2004 In Pursuit of a Past Amazon - Archaeological Researches in the Brazilian Guyana and in the Amazon Region. Translated by S. Rydén and P. Stenborg. Göteborg.

Oliver, J.

1989 The Archaeological, linguistic and etnohistorical evidence for the expansion of Arawakan into Northwestern Venezuela and Northeastern Colombia, University of Illinois.

Petersen, J., E. G. Neves e W. I. Woods 2005 Tropical Forest Archaeology in Central Amazonia: Landscape Transformation and Sociopolitical Complexity. Paper presented at the 70th annual meeting of the Society for American Archaeology, Salt Lake City.

Petersen, J. B.

1996 Archaeology of Trants, Montserrat.3. Chronological and settlement data. Annals Of Carnegie Museum 65(4):323-361.

Petersen, J. B., E. G. Neves, R. N. Bartone e M. A. Arroyo-Kalin 2004 An Overview of Amerindian Cultural Chronology in the Central Amazon. In paper presented at the 69th SAA Annual Meeting, Montreal.

Petersen, J. B., E. G. Neves e M. J. Heckenberger 2001 Gift from the past: terra preta and prehistoric occupation in Amazonia. In Unknown Amazon. Culture in Nature in Ancient Brazil, edited by C. McEwan, C. Barreto and E. G. Neves, pp. 86-107. 1st ed. The British Museum Press, London.

Porro, A. 
1995 O povo das aguas: ensaios de etno-historia amazônica. Vozes (Petrópolis) - EdUSP, São Paulo.

Prous, A.

1991 Arqueologia brasileira. Editora UnB, Brasília.

Rebellato, L.

2006 Interpretando a Variabilidade Cerâmica e as Assinaturas Químicas e Físicas do Solo no Sítio Arqueológico Hatahara. MAE/USP (Relatório de Qualificação).

Robrahn-González, E.

1996 A ocupação ceramista pré-colonial do Brasil central: origens e desenvolvimento. Tese de Doutoramento, FFLCH/ USP.

Roosevelt, A.

1980. Parmana: Prehistoric maize and manioc subsistence along the Amazon and Orinoco. Academic Press., New York.

1989 Resource management in Amazonia before the conquest: Beyond ethnographic projection. In Resource Management in Amazonia: indigenous and folk strategies, edited by D. A. Posey and W. Balée, pp. 30-62. vol. 7, A. i. E. Botany, general editor. The New York Botanical Garden, New York.

1991 Determinismo ecológico na interpretação do desenvolvimento social indígena da Amazônia. In Origens, adaptações e diversidade biologica do homem nativo da Amazônia, edited by W. A. Neves, pp. 103-142. 1st ed. MPEG - CNPq - SCT, Belém do Pará.

1991 Moundbuilders of the Amazon. Geophysiscal archaeology on Marajo Island, Brazil. Academic Press, New York.

1992 Arqueologia Amazônica. In História dos Índios no Brasil, edited by M. Carneiro da Cunha, pp. 53-86. 2nd ed. Compahia das Letras - FAPESP - SMC (São Paulo) - Editora Schwarcz, São Paulo.

1995 Early pottery in the Amazon: twenty years of scholarly obscurity. In The emergence of pottery: technology and innovation in ancient societies, edited by W. K. Barnett and J. W. Hoopes, pp. 115-131. Smithsonian series in archaeological inquiry, R. M. Adams and B. D. SMith, general editor. Smithsonian Institution, Washington.

Roosevelt, A., J. Douglas e L. Brown

2002 The Migrations and Adaptations of the First Americans: Clovis and PréClovis Viewed from South America. In The First Americans, The Pleistocene Colonization of the New World, edited by N. Jablonski, pp. 159-235. vol. 27. Memoirs of the California Academy of Sciences, San Francisco. 
Roosevelt, A., R. A. Housley, M. I. da Silveira, S. Maranca e R. Johnson 1991 Eighth millenium pottery from a prehistoric shell midden in the Brazilian Amazon. Science 254(5038):1621-1624.

Roosevelt, A., M. Lima da Costa, C. Lopes Machado, M. Michab, N. Mercier, H. Valladas, J. Feathers, W. Barnett, M. Imazio da Silveira, A. Henderson, J. Silva, B.

Chernoff, D. S. Reese, J. A. Holman, N. Toth e K. Schick 1996 Paleoindian cave dwellers in the Amazon: the peopling of the Americas. Science 272 (5260):373-384.

Rye, O. S.

1981 Pottery Technology principles and reconstruction. Manuals on archaeology 4. Taraxacum Inc., Washington.

Schaan, D.

2004 The Camutins Chiefdom, University of Pittsburgh, PhD Dissertation.

Shepard, A. O.

1956 Ceramics for the archaeologist. Washington, Carnegie Institute of Washington, 1956.

Schiffer, M. B., A. P. Sullivan e T. C. Klinger

1978 The design of archaeological surveys. World Archaeology 10:1-28.

Simões, M. F.

1972 Índice de fases Arqueológicas Brasileiras - 1950-1971. Museu Paraense

Emílio Goeldi.

1974 Contribução á arqueologia dos arredores do baixo rio Negro, Amazonas. Programa Nacional de Pesquisa Arqueológicas. Resultados preliminares do quinto ano 1969-1970. Publicações avulsas (5):165-188.

1987 Pesquisas arqueológicas no baixo/medio Rio Madeira (Amazonas).

Revista de Arqueologia, Belém 4(1):117-133.

Souza, L. C. G. F. d.

1970 Projeto Rondon V - Relatório individual de Luiz Carlos Guedes Freire de

Souza (Arqueologia) e documentos avulsos. Ministério do Interior.

Steward, J.

1948 Culture areas of the tropical rainforest. In The handbook of South American indians, edited by J. Steward, pp. 883-903. vol. 3. Bureau of American Ethnology, Smithsonian Institution (Bulletin 143), Washington DC.

Tamanaha, E. K.

2006 Estudo de uma Estrutura Artificial no Sítio Hatahara, rio Solimões, Estado do Amazonas. Museu de Arqueologia e Etnologia, Relatório Final do Projeto de Iniciação Científica. MAE, USP, FAPESP.

Viveiros de Castro, E. 
1996 Images of nature and society in Amazonian ethnology. Annual Review of Anthropology 25(1):179-200.

Wüst, I.

1994 The Eastern Bororo from na Archaeological Perspective. I Roosevelt, A.C. (ed). Amazonian Indians. From prehistory to present. Tucson \& London, the University of Arizona Press: 315-342.

Wüst, I. e C. Barreto

1999 The ring villages of central Brazil: a challenge for Amazonian archaeology. Latin American Antiquity 10(1): 3-23. 
Anexos 


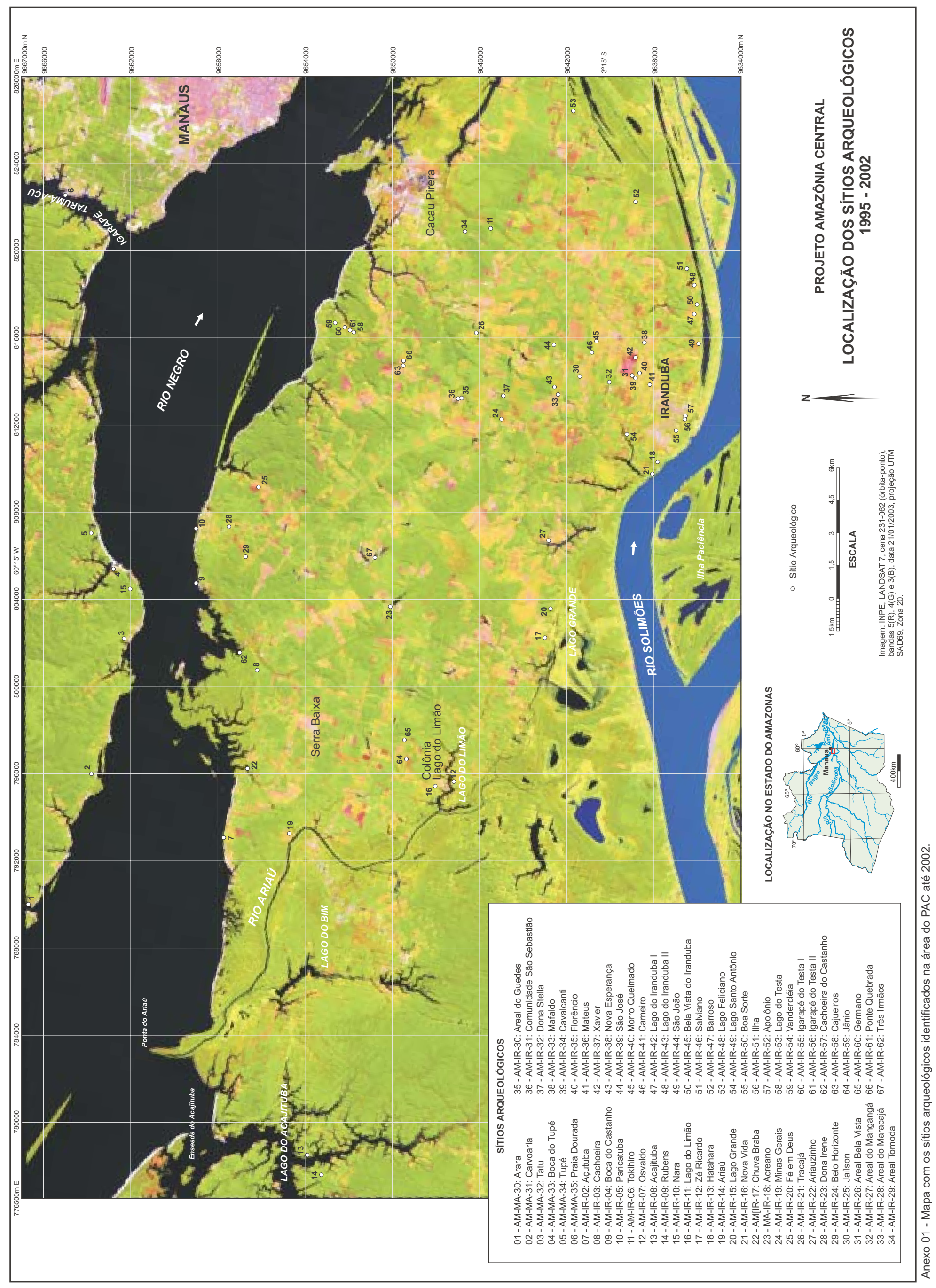




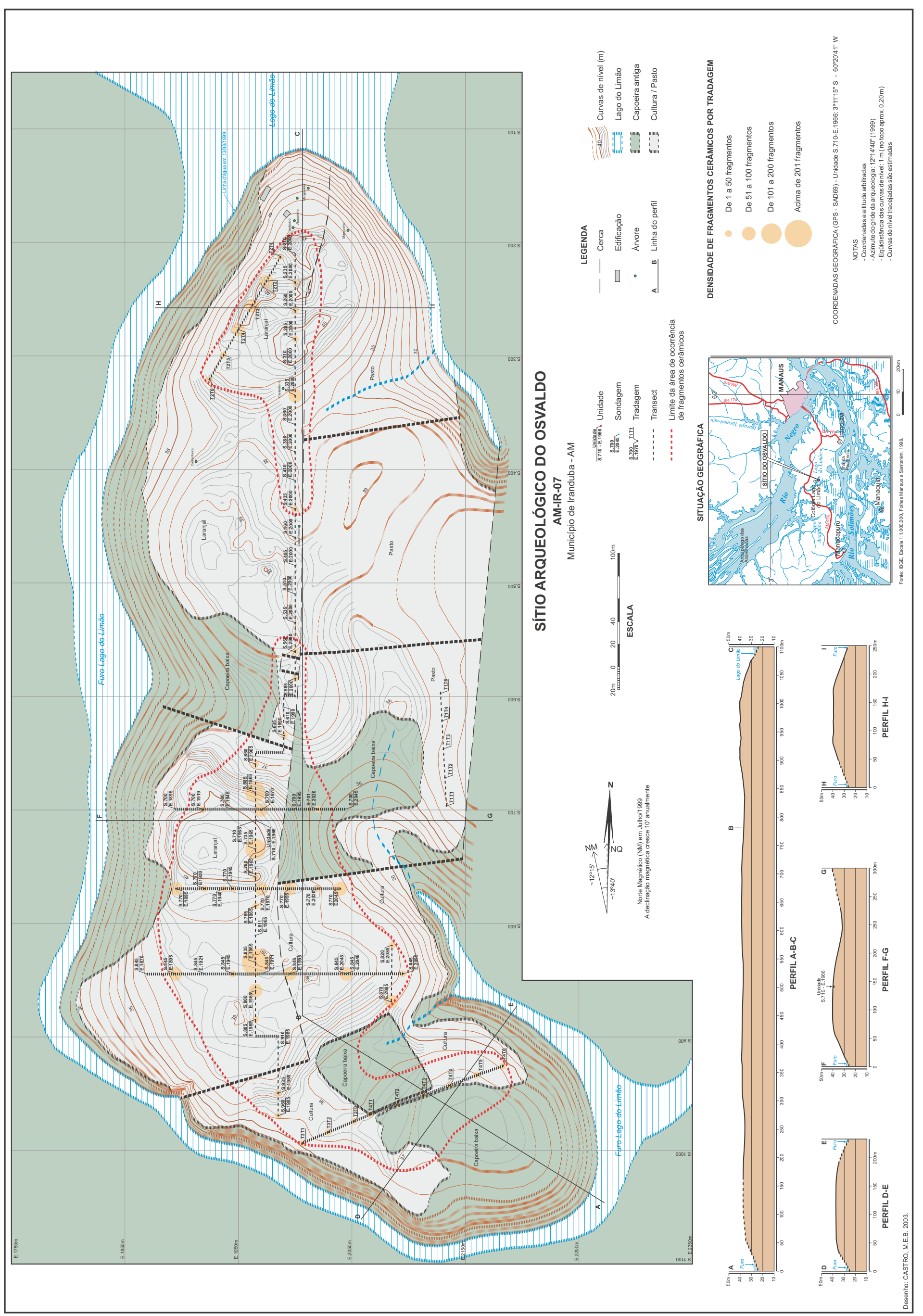


Datas radiocarbônicas (não calibradas) obtidas na escavação do sítio Osvaldo (agosto 1999).

\begin{tabular}{|c|c|c|c|c|}
\hline Amostra (PN) ${ }^{1}$ & Proveniência & Prof. (cm) & Data (1i ) & $\mathrm{N}^{\circ} \mathrm{lab}$ \\
\hline 497 & S710 E1966 & Z $41^{2}$ & $1550 \pm 40 \mathrm{BP}$ & Beta 143608 \\
\hline 498 & S710 E1966 & Z $41^{3}$ & $1290 \pm 30 \mathrm{BP}$ & Beta 143609 \\
\hline 499 & S710 E1966 & Z $35^{4}$ & $1370 \pm 40 \mathrm{BP}$ & Beta 143610 \\
\hline 234 & S710 E1966 & Z 34 & $1730 \pm 90 \mathrm{BP}$ & Beta 143611 \\
\hline 248 & S710 E1966 & Z 36 & $1330 \pm 40 \mathrm{BP}$ & Beta 143612 \\
\hline 362 & S710 E1966 & Z 45 & $1290 \pm 40 \mathrm{BP}$ & Beta 143613 \\
\hline 368 & S710 E1966 & Z 42 & $1360 \pm 50 \mathrm{BP}$ & Beta 143614 \\
\hline 167 & S710 E1966 & Z 54 & $1440 \pm 70 \quad \mathrm{BP}$ & Beta 143615 \\
\hline 170 & S710 E1966 & z $50-60^{5}$ & $1350 \pm 30 \mathrm{BP}$ & Beta 143616 \\
\hline 435 & S710 E1966 & Z 61 & $1340 \pm 40 \mathrm{BP}$ & Beta 143617 \\
\hline 505 & S710 E1966 & Z 66 & $1350 \pm 40 \mathrm{BP}$ & Beta 143618 \\
\hline 456 & S710 E1966 & Z 73 & $1320 \pm 60 \mathrm{BP}$ & Beta 143619 \\
\hline 457 & S710 E1966 & Z 76 & $1310 \pm 40 \mathrm{BP}$ & Beta 143620 \\
\hline 471 & S710 E1966 & z $80-90^{6}$ & $1980 \pm 80 \mathrm{BP}$ & Beta 143621 \\
\hline 474 & S710 E1966 & Z $90-100^{7}$ & $2120 \pm 40 \mathrm{BP}$ & Beta 143622 \\
\hline 267 & S845 E1921 SE & Z $50-60^{8}$ & $1740 \pm 30 \mathrm{BP}$ & Beta 143624 \\
\hline 270 & S845 E1921 SE & Z $60-70^{9}$ & $1260 \pm 30 \mathrm{BP}$ & Beta 143623 \\
\hline 581 & S845 E2046 SE & Z 40-43 & $1100 \pm 40 \mathrm{BP}$ & Beta 143626 \\
\hline 332 & S700 E1895 SE & Z 20-30 & $1350 \pm 40 \mathrm{BP}$ & Beta 143627 \\
\hline
\end{tabular}

1 Todas as amostras são de fragmentos de carvão

2 perfil

3 perfil

4 perfil

5 associado à fragmento diagnóstico

6

7

7 peneira

8 peneira

9 Peneira

Anexo 03 (fonte: Neves 2003) 


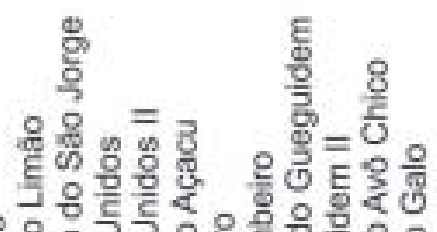

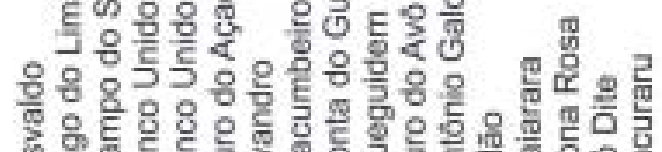

摸

\$

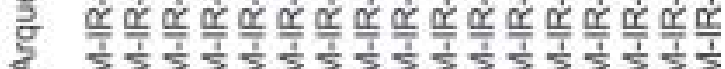

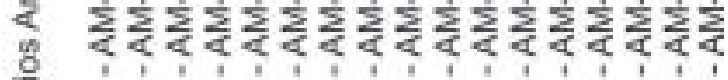

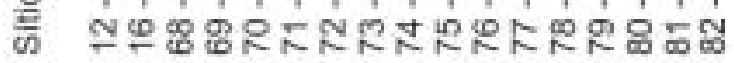

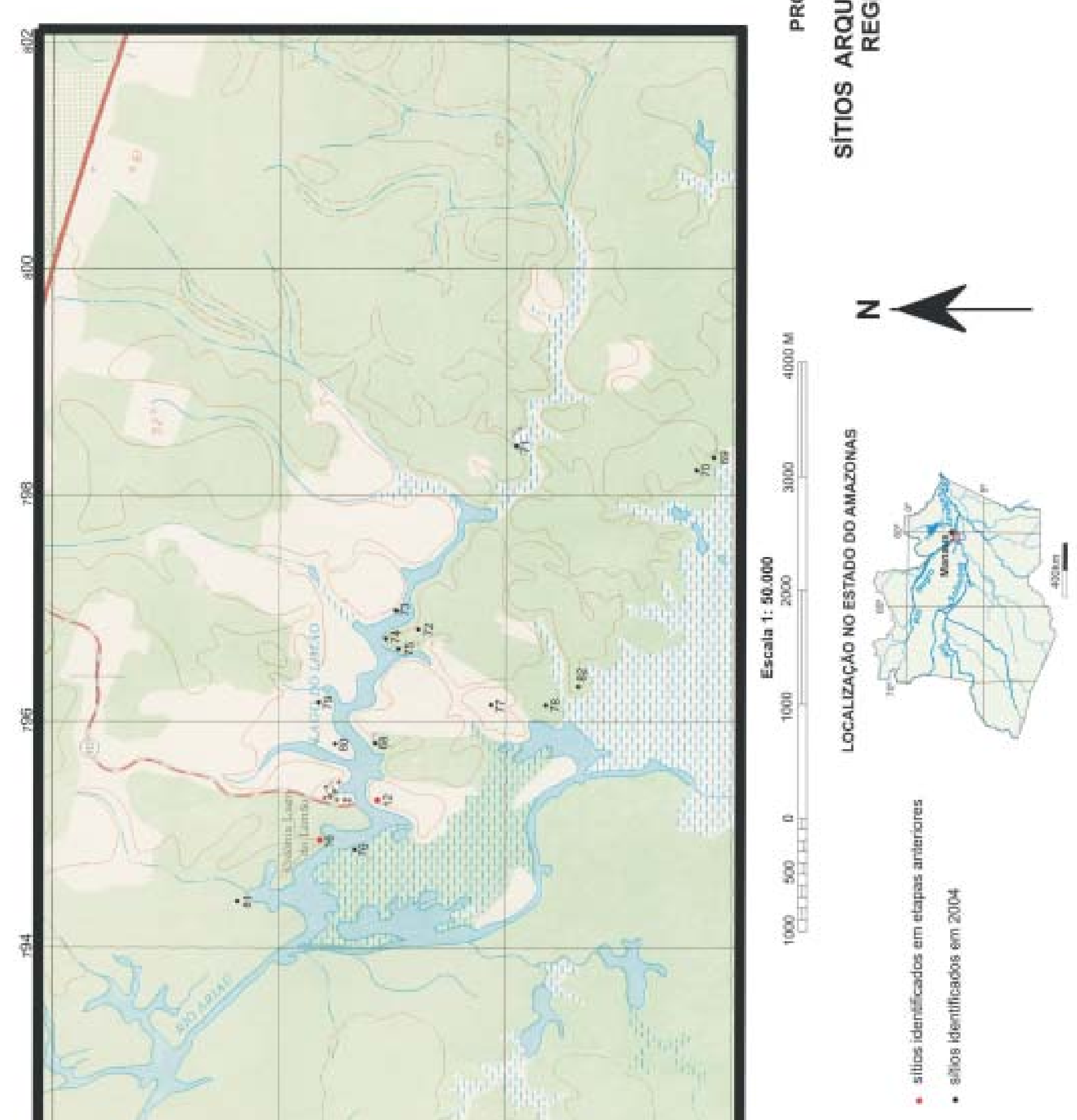

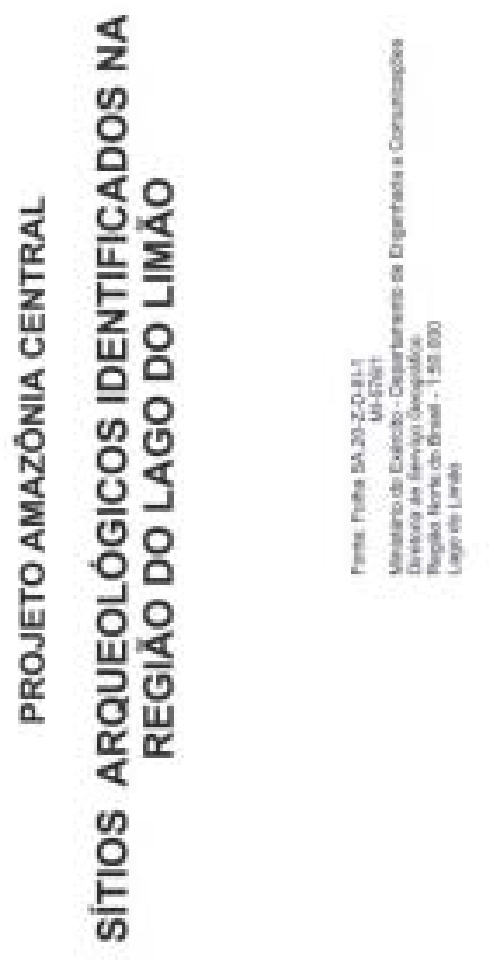

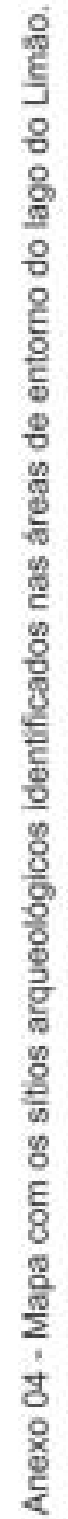


MUSEU DE ARQUEOLOGIA E ETNOLOGIA

UNIVERSIDADE DE SÃO PAULO

FICHA DE NÚMEROS DE PROVENIÊNCIA

Projeto:

Setor: Sítio: Data:

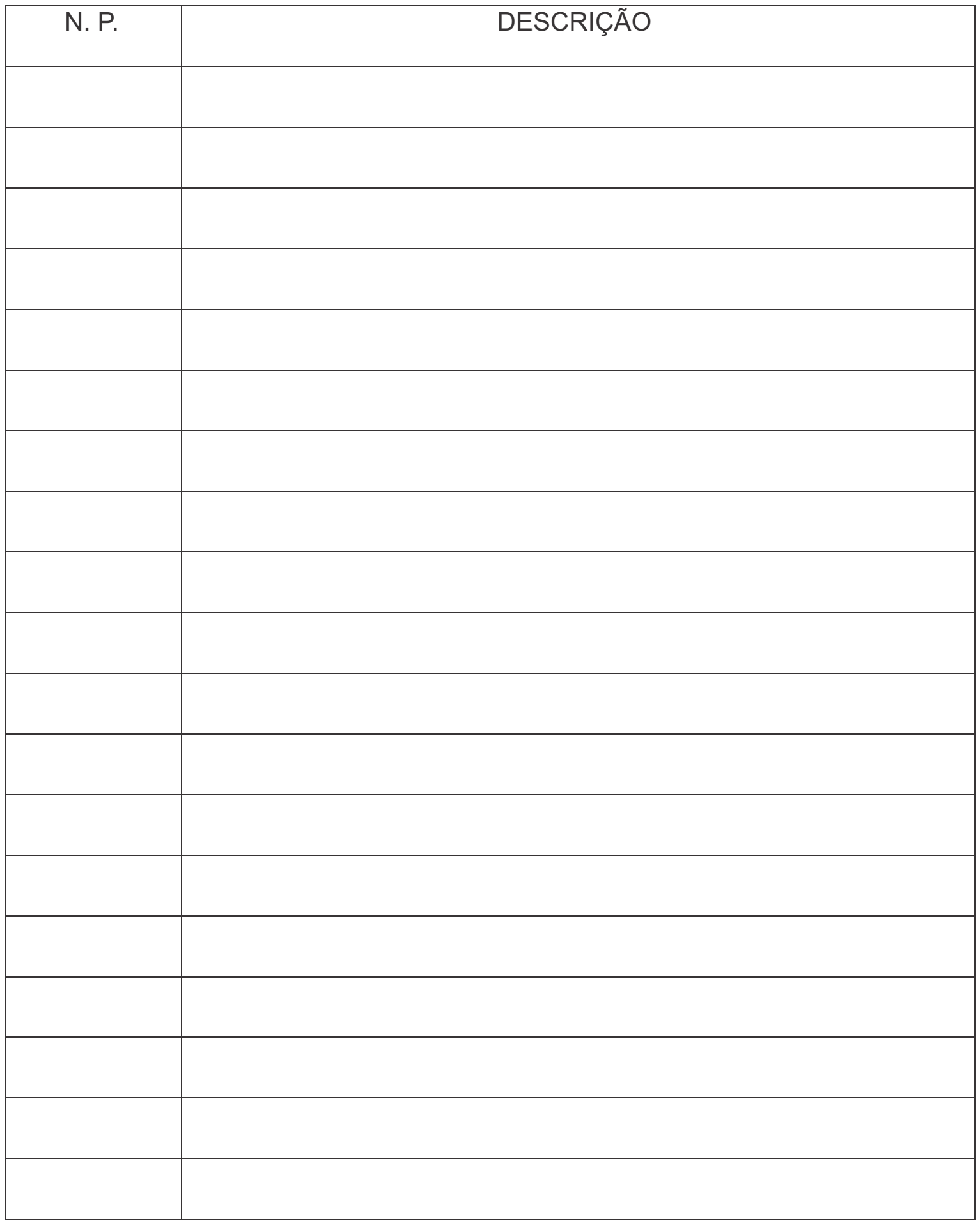

Sigla:

Resp: 


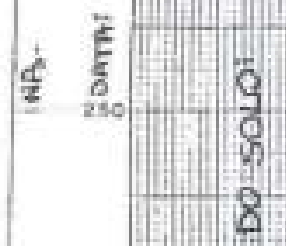

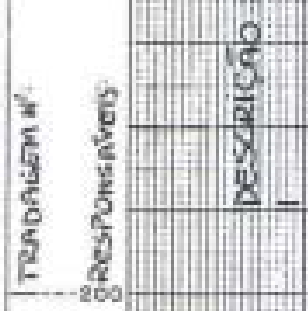

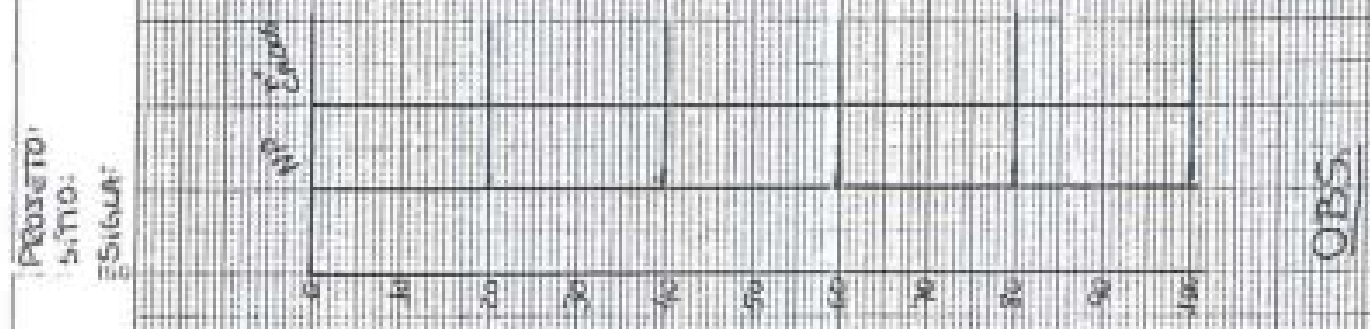

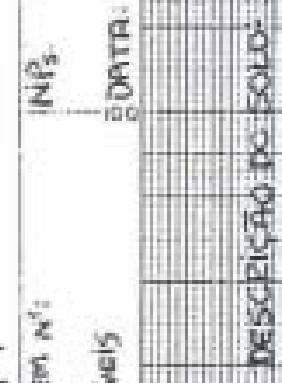

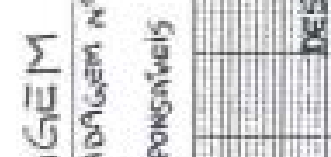

亭起

$\frac{\pi}{\alpha}$

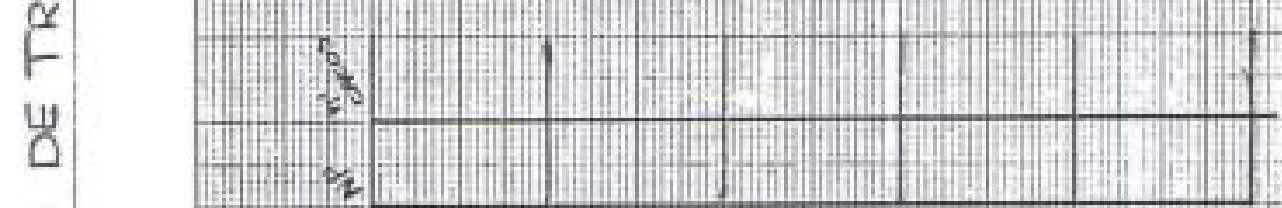

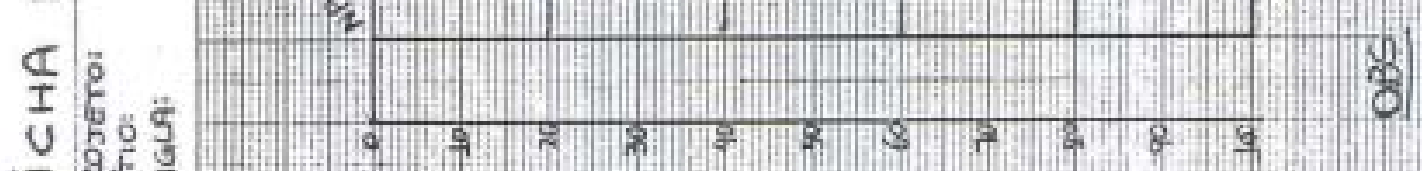

L灰步 


\section{MUSEU DE ARQUEOLOGIA E ETNOLOGIA UNIVERSIDADE DE SÃO PAULO FICHA DE SONDAGEM}

Projeto: Sítio:

Sigla: Sond. $\mathrm{N}^{\circ}$.

Data: Coletor: Resp.:

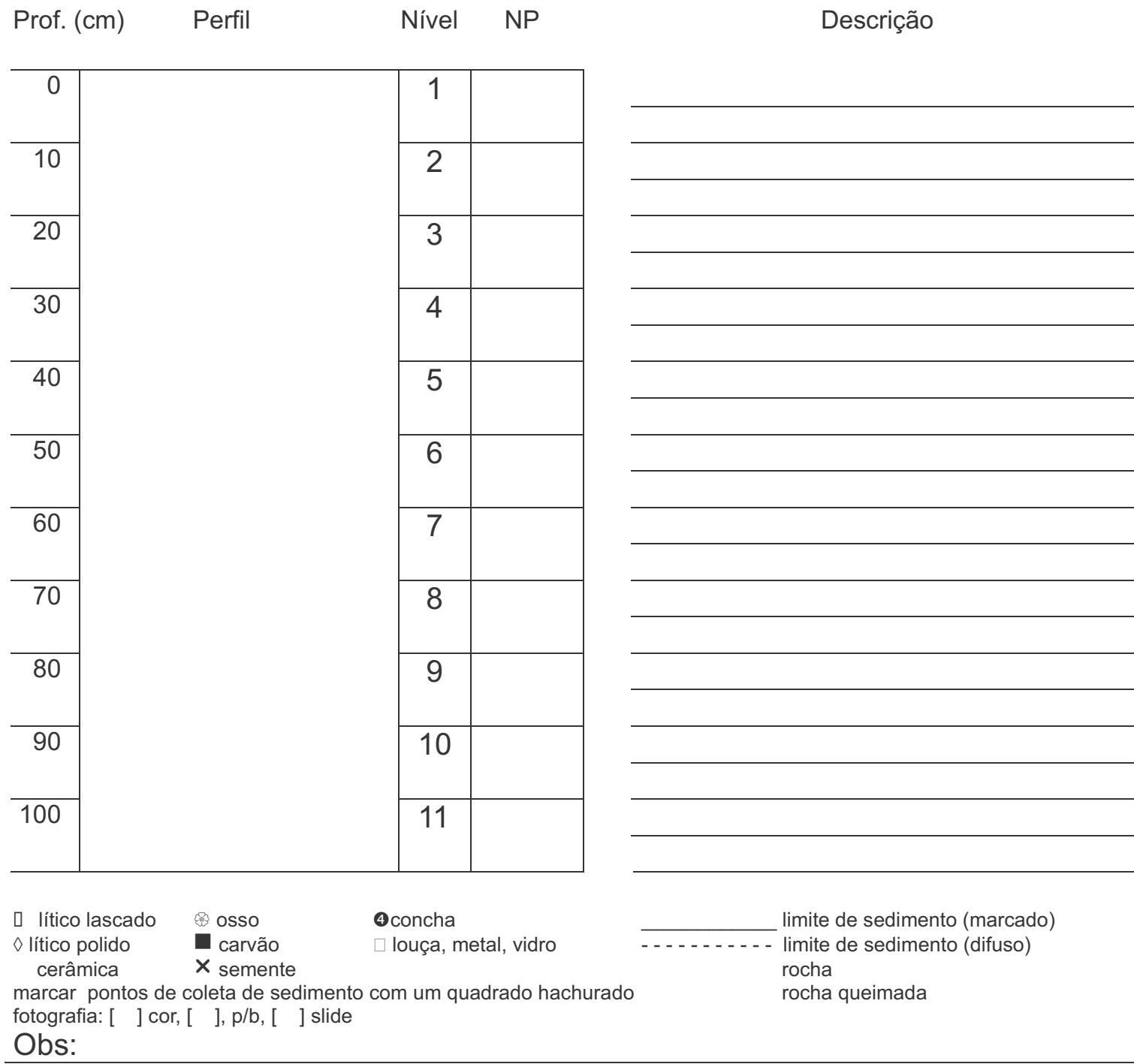




\section{MUSEU DE ARQUEOLOGIA E ETNOLOGIA \\ UNIVERSIDADE DE SÃO PAULO \\ FICHA DE NIVEL DE ESCAVAÇÃO}

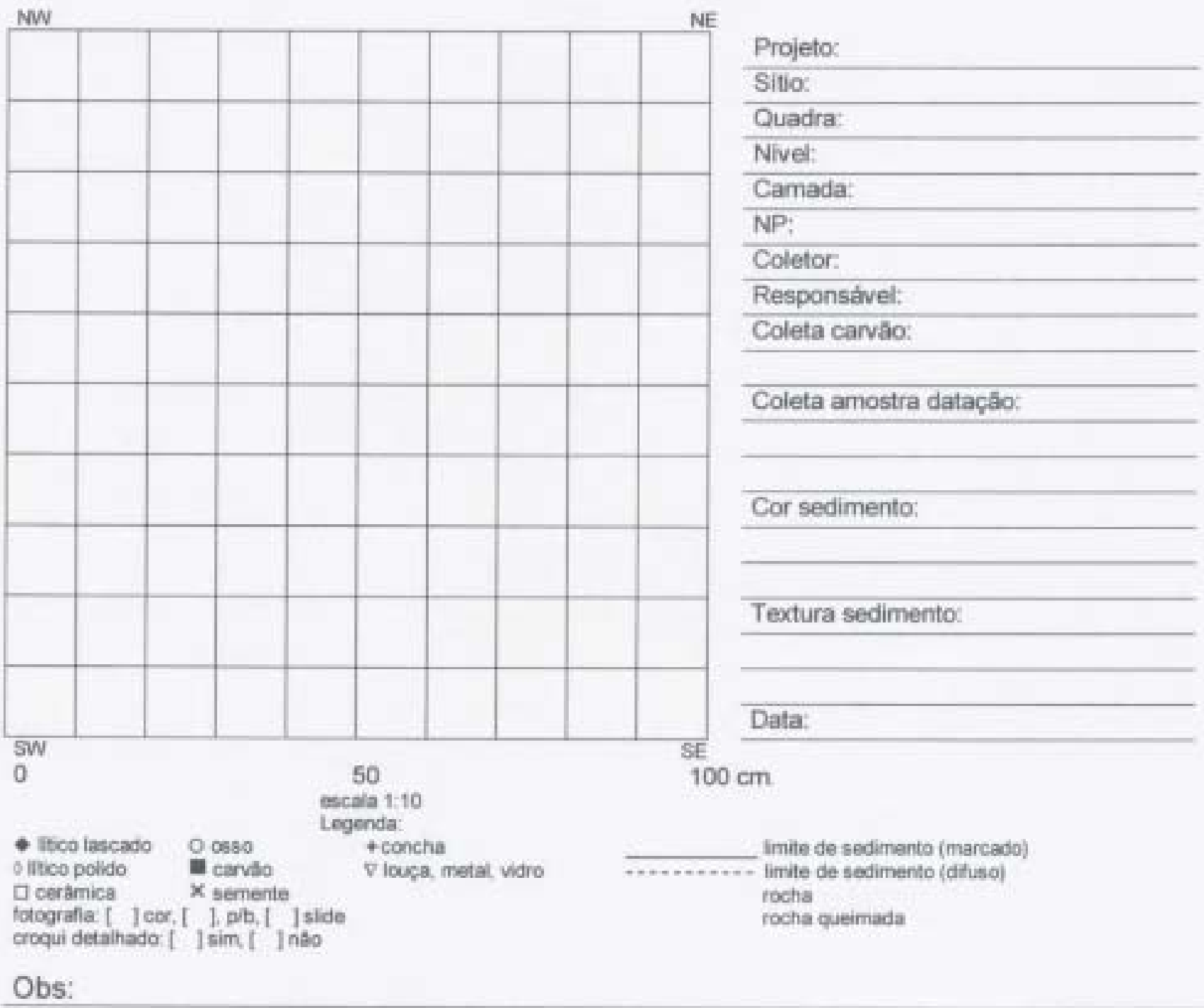



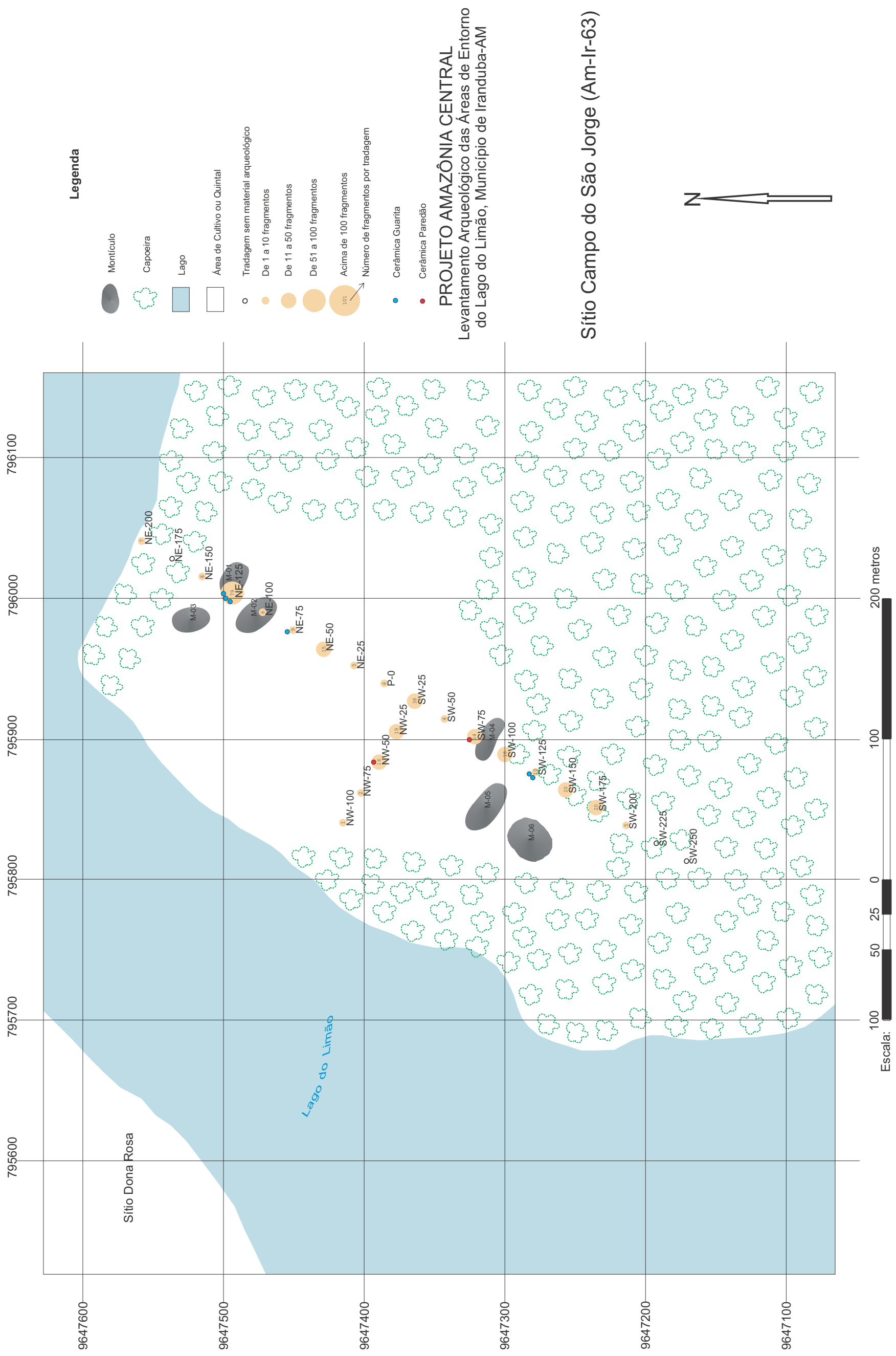


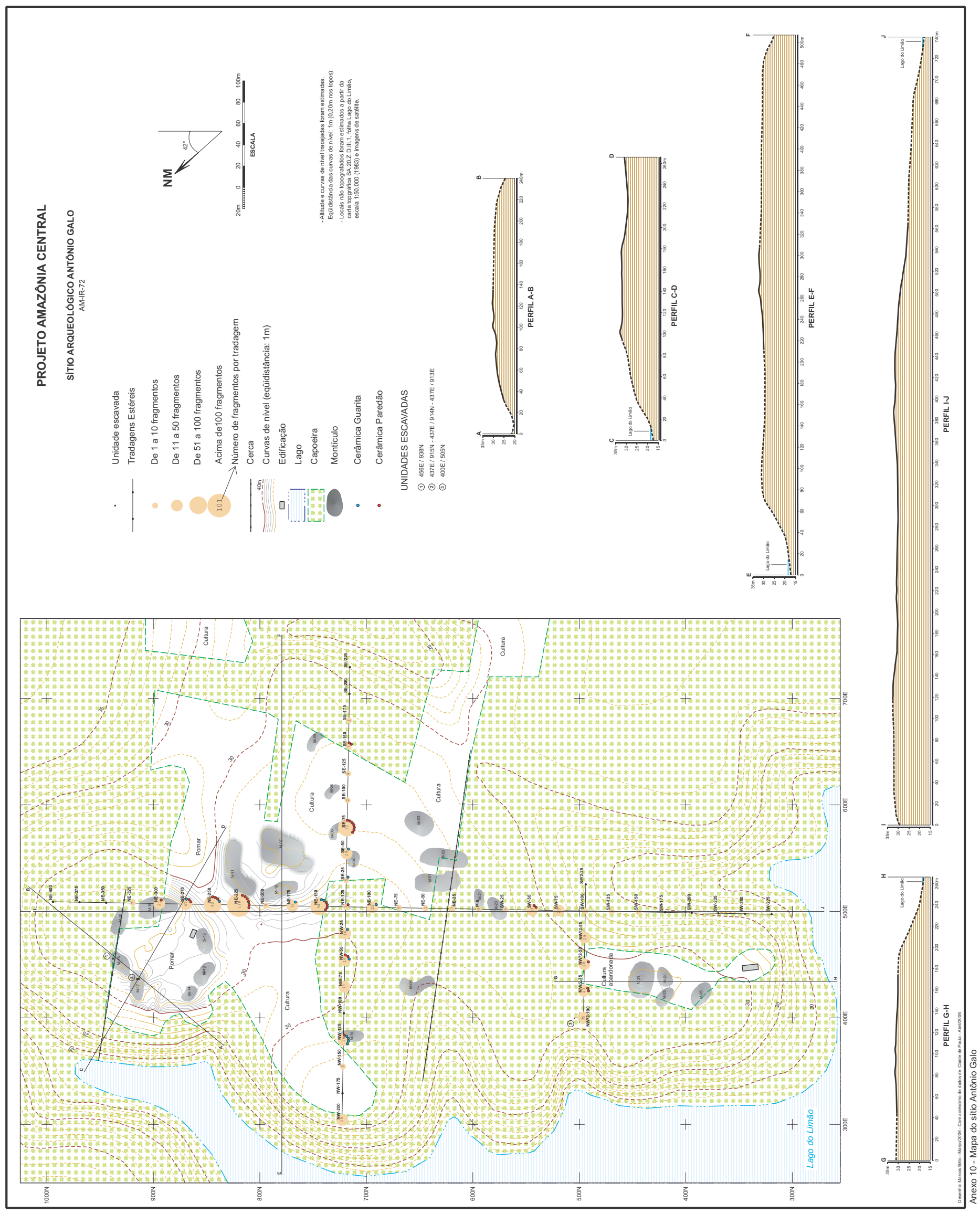



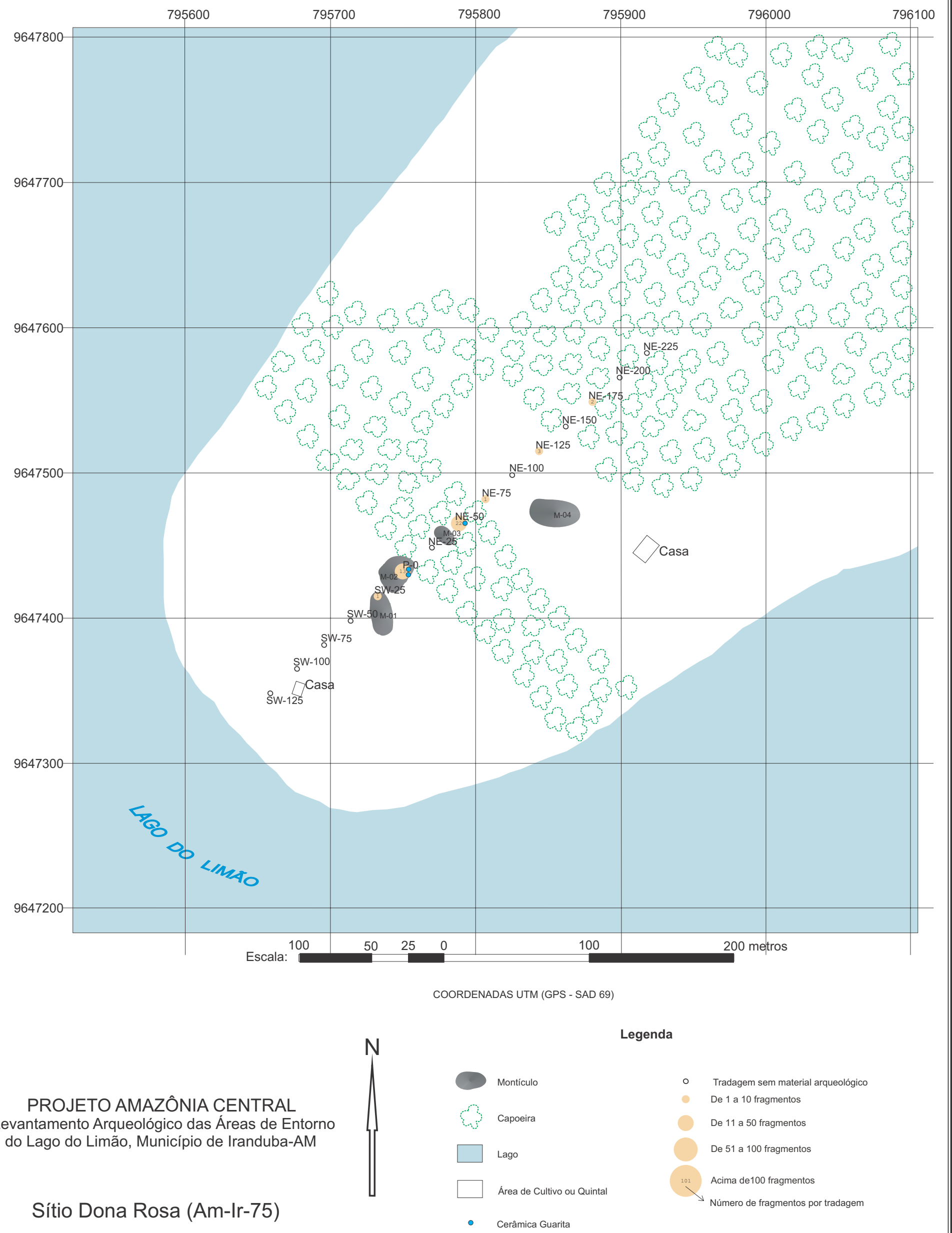

Sítio Dona Rosa (Am-Ir-75) 

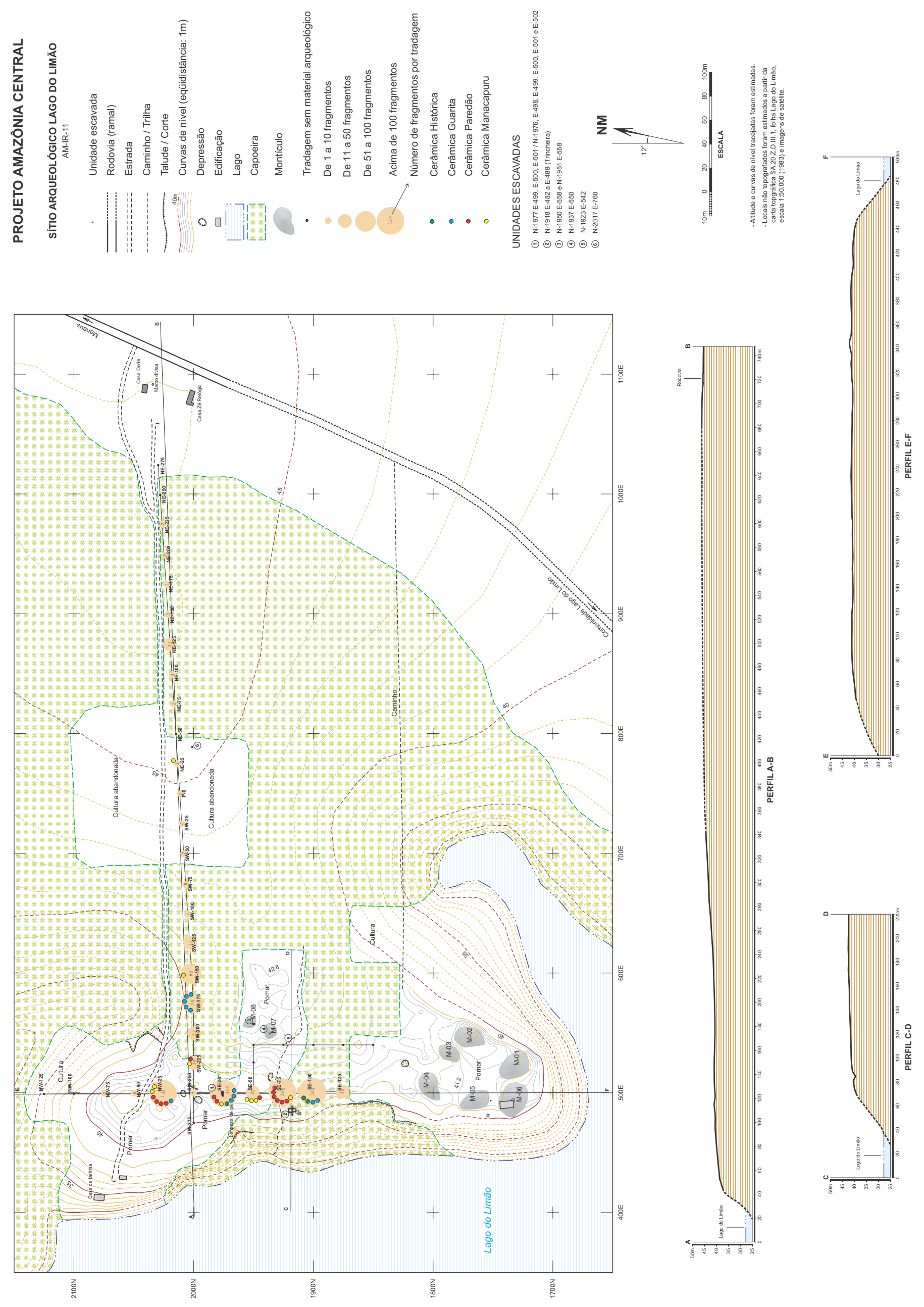


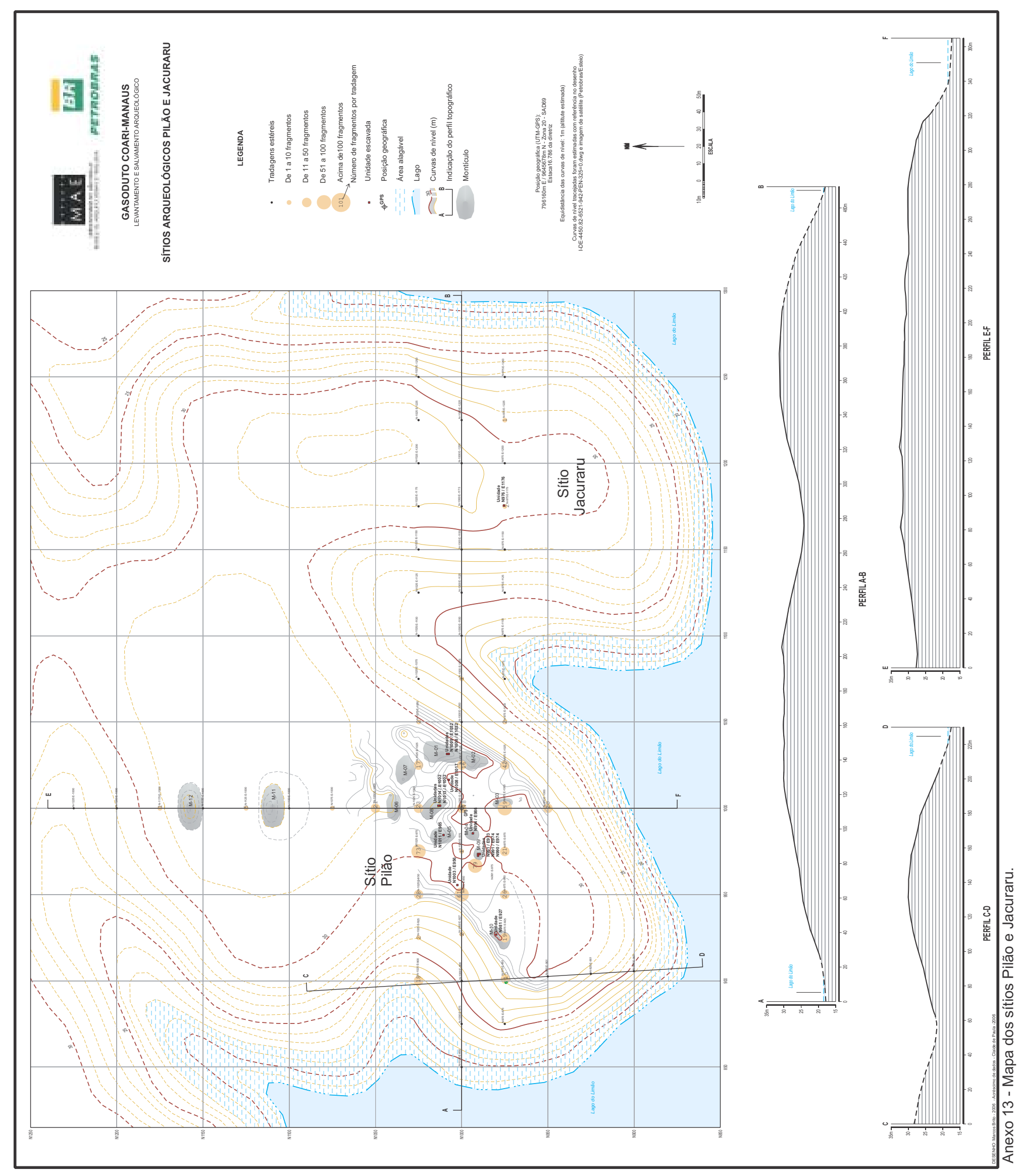


MUSEU DE ARQUEOLOGIA E ETNOLOGIA

UNIVERSIDADE DE SÃO PAULO

FICHA DE CATALOGAÇÃO DE OSSOS

Número

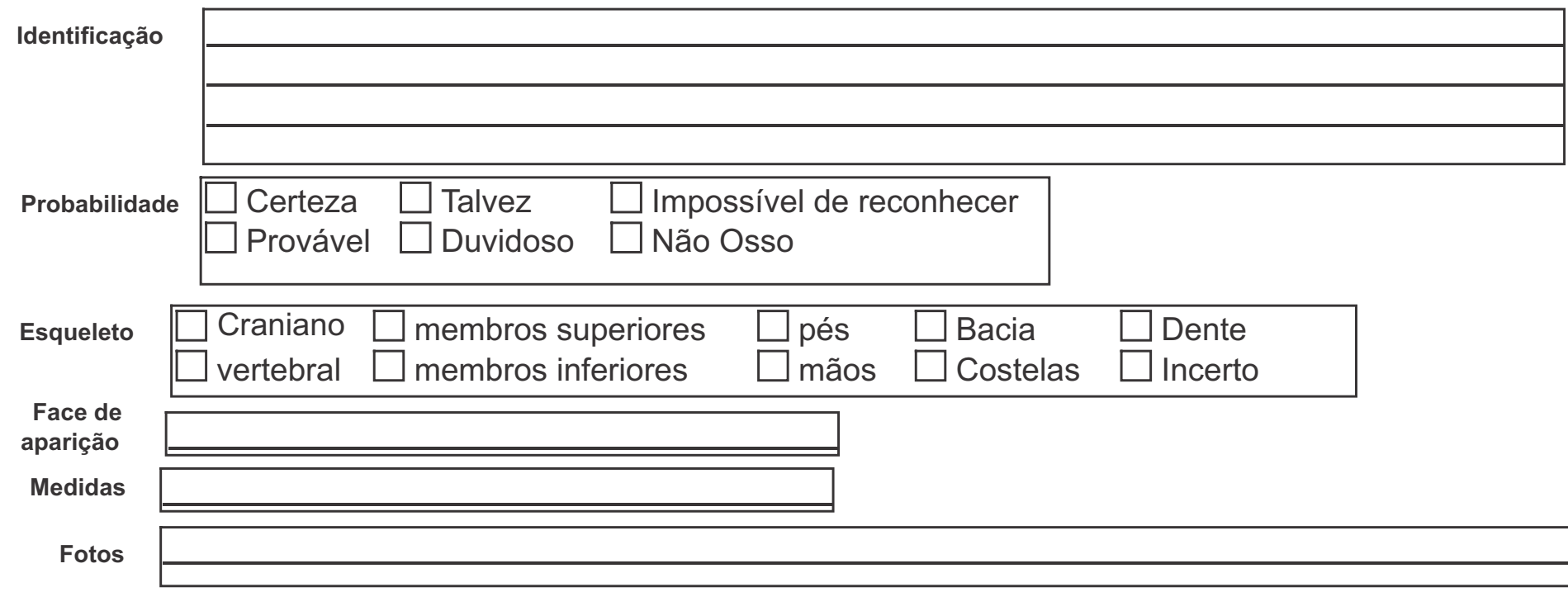

Fase de desmontagem

Nível

OBS.

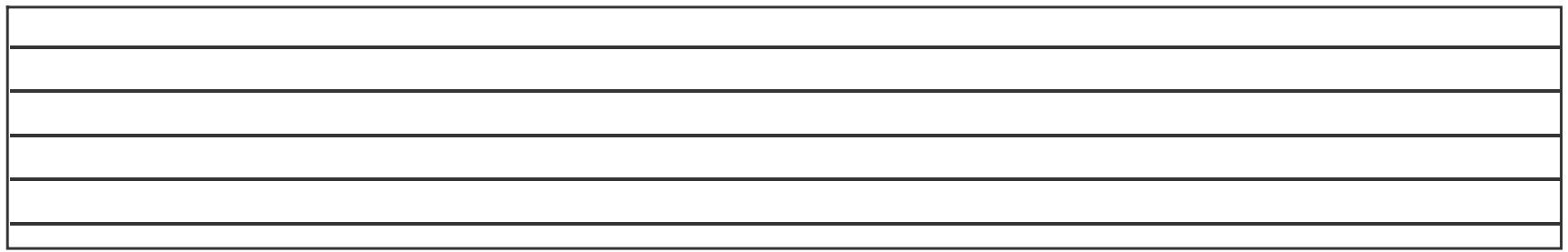


Exemplares do tipo 1 - Cuia com Pedestal

(Exclusivamente associados à fase Paredão)

Sítio Pilão

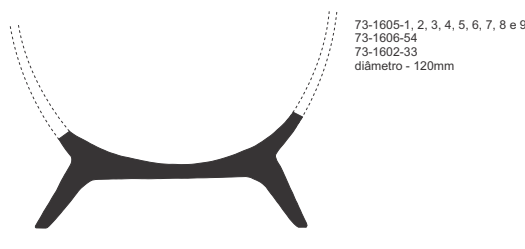

73-1966-1
diâmetro- $180 \mathrm{~mm}$
Sítio Lago do Limão
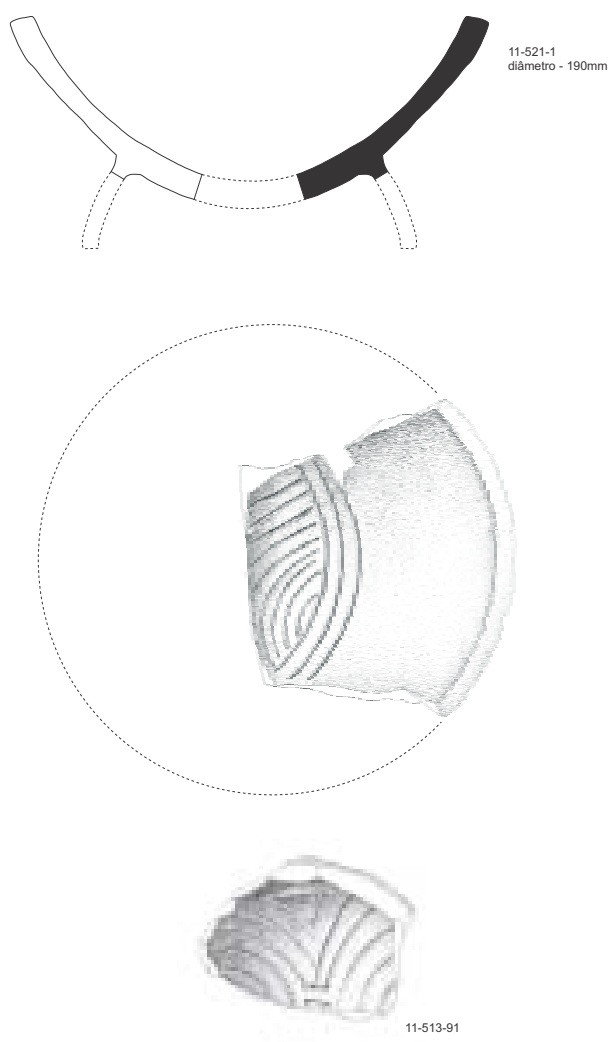

Sítio Antônio Galo

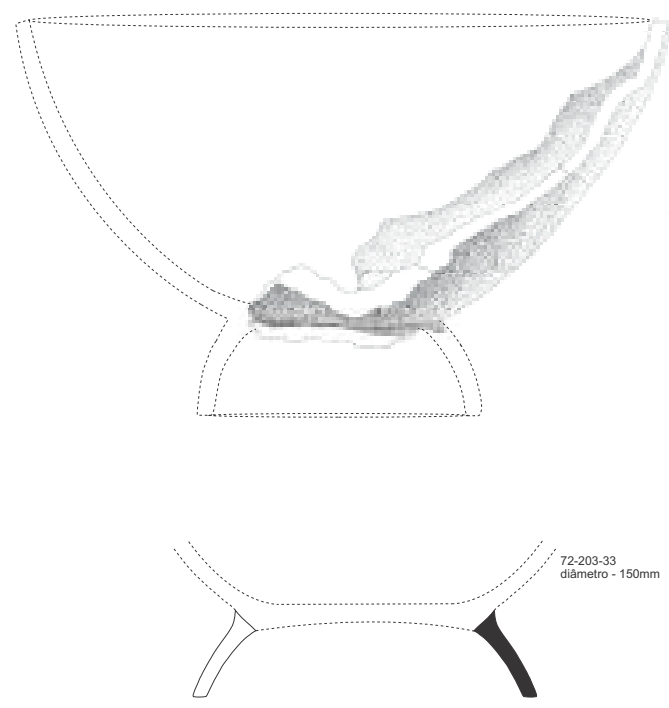

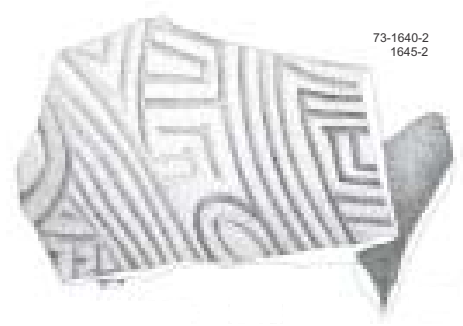




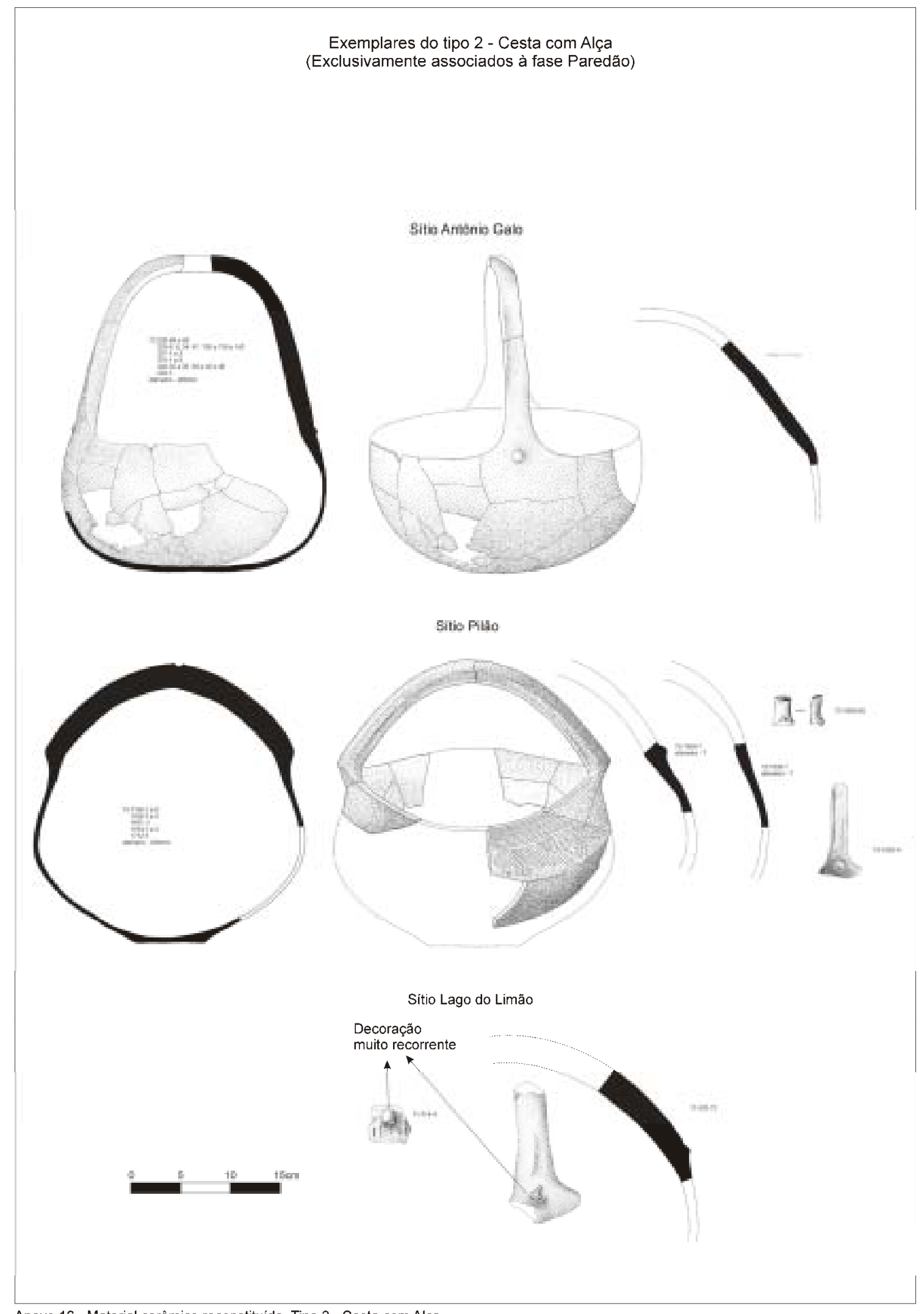

Anexo 16 - Material cerâmico reconstituído Tipo 2 - Cesta com Alça. 


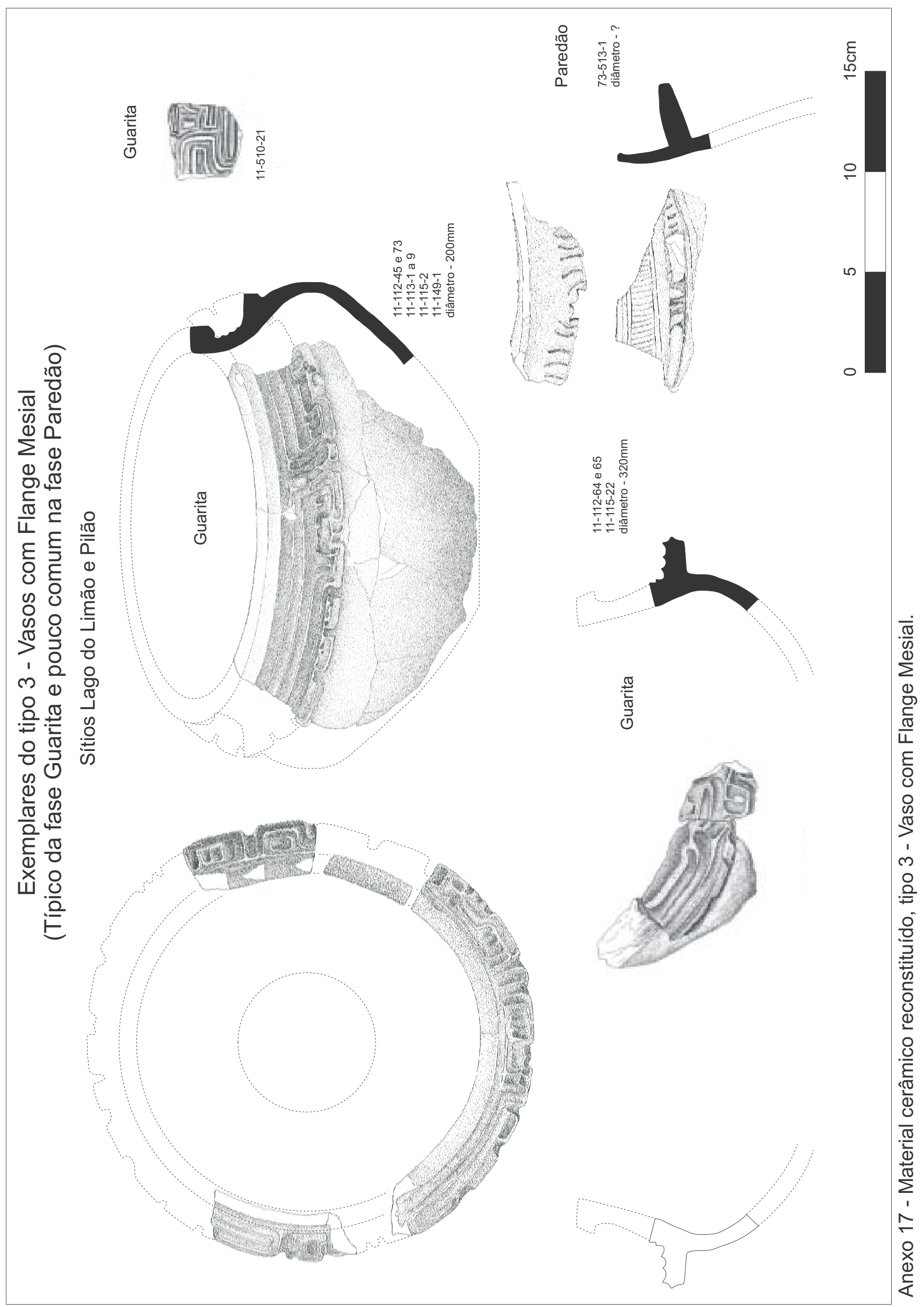




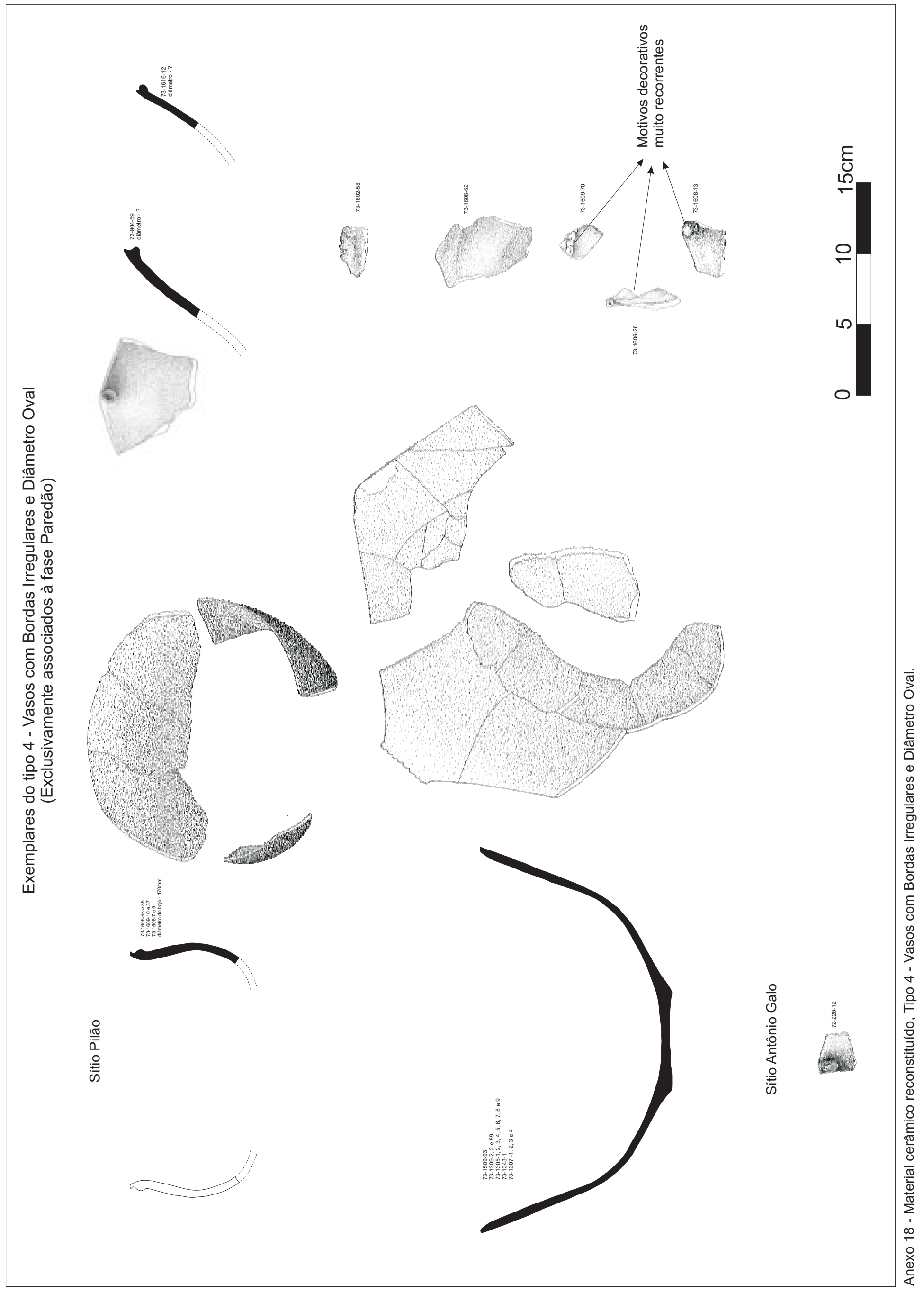




\section{Exemplares do tipo 5 - Aguidar}

Sítio Pilão

(Exemplares associados à fase Paredão)
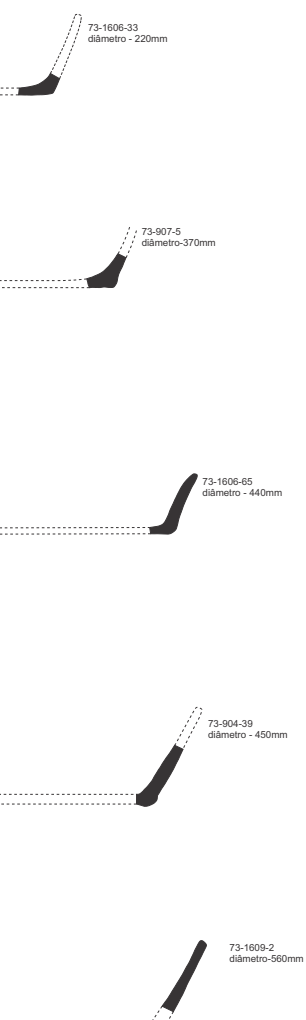

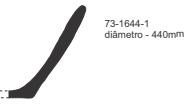

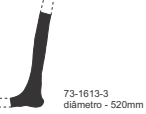

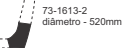
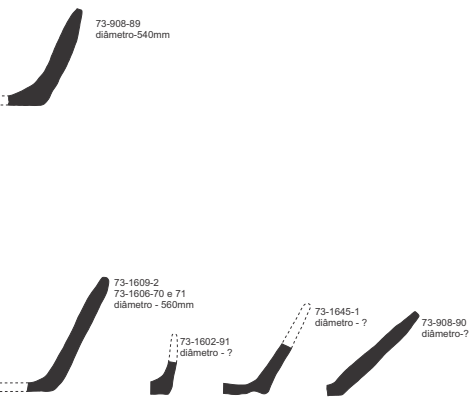

Sítio Lago do Limão

(Exemplares não associados a fase, pois o contexto onde foram encontrados era multicomponencial)
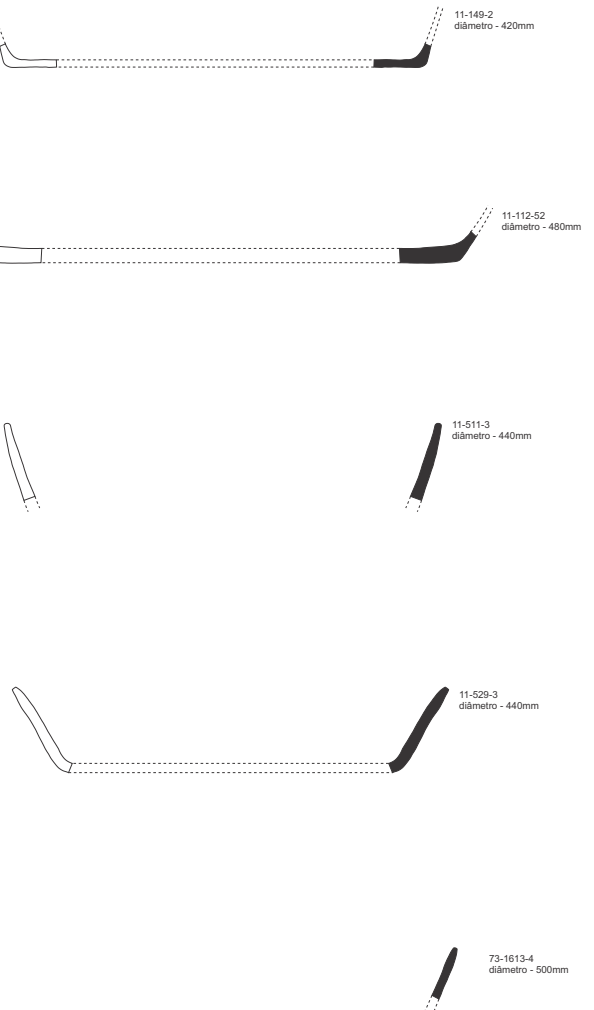

Sítio Antônio Galo

(Exemplares associados à fase Paredão)
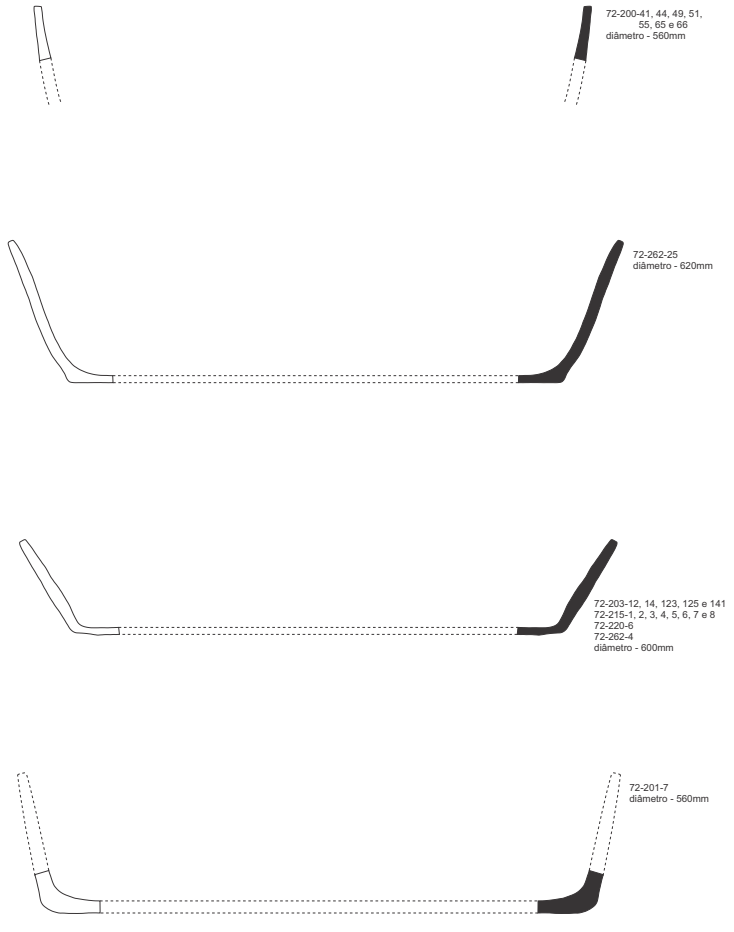
Sítio Pilão (Exemplares associados à fase Paredão)

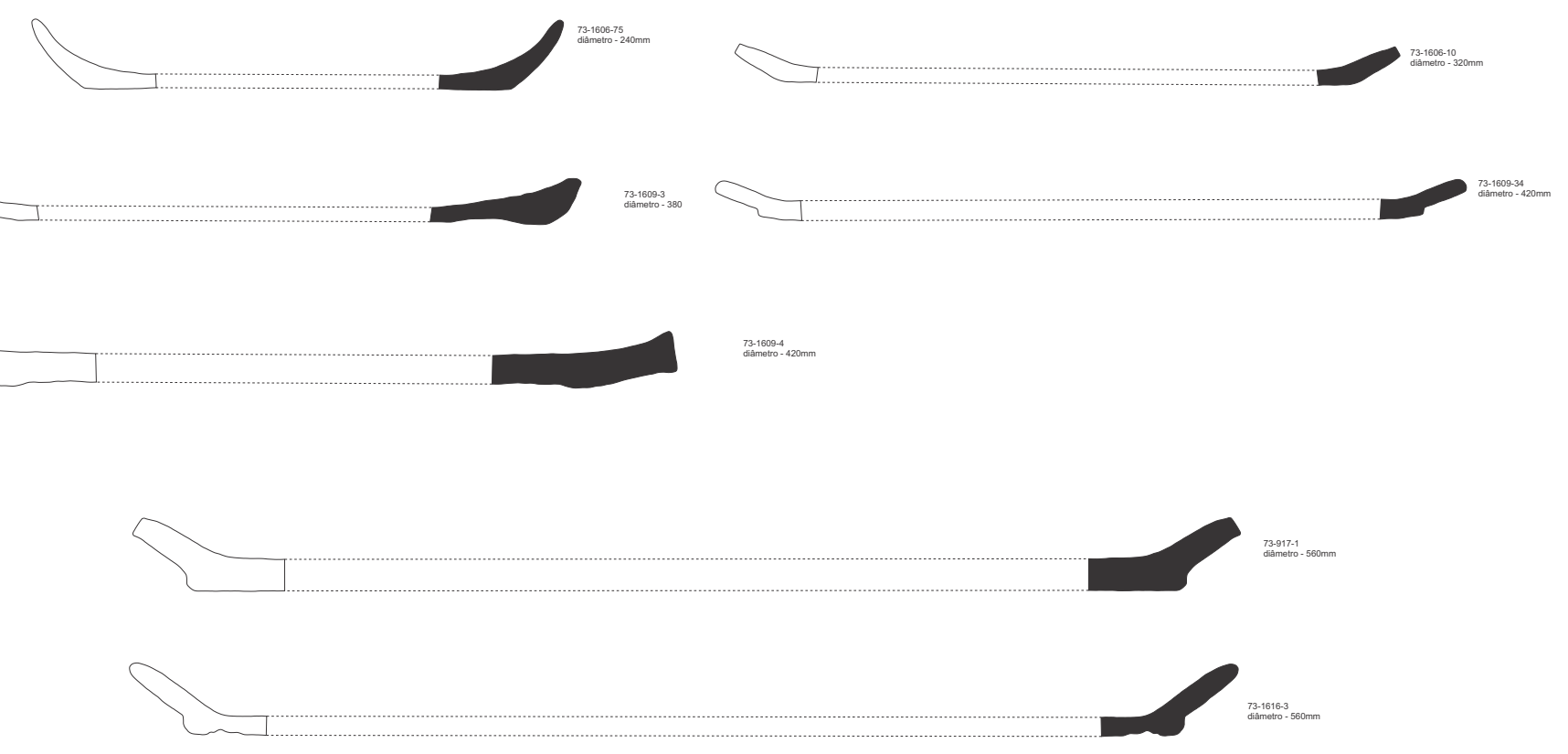

Sítio Lago do Limão

(Exemplares não associados a fases, pois o contexto onde foram encontrados era multicomponencial)
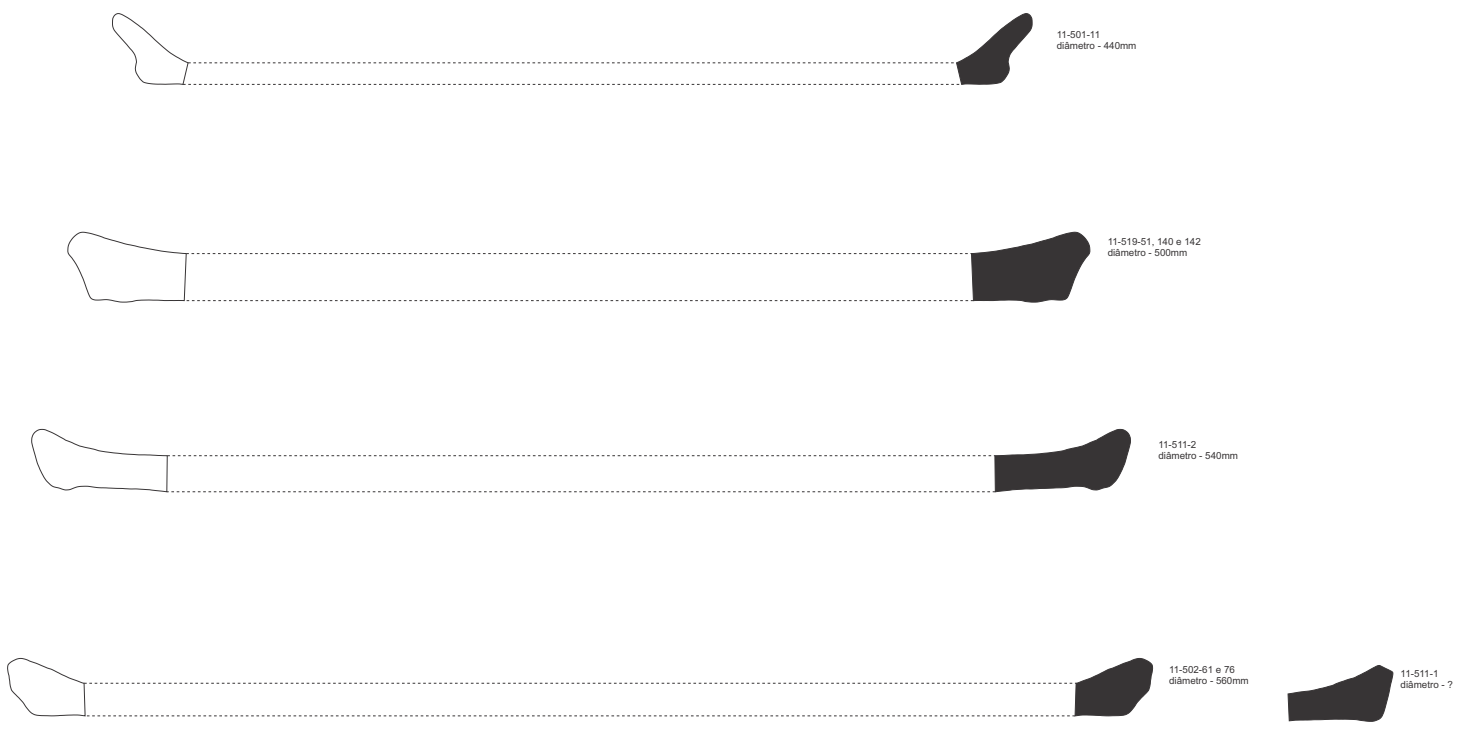

Sítio Antônio Galo (Exemplar Associado à fase Paredão) 


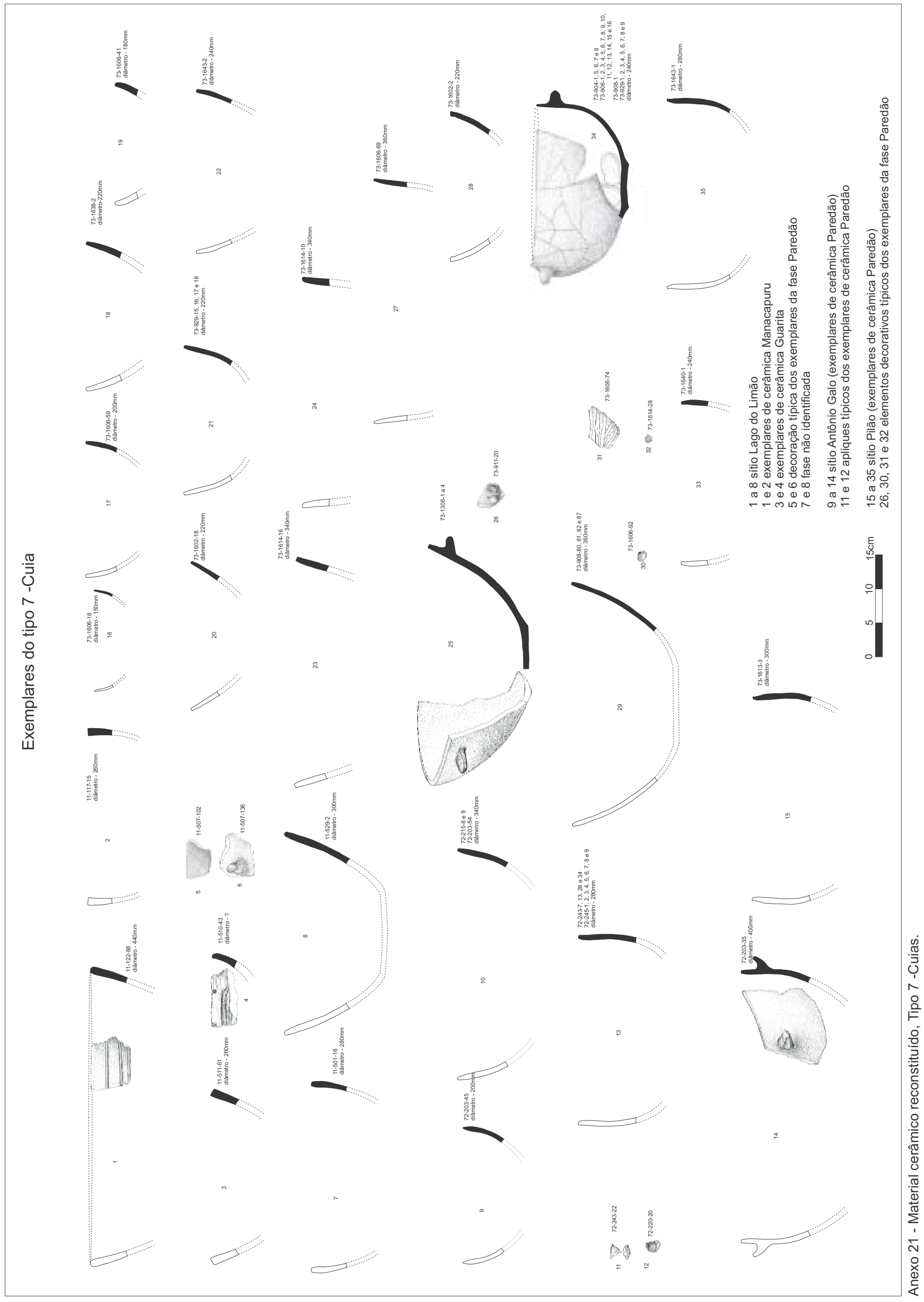




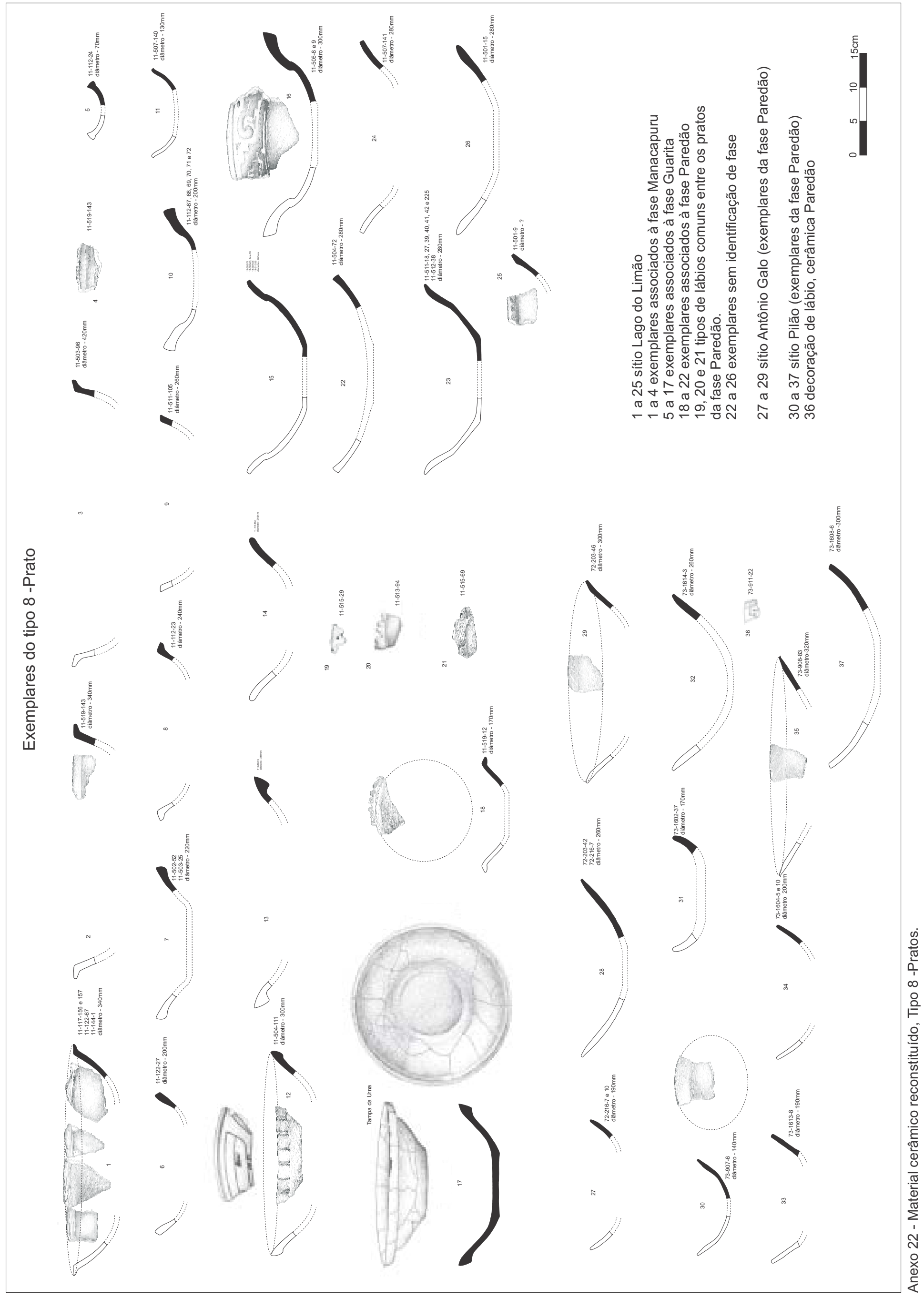



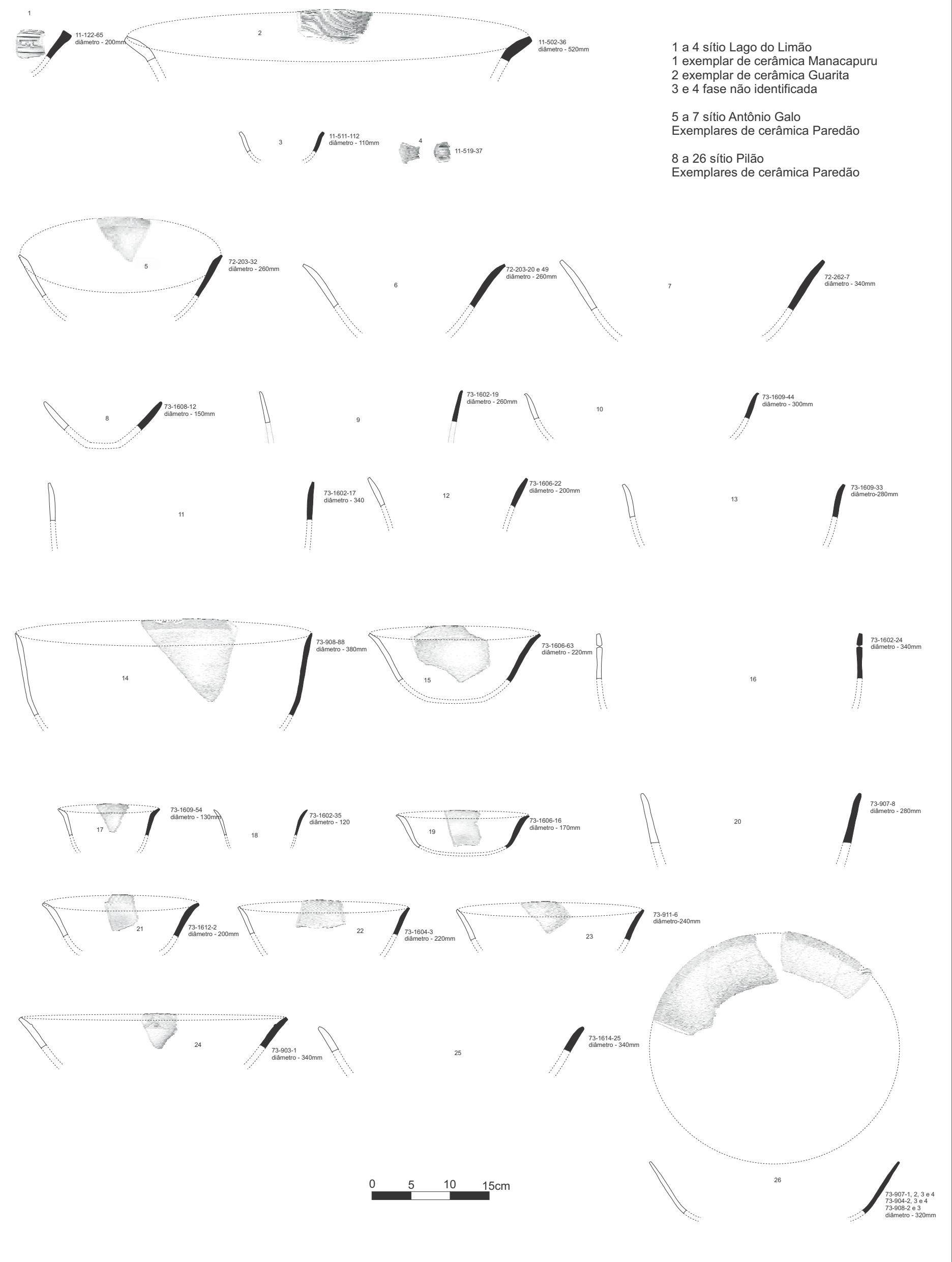


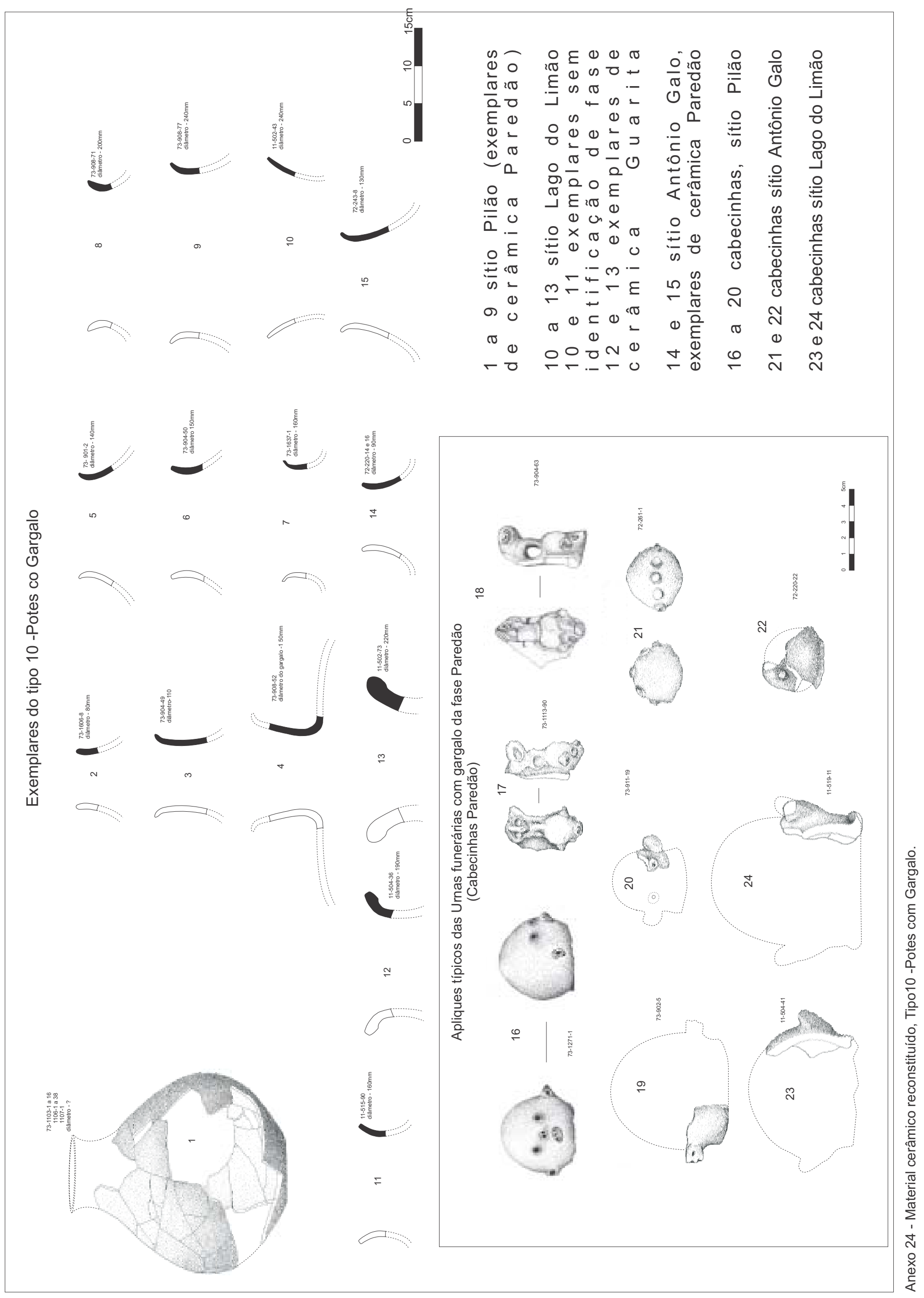




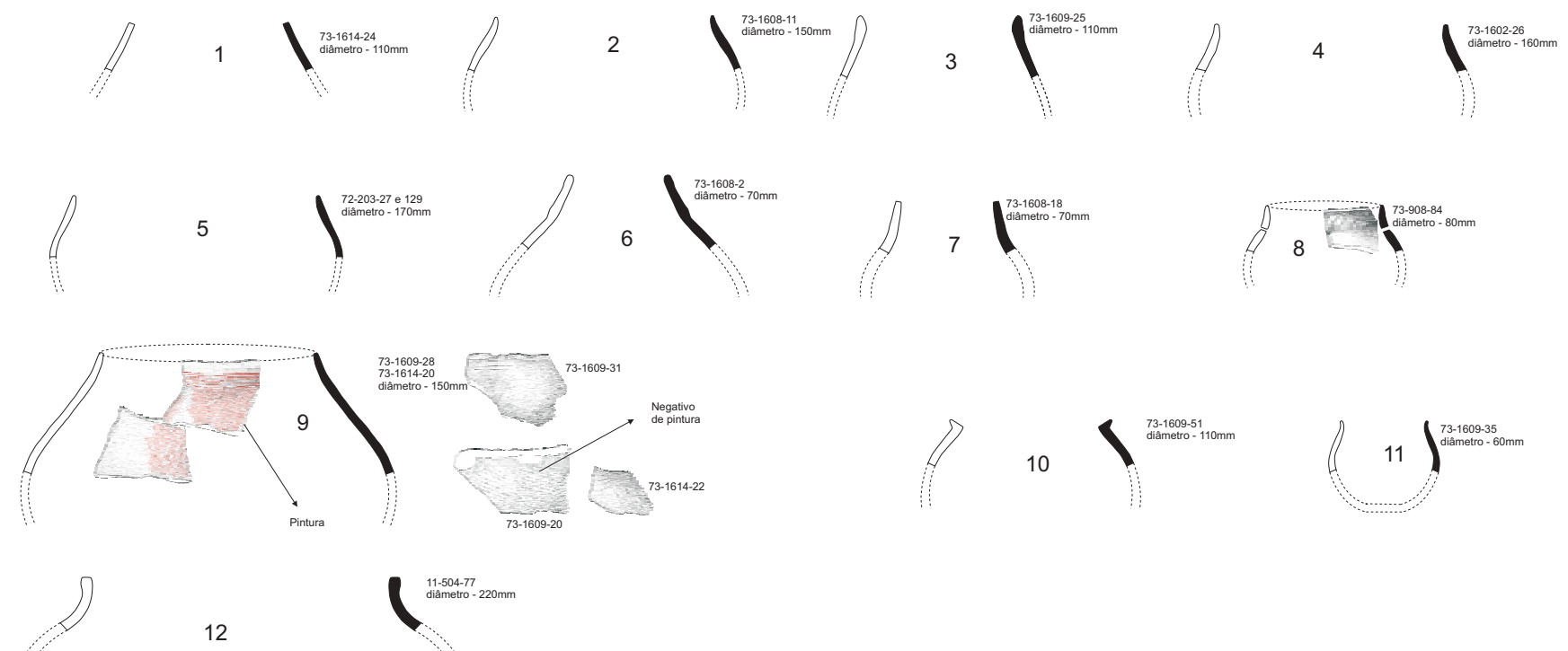

12
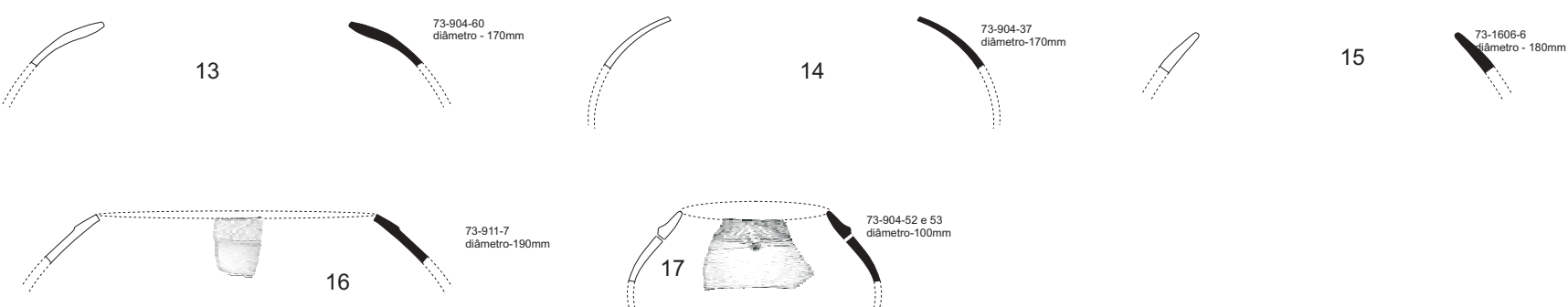

18
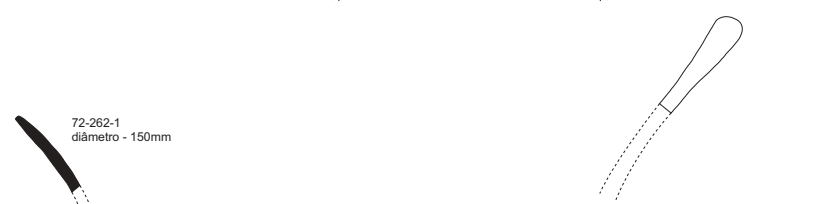

19

1 a 11 sítio Pilão

Exemplares de cerâmica Paredão

(vasos com boca restritiva e

tendência a formação de pescoço)

12 Sítio Lago do Limão

Exemplar de cerâmica Guarita

13 a 17 sítio Pilão

Exemplares de cerâmica Paredão

(vasos com boca muito restritiva)

18 sítio Antônio Galo

$21 \quad$ L $23.911-10.10 \mathrm{~mm}$

Exemplar de cerâmica Paredão

19 sítio Lago do Limão

Exemplar de cerâmica Manacapuru

22

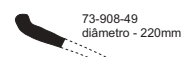

20 sítio Lago do Limão

exemplar de cerâmica Paredão

(vasos com boca muito restritiva e

tendência a formação de pescoço)

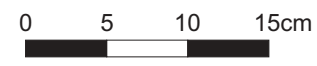

21 sítio Antônio Galo

Exemplae de cerâmica Paredão

22 sítio Pilão

Exemplar de cerâmica Paredão 


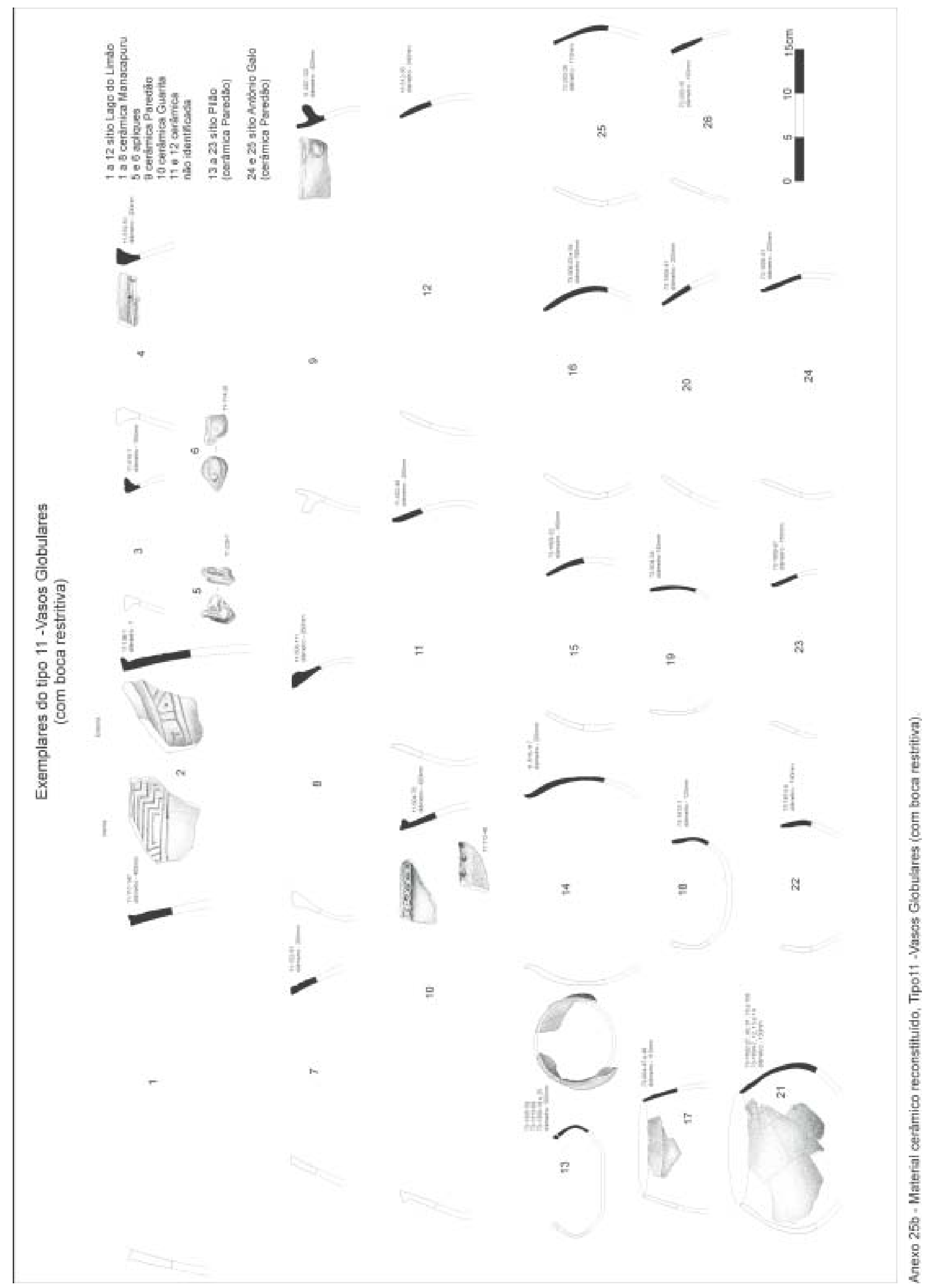




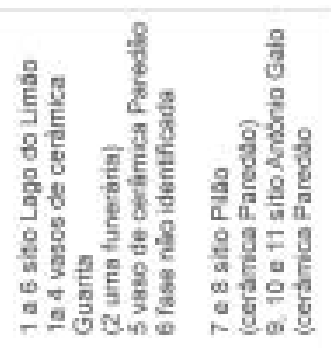

t)
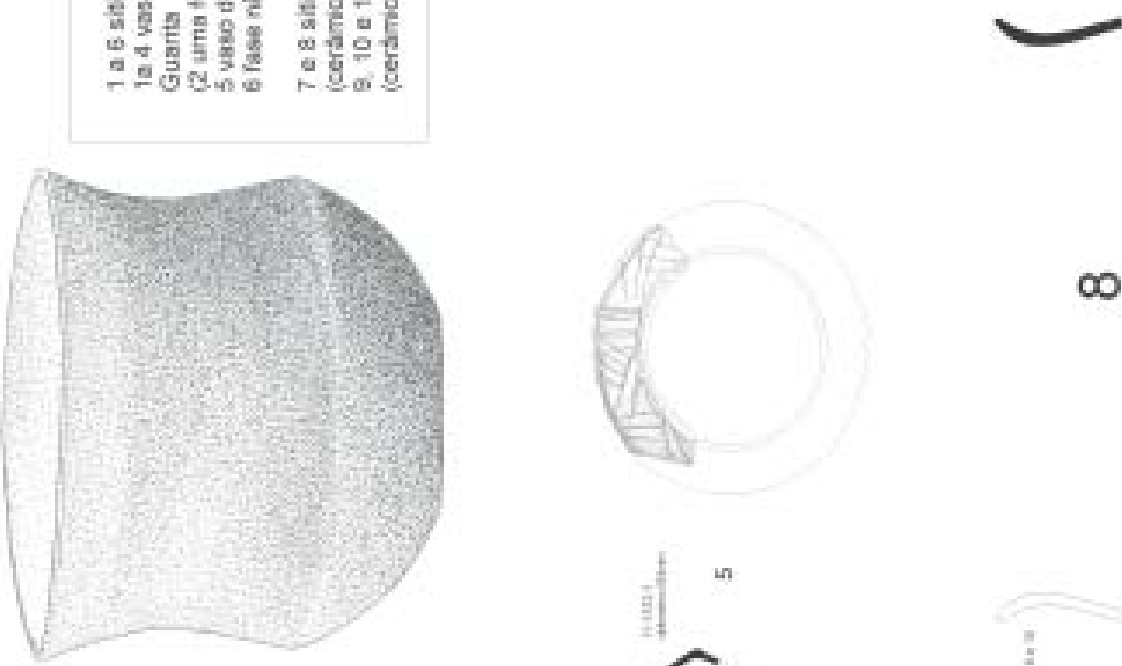

$\infty$
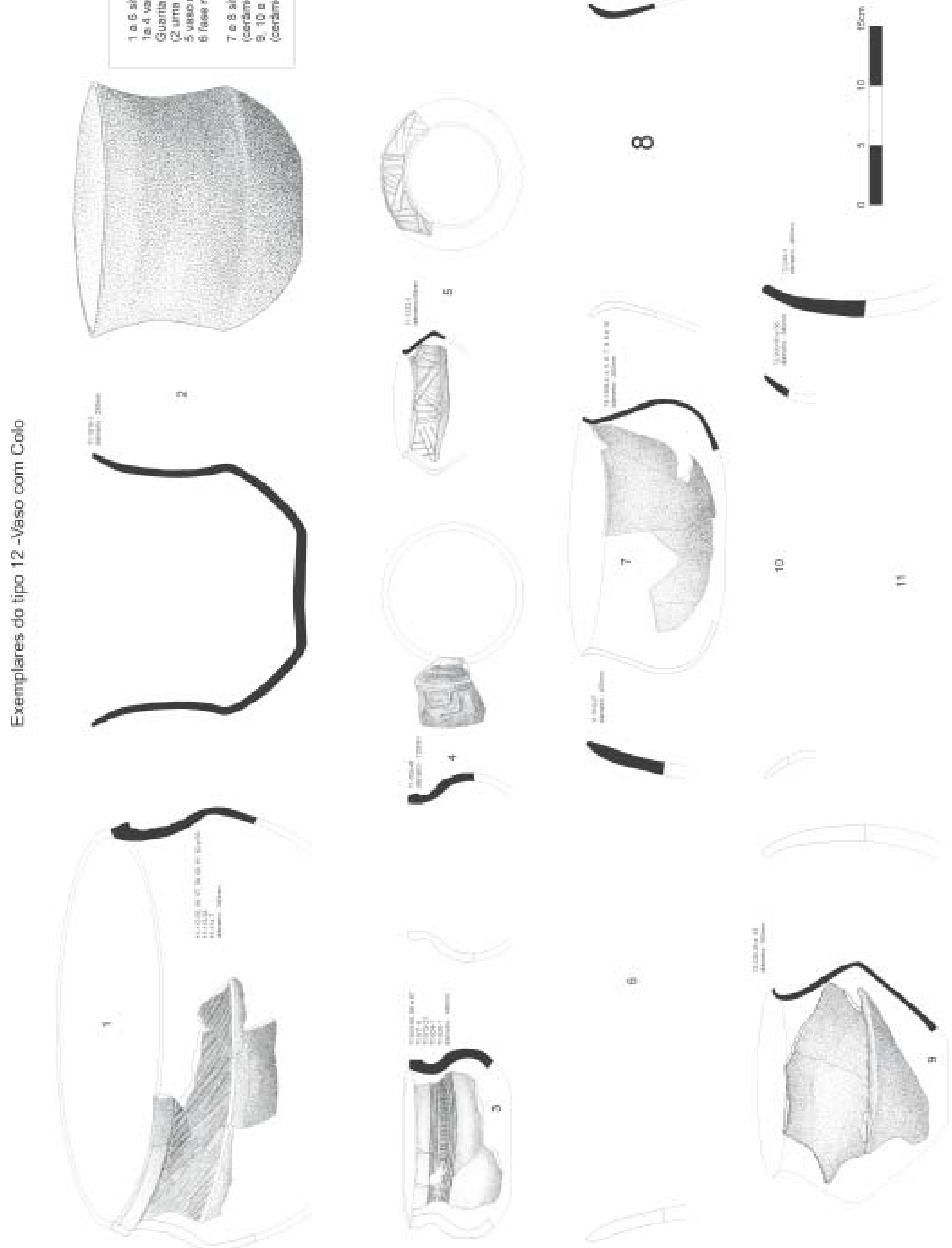


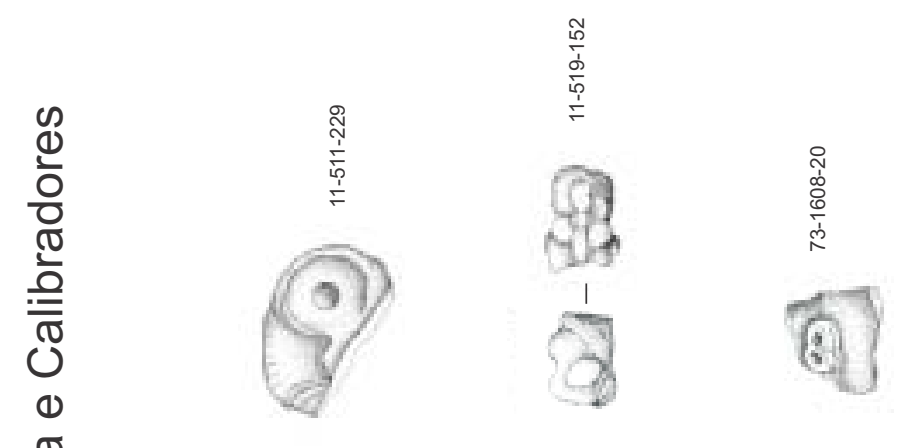

$\frac{\pi}{\frac{\pi}{E}}$

ชั

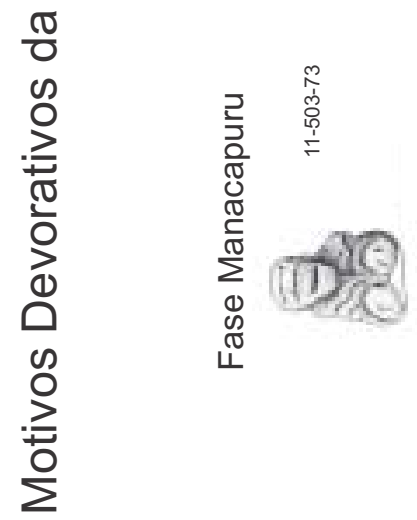

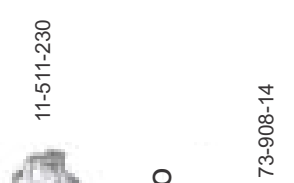

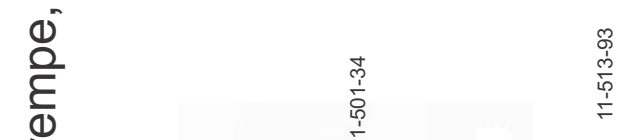

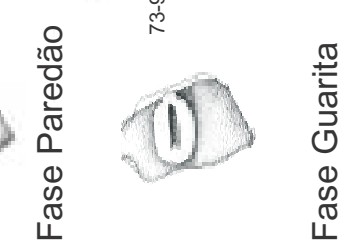
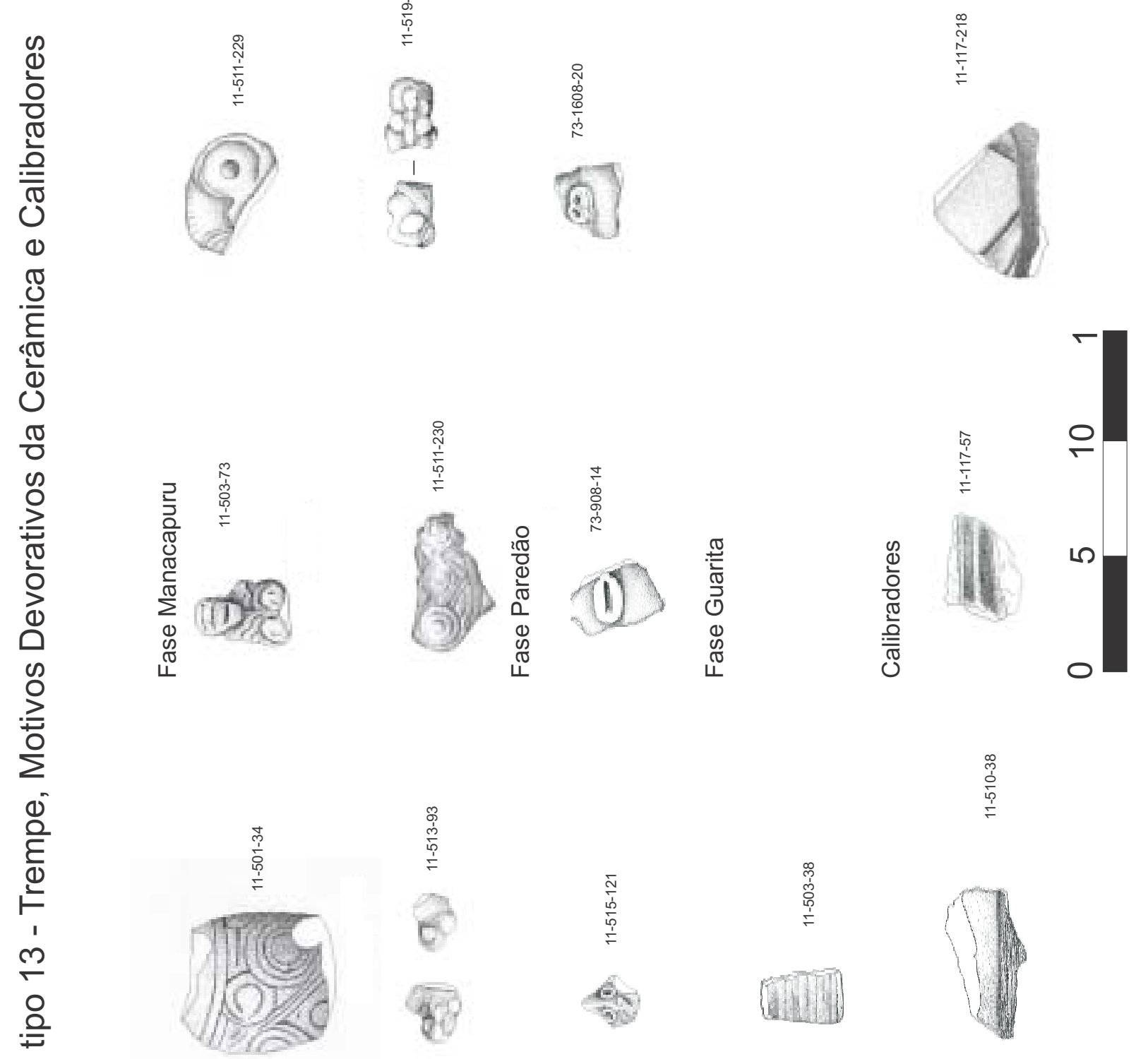

응

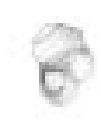

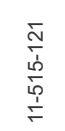
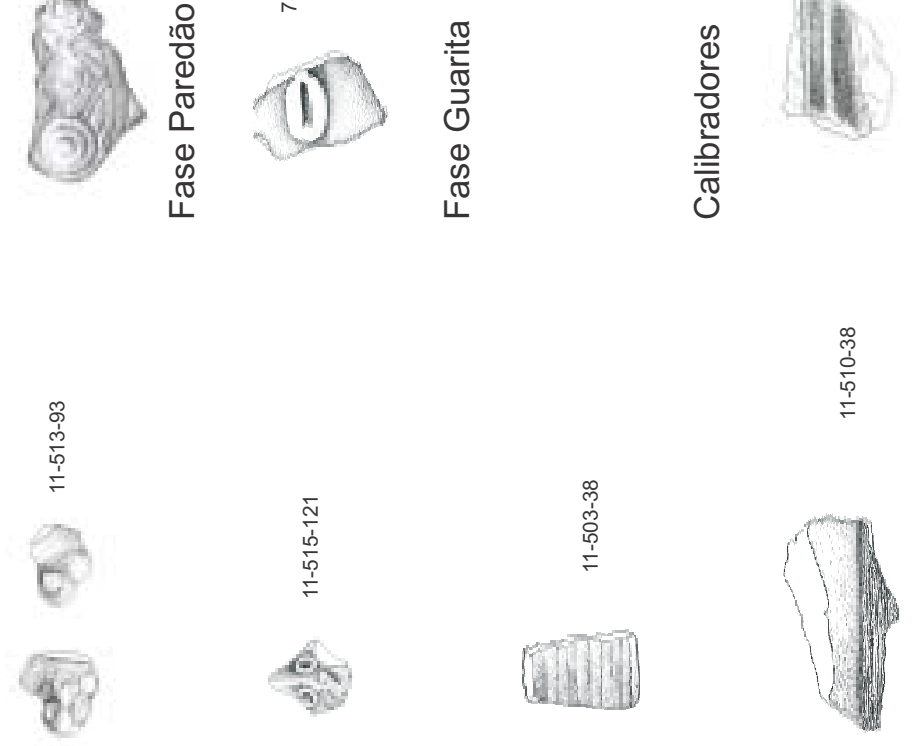

$\frac{\frac{1}{0}}{\frac{2}{2}}$

Inll

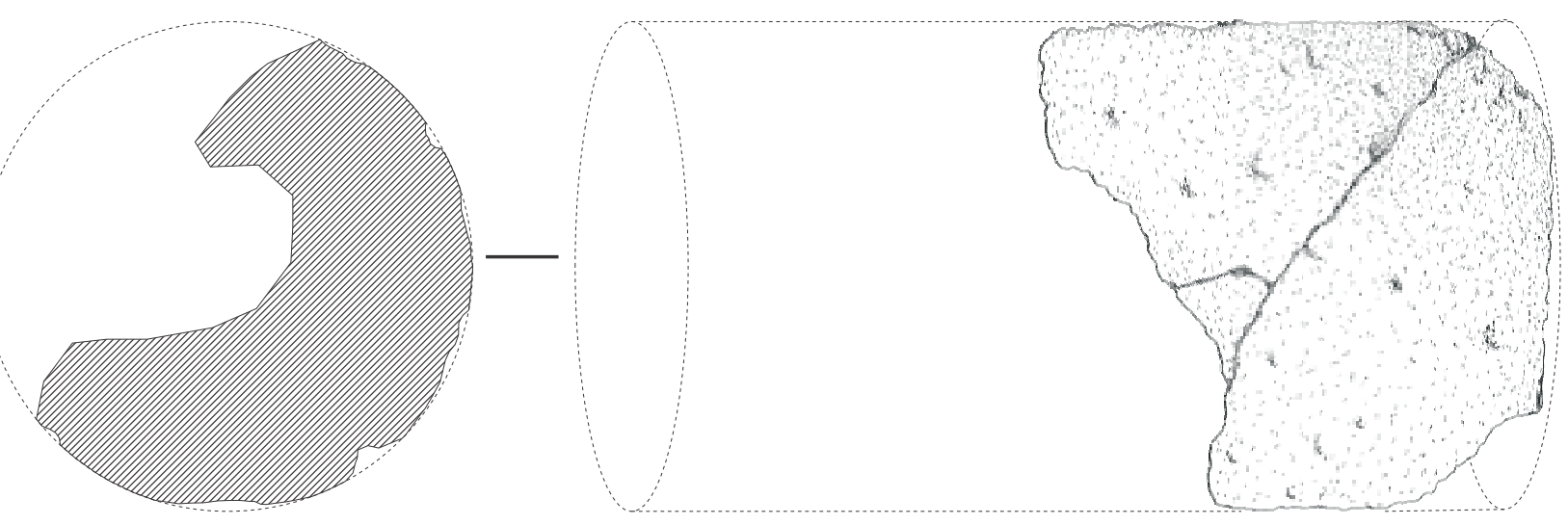


Sítio Antônio Galo bases planas (fase Paredão)
Sítio Pilão bases planas (fase Paredão)
Sítio Lago do Limão bases planas (fase não identificada)

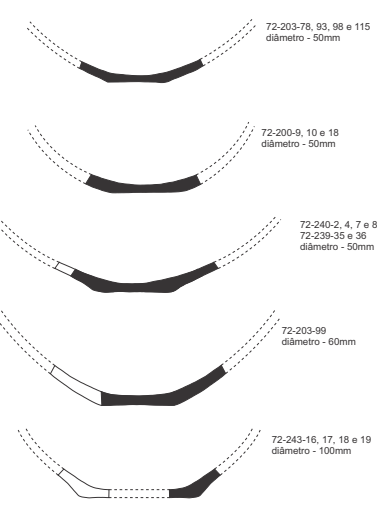

Sítio Lago do Limão bases em pedestal

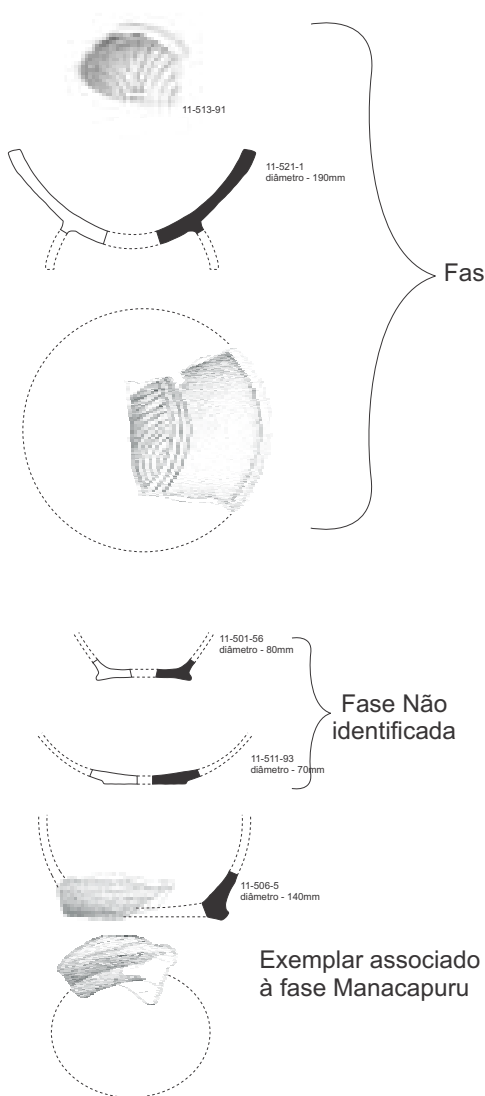

Sítio Pilão

bases côncavas (fase Paredão)

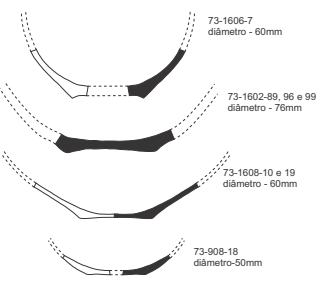

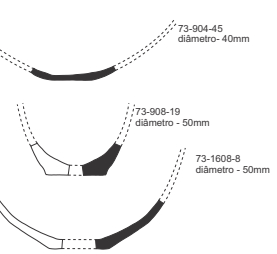

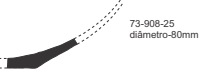

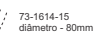
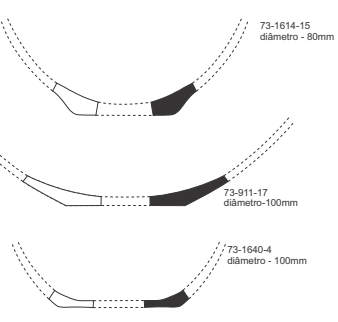

Sítio Pilão

bases em pedestal (fase Paredão)
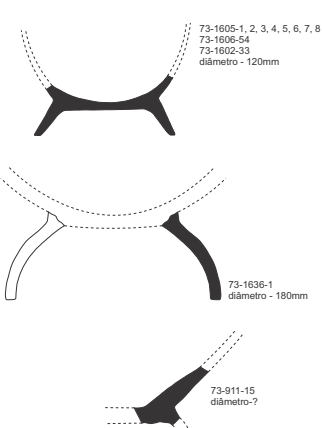

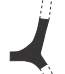
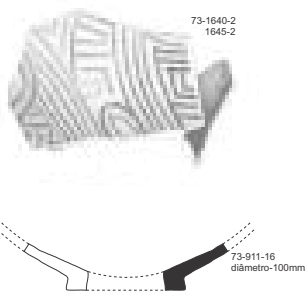

Sítio Antônio Galo bases côncavas (fase Paredão)

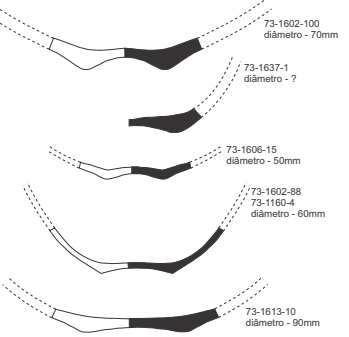

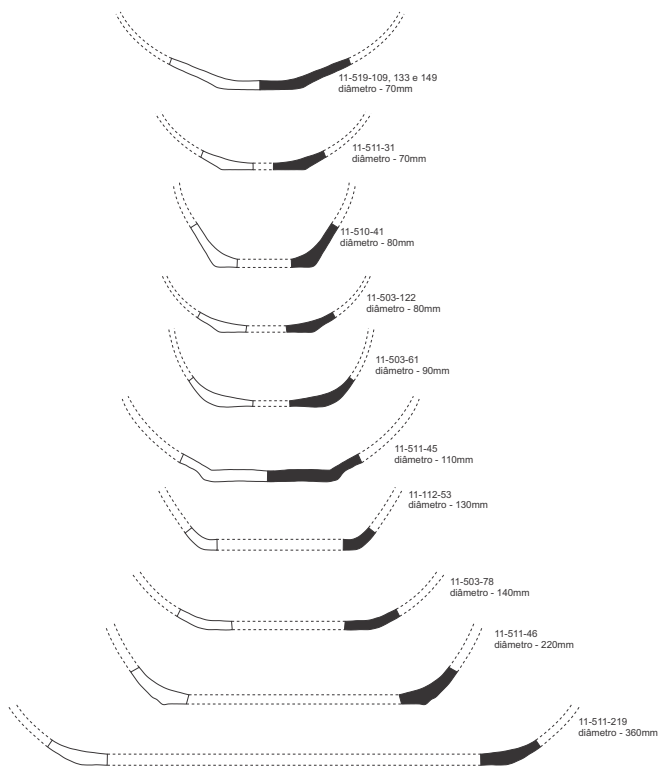

Sítio Antônio Galo bases em pedestal (fase Paredão)

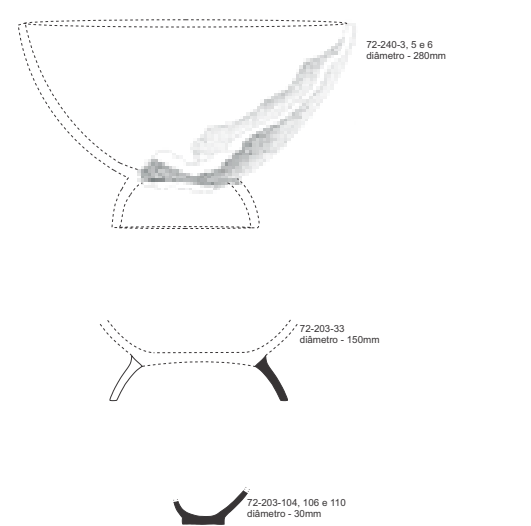

Sítio Lago do limão bases côncavas (fase não identificada)

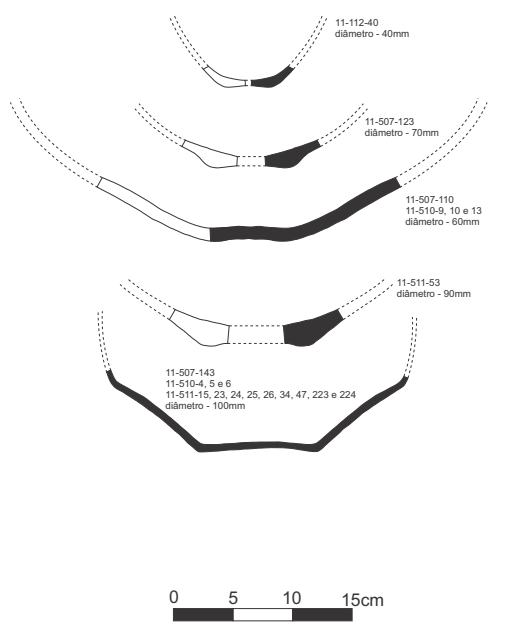

